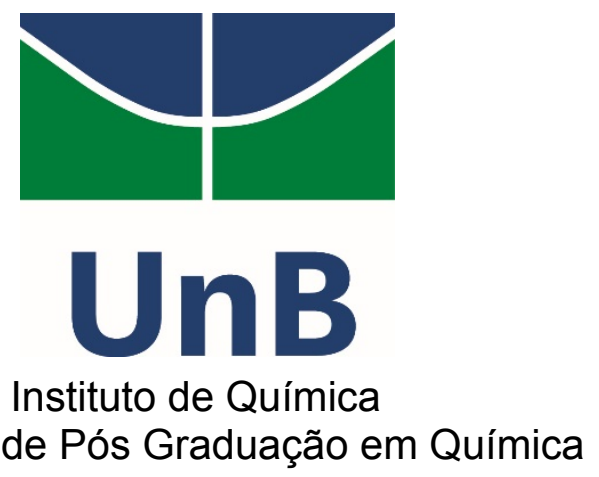

Programa de Pós Graduação em Química

\title{
Estudos Estruturais e de Interação de Novos Inibidores e Ativadores da Tirosinase
}

\author{
Diego Arantes Teixeira Pires
}

Tese de Doutorado

Orientadora: Dra. Claudia Jorge do Nascimento

Brasília

Agosto de 2016 

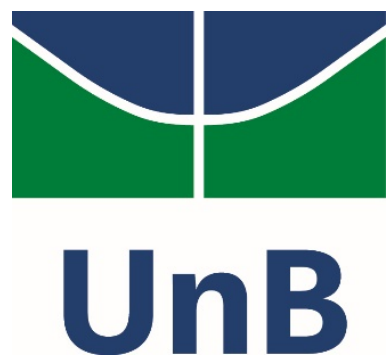

Instituto de Química

Programa de Pós Graduação em Química

\title{
Estudos Estruturais e de Interação de Novos Inibidores e Ativadores da Tirosinase
}

\author{
Diego Arantes Teixeira Pires
}

Tese de Doutorado apresentada ao Programa de Pós-Graduação em Química da Universidade Brasília como parte integrante dos requisitos exigidos para obtenção do título de Doutor em Química.

Orientadora: Dra. Claudia Jorge do Nascimento

Área de Concentração: Química Orgânica

Brasília, 04 de Agosto de 2016 


\section{Folha de Aprovação}

Comunicamos a aprovação da Defesa de Tese de Doutorado do (a)

aluno (a) Diego Arantes Teixeira Pires, matrícula no 12/0178567, intitulada

"Estudos Estruturais e de Interação de Novos Inibidores e Ativadores da

Tirosinase", apresentada no (a) Auditório Verde do Instituto de Química (IQ) da Universidade de Brasília (UnB) em 4 de agosto de 2016.

Prof. Dr. Cláudia Jorge do Nascimento Presidente de Banca (IQ/UnB)

Profa Dra Aline Lima de Oliveira Membro Titular (IQ/UnB)

Prof. Dr. Guilherme Dotto Brand Membro Titular (IQ/UnB)

Prof. Dr. Luciano Morais Lião Membro Titular (IQ/UFG)

Profa Dra Amarilis de Vicente Finageiv Neder Membro Titular (IQ/UnB)

Prof. Dr. José Alves Dias Membro Suplente (IQ/UnB) 


\section{Agradecimentos}

Gostaria de agradecer primeiramente à Professora Claudia pela orientação, paciência, conselhos, ensinamentos, dedicação, amizade e confiança. Sou muito grato por todo o aprendizado nesses quase 10 anos de trabalho juntos. Espero continuar trabalhando e aprendendo com você por pelo menos mais 10 anos. Obrigado por tudo.

Aos meus pais e familiares por todo o apoio, ajuda e paciência ao longo desses anos.

Ao Professor Figueroa pela orientação, confiança, disponibilidade, ensinamentos e por deixar as portas do seu laboratório sempre abertas.

Ao Carlos Bloch pela orientação, ensinamentos, rigor científico e por toda a colaboração. À Maura por toda a ajuda, orientação, disponibilidade, brincadeiras, lanches e esporros, certamente o trabalho ficou mais divertido com você.

Ao Professor Fabio Almeida pelo uso do equipamento de $800 \mathrm{MHz}$ no CNRMN/IBqM/UFRJ para realização da segunda etapa desse trabalho.

Aos colegas do Laboratório de Espectrometria de Massa: Luísa, Nathy, Sophia, Éder, Sifu, Mari, Bia, Ingrid, Giselle, Eduardo e Marcelo por toda a ajuda.

Ao Professor Luciano Paulino por disponibilizar seu laboratório para a realização dos testes biológicos.

Aos colegas do IME: Denise, Marcelle e Edijane por toda a ajuda, paciência, colaboração e almoços. Certamente minhas estadias no Rio de Janeiro foram mais agradáveis graças a vocês.

À Kênia pela amizade, passeios, baladas, risadas, hospedagem, carinho, idas ao IME no final de semana, lanches e por sempre ficar me ouvindo até de madrugada, seja para fazer fofoca ou reclamar das coisas. As idas ao Rio de Janeiro não teria a mesma graça sem você. Obrigado por tudo.

À Priscila e à Bárbara por sempre me receberem bem no Rio, pelas baladas, lanches e risadas. Rio de Janeiro ficou mais divertido com vocês.

Aos colegas de IFG: Ernani, Henrique, Chris, Leonardo, Rosmany e Marizângela. Ao Luiz Loja pela amizade, por sempre me ouvir, pelas 
colaborações, baladas e viagens, certamente meus dias de doutorado foram mais divertidos. À Camilla pelas brincadeiras, risadas, caronas, lanches, JIF, almoços, jantares e amizade. Trabalhar durante o doutorado foi muito mais prazeroso e teve uma vantagem: conhecer você. Obrigado por toda a ajuda e por me aturar. À Janaína pelas diversões, risadas, fofocas, caronas, amizade, viagens e JIF. O IFG era bem mais divertido com a sua presença. À Nathalie pela amizade, risadas, caronas, viagens, lanches, provas, aulas de laboratório, carnavais e baladas. O IFG não é o mesmo sem você.

À Natasha e Thaisa pela amizade, saídas, viagens, baladas e por me aturarem. À Flora e Thais pela a amizade de longos anos.

Aos amigos Miguel, Saulo, Marcus, Julia, Roberta, Mayra e Fabíola pelas saídas, baladas, tequila, viagens, pré-caju, IPVA, cafés, açaí, almoços e jantares. Os tempos de doutorado foram muito mais divertido com vocês. Ao Ricardo pela amizade, baladas, viagens, cervejas, comidas, carnavais e por sempre me ouvir. Certamente deixou o período do meu doutorado muito mais animado. Obrigado por tudo.

À Professora Patrícia Lootens pela amizade, conselhos e ensinamentos. Certamente contribuiu muito para a minha formação.

Ao Professor Laurent e à Isabella por toda a ajuda com a parte de docking molecular, ensinamentos e disponibilidade. Vocês contribuíram muito para o trabalho.

Ao Professor Robson Ricardo pela amizade e por toda a ajuda junto a parte de síntese e colaborações. Foi um prazer trabalhar com você.

À Embrapa Recursos Genéticos e Biotecnologia, Instituto Militar de Engenharia (IME), Universidade de Brasília (UnB), Instituto Federal de Educação, Ciência e Tecnologia de Goiás (IFG), Centro Nacional de Ressonância Magnética Nuclear (CNRMN) e ao Laboratório Nacional de Computação Científica (LNCC) pelo apoio institucional. À CAPES, CNPq, UnB e IFG pelo apoio financeiro. 


\section{Índice}

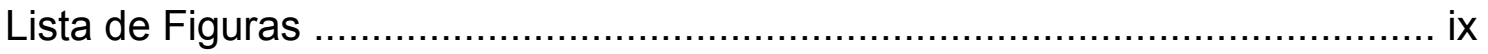

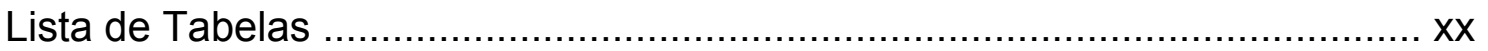

Lista de Abreviaturas e Acrônimos ............................................................... xxii

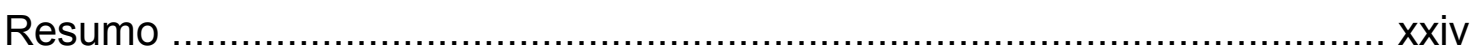

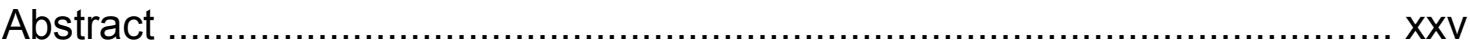

Capítulo I

Estudos Estruturais e de Interação de novos Inibidores da Tirosinase

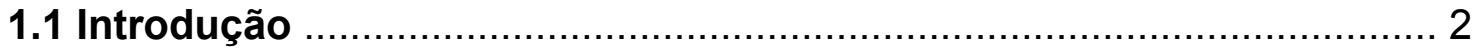

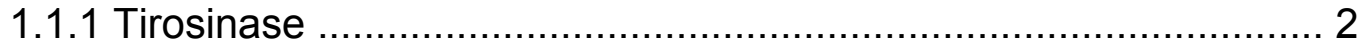

1.1.2 RMN no Estudo de Interação Proteína-Ligante ........................... 9

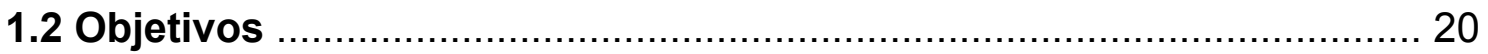

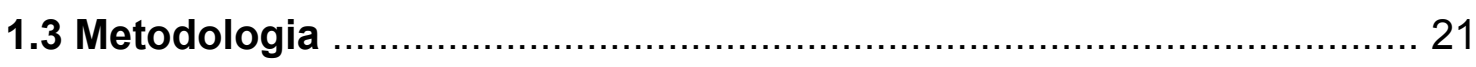

1.3.1 Síntese e Caracterização de Possíveis inibidores

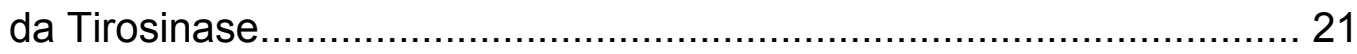

1.3.2 Estudo do Equilíbrio Tautomérico Ceto-Enólico por RMN ........... 24

1.3.3 Estudo do Equilíbrio Tautomérico Ceto-Enólico por

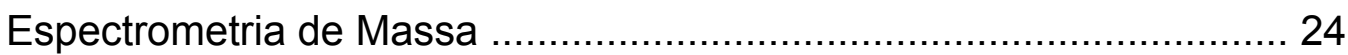

1.3.4 Estudo do Equilíbrio Tautomérico Ceto-Enólico

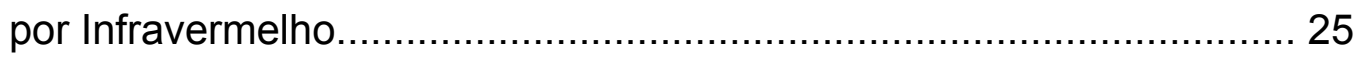

1.3.5 Estudo do Equilíbrio Tautomérico Ceto-Enólico por

Cálculos de Mecânica Quântica ...................................................... 25

1.3.6 Teste Biológico: Atividade em Relação à Enzima Tirosinase ...... 25

1.3.7 Deslocamento Químico, Relaxação e Difusão no Estudo de Interação Ligante-Enzima por RMN.............................................. 26

1.3.8 STD no Estudo de Interação Ligante-Enzima por RMN .............. 27

1.3.9 INPHARMA no Estudo de Interação Ligante-Enzima por RMN.... 28

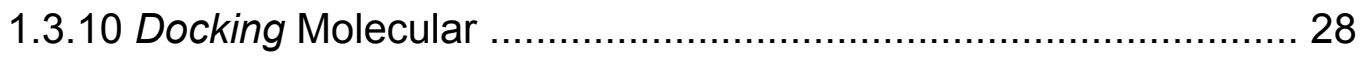

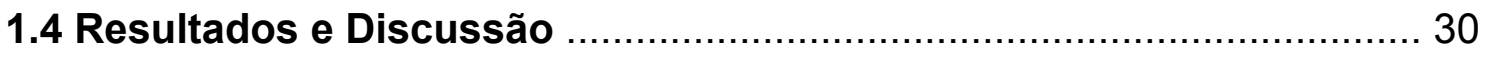

1.4.1 Síntese e Caracterização de Possíveis inibidores da

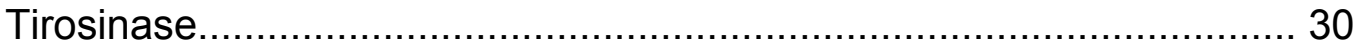


1.4.2 Estudo do Equilíbrio Tautomérico Ceto-Enólico por RMN 33

1.4.3 Estudo do Equilíbrio Tautomérico Ceto-Enólico por

Espectrometria de Massa

1.4.4 Estudo do Equilíbrio Tautomérico Ceto-Enólico por

Infravermelho.

1.4.5 Estudo do Equilíbrio Tautomérico Ceto-Enólico por

Cálculos de Mecânica Quântica 56

1.4.6 Teste Biológico: Atividade em Relação à Enzima Tirosinase ...... 57

1.4.7 Deslocamento Químico, Relaxação e Difusão no Estudo

de Interação Ligante-Enzima por RMN 60

1.4.8 STD no Estudo de Interação Ligante-Enzima por RMN 67

1.4.9 INPHARMA no Estudo de Interação Ligante-Enzima por RMN ... 82

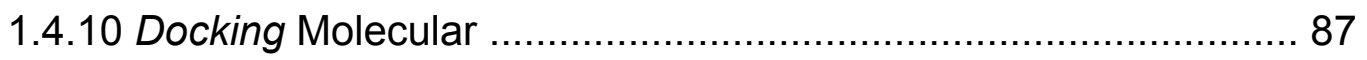

1.5 Conclusão 94

Capítulo II

Estudos Estruturais e de Interação de Análogo Sintético da Somatostatina como Ativador da Tirosinase

2.1 Introdução 96

2.1.1 Somatostatina e Análogos Sintéticos 96

2.1.2 Ressonância Magnética Nuclear (RMN) no Estudo de Peptídeos 101

2.2 Objetivos 103

2.3 Metodologia 104

2.3.1 Síntese do Peptídeo Análogo à Somatostatina 105

2.3.2 Purificação e Caracterização do Peptídeo Análogo Sintético......107

2.3.3 Determinação Estrutural do Peptídeo Análogo Sintético 108

2.3.4 Teste Biológico: Atividade com relação à Enzima Tirosinase .....110

2.3.5 Interação do Peptídeo Análogo com a Tirosinase por RMN .......111

2.3.6 Docking Molecular .............................................................. 111

2.3.7 Interação do Peptídeo Análogo com a Tirosinase por Espectrometria de Massa 112

2.4 Resultados e Discussão 114

2.4.1 Síntese do Peptídeo Análogo à Somatostatina 114 
2.4.2 Purificação e Caracterização do Peptídeo Análogo Sintético .....115

2.4.3 Determinação Estrutural do Peptídeo Análogo Sintético ........... 124

2.4.4 Teste Biológico: Atividade com relação à Enzima Tirosinase .... 128

2.4.5 Interação do Peptídeo Análogo com a Tirosinase por RMN ...... 131

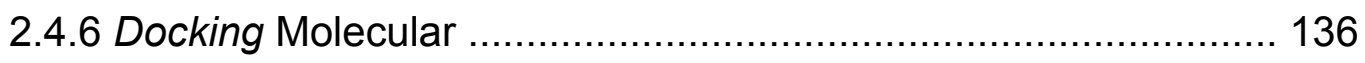

2.4.7 Interação do Peptídeo Análogo com a Tirosinase por

Espectrometria de Massa ............................................................... 144

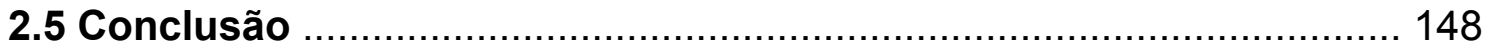

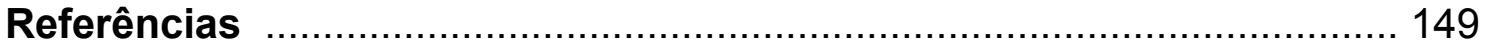

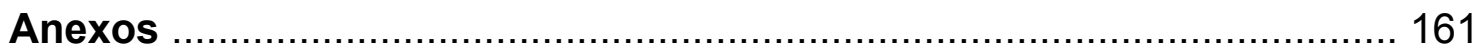




\section{Lista de Figuras}

Figura 1.1: Reações envolvidas para a produção de melanina a partir da tirosina. As duas primeiras etapas são catalisadas pela enzima tirosinase.

Figura 1.2: Ciclo catalítico da tirosinase para a hidroxilação de monofenóis, indicando os três tipos diferentes de tirosinase ao longo do ciclo e também a participação do cobre.

Figura 1.3: Reações envolvidas para a produção de neuromelanina a partir da dopamina. [E] indica a presença da enzima tirosinase.

Figura 1.4: Estruturas do ácido kojic e do ácido ascórbico, dois potentes inibidores da tirosinase. 6

Figura 1.5: Exemplos de fenois e polifenois inibidores da tirosinase ............... 7

Figura 1.6: Exemplos de compostos carbonilados inibidores da tirosinase ................................................................................................... 7

Figura 1.7: Estrutura de alguns compostos ativadores da tirosinase ............... 8

Figura 1.8: Estrutura do ligante e deslocamento químico de ${ }^{1} \mathrm{H}-\mathrm{RMN}$ dos átomos $\mathrm{H} 5, \mathrm{H} 10(13), \mathrm{H} 9(12), \mathrm{H} 3$ e $\mathrm{H} 4$ livres (0\% de BSA) e também na presença de BSA (1, 2 e 3\%). É observada uma variação de deslocamento químico desses átomos, indicando a participação dos mesmos na interação com a enzima. Os outros átomos não sofreram variação de deslocamento químico na presença do BSA. O estudo contou também com a presença e a ausência de FU (5-fluorouracila), utilizado no tratamento de câncer de mama. 10

Figura 1.9: Relação dos tempos de relaxação $T_{1}$ e $T_{2}$ com o tempo de correlação (tempo de correlação pode ser definido como o tempo médio que uma molécula leva para rodar um radiano; assim para moléculas maiores e meios mais viscosos, os movimentos moleculares se tornam mais lentos).

Figura 1.10: Estrutura de um ligante envolvido na interação com a proteína HSA. Valores em preto indicam o coeficiente de difusão do ligante livre e em azul na presença da proteína $\left(\mathrm{D} \times 10^{10}\left(\mathrm{~m}^{2} / \mathrm{s}\right)\right)$. A variação observada indica os possíveis átomos envolvidos na interação. Os outros hidrogênios não sofreram variação no valor do coeficiente de difusão.

Figura 1.11: Relação entre o NOE e o tamanho da molécula $\left(\omega_{0} T_{c}\right) \ldots \ldots \ldots \ldots 15$

Figura 1.12: Experimento de STD. (1) Saturação seletiva da proteína. (2) Transferência de saturação da proteína para os hidrogênios do ligante que estão envolvidos na interação. (3) Detecção do ligante, havendo um 
incremento da intensidade dos sinais que interagiram com a proteína. Quando maior a interação do átomo do ligante com a proteína, maior será o incremento do seu sinal.

Figura 1.13: Interação de um inibidor com um peptídeo $\beta$-amiloide. A) Espectro do ligante livre. B) Espectro de STD, indicando apenas os hidrogênios envolvidos na interação. C) Espectro de STD de um ligante que não interage com a biomolécula, indicando que nenhum hidrogênio participou da interação inexistente. 16

Figura 1.14: Esquema do experimento INPHARMA. (1) Durante o mixing time do NOESY, quando um ligante $L_{1}$ se liga ao receptor, os prótons de $L_{1}$ que participam da interação transferem magnetização para os prótons do receptor. (2) Durante o mesmo mixing time, o ligante $L_{1}$ irá se dissociar do receptor, permitindo que um segundo ligante $L_{2}$ se ligue no mesmo sítio do receptor. (3) A magnetização que havia sido transferida de $L_{1}$ para o receptor, agora pode ser transferida novamente do receptor para os prótons de $L_{2}$. $O$ espectro NOESY irá apresentar sinais de correlação entre $L_{1}$ e $L_{2}$, chamados de INPHARMA NOE. 18

Figura 1.15: Exemplo de INPHARMA envolvendo dois ligantes $B$ e $C$ com a proteína GPR 40 (classe das proteínas G). Observou-se sinais de INPHARMA NOE no espectro de NOESY (sinais identificados em verde) entre os ligantes. Identificou-se também que os hidrogênios $3,4,5,6,7$ e 8 do ligante $B$ interagiram com a proteína no mesmo local que os hidrogênio $3,4,5,12,13$ e 14 do ligante $\mathrm{C}$. 19

Figura 1.16: Rota sintética envolvida na preparação dos compostos 1 a 5 e 11 a 16. Condições de reação: (i) $\mathrm{DBU}, \mathrm{CHCl}_{3}$, refluxo; (ii) $\mathrm{DBU}, \mathrm{CHCl}_{3}$, temperatura ambiente; (iii) $\mathrm{DBU}, \mathrm{CH}_{3} \mathrm{CN}$, refluxo; (iv) $\mathrm{Hg}(\mathrm{OAc})_{2}, \mathrm{NaOAc}$, $\mathrm{CH}_{3} \mathrm{COOH}$, refluxo; (v) DMAP, $\mathrm{Ac}_{2} \mathrm{O}, \mathrm{Et}_{3} \mathrm{~N}, \mathrm{CHCl}_{3}$, temperatura ambiente. 23

Figura 17: Rota sintética envolvida na preparação dos compostos 7, 8, 9 e 10. 23

Figura 1.18: Estruturas do possível equilíbrio ceto-enólico para o composto 1 , apresentando as formas ceto-enólica e dicetônica, respectivamente. 33

Figura 1.19: Espectros de ${ }^{1} \mathrm{H}-\mathrm{RMN}$ do composto $1 \mathrm{em}$ acetona a diferentes temperaturas. Expansão da região de 6,5 a 8,0 ppm. É observado o hidrogênio 3 próximo a $6,66 \mathrm{ppm}$. 35

Figura 1.20: Espectros de ${ }^{1} \mathrm{H}-\mathrm{RMN}$ do composto 1 em DMSO a diferentes temperaturas. Expansão da região de 6,4 a 8,0 ppm. É observado o hidrogênio 3 próximo a $6,59 \mathrm{ppm}$. 35

Figura 1.21: Espectros de ${ }^{1} \mathrm{H}-\mathrm{RMN}$ do composto $1 \mathrm{em}$ metanol a diferentes temperaturas. Expansão da região de 6,35 a 8,00 ppm. É observado o hidrogênio 3 próximo a 6,70 ppm. 
Figura 1.22: Espectros de ${ }^{1} \mathrm{H}-\mathrm{RMN}$ do composto 1 em acetona a diferentes temperaturas. Expansão da região alifática. São observados os hidrogênios 3' e 5' próximos a 2,35 ppm. 36

Figura 1.23: Espectros de ${ }^{1} \mathrm{H}-\mathrm{RMN}$ do composto 1 em DMSO a diferentes temperaturas. Expansão da região alifática. São observados os hidrogênios 3' e 5' próximos a 2,27 ppm. 36

Figura 1.24: Espectros de ${ }^{1} \mathrm{H}-\mathrm{RMN}$ do composto $1 \mathrm{em}$ metanol a diferentes temperaturas. Expansão da região alifática. São observados os hidrogênios 3' e 5' próximos a 2,34 ppm. 36

Figura 1.25: Estrutura do composto 1, indicando o favorecimento da rotação da ligação C3-C1' com o aumento da temperatura, fato que pode levar a uma equiparação dos ambientes magnéticos dos hidrogênio 3' e 5'..... 37

Figura 1.26: Espectros de ${ }^{1} \mathrm{H}-\mathrm{RMN}$ com variação da taxa de troca. Observa-se a variação na multiplicidade e na largura dos sinais em relação à taxa de troca (figura adaptada do curso Biochemical Applications of NMR Spectroscopy: Chemical Exchange in NMR Spectroscopy, disponível no site http://www.bioc.aecom.yu.edu/labs/girvlab/nmr/course/). 38

Figura 1.27: Espectros de ${ }^{1} \mathrm{H}-\mathrm{RMN}$ a 15 e $25{ }^{\circ} \mathrm{C}$ do composto 1 , em DMSO, com expansão da região de mais alto deslocamento químico. Observa-se o sinal alargado próximo a 11,5 ppm, referente ao hidrogênio $7^{\prime}$ 38

Figura 1.28: Espectros de ${ }^{1} \mathrm{H}-\mathrm{RMN}$ a $0,5,15,25,35$ e $45^{\circ} \mathrm{C}$ do composto 1 , em acetona, com expansão da região de mais alto deslocamento químico. Observa-se o sinal alargado próximo a 10,4 ppm, referente ao hidrogênio $7^{\prime}$........ 39

Figura 1.29: Expansão dos espectros de APT do composto 1 em acetona, a diferentes temperaturas $\left(15,25\right.$ e $\left.45{ }^{\circ} \mathrm{C}\right)$. É observado o sinal do carbono $1^{\prime}$ próximo a 110,3 ppm. 40

Figura 1.30: Expansão dos espectros de APT do composto 1 em DMSO, a diferentes temperaturas $\left(15,25\right.$ e $\left.75{ }^{\circ} \mathrm{C}\right)$. É observado o sinal do carbono $1^{\prime}$ próximo a 108,0 ppm 40

Figura 1.31: Expansão dos espectros de APT do composto 1 em metanol, a diferentes temperaturas $\left(15,25\right.$ e $\left.55^{\circ} \mathrm{C}\right)$. É observado o sinal do carbono 1 ' próximo a 110,1 ppm. 40

Figura 1.32: Espectros de ${ }^{13} \mathrm{C}-\mathrm{RMN}$ do composto $1 \mathrm{em}$ acetona, a diferentes temperaturas $\left(15,25\right.$ e $\left.45^{\circ} \mathrm{C}\right)$. Expansão da região alifática. É observado o sinal referente aos carbonos 3' e 5' próximos a 47,6 ppm. 41 
Figura 1.33: Espectros de ${ }^{13} \mathrm{C}-\mathrm{RMN}$ do composto 1 em DMSO, a diferentes temperaturas $\left(15,25\right.$ e $\left.75^{\circ} \mathrm{C}\right)$. Expansão da região alifática. É observado o sinal referente aos carbonos 3' e 5' próximos a 46,5 ppm. 41

Figura 1.34: Espectros de ${ }^{13} \mathrm{C}-\mathrm{RMN}$ do composto $1 \mathrm{em}$ metanol, a diferentes temperaturas $\left(15,25\right.$ e $\left.55^{\circ} \mathrm{C}\right)$. Expansão da região alifática. É observado o sinal referente aos carbonos 3' e 5' próximos a 47,9 ppm. 42

Figura 1.35: Espectros de ${ }^{1} \mathrm{H}-\mathrm{RMN}$ (região não-aromática) do composto $5 \mathrm{em}$ acetona, a diferentes temperaturas. São observados o hidrogênio 3 próximo a 6,24 ppm e o hidrogênio 1' próximo a 4,24 ppm 44

Figura 1.36: Espectros de ${ }^{1} \mathrm{H}-\mathrm{RMN}$ (região não-aromática) do composto $5 \mathrm{em}$ DMSO, a diferentes temperaturas. É observado o hidrogênio 3 próximo a 6,25 ppm e o hidrogênio 1' próximo a 4,48 ppm.

Figura 1.37: Espectros de APT do composto 5 em acetona, a diferentes temperaturas $\left(15,25\right.$ e $\left.45^{\circ} \mathrm{C}\right)$. É observado o sinal do carbono $1^{\prime}$ próximo a $55,8 \mathrm{ppm}$ e do carbono 3 próximo a 78,0 ppm. 45

Figura 1.38: Espectros de APT do composto 5, em DMSO, a diferentes temperaturas $\left(15,25\right.$ e $\left.75^{\circ} \mathrm{C}\right)$. É observado o sinal do carbono $1^{\prime}$ próximo a $55,1 \mathrm{ppm}$ e do carbono 3 próximo a $77,5 \mathrm{ppm}$. 45

Figura 1.39: Espectros de ${ }^{13} \mathrm{C}-\mathrm{RMN}$ do composto $5 \mathrm{em}$ acetona, a diferentes temperaturas $\left(15,25\right.$ e $\left.45{ }^{\circ} \mathrm{C}\right)$. São observados os sinais referentes aos carbonos 2' e 7' próximos a 196,2 e 197,7 ppm, respectivamente. 46

Figura 1.40: Espectros de ${ }^{13} \mathrm{C}-\mathrm{RMN}$ do composto 5 em DMSO, a diferentes temperaturas $\left(15,25\right.$ e $\left.75{ }^{\circ} \mathrm{C}\right)$. São observados os sinais referentes aos carbonos 2' e 7' próximos a 195,7 e 197,1 ppm, respectivamente. 46

Figura 1.41: Espectros de Fragmentação (MS/MS) do composto 1, em que é observada uma fragmentação de $18 \mathrm{Da}$ 48

Figura 1.42: Espectros de Fragmentação (MS/MS) do composto 2, em que são observadas fragmentações de 18 e $28 \mathrm{Da}$ 49

Figura 1.43: Espectros de Fragmentação (MS/MS) do composto 3, em que são observadas fragmentações de 18 e $28 \mathrm{Da}$. 50

Figura 1.44: Espectros de Fragmentação (MS/MS) do composto 4, em que são observadas fragmentações de 18 e $28 \mathrm{Da}$ 51

Figura 1.45: Espectros de Fragmentação (MS/MS) do composto 5, em que são observadas fragmentações de 18 e $28 \mathrm{Da}$ 52

Figura 1.46: Espectro no Infravermelho (ATR) do Composto 1. Banda larga de 3200 a $2400 \mathrm{~cm}^{-1}$ : estiramento $\mathrm{O}-\mathrm{H}$. Sinal em $1763 \mathrm{~cm}^{-1}$ : estiramento $\mathrm{C}=\mathrm{O}$. 53 
Figura 1.47: Espectro no Infravermelho (ATR) do Composto 2. Banda larga de 3200 a $2000 \mathrm{~cm}^{-1}$ : estiramento $\mathrm{O}-\mathrm{H}$. Sinal em $1758 \mathrm{~cm}^{-1}$ : estiramento $\mathrm{C}=\mathrm{O}$. 54

Figura 1.48: Espectro no Infravermelho (ATR) do Composto 3. Banda larga de 3100 a $2050 \mathrm{~cm}^{-1}$ : estiramento $\mathrm{O}-\mathrm{H}$. Sinal em $1757 \mathrm{~cm}^{-1}$ : estiramento $\mathrm{C}=\mathrm{O}$. 54

Figura 1.49: Espectro no Infravermelho (ATR) do Composto 4. Banda larga de 3100 a $2050 \mathrm{~cm}^{-1}$ : estiramento O-H. Sinal em $1762 \mathrm{~cm}^{-1}$ : estiramento $\mathrm{C}=\mathrm{O}$. 55

Figura 1.50: Espectro no Infravermelho (ATR) do Composto 5. Sinais em 1769, 1740 e $1702 \mathrm{~cm}^{-1}$ : estiramento $\mathrm{C}=\mathrm{O}$. Não foi observado sinal referente ao estiramento $\mathrm{O}-\mathrm{H}$. 55

Figura 1.51: Gráfico com o monitoramento da atividade da tirosinase na presença dos compostos $6,12,14$ e Kojic e também do ensaio branco. Utilizou-se L-tirosina como substrato. 58

Figura 1.52: Atividade dos compostos 6, 12, 14 e Kojic (controle positivo), em diferentes concentrações, em relação à atividade da enzima tirosinase. 60

Figura 1.53: Espectros de ${ }^{1} \mathrm{H}-\mathrm{RMN}$ do composto 6 na ausência da enzima (superior) e de STD (inferior). Utilizou-se $2 \mathrm{mM}$ do composto 6 e $20 \mathrm{uM}$ da enzima. Para os dois espectros foi utilizada a mesma intensidade para a escala vertical.

Figura 1.54: Espectros de ${ }^{1} \mathrm{H}-\mathrm{RMN}$ do composto 12 na ausência da enzima (superior) e de STD (inferior). Utilizou-se $2 \mathrm{mM}$ do composto 12 e $20 \mathrm{uM}$ da enzima. Para os dois espectros foi utilizada a mesma intensidade para a escala vertical

Figura 1.55: Espectros de ${ }^{1} \mathrm{H}-\mathrm{RMN}$ do composto 14 na ausência da enzima (superior) e de STD (inferior) do composto 14. Utilizou-se $2 \mathrm{mM}$ do composto 14 e 20 uM da enzima. Para os dois espectros foi utilizada a mesma intensidade para a escala vertical. 70

Figura 1.56: Espectros de ${ }^{1} \mathrm{H}-\mathrm{RMN}$ do ácido kojic na ausência da enzima (superior) e de STD (inferior). Utilizou-se $2 \mathrm{mM}$ do ácido kojic e $20 \mathrm{uM}$ da enzima. Para os dois espectros foi utilizada a mesma intensidade para a escala vertical

Figura 1.57: Espectros de ${ }^{1} \mathrm{H}-\mathrm{RMN}$ do composto 6 e ácido kojic na ausência da enzima (superior) e de STD (inferior) do composto 6 + enzima após adição do ácido Utilizou-se $2 \mathrm{mM}$ dos ligantes e $20 \mathrm{uM}$ da enzima. No espectro superior, o * indica os sinais referentes ao ácido kojic; os demais são referentes ao composto 6. São representadas as estruturas do composto 6 (esquerda) e ácido kojic (direita) 74 
Figura 1.58: Espectros de ${ }^{1} \mathrm{H}-\mathrm{RMN}$ do composto 12 e ácido kojic na ausência da enzima (superior) e de STD (inferior) do composto 12 + enzima após adição do ácido. Utilizou-se $2 \mathrm{mM}$ dos ligantes, e $20 \mathrm{uM}$ da enzima. No espectro superior, $\mathrm{o}$ * indica os sinais referentes ao ácido kojic; os demais são referentes ao composto 12. São representadas as estruturas do composto 12 (esquerda) e ácido kojic (direita). 75

Figura 1.59: Espectros de ${ }^{1} \mathrm{H}-\mathrm{RMN}$ do composto 14 e ácido kojic na ausência da enzima (superior) e de STD (inferior) do composto 14 + enzima após adição do ácido. Utilizou-se $2 \mathrm{mM}$ dos ligantes e $20 \mathrm{uM}$ da enzima. No espectro superior, $O$ * indica os sinais referentes ao ácido kojic; os demais são referentes ao composto 14 . São representadas as estruturas do composto 14 (esquerda) e ácido kojic (direita). 76

Figura 1.60: Espectros de ${ }^{1} \mathrm{H}-\mathrm{RMN}$ dos compostos 6 e 12 na ausência da enzima (superior) e de STD (inferior) dos compostos 6 e 12 em uma concentração de $2 \mathrm{mM}$, na presença de tirosinase $(20 \mathrm{uM})$. No espectro superior, $O{ }^{*}$ indica os sinais referentes ao composto 6; os demais referem-se ao composto 12. São representadas as estruturas dos compostos 6 (esquerda) e 12 (direita). 79

Figura 1.61: Espectros de ${ }^{1} \mathrm{H}-\mathrm{RMN}$ dos compostos 6 e 14 na ausência da enzima (superior) e de STD (inferior) dos compostos 6 e 14 em uma concentração de $2 \mathrm{mM}$, na presença de tirosinase $(20 \mathrm{uM})$. No espectro superior, $O{ }^{*}$ indica os sinais referentes ao composto 6; os demais referem-se ao composto 14. São representadas as estruturas dos compostos 6 (esquerda) e 12 (direita).

Figura 1.62: Espectros de ${ }^{1} \mathrm{H}-\mathrm{RMN}$ dos compostos 12 e 14 na ausência da enzima (superior) e de STD (inferior) dos compostos 12 e 14 em uma concentração de $2 \mathrm{mM}$, na presença de tirosinase $(20 \mathrm{uM})$. No espectro superior, $\mathrm{O}$ * indica os sinais referentes ao composto 12; os demais referem-se ao composto 14. São representadas as estruturas dos compostos 6 (esquerda) e 12 (direita). 81

Figura 1.63: Espectro de NOESY (superior) do composto 14 (inferior esquerda) e kojic (inferior direita) na presença da tirosinase. Utilizou-se $2 \mathrm{mM}$ dos ligantes, $20 \mathrm{uM}$ da enzima e um mixing time de $200 \mathrm{~ms}$. Destaca-se em vermelho a presença do INPHARMA NOE 83

Figura 1.64: Espectro de NOESY (superior) do composto 12 (inferior esquerda) e kojic (inferior direita) na presença da tirosinase. Utilizou-se $2 \mathrm{mM}$ dos ligantes, 20 uM da enzima e um mixing time de $200 \mathrm{~ms}$. Destaca-se em vermelho a presença do INPHARMA NOE. 84

Figura 1.65: Espectro de NOESY (superior) do composto 6 (inferior esquerda) e kojic (inferior direita) na presença da tirosinase. Utilizou-se $2 \mathrm{mM}$ dos ligantes, 20 uM da enzima e um mixing time de 200 ms. Não é observada a presença de INPHARMA NOE. 
Figura 1.66: Espectro de NOESY (superior) do composto 6 (inferior esquerda) e kojic (inferior direita) na presença da tirosinase. Utilizou-se $2 \mathrm{mM}$ dos ligantes, 20 uM da enzima e um mixing time de $400 \mathrm{~ms}$. Não é observada a presença de INPHARMA NOE. 87

Figura 1.67: Alinhamento do sítio ativo das estruturas da tirosinase de $S$. castaneoglobisporus (verde) e A. bisporus (marrom), em que os sítios são bastante conservados. Os aminoácidos diferentes entre as espécies estão destacados 88

Figura 1.68: Solução obtida pelo docking (rosa) da L-dopa, sobreposta com a conformação experimental (verde) encontrada no complexo 4p6s (código PDB) para o mesmo ligante (L-dopa). Obteve-se o valor RMSD de 1.22 $\AA$

Figura 1.69: Solução obtida pelo docking (salmão) da L-tirosina, sobreposta com a conformação experimental (verde) encontrada no complexo 4p6r (código PDB) para o mesmo ligante (L-tirosina). Obteve-se o valor RMSD de 1.47 $\AA$ 89

Figura 1.70: Solução do docking do ácido kojic que mais se assemelha às interações propostas na literatura (amarelo), sobreposta com a conformação experimental da L-dopa presente no complexo 4p6s (verde). 90

Figura 1.71: Solução do docking do composto 14 (verde) sobreposto com a solução do ácido kojic (marrom). Destaca-se o H1 (representado como esfera) do composto 14 a 3.3 A do anel indólico do Trp183. O H2 (representado como esfera) do ácido kojic é observado na mesma região 91

Figura 1.72: Solução de melhor energia para docking do composto 12 (verde) sobreposto com a solução do ácido kojic (marrom). Destaca-se o H1 do composto 12 a $3.7 \AA$ do anel indólico do Trp183. O H2 (representado como esfera) do ácido kojic é observado na mesma região. 92

Figura 1.73: Solução de segunda melhor energia para o docking do composto 12 (verde) sobreposto com a solução do ácido kojic (marrom). Destaca-se o H13/15 (representado como esfera) do composto 12 a 2,7 $\AA$ do carbono carbonílico da cadeia principal da Ala201. O H5 (representado como esfera) do ácido kojic é observado na mesma região. 93

Figura 1.74: Solução para o docking do composto 6 (rosa) sobreposto com a solução do ácido kojic (marrom). Destaca-se a hidroxila (011) do composto 6 a $2,5 \AA$ do peróxido da tirosinase. Interação similar é observada para o ácido kojic. 93

Figura 2.1: Estrutura dos quelantes DTPA, DOTA, HYNIC. DTPA é complexado com o radioisótopo ${ }^{111} \mathrm{In}$, DOTA com ${ }^{111} \mathrm{In},{ }^{68} \mathrm{Ga},{ }^{90} \mathrm{Y}$ e ${ }^{177} \mathrm{Lu}$ e HYNIC com ${ }^{99 m}$ Tc. 100 
Figura 2.2: Exemplo de imagem por cintilografia para diagnóstico de tumores (metástase). As áreas mais escuras indicam a presença da lesão. Utilizou-se ${ }^{68} \mathrm{Ga}-\mathrm{DOTA}-\mathrm{TOC}$ para tal diagnóstico. 100

Figura 2.3: Estruturas dos grupos Fmoc (protetor temporário) e t-butil, Trt e Boc (protetores permanentes)

Figura 2.4: Cromatograma do peptídeo sintético TOC a $25{ }^{\circ} \mathrm{C}$, indicando as frações P1 e P2. 116

Figura 2.5: Espectro de Massa referente à fração $\mathrm{P} 1$. Observam-se as massas $[\mathrm{M}+2 \mathrm{H}]^{2+}=518,22$ e $[\mathrm{M}+\mathrm{H}]^{+}=1035,44$ referentes ao peptídeo TOC sintético.

Figura 2.6: Espectro de Massa referente à fração $P 2$. Observam-se as massas $[\mathrm{M}+2 \mathrm{H}]^{2+}=518,22$ e $[\mathrm{M}+\mathrm{H}]^{+}=1035,44$ referentes ao peptídeo TOC sintético. 118

Figura 2.7: Espectro de $M S / M S$ utilizando o íon parental $[\mathrm{M}+2 \mathrm{H}]^{2+}=518,22$, oriundo da fração $\mathrm{P} 1$

Figura 2.8: Espectro de $M S / M S$ utilizando o íon parental $[M+2 H]^{2+}=518,22$, oriundo da fração P2.

Figura 2.9: Cromatograma das frações P1 (TOC1) e P2 (TOC2) a 30 ${ }^{\circ} \mathrm{C}$.

Figura 2.10: Cromatograma das frações P1 (TOC1) e P2 (TOC2) a 45 ${ }^{\circ} \mathrm{C}$.

Figura 2.11: Cromatograma das frações P1 (TOC1) e P2 (TOC2) a 60 ${ }^{\circ} \mathrm{C}$.

Figura 2.12: Cromatograma do composto HYNIC-TOC comercial. Foram observadas uma fração referente ao HYNIC-TOC e outra referente ao TOC livre. 123

Figura 2.13: Cromatograma do HYNIC-TOC comercial em vermelho e do TOC sintético em azul. É possível observar que o TOC livre encontrado no composto comercial apresenta o mesmo tempo de eluição da fração P1 do peptídeo sintético. 124

Figura 2.14: Região alifática dos espectros de ${ }^{1} \mathrm{H}-\mathrm{RMN}$ dos peptídeos TOC1 e TOC2. 125

Figura 2.15: Região aromática dos espectros de ${ }^{1} \mathrm{H}-\mathrm{RMN}$ dos peptídeos TOC1 e TOC2. 125

Figura 2.16: Sobreposição das 20 estruturas calculadas mais estáveis (backbone) para os peptídeos TOC1 e TOC2. 127 
Figura 2.17: Sobreposição das 20 estruturas calculadas mais estáveis (backbone + cadeias laterais) para os peptídeos TOC1 e TOC2 .................. 127

Figura 2.18: Monitoramento da atividade da enzima tirosinase apenas na presença do substrato L-dopa (Branco) e também dos compostos testados. Monitorou-se a formação do produto de degradação da L-dopa, em $495 \mathrm{~nm}$, em função do tempo.

Figura 2.19: Sobreposição dos espectros de HSQC $\left({ }^{1} \mathrm{H}-{ }^{13} \mathrm{C}\right)$ do peptídeo TOC1 livre (azul) e na presença da enzima Tirosinase (vermelho). É indicado apenas o sinal referente ao hidrogênio alfa do aminoácido $\mathrm{Trp}^{4}$, único sinal que sofreu variação de deslocamento químico na presença da enzima. 131

Figura 2.20: Sobreposição dos espectros de HSQC $\left({ }^{1} \mathrm{H}-{ }^{13} \mathrm{C}\right)$ do peptídeo TOC2 livre (azul) e na presença da enzima Tirosinase (vermelho). É indicado apenas o sinal referente ao hidrogênio alfa do aminoácido $\operatorname{Trp}^{4}$, único sinal que sofreu variação de deslocamento químico na presença da enzima. 132

Figura 2.21: Espectro de HSQC $\left({ }^{1} \mathrm{H}^{13} \mathrm{C}\right)$ do peptídeo TOC1 livre, indicando os sinais referentes às metilas. 133

Figura 2.22: Espectro de HSQC $\left({ }^{1} \mathrm{H}^{13} \mathrm{C}\right)$ do peptídeo TOC1 na presença da enzima tirosinase, indicando os sinais referentes às metilas. Esse espectro foi adquirido utilizando exatamente os mesmos parâmetros de aquisição do espectro mostrado na Figura 2.21 133

Figura 2.23: Espectros de HSQC, mostrando todos os sinais para o peptídeo TOC1 livre (espectro superior) e na presença da enzima tirosinase (espectro inferior). Ambos os espectros foram adquiridos com o mesmo número de scans e incrementos e apresentam o mesmo nível de corte (threshold). 134

Figura 2.24: Espectro de HSQC $\left({ }^{1} \mathrm{H}-{ }^{13} \mathrm{C}\right)$ do peptídeo TOC2 livre, indicando os sinais referentes às metilas. 135

Figura 2.25: Espectro de HSQC $\left({ }^{1} \mathrm{H}-{ }^{13} \mathrm{C}\right)$ do peptídeo TOC2 na presença da enzima tirosinase, indicando os sinais referentes às metilas. Esse espectro foi adquirido utilizando exatamente os mesmos parâmetros de aquisição do espectro mostrado na Figura 2.24. 135

Figura 2.26: Espectros de HSQC, mostrando todos os sinais para o peptídeo TOC2 livre (espectro superior) e na presença da enzima tirosinase (espectro inferior). Ambos os espectros foram adquiridos com o mesmo número de scans e incrementos e apresentam o mesmo nível de corte (threshold). 136

Figura 2.27: (Superior) Solução do docking da estrutura da tirosinase complexada com o modo de ligação de menor energia total do TOC1 $(\mathrm{E}$. total = $118,812 \mathrm{kcal} / \mathrm{mol}$ e $\mathrm{E}$. intermolecular $=-43,930 \mathrm{kcal} / \mathrm{mol}$ ). A estrutura experimental da L-tirosina (complexo 4p6r) está representada em verde claro. (Inferior) Solução do docking com a superfície molecular da tirosinase......... 138 
Figura 2.28: (Superior) Solução do docking da estrutura da tirosinase complexada com o modo de ligação de segunda menor energia total do TOC1 (E. total $=119,842 \mathrm{kcal} / \mathrm{mol}$ e $\mathrm{E}$. intermolecular $=-39,503 \mathrm{kcal} / \mathrm{mol})$. A ligação de hidrogênio da hidroxila do grupo fenol com o peróxido está representada através da linha pontilhada amarela. A estrutura experimental da L-tirosina (complexo 4p6r) está representada em verde claro. (Inferior) Solução do docking com a superfície molecular da tirosinase.

Figura 2.29: (Superior) Solução do docking da estrutura da tirosinase complexada com o modo de ligação de terceira menor energia total do TOC1 (E. total $=121,355 \mathrm{kcal} / \mathrm{mol}$ e $\mathrm{E}$. intermolecular $=-49,752 \mathrm{kcal} / \mathrm{mol})$. A ligação de hidrogênio da hidroxila do grupo fenol com o peróxido está representada através da linha pontilhada amarela. (Inferior) Solução do docking com a superfície molecular da tirosinase. 140

Figura 2.30: (Superior) Solução do docking da estrutura da tirosinase complexada com o modo de ligação de menor menor energia total do TOC2. A estrutura experimental da L-tirosina (complexo 4p6r) está representada em verde claro. (Inferior) Solução do docking com a superfície molecular da tirosinase. Nota-se a lisina voltada para o interior do sítio ativo. 141

Figura 2.31: (Superior) Solução do docking da estrutura da tirosinase complexada com o modo de ligação de segunda menor energia total do TOC2. A estrutura experimental da L-tirosina (complexo 4p6r) está representada em verde claro. (Inferior) Solução do docking com a superfície molecular da tirosinase. Nota-se a fenilalanina voltada para o interior do sítio ativo 142

Figura 2.32: (Superior) Solução do docking da estrutura da tirosinase complexada com o modo de ligação de terceira menor energia total do TOC2. A estrutura experimental da L-tirosina (complexo 4p6r) está representada em verde claro. (Inferior) Solução do docking com a superfície molecular da tirosinase. Nota-se a tirosina voltada para o interior do sítio ativo. 143

Figura 2.33: A) Espectro de Massa do peptídeo livre: $[\mathrm{TOC}+\mathrm{H}]+=1035,8 \mathrm{Da}$. B) Espectro de Massa do peptídeo em contato com a enzima: [TOC $+\mathrm{H}]+=$ 1035,8 Da; $[\mathrm{TOC}+\mathrm{H}+14]+=1049,8$ e $[\mathrm{TOC}+\mathrm{H}+16]+=1051,8$ 144

Figura 2.34: A) Estrutra do resído de tirosina. B) Estrutra do resíduo de tirosinase após uma hidroxilação, gerando um acréscima de $16 \mathrm{Da}$ na massa. C) Estrutura da oxidação do resíduo de tirosina diidroxilada, gerando um acréscimo de $14 \mathrm{Da}$ de massa quando comparada com o resíduo de tirosina 145

Figura 2.35: A) Fragmentação do íon $[\mathrm{M}+\mathrm{H}]+=1035,8 \mathrm{Da}$, referente ao peptídeo livre, nota-se a presença dos íons imônios referentes a tirosina $(136.08 \mathrm{Da})$ e ao triptofano $(159,1 \mathrm{Da})$. B) Fragmentação do íon $[\mathrm{M}+\mathrm{H}+16]+=$ 1051,8 Da, referente ao TOC com a tirosinase diidroxilada, nota-se um sinal referente ao íon imônio da tirosina diidroxilada (152,07 Da). C) Fragmentação do íon $[\mathrm{M}+\mathrm{H}+14]+=1051,8 \mathrm{Da}$, referente ao TOC com oxidação da tirosinase 
diidroxilada, observa-se um sinal referente ao íon imônio da oxidação da tirosina diidroxilada (150,07 Da)........................................................... 146

Figura 2.36: A) Estrutura do íon imônio da tirosina. B) Estrutura do íon imônio referente a tirosina diidroxilada. C) Estrutura do íon imônio da oxidação da tirosina diidroxilada.......................................................................... 147 


\section{Lista de Tabelas}

Tabela 1.1: Tempos de relaxação $T_{1}$ de alguns átomos de hidrogênio de um fármaco livre e após a interação com a proteína albumina humana (FigueroaVillar, 2009). A variação nos valores de $T_{1}$ permite predizer os átomos envolvidos na interação. 12

Tabela 1.2: Estrutura dos compostos enólicos e carbonílicos selecionados e sintetizados. 21

Tabela 1.3: Estrutura dos compostos 1 a 16 com o assinalamento dos átomos de hidrogênio (azul) e carbono (vermelho). (Teixeira, 2013; Teixeira, 2014). Compostos 2, 3, 4, 5, 7, 11 e 15 assinalados em CDCl3, compostos 1, 8, 9, 10,

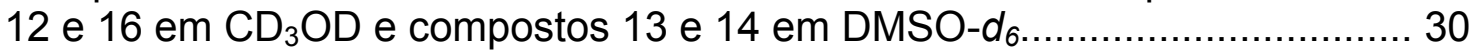

Tabela 1.4: Massa teórica e massa obtida experimentalmente para os compostos 1 a 16................................................................................ 32

Tabela 1.5: Assinalamento dos átomos de hidrogênio e carbono do composto 1 em diferentes solventes: acetona, metanol e DMSO. 33

Tabela 1.6: Assinalamento dos átomos de hidrogênio e carbono do composto 5 em diferentes solventes: acetona, metanol e DMSO.

Tabela 1.7: Diferença de energia entre as formas ceto-enólicas (enol) e dicetônicas (ceto) para os cinco compostos calculadas no vácuo, acetona, DMSO e metanol. 56

Tabela 1.8: Atividade dos 16 compostos, em porcentagem, em relação à enzima Tirosinase, utilizando L-tirosina e L-dopa como substratos. 57

Tabela 1.9: Valores de deslocamento químico ( $\delta)$ da amostra $6(2 \mathrm{mM})$ na ausência e na presença da tirosinase $(0,26$ uM e 20 uM). 61

Tabela 1.10: Valores de deslocamento químico (ס) da amostra $12(2 \mathrm{mM})$ na ausência e na presença da tirosinase $(0,26$ uM e 20 uM $)$. 61

Tabela 1.11: Valores de deslocamento químico (ס) da amostra 14 (2 mM) na ausência e na presença da tirosinase $(0,26$ uM e 20 uM). 62

Tabela 1.12: Valores de deslocamento químico ( $\delta$ ) do ácido kojic $(2 \mathrm{mM})$ na ausência e na presença da tirosinase $(0,26$ uM e 20 uM).

Tabela 1.13: Valores do tempo de relaxação longitudinal $\left(T_{1}\right)$ da amostra 6 (2 $\mathrm{mM})$ na ausência e na presença da tirosinase $(0,26$ uM e $20 \mathrm{uM})$. 63

Tabela 1.14: Valores do tempo de relaxação longitudinal $\left(T_{1}\right)$ da amostra $12(2$ $\mathrm{mM})$ na ausência e na presença da tirosinase $(0,26$ uM e $20 \mathrm{uM})$. 64 
Tabela 1.15: Valores do tempo de relaxação longitudinal $\left(T_{1}\right)$ da amostra 14 (2 $\mathrm{mM})$ na ausência e na presença da tirosinase $(0,26$ uM e $20 \mathrm{uM})$. 64

Tabela 1.16: Valores do tempo de relaxação longitudinal $\left(T_{1}\right)$ do ácido kojic (2 $\mathrm{mM}$ ) na ausência e na presença da tirosinase $(0,26$ uM e $20 \mathrm{uM})$................... 64

Tabela 1.17: Valores de coeficiente de difusão (D) da amostra 6 (2 mM) na ausência e na presença da tirosinase $(0,26$ uM e 20 uM) ............................. 65

Tabela 1.18: Valores de coeficiente de difusão (D) da amostra 12 (2 mM) na ausência e na presença da tirosinase $(0,26$ uM e 20 uM)............................. 65

Tabela 1.19: Valores de coeficiente de difusão (D) da amostra 14 (2 mM) na ausência e na presença da tirosinase $(0,26$ uM e 20 uM) .............................. 65

Tabela 1.20: Valores de coeficiente de difusão (D) do ácido kojic (2 $\mathrm{mM})$ na ausência e na presença da tirosinase $(0,26$ uM e 20 uM)............................. 66

Tabela 2.1: Sequências de aminoácidos da somatostatina-14 e da somatostatina-28. Em vermelho são indicados os resíduos de cisteína envolvidos em ponte dissulfeto. 96

Tabela 2.2: Sequências de aminoácidos dos peptídeos FOC, TOC e NOC análogos à somatostatina. Em vermelho são indicados os resíduos de aminoácido cisteína envolvidos em ponte dissulfeto e em azul o aminoácido na posição 3 , que varia entre os análogos. 98

Tabela 2.3: Massa molecular dos aminoácidos utilizados com seus respectivos grupos protetores temporários (Fmoc) e permanentes (Trt, Boc, e tButil) e massa, em miligramas, para $0,4 \mathrm{mmol}$. 105

Tabela 2.4: Gradiente de eluição para a purificação por UFLC..................... 107

Tabela 2.5: Gradiente de eluição para análises de P1 e P2 por UFLC com temperaturas de 30,40 e $60^{\circ} \mathrm{C}$.............................................................. 108

Tabela 2.6: Parâmetros de aquisição para os experimentos de RMN 2D. F1 corresponde ao número de scans por incremento e F2 o número de

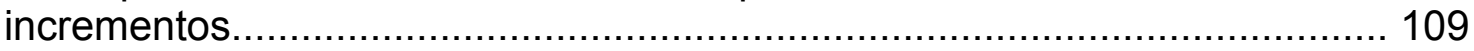

Tabela 2.7: Ângulos diedros $\Phi$ e $\Psi$ calculados para o peptídeo TOC1 ......... 126

Tabela 2.8: Ângulos diedros $\Phi$ e $\Psi$ calculados para o peptídeo TOC2 ......... 126

Tabela 2.9: Porcentagem de ativação e inibição dos compostos TOC1, TOC2 e ácido kojic em relação a atividade da enzima tirosinase, utilizando L-tirosina e L-dopa como substratos. 129 


\section{Lista de Abreviaturas e Acrônimos}

ACN: acetonitrila

APT: Attached Proton Test

BOC: terc-butiloxicarbonila

COSY: Correlated Spectroscopy

DBU: Diazabiciclo[5.4.0]undec-7-eno

DIPEA: N,N-Diisopropiletilamina

DMAP: 4-N,N-dimetilaminopiridina

DMF: N,N-Dimetilformamida

DMSO: dimetilsulfóxido

DOPA: 3,4-dihydroxy-phenylalanine

DOSY: Diffusion-ordered spectroscopy

DOTA: tetraazacyclododecane tetraacetic acid

DTPA: diethylenetriamine pentaacetic acid

EDT: 1,2-etanoditiol

EM: Espectrometria de Massa

Fmoc: Fluorenilmetiloxicarbonil

FOC: Phe $^{3}$ - octreotídeo

GH: growth hormone (hormônio do crescimento)

HBTU: [benzotriazol-1-yloxy(dimethylamino)methylidene]-dimethylazanium hexafluorophosphate

HSQC: Heteronuclear Single-Quantum Correlation

HYNIC: hydrazinonicotinyl

INPHARMA: Interligand NOE for Pharmacophore Mapping

IR: infrared (Infravermelho)

NOC: Asn $^{3}$ - octreotídeo

NOE: Nuclear Overhauser Effect (Efeito Overhauser Nuclear)

NOESY: Nuclear Overhauser Effect Spectroscopy

ppm: partes por milhão

TOC: Tyr $^{3}$ - octreotídeo

TOCSY: Total Correlated Spectroscopy

RMN: Ressonância Magnética Nuclear 
RMSD: Root of Mean Square Deviation (Desvio Quadrático Médio)

ROE: Rotating Frame Overhauser Effect (Efeito de Overhauser com referencial rotatório)

STD: Saturation Transfer Difference

TFA: Ácido Trifluoroacético

TIS: Triisopropilsilano

Trt: Tritil

$\mathbf{T}_{1}$ : Tempo de Relaxação Longitudinal ou spin-rede

$\mathbf{T}_{\mathbf{2}}$ : Tempo de Relaxação Transversal ou spin-spin

UFLC: Ultra Fast Liquid Chromatography (Cromatografia Líquida Ultra Rápida) UV: Ultravioleta 


\section{Resumo}

A tirosinase é uma enzima oxidase que contém cobre no sítio ativo e pode ser encontrada em plantas, fungos e animais. Em animais, a tirosinase está diretamente envolvida na biossíntese da melanina, sendo que a produção anormal deste pigmento pode levar a uma série de problemas dermatológicos, como hiperpigmentação, hipopigmentação, age spot, melasma, câncer de pele, dentre outros. Por esses motivos, a busca por novos inibidores e ativadores dessa enzima é de grande interesse para a medicina, indústria alimentícia e também para a agricultura. Nesse sentido, estudar o modo de interação de novos inibidores e ativadores com a tirosinase é de fundamental importância para o planejamento de novas drogas mais eficientes. Esse estudo de interação ligante-enzima é feito principalmente por Ressonância Magnética Nuclear (RMN), envolvendo análises de variações de deslocamento químico, tempos de relaxação, coeficientes de difusão e técnicas como STD e INPHARMA, além de Química Computacional. Neste trabalho, novos compostos foram sintetizados e suas caracterizações feitas por infravermelho, espectrometria de massa e RMN. Após testes biológicos, alguns desses compostos foram selecionados para estudos de interação com a tirosinase por RMN, bem como por cálculos mecânico-quânticos e de docking molecular. Os resultados alcançados permitem vislumbrar os modos de interação de ligantes com essa enzima, dando um passo fundamental para o desenho racional de novos fármacos.

Palavras-Chaves: RMN, Tirosinase, Interações. 


\begin{abstract}
Tyrosinase is an oxidase enzyme that contains copper in the active site and it can be found in plants, fungi and animals. In animals, tyrosinase is directly involved in the biosynthesis of melanin. Abnormal production of this pigment can lead to many dermatologic problems, such as hyperpigmentation, hypopigmentation, age spot, melasma, skin cancer, among others. For this reason, there is a special interest in finding new inhibitors and activators of this enzyme. Thereby, the study of the interactions mode of new inhibitors and activators with tyrosinase is very important for the planning of new and more powerful drugs. This study can be primarily done by Nuclear Magnetic Resonance (NMR) by analyzing chemical shift changes, relaxation times, diffusion coefficients and techniques such as STD and INPHARMA, among others. In this work, new compounds were characterized and studied by IR, mass spectrometry, NMR and theoretical calculations. After biological tests, some of these compounds have been selected for studying the interaction with tyrosinase by NMR and theoretical calculations. The results allow us to come up with the binding modes of ligands interaction with the enzyme, giving a key step in the rational design of new drugs.
\end{abstract}

Keywords: NMR, Tyrosinase and Interactions Drug-Enzyme. 


\section{Capítulo I}

Estudos Estruturais e de Interação de novos Inibidores da Tirosinase 


\subsection{Introdução}

\subsubsection{Tirosinase}

A tirosinase é uma enzima oxidase, multifuncional, glicosilada e que contém cobre, podendo ser encontrada em animais, plantas e fungos (Gençer, 2012; Saewan, 2011). O cobre presente na estrutura da tirosinase faz parte do sítio ativo da enzima e apresenta papel fundamental para a sua atividade (Azam, 2012). Sua massa molecular pode variar de 128 a 133 kDa.

Em animais, a tirosinase está diretamente relacionada com a biossíntese da melanina (Azam, 2012), um composto macromolecular responsável pela pigmentação e que pode determinar a coloração de pele e cabelo em mamíferos (Kim, 2002). O pigmento de melanina na pele de humanos está diretamente envolvido no mecanismo de defesa contra os raios UV oriundos do sol (Saewan, 2011), podendo se tornar com isso um grande aliado na prevenção do câncer de pele causado por queimaduras solares (Azam, 2012).

Entretanto, a produção anormal de melanina pode gerar uma série de problemas dermatológicos, tanto estéticos, como de proteção (Azam, 2012; Saewan, 2011). Por isso, a tirosinase pode estar relacionada com alguns problemas de pele como hiperpigmentação, hipopigmentação, age spot, melasma, dentre outros (Gençer, 2012; Nerya, 2004; Kim, 2002). Esta enzima pode estar relacionada também com o câncer de pele, visto que aminas fenólicas são utilizadas contra o crescimento de células tumorais e a tirosinase é capaz catalisar a degradação de tais compostos, prejudicando o tratamento (Prezioso, 1992).

A tirosinase catalisa duas reações: a hidroxilação de monofenóis, e a oxidação de difenóis (Kim, 2002; Saewan, 2011).

Em mamíferos, a tirosinase participa das duas etapas iniciais do processo de biossíntese dos dois tipos de melanina: eumelanina (pigmento de coloração preta ou marrom) e feomelanina (pigmento de coloração vermelha ou amarela) (Chang, 2009; Kim, 2005) (Figura 1.1). Inicialmente a tirosinase catalisa a reação de conversão da tirosina em L-dopa (reação de hidroxilação de monofenóis) (Gençer, 2012). Em seguida, catalisa a reação de conversão 
da L-dopa em dopaquinona (reação de oxidação de difenóis) (Gençer, 2012). Por fim, uma série de reações ocorre partindo da dopaquinona até chegar à melanina (Chang, 2009; Kim, 2005). Um esquema com as reações envolvidas para a produção de melanina a partir da tirosina e na presença da tirosinase pode ser observado na Figura 1.1.

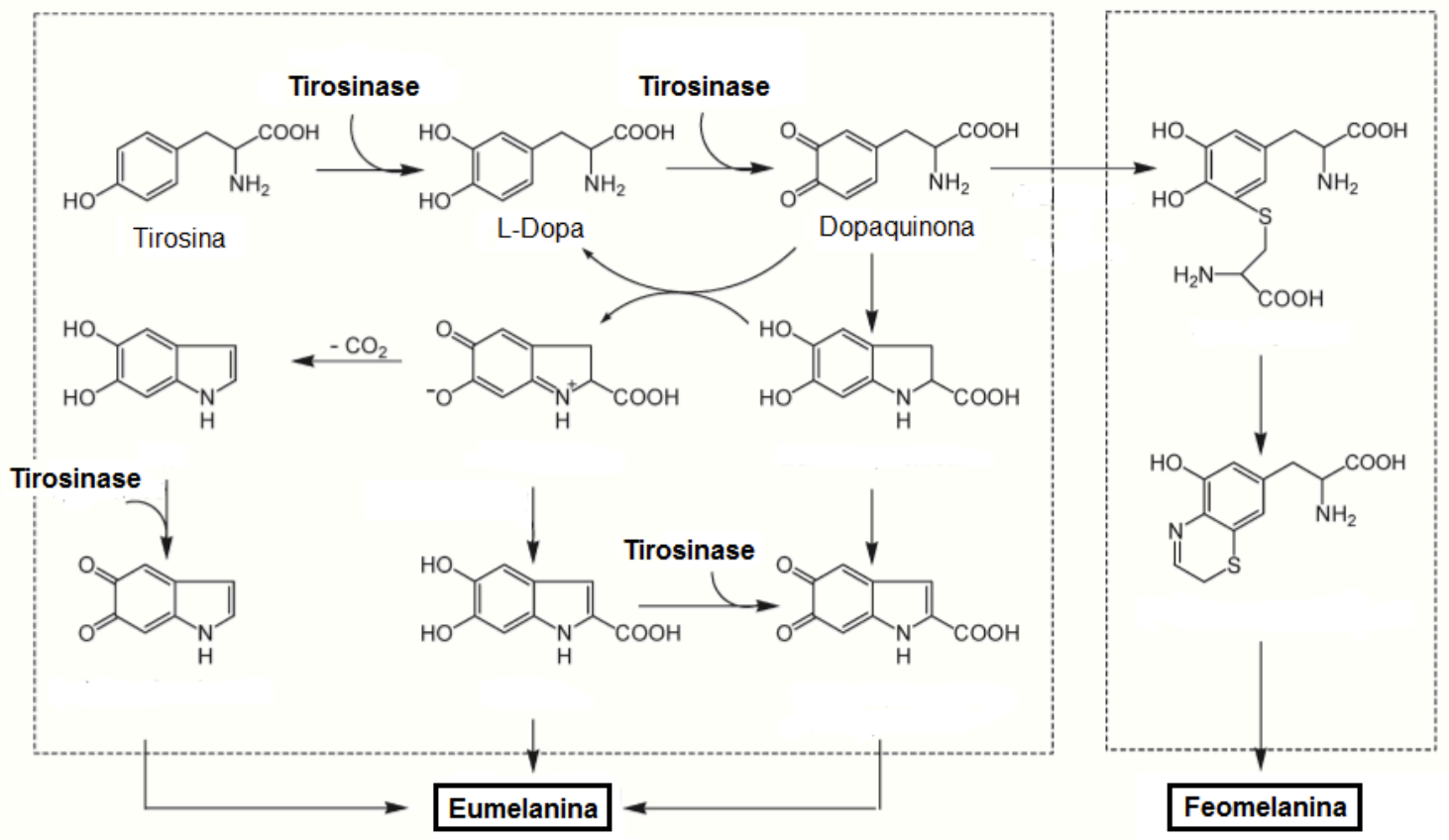

Figura 1.1: Reações envolvidas para a produção de melanina a partir da tirosina. As duas primeiras etapas são catalisadas pela enzima tirosinase (Kim, 2005).

$\mathrm{Na}$ formação de melanina, três tipos diferentes de tirosinase podem ser encontradas (met-tirosinase, oxi-tirosinase e desoxi-tirosinase), e cada tipo apresenta uma coordenação diferente para o cobre (cobre (II) para a mettirosinase e oxi-tirosinase e cobre (I) para a desoxi-tirosinase) (Chang, 2009; Kim, 2005). O ciclo catalítico da hidroxilação de monofenóis, mostrando a participação dos átomos de cobre (II) e (I), pode ser observado na Figura 1.2. Os dois átomos de cobre presentes no sítio ativo da enzima são coordenados por três histidinas cada um: His42, His69 e His60 para o primeiro cobre e His204, His208 e His231 para o segundo (Sendovski, 2011). 


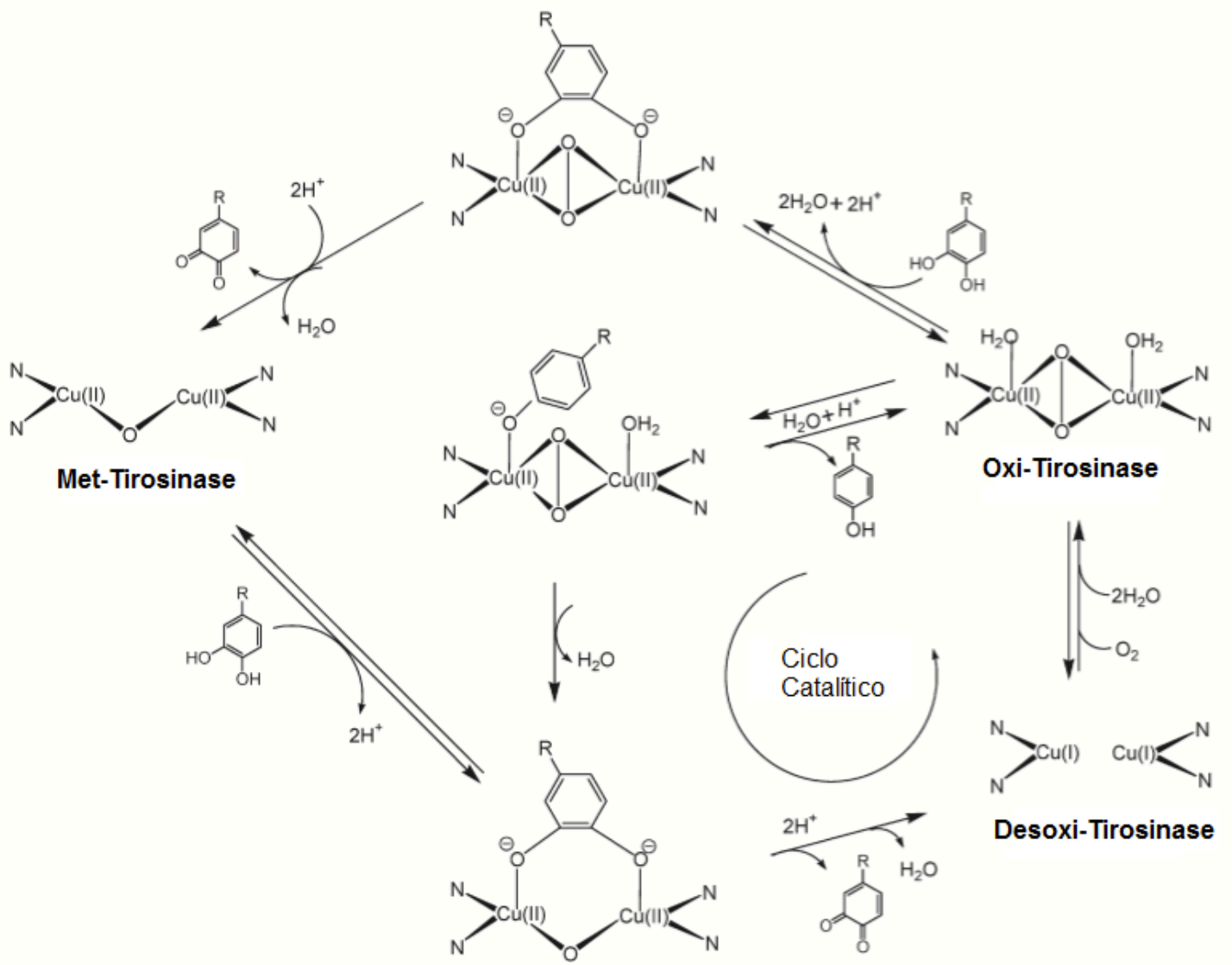

Figura 1.2: Ciclo catalítico da tirosinase para a hidroxilação de monofenóis, indicando os três tipos diferentes de tirosinase ao longo do ciclo e também a participação do cobre (Kim, 2005).

A tirosinase pode estar relacionada também com a produção de melanina cerebral (neuromelanina) (Iuliis, 2008; Xu, 1997; Xu, 1998). Nesse processo, a enzima catalisa a reação de oxidação da dopamina em dopaminoquinona que, após uma série de reações, leva à produção de neuromelanina (Figura 1.3). Subprodutos da reação de oxidação da dopamina em dopaminoquinona podem modificar irreversivelmente a função de determinadas proteínas e causar sérios danos neurológicos, podendo agravar doenças neurodegenerativas, como Parkinson e Huntington (Asanuma, 2003; Iuliis, 2008; Xu, 1997; Xu, 1998). 


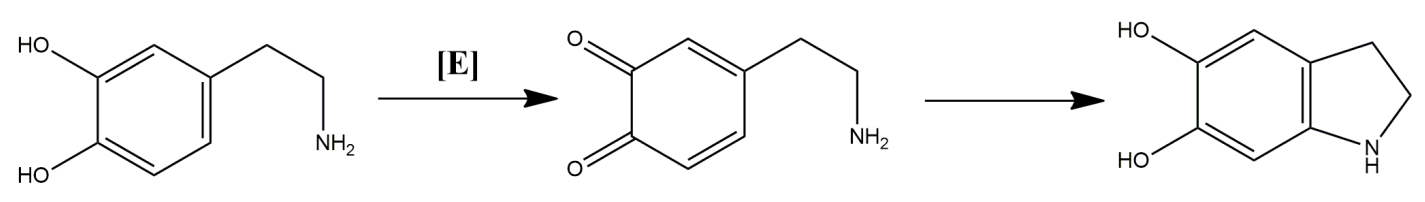

Dopamina

Dopaminoquinona

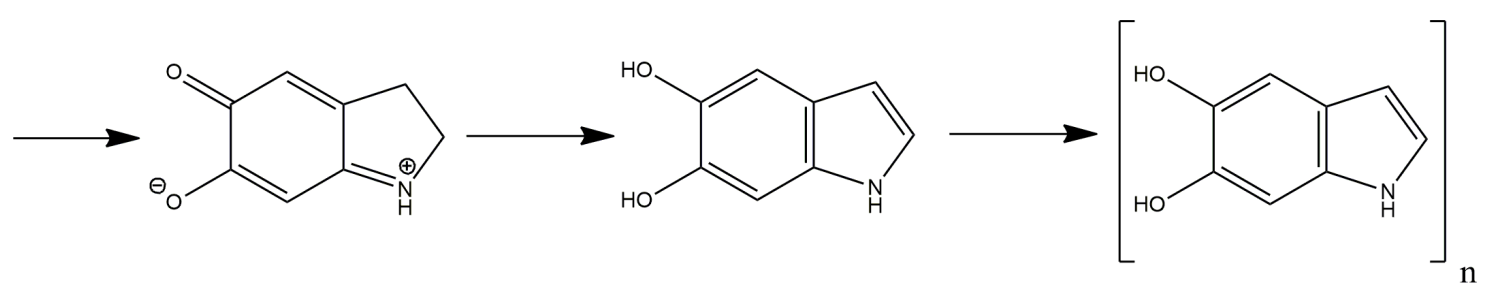

Neuromelanina

Figura 1.3: Reações envolvidas para a produção de neuromelanina a partir da dopamina. [E] indica a presença da enzima tirosinase (luliis, 2008).

A tirosinase também apresenta papel importante na área de alimentos, como em frutas, verduras, cogumelos e camarões (Gençer, 2012). Por ser uma oxidase, essa enzima catalisa reações de oxidação em alimentos, levando à sua degradação e, consequentemente, à perda de seus valores nutricionais, além de seu escurecimento (Kim, 2002). Esse processo pode gerar grandes prejuízos econômicos para os produtores de alimentos e para a indústria alimentícia.

Em insetos, a tirosinase apresenta grande atuação não só na produção de melanina, mas também na cicatrização de feridas, no encapsulamento de parasitas e na formação do esqueleto (Kim, 2002), desempenhando papel fundamental para a manutenção do ciclo da vida desses organismos.

Considerando isso, a busca por novos inibidores da tirosinase é de grande interesse, funcionalidade e aplicabilidade. Na medicina, novos inibidores podem agir contra o melasma, o câncer de pele e doenças neurodegenerativas, como o Parkinson e o Huntington, enquanto que na área de cosméticos podem ser utilizados para combater a hiperpigmentação, age spot (doença senil) e queimaduras solares (Azam, 2012; Emami, 2012; Saewan, 2011). Na indústria alimentícia, podem evitar o escurecimento e a perda nutricional de alimentos, como cogumelos e camarões (Chang, 2009; Emami, 2012; Kim, 2002; Kim, 2005), minimizando a perda de valor de mercado e prejuízos econômicos para a indústria. Inibidores da tirosinase apresentam ampla aplicação também na agricultura, sendo muito utilizados 
para o controle e o combate a insetos, uma vez que, como exposto anteriormente, a tirosinase pode apresentar um papel essencial para a manutenção da vida de alguns insetos (Kim, 2002).

Os inibidores da tirosinase mais estudados e eficientes são o ácido kojic e o ácido ascórbico (Figura 1.4), ambos inibidores competitivos (Chang, 2009; Kim, 2005; Ubeid, 2012). Apesar de serem ótimos inibidores, ambos são quimicamente instáveis, oxidando-se facilmente na presença do ar e também se degradando gradativamente na presença de luz, o que implica na perda de suas atividades. Com isso, busca-se novos inibidores para a tirosinase com alta eficiência e maior estabilidade.

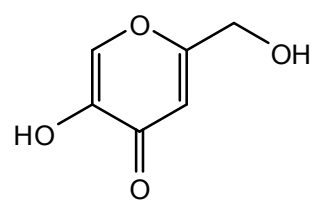

Ácido Kojic

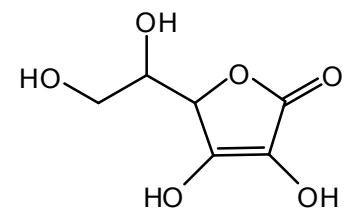

Ácido Ascórbico

Figura 1.4: Estruturas do ácido kojic e do ácido ascórbico, dois potentes inibidores da tirosinase.

Os modos de ligação do ácido kojic com a enzima tirosinase não são muito bem descritos na literatura. É conhecido que este ácido se liga à enzima pelo sítio do cobre (Battaini, 2000; Sendovski, 2011). Um dos possíveis modo de ligação do ácido kojic com a tirosinase seria uma coordenação bidentada da carbonila e da hidroxila em orto com o átomo de cobre do sítio ativo, quelando o metal (Battaini, 2000). Outro modo de ligação possível, completamente diferente do primeiro modo descrito, seria por uma interação do grupo hidroximetila do ácido kojic com o cobre do sítio ativo da enzima (Sendovski, 2011).

O planejamento de novos inibidores da tirosinase pode ser realizado visando moléculas que atuem diretamente no átomo de cobre, que está presente no sítio ativo da molécula (Nerya, 2004). Como exemplos podem ser citadas moléculas da classe dos fenóis e polifenóis (Nerya, 2004; Vontzalidou, 2012), compostos semelhantes à tirosina e à L-dopa (Figura 1.1). Essa classe de compostos pode inibir a tirosinase competitivamente, visto que, devido à similaridade estrutural, irão competir pelo sítio ativo da enzima nas reações de 
hidroxilação ou oxidação (Chang, 2009). Flavonoides, por exemplo, são polifenóis naturalmente encontrados em diversas plantas e que inibem a tirosinase (Chang, 2009; Kim, 2005; Saewan, 2011). Estes compostos apresentam muita semelhança estrutural com a L-dopa, o que leva à competição pelo sítio ativo da enzima, diminuindo a atividade enzimática (Chang, 2009). Alguns fenóis e polifenóis inibidores da tirosinase podem ser vistos na Figura 1.5.
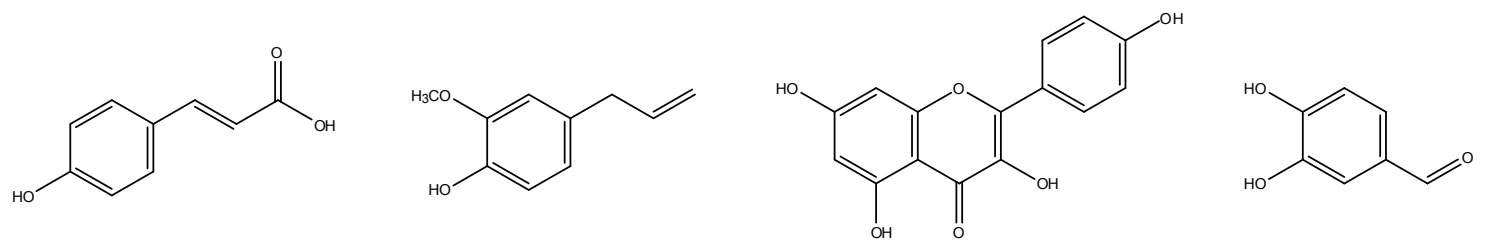

Figura 1.5: Exemplos de fenóis e polifenóis inibidores da tirosinase (Chang, 2009, Emani, 2012; Kim, 2005).

Outro grupo de moléculas já identificado como inibidores da tirosinase são moléculas contendo carbonilas, como as de aldeídos e cetonas (Chang. 2009; Kim, 2005). Compostos carbonilados podem se coordenar ao cobre presente no sítio ativo da enzima, quelando o metal e anulando a atividade da enzima (Nerya, 2004). Com esse pressuposto, novas moléculas carboniladas e policarbonílicas podem apresentar grande potencial para inibir a tirosinase. Alguns exemplos de compostos carbonilados inibidores desta biomolécula podem ser vistos na Figura 1.6.<smiles>O=C1CCCC(=O)C1CC1C(=O)CCCC1=O</smiles><smiles>O=CC=Cc1ccccc1</smiles>

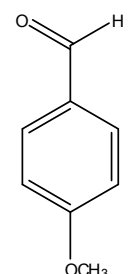<smiles>O=C(/C=C/c1ccccc1)c1ccccc1</smiles>

Figura 1.6: Exemplos de compostos carbonilados inibidores da tirosinase (Khan, 2006; Kim, 2005; Nerya, 2004).

Apesar de a busca por novos inibidores da tirosinase ser comum na literatura e apresentar ampla aplicabilidade, ativadores da enzima podem também ser de grande importância, uma vez que aumentam sua atividade catalítica (Seo, 2003). Os mecanismos de ativação podem envolver 
modificação da conformação da enzima pela interação em um sítio alostérico ou mesmo a remoção de um inibidor do meio (Dubois, 2012; Seo, 2003).

A ativação da enzima potencializa a síntese de melanina e dessa forma, ativadores podem ser utilizados no combate à hipopigmentação, como vitiligo e albinismo (Guan, 2008; Seo, 2003). É reportado na literatura que a formação de um subproduto na reação de oxidação da L-dopa em dopaquinona (Figura 1.1) é capaz de inibir a proliferação de células tumorais (Parvez, 2007). Esse fato faz com que a ativação da enzima - para consequente aumento na produção desse subproduto - seja um aliado no combate ao câncer de pele (Parvez, 2007). Além disso, a ausência de melanina na pele, causada pelo albinismo, promove uma maior susceptibilidade desta a queimaduras solares e ao câncer de pele, tornando os ativadores dessa enzima aliados no combate à hipopigmentação e também na prevenção ao câncer de pele. Alguns exemplos de ativadores da tirosinase podem ser vistos na Figura 1.7.

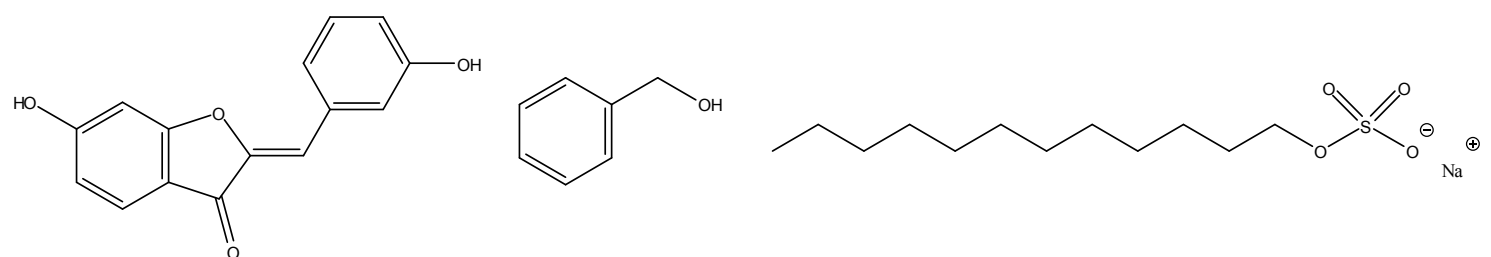

Figura 1.7: Estrutura de alguns compostos ativadores da tirosinase (Dubois, 2012; Seo, 2003).

Segundo estatística do INCA (Instituto Nacional do Câncer, vinculado ao Ministério da Saúde), o câncer de pele é o tipo de câncer mais frequente no Brasil e corresponde a $25 \%$ de todos os tumores malignos registrados no País, apresentando alta possibilidade de metástase (http://www2.inca.gov.br/wps/wcm/connect/tiposdecancer/site/home/pele_mela noma, acessado em 17/05/2016). Nesse sentido, o planejamento de inibidores e ativadores da tirosinase e a compreensão do fenômeno de ativação/inibição da enzima são de grande importância para a avaliação de novas drogas a serem utilizadas em tratamentos dessa doença.

Uma compreensão das interações proteína-ligante pode auxiliar no planejamento e no desenvolvimento de novos compostos com maior atividade biológica. $\mathrm{O}$ estudo dessas interações pode facilitar o entendimento sobre o funcionamento de um determinado sistema biológico, permitindo a 
compreensão dos mecanismos de regulação desse sistema, seja aumentando ou diminuindo sua atividade (Williams, 2013). Estudos da interação alvo-ligante podem auxiliar na identificação do sítio ativo da enzima e também mapear os átomos envolvidos na interação (Williams, 2013). Isso permite obter a relação estrutura-atividade do ligante $e$, consequentemente, propor modificações estruturais para otimizar sua atividade (Bohm, 2003; Williams, 2013).

Existem diversas ferramentas para proceder estudos de interação, como por exemplo, Ressonância Magnética Nuclear (RMN), Calorimetria e Química Computacional, dentre outras (Bohm, 2003; Nienhaus, 2010; Williams, 2013). Tais ferramentas podem fornecer informações complementares e serem de extrema utilidade no planejamento de novas drogas.

\subsubsection{Ressonância Magnética Nuclear (RMN) no Estudo de Interação Proteína-Ligante}

A RMN é de extrema importância para o planejamento e o desenvolvimento de novas drogas, principalmente por possibilitar 0 mapeamento dos átomos envolvidos na interação alvo-ligante (Ludwig, 2009), o que permite caracterizar a estrutura e a atividade de um ligante, baseando-se nas interações não covalentes envolvidas.

Estudos de interação por RMN podem ser realizados observando a variação de algumas propriedades após a interação do ligante pelo alvo (Stockman, 2002). O ligante, geralmente uma molécula pequena, irá apresentar parâmetros de RMN espectrais diferentes do alvo, que geralmente é uma proteína de alto peso molecular. Essa diferença leva à variação de parâmetros como coeficiente de difusão, tempos de relaxação, NOE, dentre outros, permitindo identificar determinadas interações e os átomos envolvidos nesse processo (Ludwig, 2009; Meyer, 2003).

Ao realizar estudos de interação proteína/ligante por RMN, é possível observar os sinais da proteína e/ou do ligante. No caso de observação das proteínas, por serem moléculas estruturalmente mais complexas que o ligante, é necessária a realização de experimentos em três dimensões e, dependendo do caso, também a marcação isotópica com nitrogênio-15 e carbono-13 (Meyer, 2003; Moore, 1999). Entretanto, nem sempre é possível proceder 
estudos de interação observando a proteína, seja pelo tamanho da enzima, cuja massa pode exceder o limite permitido por RMN (que é o caso da tirosinase), seja por falta de protocolo para a marcação isotópica. Nesses casos, a alternativa é observar o ligante, em que os estudos de interação podem ser realizados com experimentos ${ }^{1} \mathrm{H}-\mathrm{RMN}$ ou em duas dimensões, como HSQC, COSY e TOCSY (Moore, 1999, Roberts, 2000), analisando-se parâmetros como deslocamento químico, tempos de relaxação, coeficiente de difusão e NOEs (Moore, 1999; Roberts, 2000).

Ao proceder estudos de interação observando-se o ligante, em geral são utilizadas concentrações na escala de micromolar $(\mu \mathrm{M})$ para a proteína e de milimolar (mM) para o ligante (Rennó, 2012; Soares, 2013). Com isso, apenas os sinais do ligante são observados nos experimentos. Além disso, a biomolécula apresenta um tempo de relaxação maior do que o ligante, permitindo assim observar apenas os sinais deste último (Diercks, 2001).

Um dos parâmetros de RMN que pode ser utilizado para estudar a interação alvo-ligante é o deslocamento químico (ס) (Meyer, 2003, Yao, 2014). O campo magnético sentido por cada átomo do ligante irá depender do ambiente químico em que o mesmo se encontra na molécula (Gil, 2002). Com isso, ao interagir com uma proteína, determinados átomos do ligante podem ter seus ambientes químicos modificados, causando uma mudança no deslocamento químico. Um exemplo pode ser observado na Figura 1.8, mostrando a interação de determinados átomos de um ligante com a proteína BSA (albumina sérica bovina), em diferentes concentrações, pela variação no deslocamento químico (Sulkowska, 2005). 


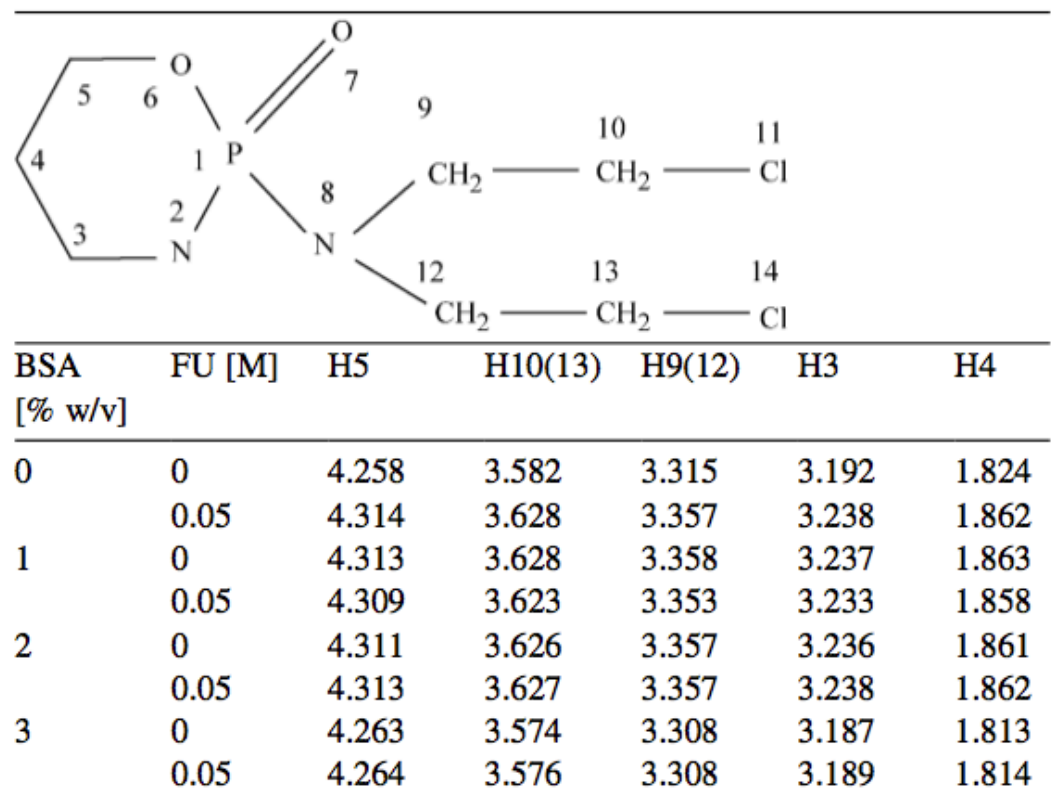

Figura 1.8: Estrutura do ligante e valores de deslocamento químico de ${ }^{1} \mathrm{H}-\mathrm{RMN}$ dos átomos $\mathrm{H} 5, \mathrm{H} 10(13), \mathrm{H} 9(12), \mathrm{H} 3$ e $\mathrm{H} 4$ livres ( $0 \%$ de BSA) e também na presença de BSA (1, 2 e $3 \%$ ). É observada uma variação do deslocamento químico desses átomos, indicando a participação dos mesmos na interação com a enzima. Os outros átomos não sofreram variação de deslocamento químico na presença do BSA. O estudo contou também com a presença e a ausência de FU (5-fluorouracil), utilizado no tratamento de câncer de mama (Sulkowska, 2005).

Outro parâmetro de RMN que pode ser utilizado nos estudos de interação alvo-ligante é o tempo de relaxação (Corbini, 2006; Figueroa-Villar, 2009; Luo, 1999; Ludwig, 2009). Relaxação é um processo que corresponde ao retorno de um sistema para o estado de equilíbrio após uma perturbação. Em RMN, o processo de relaxação é temporal, no qual os tempos de relaxação respeitam a dinâmica de interação de cada núcleo com outros spins nucleares, e também com o meio (Gil, 2002). Com isso, os tempos de relaxação observados por RMN podem mapear os átomos de um ligante envolvidos na interação com uma biomolécula.

Existem dois tipos diferentes de tempos de relaxação em RMN, $T_{1}$ e $T_{2}$. $\mathrm{O} \mathrm{T}_{1}$ (tempo de relaxação longitudinal ou spin-rede) indica a perda do excesso de energia de um spin para o meio, o que pode correlacionar a interação desse spin com o meio (Gil, 2002). Neste tempo de relaxação, monitora-se a relaxação da magnetização ao longo do eixo $z$ em função do tempo. $O T_{2}$ (tempo de relaxação transversal ou spin-spin) indica a perda do excesso de energia de um spin para outro spin, o que pode correlacionar a interação direta entre os spins (Gil, 2002). Neste tempo de relaxação, monitora-se a relaxação da magnetização ao longo dos eixos x e y em função do tempo. 
Moléculas com baixo e médio peso molecular (menor tempo de correlação) apresentam tempos de relaxação maiores, enquanto que moléculas com alto peso molecular (maior tempo de correlação), como proteínas, apresentam tempos de relaxação menores (Diercks, 2001, Figueiredo, 2007). Um gráfico com a relação do tempo de relaxação e o tamanho da molécula pode ser visto na Figura 1.9. Com base nessa diferença, quando uma molécula pequena se liga a uma molécula com alto peso molecular, como uma proteína, a primeira passa a fazer parte do macrossistema, adotando assim tempos de relaxação também menores (Diercks, 2001, Figueiredo, 2007). Dessa forma, observando-se essa variação nos tempos de relaxação do ligante livre com o ligante na presença da proteína pode-se ter um mapeamento dos átomos do ligante envolvidos em tal interação.

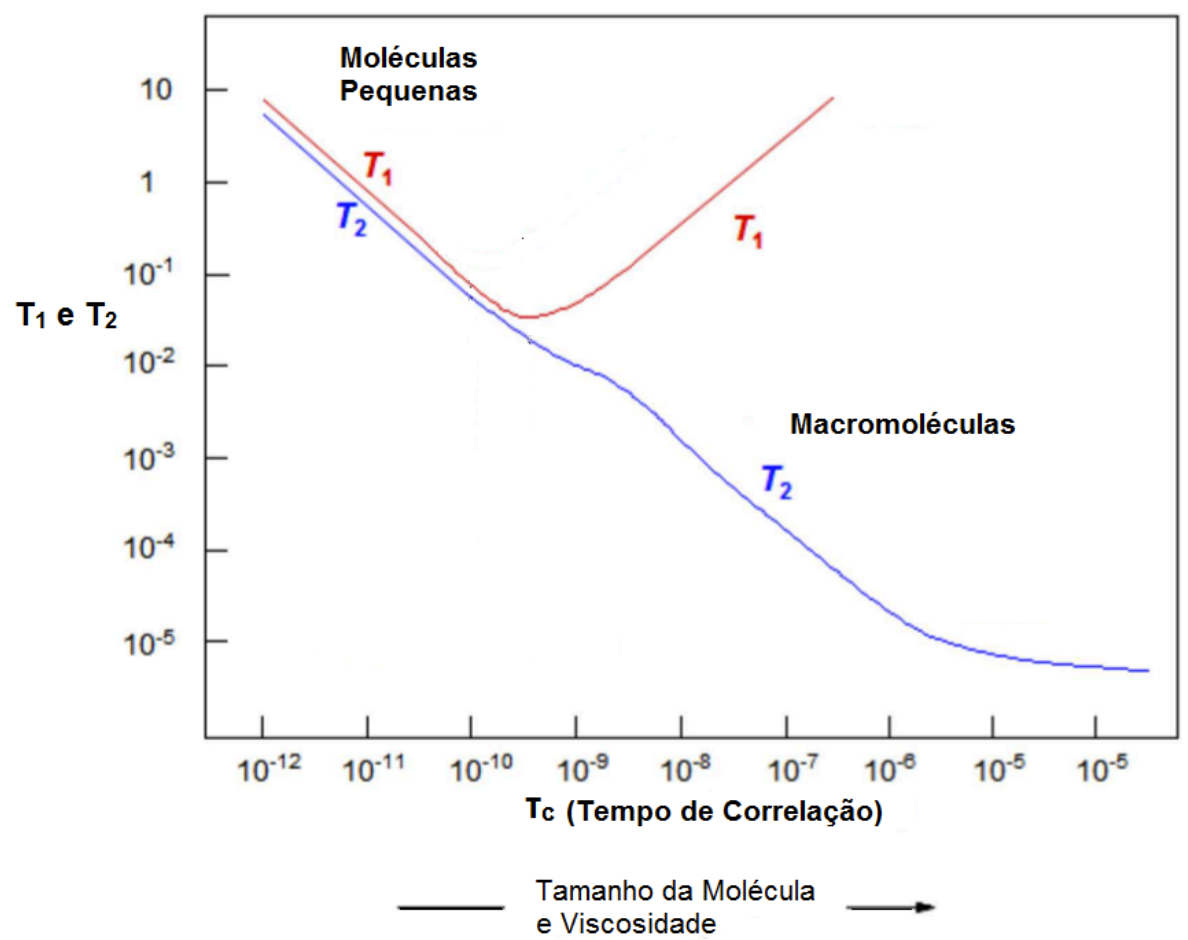

Figura 1.9: Relação dos tempos de relaxação $T_{1}$ e $T_{2}$ com o tempo de correlação (tempo de correlação pode ser definido como o tempo médio que uma molécula leva para rodar um radiano; assim para moléculas maiores e meios mais viscosos, os movimentos moleculares se tornam mais lentos) (Bloembergen, 1948 - com adaptações).

Um exemplo da utilização dos tempos de relaxação em estudos de interação pode ser visto na Tabela 1.1, em que é mostrada a interação de um fármaco comercial com a albumina humana, proteína mais abundante no 
plasma sanguíneo e que apresenta como uma das principais funções a de transporte (Figueroa-Villar, 2009). É possível notar a variação no tempo de relaxação de alguns átomos do fármaco livre quando comparado com os mesmos átomos do fármaco na presença da proteína, sendo possível identificar os átomos envolvidos na interação.

Tabela 1.1: Tempos de relaxação $T_{1}$ de alguns átomos de hidrogênio de um fármaco livre e após a interação com a proteína albumina humana (Figueroa-Villar, 2009). A variação nos

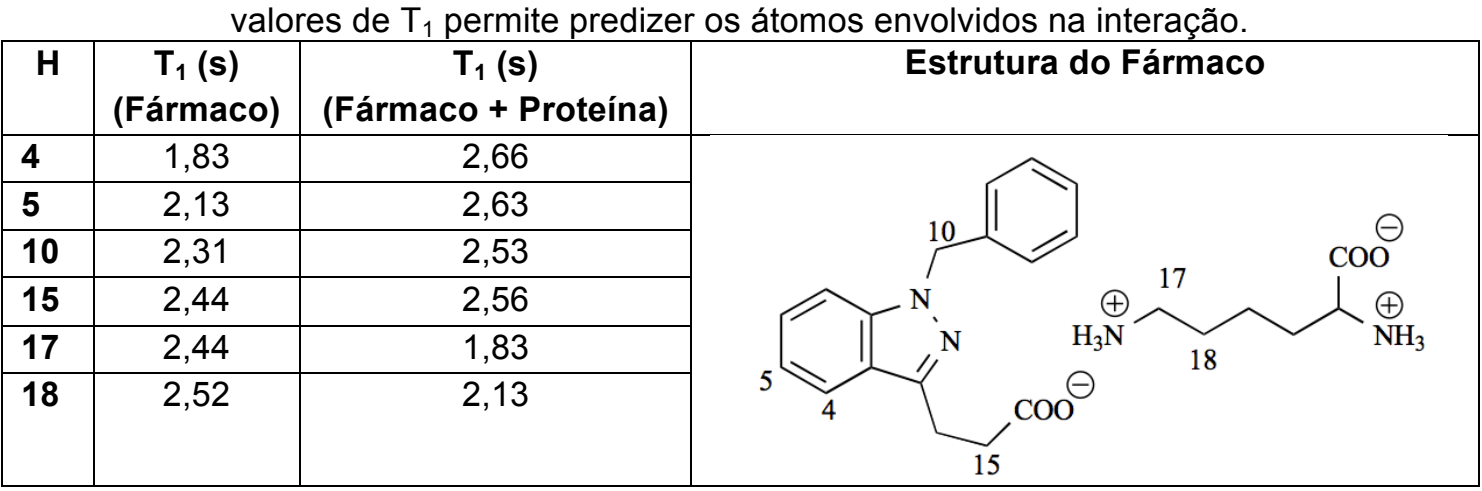

O coeficiente de difusão (D) também é um parâmetro de RMN utilizado para estudar interação ligante-proteína (Ludwig, 2009; Luo, 1999; Yan, 2002). A difusão molecular representa os movimentos aleatórios que uma molécula realiza devido à energia térmica do sistema; o coeficiente de difusão representa o deslocamento molecular resultante da difusão (Souza, 2009). O coeficiente de difusão irá depender da temperatura, da pressão e da composição da solução, além do que pode estar relacionado com o tempo de relaxação, visto que este depende da reorientação molecular, processo relacionado com a difusão (Souza, 2009).

O coeficiente de difusão (D) pode ser útil no estudo de interação devido à sua relação com o tamanho da molécula, conforme pode ser observado na Equação 1.1. Além disso, o coeficiente de difusão é muito sensível a mudanças estruturais e aos processos de interação (Souza, 2009; Yan, 2002). Moléculas com alto peso molecular, como as proteínas, apresentam menores valores de coeficiente de difusão, enquanto que moléculas de baixo peso molecular, como alguns ligantes, apresentam maiores valores de coeficiente de difusão (Diercks, 2001, Figueiredo, 2007). Com isso, quando alguns átomos de hidrogênio de um ligante passam a interagir com a proteína, seus coeficientes de difusão variam de maiores valores para menores valores, dando indícios dos átomos envolvidos em tal interação. 


\begin{tabular}{|c|}
\hline $\mathbf{D}=\mathbf{K}_{\mathrm{B}} \cdot \mathbf{T} / \mathbf{f}$ \\
em que \\
$\mathbf{f}=\mathbf{c} . \boldsymbol{\pi} \cdot \boldsymbol{\eta} \cdot \mathbf{r}^{3}$
\end{tabular}

Equação 1.1: Relação do coeficiente de difusão (D) com o tamanho da molécula (r). D: coeficiente de difusão, $\mathrm{K}_{\mathrm{B}}$ : constante de Boltzmann, $\mathrm{T}$ : temperatura da solução, f: fator de fricção, n: viscosidade da amostra, c: coeficiente de atrito e r: raio hidrodinâmico da partícula

(Souza, 2009).

Um exemplo da utilização do coeficiente de difusão (D) em estudo de interação pode ser observado na Figura 1.10, em que é mostrada a variação do $D$ de alguns átomos do ligante após a interação com a HSA (albumina sérica humana) (Luo, 1999). Com isso, é possível mapear os átomos do ligante envolvidos na interação.

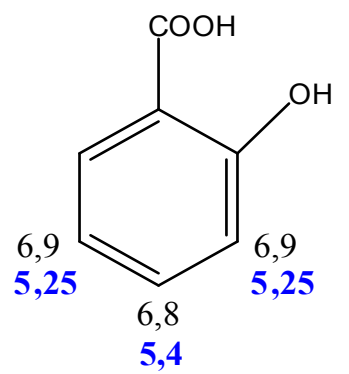

Figura 1.10: Estrutura de um ligante envolvido na interação com a proteína HSA. Valores em preto indicam o coeficiente de difusão do ligante livre e em azul na presença da proteína $\left(\operatorname{Dx} 10^{10}\left(\mathrm{~m}^{2} / \mathrm{s}\right)\right)$. A variação observada indica os possíveis átomos envolvidos na interação. Os outros hidrogênios não sofreram variação no valor do coeficiente de difusão (Luo, 1999).

O Efeito de Overhauser Nuclear (NOE) também é um parâmetro que pode ser utilizado para estudar interação ligante-alvo (Meyer, 2003; Roberts, 2000). Quando um núcleo é perturbado por uma irradiação e a intensidade do sinal de outro núcleo espacialmente próximo é alterada, seja aumentada ou diminuída, esse efeito é chamado de NOE (Gonsalves, 2007). O NOE irá depender da distância espacial entre os átomos, não sendo dependente da existência de acoplamento escalar entre eles, e sim da existência de um acoplamento dipolar entre os átomos espacialmente próximos (Pavia, 2010). O NOE está relacionado ao processo de relaxação dipolar: quando dois núcleos estão espacialmente próximos, a relaxação de um irá interferir na relaxação do outro, o que irá gerar uma mudança na intensidade do sinal (Harris, 1986). 
Quando ocorre uma interação entre o ligante e uma proteína, o NOE pode mudar drasticamente. Essa variação é o fundamento de vários experimentos para estudar a interação ligante/proteína (Figueiredo, 2007). Esta mudança no NOE ocorre por transferência de NOE ou NOE transferido (trNOE) (Stockman, 2002). É possível observar e caracterizar uma interação notando diferença de tr-NOE entre a molécula livre e a molécula ligada à proteína.

Moléculas com baixo e médio peso molecular apresentam valores de NOEs positivos, enquanto que moléculas com alto peso molecular, como proteínas/enzimas, apresentam NOEs fortemente negativos (Figura 1.11) (Figueiredo, 2007). Com isso, quando uma molécula pequena se liga a uma molécula com alto peso molecular, como uma proteína, a primeira passa a fazer parte da molécula maior, adotando e variando o NOE para o novo estado: NOE fortemente negativo (Figueiredo, 2007). Esse tr-NOE reflete a interação do ligante com o receptor.

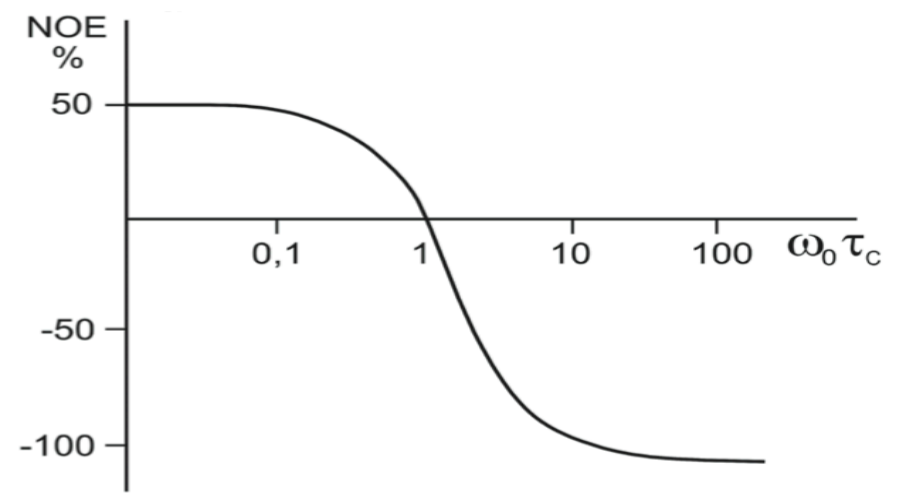

Figura 1.11: Relação entre o NOE e o tamanho da molécula $\left(\omega_{0} T_{c}\right)$ (Figueiredo, 2007).

O tr-NOE é uma das bases do experimento de STD (Saturation Transfer Difference), utilizado para caracterizar as interações em um complexo ligante/proteína (Angulo, 2010, Zhou, 2013). Pelo STD é possível identificar os sinais do ligante envolvidos na interação com o receptor (McCoy, 2005, Viegas, 2011).

O método de STD é baseado na transferência de saturação da proteína para o ligante. Inicialmente aplica-se uma radiação seletiva em algum sinal referente à proteína para saturar os sinais da mesma; em seguida ocorre uma transferência da saturação, por difusão, da proteína para o ligante, saturando 
assim apenas os sinais dos hidrogênios do ligante que interagiram com a proteína (Stockman, 2002). Por fim, ocorre a detecção do ligante em solução, observando um incremento na intensidade dos sinais referentes aos átomos que interagiram com a proteína (Stockman, 2002). Um esquema do experimento de STD pode ser visto na Figura 1.12.
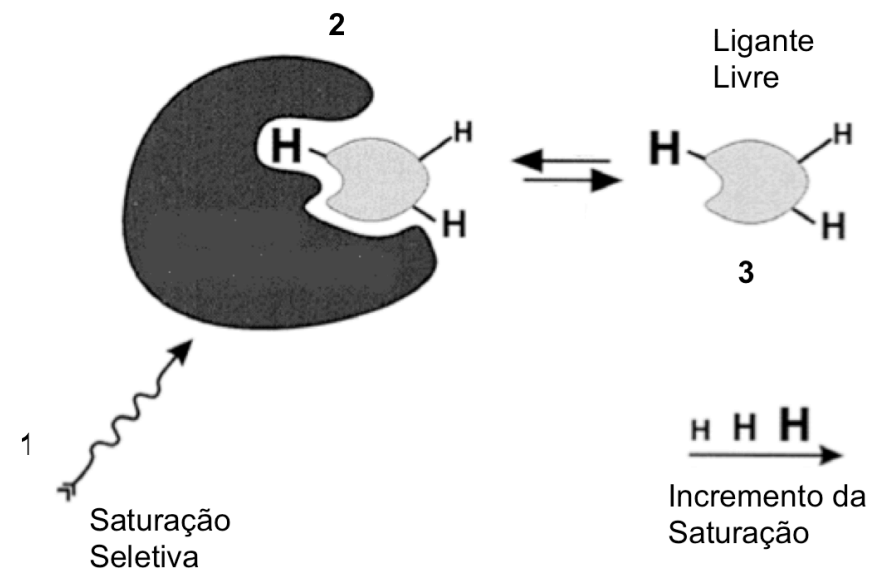

Figura 1.12: Experimento de STD. (1) Saturação seletiva da proteína. (2) Transferência de saturação da proteína para os hidrogênios do ligante que estão envolvidos na interação. (3)

Detecção do ligante, havendo um incremento da intensidade dos sinais dos átomos que interagiram com a proteína. Quanto mais próximos os átomo do ligante estão da proteína, maior será o incremento do seu sinal (Mayer, 2001).

No experimento de STD ocorre uma variação na intensidade dos sinais do ligante que interagiram com a proteína (Figueiredo, 2007). Sendo assim, subtraindo o espectro do ligante livre do espectro do ligante saturado, permanecerão apenas os sinais dos hidrogênios envolvidos na interação com a macromolécula (Stockman, 2002). Um exemplo de STD pode ser visto na Figura 1.13, mostrando a interação de um inibidor para combater o mal de Alzheimer com um peptídeo $\beta$-amiloide (Wang, 2004). O experimento de STD permite mapear os átomos de hidrogênio do ligante envolvidos na interação. 


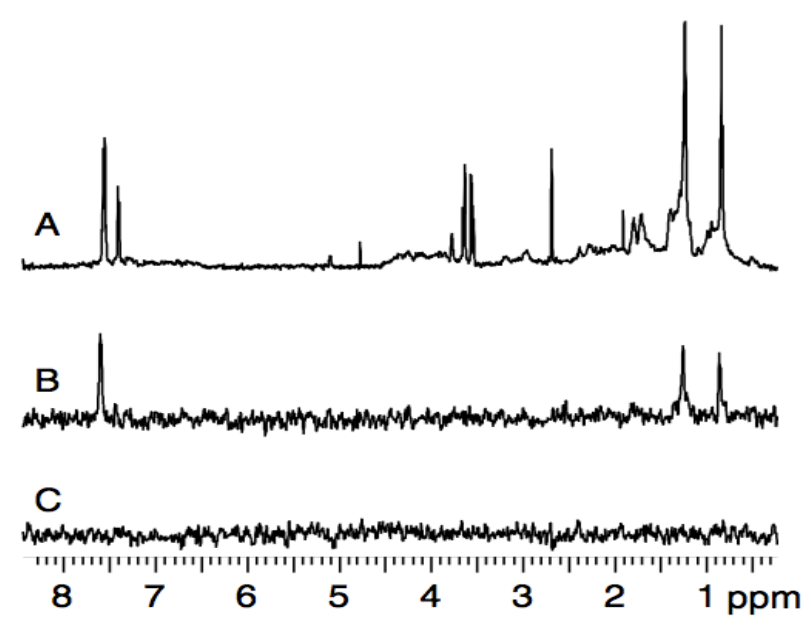

Figura 1.13: Interação de um inibidor com um peptídeo $\beta$-amiloide. A) Espectro do ligante livre. B) Espectro de STD, indicando apenas os hidrogênios envolvidos na interação. C) Espectro de STD de um ligante que não interage com a biomolécula, indicando que nenhum hidrogênio participou da interação inexistente (Wang, 2004).

Um outro experimento de RMN que pode ser utilizado para estudar a interação ligante/receptor é o INPHARMA (Interligand Noe for PHARmacophore MApping). Difusão de spin e NOE transferido (tr-NOE) também são a base desse experimento (Carlomagno, 2012).

O INPHARMA permite observar a orientação de ligantes no sítio do receptor, e para isso, são utilizados dois ligantes $\left(L_{1}\right.$ e $\left.L_{2}\right)$ competitivos pelo mesmo sítio e com baixa ou média afinidade pelo receptor (Orts, 2008; Orts, 2012).

O INPHARMA consiste em um experimento de NOESY de uma solução com dois ligantes competitivos mais um receptor. Durante o mixing time do NOESY, quando um ligante $L_{1}$ se liga ao receptor, os prótons de $L_{1}$ que participam da interação transferem magnetização para os prótons do receptor (Orts, 2009; Sanchez-Pedregal, 2005). Quando o ligante $L_{1}$ se dissocia do receptor, o segundo ligante (competitivo) $L_{2}$ pode se ligar ao mesmo sítio do receptor. A magnetização que havia sido transferida de $L_{1}$ para o receptor, agora pode ser transferida do receptor para os prótons de $L_{2}$ (desde que o local de interação no receptor tenha sido o mesmo) (Orts, 2009; Sanchez-Pedregal, 2005). Com isso, ocorre uma transferência de magnetização indireta de $L_{1}$ para $L_{2}$, mediada pelo receptor. Este fato irá gerar um sinal de correlação no NOESY, chamado de INPHARMA NOE, entre os ligantes $L_{1}$ e $L_{2}$, mesmo que os ligantes nunca tenham estado próximos espacialmente (Carlomagno, 2012; 
Orts, 2009; Sanchez-Pedregal, 2005). Um esquema sobre o INPHARMA pode ser visto na Figura 1.14.

1
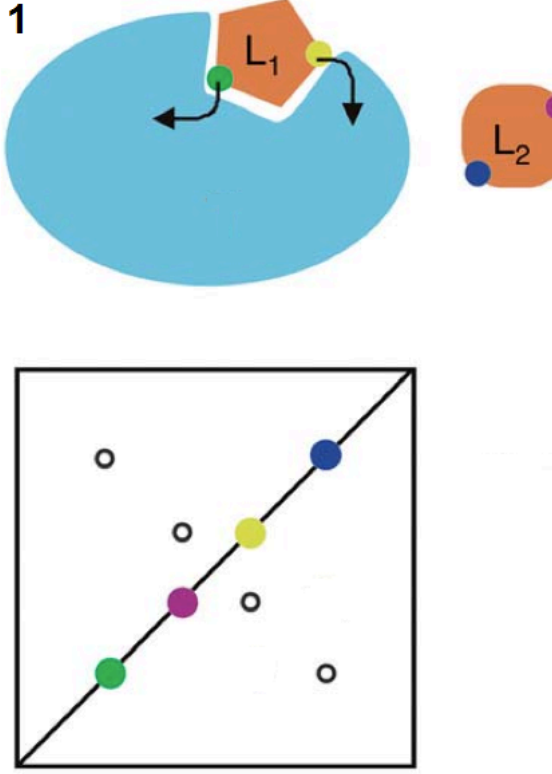

2D NOESY

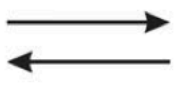

2
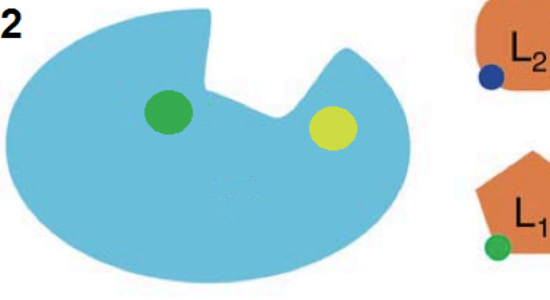

$L_{1}$

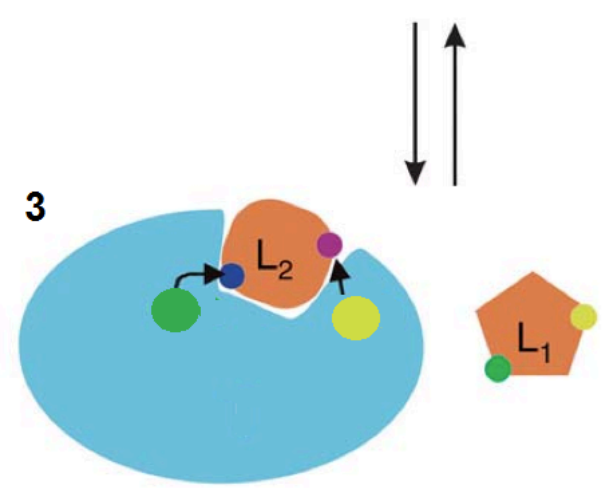

\section{○ INPHARMA NOE}

Figura 1.14: Esquema do experimento INPHARMA. (1) Durante o mixing time do NOESY, quando um ligante $L_{1}$ se liga ao receptor, os prótons de $L_{1}$ que participam da interação transferem magnetização para os prótons do receptor. (2) Durante o mesmo mixing time, o ligante $L_{1}$ irá se dissociar do receptor, permitindo que um segundo ligante $L_{2}$ se ligue no mesmo sítio do receptor. (3) A magnetização que havia sido transferida de $L_{1}$ para o receptor, agora pode ser transferida novamente do receptor para os prótons de $L_{2}$. O espectro NOESY irá apresentar sinais de correlação entre $L_{1}$ e $L_{2}$, chamados de INPHARMA NOE (Carlomagno, 2012).

O NOE observado entre os hidrogênios de $L_{1}$ e $L_{2}$ é um efeito da difusão de spin e do tr-NOE intermediado pelos prótons do receptor (Carlomagno, 2012), e para isso, os hidrogênios de $L_{1}$ e $L_{2}$ devem ter passado ou estado próximos aos mesmos hidrogênios do receptor durante a interação. Com isso, o INPHARMA permite identificar se dois ligantes estão interagindo no mesmo sítio do receptor (Carlomagno, 2012; Skjaerven, 2013). Além disso, é possível identificar o modo de ligação de um ligante desconhecido, utilizando para isso um segundo ligante com o modo de interação já conhecido (Krim, 2012; Stauch, 2012).

Para o INPHARMA funcionar de maneira mais adequada, é necessário que os dois ligantes tenham afinidade baixa ou moderada pelo receptor, com $\mathrm{K}_{d}$ variando entre $\mathrm{mM}$ e $\mu \mathrm{M}$ (Bartoschek, 2010; Carlomagno, 2012). Os ligantes 
devem interagir com o receptor para ocorrer a transferência de magnetização e logo se dissociarem para haver a interação e a transferência de magnetização com o segundo receptor. Ligantes com afinidade alta (nM) podem interferir nesse processo, dificultando essa transferência de magnetização para os dois ligantes.

Os ligantes também devem possuir um valor de $\mathrm{K}_{\mathrm{d}}$ próximos entre si. Valores de $\mathrm{K}_{d}$ muito diferentes entre os ligantes podem causar uma diminuição da intensidade do INPHARMA NOE (Carlomagno, 2012), visto que um ligante passará mais tempo no sítio do receptor do que o outro ligante e, com isso, a troca de magnetização passa a ser desigual.

Um exemplo de INPHARMA pode ser observado na Figura 1.15. Foi realizado um experimento de NOESY com dois ligantes competitivos mais 0 receptor GPR40 (classe de proteína G) (Bartoschek, 2010). O espectro mostra sinais de INPHARMA NOEs entre os dois ligantes, o que permite concluir que ambos os ligantes interagiram no mesmo sítio da proteína. Identificou-se também quais os prótons dos dois ligantes que interagiram com os mesmos átomos do receptor.

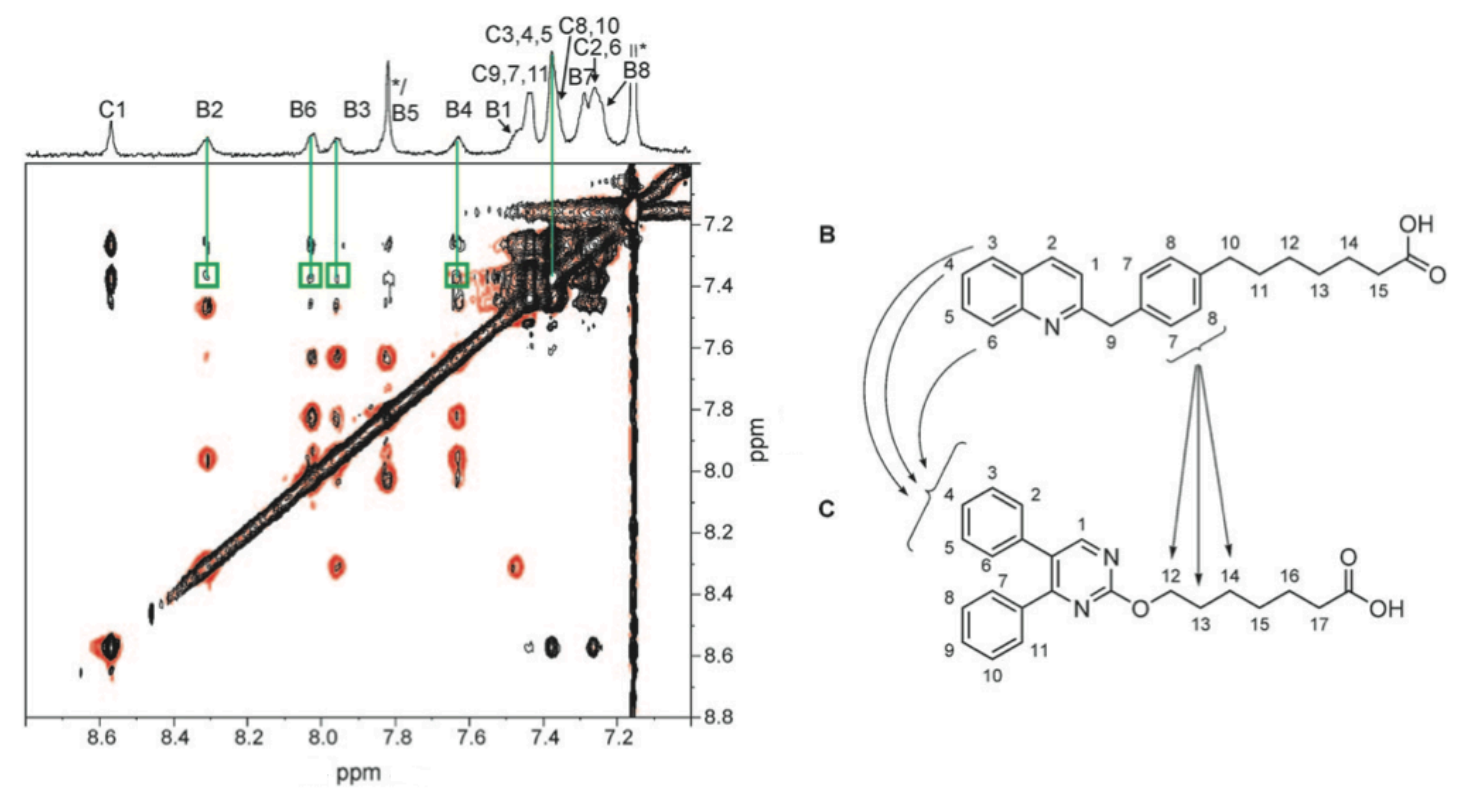

Figura 1.15: Exemplo de INPHARMA envolvendo dois ligantes B e C com a proteína GPR 40 (classe das proteínas $\mathrm{G}$ ). Observou-se sinais de INPHARMA NOE no espectro de NOESY (sinais identificados em verde) entre os ligantes. Identificou-se também que os hidrogênios 3,4 , $5,6,7$ e 8 do ligante $B$ interagiram com a proteína no mesmo local que os hidrogênio $3,4,5$, 12, 13 e 14 do ligante C (Bartoschek, 2010). 


\subsection{Objetivos}

- Selecionar novos compostos com possível atividade em relação à enzima tirosinase e realizar estudos estruturais, por espectroscopia e cálculos teóricos, desses compostos.

- Proceder ensaios biológicos para a avaliação da atividade dos compostos selecionados em relação à enzima tirosinase.

- Estudar a interação dos compostos com a tirosinase por RMN e cálculos teóricos. 


\subsection{Metodologia}

\subsubsection{Síntese e Caracterização de Possíveis inibidores da Tirosinase}

Realizou-se a síntese de compostos fenólicos e carbonílicos listados na Tabela 1.2. Tais compostos foram sintetizados pelo grupo de pesquisa do professor Robson Ricardo Teixeira (UFV).

Tabela 1.2: Estrutura dos compostos enólicos e carbonílicos selecionados e sintetizados.

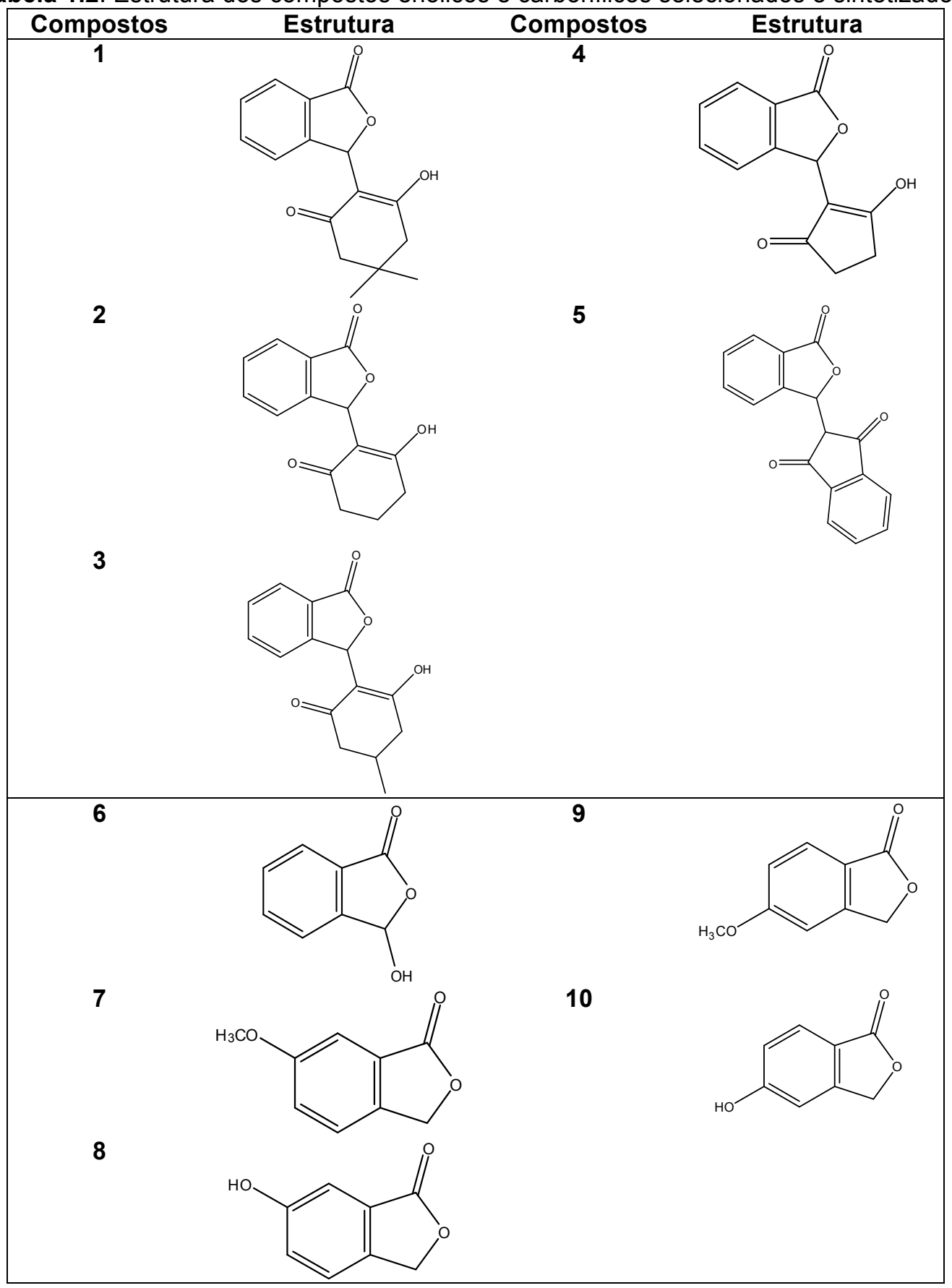




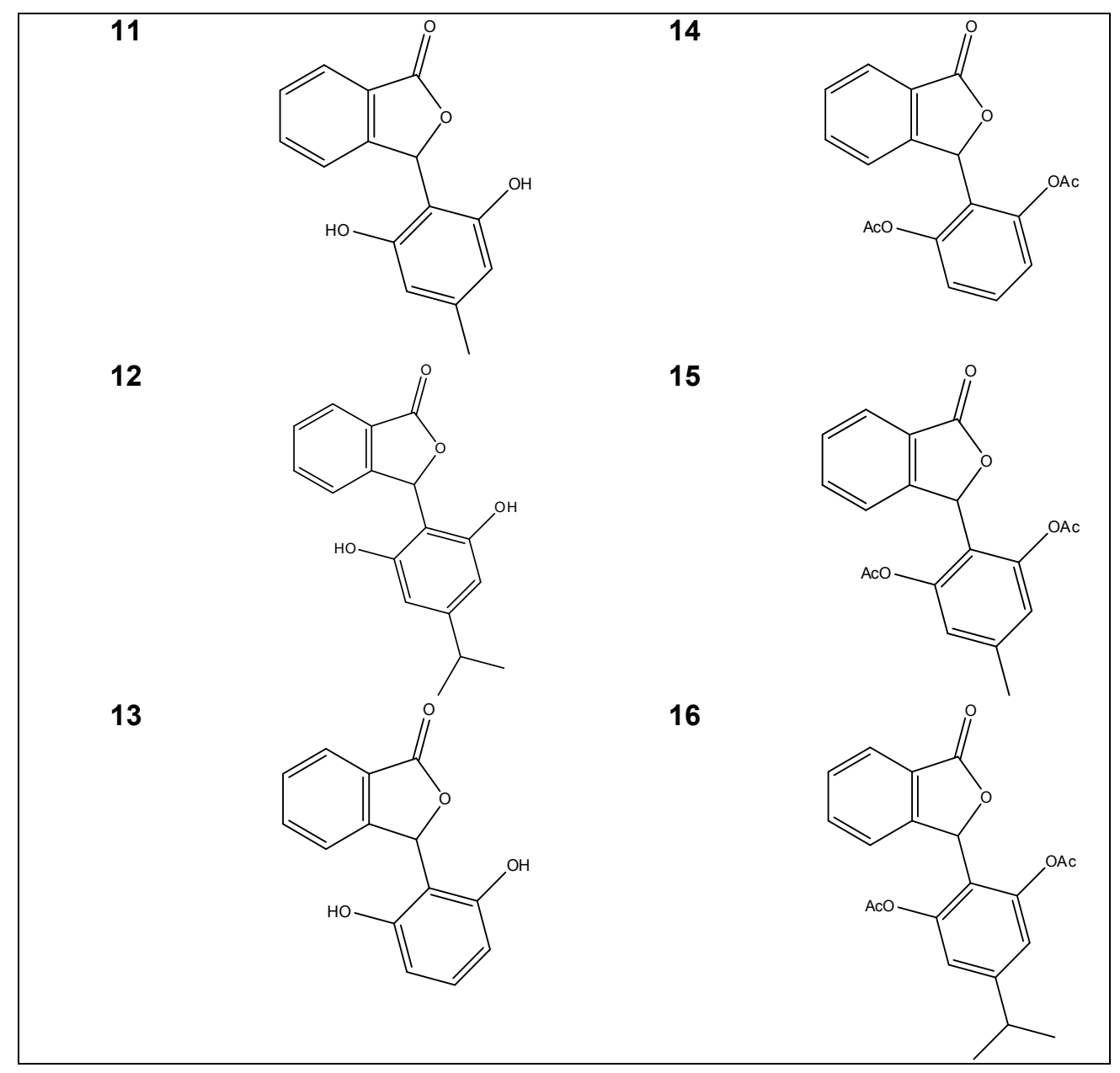

O composto 6 (ácido ftalaldeídico) foi adquirido comercialmente (SigmaAldrich). A rota sintética e a metodologia para a obtenção dos compostos 1-5 e 11-16 pode ser observada na Figura 1.16 (Teixeira, 2013) e para os compostos 7 a 10 na Figura 1.17 (Teixeira, 2014). 


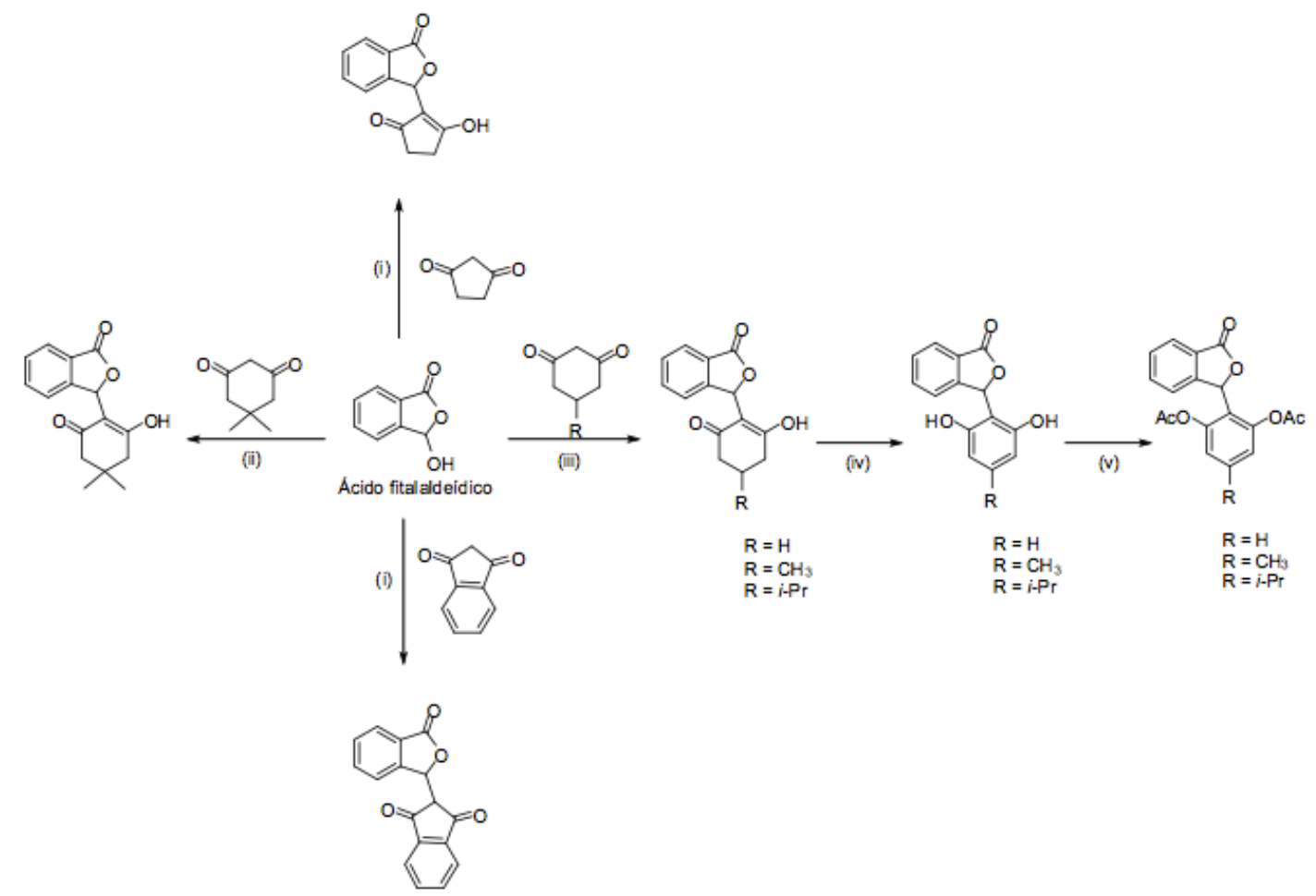

Figura 1.16: Rota sintética envolvida na preparação dos compostos 1 a 5 e 11 a 16. Condições de reação: (i) $\mathrm{DBU}, \mathrm{CHCl}_{3}$, refluxo; (ii) $\mathrm{DBU}, \mathrm{CHCl}_{3}$, temperatura ambiente; (iii) $\mathrm{DBU}, \mathrm{CH}_{3} \mathrm{CN}$, refluxo; (iv) $\mathrm{Hg}(\mathrm{OAc})_{2}, \mathrm{NaOAc}, \mathrm{CH}_{3} \mathrm{COOH}$, refluxo; (v) DMAP, $\mathrm{Ac}_{2} \mathrm{O}, \mathrm{Et}_{3} \mathrm{~N}, \mathrm{CHCl}_{3}$, temperatura ambiente (Teixeira, 2013).

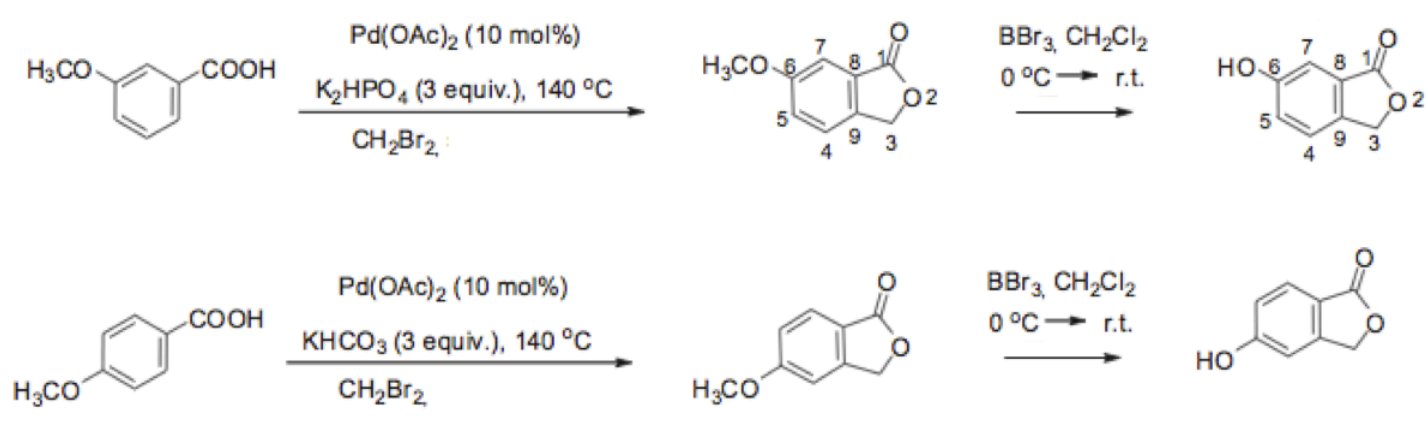

Figura 1.17: Rota sintética envolvida na preparação dos compostos 7, 8, 9 e 10 (Teixeira, 2014).

Todos os compostos sintetizados foram caracterizados por RMN (Teixeira, 2013; Teixeira, 2014), em um espectrômetro Avance DRX 400 (400 $\mathrm{MHz}$ para hidrogênio), utilizando-se como solvente $\mathrm{DMSO}-d_{6}$ para os compostos 13 e 14, $\mathrm{CD}_{3} \mathrm{OD}$ para os compostos 1, 8, 9, 10, 12 e 16, e $\mathrm{CDCl}_{3}$ para os compostos $2,3,4,5,7,11$ e 15 . O assinalamento das moléculas foi feito com os espectros de ${ }^{1} \mathrm{H},{ }^{13} \mathrm{C}$, COSY, HSQC e HBMC. 
Procedeu-se à caracterização dos compostos listados por Espectrometria de Massa do tipo electrospray (ESI-MS). Os espectros foram obtidos em um espectrômetro micrOTOF - QII (Bruker) no modo positivo de aquisição. As amostras foram analisadas utilizando acetonitrila contendo $1 \%$ de ácido fórmico como solvente, uma voltagem no capilar de 4,5 kV e um fluxo de 2,0 $\mu \mathrm{L} / \mathrm{min}$. Para a calibração, utilizou-se um calibrante externo próprio para ionização do tipo electrospray (ESI-Tuning Mix - Agilent Technologies). A solução para calibrar o equipamento foi preparada utilizando $500 \mu \mathrm{L}$ do calibrante, $10 \mu \mathrm{L}$ de $\mathrm{ACN}$ e $10 \mu \mathrm{L}$ de $\mathrm{H}_{2} \mathrm{O}$.

\subsubsection{Estudo do Equilíbrio Tautomérico Ceto-Enólico por RMN}

Os experimentos de RMN foram realizados em um espectrômetro de $600 \mathrm{MHz}$ para a frequência do hidrogênio (Premium Compact, Varian), com uma sonda de $5 \mathrm{~mm}$. Os cinco compostos (1 a 5 ) foram analisados em diferentes solventes e diferentes temperaturas para os experimentos de ${ }^{1} \mathrm{H}$ RMN: acetona- $\mathrm{d}_{6}$ (de 15 a $45{ }^{\circ} \mathrm{C}$, em incrementos de 10 graus), metanol- $\mathrm{d}_{4}$ (de 15 a $55{ }^{\circ} \mathrm{C}$, em incrementos de 10 graus) e DMSO-d 6 (de 15 a $75{ }^{\circ} \mathrm{C}$, em incrementos de 10 graus). Adquiriu-se também espectros de ${ }^{1} \mathrm{H}-\mathrm{RMN}$ do composto 1 em acetona a 0 e $5{ }^{\circ} \mathrm{C}$. Foram adquiridos espectros de ${ }^{13} \mathrm{C}-\mathrm{RMN}$ e APT nos mesmos três solventes e em diferentes temperaturas: acetona- $\mathrm{d}_{6}$ (15, 25 e $\left.45{ }^{\circ} \mathrm{C}\right)$, metanol-d $4\left(15,25\right.$ e $\left.55^{\circ} \mathrm{C}\right)$ e DMSO-d 6 (15, 25 e $\left.75{ }^{\circ} \mathrm{C}\right)$. Tais solventes foram escolhidos pela solubilidade da amostra. Utilizou-se o sinal do solvente para referenciar os espectros. Experimentos de ${ }^{1} \mathrm{H}-\mathrm{RMN}$ foram realizados com 32 scans (janela espectral de 0 a 14 ppm), ${ }^{13} \mathrm{C}-\mathrm{RMN}$ com 2000 scans (janela espectral de 0 a 300 ppm) e APT com 3000 scans (janela espectral de 0 a $300 \mathrm{ppm}$ ).

\subsubsection{Estudo do Equilíbrio Tautomérico Ceto-Enólico por Espectrometria de Massa}

Os experimentos foram realizados em um espectrômetro micrOTOF QII (Bruker) no modo positivo de aquisição. As amostras foram analisadas utilizando acetonitrila contendo $1 \%$ de ácido fórmico como solvente, uma 
voltagem no capilar de 4,5 kV e um fluxo de 2,0 $\mu \mathrm{L} / \mathrm{min}$. Para a calibração, utilizou-se um calibrante externo próprio para ionização do tipo Electrospray (ESI-Tuning Mix - Agilent Technologies). A solução para calibrar o equipamento foi preparada utilizando $500 \mu \mathrm{L}$ do calibrante, $10 \mu \mathrm{L}$ de $\mathrm{ACN}$ e $10 \mu \mathrm{L}$ de $\mathrm{H}_{2} \mathrm{O}$. Foram adquiridos experimentos de Massa/Massa (MS/MS) dos cincos compostos, referentes aos íons precursores de cada um.

\subsubsection{Estudo do Equilíbrio Tautomérico Ceto-Enólico por Infravermelho}

As análises na região do infravermelho (IV) foram realizadas em um equipamento Varian 660-IR com acessório GladiATR, empregando-se a técnica reflectância total atenuada (ATR). Os espectros dos compostos 1 a 5 foram adquiridos direto da amostra em estado sólido, sem tratamento prévio com solventes.

\subsubsection{Estudo do Equilíbrio Tautomérico Ceto-Enólico por Cálculos de Mecânica Quântica}

A energia e a geometria dos compostos 1 a 5 foram otimizadas pelo programa Spartan`14 (Shao, 2006), utilizando o método DFT-B3LYP. Realizouse a otimização dos compostos nas formas cetônica e enólica, separadamente. Os cálculos foram realizados sem a presença de solvente (vácuo) com a base $6-311++G^{* *}$ e considerando a presença do solvente (apenas a constante dielétrica), com a base $6-31 \mathrm{G}^{*}$.

\subsubsection{Teste Biológico: Atividade em Relação à Enzima Tirosinase}

Os ensaios biológicos de inibição e ativação da enzima tirosinase foram realizados com os 16 compostos listados na Tabela 1.2. Os testes foram feitos em microplacas de 96 poços, monitorados em uma leitora de microplaca EL808 IU (Biotek) em 495 nm (Khatib, 2005; Kubo, 2003; Shin 1998). As medidas foram realizadas a cada 16 segundos durante $30 \mathrm{~min}$. Utilizou-se a enzima tirosinase de cogumelo para os estudos (Tyrosinase from Mushroom, 3610 unidades de atividade/mg, Sigma Aldrich). 
Inicialmente realizou-se os testes de atividade da enzima na presença apenas dos substratos L-dopa e L-tirosina (branco), monitorando o produto de degradação (formação de dopaminocromo) de ambos em $495 \mathrm{~nm}$ por 30 minutos (Khatib, 2005; Kubo 2003; Shin 1998). Em seguida, observou-se a atividade da enzima na presença dos compostos listados, com ambos os substratos, separadamente. Por fim, procedeu-se os testes também com um inibidor já conhecido na literatura, o ácido Kojic (controle positivo). Cada análise foi realizada em triplicata.

Ensaios de bioatividade foram realizados utilizando $40 \mu \mathrm{L}$ do composto a ser testado (apenas tampão no ensaio branco), $40 \mu \mathrm{L}$ do substrato (L-dopa ou L-tirosina), $80 \mu \mathrm{L}$ de tampão fosfato e $40 \mu \mathrm{L}$ da enzima, totalizando $200 \mu \mathrm{L}$ de volume final (Shin, 1998). As concentrações nos volumes finais foram de 512 $\mu \mathrm{M}$ para o composto a ser testado, $0,1 \mathrm{mM}$ do substrato, 50 unidades de atividade/mL de enzima e 66,67 mM de tampão fosfato $\mathrm{pH} \mathrm{6,8} \mathrm{(Khatib,} \mathrm{2005;}$ Kubo, 2003; Shin, 1998). Os compostos testados foram inicialmente solubilizados em DMSO e posteriormente diluídos, por questões de solubilidade, sendo a concentração de DMSO na solução final igual a $10 \%$.

Para os compostos que apresentaram maiores atividades (acima de $50 \%$ ), realizou-se novamente o ensaio, variando a concentração do composto a ser testado: $512 \mu \mathrm{M}, 256 \mu \mathrm{M}, 128 \mu \mathrm{M}, 64 \mu \mathrm{M}, 32 \mu \mathrm{M}, 16 \mu \mathrm{M}$ e $8 \mu \mathrm{M}$.

Para calcular a porcentagem de atividade, utilizou-se o t(1/2) (metade do tempo para alcançar a atividade máxima da enzima) do ensaio branco como parâmetro base para comparação com os compostos a serem testados.

\subsubsection{Deslocamento Químico, Relaxação e Difusão no Estudo de Interação Ligante-Enzima por RMN}

Os estudos de interação por RMN foram realizados com os compostos 6, 12, 14 e o ácido kojic. Os experimentos foram adquiridos em um espectrômetro PremiumCOMPACT (600 MHz para hidrogênio), com uma sonda de $5 \mathrm{~mm}$ e temperatura de $25^{\circ} \mathrm{C}$.

Para observar o deslocamento químico no estudo de interação, realizouse experimentos de ${ }^{1} \mathrm{H}-\mathrm{RMN}$ dos ligantes livres, e em seguida, dos ligantes na presença da enzima tirosinase. Os experimentos foram adquiridos com 32 
scans, janela espectral de 0 a 14 ppm e $D_{2} \mathrm{O} / \mathrm{DMSO}-d_{6}(90 \% / 10 \%)$ como solvente. A concentração dos ligantes foi de $2 \mathrm{mM}$, e a da enzima, 0,26 $\mu \mathrm{M}$ e $20 \mu \mathrm{M}$.

Foram adquiridos os espectros DOSY dos ligantes livres, e em seguida, dos ligantes na presença da tirosinase. Utilizou-se o experimento DONESHOT, com 16 scans, 15 incrementos, tempo de gradiente (diffusion gradiente lenght) de 2 ms e tempo de difusão (diffusion delay) de 50,0 ms. Utilizou-se $\mathrm{D}_{2} \mathrm{O} / \mathrm{DMSO}-d_{6}(90 \% / 10 \%)$ como solvente, concentração dos ligantes de $2 \mathrm{mM}$ e a concentração da enzima de $0,26 \mu \mathrm{M}$ e $20 \mu \mathrm{M}$.

Os tempos de relaxação $T_{1}$ foram medidos utilizando a sequência inversão-recuperação para os ligantes na ausência e na presença da enzima. Foi utilizado um tempo de relaxação (d1) de $50 \mathrm{~s}$ com tempo total de experimento de 0,2 h. Utilizou-se $\mathrm{D}_{2} \mathrm{O} / \mathrm{DMSO}-d_{6}(90 \% / 10 \%)$ como solvente, concentração dos ligantes de $2 \mathrm{mM}$ e a concentração da enzima de 0,26 $\mu \mathrm{M}$ e $20 \mu \mathrm{M}$.

\subsubsection{STD no Estudo de Interação Ligante-Enzima por RMN}

Os experimentos foram realizados com os compostos 6, 12, 14 e ácido kojic, em um espectrômetro PremiumCOMPACT (600 MHz para hidrogênio), com uma sonda de $5 \mathrm{~mm}$ e temperatura de $25{ }^{\circ} \mathrm{C}$.

Realizou-se o experimento de STD dos ligantes na presença da tirosinase (composto 6 + enzima; composto 12 + enzima; composto $14+$ enzima e ácido kojic + enzima). Procedeu-se também os experimentos de STD acrescentando o ácido kojic às soluções dos ligantes já com a tirosinase (composto 6 + enzima + kojic; composto 12 + enzima + kojic e composto 14 + enzima + kojic) e também acrescentando os ligantes à solução do ácido kojic já contendo a enzima (kojic + enzima + composto 6; kojic + enzima + composto 12 e kojic + enzima + composto 14). Realizou-se também o experimento de STD com os seguintes pares de ligantes: 6 e 12; 6 e 14; e 12 e 14 (composto 6 + composto 12 + enzima; composto 6 + composto 12 + enzima e composto 12 + composto 14 + enzima).

O experimento foi realizado com 64 scans, trim pulse de $40 \mathrm{~ms}$ e $46 \mathrm{~dB}$, frequência de referência (off resonance) de $40.000 \mathrm{~Hz}$, frequências de 
saturação (on resonance) de $300 \mathrm{~Hz}, 600 \mathrm{~Hz}, 900 \mathrm{~Hz}, 1200 \mathrm{~Hz}, 1800 \mathrm{~Hz}$ e $2400 \mathrm{~Hz}, \mathrm{D}_{2} \mathrm{O} / \mathrm{DMSO}-d_{6}(90 \% / 10 \%)$ como solvente, concentração dos ligantes de $2 \mathrm{mM}$ e a concentração da enzima de $0,26 \mu \mathrm{M}$ e $20 \mu \mathrm{M}$.

\subsubsection{INPHARMA no Estudo de Interação Ligante-Enzima por RMN}

Os experimentos foram realizados com os compostos 6, 12, 14 e ácido kojic, em um espectrômetro PremiumCOMPACT (600 MHz para hidrogênio), com uma sonda de $5 \mathrm{~mm}$ e temperatura de $25^{\circ} \mathrm{C}$.

Foram adquiridos espectros NOESY para o composto 6 + ácido kojic, composto 12 + ácido kojic e composto 14 + ácido kojic, todos na presença da tirosinase, utilizando-se 32 scans, 512 incrementos e $200 \mathrm{~ms}$ de tempo de mistura (mixing time). Para a amostra 6, realizou-se também o experimento com 400 ms de tempo de mistura. Utilizou-se $D_{2} \mathrm{O} / \mathrm{DMSO}-d_{6}(90 \% / 10 \%)$ como solvente, concentração dos ligantes de $2 \mathrm{mM}$ e a concentração da enzima de $0,26 \mu \mathrm{M}$ e $20 \mu \mathrm{M}$.

\subsubsection{Docking Molecular}

Os estudos de docking molecular foram realizados em colaboração com o Prof. Dr. Laurent Emmnanuel Dardenne, do Laboratório Nacional de Computação Científica (LNCC - Petrópolis, RJ).

Avaliou-se, por docking molecular, os possíveis modos de ligação dos compostos 6, 12 e 14, assim como a reprodução do modo de ligação experimental do ácido kojic, L-dopa e L-tirosina. Todas as análises foram feitas com a estrutura da oxi-tirosinase de Streptomyces castaneoglobisporus (ScTyr, PDB 1wx2), a qual possui no sítio de ligação dois íons de $\mathrm{Cu}^{2+}$, um grupo peróxido (O-O) e uma molécula de água estrutural. Esta estrutura foi alinhada com a tirosinase de Agaricus bisporus (AbTyr, PDB 2y9w), a qual foi utilizada nos estudos experimentais, com o objetivo de comparar o sítio ativo das duas enzimas.

Os estados de protonação das histidinas $37,62,53,193,189$ e 215 foram alterados para ND1 para coordenarem os metais (histidina neutra em ND1). Os ligantes utilizados para o estudo de redocking foram: (i) L-tirosina, 
PDB 4p6r, (ii) L-dopa, PDB 4p6s, e (iii) kojic, PDB 3nq1. Para os estudos de docking, os compostos 6, 12 e 14 foram desenhados no Maestro Suite 2014 (version 9.7, Schrödinger, LLC, New York, NY, 2014) e a estrutura tridimensional foi gerada e otimizada utilizando a ferramenta LigPrep (version 2.9, Schrödinger, LLC, New York, NY, 2014).

Os estudos de docking foram realizados utilizando o programa DockThor (Magalhães, 2004; Magalhães, 2014) tendo como parâmetros:

- grade de energia: $X=-9.21 . Y=-29.16, Z=-44.34$ (centro de coordenadas da L-tirosina), tamanho total de $22 \AA$ em cada eixo e discretização de $0.25 \AA$.

- algoritmo genético: 1.000 .000 de avaliações, população inicial com 1.000 indivíduos, 30 execuções do algoritmo.

As cargas parciais e os tipos de átomos da proteína foram definidos para o campo de força MMFF94S utilizando a ferramenta PdbThorBox, enquanto que para os ligantes e cofatores foi utilizada a ferramenta MMFFLigand. 


\subsection{Resultados e Discussão}

\subsubsection{Síntese e Caracterização de Possíveis inibidores da Tirosinase}

Compostos carbonílicos e/ou fenólicos são possíveis inibidores da tirosinase, uma vez que carbonilas podem se coordenar ao cobre (metal presente no sítio ativo da enzima). A formação de quelatos com o metal pode diminuir ou mesmo anular a atividade da enzima, consistindo em um importante mecanismo inibidor (Nerya, 2004). Além disso, a tirosinase está envolvida em reações de hidroxilação e oxidação de fenóis, tornando os compostos fenólicos importantes aliados na inibição da enzima, visto que podem competir com a tirosina ou a L-dopa (substratos fenólicos) nessas reações (Nerya, 2004; Vontzalidou, 2012).

Os compostos 1 a 16 foram sintetizados e caracterizados por RMN e Infravermelho, com exceção do composto 6, que foi obtido comercialmente. Com isso, foi possível confirmar as estruturas esperadas para os compostos. As estruturas dos 15 compostos e seu completo assinalamento podem ser vistos na Tabela 1.3, conforme realizado pelo grupo de pesquisa do Professor Robson Ricardo Teixeira (UFV) (Teixeira, 2013; Teixeira, 2014).

Tabela 1.3: Estrutura dos compostos 1 a 16 com o assinalamento dos átomos de hidrogênio (azul) e carbono (vermelho). (Teixeira, 2013; Teixeira, 2014). Compostos 2, 3, 4, 5, 7, 11 e 15 assinalados em $\mathrm{CDCl}_{3}$; compostos 1, 8, 9, 10, 12 e 16 em $\mathrm{CD}_{3} \mathrm{OD}$ e compostos 13 e 14 em DMSO- $d_{6}$.

Composto Estrutura com Assinalamento Composto




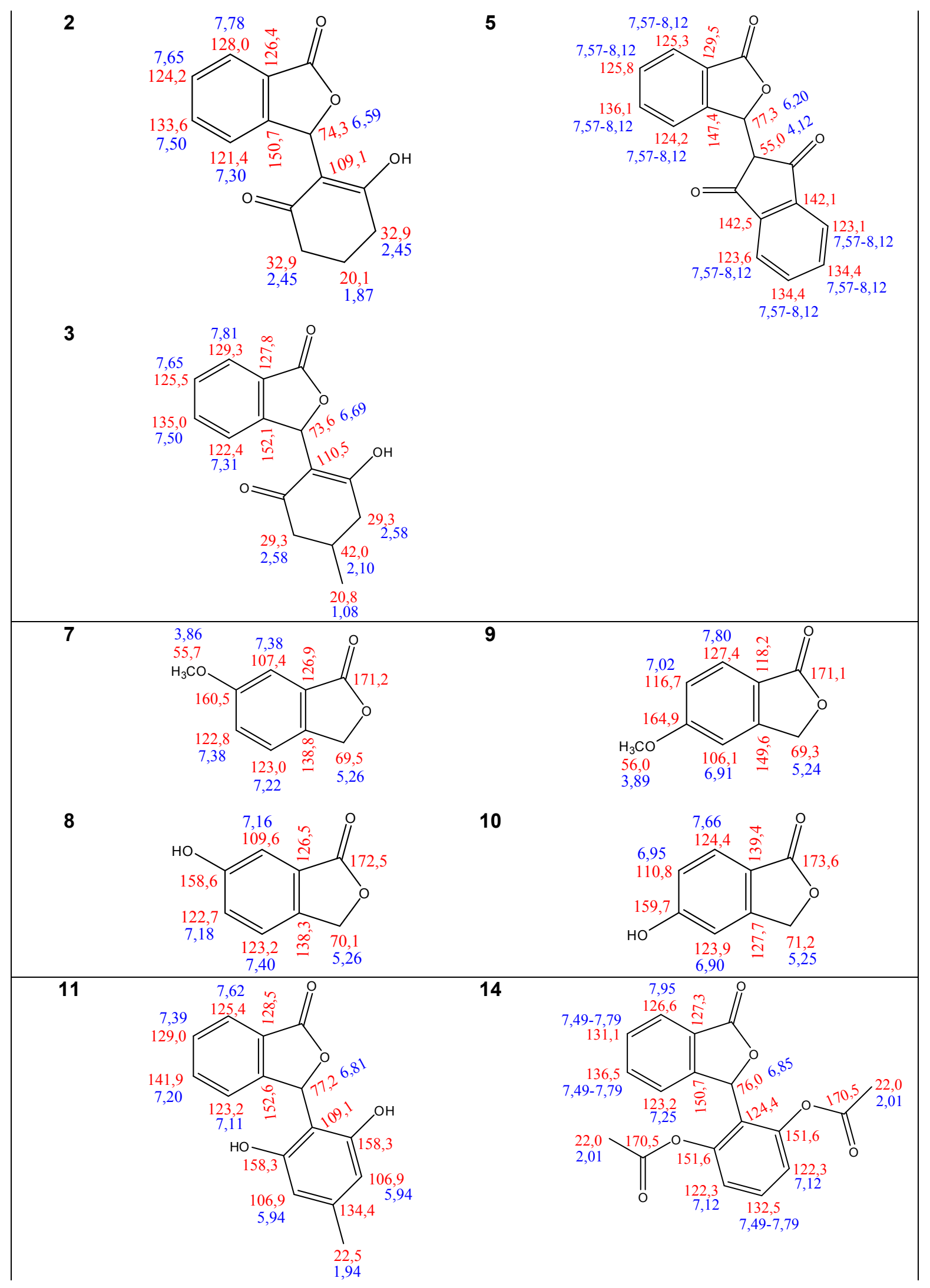


12

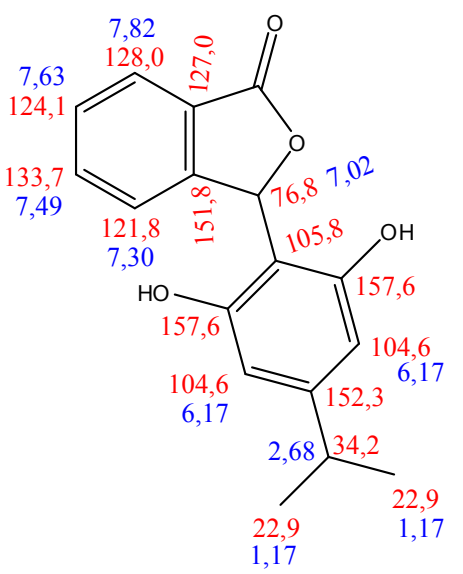

13

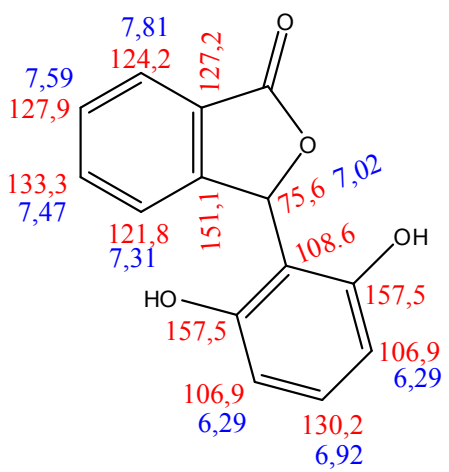

15

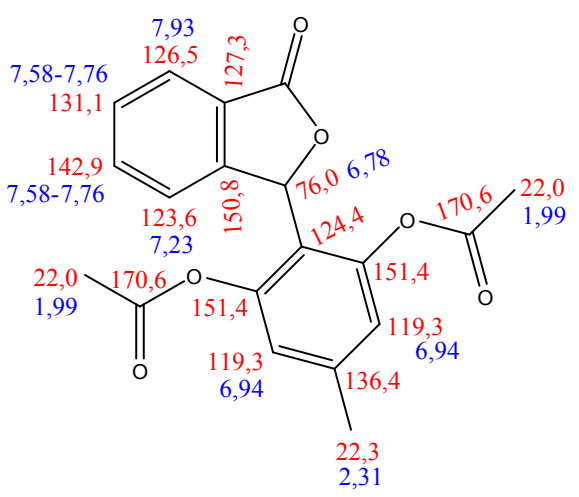

16

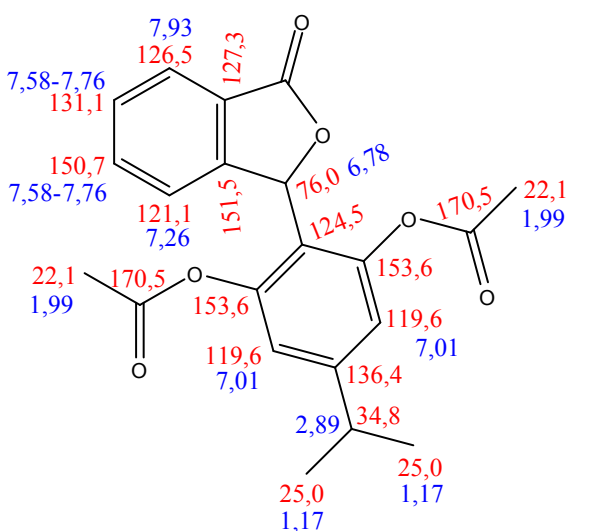

Realizou-se também a caracterização dos compostos sintéticos de 1 a 16 por Espectrometria de Massa. As massas teórica e experimental obtidas para cada composto podem ser observadas na Tabela 1.4. Os correspondentes espectros encontram-se nos Anexos 1 a 16.

Tabela 1.4: Massa teórica e massa obtida experimentalmente para os compostos 1 a 16.

\begin{tabular}{ccc}
\hline Composto & ${\text { Massa Teórica }[\mathbf{M + H}]^{+}}$ & Massa Experimental $[\mathbf{M + H}]^{+}$ \\
\hline $\mathbf{1}$ & 273,1123 & 273,1144 \\
$\mathbf{2}$ & 245,0808 & 245,0813 \\
$\mathbf{3}$ & 259,0965 & 259,0984 \\
$\mathbf{4}$ & 231,0651 & 231,0647 \\
$\mathbf{5}$ & 279,0651 & 279,0635 \\
$\mathbf{6}$ & 151,0390 & 151,0383 \\
$\mathbf{7}$ & 165,0546 & 165,0608 \\
$\mathbf{8}$ & 151,0390 & 151,0370 \\
$\mathbf{9}$ & 165,0546 & 165,0588 \\
$\mathbf{1 0}$ & 151,0390 & 151,0434 \\
\hline
\end{tabular}




\begin{tabular}{lll}
\hline 11 & 257,0808 & 257,0817 \\
12 & 285,1121 & 285,1095 \\
13 & 243,0651 & 243,0636 \\
14 & 327,0863 & 327,0808 \\
15 & 341,1020 & 341,0940 \\
16 & 369,1332 & 369,1240 \\
\hline
\end{tabular}

\subsubsection{Estudo do Equilíbrio Tautomérico Ceto-Enólico por RMN}

Os compostos 1 a 5 podem apresentar um equilíbrio tautomérico cetoenólico e apresentar as formas dicetônica e/ou ceto-enólica, como exemplificado na Figura 1.18 para o composto 1. Por isso, realizou-se estudos desse equilíbrio por RMN em diferentes condições de solvente e temperatura.
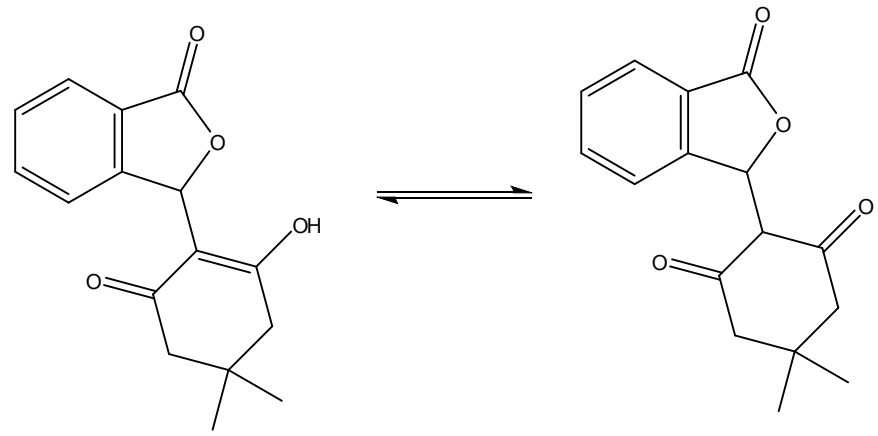

Figura 1.18: Estruturas do possível equilíbrio ceto-enólico para o composto 1, apresentando as formas ceto-enólica e dicetônica, respectivamente.

O assinalamento dos átomos de hidrogênio e carbono do composto 1 nos diferentes solventes (acetona- $d_{6}$, DMSO- $d_{6}$ e metanol- $d_{4}$ ) podem ser notados na tabela 1.5. Para o assinalamento nos diferentes solventes, foram realizados experimentos de ${ }^{1} \mathrm{H}-\mathrm{RMN},{ }^{13} \mathrm{C}-\mathrm{RMN}, \mathrm{COSY}, \mathrm{HSQC}$ e HMBC, todos a $25^{\circ} \mathrm{C}$.

Tabela 1.5: Assinalamento dos átomos de hidrogênio e carbono do composto 1 em diferentes solventes: acetona, metanol e DMSO.

\begin{tabular}{|c|c|c|c|c|c|c|}
\hline & \multicolumn{2}{|c|}{ Acetona } & \multicolumn{2}{c|}{ Metanol } & \multicolumn{2}{c|}{ DMSO } \\
\hline Átomo & $\mathrm{H}$ & $\mathrm{C}$ & $\mathrm{H}$ & $\mathrm{C}$ & $\mathrm{H}$ & $\mathrm{C}$ \\
\hline $\mathbf{1}$ & - & 171,6 & - & 174,2 & - & 170,8 \\
\hline $\mathbf{3}$ & 6,66 & 75,0 & 6,70 & 76,5 & 6,59 & 74,3 \\
\hline $\mathbf{4}$ & 7,34 & 122,3 & 7,31 & 122,7 & 7,29 & 121,4 \\
\hline
\end{tabular}




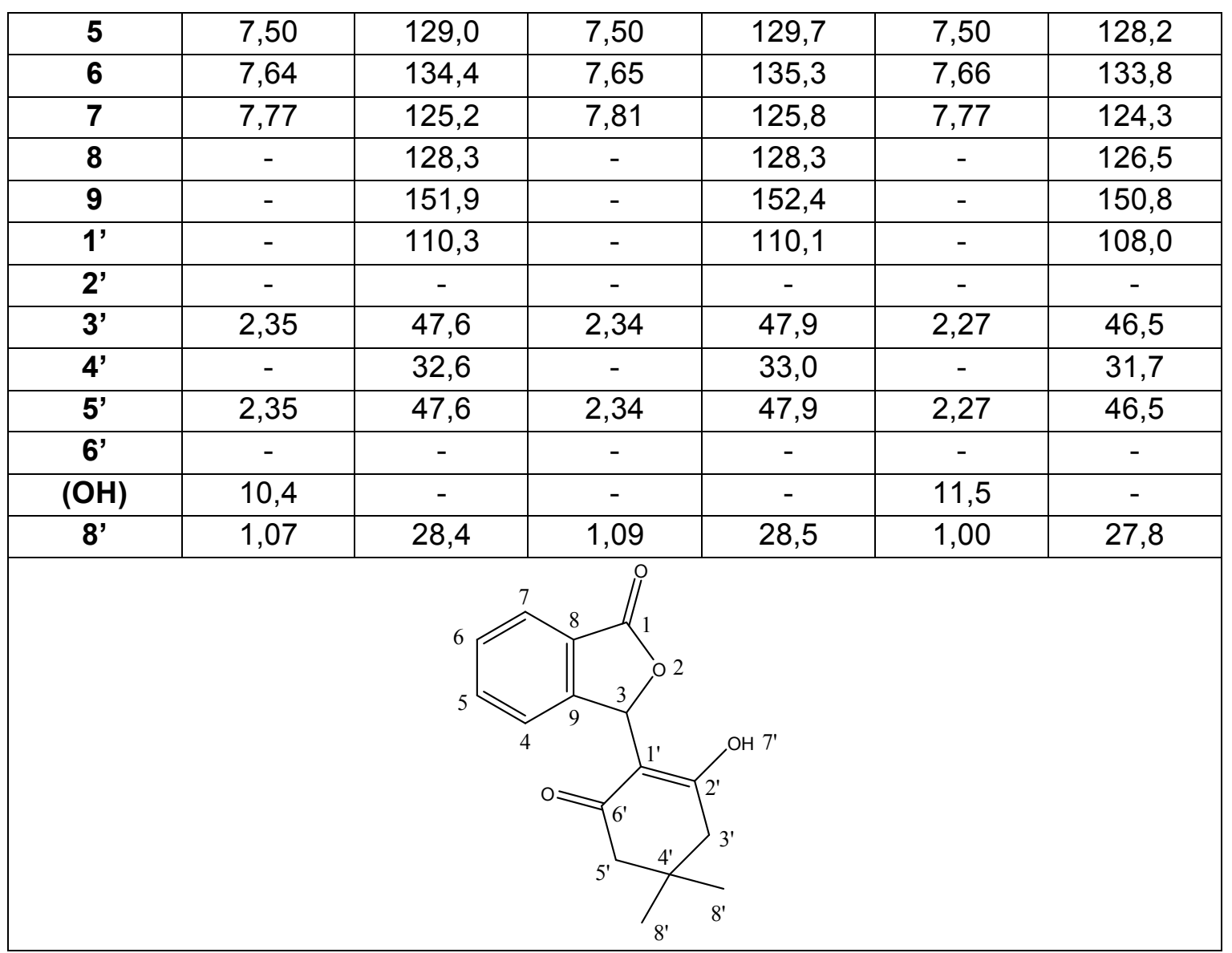

Para os estudos de tautomeria, foram adquiridos espectros de hidrogênio a diferentes temperaturas nos três solventes: acetona- $d_{6}$ (de 15 a 45 $\left.{ }^{\circ} \mathrm{C}\right)$, DMSO- $d_{6}\left(\right.$ de 15 a $75{ }^{\circ} \mathrm{C}$ ) e metanol- $d_{4}$ (de 15 a $55^{\circ} \mathrm{C}$ ). Para os estudos em acetona e metanol, o limite superior de temperatura foi delimitado pela temperatura de ebulição do solvente: $56-57{ }^{\circ} \mathrm{C}$ e $64,7{ }^{\circ} \mathrm{C}$, respectivamente. Por isso a diferença das faixas de temperatura utilizadas.

Para o estudo do equilíbrio ceto-enólico foi observada a multiplicidade do hidrogênio-3 (simpleto para a forma ceto-enólica e dupleto para a forma dicetônica) e também a presença (forma dicetônica) ou ausência (ceto-enólica) de sinal referente ao hidrogênio na posição 1'.

A expansão da região aromática dos espectros de ${ }^{1} \mathrm{H}-\mathrm{RMN}$ do composto 1 em acetona, DMSO e metanol, a diferentes temperaturas, pode ser vista nas Figuras 1.19, 1.20 e 1.21, respectivamente. 


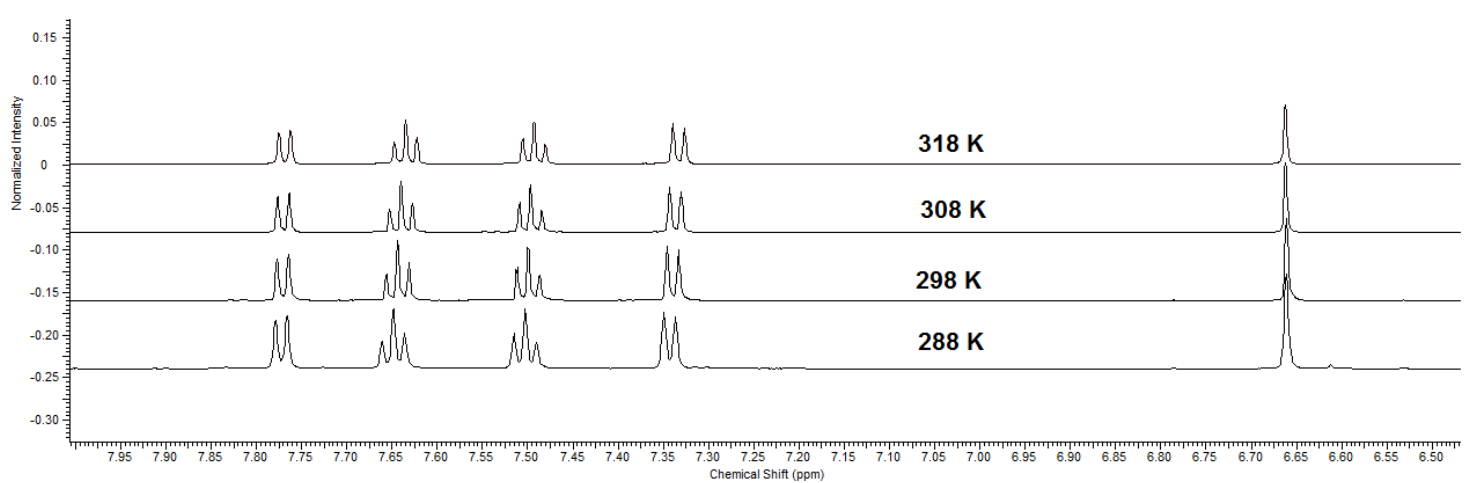

Figura 1.19: Espectros de ${ }^{1} \mathrm{H}-\mathrm{RMN}$ do composto 1 em acetona- $d_{6}$ a diferentes temperaturas. Expansão da região de 6,5 a 8,0 ppm. É observado o hidrogênio 3 próximo a 6,66 ppm.

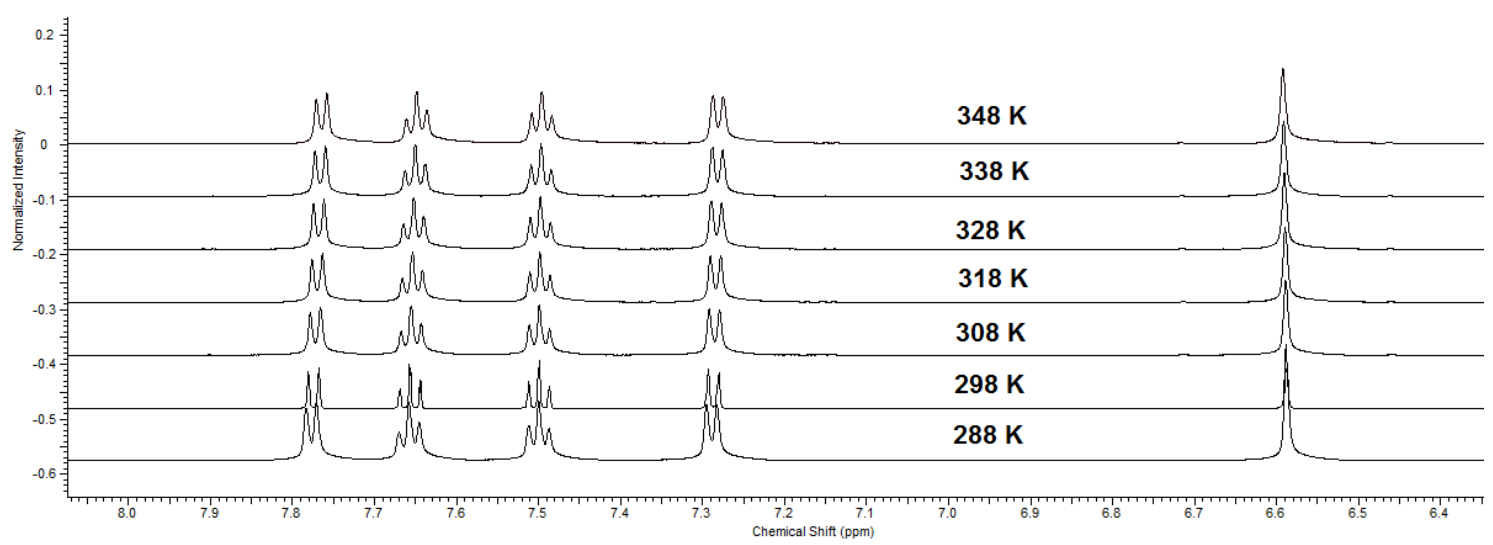

Figura 1.20: Espectros de ${ }^{1} \mathrm{H}-\mathrm{RMN}$ do composto 1 em DMSO- $d_{6}$ a diferentes temperaturas. Expansão da região de 6,4 a 8,0 ppm. É observado o hidrogênio 3 próximo a 6,59 ppm.

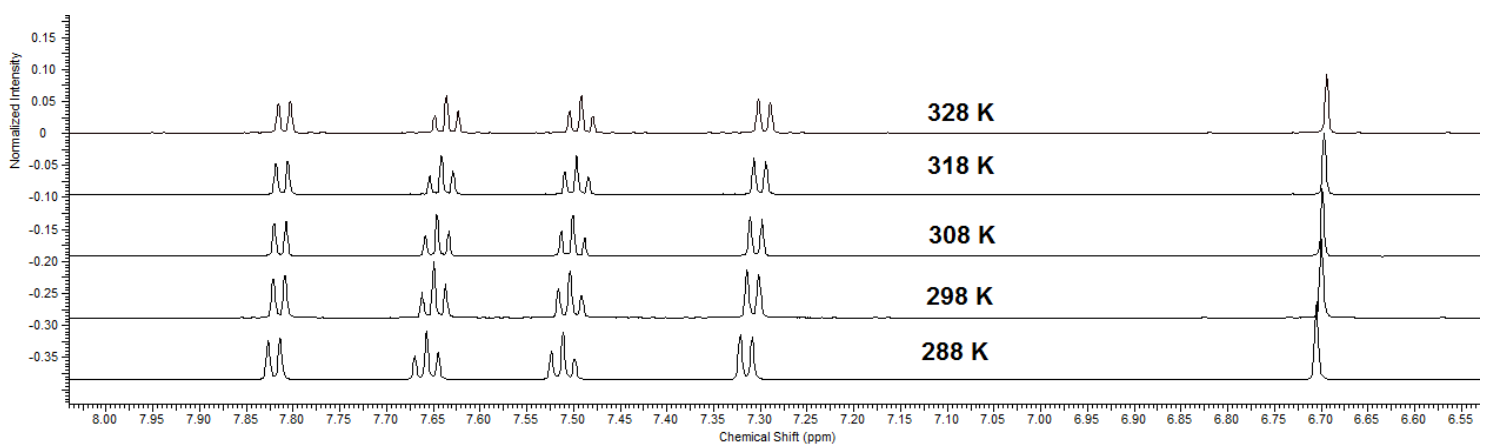

Figura 1.21: Espectros de ${ }^{1} \mathrm{H}-\mathrm{RMN}$ do composto 1 em metanol- $d_{4}$ a diferentes temperaturas. Expansão da região de 6,35 a 8,00 ppm. É observado o hidrogênio 3 próximo a 6,70 ppm.

Pelos espectros das Figuras 1.19, 1.20 e 1.21, é observado o hidrogênio 3 como um simpleto e integração referente a um único hidrogênio, sendo que tanto a multiplicidade como sua integração não variaram com o aumento da temperatura. Com isso, temos indícios de que o composto 1 apresenta-se na forma ceto-enólica nos três solventes, mesmo em diferentes temperaturas. 
A expansão da região alifática dos espectros de ${ }^{1} \mathrm{H}-\mathrm{RMN}$ do composto 1 em acetona, DMSO e metanol, a diferentes temperaturas, pode ser vista nas

Figuras 1.22, 1.23 e 1.24, respectivamente.

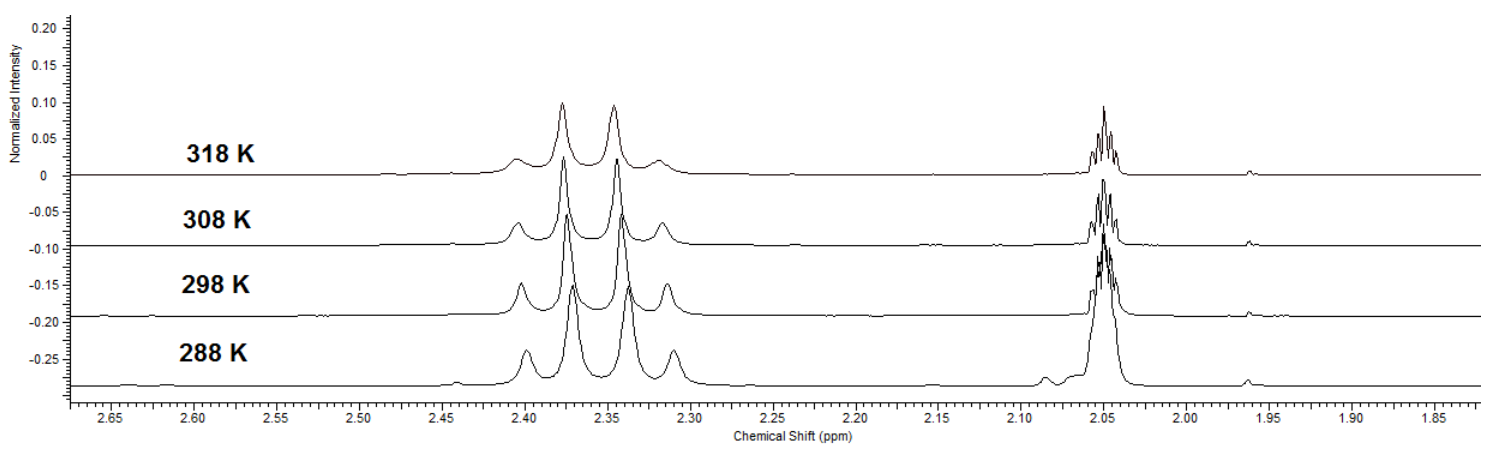

Figura 1.22: Espectros de ${ }^{1} \mathrm{H}-\mathrm{RMN}$ do composto 1 em acetona- $d_{6}$ a diferentes temperaturas. Expansão da região alifática. São observados os hidrogênios 3' e 5' próximos a 2,35ppm.

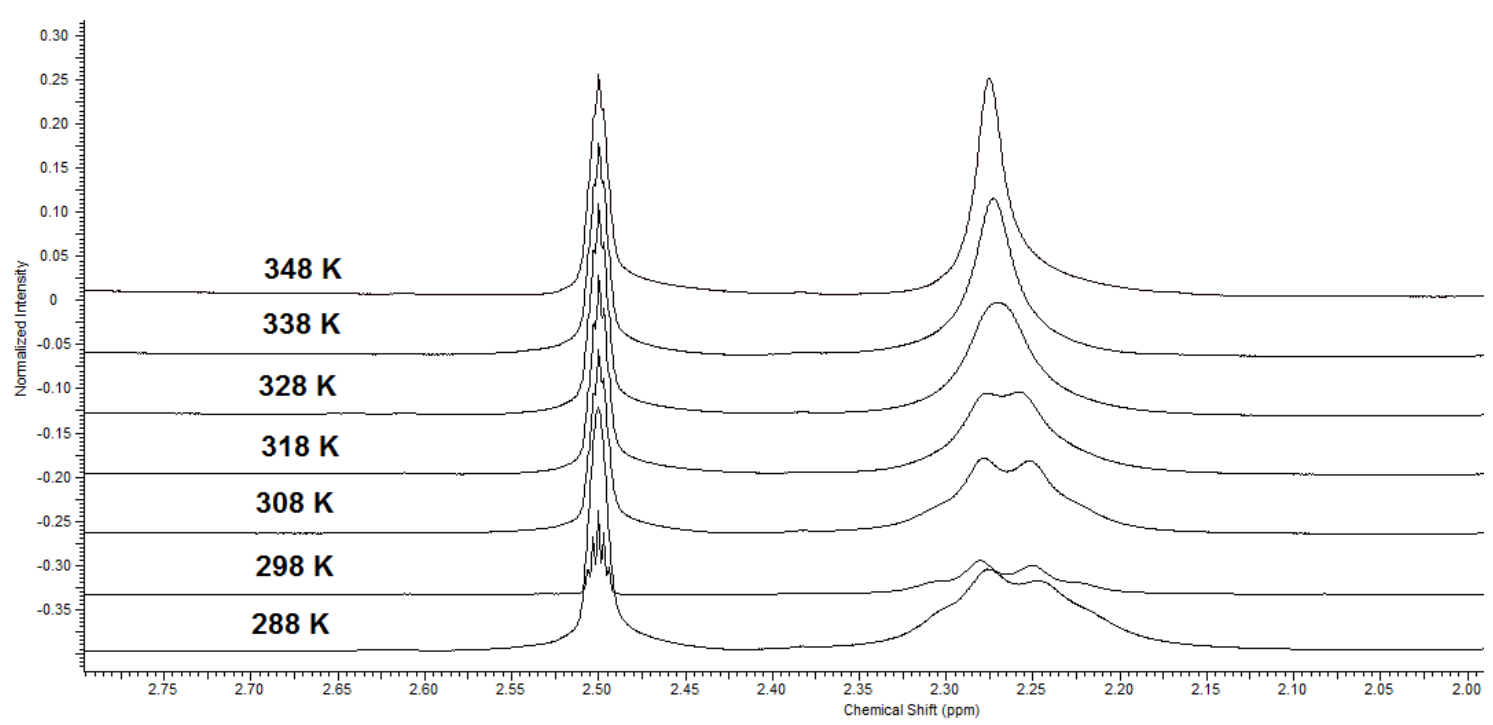

Figura 1.23: Espectros de ${ }^{1} \mathrm{H}-\mathrm{RMN}$ do composto 1 em DMSO- $d_{6}$ a diferentes temperaturas. Expansão da região alifática. São observados os hidrogênios 3' e 5' próximos a 2,27 ppm.

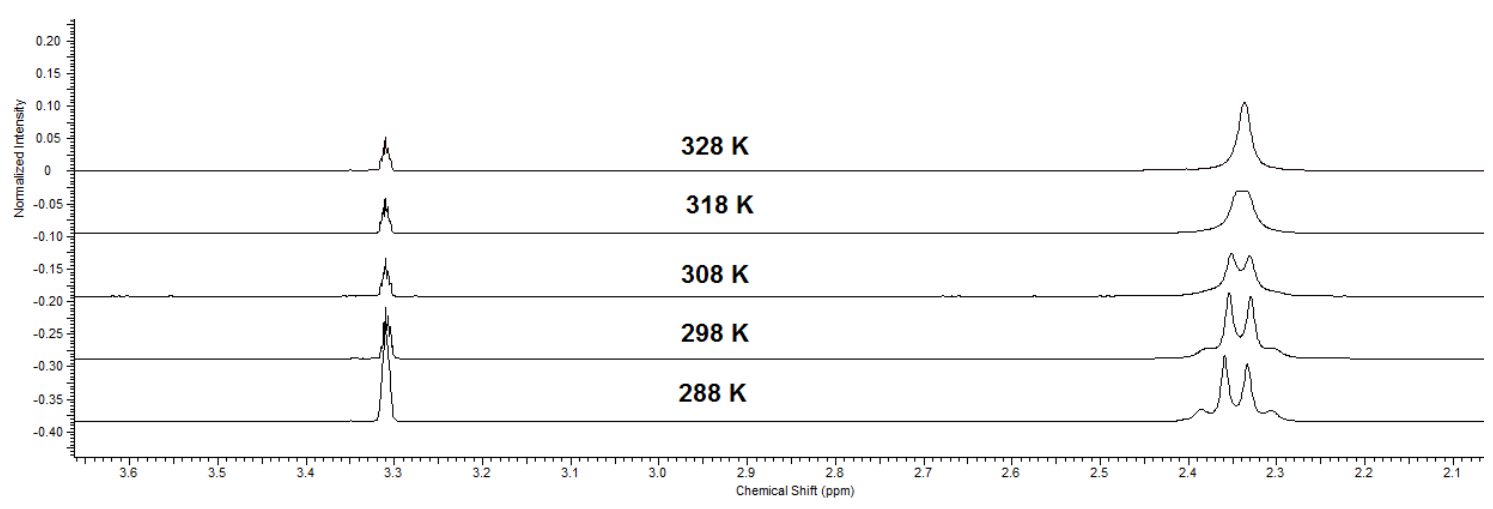

Figura 1.24: Espectros de ${ }^{1} \mathrm{H}-\mathrm{RMN}$ do composto 1 em metanol- $d_{4}$ a diferentes temperaturas. Expansão da região alifática. São observados os hidrogênios 3' e 5' próximos a 2,34ppm. 
Pelos espectros nas Figuras 1.22, 1.23 e 1.24, não se observa o sinal referente ao hidrogênio 1'. Com isso, pode-se concluir que o composto 1 apresenta-se na forma ceto-enólica nos três solventes, mesmo em diferentes temperaturas.

Observou-se também uma mudança na multiplicidade dos sinais referentes aos hidrogênios 3' e 5' com o aumento da temperatura. Em temperaturas mais baixas os hidrogênios 3' acoplam entre si, uma vez que são diasterotópicos devido ao centro quiral no carbono 3; o mesmo ocorre com os hidrogênios 5'. Ou seja, o sinal resultante são dois dupletos. Um aumento da temperatura favorece a rotação na ligação C3-C1' (Figura 1.25), o que faz com que os hidrogênios 3' e 5' passem aos poucos de um regime de troca lenta para um regime de troca rápida $e$, como consequência, todos experimentam pouco a pouco o mesmo ambiente magnético. Assim, quanto maior a temperatura, maior também a tendência destes sinais em se apresentarem como um único sinal (simpleto). Isso é observado nos três solventes estudados. A Figura 1.26 (Bain, 2003) mostra um exemplo da influência da temperatura na multiplicidade de dois hidrogênios. A temperaturas mais baixas são observados dois sinais, pois estão em regime de troca lenta. À medida que a temperatura aumenta os sinais se aproximam até que haja a coalescência dos sinais (regime de troca intermediária) e, posteriormente, um único simpleto (troca rápida).

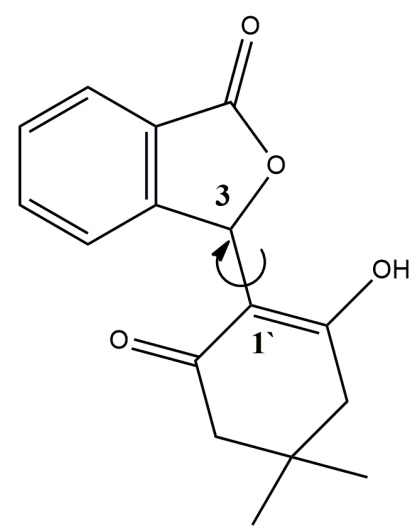

Figura 1.25: Estrutura do composto 1, indicando o favorecimento da rotação da ligação C3-C1' com o aumento da temperatura, fato que pode levar a uma equiparação dos ambientes magnéticos dos hidrogênio 3' e 5'. 


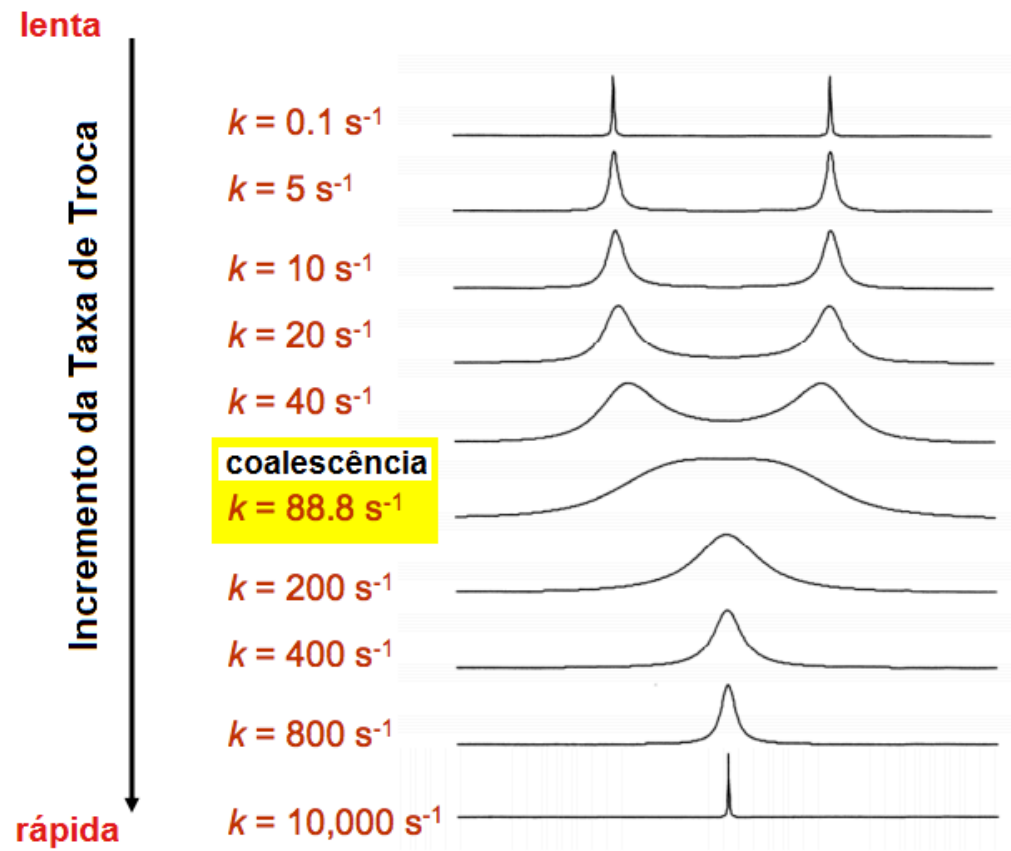

Figura 1.26: Espectros de ${ }^{1} \mathrm{H}-\mathrm{RMN}$ com variação da taxa de troca para os grupos metila da dimetilformamida (DMF). Observa-se a variação na multiplicidade e na largura dos sinais em relação à taxa de troca (figura adaptada do curso Biochemical Applications of NMR Spectroscopy: Chemical Exchange in NMR Spectroscopy, disponível no site http://www.bioc.aecom.yu.edu/labs/girvlab/nmr/course).

Em DMSO a 15 e $25^{\circ} \mathrm{C}$, observa-se um sinal alargado próximo a 11,5 ppm, referente ao hidrogênio $\mathrm{OH}$ envolvido em ligação de hidrogênio (Figura 1.27). Esse mesmo hidrogênio pode ser observado em acetona a 0,5 e $15^{\circ} \mathrm{C}$. (Figura 1.28). Isso confirma a forma ceto-enólica nesses solventes.

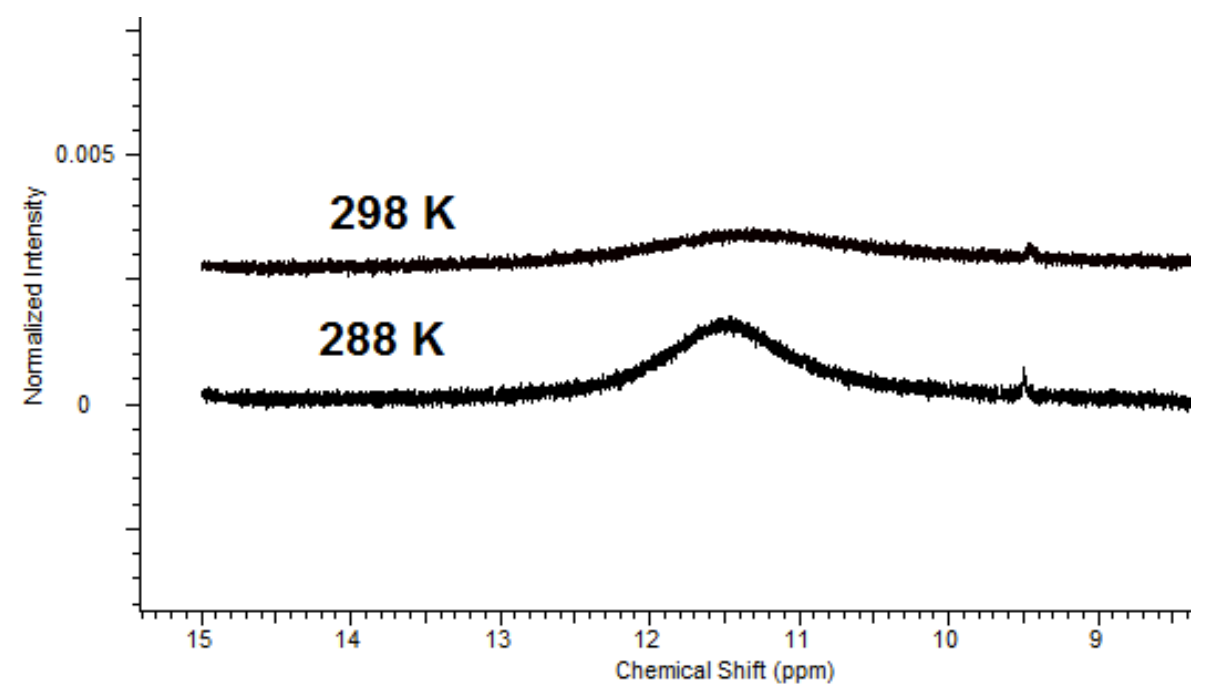

Figura 1.27: Espectros de ${ }^{1} \mathrm{H}-\mathrm{RMN}$ a 15 e $25^{\circ} \mathrm{C}$ do composto 1 , em DMSO- $d_{6}$, com expansão da região de mais alto deslocamento químico. Observa-se o sinal alargado próximo a 11,5 ppm, referente ao hidrogênio 7'. 


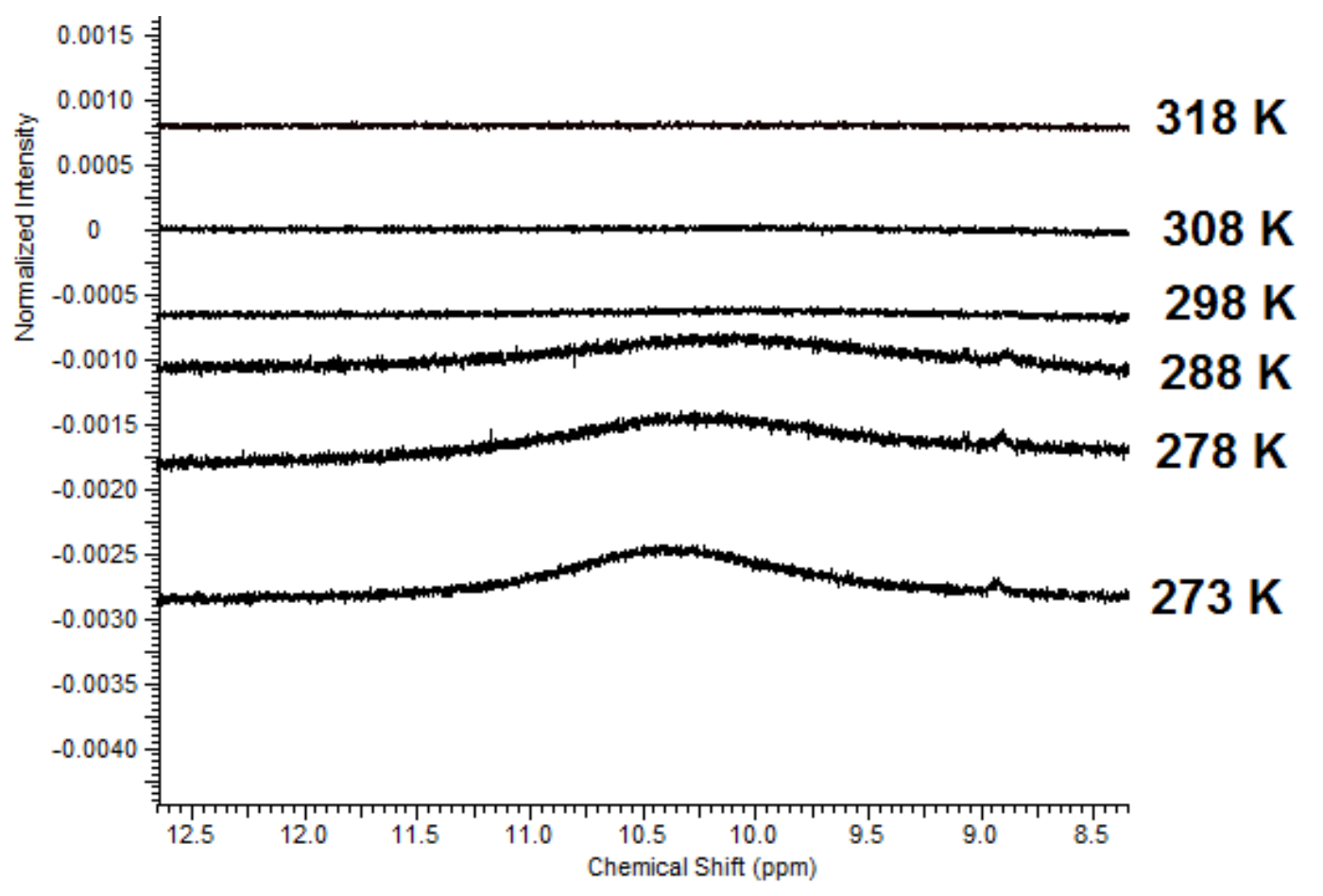

Figura 1.28: Espectros de ${ }^{1} \mathrm{H}-\mathrm{RMN}$ a $0,5,15,25,35$ e $45^{\circ} \mathrm{C}$ do composto 1 , em acetona- $d_{6}$, com expansão da região de mais alto deslocamento químico. Observa-se o sinal alargado próximo a 10,4 ppm, referente ao hidrogênio 7'.

Experimentos de APT também podem ser úteis no estudo do equilíbrio tautomérico ceto-enólico. Este experimento consegue diferenciar os carbonos de grupos $-\mathrm{CH}_{3} \mathrm{e}-\mathrm{CH}$ de $-\mathrm{CH}_{2}$ e $\mathrm{C}$ quaternário. Com isso, pode-se observar os sinais referentes ao carbono $1^{\prime}$, em que um carbono quaternário (sinal positivo) indicaria a presença da forma ceto-enólica e um $-\mathrm{CH}$ (sinal negativo) indicaria uma forma dicetônica.

Os espectros de APT do composto 1 em acetona, DMSO e metanol, a diferentes temperaturas, podem ser vistos nas Figuras 1.29, 1.30 e 1.31, respectivamente. 


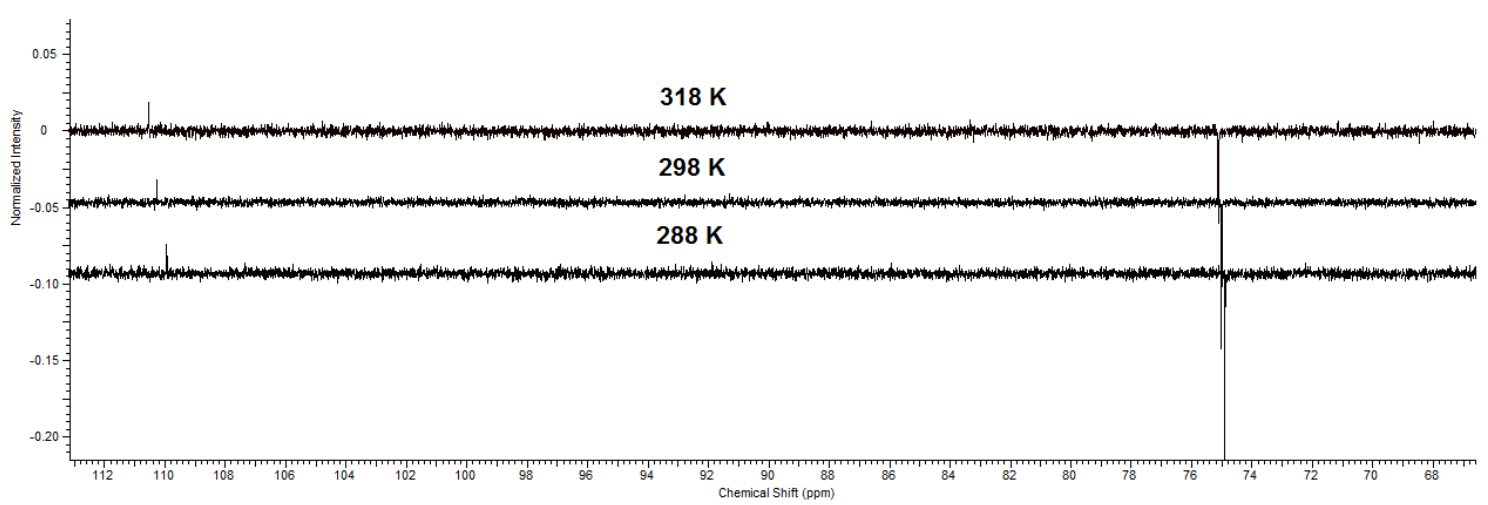

Figura 1.29: Expansão dos espectros de APT do composto 1 em acetona- $d_{6}$, a diferentes temperaturas $\left(15,25\right.$ e $\left.45^{\circ} \mathrm{C}\right)$. É observado o sinal do carbono 1' próximo a 110,3 ppm.

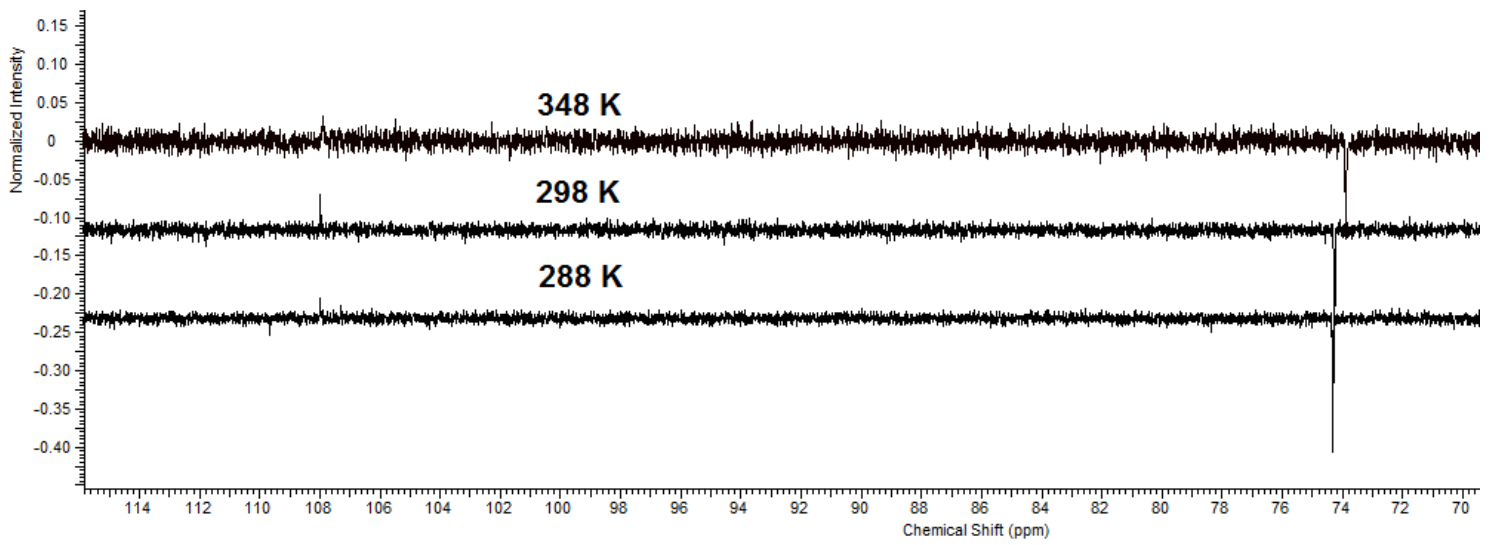

Figura 1.30: Expansão dos espectros de APT do composto 1 em DMSO- $d_{6}$, a diferentes temperaturas $\left(15,25\right.$ e $\left.75^{\circ} \mathrm{C}\right)$. É observado o sinal do carbono 1' próximo a 108,0 ppm.

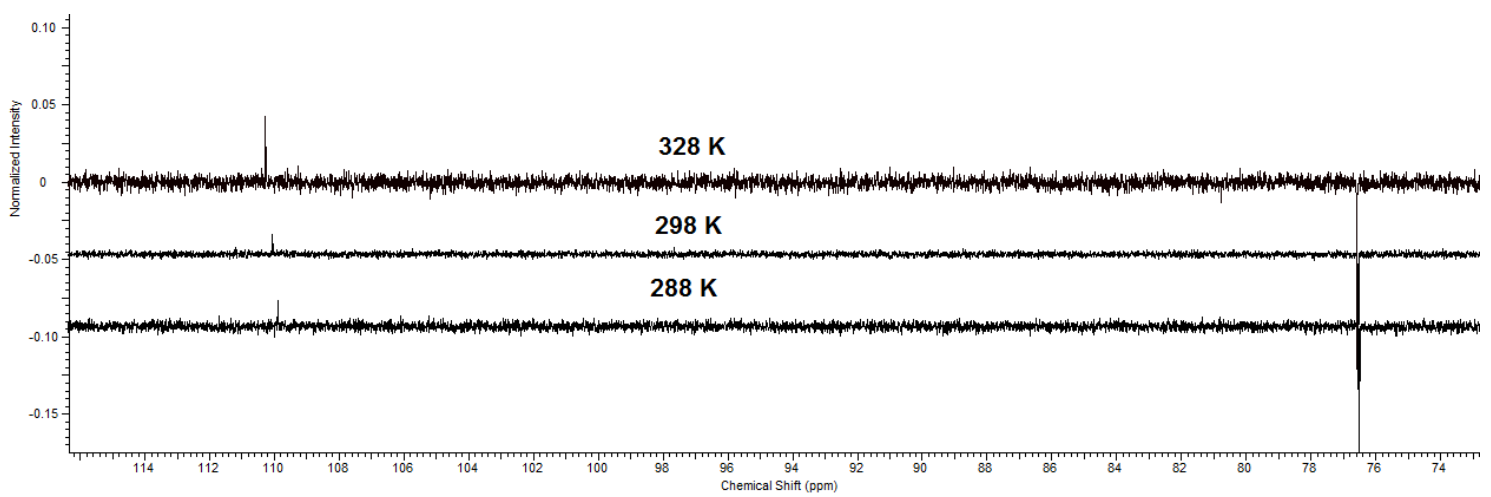

Figura 1.31: Expansão dos espectros de APT do composto 1 em metanol- $d_{4}$, a diferentes temperaturas $\left(15,25\right.$ e $\left.55^{\circ} \mathrm{C}\right)$. É observado o sinal do carbono 1' próximo a 110,1 ppm.

Nota-se que os sinais referentes ao carbono 1' apresentaram um sinal positivo em todos os solventes, indicando um carbono quaternário e uma forma enólica. Observa-se também que este sinal não sofreu variação com o aumento de temperatura, indicando que mesmo a temperaturas mais elevadas a forma ceto-enólica prevalece nos três solventes. 
Os espectros de ${ }^{13} \mathrm{C}-\mathrm{RMN}$ do composto $1 \mathrm{em}$ acetona, DMSO e metanol, a diferentes temperaturas, podem ser vistos nas Figuras 1.32, 1.33 e 1.34, respectivamente (região alifática do espectro).

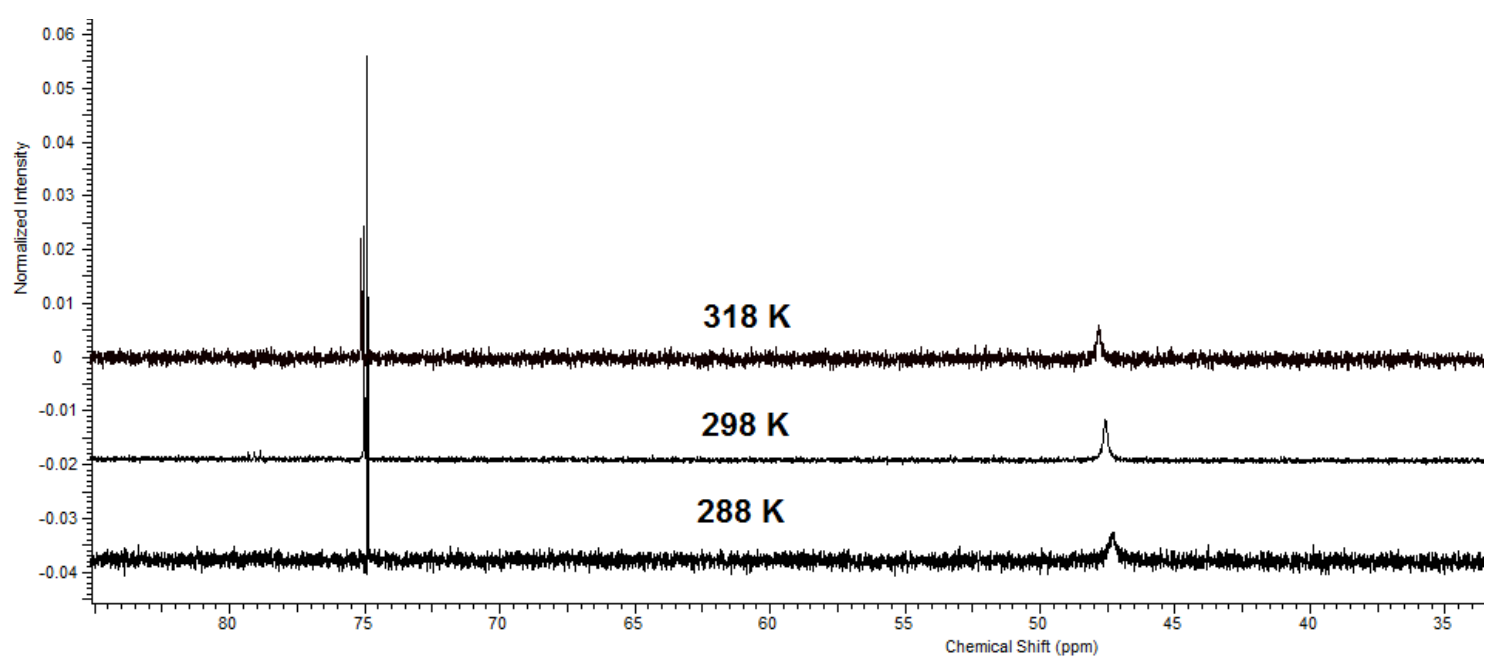

Figura 1.32: Espectros de ${ }^{13} \mathrm{C}-\mathrm{RMN}$ do composto 1 em acetona- $d_{6}$, a diferentes temperaturas $\left(15,25\right.$ e $\left.45^{\circ} \mathrm{C}\right)$. Expansão da região alifática. É observado o sinal referente aos carbonos 3' e 5' próximos a 47,6 ppm.

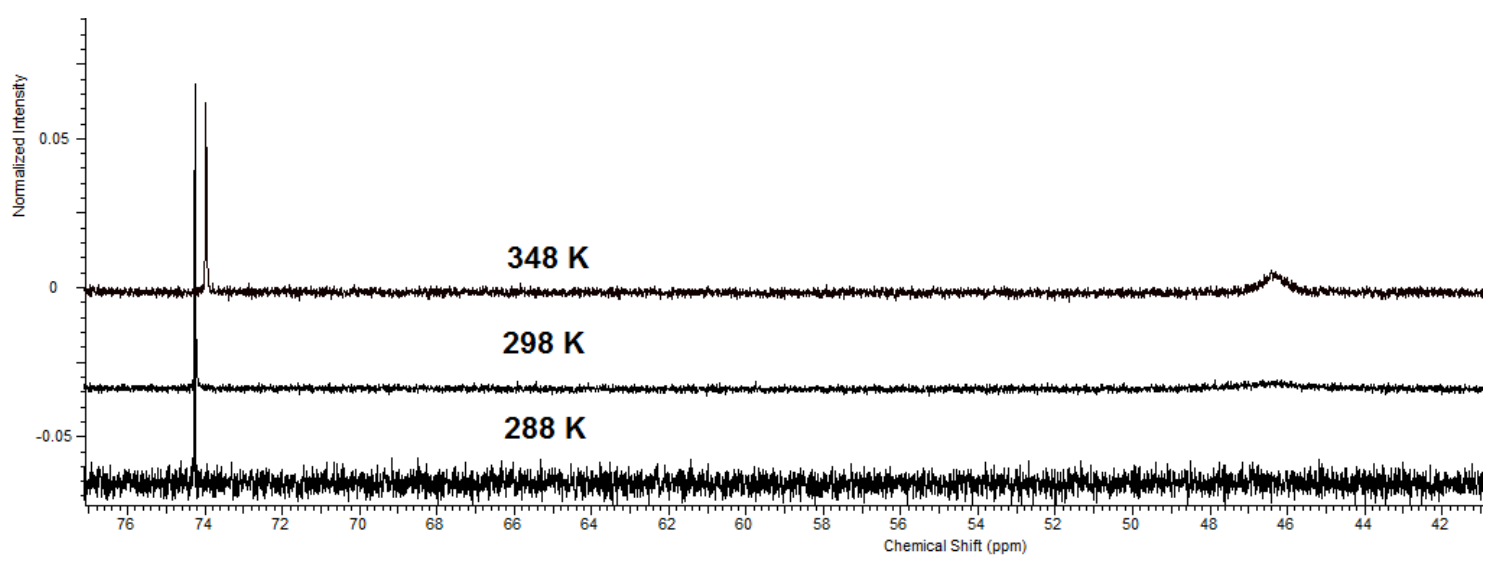

Figura 1.33: Espectros de ${ }^{13} \mathrm{C}-\mathrm{RMN}$ do composto 1 em DMSO- $d_{6}$, a diferentes temperaturas $\left(15,25\right.$ e $\left.75^{\circ} \mathrm{C}\right)$. Expansão da região alifática. É observado o sinal referente aos carbonos $3^{\prime} \mathrm{e}$ 5' próximos a $46,5 \mathrm{ppm}$. 


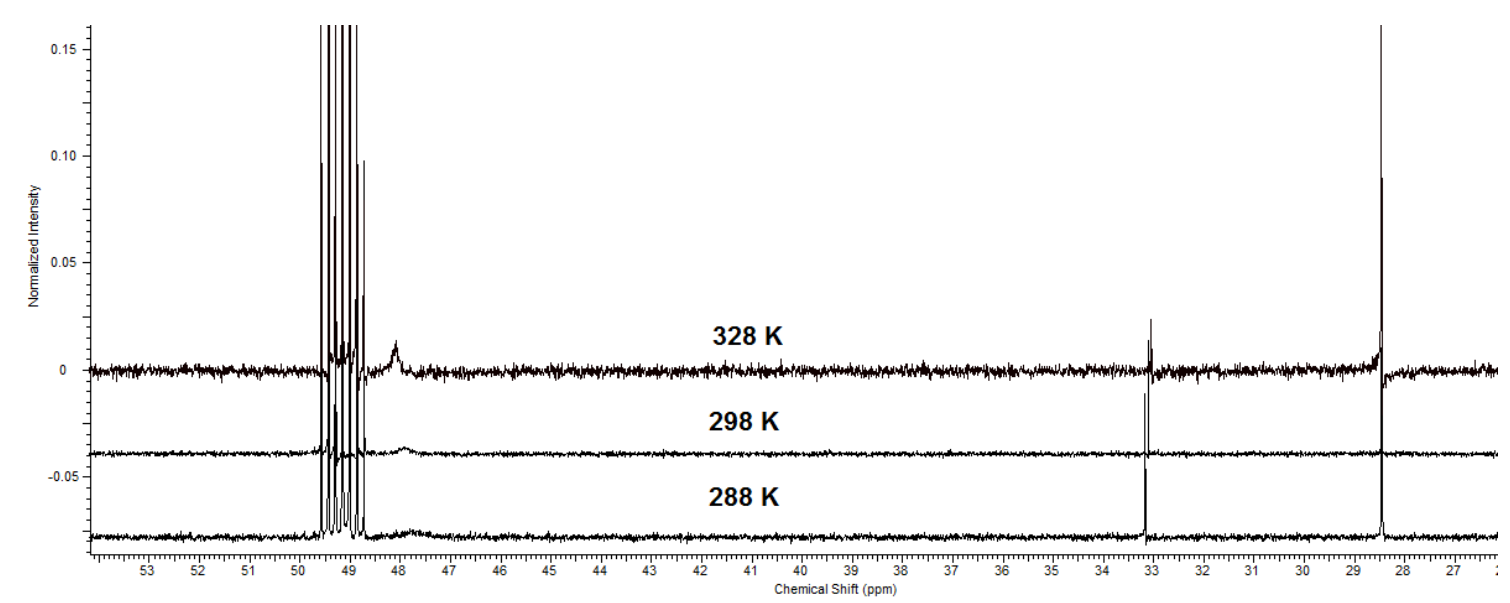

Figura 1.34: Espectros de ${ }^{13} \mathrm{C}-\mathrm{RMN}$ do composto $1 \mathrm{em}$ metanol- $d_{4}$, a diferentes temperaturas $\left(15,25\right.$ e $\left.55^{\circ} \mathrm{C}\right)$. Expansão da região alifática. É observado o sinal referente aos carbonos $3^{\prime}$ e 5' próximos a $47,9 \mathrm{ppm}$.

O sinal referente aos carbonos 3' e 5' apresenta um maior alargamento do que os outros sinais observados nos espectros de carbono deste composto, mostrando-se mais estreito em temperaturas mais elevadas. Isso ocorre pelo mesmo motivo anteriormente explicado para os hidrogênios 3' e 5', com a diferença de que nas temperaturas estudadas não foi possível observar os sinais separados para os dois carbonos (Figura 1.26).

Para os compostos 2,3 e 4 , foram notados os mesmos resultados e fenômenos observados para o composto 1. Com isso, os compostos 2, 3 e 4 também foram caraterizados na forma ceto-enólica pelos experimentos de ${ }^{1} \mathrm{H}$ RMN e APT, e que tanto o solvente como a temperatura não influenciaram nesse equilíbrio tautomérico. A variação de duas metilas no anel de seis membros para uma metila ou nenhuma metila, ou a substituição do anel de seis membros para um anel de cinco membros não alteraram o equilíbrio em estudo. As tabelas com os assinalamentos dos compostos 2, 3 e 4, assim como os espectros de ${ }^{1} \mathrm{H}-\mathrm{RMN},{ }^{13} \mathrm{C}-\mathrm{RMN}$ e APT podem ser vistos nos anexos de 17 a 61 .

O assinalamento dos átomos de hidrogênio e carbono do composto 5 nos diferentes solventes (acetona, DMSO e metanol) pode ser notado na Tabela 1.6. 
Tabela 1.6: Assinalamento dos átomos de hidrogênio e carbono do composto 5 em diferentes solventes: acetona, metanol e DMSO.

\begin{tabular}{|c|c|c|c|c|c|c|}
\hline & \multicolumn{2}{|c|}{ Acetona } & \multicolumn{2}{|c|}{ Metanol } & \multicolumn{2}{|c|}{ DMSO } \\
\hline Átomo & $\mathrm{H}$ & C & $\mathrm{H}$ & C & $\mathrm{H}$ & C \\
\hline 1 & - & 170,0 & - & - & - & 169,3 \\
\hline 3 & 6,24 & 78,0 & - & - & 6,25 & 77,5 \\
\hline 4 & 7,82 & 123,6 & - & - & 7,80 & 122,9 \\
\hline 5 & 7,86 & 126,0 & - & . & 7,85 & 124,9 \\
\hline 6 & 7,66 & 130,4 & - & - & 7,64 & 129,5 \\
\hline 7 & 8,00 & 137,2 & - & - & 8,01 & 136,5 \\
\hline 8 & - & 127,2 & - & - & - & 125,3 \\
\hline 9 & - & 149,0 & - & - & - & 148,0 \\
\hline 1 ' & 4,23 & 55,8 & - & - & 4,48 & 55,1 \\
\hline 2' & - & 196,2 & - & - & - & 195,7 \\
\hline 3 & 7,90 & 123,9 & - & - & 7,89 & 123,0 \\
\hline $4 '$ & 7,99 & 137,2 & - & - & 8,00 & 136,6 \\
\hline 5 & 7,82 & 135,2 & - & - & 7,81 & 134,5 \\
\hline 6' & 8,03 & 124,0 & - & - & 8,05 & 123,2 \\
\hline $7^{\prime}$ & - & 197,7 & - & - & - & 197,1 \\
\hline $8^{\prime}$ & - & 143,4 & - & - & - & 141,8 \\
\hline 9' & - & 143,8 & - & - & - & 142,2 \\
\hline
\end{tabular}

O composto 5 se apresentou praticamente insolúvel em metanol, o que inviabilizou a realização dos experimentos de RMN nesse solvente.

A expansão da região não-aromática dos espectros de ${ }^{1} \mathrm{H}-\mathrm{RMN}$ do composto 5 em acetona e DMSO, a diferentes temperaturas, pode ser vista nas Figuras 1.35 e 1.36, respectivamente. 


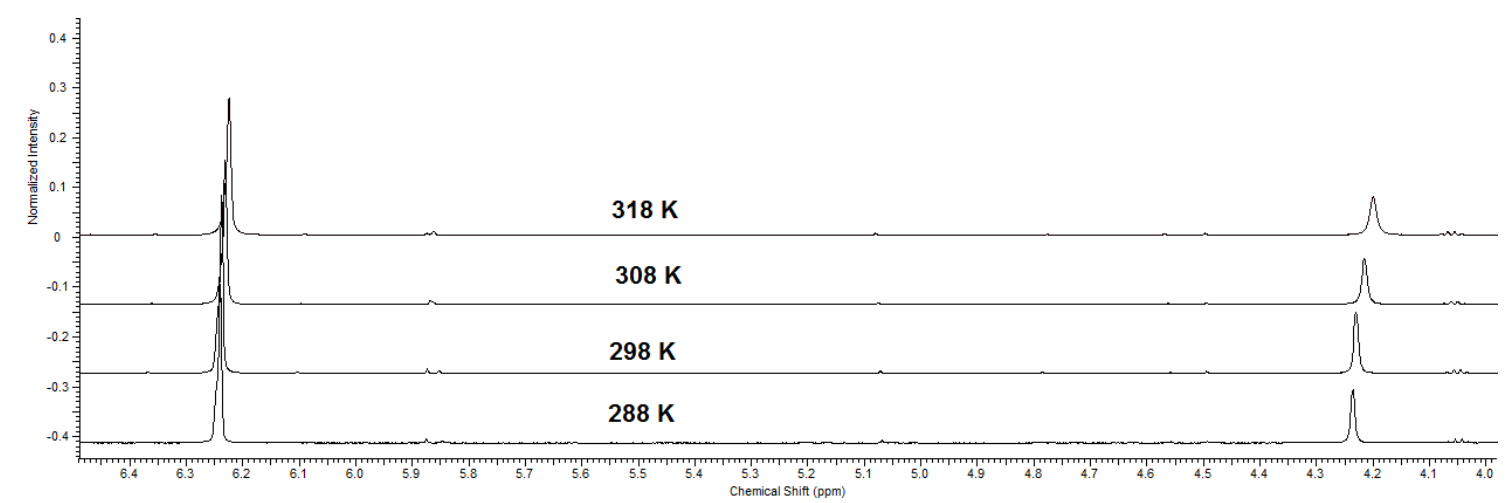

Figura 1.35: Espectros de ${ }^{1} \mathrm{H}-\mathrm{RMN}$ (região não-aromática) do composto 5 em acetona- $d_{6}$, a diferentes temperaturas. São observados o hidrogênio 3 próximo a 6,24 ppm e o hidrogênio 1' próximo a 4,24 ppm.

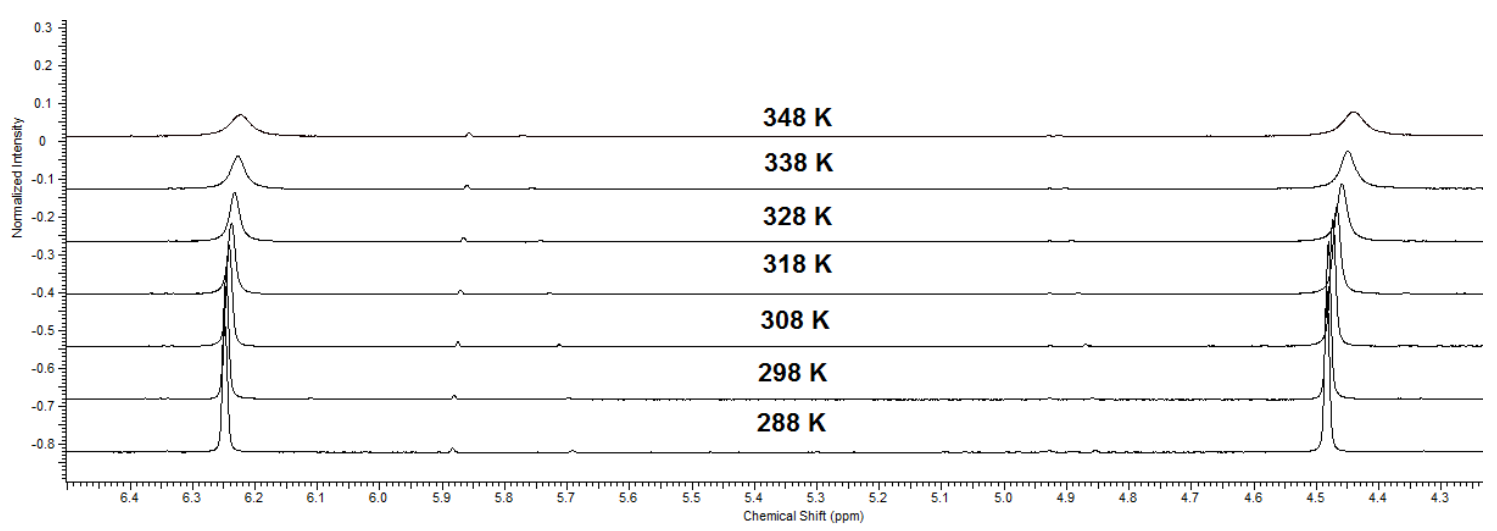

Figura 1.36: Espectros de ${ }^{1} \mathrm{H}-\mathrm{RMN}$ (região não-aromática) do composto 5 em DMSO-d 6 , a diferentes temperaturas. É observado o hidrogênio 3 próximo a 6,25 ppm e o hidrogênio 1' próximo a 4,48 ppm.

Nos espectros das Figuras 1.35 e 1.36, observou-se um sinal para $o$ hidrogênio-3, fato igualmente notado para os outros compostos. Diferentemente dos demais compostos anteriormente analisados, observou-se um sinal referente ao hidrogênio-1', sugerindo a forma dicetônica para o composto 5 tanto em acetona como em DMSO. Tal fato também foi observado em diferentes temperaturas, indicando que a temperatura não influenciou no equilíbrio, sendo a forma dicetônica também observada em temperaturas mais elevadas.

Os espectros de APT do composto 5 em acetona e DMSO, a diferentes temperaturas, podem ser vistos nas Figuras 1.37 e 1.38, respectivamente. 


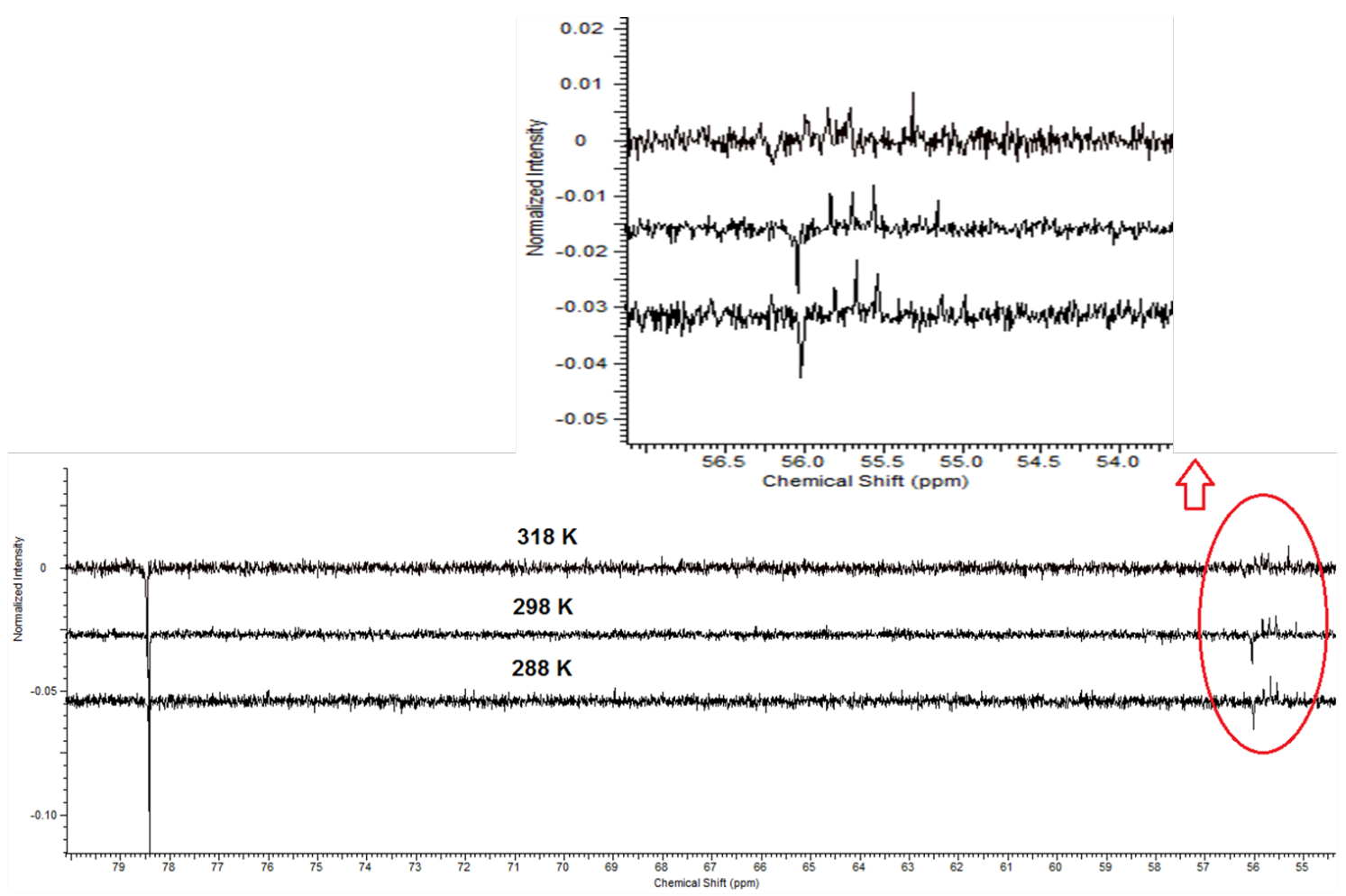

Figura 1.37: Espectros de APT do composto 5 em acetona- $d_{6}$, a diferentes temperaturas (15, 25 e $45^{\circ} \mathrm{C}$ ). É observado o sinal do carbono 1' próximo a 55,8 ppm e do carbono 3 próximo a $78,0 \mathrm{ppm}$.

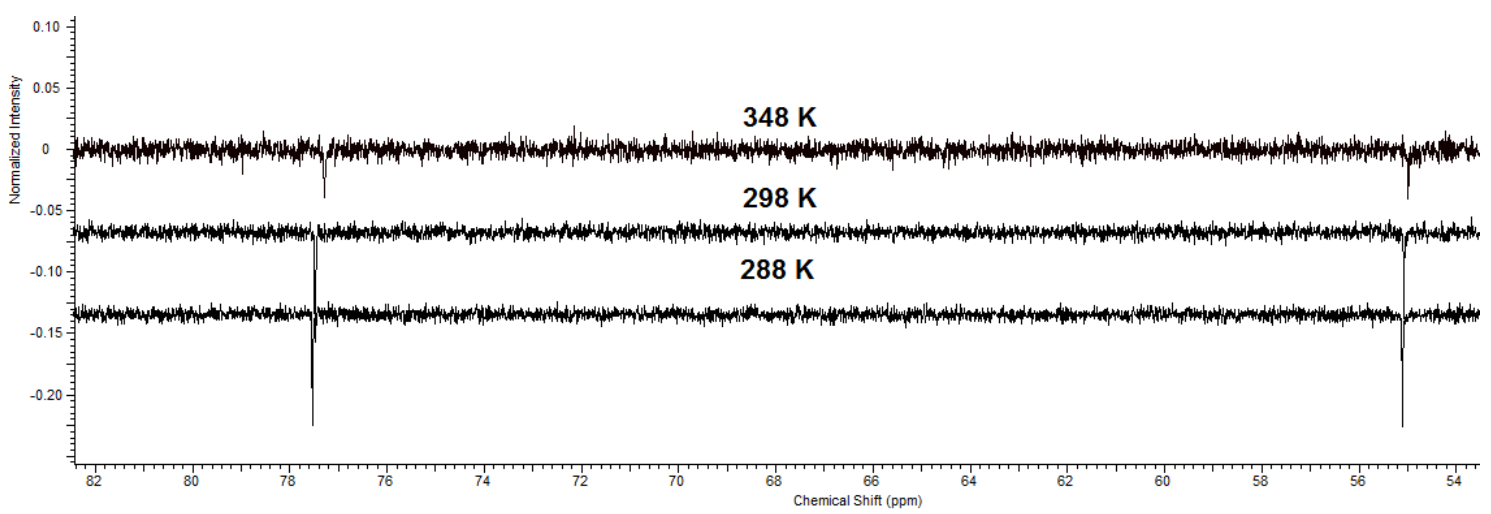

Figura 1.38: Espectros de APT do composto 5, em DMSO- $d_{6}$, a diferentes temperaturas (15, 25 e $75^{\circ} \mathrm{C}$ ). É observado o sinal do carbono 1' próximo a 55,1 ppm e do carbono 3 próximo a 77,5 ppm.

Nota-se que o sinal referente ao carbono 3 apresenta uma orientação negativa, indicando um $-\mathrm{CH}$, e o sinal referente ao carbono 1' apresenta também uma orientação negativa, indicando um $-\mathrm{CH}$, e por consequência, confirmando a forma dicetônica para o composto 5 tanto em acetona como em DMSO.

Os espectros de ${ }^{13} \mathrm{C}-\mathrm{RMN}$ do composto 5 em acetona e DMSO, a diferentes temperaturas, podem ser vistos nas Figuras 1.39 e 1.40 . 


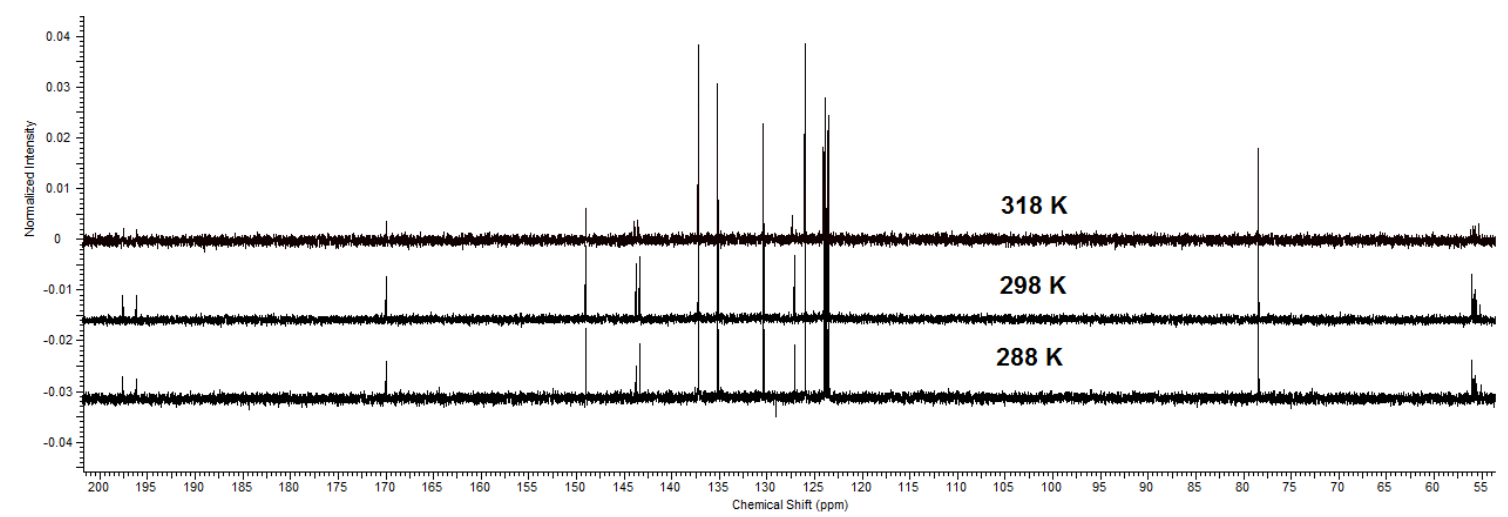

Figura 1.39: Espectros de ${ }^{13} \mathrm{C}-\mathrm{RMN}$ do composto 5 em acetona- $d_{6}$, a diferentes temperaturas $\left(15,25\right.$ e $\left.45^{\circ} \mathrm{C}\right)$. São observados os sinais referentes aos carbonos 2' e 7' próximos a 196,2 e 197,7 ppm, respectivamente.

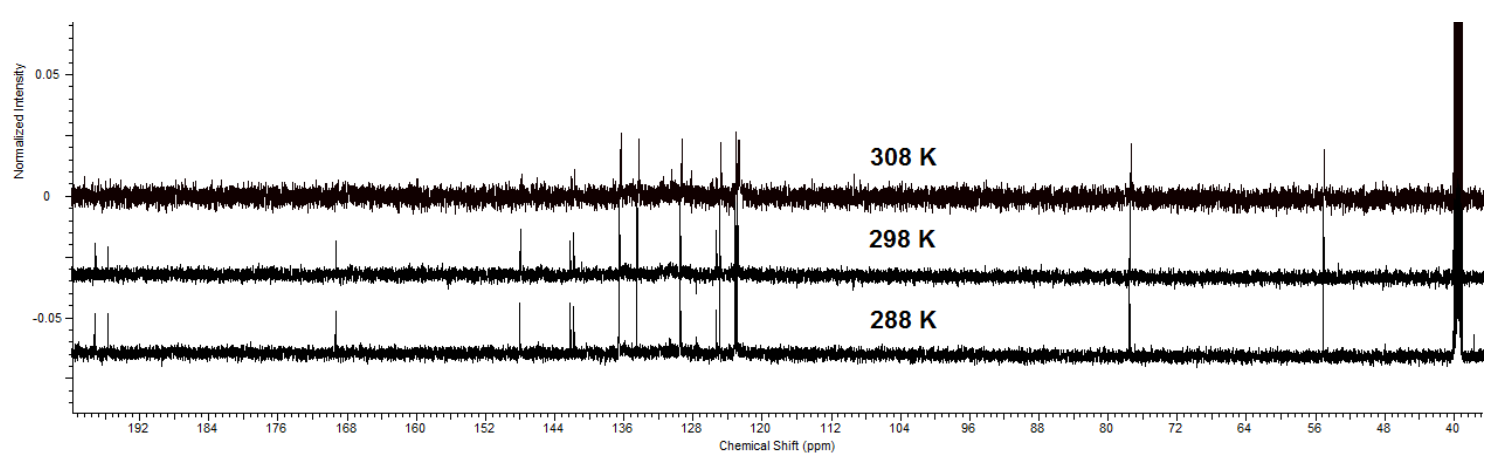

Figura 1.40: Espectros de ${ }^{13} \mathrm{C}-\mathrm{RMN}$ do composto $5 \mathrm{em}$ DMSO- $d_{6}$, a diferentes temperaturas $\left(15,25\right.$ e $\left.75^{\circ} \mathrm{C}\right)$. São observados os sinais referentes aos carbonos 2' e 7' próximos a 195,7 e $197,1 \mathrm{ppm}$, respectivamente.

São observados dois sinais na região de carbonilas, referentes aos carbonos 2' e 7', confirmando a forma dicetônica para o composto 5, tanto em acetona como em DMSO. Este fato também é notado em temperaturas elevadas.

Assim, segundo os resultados apresentados, observou-se que para os compostos 1, 2, 3, 4 e 5 tanto o solvente como a temperatura não influenciaram no equilíbrio tautomérico, estando presente apenas a forma cetoenólica para os quatro primeiros compostos, e a forma dicetônica para o último composto. Além disso, a temperatura também não influenciou o equilíbrio cetoenólico em nenhum dos compostos estudados.

Os compostos 1, 2 e 3 apresentaram unicamente a forma ceto-enólica, indicando que a presença de um ou dois grupos metílicos no anel de seis membros não interferiu nesse equilíbrio. Além disso, observou-se uma coalescência dos carbonos 3' e 5' nesses compostos. Observando os 
compostos 2 e 4, notou-se que a substituição de um anel de seis para cinco membros não interferiu no equilíbrio tautomérico.

Diferentemente dos compostos 1, 23 e 4, o composto 5 apresenta um anel aromático fundido ao anel de cinco membros. Esse anel pode ser 0 responsável pela presença da forma dicetônica, uma vez que nessa forma pode ocorrer uma estabilização por ressonância. Comparando os compostos 4 e 5, notou-se que a presença do anel aromático interferiu no equilíbrio tautomérico, havendo um predomínio da forma dicetônica.

\subsubsection{Estudo do Equilíbrio Tautomérico Ceto-Enólico por Espectrometria de Massa}

Ao realizar espectros de fragmentação (MS/MS), é possível obter informações importantes sobre a estrutura (principalmente dos grupos funcionais) dos compostos estudados. Hidroxilas de álcoois, fenóis e enóis podem ser identificadas pela fragmentação de $18 \mathrm{Da}$, referente à desidratação do grupo $\mathrm{OH}$ na forma $\mathrm{H}_{2} \mathrm{O}$ (Jiang, 2006; Pavia, 2010; Silverstein, 2007). Carbonilas de cetonas podem ser identificadas pela fragmentação de $28 \mathrm{Da}$, referente à perda da carbonila na forma de CO (Jiang, 2006; Pavia, 2010; Silverstein, 2007). Essas duas fragmentações características, dentre as diversas outras fragmentações possíveis, podem auxiliar em uma possível identificação das formas enólicas e cetônicas. Os espectros de fragmentação dos compostos 1, 2, 3, 4 e 5 podem ser vistos nas Figuras 1.41, 1.42, 1.43, 1.44 e 1.45 , respectivamente. 


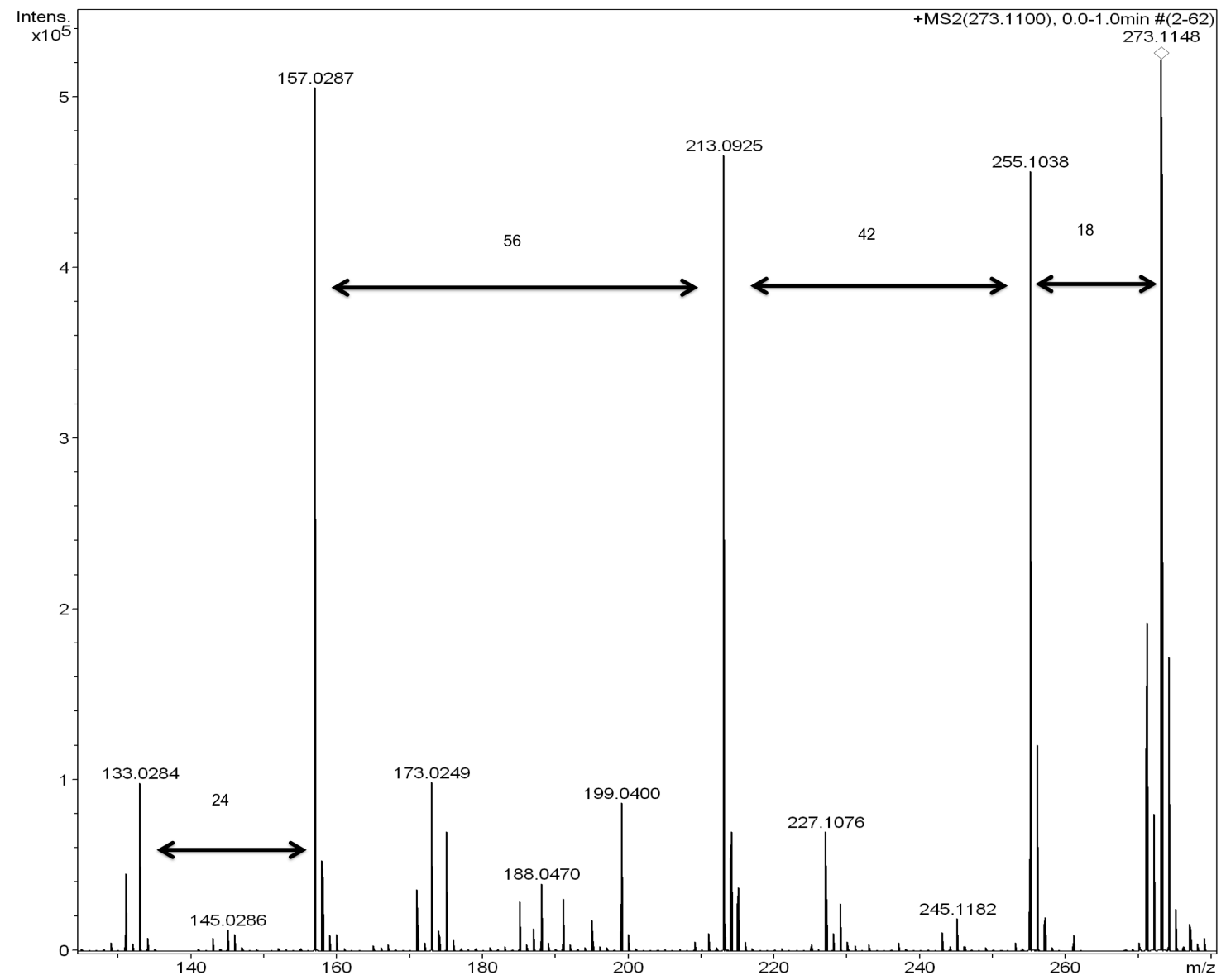

Figura 1.41: Espectros de Fragmentação (MS/MS) do composto 1, em que é observado uma fragmentação de $18 \mathrm{Da}$.. 


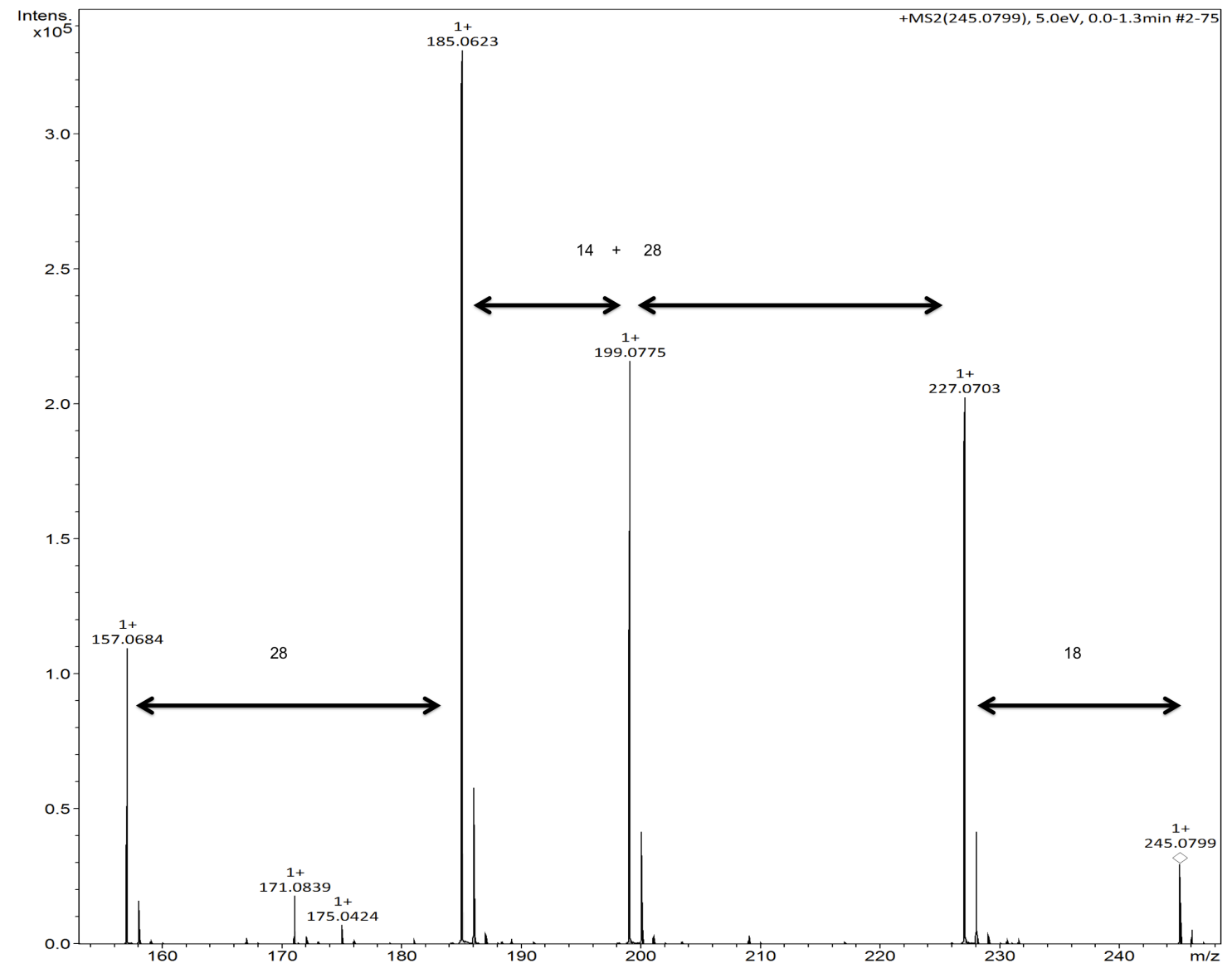

Figura 1.42: Espectros de Fragmentação (MS/MS) do composto 2, em que são observadas fragmentações de 18 e $28 \mathrm{Da}$. 


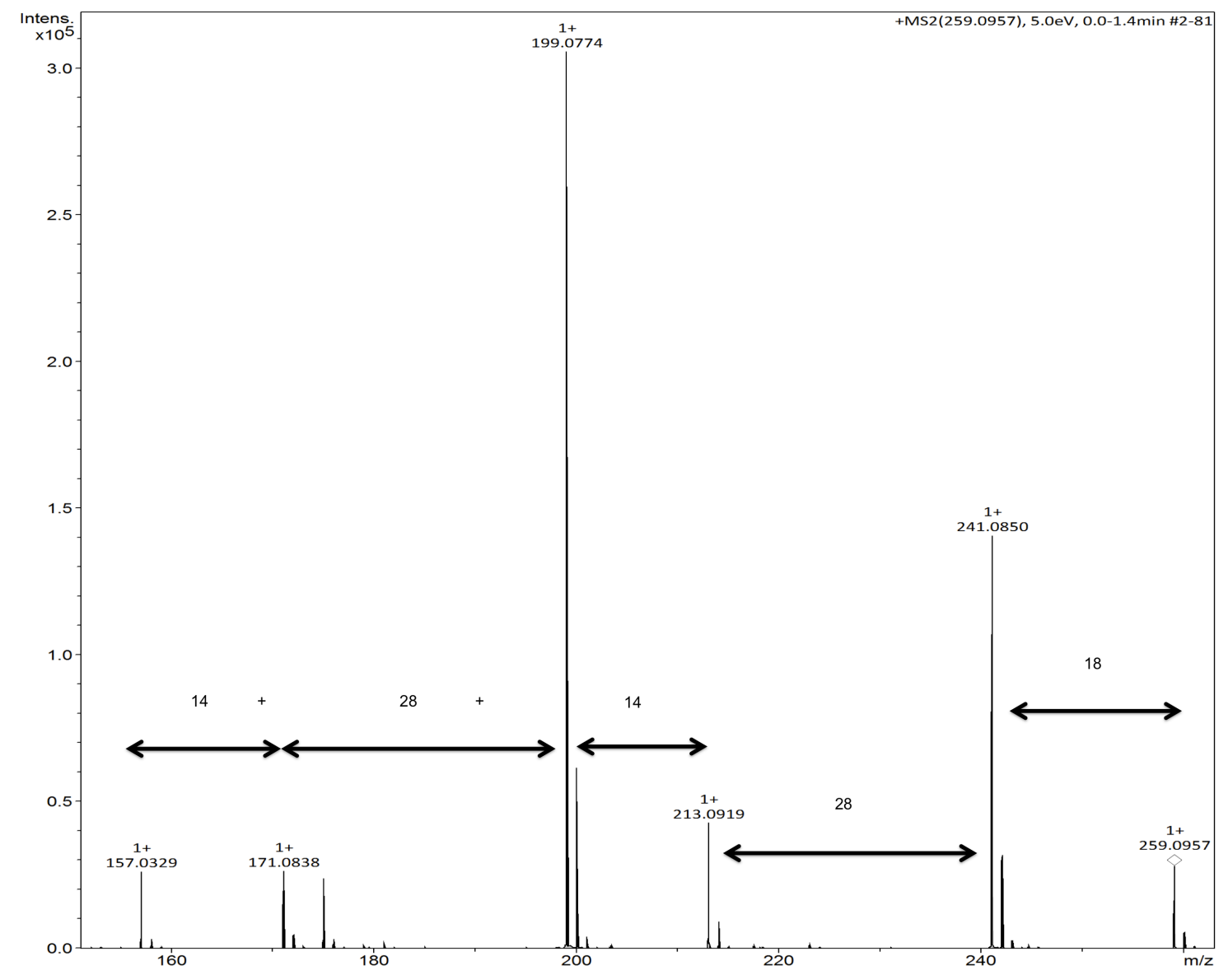

Figura 1.43: Espectros de Fragmentação (MS/MS) do composto 3, em que são observadas fragmentações de 18 e $28 \mathrm{Da}$. 


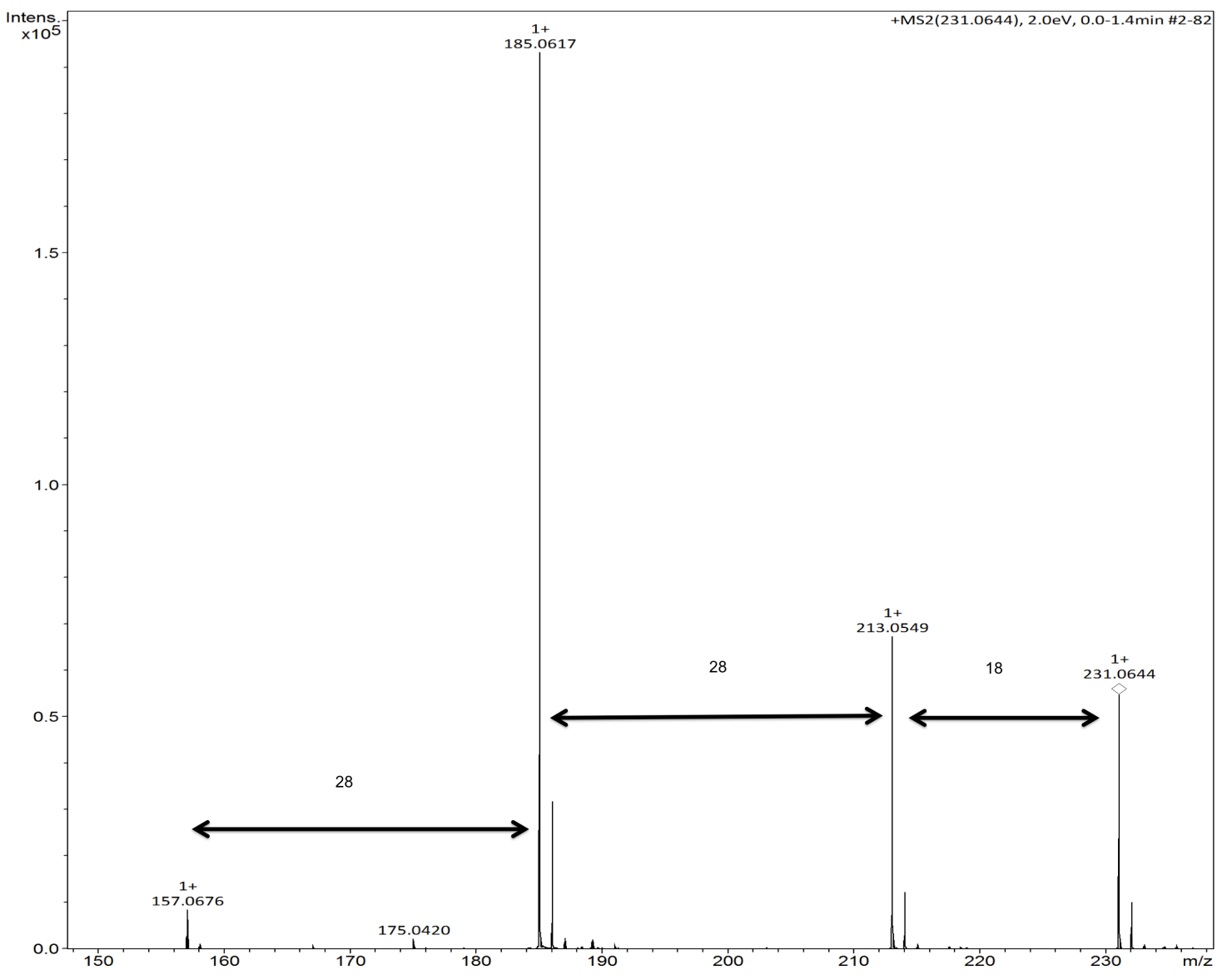

Figura 1.44: Espectros de Fragmentação (MS/MS) do composto 4, em que são observadas fragmentações de 18 e $28 \mathrm{Da}$. 


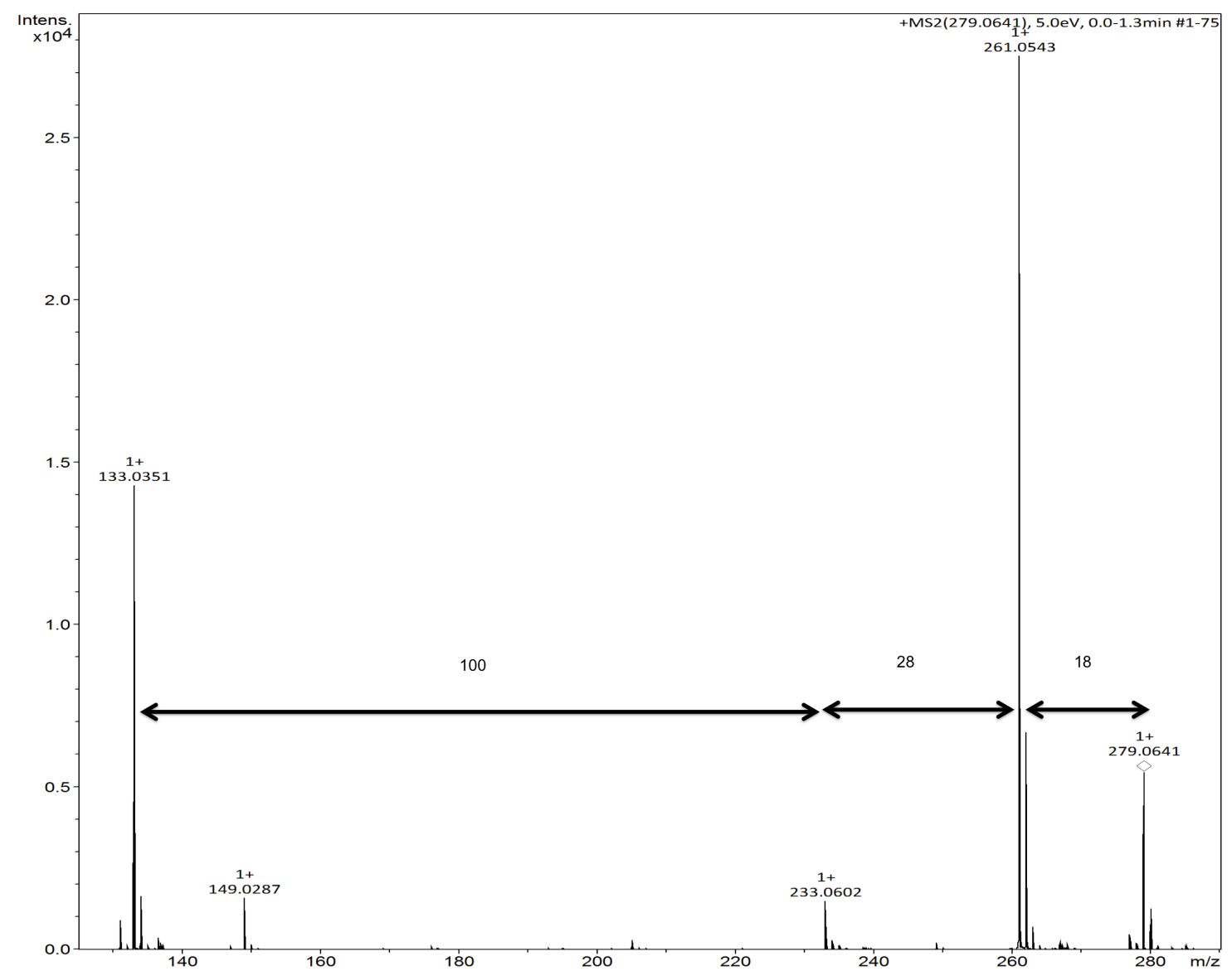

Figura 1.45: Espectros de Fragmentação (MS/MS) do composto 5, em que são observadas fragmentações de 18 e 28 Da.

Notou-se que os cinco compostos apresentaram uma fragmentação de $18 \mathrm{Da}$, referente a uma desidratação, que pode ocorrer devida à presença do grupo $\mathrm{OH}$, o que indicaria a forma ceto-enólica nos cinco compostos. Entretanto, anéis de lactonas de cinco membros apresentam fragmentações características de $18 \mathrm{Da}$ (perda de $\mathrm{H}_{2} \mathrm{O}$ ) e $28 \mathrm{Da}$ (perda de CO) (Crotti, 2004), ambas observadas nas Figuras de 1.41 à 1.45. Com isso, fica inconclusivo identificar a fragmentação de $18 \mathrm{Da}$ observadas nos Espectros de Massa como sendo do possível grupo enol ou do anel de cinco membros da lactona, impossibilitando a caracterização do equilíbrio ceto-enólico, no estado gasoso, por Espectrometria de Massa.

\subsubsection{Estudo do Equilíbrio Tautomérico Ceto-Enólico por Infravermelho}


Os espectros de Infravermelho dos compostos 1, 2, 3, 4 e 5 podem ser vistos nas Figuras 1.46, 1.47, 1.48, 1.49 e 1.50, respectivamente. Hidroxilas podem ser facilmente identificadas pelo estiramento da ligação O-H entre 3300 e $3600 \mathrm{~cm}^{-1}$ e carbonilas pelo estiramento da ligação $\mathrm{C}=\mathrm{O}$, entre 1850 e 1650 $\mathrm{cm}^{-1}$, dentre outros (Pavia, 2010; Silverstein, 2007). Para os compostos 1, 2, 3 e 4 , os espectros apresentaram sinais referentes aos estiramentos das ligações $\mathrm{O}-\mathrm{H}$ e $\mathrm{C}=\mathrm{O}$, caracterizando tais estruturas na forma ceto-enólica. $\mathrm{O}$ espectro referente ao composto 5 apresentou sinais referentes ao estiramento da ligação $\mathrm{C}=\mathrm{O}$, não apresentando sinais referentes ao estiramento $\mathrm{O}-\mathrm{H}$, caracterizando tal estrutura na forma dicetônica.

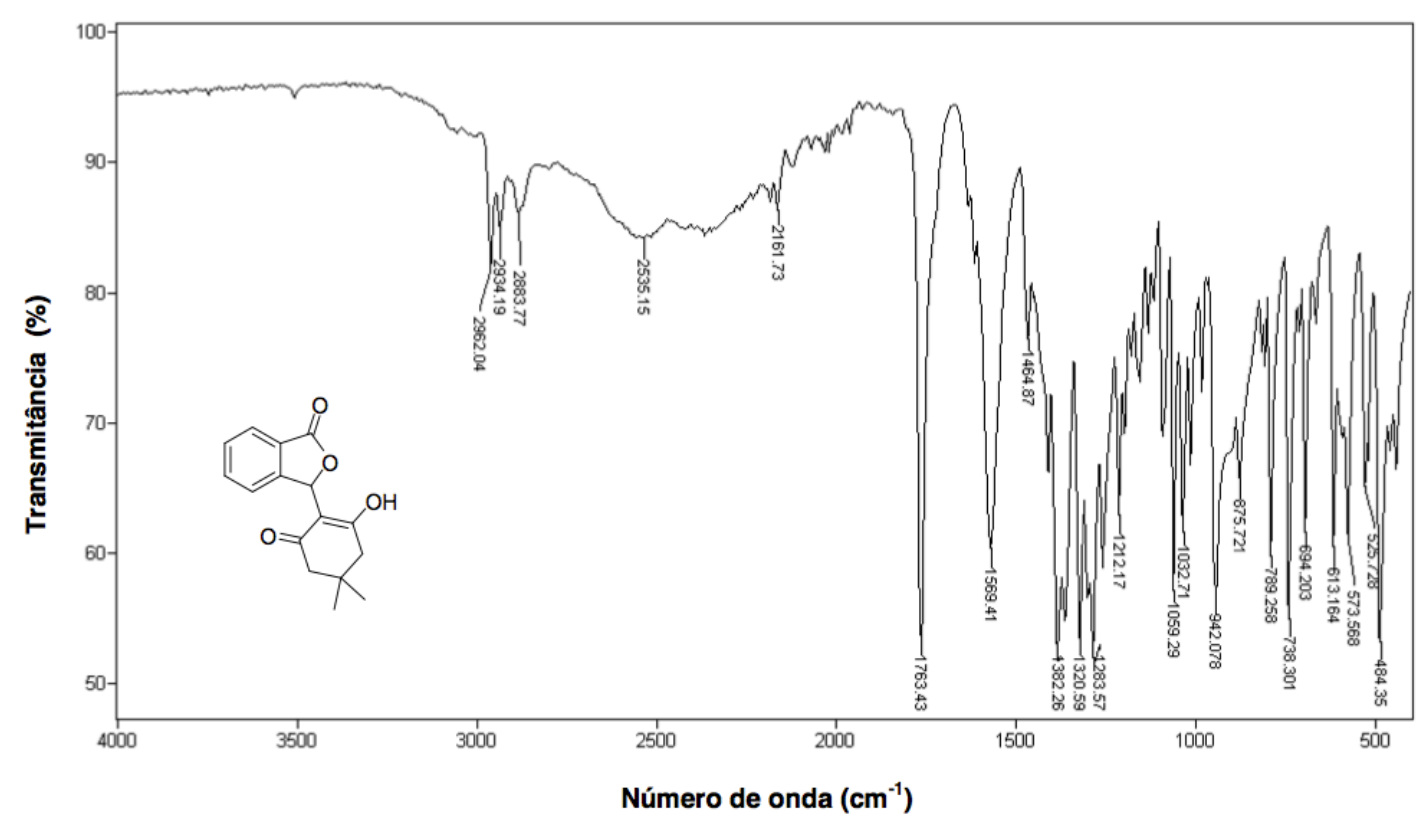

Figura 1.46: Espectro no Infravermelho (ATR) do Composto 1. Banda larga de 3200 a 2400 $\mathrm{cm}^{-1}$ : estiramento $\mathrm{O}-\mathrm{H}$. Sinal em $1763 \mathrm{~cm}^{-1}$ : estiramento $\mathrm{C}=\mathrm{O}$. 


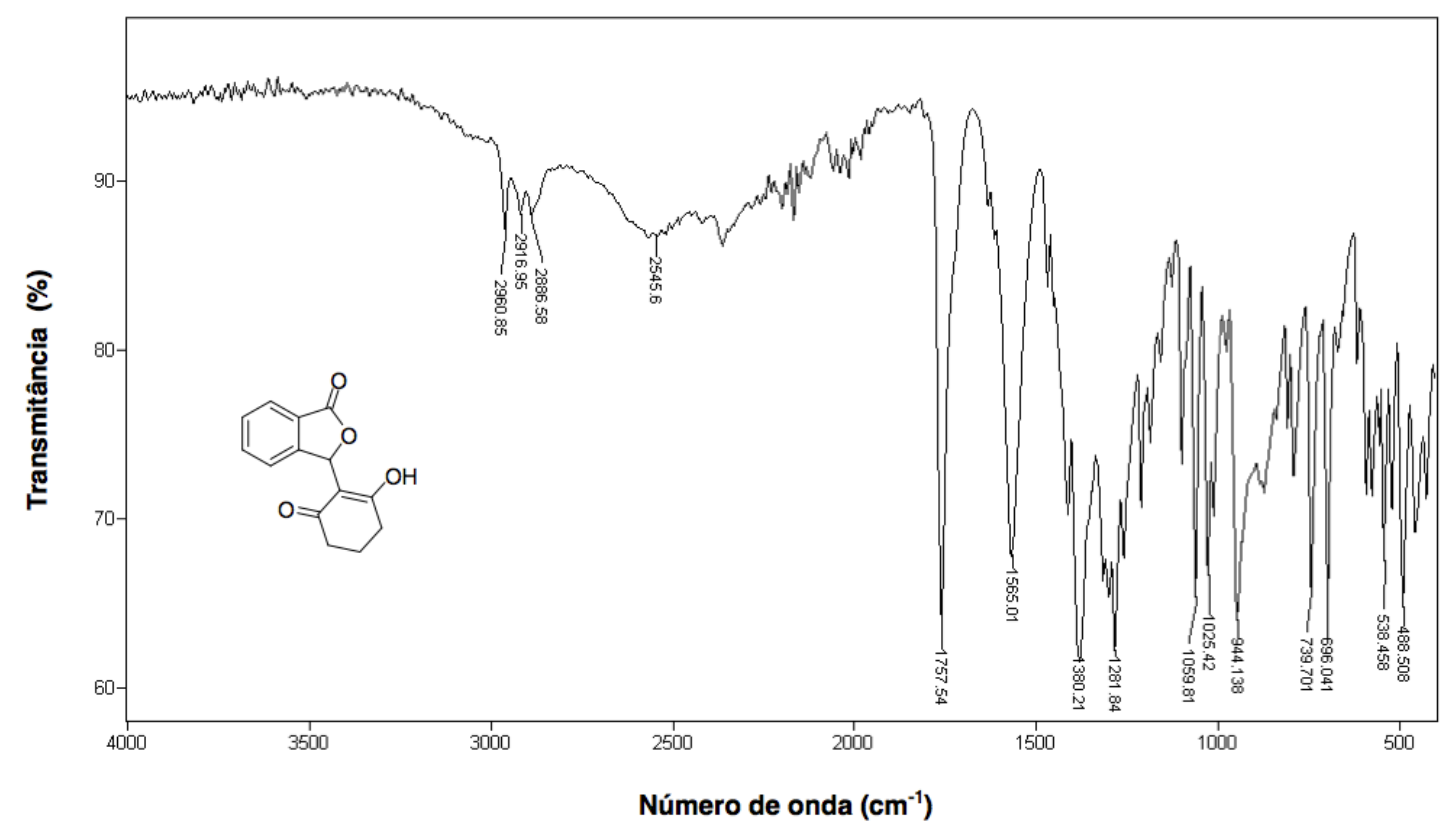

Figura 1.47: Espectro no Infravermelho (ATR) do Composto 2. Banda larga de 3200 a 2000 $\mathrm{cm}^{-1}$ : estiramento O-H. Sinal em $1758 \mathrm{~cm}^{-1}$ : estiramento $C=O$.

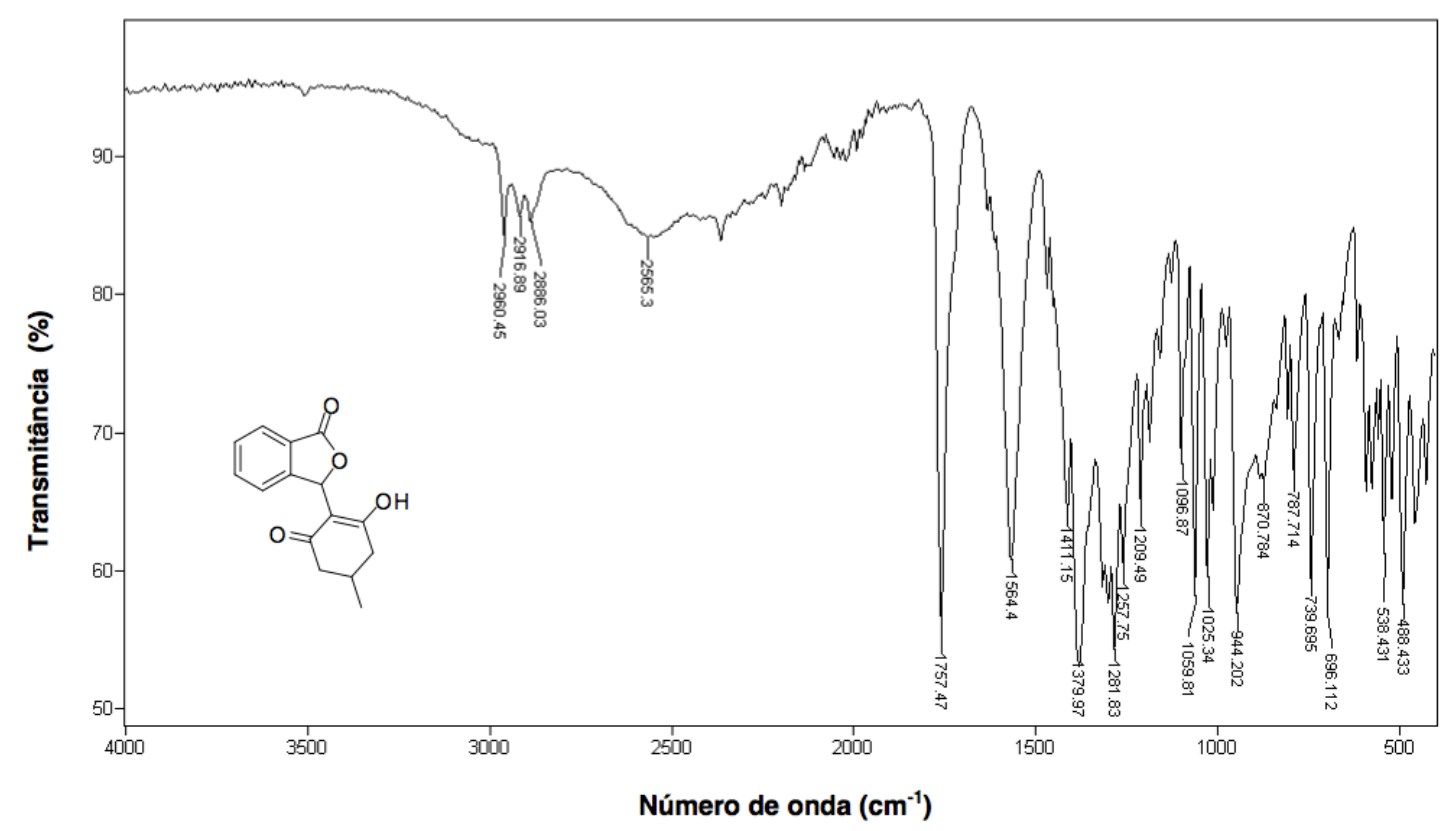

Figura 1.48: Espectro no Infravermelho (ATR) do Composto 3. Banda larga de 3100 a 2050 $\mathrm{cm}^{-1}$ : estiramento O-H. Sinal em $1757 \mathrm{~cm}^{-1}$ : estiramento $\mathrm{C}=\mathrm{O}$. 


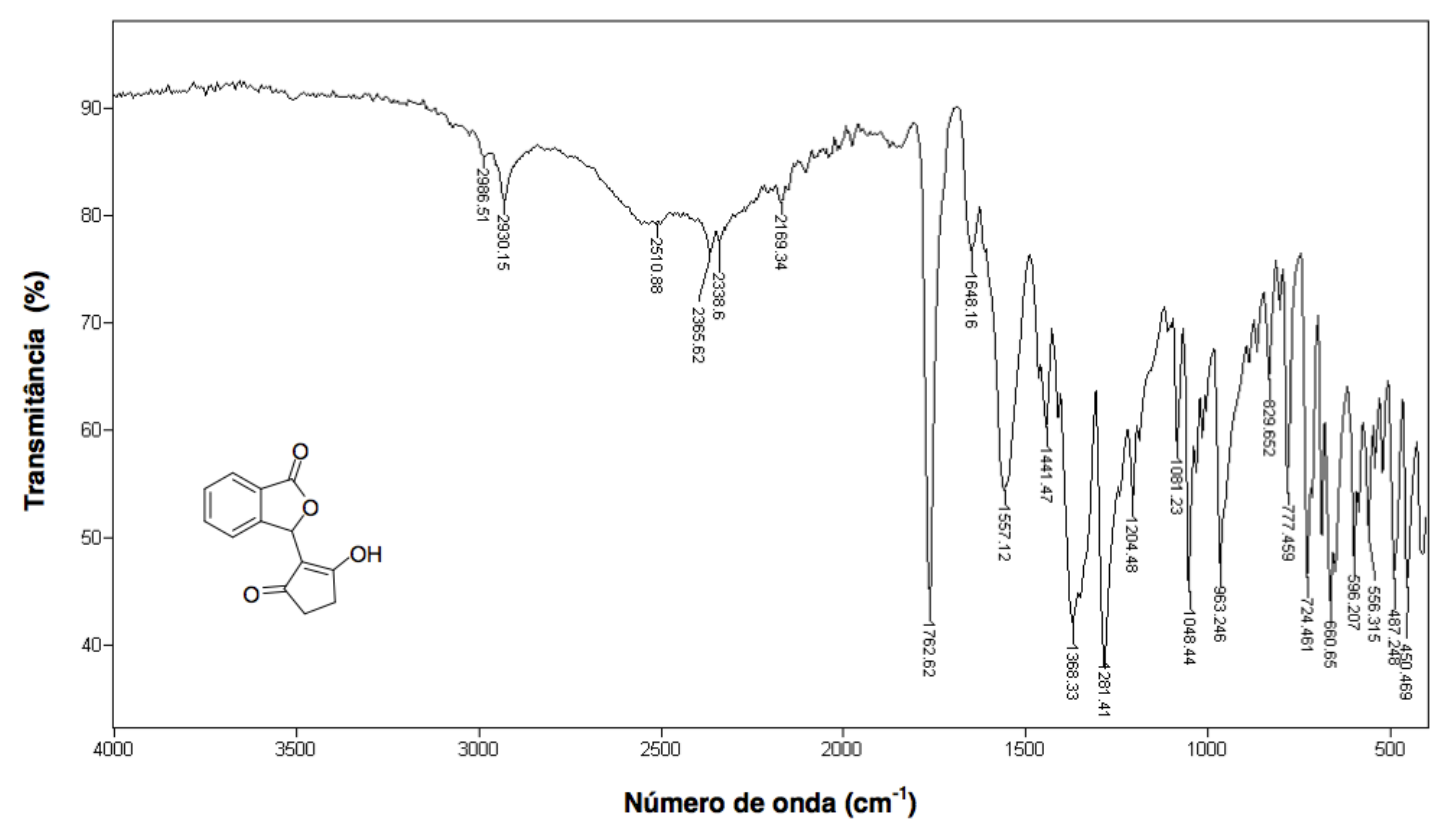

Figura 1.49: Espectro no Infravermelho (ATR) do Composto 4. Banda larga de 3100 a 2050 $\mathrm{cm}^{-1}$ : estiramento O-H. Sinais em $1762 \mathrm{~cm}^{-1}$ : estiramento $\mathrm{C}=\mathrm{O}$.

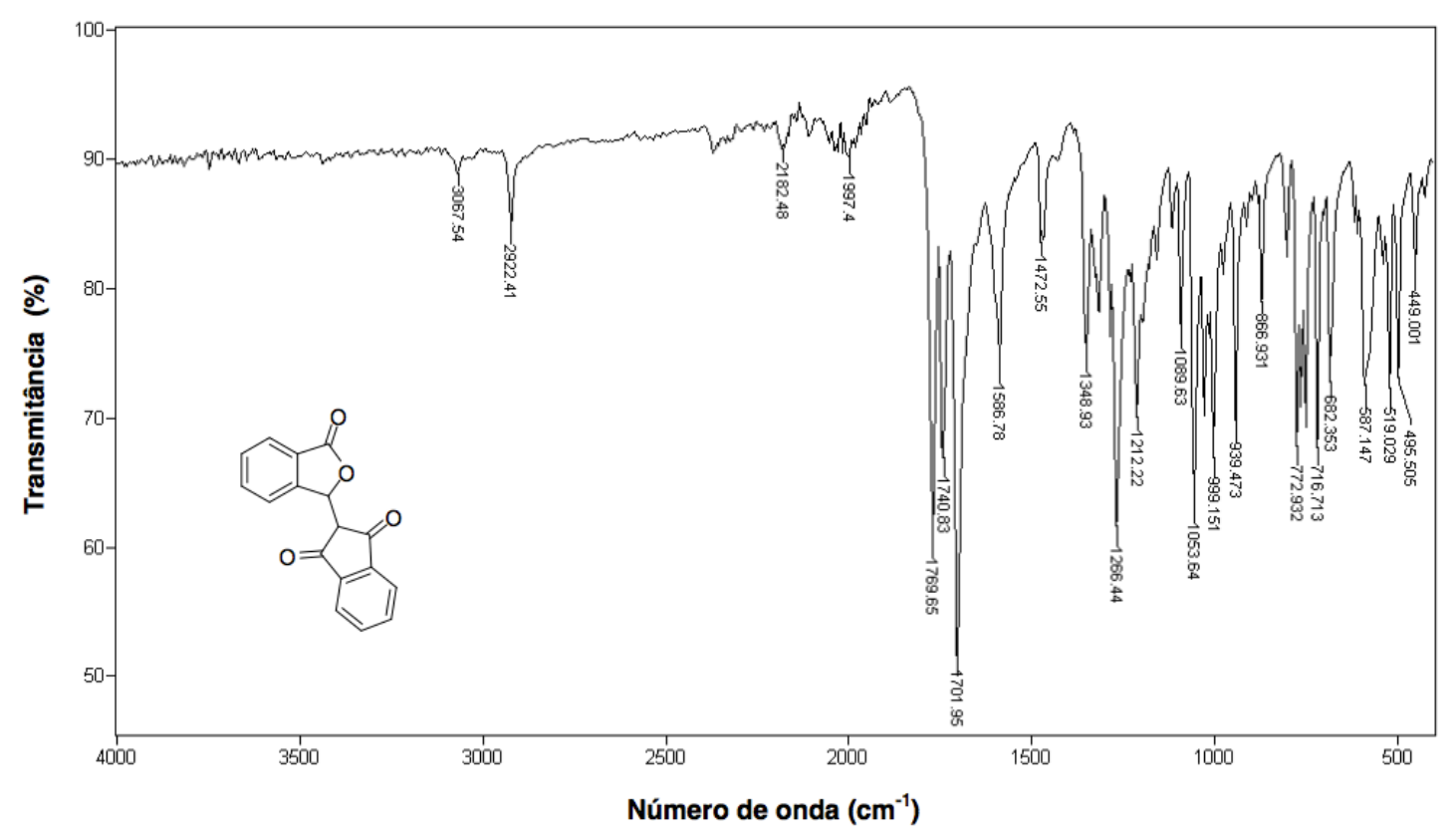

Figura 1.50: Espectro no Infravermelho (ATR) do Composto 5. Sinais em 1769, 1740 e 1702 $\mathrm{cm}^{-1}$ : estiramento $\mathrm{C}=\mathrm{O}$. Não foi observado sinal referente ao estiramento $\mathrm{O}-\mathrm{H}$.

Por Infravermelho, os compostos 1, 2, 3 e 4 apresentaram apenas a forma ceto-enólica no estado sólido, o que vai de acordo com o observado no estado líquido por RMN. O composto 5 apresentou-se na forma dicetônica no estado sólido por Infravermelho, e também no estado líquido, por RMN. O 
estado físico (sólido e líquido) dos compostos 1, 2, 3, 4 e 5 não alterou o equilíbrio tautomérico.

\subsubsection{Estudo do Equilíbrio Tautomérico Ceto-Enólico por Cálculos de Mecânica Quântica}

As energias das formas ceto-enólicas (enol) e dicetônicas (ceto) foram calculadas para os cincos compostos, tanto na ausência como na presença de solvente (acetona, metanol e DMSO). Os resultados da diferença de energia entre as formas ceto-enólica e dicetônica podem ser vistos na Tabela 1.7.

Tabela 1.7: Diferença de energia entre as formas ceto-enólicas (enol) e dicetônicas (ceto) para os cinco compostos calculadas no vácuo, acetona, DMSO e metanol. A energia das formas enólicas foram zeradas e as energias da forma cetônica foram normalizadas em relação à energia da forma enólica.

\begin{tabular}{|c|c|c|c|c|c|}
\hline \multicolumn{2}{|c|}{ Composto } & $\begin{array}{c}\Delta E_{\text {vácuo }} \\
(\mathbf{k J} / \text { mol })\end{array}$ & $\begin{array}{c}\Delta \mathrm{E}_{\text {acetona }} \\
(\mathbf{k J} / \mathbf{m o l})\end{array}$ & $\begin{array}{c}\Delta \mathrm{E}_{\text {DMso }} \\
(\mathbf{k J} / \mathbf{m o l})\end{array}$ & $\begin{array}{c}\Delta \mathrm{E}_{\text {metanol }} \\
(\mathbf{k J} / \mathbf{m o l})\end{array}$ \\
\hline \multirow{2}{*}{1} & Enol & 0 & 0 & 0 & 0 \\
\cline { 2 - 6 } & Ceto & $+14,43$ & $+6,12$ & $+5,19$ & $+7,09$ \\
\hline \multirow{2}{*}{2} & Enol & 0 & 0 & 0 & 0 \\
\cline { 2 - 6 } & Ceto & $+18,13$ & $+2,86$ & $+2,53$ & $+4,58$ \\
\hline \multirow{2}{*}{3} & Enol & 0 & 0 & 0 & 0 \\
\cline { 2 - 6 } & Ceto & $+18,75$ & $+3,71$ & $+3,22$ & $+5,16$ \\
\hline \multirow{2}{*}{4} & Enol & & & & $+24,87$ \\
\cline { 2 - 6 } & Ceto & $+22,56$ & $+24,61$ & $+25,02$ & 0 \\
\hline \multirow{2}{*}{5} & Enol & 0 & 0 & $-22,78$ & $-25,10$ \\
\cline { 2 - 6 } & Ceto & $-23,37$ & $-23,29$ & & \\
\hline
\end{tabular}

Os cálculos teóricos indicaram um predomínio da forma enólica para os compostos 1, 2, 3 e 4, e da forma dicetônica para o composto 5. Além disso, foi notado que a presença do solvente não alterou a forma mais estável quando comparado aos resultados para os cálculos realizados na ausência de solvente. Para os compostos 1, 2, 3 e 4, os dados de modelagem molecular foram equivalentes aos dados experimentais (RMN, Espectrometria de Massa e Infravermelho). Para o composto 5, os dados de modelagem molecular foram equivalentes aos dados experimentais de RMN e Infravermelho. 
Os resultados do estudo tautomério ceto-enólico por RMN, Espectrometria de Massa, Infravermelho e Modelagem Molecular foram publicados, e o artigo pode ser visto no anexo 62 (Pires, 2016).

\subsubsection{Teste Biológico: Atividade em Relação à Enzima Tirosinase}

Investigou-se a atividade dos 16 compostos estudados (Tabela 1.2) em relação à enzima tirosinase. Tais compostos poderiam apresentar atividade em relação à tirosinase, visto que são compostos carbonílicos (que podem se coordenar ao cobre no sítio ativo da enzima) e/ou fenólicos (em que a enzima consegue oxidar fenóis e difenóis).

Os resultados da atividade dos 16 compostos (Tabela 1.2) em relação à enzima tirosinase podem ser vistos na Tabela 1.8, em que se utilizou uma concentração de $512 \mu \mathrm{M}$ para cada composto testado. Utilizou-se o $\mathrm{t}(1 / 2)$ (tempo para alcançar a metade da atividade máxima da enzima) do ensaio branco para calcular a porcentagem de atividade de cada composto, sendo 13,06 minutos para a L-tirosina e 6,66 minutos para a L-dopa.

Tabela 1.8: Atividade dos 16 compostos, em porcentagem, em relação à enzima Tirosinase, utilizando L-tirosina e L-dopa como substratos.

\begin{tabular}{|c|c|c|c|c|}
\hline & \multicolumn{2}{|c|}{ L-tirosina } & \multicolumn{2}{c|}{ L-dopa } \\
\hline Compostos & \% de Inibição & $\%$ de Ativação & $\%$ de Inibição & $\%$ de Ativação \\
\hline 1 & 6,36 & - & 1,34 & - \\
\hline 2 & - & 5,45 & - & 7,43 \\
\hline 3 & & 4,61 & - & 4,86 \\
\hline 4 & 1,72 & - & - & 4,86 \\
\hline 5 & 5,52 & - & - & 1,11 \\
\hline 6 & 88,64 & - & 42,63 & - \\
\hline 7 & 1,30 & - & - & 3,91 \\
\hline 8 & 10,16 & - & - & 3,55 \\
\hline 9 & 22,89 & - & 23,30 & - \\
\hline 10 & 31,58 & - & 15,40 & - \\
\hline 11 & 7,10 & - & 15,50 & - \\
\hline 12 & 82,13 & - & 15,97 & - \\
\hline 13 & 4,22 & - & - & 12,11 \\
\hline 14 & 94,37 & - & 27,64 & - \\
\hline 15 & 5,26 & - & 4,94 & - \\
\hline 16 & 4,47 & - & 10,17 & - \\
\hline Kojic & 98,32 & - & 95,72 & - \\
\hline
\end{tabular}


Os compostos 6, 12 e 14 foram os que apresentaram as maiores atividades de inibição em relação à enzima. Um gráfico com a atividade desses três compostos, em relação ao tempo, mostrando também a atividade na presença do controle positivo (ácido Kojic) e do branco (apenas a L-tirosina) pode ser visto na Figura 1.51.

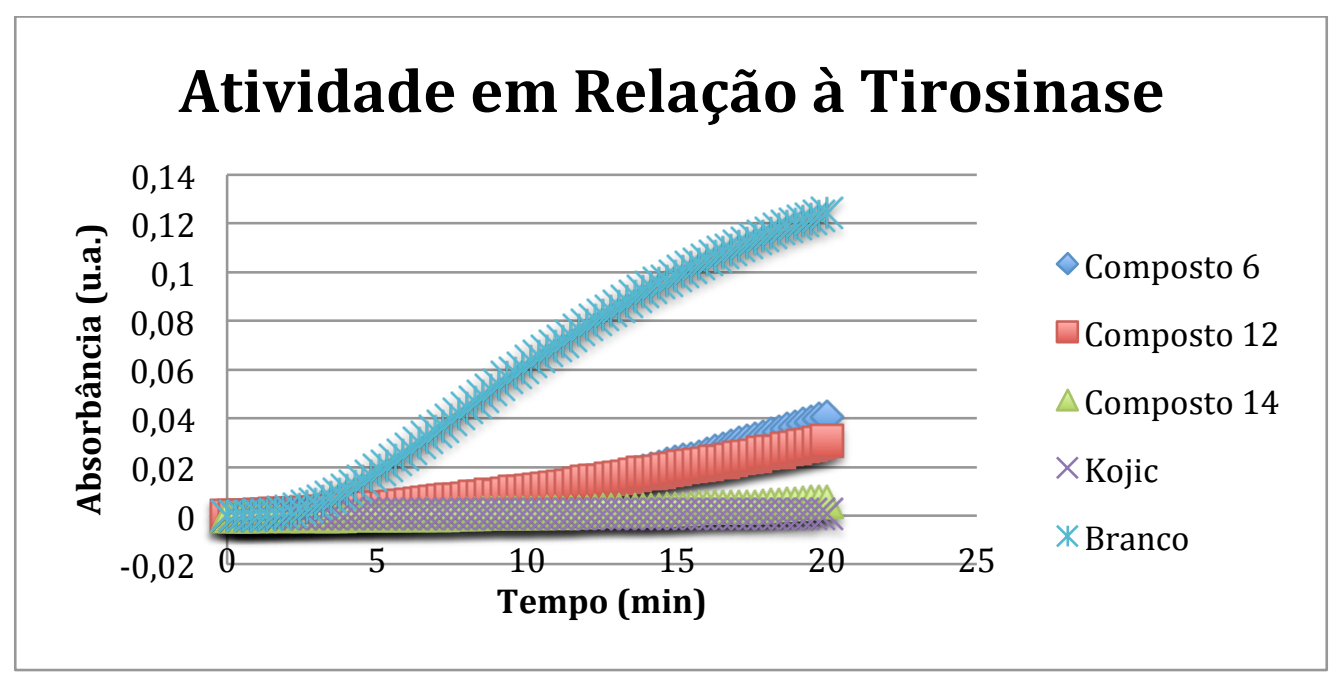

Figura 1.51: Gráfico com o monitoramento da atividade da tirosinase na presença dos compostos 6, 12, 14 e Kojic e também do ensaio branco. Utilizou-se L-tirosina como substrato.

Os compostos de 1 a 5 não apresentaram atividades relevantes em relação à enzima estudada. $O$ composto 5 , mesmo se apresentando na forma dicetônica e, em princípio, com mais carbonilas disponíveis para se coordenar ao cobre no sítio ativo da enzima, também não apresentou atividade relevante.

O composto 6 apresentou $88 \%$ de inibição da tirosinase, quando se utilizou L-tirosina como substrato. A variação da posição da hidroxila e a substituição do $-\mathrm{OH}$ pelo grupo $-\mathrm{OCH}_{3}$, como observado nos compostos $7,8,9$ e 10, causaram uma diminuição significativa na atividade em relação a enzima, indicando que diferentes substituintes no anel aromático e alteração na posição da hidroxila acarretam em perda de atividade. Grupos $-\mathrm{OH}$ e $-\mathrm{OCH}_{3}$, quando na posição 5 (compostos 9 e 10), apresentaram maiores atividades do que quando na posição 6 (compostos 7 e 8), fato que pode ser justificado pela proximidade de tais grupos com a carbonila, possível local de interação com a enzima. Os compostos com $-\mathrm{OH}$ apresentaram maior atividade quando comparados àqueles com o grupo $-\mathrm{OCH}_{3}$. 
Dentre os compostos fenólicos 11, 12 e 13, o composto 12 foi o único que apresentou uma atividade relevante, com $82 \%$ de inibição com L-tirosina como substrato. A substituição do grupo isopropila pelo grupo metila (composto 11) ou a retirada do grupo isopropila (composto 13) causou uma diminuição significativa na atividade dos compostos, indicando que o grupo isopropila pode desempenhar papel importante na inibição da enzima.

Realizou-se a substituição dos grupos $-\mathrm{OH}$ fenólicos dos compostos 11 , 12 e 13 por grupos acetila (compostos 14, 15 e 16). Notou-se que o composto 14 apresentou a maior atividade de inibição da tirosinase, com 94\%, quando a L-tirosina é o substrato. A substituição de grupos $-\mathrm{OH}$ por acetilas causou um aumento na atividade dos compostos, indicando que as carbonilas dos grupos acetila podem apresentar papel importante na atividade. Notou-se também que a introdução de um grupo metila (composto 15) ou um grupo isopropila (composto 16) causaram uma diminuição significativa na atividade quando comparados ao composto 14 .

Vale ressaltar que o composto 6 , que apresentou $88 \%$ de inibição da enzima, é o precursor para sintetizar os compostos 12 e 14, que apresentaram 82 e 94\% de inibição, respectivamente, indicando que modificações podem aumentar a atividade dos compostos em relação à tirosinase. Entretanto, o composto 6 também é o precursor para proceder à síntese dos compostos 1, 2, $3,4,5,11,13,15$ e 16, que não apresentaram atividades significativas em relação à enzima.

Realizou-se um monitoramento das atividades dos compostos 6, 12, 14 e Kojic (compostos com as maiores atividades - superior a 50\%) em diferentes concentrações, em relação à tirosinase (Figura 1.52). As concentrações utilizadas foram de $512,256,128,64,32,16$ e $8 \mu \mathrm{M}$. 


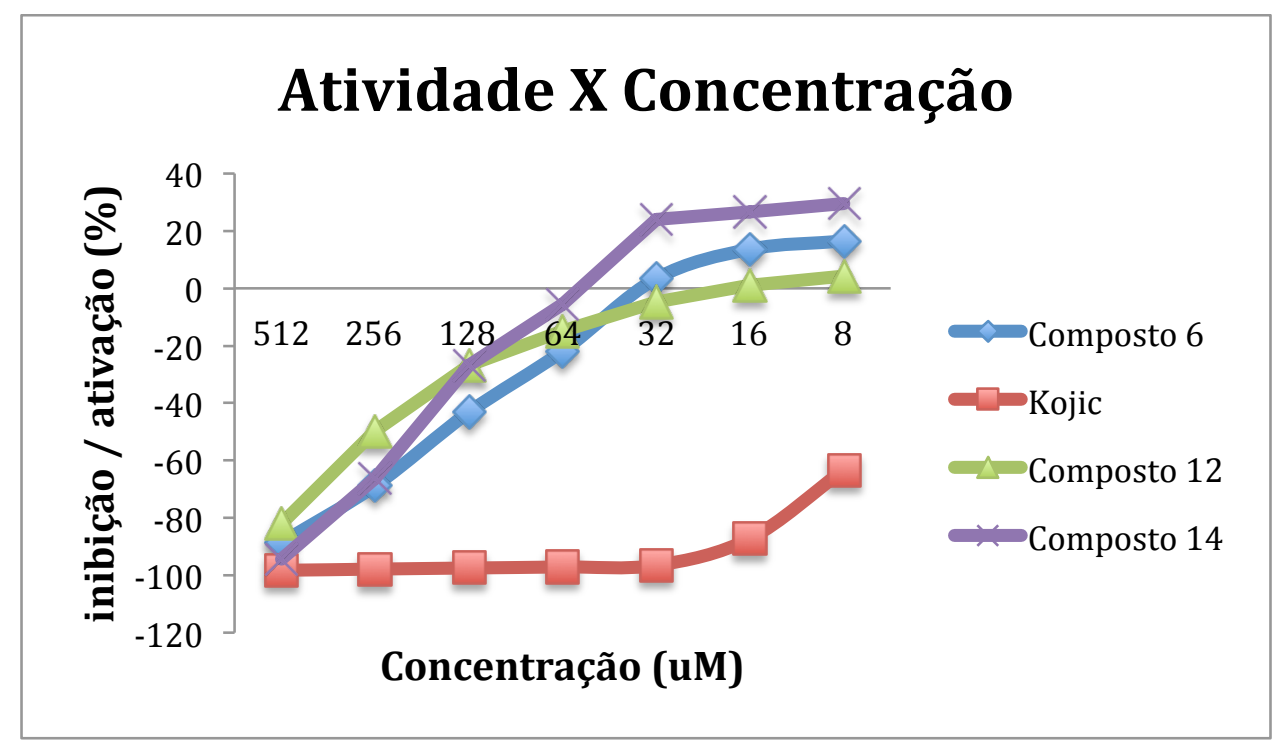

Figura 1.52: Atividade dos compostos 6, 12, 14 e Kojic (controle positivo), em diferentes concentrações, em relação à atividade da enzima tirosinase.

Notou-se que o ácido Kojic (controle positivo), inibidor já conhecido na literatura, manteve seus altos índices de inibição mesmo em concentrações mais baixas, como em $8 \mu \mathrm{M}$ (63\% de inibição). Os compostos 6, 12 e 14 não mantiveram seus altos índices de inibição com a diminuição da concentração, em que próximos a $64 \mu \mathrm{M}$ já apresentaram inibição pouco relevantes. Os compostos 6, 12 e 14 apresentaram altos índices de inibição com $512 \mu \mathrm{M}$ (88, 82 e $84 \%$, respectivamente), entretanto, em concentrações mais baixas, como em $8 \mu \mathrm{M}$, os mesmos foram capazes de ativar a enzima em 16, 4 e 29\%, respectivamente. Com isso, dependendo das concentrações utilizadas, os compostos 6 e 14 podem inibir ou ativar a enzima.

\subsubsection{Deslocamento Químico, Relaxação e Difusão no Estudo de Interação Ligante-Enzima por RMN}

Realizou-se estudos de RMN envolvendo deslocamento químico, tempo de relaxação e coeficiente de difusão dos ligantes na ausência e na presença da enzima para mapear os possíveis átomos dos ligantes envolvidos na interação com a enzima tirosinase. Esses estudos foram feitos apenas com os compostos 6, 12 e 14, que apresentaram as maiores atividades em relação à enzima. Realizou-se também o estudo do ácido kojic, inibidor já conhecido da tirosinase, para controle positivo. 
Para trabalhar com as mesmas proporções ligante:enzima utilizadas no teste biológico (7690:1 quando se utilizou a concentração de $512 \mu \mathrm{M}$ de ligante e 100:1 quando se utilizou $8 \mu \mathrm{M}$ de ligante), utilizou-se uma concentração de 2 $\mathrm{mM}$ de ligante e de 0,26 $\mu \mathrm{M}$ e $20 \mu \mathrm{M}$ de enzima (as mesmas proporções para os extremos de concentração do teste biológico).

Os dados de deslocamento químico para os compostos 6, 12, 14 e kojic na ausência e na presença da tirosinase podem ser vistos nas Tabelas 1.9, $1.10,1.11$ e 1.12, respectivamente.

Tabela 1.9: Valores de deslocamento químico $(\delta)$ do composto $6(2 \mathrm{mM})$ na ausência e na presença da tirosinase $(0,26 \mu \mathrm{M}$ e $20 \mu \mathrm{M})$.

\begin{tabular}{|c|c|c|c|}
\hline Hidrogênio & $\begin{array}{c}\delta_{\text {composto } 6} \\
\text { (ppm) }\end{array}$ & $\begin{array}{c}\delta \text { composto } 6+ \\
\text { Enzima } 0,26 \text { uM }(\mathrm{ppm})\end{array}$ & $\begin{array}{c}\delta \text { composto } 6+ \\
\text { Enzima } 20 \text { uM }(\mathrm{ppm})\end{array}$ \\
\hline $\mathrm{H} 1$ & 7,72 & 7,72 & 7,71 \\
\hline $\mathrm{H} 2$ & 7,56 & 7,56 & 7,57 \\
\hline $\mathrm{H} 3$ & 7,67 & 7,67 & 7,67 \\
\hline $\mathrm{H} 4$ & 7,53 & 7,53 & 7,53 \\
\hline $\mathrm{H} 7$ & 6,61 & 6,61 & 6,61 \\
\hline & & $\begin{array}{l}\mathrm{OH}_{11} \\
11 \\
\end{array}$ & \\
\hline
\end{tabular}

Tabela 1.10: Valores de deslocamento químico $(\boldsymbol{\delta})$ do composto $12(2 \mathrm{mM})$ na ausência e na presença da tirosinase $(0,26 \mu \mathrm{M}$ e $20 \mu \mathrm{M})$.

\begin{tabular}{|c|c|c|c|}
\hline Hidrogênio & $\boldsymbol{\delta}_{\text {composto 12 } \mathbf{( p p m ) ~}}$ & $\begin{array}{c}\boldsymbol{\delta} \text { composto 12+ } \\
\text { Enzima 0,26 um }(\mathbf{p p m})\end{array}$ & $\begin{array}{c}\boldsymbol{\delta} \text { composto 6 + } \\
\text { Enzima 20 um }(\mathbf{p p m})\end{array}$ \\
\hline $\mathrm{H} 1$ & 7,75 & 7,75 & 7,75 \\
\hline $\mathrm{H} 2$ & 7,58 & 7,58 & 7,58 \\
\hline $\mathrm{H} 3$ & 7,44 & 7,44 & 7,44 \\
\hline $\mathrm{H} 4$ & 7,23 & 7,23 & 7,23 \\
\hline $\mathrm{H} 7$ & 6,93 & 6,93 & 6,93 \\
\hline $\mathrm{H} 13 / \mathrm{H} 15$ & 6,22 & 6,22 & 6,22 \\
\hline $\mathrm{H} 17$ & 2,60 & 2,60 & 2,60 \\
\hline $\mathrm{H} 18 / \mathrm{H} 19$ & 0,99 & 0,99 & 0,99 \\
\hline
\end{tabular}




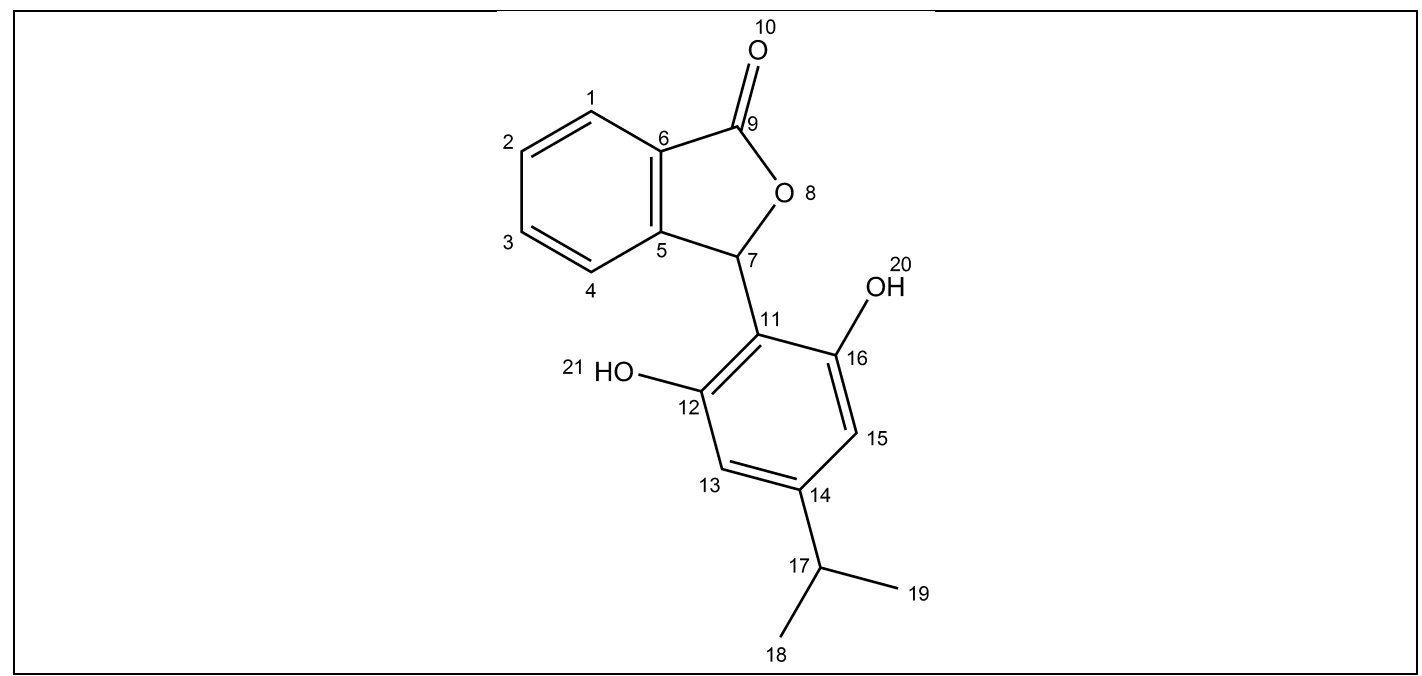

Tabela 1.11: Valores de deslocamento químico $(\bar{\delta})$ do composto 14 (2 mM) na ausência e na presença da tirosinase $(0,26 \mu \mathrm{M}$ e $20 \mu \mathrm{M})$.

\begin{tabular}{|c|c|c|c|}
\hline Hidrogênio & $\delta$ composto 14 (ppm) & $\begin{array}{c}\delta \text { composto } 14+ \\
\text { Enzima } 0,26 \text { uM }(p p m)\end{array}$ & $\begin{array}{c}\delta \text { composto } 6+ \\
\text { Enzima } 20 \text { uM }(p p m)\end{array}$ \\
\hline 1 & 7,87 & 7,87 & 7,87 \\
\hline 2 & 7,63 & 7,64 & 7,64 \\
\hline 3 & 7,54 & 7,55 & 7,55 \\
\hline 4 & 7,17 & 7,17 & 7,17 \\
\hline 7 & 6,72 & 6,72 & 6,72 \\
\hline $13 / 15$ & 7,03 & 7,03 & 7,03 \\
\hline 14 & 7,45 & 7,45 & 7,45 \\
\hline $19 / 22$ & 1,92 & 1,91 & 1,91 \\
\hline & 23 & $\left.\right|_{\substack{24 \\
15}} ^{17}$ & \\
\hline
\end{tabular}

Tabela 1.12: Valores de deslocamento químico (ס) do ácido kojic (2 mM) na ausência e na presença da tirosinase $(0,26 \mu \mathrm{M}$ e $20 \mu \mathrm{M})$.

\begin{tabular}{|c|c|c|c|}
\hline Hidrogênio & $\boldsymbol{\delta}_{\text {Kojic }}(\mathbf{p p m})$ & $\begin{array}{c}\boldsymbol{\delta}_{\text {Kojic }+} \\
\text { Enzima 0,26 uM (ppm) }\end{array}$ & $\begin{array}{c}\boldsymbol{\delta} \text { Kojic + } \\
\text { Enzima 20 uM (ppm) }\end{array}$ \\
\hline H2 & 7,91 & 7,90 & 7,90 \\
\hline H5 & 6,41 & 6,40 & 6,40 \\
\hline H7 & 4,33 & 4,33 & 4,33 \\
\hline
\end{tabular}




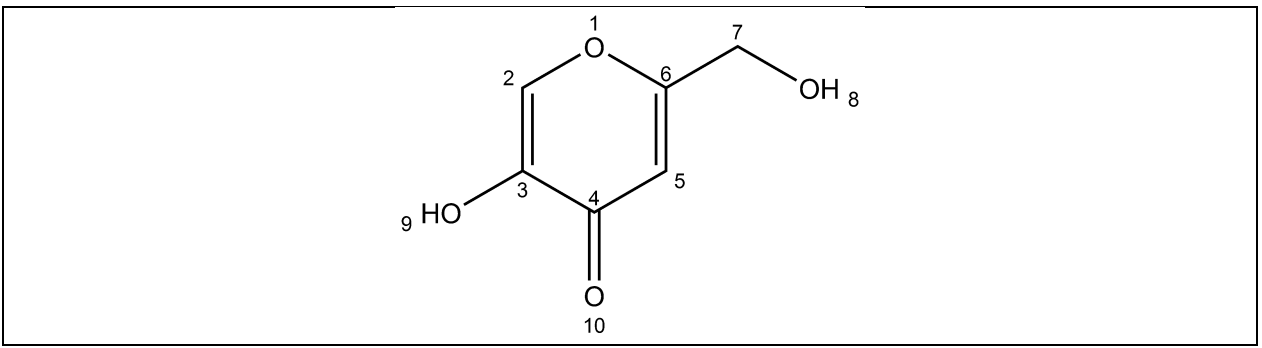

Ao interagir com uma proteína, determinados átomos de um ligante podem ter seus ambientes químicos modificados, causando uma mudança nos valores de deslocamento químico. Com isso, o deslocamento químico pode ser utilizado para mapear os átomos de um ligante envolvidos em uma interação com uma macromolécula.

Observando, no entanto, os valores de deslocamento químico nas Tabelas 1.9, 1.10, 1.11 e 1.12, notou-se que não houve variação significativa desses valores após adição da enzima (mesmo em diferentes concentrações). A ausência de variação de deslocamento químico para os hidrogênios não indica necessariamente ausência de interação entre a enzima e os ligantes. Uma prova disso é o resultado invariável para o ácido kojic, um bom inibidor da tirosinase já conhecido na literatura, assim como sua interação com a enzima. A variação do deslocamento químico de hidrogênios envolvidos em interação está relacionada com as populações e com a dinâmica da interação, o que pode levar a resultados como os que foram apresentados. Medidas dos tempos de relaxação e dos coeficientes de difusão são mais sensíveis para o mapeamento das interações ligante-enzima.

Os dados obtidos para os tempos de relaxação longitudinal dos compostos 6, 12, 14 e kojic na ausência e na presença da tirosinase podem ser vistos nas Tabelas $1.13,1.14,1.15$ e 1.16.

Tabela 1.13: Valores do tempo de relaxação longitudinal $\left(T_{1}\right)$ do composto $6(2 \mathrm{mM})$ na ausência e na presença da tirosinase $(0,26 \mu \mathrm{M}$ e $20 \mu \mathrm{M})$.

\begin{tabular}{|c|c|c|c|}
\hline Hidrogênio & $\mathbf{T}_{\text {1 composto 6 }} \mathbf{( s )}$ & $\begin{array}{c}\mathbf{T}_{\text {1 composto 6 + }} \\
\text { Enzima 0,26 um }\end{array}$ & $\begin{array}{c}\mathbf{T}_{\text {1 composto 6 }} \\
\text { Enzima 20 um }\end{array}$ \\
\hline $\mathrm{H} 1$ & $\mathbf{s})$ & 4,2 \\
\hline $\mathrm{H} 2$ & 7,7 & 5,9 & 3,6 \\
\hline $\mathrm{H} 3$ & 5,7 & 4,5 & 3,4 \\
\hline $\mathrm{H} 4$ & 5,1 & 4,0 & 3,2 \\
\hline $\mathrm{H} 7$ & 5,1 & 3,9 & 5,5 \\
\hline
\end{tabular}


Tabela 1.14: Valores do tempo de relaxação longitudinal $\left(T_{1}\right)$ do composto $12(2 \mathrm{mM})$ na ausência e na presença da tirosinase $(0,26 \mu \mathrm{M}$ e $20 \mu \mathrm{M})$.

\begin{tabular}{|c|c|c|c|}
\hline Hidrogênio & $\mathrm{T}_{1 \text { composto } 12}(\mathrm{~s})$ & $\begin{array}{c}T_{1 \text { composto } 12+} \\
\text { Enzima } 0,26 \text { um }(\mathrm{s})\end{array}$ & $\begin{array}{l}T_{1} \text { composto } 12+ \\
\text { Enzima } 20 \text { uM }(\mathrm{S})\end{array}$ \\
\hline $\mathrm{H} 1$ & 2,1 & 1,5 & 1,3 \\
\hline $\mathrm{H} 2$ & 1,8 & 1,7 & 1,0 \\
\hline $\mathrm{H3}$ & 1,8 & 1,8 & 1,0 \\
\hline $\mathrm{H} 4$ & 1,9 & 1,6 & 1,2 \\
\hline $\mathrm{H} 7$ & 2,4 & 2,1 & 1,5 \\
\hline $\mathrm{H} 13 / \mathrm{H} 15$ & 1,7 & 1,3 & 1,1 \\
\hline $\mathrm{H} 17$ & 1,7 & 1,6 & 1,4 \\
\hline $\mathrm{H} 18 / \mathrm{H} 19$ & 0,9 & 0,8 & 0,7 \\
\hline
\end{tabular}

Tabela 1.15: Valores do tempo de relaxação longitudinal $\left(T_{1}\right)$ do composto 14 (2 mM) na ausência e na presença da tirosinase $(0,26 \mu \mathrm{M}$ e $20 \mu \mathrm{M})$.

\begin{tabular}{|c|c|c|c|}
\hline Hidrogênio & $\mathrm{T}_{1 \text { composto } 14}(\mathrm{~s})$ & $\begin{array}{c}\mathrm{T}_{1} \text { composto } 14+ \\
\text { Enzima } 0,26 \text { uM }(\mathrm{s})\end{array}$ & $\begin{array}{l}T_{1} \text { composto } 14+ \\
\text { Enzima } 20 \text { uM }(\mathrm{s})\end{array}$ \\
\hline 1 & 2,8 & 2,7 & 2,3 \\
\hline 2 & 1,7 & 1,6 & 1,4 \\
\hline 3 & 1,9 & 1,7 & 1,4 \\
\hline 4 & 2,4 & 2,3 & 2,0 \\
\hline 7 & 4,8 & 4,4 & 3,5 \\
\hline $13 / 15$ & 1,7 & 1,5 & 1,3 \\
\hline 14 & 2,7 & 2,6 & 2,2 \\
\hline $19 / 22$ & 2,8 & 1,7 & 1,5 \\
\hline
\end{tabular}

Tabela 1.16: Valores do tempo de relaxação longitudinal $\left(T_{1}\right)$ do ácido kojic (2 mM) na ausência e na presença da tirosinase $(0,26 \mu \mathrm{M}$ e $20 \mu \mathrm{M})$.

\begin{tabular}{|c|c|c|c|}
\hline Hidrogênio & $T_{1 \text { Kojic }}(s)$ & $\begin{array}{c}T_{1} \text { Kojic }+ \\
\text { Enzima } 0,26 \text { uM (s) }\end{array}$ & $\begin{array}{c}\mathrm{T}_{1} \text { Kojic }+ \\
\text { Enzima } 20 \text { uM (s) }\end{array}$ \\
\hline $\mathrm{H} 2$ & 6,5 & 6,4 & 3,5 \\
\hline H5 & 3,9 & 4,1 & 4,8 \\
\hline $\mathrm{H} 7$ & 2,2 & 2,2 & 2,1 \\
\hline
\end{tabular}

Moléculas com baixo e médio peso molecular apresentam tempos de relaxação maiores, enquanto que moléculas com alto peso molecular apresentam tempos de relaxação menores (Diercks, 2001; Figueiredo, 2007). Com base nessa diferença, quando uma molécula pequena se liga a uma molécula com alto peso molecular, como uma proteína, a primeira passa a fazer parte do macrossistema, adotando assim tempos de relaxação também menores (Diercks, 2001; Figueiredo, 2007).

A variação nos valores de $T_{1}$ da molécula após adição da enzima observada nas Tabelas 1.13, 1.14, 1.15 e 1.16 sugere interação entre todos os ligantes e a tirosinase. 
Os dados de coeficiente de difusão envolvendo os compostos 6, 12, 14 e kojic na ausência e na presença da tirosinase podem ser vistos nas Tabelas $1.17,1.18,1.19$ e 1.20 .

Tabela 1.17: Valores de coeficiente de difusão (D) do composto 6 (2 mM) na ausência e na presença da tirosinase $(0,26 \mu \mathrm{M}$ e $20 \mu \mathrm{M})$.

\begin{tabular}{|c|c|c|c|}
\hline Hidrogênio & $\begin{array}{l}D_{\text {composto } 6} \\
\left(10^{-10} \mathrm{~m}^{2} / \mathrm{s}\right)\end{array}$ & $\begin{array}{l}\text { D composto } 6+ \\
\text { Enzima } 0,26 \text { uM } \\
\left(10^{-10} \mathrm{~m}^{2} / \mathrm{s}\right)\end{array}$ & $\begin{array}{c}\text { D composto } 6+ \\
\text { Enzima } 20 \text { um } \\
\left(10^{-10} \mathrm{~m}^{2} / \mathrm{s}\right)\end{array}$ \\
\hline $\mathrm{H} 1$ & 3,56 & 3,14 & 2,04 \\
\hline $\mathrm{H} 2$ & 3,51 & 3,40 & 2,56 \\
\hline $\mathrm{H} 3$ & 3,92 & 3,80 & 2,49 \\
\hline $\mathrm{H} 4$ & 4,73 & 4,82 & 3,51 \\
\hline $\mathrm{H} 7$ & - & - & - \\
\hline
\end{tabular}

Tabela 1.18: Valores de coeficiente de difusão (D) do composto 12 (2 mM) na ausência e na presença da tirosinase $(0,26 \mu \mathrm{M}$ e $20 \mu \mathrm{M})$.

\begin{tabular}{|c|c|c|c|}
\hline Hidrogênio & $\begin{array}{l}D_{\text {composto } 12} \\
\left(10^{-10} \mathrm{~m}^{2} / \mathrm{s}\right)\end{array}$ & $\begin{array}{c}\text { D composto } 12+ \\
\text { Enzima } 0,26 \mathrm{um} \\
\left(10^{-10} \mathrm{~m}^{2} / \mathrm{s}\right)\end{array}$ & $\begin{array}{c}\text { D composto } 12+ \\
\text { Enzima } 20 \mathrm{um} \\
\left(10^{-10} \mathrm{~m}^{2} / \mathrm{s}\right)\end{array}$ \\
\hline $\mathrm{H} 1$ & 1,85 & 1,83 & 1,37 \\
\hline $\mathrm{H} 2$ & 1,61 & 1,58 & 1,55 \\
\hline $\mathrm{H3}$ & 1,62 & 1,65 & 1,49 \\
\hline $\mathrm{H} 4$ & 1,93 & 2,03 & 2,08 \\
\hline $\mathrm{H} 7$ & 1,79 & 1,76 & 1,41 \\
\hline $\mathrm{H} 13 / \mathrm{H} 15$ & 1,86 & 1,81 & 1,47 \\
\hline $\mathrm{H} 17$ & 1,78 & 1,68 & 1,27 \\
\hline $\mathrm{H} 18 / \mathrm{H} 19$ & 1,71 & 1,86 & 1,34 \\
\hline
\end{tabular}

Tabela 1.19: Valores de coeficiente de difusão (D) do composto $14(2 \mathrm{mM})$ na ausência e na presença da tirosinase $(0,26 \mu \mathrm{M}$ e $20 \mu \mathrm{M})$.

\begin{tabular}{|c|c|c|c|}
\hline Hidrogênio & $\begin{array}{l}D_{\text {composto } 14} \\
\left(10^{-10} \mathrm{~m}^{2} / \mathrm{s}\right)\end{array}$ & $\begin{array}{c}\text { composto } 14+ \\
\text { Enzima } 0,26 \text { uM } \\
\left(10^{-10} \mathrm{~m}^{2} / \mathrm{s}\right)\end{array}$ & $\begin{array}{c}\text { composto } 14+ \\
\text { Enzima } 20 \mathrm{uM} \\
\left(10^{-10} \mathrm{~m}^{2} / \mathrm{s}\right)\end{array}$ \\
\hline 1 & 1,54 & 1,55 & 1,25 \\
\hline 2 & 1,68 & 1,66 & 1,08 \\
\hline 3 & 1,53 & 1,32 & 0,90 \\
\hline 4 & 1,58 & 1,44 & 1,40 \\
\hline 7 & 1,60 & 1,62 & 1,85 \\
\hline $13 / 15$ & 1,58 & 1,32 & 0,74 \\
\hline 14 & - & 2,08 & 1,76 \\
\hline $19 / 22$ & - & - & - \\
\hline
\end{tabular}


Tabela 1.20: Valores de coeficiente de difusão (D) do ácido kojic (2 mM) na ausência e na

\begin{tabular}{|c|c|c|c|}
\hline Hidrogênio & $\begin{array}{c}D_{\text {Kojic }} \\
\left(10^{-10} \mathrm{~m}^{2} / \mathrm{s}\right)\end{array}$ & $\begin{array}{c}D_{\text {Kojic }+} \\
\text { Enzima } 0,26 \text { uM } \\
\left(10^{-10} \mathrm{~m}^{2} / \mathrm{s}\right)\end{array}$ & $\begin{array}{c}{\text { D } \text { Kojic }} \\
\text { Enzima } 20 \text { um } \\
\left(10^{-10} \mathrm{~m}^{2} / \mathrm{s}\right)\end{array}$ \\
\hline $\mathrm{H} 2$ & 4,21 & 3,33 & 1,77 \\
\hline $\mathrm{H} 5$ & 3,94 & 3,59 & 2,19 \\
\hline $\mathrm{H} 7$ & 3,98 & 3,24 & 2,43 \\
\hline
\end{tabular}

O coeficiente de difusão é outro parâmetro utilizado para estudos de interação ligante/macromolécula, sendo muito sensível a mudanças estruturais e aos processos de interação.

Moléculas com alto peso molecular apresentam menores valores de coeficiente de difusão, enquanto que moléculas de baixo peso molecular apresentam maiores valores de coeficiente de difusão (Diercks, 2001; Figueiredo, 2007). Com isso, quando alguns átomos de hidrogênio de um ligante passam a interagir com a proteína, seus coeficientes de difusão variam de valores maiores para menores, dando indícios dos átomos envolvidos em tal interação.

As Tabelas 1.17, 1.18, 1.19 e 1.20 mostram uma variação nos valores dos coeficientes de difusão de todos os átomos, sendo que a maioria dos hidrogênios tiveram seus valores de D diminuídos, sugerindo interação entre os ligantes e a tirosinase, resultado análogo ao que foi observado para os tempos de relaxação.

Observando as variações de $T_{1}$ e $D$ para o composto 6 , nota-se que todos os átomos de hidrogênio estão envolvidos na interação com a tirosinase. Esses dados podem indicar a importância do anel aromático na atividade dessa molécula, visto que todos os átomos de hidrogênios aromáticos estariam interagindo com a tirosinase, e ao acrescentar um substituinte no anel aromático, o composto perde a sua atividade (Tabelas 1.2 e 1.8).

Analisando os dados para o composto 12, além dos hidrogênios aromáticos, é observado que também o grupo isopropila, juntamente com os hidrogênios 13 e 15, participaram da interação, fato que pode ser essencial para a atividade dessa moléculas, visto que a retirada do grupo isopropila ou a substituição por uma metila, causa a inatividade da molécula (Tabelas 1.2 e 1.8). 
Para o composto 14, observou-se que os átomos de hidrogênio dos dois anéis aromáticos estão envolvidos na interação com a tirosinase pela variação de $T_{1}$ e $D$, sugerindo a importância desses anéis aromáticos para a atividade desse composto. Ao acrescentar um grupo metila ou isopropila no segundo anel aromático, a molécula diminui a sua atividade (Tabelas 1.2 e 1.8). Os dados de $T_{1}$ também sugerem que os hidrogênios $\mathrm{H} 19$ e H22 (metilas terminais) são importantes na interação da enzima com o ligante.

Para os compostos 6, 12, 14 e kojic, observamos variações em todos os átomos de hidrogênio pelo tempo de relaxação e também pelo coeficiente de difusão, indicando que as moléculas, como um todo, participam da interação. Isso faz sentido uma vez que, por serem moléculas relativamente pequenas, todos os átomos dos compostos podem estar interagindo com a tirosinase, havendo espaço para tal no sítio ativo.

\subsubsection{STD no Estudo de Interação Ligante-Enzima por RMN}

O experimento de STD é baseado na transferência de saturação da proteína para o ligante, tornando possível com isso a identificação dos átomos do ligante que receberam essa saturação, e por consequência, participaram da interação. Por esse motivo, o STD permite mapear os átomos de hidrogênio do ligante envolvidos em uma interação com uma macromolécula.

\subsubsection{1 - STD ligante/enzima}

Os espectros de ${ }^{1} \mathrm{H}-\mathrm{RMN}$ e STD para os compostos 6, 12 e 14 podem ser vistos nas Figuras 1.53, 1.54 e 1.55. 

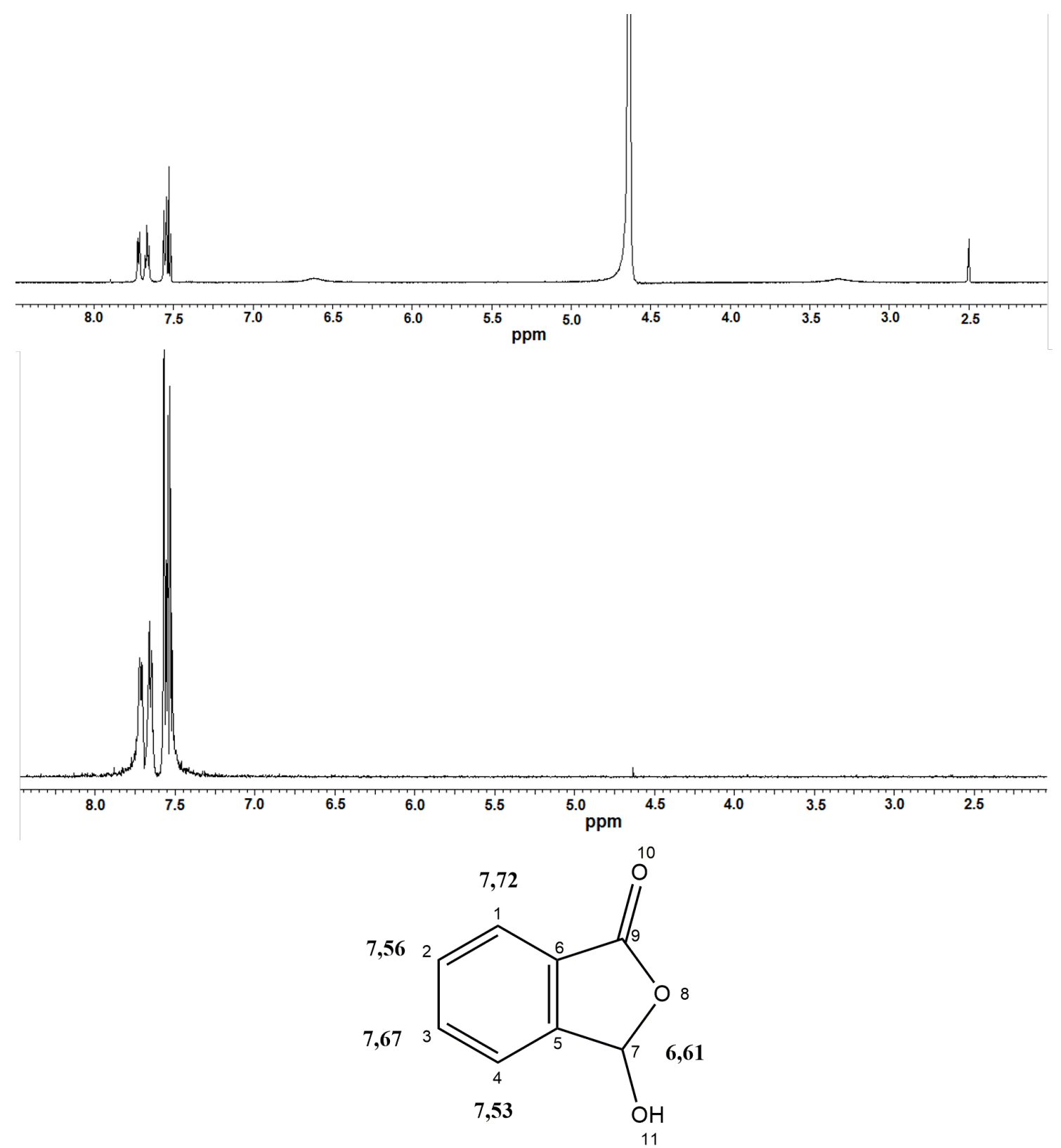

Figura 1.53: Espectros de ${ }^{1} \mathrm{H}-\mathrm{RMN}$ do composto 6 na ausência da enzima (superior) e de STD (inferior). Utilizou-se $2 \mathrm{mM}$ do composto 6 e $20 \mu \mathrm{M}$ da enzima. Para os dois espectros foi utilizada a mesma intensidade para a escala vertical. 

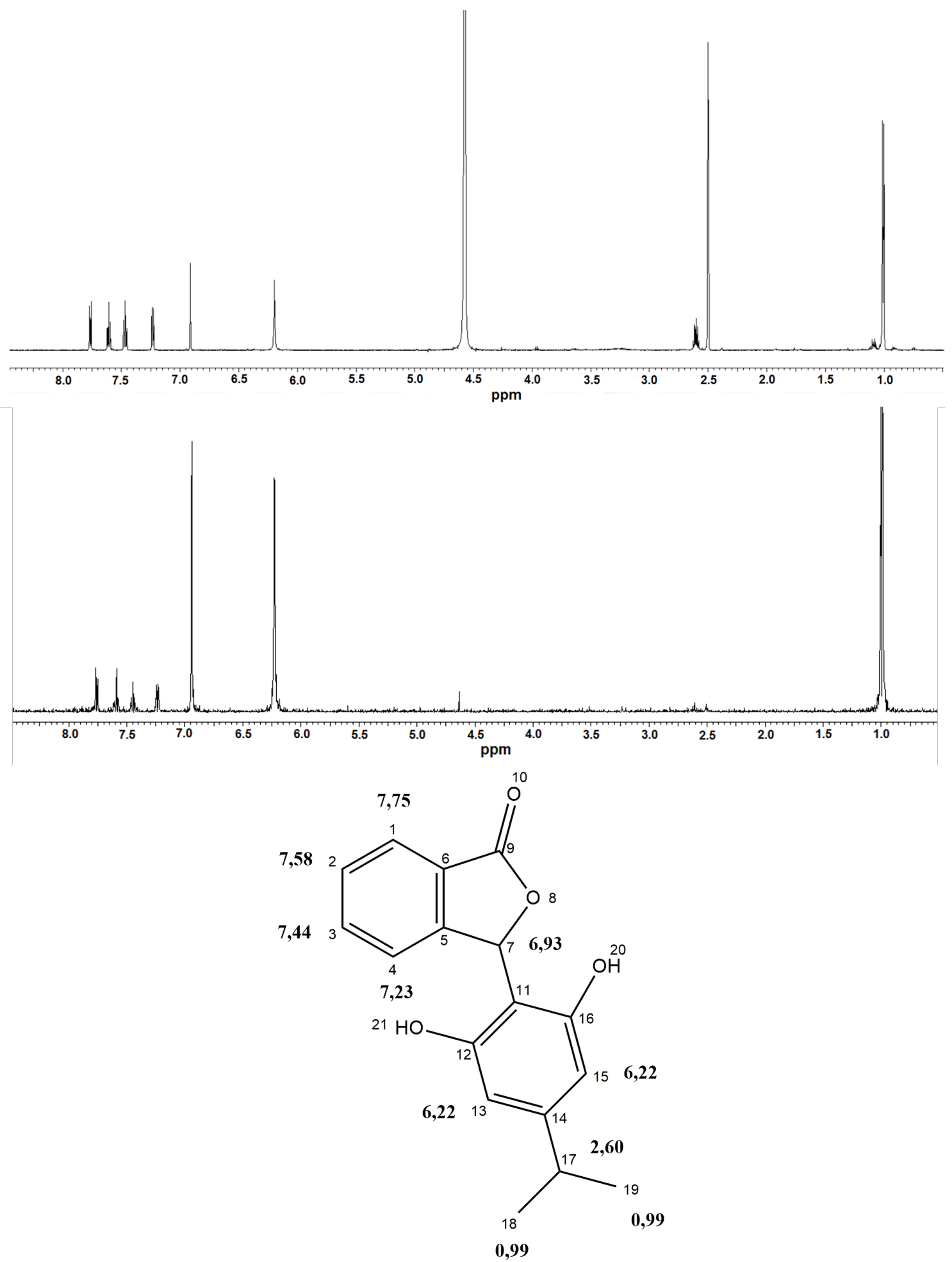

Figura 1.54: Espectros de ${ }^{1} \mathrm{H}-\mathrm{RMN}$ do composto 12 na ausência da enzima (superior) e de STD (inferior). Utilizou-se $2 \mathrm{mM}$ do composto 12 e $20 \mu \mathrm{M}$ da enzima. Para os dois espectros foi utilizada a mesma intensidade para a escala vertical. 


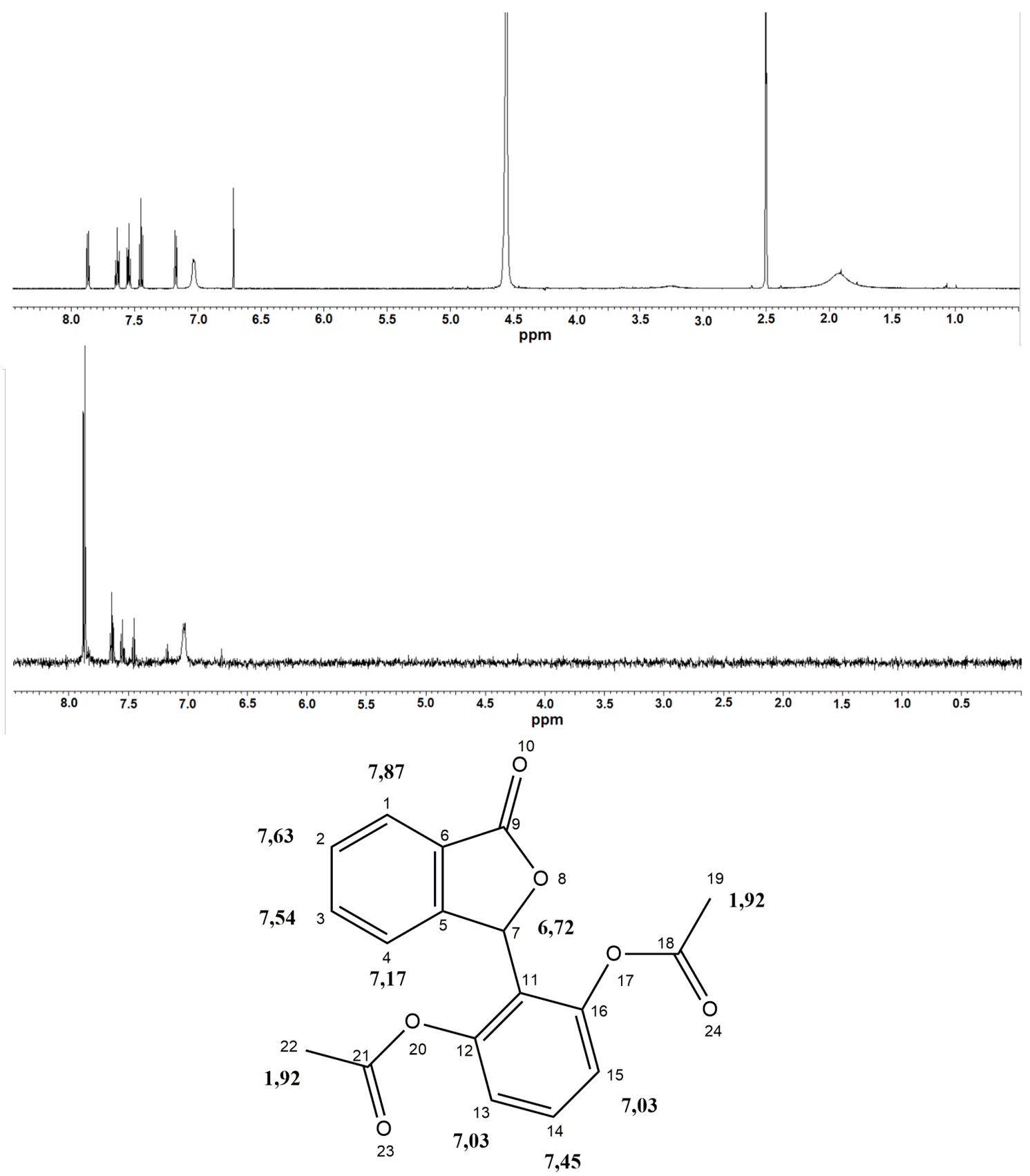

Figura 1.55: Espectros de ${ }^{1} \mathrm{H}-\mathrm{RMN}$ do composto 14 na ausência da enzima (superior) e de STD (inferior) do composto 14. Utilizou-se $2 \mathrm{mM}$ do composto 14 e $20 \mu \mathrm{M}$ da enzima. Para os dois espectros foi utilizada a mesma intensidade para a escala vertical.

Para os três compostos, os espectros sugerem que praticamente todos os hidrogênios dos ligantes estão envolvidos na interação com a tirosinase.

Observando os experimentos de STD para o composto 6, notou-se uma maior intensidade dos sinais referente aos hidrogênios 2 e 4, indicando um maior contato desses átomos com a tirosinase. Este fato justifica a importância do anel aromático para atividade desse composto (similar ao observado por $\mathrm{T}_{1}$ 
e D), em que a substituição do $\mathrm{H}-2$ ou $\mathrm{H}-3$ por $-\mathrm{OCH}_{3}$ ou $-\mathrm{OH}$ gera uma perda da atividade.

Para o composto 12, observa-se no espectro STD uma maior intensidade dos sinais relativos aos hidrogênios 7, 13/15 e 18/19, indicando que estes receberam uma quantidade maior de NOE transferido pela enzima, estando em maior contato com a tirosinase do que os outros átomos de hidrogênio. Pelo STD, é possível confirmar a importância do grupo isopropila para a atividade (maior intensidade para os $\mathrm{H} 18 / 19$ ). Ao retirar este grupo ou substituir por uma metila, observa-se uma diminuição da atividade.

No caso do composto 14, o espectro STD mostra que o sinal do $\mathrm{H}-1$ foi o mais intenso, indicando a importância desse hidrogênio na interação do composto com a tirosinase. Diferentemente do composto 12, o H-1 apresenta baixíssima intensidade, mostrando que esse hidrogênio não está envolvido fortemente na interação com a enzima. O mesmo é observado para os hidrogênios H19 e H22, que não são observados no espectro STD.

No composto 12, o H-7 apareceu com maior intensidade no espectro de STD, indicando uma maior interação desse átomo. Já no composto $14,0 \mathrm{H}-7$ aparece com uma menor intensidade no espectro de STD, indicando que o mesmo apresenta uma menor interação. A presença do grupo acetila no lugar das hidroxilas, e a ausência do grupo isopropila mudaram o modo de interação da molécula com a enzima. Provavelmente, a introdução dos grupos acetilas e consequente aumento do volume da molécula naquela região impede que o composto 14 entre na cavidade do sítio ativo por esse lado (como deve ocorrer no composto 12), favorecendo a interação preferencial pelo outro anel aromático da da molécula.

Todos esses resultados estão de acordo com aqueles observados nas medições de $T_{1}$ e coeficiente de difusão. $O$ fato de a maioria dos átomos de hidrogênio dos compostos 6, 12 e 14 estarem envolvidos na interação com a enzima tirosinase dá indícios de que as moléculas como um todo participam dessa interação. Isso pode ser explicado pelo fato de serem moléculas relativamente pequenas, sendo possível sua penetração no sítio ativo da enzima.

Os espectros de ${ }^{1} \mathrm{H}-\mathrm{RMN}$ e STD para do ácido kojic podem ser vistos na Figura 1.56. Para esse composto, observa-se que apenas o sinal referente ao 
hidrogênio 2 aparece no espectro de STD, indicando que esse átomo está fortemente envolvido na interação com a tirosinase, o que corrobora os resultados dos experimentos de $\mathrm{T}_{1}$ e DOSY, que mostraram que a maior variação exatamente para o $\mathrm{H}-2$.
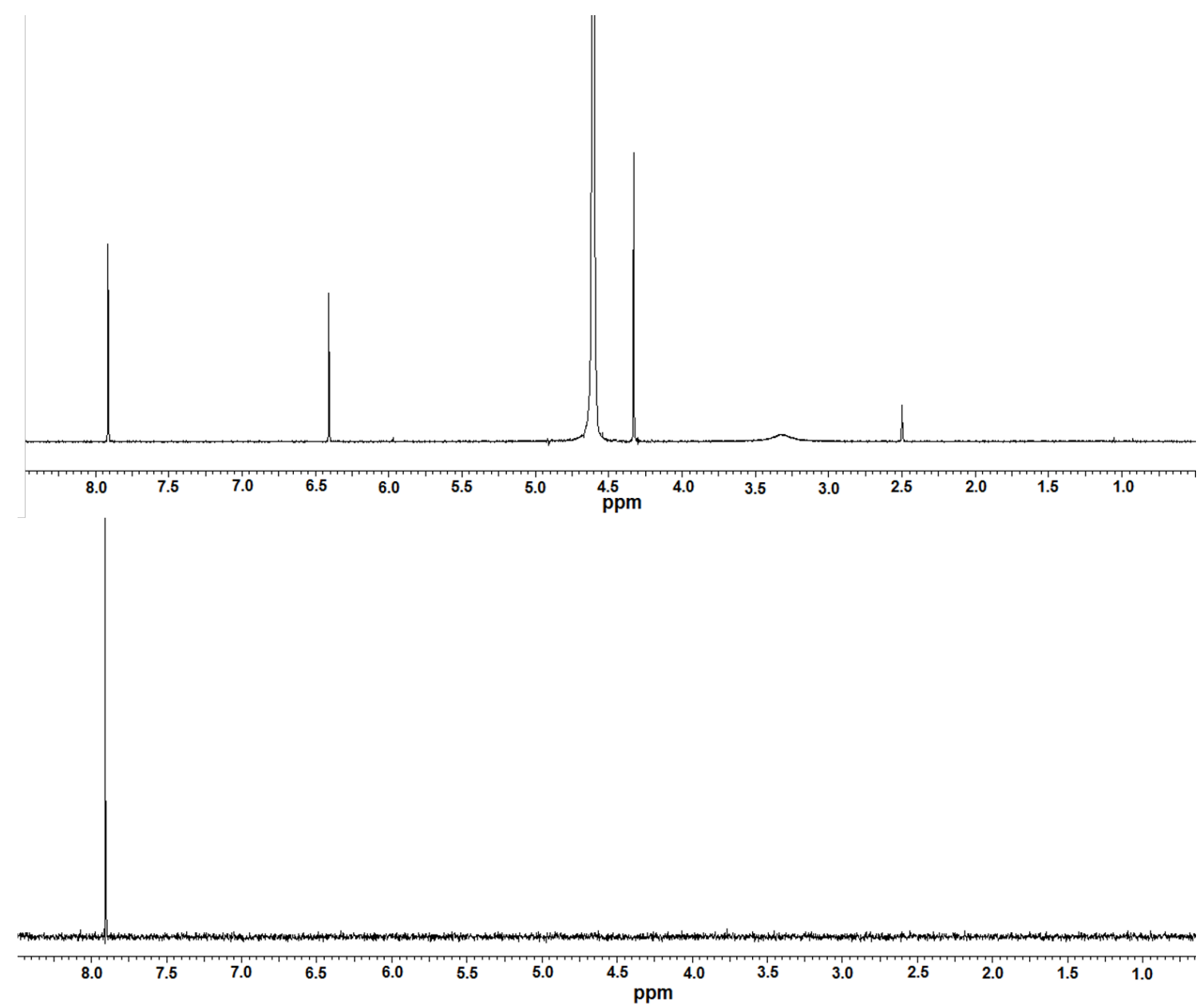

4,33<smiles>O=c1cc(CO)occ1O</smiles>

Figura 1.56: Espectros de ${ }^{1} \mathrm{H}-\mathrm{RMN}$ do ácido kojic na ausência da enzima (superior) e de STD (inferior). Utilizou-se $2 \mathrm{mM}$ do ácido kojic e $20 \mu \mathrm{M}$ da enzima. Para os dois espectros foi utilizada a mesma intensidade para a escala vertical.

Realizou-se também os mesmos experimentos de STD com uma concentração de 0,26 $\mu \mathrm{M}$ de enzima e a mesma concentração de $2 \mathrm{mM}$ de 
ligante. Os espectros resultantes para os compostos 6, 12, 14 e kojic nessas concentrações podem ser vistos nos Anexos de 63 a 66. Os resultados observados nessa menor concentração de tirosinase foram os mesmos obtidos para $20 \mu \mathrm{M}$ de enzima. Os sinais dos hidrogênios observados a $20 \mu \mathrm{M}$ foram os mesmos observados a $0,26 \mu \mathrm{M}$, apenas com uma menor intensidade (menor razão sinal/ruído, como é de se esperar), indicando que, apesar de uma menor concentração de enzima, o modo de interação do ligante com a tirosinase foi o mesmo, estando os mesmos hidrogênios envolvidos em tal processo.

1.4.8.2 - Estudos de competição entre os ligantes por STD

Foram realizados experimentos de STD para os compostos 6, 12 e 14 já em contato com a enzima, adicionando-se, em seguida, o ácido kojic (Figuras $1.57,1.58$ e 1.59). 

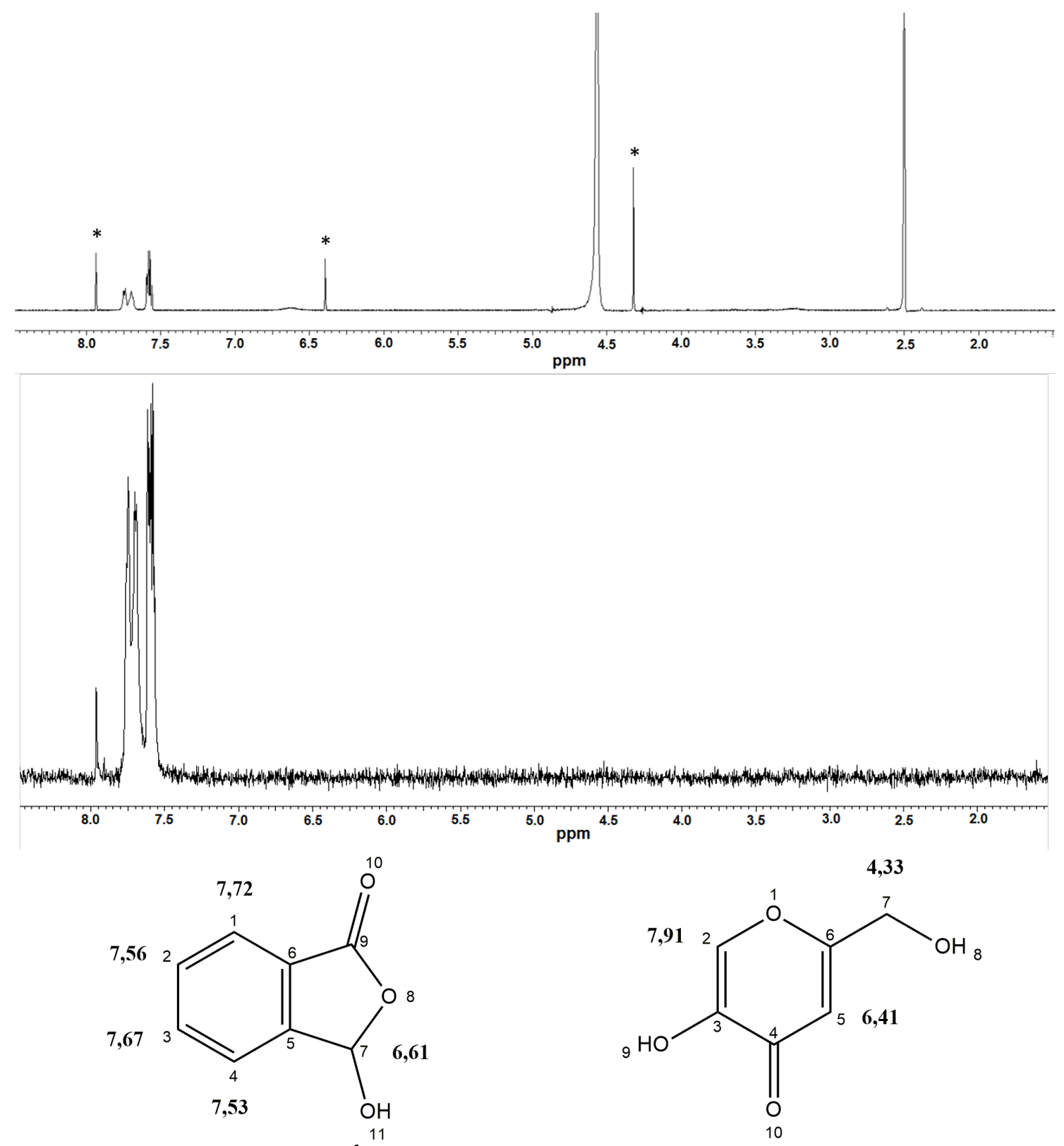

Figura 1.57: Espectros de ${ }^{1} \mathrm{H}-\mathrm{RMN}$ do composto 6 e ácido kojic na ausência da enzima (superior) e de STD (inferior) do composto 6 + enzima após adição do ácido. Utilizou-se $2 \mathrm{mM}$ dos ligantes e $20 \mu \mathrm{M}$ da enzima. No espectro superior, o * indica os sinais referentes ao ácido kojic; os demais são referentes ao composto 6 . São representadas as estruturas do composto 6 (esquerda) e ácido kojic (direita). 

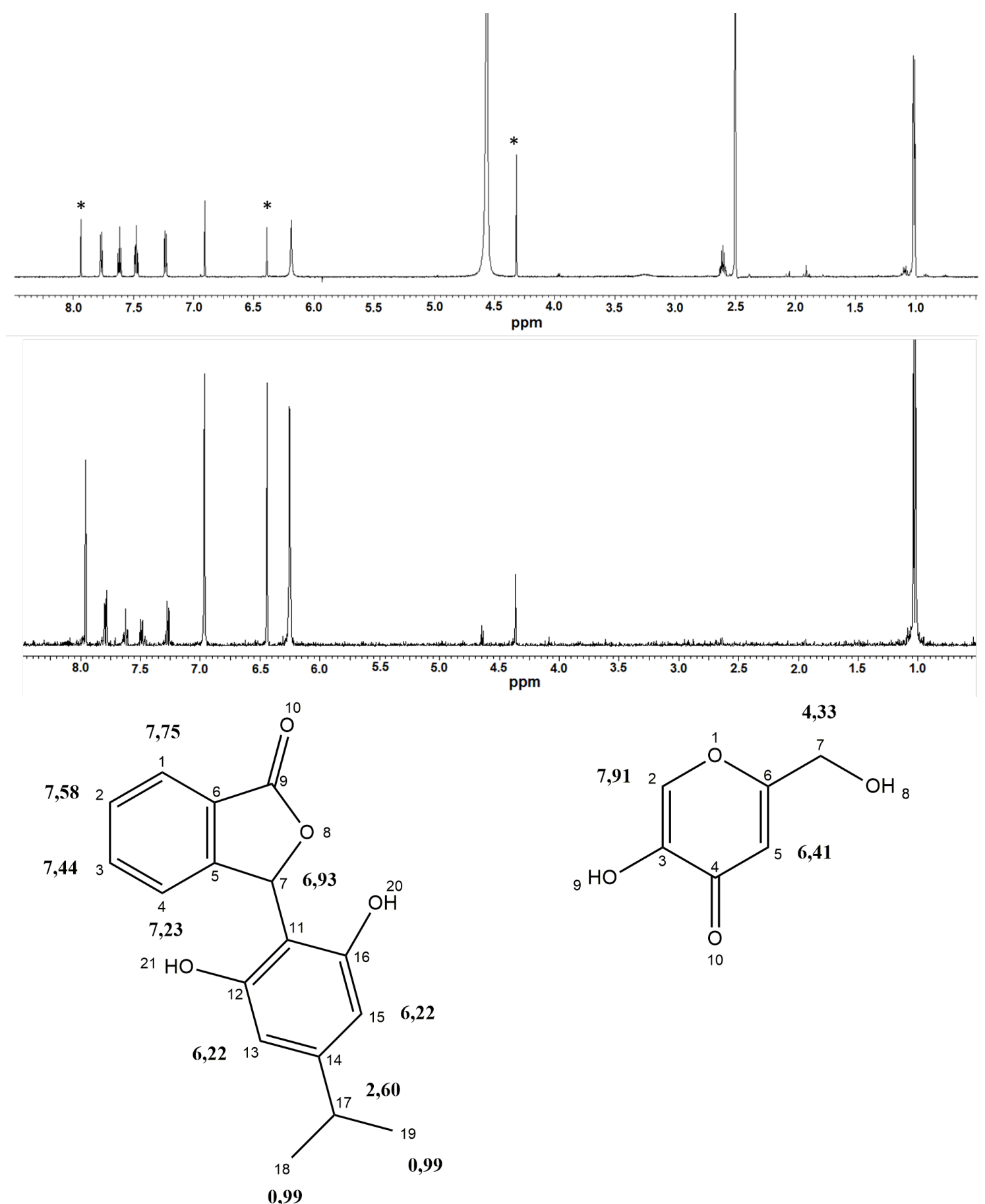

Figura 1.58: Espectros de ${ }^{1} \mathrm{H}-\mathrm{RMN}$ do composto 12 e ácido kojic na ausência da enzima (superior) e de STD (inferior) do composto 12 + enzima após adição do ácido. Utilizou-se $2 \mathrm{mM}$ dos ligantes, e $20 \mu \mathrm{M}$ da enzima. No espectro superior, o * indica os sinais referentes ao ácido kojic; os demais são referentes ao composto 12 . São representadas as estruturas do composto 12 (esquerda) e ácido kojic (direita). 

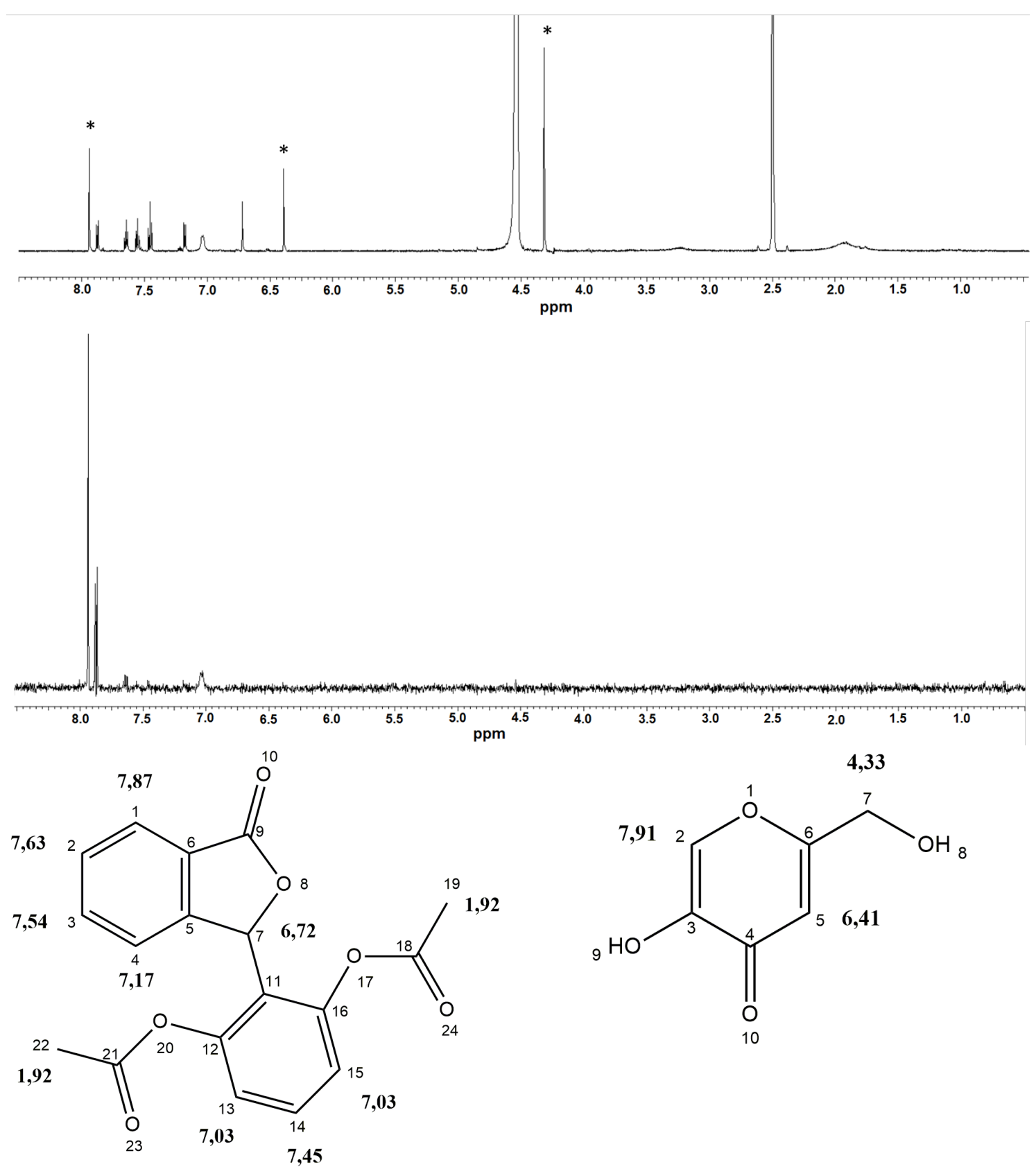

Figura 1.59: Espectros de ${ }^{1} \mathrm{H}-\mathrm{RMN}$ do composto $14 \mathrm{e}$ ácido kojic na ausência da enzima (superior) e de STD (inferior) do composto 14 + enzima após adição do ácido. Utilizou-se $2 \mathrm{mM}$ dos ligantes e $20 \mu \mathrm{M}$ da enzima. No espectro superior, o * indica os sinais referentes ao ácido kojic; os demais são referentes ao composto 14 . São representadas as estruturas do composto 14 (esquerda) e ácido kojic (direita).

Para os três casos, observou-se os sinais do ligante e do ácido kojic no mesmo espectro de STD, indicando que os dois compostos interagem com a enzima, competindo pelo sítio ativo.

Os sinais do composto 6 foram mais intensos do que os sinais do ácido kojic. No espectro de STD, houve uma variação na intensidade dos sinais do composto 6 na presença do ácido kojic quando comparado com o composto 6 
sozinho (Figura 1.53). Este fato indica que os dois inibidores estariam competindo pelo sítio ativo da enzima (Wang, 2004).

Para o composto 12, o espectro de STD, mostrou uma variação na intensidade dos sinais do composto 12 na presença do ácido kojic quando comparado com o composto 12 sozinho (Figura 1.54), além da presença de novos sinais referentes ao ácido kojic quando comparado com o STD do ácido kojic isolado (Figura 1.56). Este fato também indica que os dois inibidores estariam competindo pelo mesmo sítio da enzima.

No caso do composto 14 , houve uma variação na intensidade dos sinais na presença do ácido kojic quando comparado com o composto 14 sozinho (Figura 1.55). Este fato indica que os dois inibidores estariam competindo pelo sitio ativo da enzima. Importante observar que, diferentemente dos compostos 6 e 12, o sinal referente ao kojic aparece mais intenso no STD, indicando uma maior interação dessa molécula com a enzima quando comparado aos casos anteriores. Observou-se também que os sinais dos hidrogênios 2, 3, 13 e 15 do composto 14 aparecem com menor intensidade no STD na presença do kojic quando comparado ao STD do composto 14 livre, indicando uma menor interação do composto 14 com a presença do kojic.

Realizou-se os mesmos experimentos de STD envolvendo os compostos 6, 12 e 14 com a enzima, e em seguida, adicionando o ácido kojic, entretanto, com uma concentração de 0,26 $\mu \mathrm{M}$ de enzima. Os espectros podem ser vistos nos Anexos 67 a 69. Os resultados desses experimentos foram similares aos experimentos utilizando uma concentração maior de enzima, sempre aparecendo os sinais dos compostos $(6,12$ ou 14) e do kojic no mesmo espectro, indicando que os dois compostos estariam interagindo com a enzima e competindo pelo mesmo sítio (observado pela variação na intensidade dos sinais de STD ao adicionar o ácido kojic). Entretanto, para uma menor concentração de enzima, nota-se uma seletividade diferente, pois sinais do ácido kojic apareceram mais intensos, indicando uma maior interação desse ácido quando comparamos com os compostos 6, 12 e 14. Isso deve estar diretamente relacionado ao fato de que o ácido kojic é um inibidor mais forte que os demais compostos.

Procedeu-se também os experimentos de STD de amostras do ácido kojic com a enzima, para em seguida, adicionar os compostos 6, 12 e 14. Tais 
experimentos foram realizados com as concentrações de 0,26 $\mu \mathrm{M}$ e $20 \mu \mathrm{M}$ de enzima. Os espectros obtidos encontram-se nos anexos de 70 a 75 .

Os resultados dos experimentos de STD adicionando os compostos 6 , 12 e 14 à solução contendo ácido kojic + enzima foram os mesmos ao adicionar o ácido kojic à solução contendo os compostos 6, 12 e 14 já na presença da enzima. Os compostos 6, 12 e 14, mesmo sendo inibidores mais fracos que o kojic, conseguiram entrar no sítio ativo da enzima mesmo quando o ácido kojic já estava na solução, aparecendo sempre os sinais de ambos os compostos nos espectros (indicando interação das duas moléculas com o receptor). Entretanto, nota-se uma variação na intensidade dos sinais nos experimentos de STD, quando comparamos os compostos livres e depois os compostos na presença do ácido kojic, indicando competição pelo sítio ativo e que ela independe da ordem de adição dos compostos.

O sítio de interação do ácido kojic com a tirosinase já é conhecido na literatura: sítio do cobre (Vontzalidou, 2012). Observando os resultados dos experimentos de STD, temos evidência de uma competição entre os compostos 6, 12 e 14 com o ácido kojic pelo mesmo sítio ativo, o que leva a concluir que esses compostos também interagem com a tirosinase pelo sítio do cobre.

Realizou-se também experimentos de STD com soluções contendo os compostos 6 e 12, 6 e 14 e 12 e 14 ( 2 mM de cada), para em seguida adicionar a enzima $(20 \mu \mathrm{M})$ e observar eventual competição entre os compostos (Figuras $1.60,1.61$ e 1.62). 

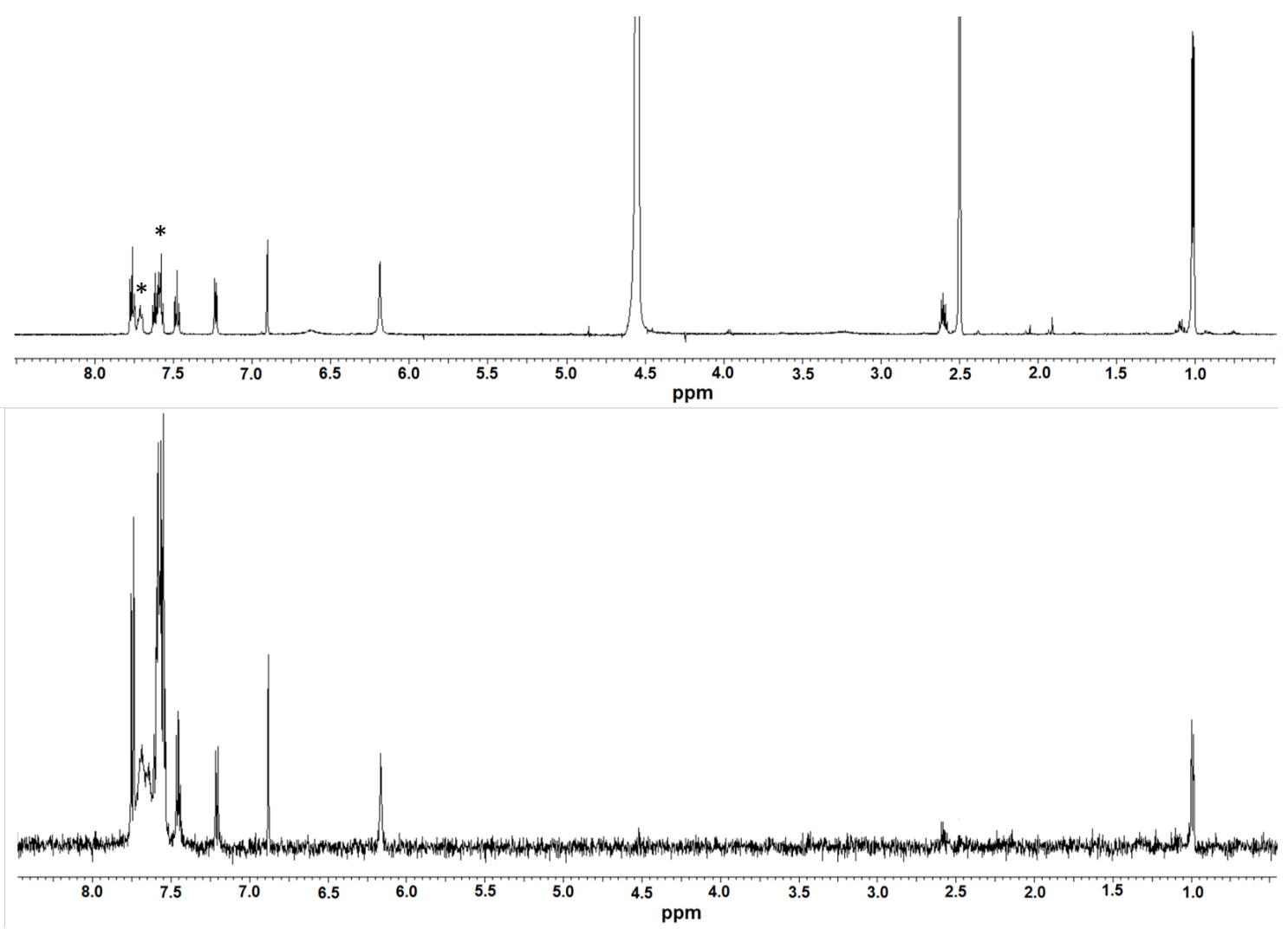<smiles>O=C1OC(O)c2c([18OH])ccc([18OH])c21</smiles>

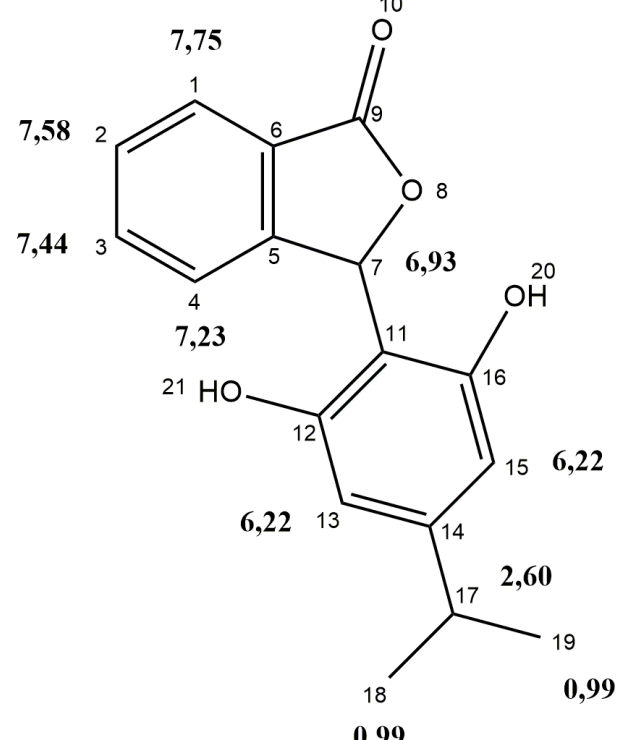

Figura 1.60: Espectros de ${ }^{1} \mathrm{H}-\mathrm{RMN}$ dos compostos 6 e 12 na ausência da enzima (superior) e de STD (inferior) dos compostos 6 e 12 em uma concentração de $2 \mathrm{mM}$, na presença de tirosinase $(20 \mu \mathrm{M})$. No espectro superior, 0 * indica os sinais referentes ao composto 6 ; os demais referem-se ao composto 12. São representadas as estruturas dos compostos 6 (esquerda) e 12 (direita). 


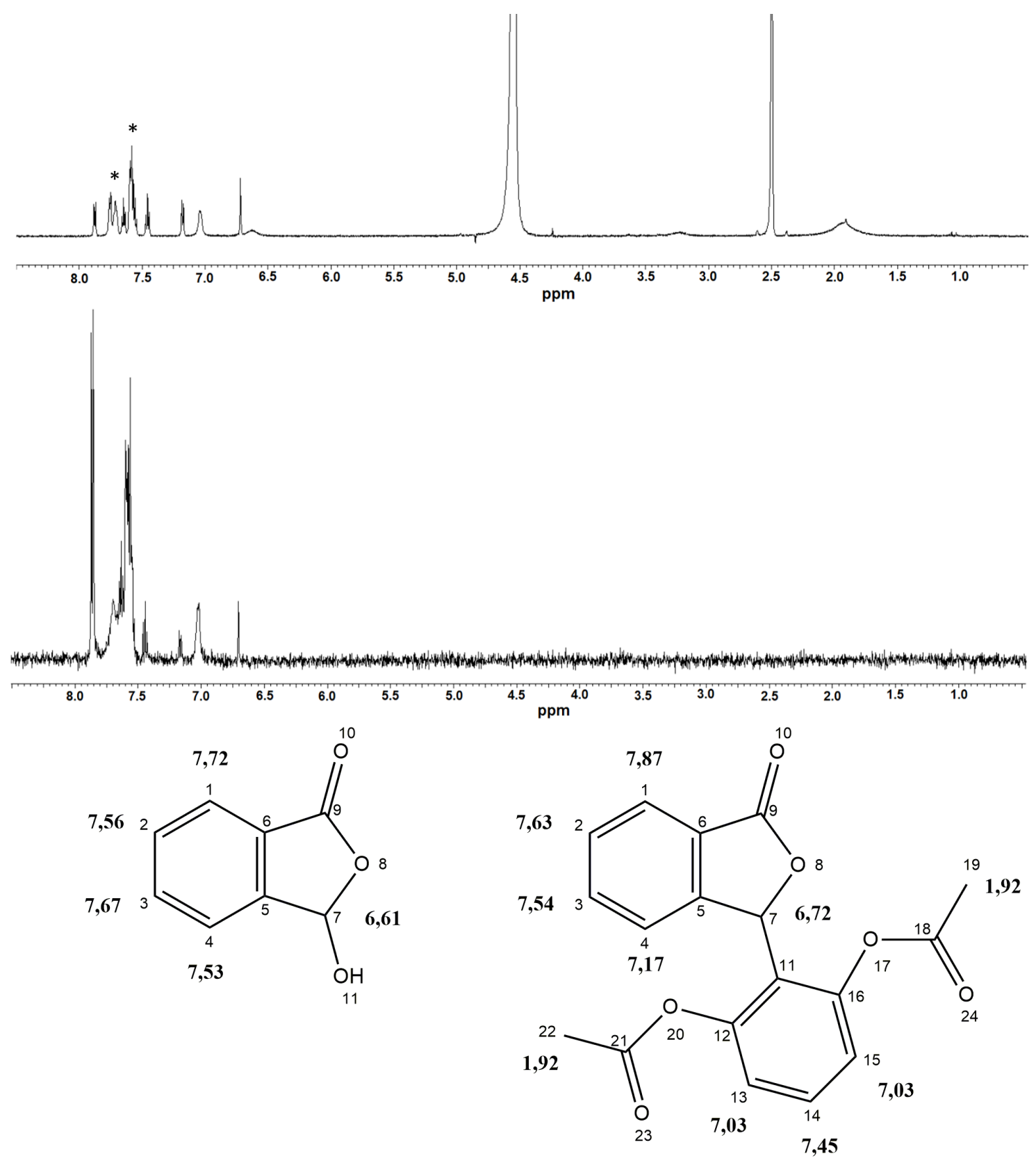

Figura 1.61: Espectros de ${ }^{1} \mathrm{H}-\mathrm{RMN}$ dos compostos 6 e 14 na ausência da enzima (superior) e de STD (inferior) dos compostos 6 e 14 em uma concentração de $2 \mathrm{mM}$, na presença de tirosinase $(20 \mu \mathrm{M})$. No espectro superior, o * indica os sinais referentes ao composto 6; os demais referem-se ao composto 14. São representadas as estruturas dos compostos 6 (esquerda) e 14 (direita). 

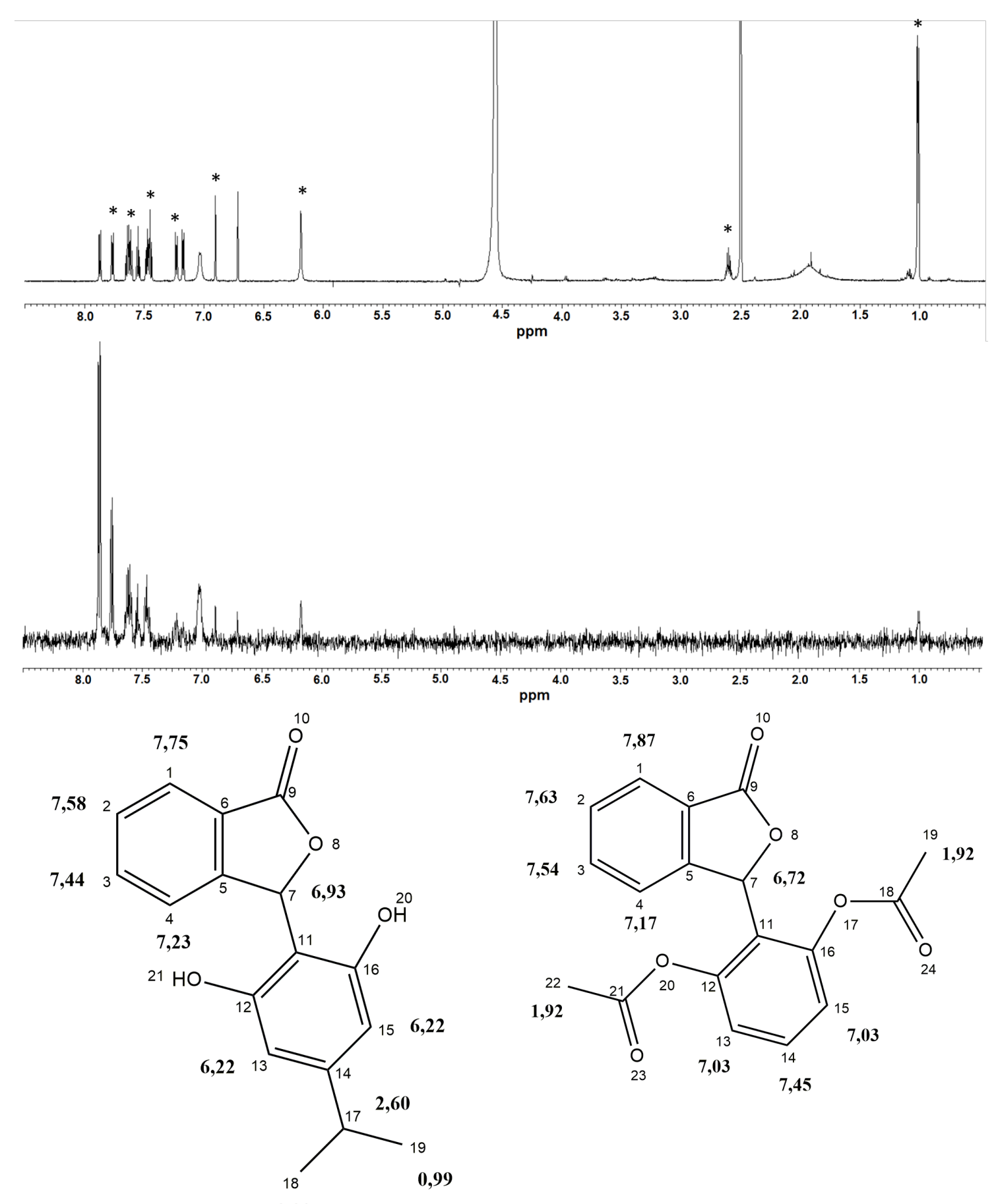

Figura 1.62: Espectros de ${ }^{1} \mathrm{H}-\mathrm{RMN}$ dos compostos 12 e 14 na ausência da enzima (superior) e de STD (inferior) dos compostos 12 e 14 em uma concentração de $2 \mathrm{mM}$, na presença de tirosinase $(20 \mu \mathrm{M})$. No espectro superior, $o^{*}$ indica os sinais referentes ao composto 12; os demais referem-se ao composto 14 . São representadas as estruturas dos compostos 12 (esquerda) e 14 (direita).

Em todos os três casos, pode-se notar que nos espectros de STD são observados sinais dos dois ligantes, o que indica a interação dos dois compostos com a enzima. Ao compararmos os espectros de hidrogênio e STD, 
observa-se ainda, para todos os casos, uma variação na intensidade dos sinais de ambos os ligantes, indicando que os dois compostos estariam competindo pelo mesmo sítio do receptor.

O mesmo estudo por STD envolvendo os pares 6 e 12, 6 e 14, 12 e 14 foi realizado utilizando também $0,26 \mu \mathrm{M}$ de concentração para a enzima (Anexos 76 a 78). A diminuição da concentração da enzima não alterou os resultados. De forma análoga, também foram observados nestes novos experimentos os sinais referentes aos dois compostos e a variação de intensidade quando comparados aos compostos isolados. Com isso, na concentração de 0,26 $\mu \mathrm{M}$, também ficou evidente a interação dos pares com a enzima e a competição entre eles pelo mesmo sítio da enzima.

Notou-se a interação dos compostos 6, 12, 14 e ácido kojic com a tirosinase pelos experimentos de STD, observando também a competitividade dos compostos, quando analisado aos pares, pelo mesmo sítio da enzima. Como o sítio de interação do ácido kojic já é conhecido na literatura (Vontzalidou, 2012), por analogia, temos indícios que os demais compostos também estão interagindo com a enzima pelo sítio do cobre.

\subsubsection{INPHARMA no Estudo de Interação Ligante-Enzima por RMN}

O INPHARMA consiste em um experimento de NOESY de uma solução contendo dois ligantes competitivos mais um receptor. Caso a interação dos dois ligantes ocorra no mesmo local do receptor, e de forma competitiva, irá ocorrer uma transferência de magnetização indireta de um ligante para o outro, mediada pelo receptor. Com isso, será observado um sinal de correlação entre os ligantes (INPHARMA NOE) no espectro de NOESY, mesmo que os ligantes nunca tenham estado próximos espacialmente.

Os espectros de NOESY dos compostos 14, 12 e $6(2 \mathrm{mM})$ na presença do ácido kojic $(2 \mathrm{mM})$ e da tirosinase $(20 \mu \mathrm{M})$, com um mixing time de $200 \mathrm{~ms}$, podem ser observados nas Figuras 1.63, 1.64 e 1.65. 

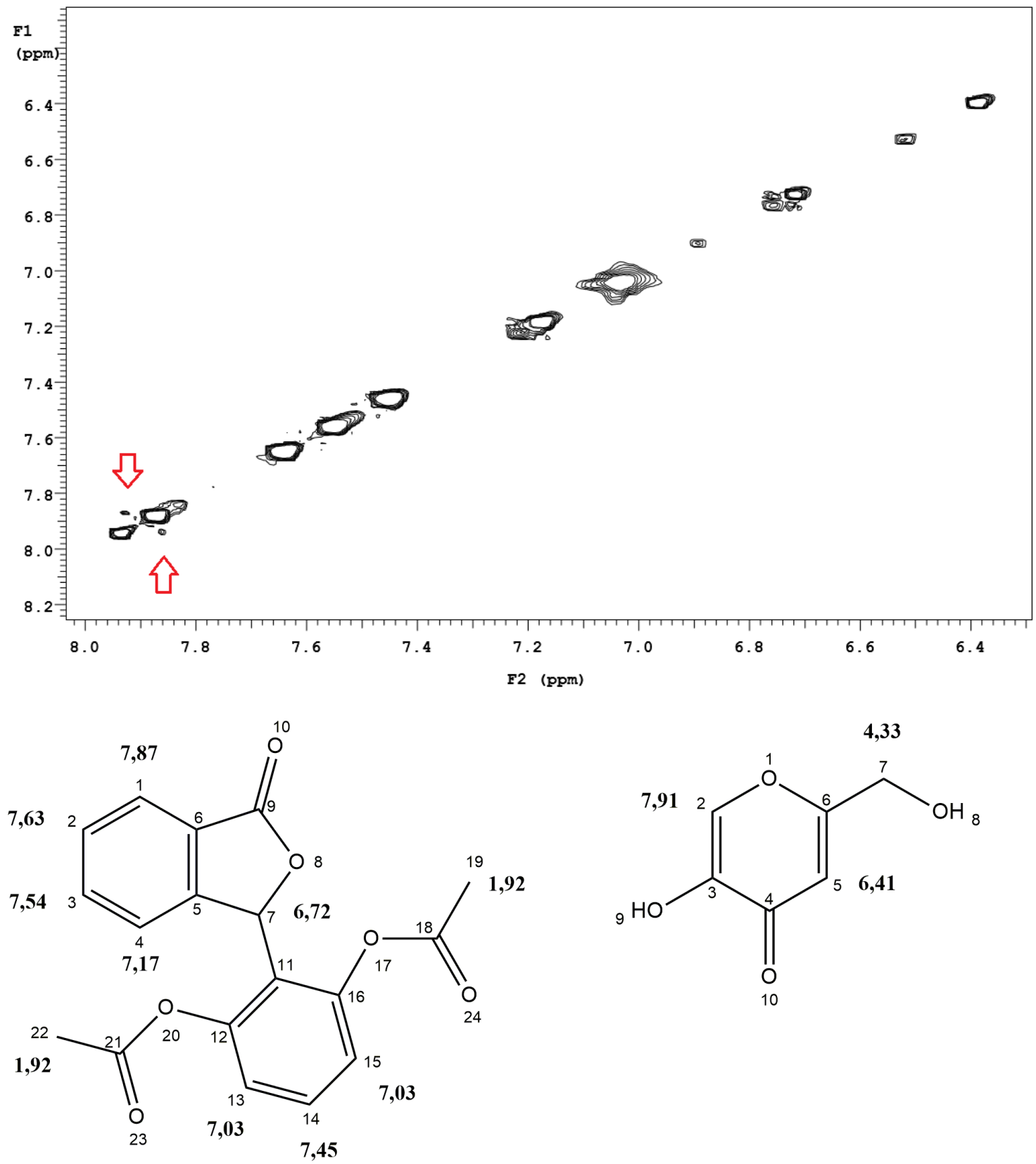

Figura 1.63: Espectro de NOESY (superior) do composto 14 (inferior esquerda) e kojic (inferior direita) na presença da tirosinase. Utilizou-se $2 \mathrm{mM}$ dos ligantes, $20 \mu \mathrm{M}$ da enzima e um mixing time de 200 ms. Destaca-se em vermelho a presença do INPHARMA NOE entre H1 do composto 14 e $\mathrm{H} 2$ do ácido kojic. 

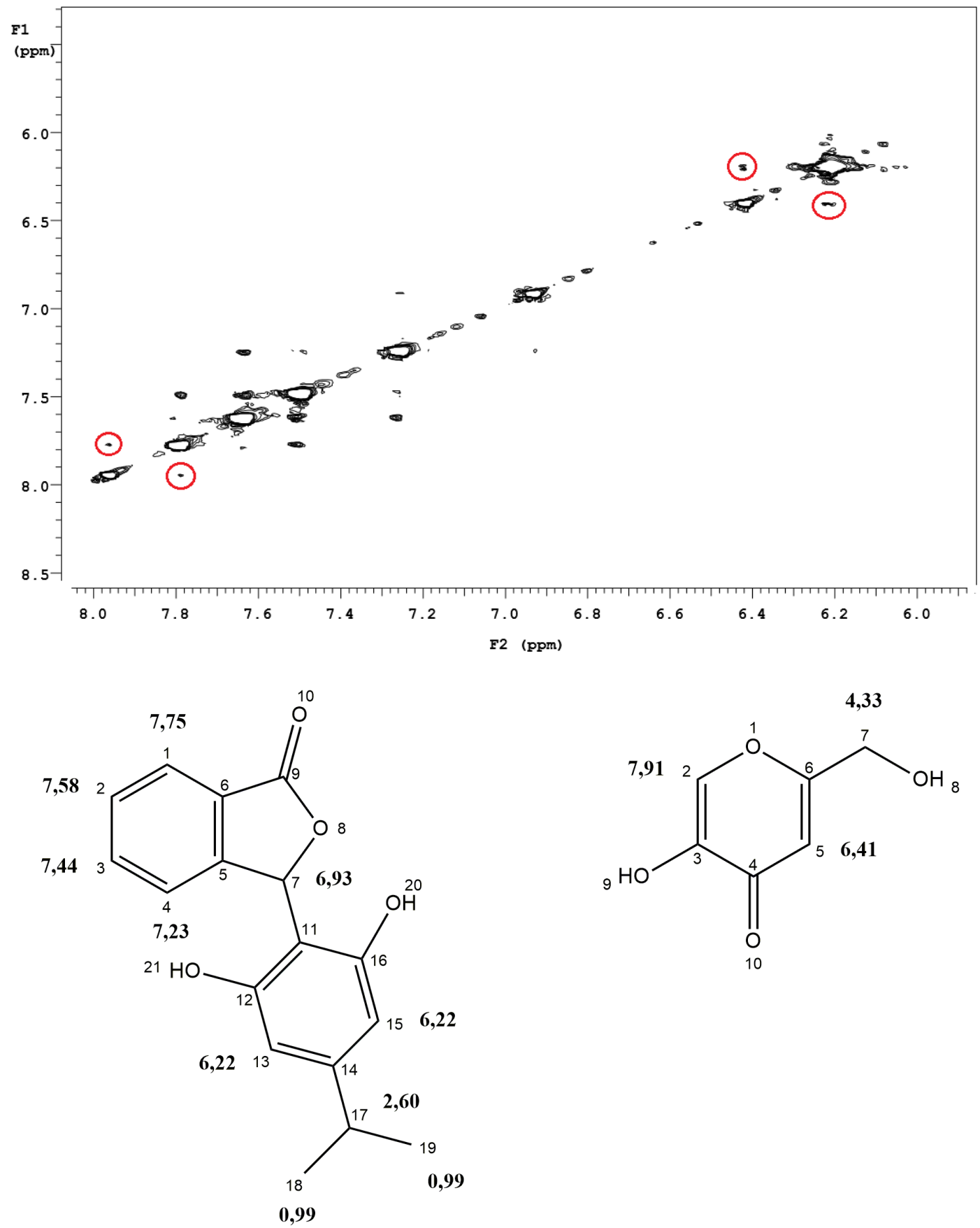

Figura 1.64: Espectro de NOESY (superior) do composto 12 (inferior esquerda) e kojic (inferior direita) na presença da tirosinase. Utilizou-se $2 \mathrm{mM}$ dos ligantes, $20 \mu \mathrm{M}$ da enzima e um mixing time de 200 ms. Destaca-se em vermelho a presença do INPHARMA NOE entre H1 do composto 12 com H2 do kojic e entre H13/15 do composto 12 com H5 do kojic. 

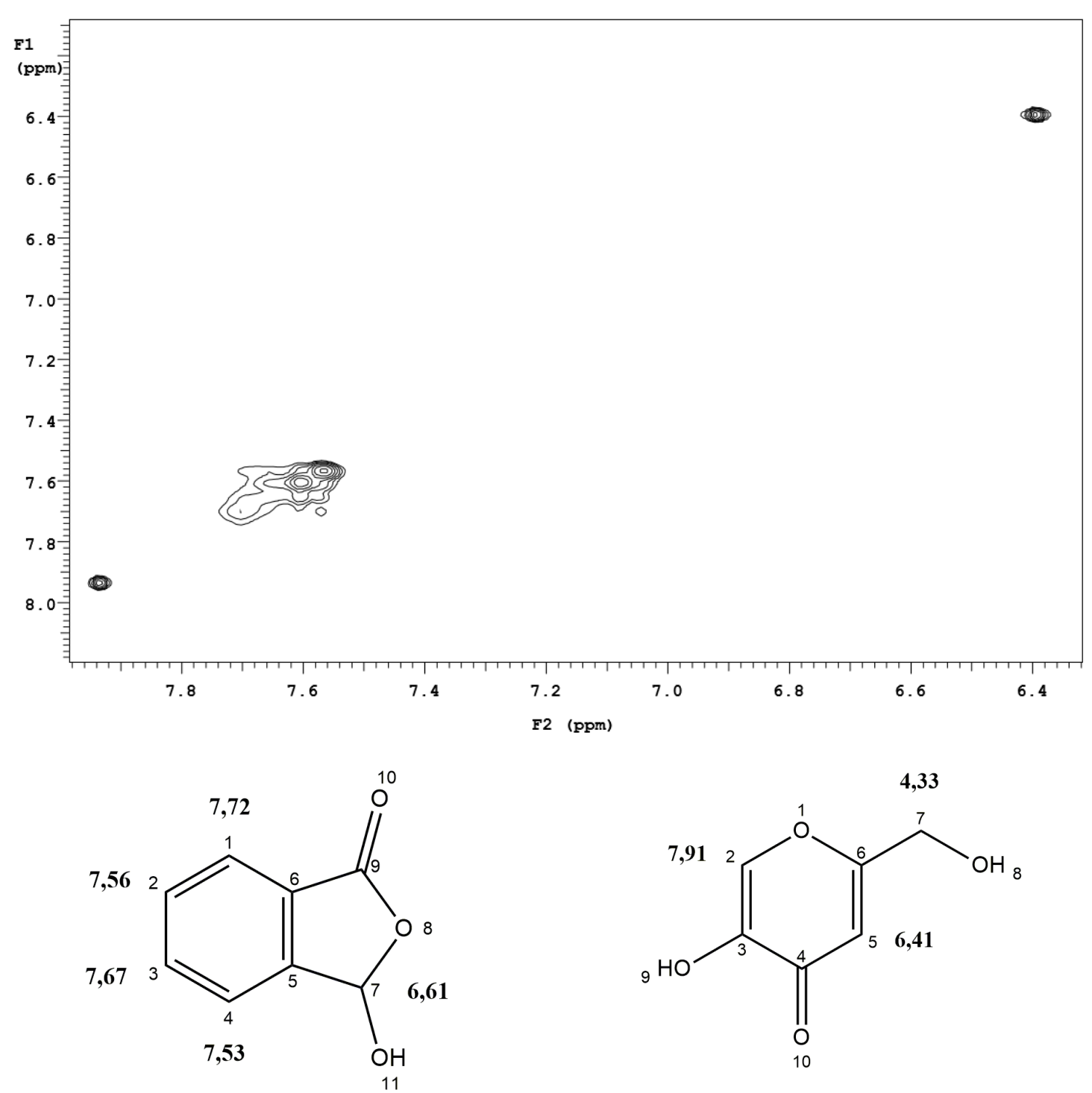

Figura 1.65: Espectro de NOESY (superior) do composto 6 (inferior esquerda) e kojic (inferior direita) na presença da tirosinase. Utilizou-se $2 \mathrm{mM}$ dos ligantes, $20 \mu \mathrm{M}$ da enzima e um mixing time de 200 ms. Não é observada a presença de INPHARMA NOE.

Analisando o espectro de NOESY da Figura 1.63, nota-se a presença de INPHARMA NOE entre o $\mathrm{H} 1$ do composto 14 e o $\mathrm{H} 2$ do ácido kojic. Este fato indica que ambos os ligantes interagem no mesmo sítio da tirosinase de forma competitiva, sendo que os hidrogênios mencionados interagem com os mesmos átomos do receptor. O mesmo fato é observado para o composto 12 (Figura 1.64), em que é observado INPHARMA NOE entre o $\mathrm{H} 1$ do composto 12 com o $\mathrm{H} 2$ do kojic e também entre $\mathrm{H} 13 / 15$ do composto 12 com o H5 do kojic.

A interação do ácido kojic já é conhecida na literatura por ocorrer no sítio do cobre da tirosinase (Vontzalidou, 2012). Com isso, os dados dos 
experimentos de INPHARMA mostram que os compostos 12 e 14 também estão interagindo pelo mesmo sítio, e de forma competitiva, fato que vai de acordo com o observado pelos experimentos de STD.

Para o composto 6 (Figura 1.65), não se observou INPHARMA NOE entre este ligante e o ácido kojic. Entretanto, este fato não indica que não houve uma competição entre os ligantes pelo mesmo sítio da enzima. Diferença nos valores de $\mathrm{Kd}$ entre os ligantes diminuem a intensidade dos INPHARMA NOEs, enquanto que valores próximos de $\mathrm{Kd}$ aumentam a intensidade deste sinal (Carlomagno 2012). Com isso, a diferença de Kd entre os dois compostos pode ser suficientemente grande para que o sinal de INPHARMA NOE não seja observado, visto que a competição destes dois ligantes pelo mesmo sítio é observada pelo experimento de STD.

Realizou-se também o experimento de NOESY do composto 6 e do ácido kojic $(2 \mathrm{mM})$, na presença da tirosinase $(20 \mu \mathrm{M})$, com um mixing time de $400 \mathrm{~ms}$ (Figura 1.66), visto que este parâmetro pode interferir na intensidade dos picos de NOE. Entretanto, não foi observado sinal de correlação entre os ligantes.

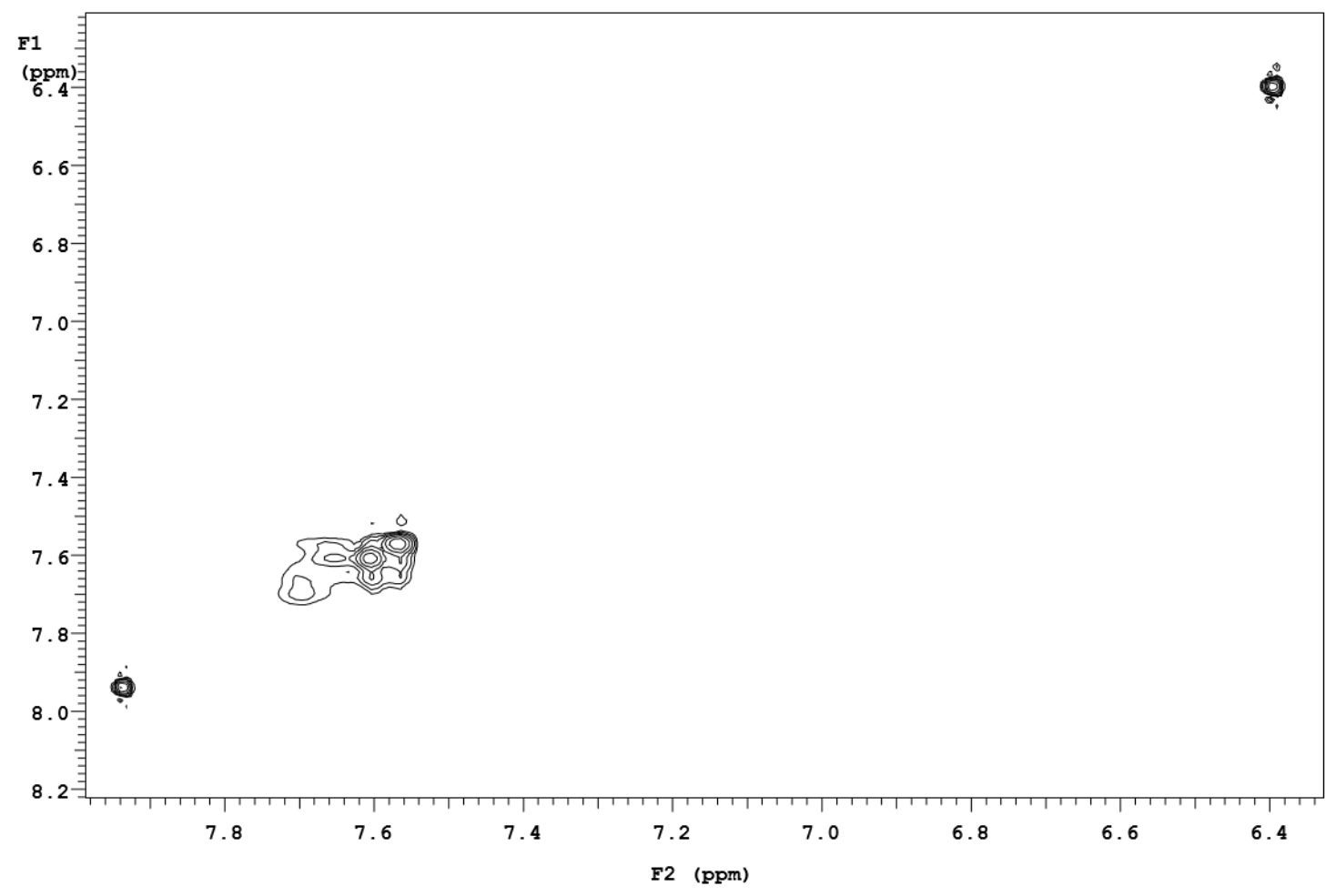



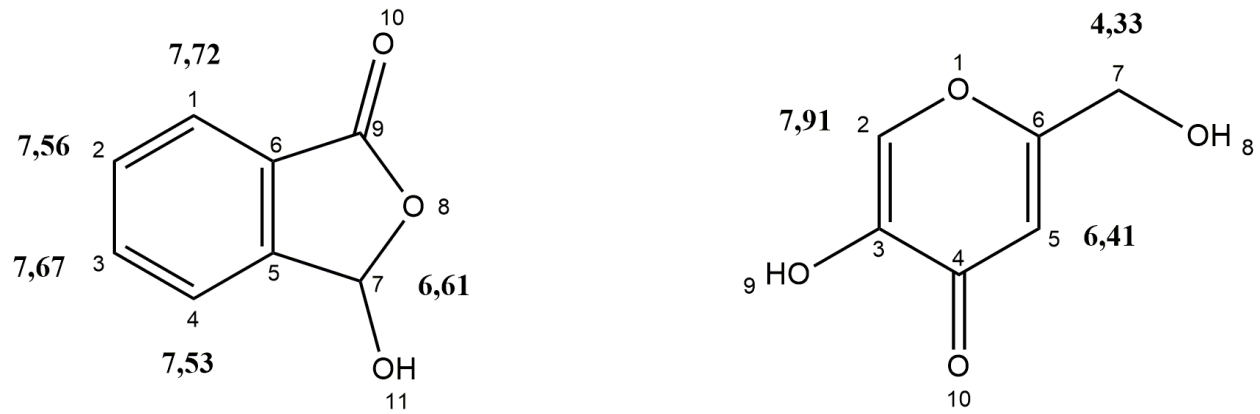

Figura 1.66: Espectro de NOESY (superior) do composto 6 (inferior esquerda) e kojic (inferior direita) na presença da tirosinase. Utilizou-se $2 \mathrm{mM}$ dos ligantes, $20 \mu \mathrm{M}$ da enzima e um mixing time de 400 ms. Não é observada a presença de INPHARMA NOE.

Procedeu-se os mesmos experimentos de INPHARMA envolvendo os compostos 14, 12 e $6(2 \mathrm{mM})$ na presença do ácido kojic ( $2 \mathrm{mM})$ e da tirosinase com um concentração mais baixa $(0,26 \mu \mathrm{M})$. Os espectros podem ser observados nos anexos de 79 a 82. Os resultados observados foram os mesmos que para $20 \mu \mathrm{M}$ de enzima. Novamente foram observados sinais de INPHARMA NOE entre o composto 14 e kojic e também para o composto $12 \mathrm{e}$ o kojic. Não foram observados sinais de correlação entre o composto 6 e 0 kojic. Nota-se que, mesmo com um concentração mais baixa de enzima, ocorre um competição entre os compostos 14/kojic e 12/kojic pelo mesmo sítio da enzima.

\subsubsection{Docking Molecular}

Os estudos de docking foram realizados com a tirosinase de $S$. castaneoglobisporus (forma oxy) pois não foram encontrados dados no PDB de A. bisporus na forma oxy, tirosinase empregada nos estudos experimentais. Com isso, realizou-se um alinhamento do sítio ativo da tirosinase das duas espécies ( $S$. castaneoglobisporus na forma oxy com a $A$. bisporus na forma desoxy) para comparação de similaridade (Figura 1.67). Apesar de alguns aminoácidos serem diferentes, de forma geral, o sítio ativo é bastante conservado entre os dois organismos. Os resíduos distintos entre as duas enzimas estão descritos na Figura 1.67. 


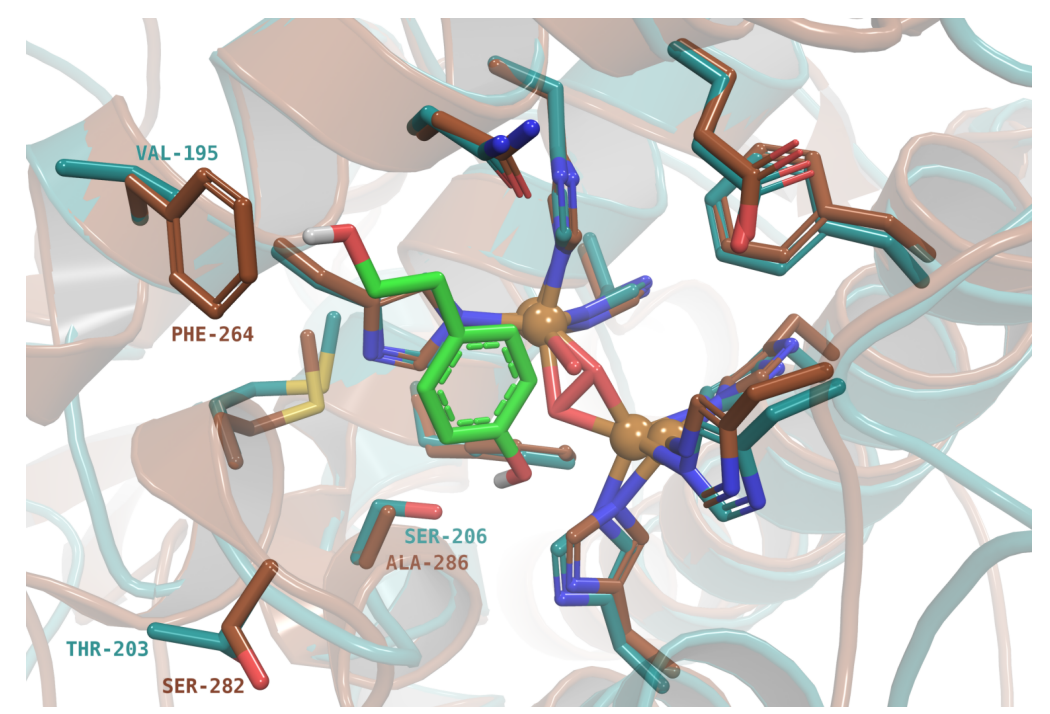

Figura 1.67: Alinhamento do sítio ativo das estruturas da tirosinase de $S$. castaneoglobisporus (verde) e A. bisporus (marrom), em que os sítios são bastante conservados. Os aminoácidos diferentes entre as espécies estão destacados.

Os estudos de redocking da L-dopa e L-tirosina foram feitos para validar o protocolo de docking utilizado. Em ambos os casos, o programa DockThor foi capaz de encontrar o modo de ligação experimental com sucesso utilizando o critério de desvio quadrático médio (RMSD) menor ou igual a 2,0 A. O modo de ligação de melhor energia para L-dopa obteve RMSD = 1,22 $\AA$. O modo de ligação experimental da L-tirosina foi encontrado como a segunda solução de melhor energia, diferindo da primeira solução em apenas $0,134 \mathrm{kcal} / \mathrm{mol}$ e obtendo RMSD = 1,47 $\AA$. As soluções de redocking obtidas para a L-dopa e para a L-tirosina podem ser vistas nas Figuras 1.68 e 1.69, respectivamente. Observa-se a proximidade das hidroxilas da L-dopa e da L-tirosina com os íons de cobre e o grupo peróxido da tirosinase. 


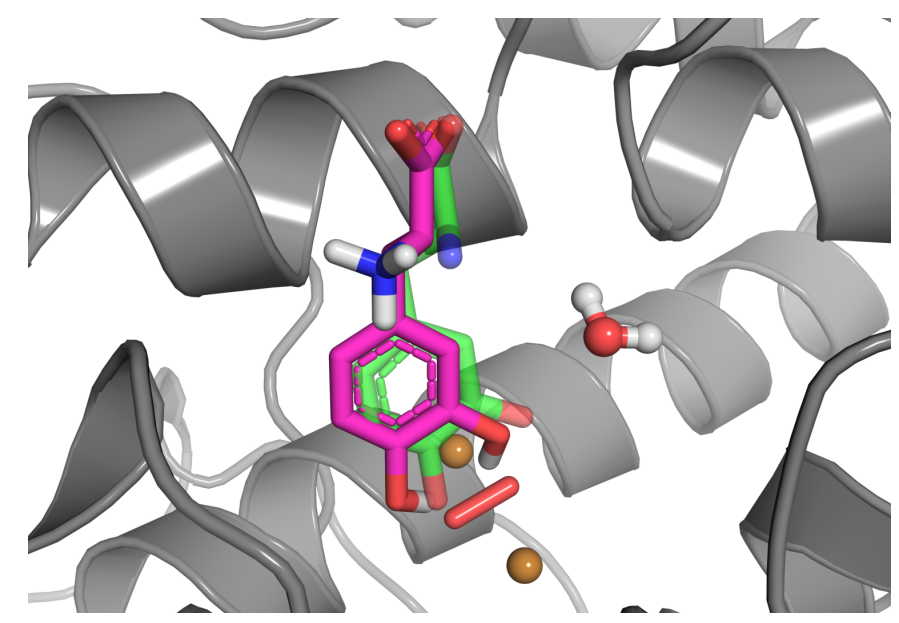

Figura 1.68: Solução obtida pelo redocking (rosa) da L-dopa, sobreposta com a conformação experimental (verde) encontrada no complexo 4p6s (código PDB) para o mesmo ligante (Ldopa). (RMSD = 1,22 A).

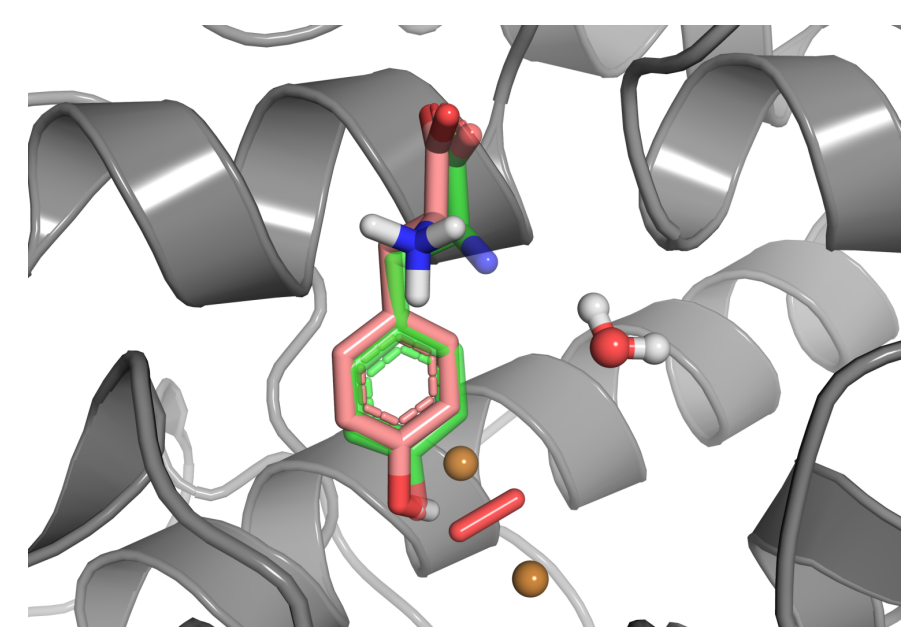

Figura 1.69: Solução obtida pelo redocking (salmão) da L-tirosina, sobreposta com a conformação experimental (verde) encontrada no complexo 4p6r (código PDB) para o mesmo ligante (L-tirosina). (RMSD = 1,47 $\AA$ ).

Dentre os diversos modos de ligação previstos pelo programa DockThor para o ácido kojic, o modo de ligação proposto na literatura (i.e. ligado aos íons de cobre em um perfil de interação bidentado com a orto-hidroxila e a carbonila) (Battaini, 2000; Sendovski, 2011) foi encontrado como a solução de $6^{\mathrm{a}}$ melhor energia, porém com energia significativamente similar à da melhor solução (diferença de $0,596 \mathrm{kcal} / \mathrm{mol}$ na energia total e $0,667 \mathrm{kcal} / \mathrm{mol}$ na energia de interação intermolecular, respectivamente -2,933 kcal/mol e -21,167 $\mathrm{kcal} / \mathrm{mol}$ para a solução de $6^{\mathrm{a}}$ melhor energia total). A solução do docking obtida para o kojic pode ser vista na Figura 1.70. Observa-se a proximidade da carbonila e da hidroxila (em orto) do kojic com os íons de cobre e peróxido da tirosinase. 


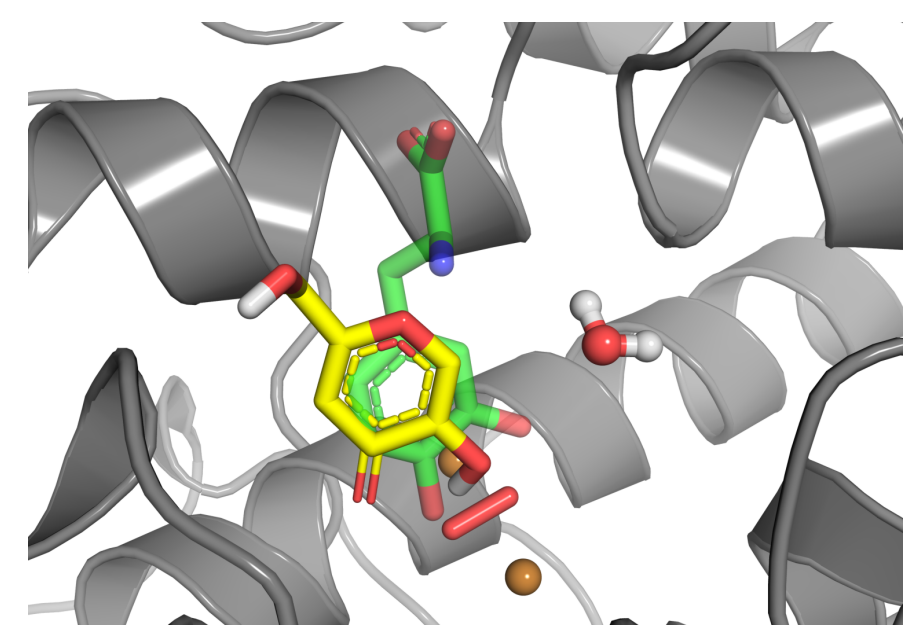

Figura 1.70: Solução do docking do ácido kojic que mais se assemelha às interações propostas na literatura (amarelo), sobreposta com a conformação experimental da L-dopa presente no complexo 4p6s (verde).

As análises de docking envolvendo os compostos 6, 12 e 14 foram realizadas considerando o modo de ligação do ácido kojic encontrado na $6^{\text {a }}$ solução de melhor energia, similar ao proposto na literatura (Battaini, 2000; Sendovski, 2011).

Para as resultados de docking do composto 14 , as duas soluções de melhor energia preditas pelo programa DockThor possuem modos de ligação que corroboram os resultados observados nos experimentos de INPHARMA, com o $\mathrm{H} 1$ do composto 14 interagindo na mesma região que $\circ \mathrm{H} 2$ do ácido kojic, especificamente com o anel indólico do $\operatorname{Trp183}(\sim 3,3 \AA)$. A segunda solução de melhor energia é a que possui a maior similaridade de posição entre estes dois átomos, e difere-se da solução de melhor energia por apenas $0,732 \mathrm{kcal} / \mathrm{mol}$ na energia total $(23,778 \mathrm{kcal} / \mathrm{mol})$ e $0,178 \mathrm{kcal} / \mathrm{mol}$ na energia de interação intermolecular $(-19,989 \mathrm{kcal} / \mathrm{mol})$. A solução do docking do composto 14 pode ser observada na Figura 1.71. 


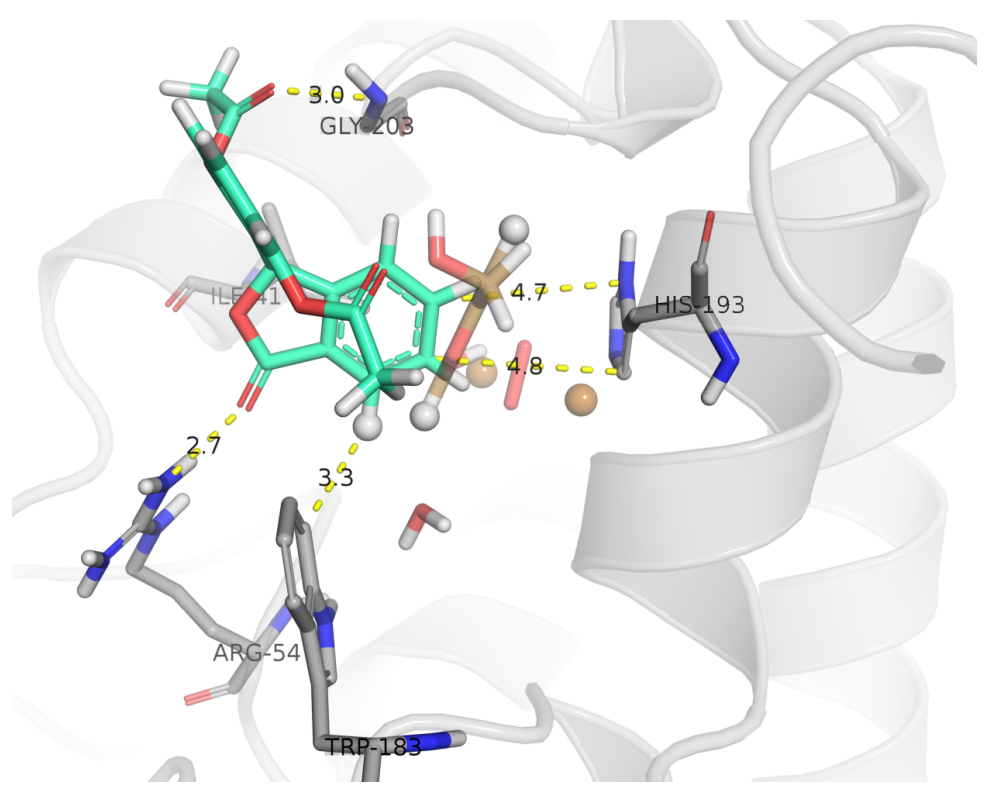

Figura 1.71: Solução do docking do composto 14 (verde) sobreposto com a solução do ácido kojic (marrom). Destaca-se o H1 (representado como esfera) do composto 14 a 3,3 $\AA$ do anel indólico do Trp183. O H2 (representado como esfera) do ácido kojic é observado na mesma região.

Para os resultados do docking do composto 12 , as duas soluções de melhor energia preditas pelo programa DockThor possuem modos de ligação que indicam interações entre os mesmos pares de átomos apontados pelos experimentos de INPHARMA: (i) H1 do composto 12 interagindo na mesma região que $\mathrm{o} \mathrm{H} 2$ do ácido kojic (solução de melhor energia), interagindo com $\mathrm{o}$ anel indólico do Trp183 ( 3,7 Å), e (ii) H13/15 do composto 12 interagindo na mesma região que o $\mathrm{H} 5$ do ácido kojic (solução de segunda melhor energia), interagindo com o carbono carbonílico da cadeia principal da Ala201 (3,0 Å). As duas soluções possuem energias similares, sendo $-19,901 \mathrm{kcal} / \mathrm{mol}$ e $-18,662$ $\mathrm{kcal} / \mathrm{mol}$ para a energia de interação intermolecular, $17,173 \mathrm{kcal} / \mathrm{mol}$ e 17,828 $\mathrm{kcal} / \mathrm{mol}$ para a energia total. As soluções de melhor energia e segunda melhor energia do docking para o composto 12 podem ser vistas na Figuras $1.72 \mathrm{e}$ 1.73 , respectivamente. 


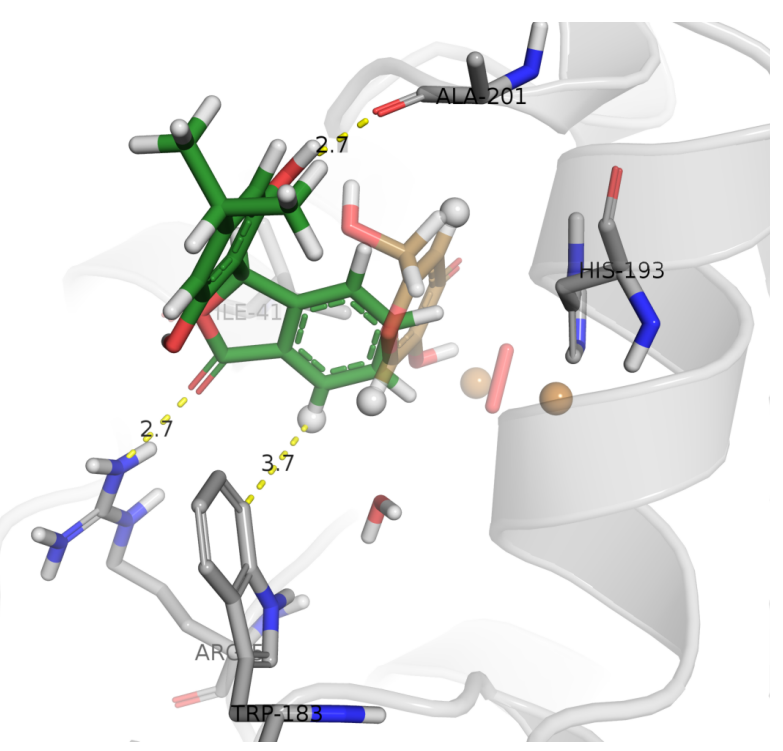

Figura 1.72: Solução de melhor energia para docking do composto 12 (verde) sobreposto com a solução do ácido kojic (marrom). Destaca-se o H1 do composto 12 a 3,7 $\AA$ do anel indólico do

Trp183. O H2 (representado como esfera) do ácido kojic é observado na mesma região.

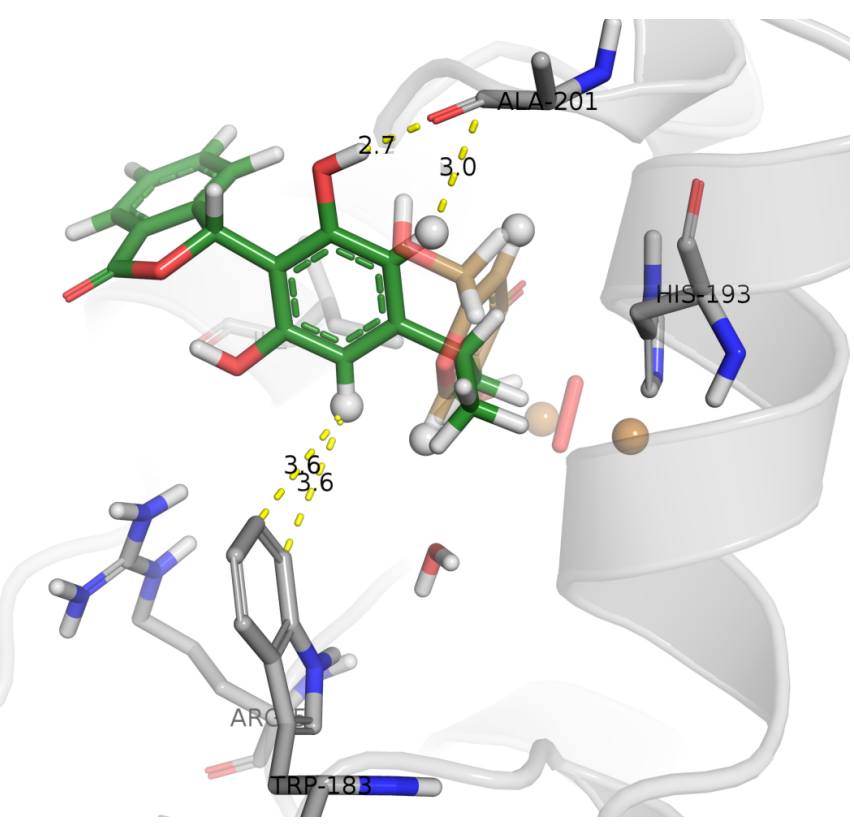

Figura 1.73: Solução de segunda melhor energia para o docking do composto 12 (verde) sobreposto com a solução do ácido kojic (marrom). Destaca-se o H13/15 (representado como esfera) do composto 12 a 2,7 $\AA$ do carbono carbonílico da cadeia principal da Ala201. O H5

(representado como esfera) do ácido kojic é observado na mesma região.

De acordo com a localização dos átomos H1 e H13/15 do composto 12, acreditamos que as interações observadas experimentalmente com a enzima, considerando respectivamente os átomos $\mathrm{H} 5$ e $\mathrm{H} 2$ do ácido kojic, não ocorram ao mesmo tempo, mas sim para modos de ligação distintos do composto 12 , como os propostos pelos experimentos de docking. 
Segundo os resultados do docking para o composto 6 , a solução de melhor energia possui a hidroxila do 011 orientada para o interior do sítio, interagindo diretamente com o peróxido de forma similar ao ácido kojic. Possui energia total igual a $-13,663 \mathrm{kcal} / \mathrm{mol}$ e energia de interação intermolecular igual a $-18,709 \mathrm{kcal} / \mathrm{mol}$. Tal solução pode ser observada na Figura 1.74 .

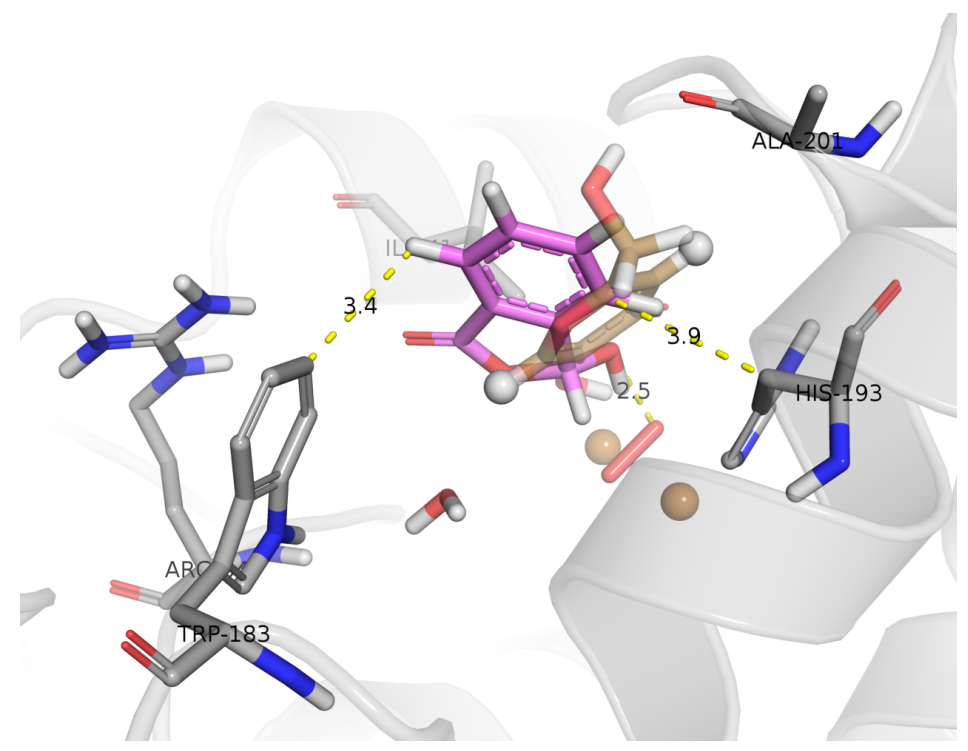

Figura 1.74: Solução para o docking do composto 6 (rosa) sobreposto com a solução do ácido kojic (marrom). Destaca-se a hidroxila (011) do composto 6 a 2,5 A do peróxido da tirosinase. Interação similar é observada para o ácido kojic.

Os cálculos mostram que os compostos 6, 12 e 14, como um todo, estão dentro do sítio ativo da tirosinase, indicando proximidade de todos os átomos de hidrogênio desses compostos com a enzima. Esses dados estão de total acordo com o que foi observado nos experimentos de STD, $\mathrm{T}_{1}$ e DOSY.

Além disso, as energias de interação intermolecular sugerem que os compostos 6, 12, 14 e kojic podem ser ordenados de acordo com a respectiva atividade biológica (tabela 1.8): kojic $(-21.167 \mathrm{kcal} / \mathrm{mol})>14(-19.989 \mathrm{kcal} / \mathrm{mol})$ $>12(-19.901 \mathrm{kcal} / \mathrm{mol})>6(-17.173 \mathrm{kcal} / \mathrm{mol})$, mostrando que o docking foi capaz de prever qual composto apresentaria a maior ou menor atividade biológica obtida experimentalmente. 


\subsection{Conclusão}

Alguns dos compostos carbonílicos selecionados e estudados apresentaram a possibilidade de duas formas tautoméricas, sendo tal equilíbrio estudado e caracterizado por RMN, Infravermelho e Espectrometria de Massa. Observou-se que temperatura, solvente e estado físico não influenciaram a forma predominante no equilíbrio, prevalecendo a forma enólica para os compostos 1, 2, 3 e 4 e a forma cetônica para o composto 5 .

Notou-se que alguns novos compostos fenólicos e carbonílicos apresentaram atividade de inibição em relação à tirosinase, variando entre $82 \mathrm{e}$ 94\% de inibição (compostos 6, 12 e 14). Os novos compostos estudados não foram tão efetivos como inibidores, quando comparados a compostos já conhecidos na literatura, como o ácido kojic. Entretanto, essa atividade moderada de inibição permitiu realizar estudos de interação desses compostos com a enzima por RMN, visto que esses estudos não são possíveis com moléculas que apresentem alta afinidade pela enzima.

Os estudos de interação por RMN possibilitaram realizar o mapeamento dos átomos dos ligantes envolvidos na interação com a tirosinase, além de observar a relação estrutura/atividade desses compostos. Notou-se que $T_{1}$, DOSY e STD foram experimentos adequados para realizar tal mapeamento, indicando a participação de todos os átomos de hidrogênio na interação com a tirosinase. Além disso, experimentos de STD e INPHARMA permitiram caracterizar os modos de inibição desses compostos como sendo competitivos. Foi possível identificar também como grupos hidroxila, metila, isopropila, e suas respectivas posições, podem influenciar na atividade biológica desses compostos.

Os modos de ligação dos ligantes com a enzima identificados por RMN também foram observados por docking molecular, indicando que estudos teóricos podem prever o modo de ligação e também a afinidade de determinados compostos pela tirosinase.

Os estudos de interação desses novos ligantes com a tirosinase, tanto por RMN, como por docking molecular, podem auxiliar no desenho e planejamento racional de novos fármacos com maiores atividades. 


\section{Capítulo II}

Estudos Estruturais e de Interação de Análogo Sintético da Somatostatina como Ativador da Tirosinase 


\subsection{Introdução}

\subsubsection{Somatostatina e Análogos Sintéticos}

A somatostatina é um neuropeptídeo cíclico que pode ser encontrado em duas formas ativas: somatostatina-14 e somatostatina-28, cujas sequências de aminoácidos apresentam 14 e 28 resíduos, respectivamente, e podem ser vistas na Tabela 2.1 (Bousquet, 2004; Guillermet-Guibert, 2005; Krenning, 1993; Wild, 2003). Pode atuar em diversos processos no organismo humano, como: regulação do sistema endócrino, inibição do hormônio do crescimento, modulação de neurotransmissores, regulação do sistema motor e cognitivo, inibição da mobilidade intestinal, absorção de nutrientes e íons, regulação do sistema imunológico e inibição da proliferação de células normais e tumorais (Behera, 2013; Bousquet, 2004; Guillermet-Guibert, 2005; Lamberts, 2002; Schartinger, 2013; Wild, 2003). No corpo humano, a somatostatina pode ser produzida pelos sistemas endócrino, gastrointestinal, imune e neural (Guillermet-Guibert 2005, Schartinger 2013). Por atuar em diversos processos biológicos, tais peptídeos se tornaram alvo de vários estudos.

Tabela 2.1: Sequências de aminoácidos da somatostatina-14 e da somatostatina-28. Em vermelho são indicados os resíduos de cisteína envolvidos em ponte dissulfeto

\begin{tabular}{|l|l|}
\hline \multicolumn{1}{|c|}{ Peptídeo } & \multicolumn{1}{c|}{ Sequência de Aminoácidos } \\
\hline Somatostatina-14 & $\begin{array}{l}\mathrm{Ala}^{1}-\mathrm{Gly}^{2}-\mathrm{Cys}^{3}-\mathrm{Lys}^{4}-\mathrm{Asn}^{5}-\mathrm{Phe}^{6}-\mathrm{Phe}^{\prime}-\mathrm{Trp}^{8}-\mathrm{Lys}^{9}-\mathrm{Thr}^{10}- \\
\mathrm{Phe}^{11}-\mathrm{Thr}^{12}-\mathrm{Ser}^{13}-\mathrm{Cys}^{14}\end{array}$ \\
\hline Somatostatina-28 & $\begin{array}{l}\mathrm{Ser}^{1}-\mathrm{Ala}^{2}-\mathrm{Asn}^{3}-\mathrm{Ser}^{4}-\mathrm{Asn}^{5}-\mathrm{Pro}^{6}-\mathrm{Ala}^{\prime}-\mathrm{Met}^{8}-\mathrm{Ala}^{9}-\mathrm{Pro}^{10}- \\
\mathrm{Arg}^{11}-\mathrm{Glu}^{12}-\mathrm{Arg}^{13}-\mathrm{Lys}^{14}-\mathrm{Ala}^{15}-\mathrm{Gly}^{16}-\mathrm{Cys}^{17}-\mathrm{Lys}^{18}-\mathrm{Asn}^{19}- \\
\mathrm{Ph}^{20}-\mathrm{Phe}^{21}-\mathrm{Trp}^{22}-\mathrm{Lys}^{23}-\mathrm{Thr}^{24}-\mathrm{Phe}^{25}-\mathrm{Thr}^{26}-\mathrm{Ser}^{27}-\mathrm{Cys}^{28}\end{array}$ \\
\hline
\end{tabular}

A atividade biológica da somatostatina ocorre pelo reconhecimento e pela interação da mesma com cinco tipos de receptores, chamados de receptores de somatostatina, que pertencem à família de receptores acoplados a Proteínas-G (Bousquet, 2004; Guillermet-Guibert, 2005; Krenning, 1993; Lamberts, 2002; Schartinger, 2013; Wild, 2003). Os cinco diferentes receptores de somatostatina apresentam alta afinidade pelas somatostatina-14 e somatostatina-28 nativas (Guillermet-Guibert, 2005; Schartinger, 2013). 
Receptores de somatostatina podem ser encontrados na membrana de células do sistema nervoso, pâncreas, tireoide, pulmão e sistema imunológico, o que permite a atuação da somatostatina nesses locais (Guillermet-Guibert, 2005). Também podem ser encontrados em células cancerígenas, como em tumores no cérebro, próstata, pulmão, pâncreas, tireoide, mama, dentre outros (Behera, 2013; Bousquet, 2004; Gabriel, 2007; Krenning, 1993; Schartinger, 2013; Wild, 2003).

Dentre as diversas atividades que a somatostatina pode exercer, duas recebem um destaque: a inibição da proliferação de determinadas células e também a de induzir a apoptose (Bousquet, 2004; Guillermet-Guibert, 2005; Scarpignato, 2001; Schartinger, 2013). A ação antiproliferativa da somatostatina pode estar relacionada com a inibição do hormônio do crescimento e de fatores de crescimento ( $\mathrm{GH}$ e insulina), inibição da angiogênese e também pela modulação do sistema imune (Bousquet, 2004; Guillermet-Guibert, 2005; Krenning, 1993).

Como é possível encontrar receptores de somatostatina em determinadas células tumorais, a somatostatina pode controlar o crescimento destas células cancerígenas e também induzir a apoptose das mesmas, o que pode tornar esse neuropeptídeo um grande aliado no combate a alguns tipos de câncer (Bousquet, 2004; Guillermet-Guibert, 2005; Krenning, 1993; Lamberts, 1991; Schartinger, 2013). Por exemplo, receptores 1 da somatostatina são encontrados em tumores na próstata, tireoide e pâncreas; receptores 2 são encontrados em tumores gastrointestinais, neuroendócrinos, neuroblastomas, mama, pulmão, leucemia e pâncreas; receptores $3 \mathrm{em}$ tumores na mama, tireoide e ovário; receptores $5 \mathrm{em}$ tumores no sistema gástrico, tireoide e próstata; receptores 4 , que ainda não foram detectados em tumores (Bousquet, 2004; Lamberts, 1991).

Entretanto, tanto a somatostatina-14 como a somatostatina-28 apresentam um tempo de meia-vida muito curto no plasma sanguíneo, variando entre 1 e 3 minutos, devido à degradação enzimática natural (Behera, 2013; Guillermet-Guibert, 2005; Melacini, 1997; Scarpignato, 2001). Por esse motivo, fica inviável a utilização das somatostatinas no combate a determinados tipos de câncer que apresentam os receptores específicos. Com isso, busca-se novos peptídeos sintéticos análogos à somatostatina nativa, que 
apresentem maior estabilidade e atividade biológica semelhante para serem utilizados principalmente no combate ao câncer (Behera, 2013; Bousquet, 2004; Guillermet-Guibert, 2005; Melacini, 1997).

Existem diversos peptídeos sintéticos análogos à somatostatina em estudo, sendo o octreotídeo, denominado FOC (Phe ${ }^{3}$-octreotídeo), o mais estudado (Behera, 2013; Lamberts, 1991; Melacini, 1997; Scarpignato, 2001). O peptídeo FOC é mais resistente à degradação enzimática, apresentando um tempo de meia-vida no plasma de 90 minutos (Guillermet-Guibert, 2005). Existem também outros análogos, derivados do octreotídeo FOC, como o TOC (Tyr ${ }^{3}$-octreotídeo) e também o NOC (Asn ${ }^{3}$-octreotídeo) que podem desempenhar atividades semelhantes à somatostatina (Behera, 2013; Jong, 1997; Lamberts, 1991; Scarpignato, 2001; Schartinger, 2013; Wild, 2003). As sequências de aminoácidos FOC, TOC e NOC podem ser vistas na Tabela 2.2.

Tabela 2.2: Sequências de aminoácidos dos peptídeos FOC, TOC e NOC análogos à somatostatina. Em vermelho são indicados os resíduos de aminoácido cisteína envolvidos em ponte dissulfeto e em azul o aminoácido na posição 3, que varia entre os análogos.

\begin{tabular}{|c|c|}
\hline Análogo & Sequência de Aminoácidos \\
\hline FOC & 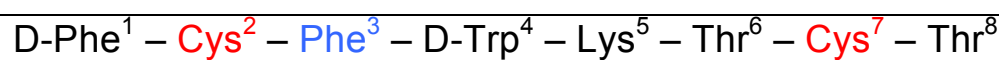 \\
\hline TOC & D-Phe ${ }^{1}-$ Cys $^{2}-$ Tyr $^{3}-$ D-Trp ${ }^{4}-$ Lys $^{5}-$ Thr $^{6}-$ Cys $^{7}-$ Thr $^{8}$ \\
\hline NOC & D-Phe ${ }^{1}-\mathrm{Cys}^{2}-\mathrm{Asn}^{3}-\mathrm{D}-\mathrm{Trp}^{4}-\mathrm{Lys}^{5}-\mathrm{Thr}^{6}-\mathrm{Cys}^{7}-\mathrm{Thr}^{8}$ \\
\hline
\end{tabular}

A introdução de D-aminoácidos nas posições 1 e 4 dos peptídeos análogos aumenta seu tempo de meia-vida, deixando o peptídeo mais resistente à degradação, pois dificulta a clivagem enzimática (Scarpignato, 2001). Além disso, os aminoácidos nas posições 3, 4, 5 e 6 são essenciais para a atividade biológica e o reconhecimento com os receptores (Scarpignato, 2001; Wild, 2003). Para manter a atividade biológica dos análogos, os aminoácidos na posição 3 podem variar entre Phe, Tyr, Asn ou His; na posição 4 deve ser sempre Trp, na posição 5 sempre Lys e, na posição 6 . Thr ou Val (Behera, 2013; Melacini, 1997; Scarpignato, 2001).

Apesar dos peptídeos análogos apresentarem atividades biológicas semelhantes à somatostatina, eles não apresentam afinidade pelos 5 tipos de receptores da somatostatina. Os análogos apresentam alta afinidade pelos receptores 2 e 5, afinidade moderada pelo receptor 3 e não apresentam 
afinidade pelos receptores 1 e 4 (Guillermet-Guibert, 2005; Lamberts, 1991; Scarpignato, 2001; Wild, 2003). Com isso, existe certa restrição da atividade dos análogos quando comparados à somatostatina nativa. Entretanto, as atividades dos análogos para os receptores 2, 3 e 5 são semelhantes às da somatostatina. Como consequência, análogos da somatostatina também podem regular a proliferação de células cancerígenas e sua apoptose, desde que estas apresentem os receptores 2, 3 e 5, como identificado em células de tumores gastrointestinais, neuroendócrinos, neuroblastomas, mama, pulmão, leucemia, pâncreas, tireoide, ovário e próstata (Bousquet, 2004; Lamberts, 1991; Lamberts, 2002). Com maior estabilidade no plasma e regulando a proliferação e a apoptose de células cancerígenas, os peptídeos análogos à somatostatina podem ser uma alternativa no combate ao câncer. Além disso, os peptídeos análogos apresentam menor toxicidade no combate ao câncer do que os medicamentos convencionalmente utilizados (Scarpignato, 2001).

Além de serem promissores no combate ao câncer, os octreotídeos análogos à somatostatina também podem apresentar papel de destaque no diagnóstico desses tumores (Behera, 2013; Gabriel, 2007; Scarpignato, 2001; Schartinger, 2013). Por apresentarem afinidade com os receptores 2, 3 e 5, presentes nas células de alguns tipos de tumores, peptídeos análogos podem ser conjugados com compostos quelantes e, em seguida, complexados com radioisótopos. Esses complexos podem ser utilizados no diagnóstico de determinados tumores por meio de exames de cintilografia por imagem, permitindo localizar a existência de tumores, assim como as dimensões do mesmo (Behera, 2013; Gabriel, 2007; Lamberts, 2002; Scarpignato, 2001; Wild, 2003). Tumores com receptores de somatostatina 2, 3 e 5 podem ser detectados utilizando essa técnica.

Compostos quelantes são conjugados ao análogo por meio do aminoácido na posição 1 pelo N-terminal (Behera, 2013; Krenning, 1993). Os compostos quelantes mais utilizados são DTPA, HYNIC e DOTA, cujas estruturas podem ser vistas na Figura 2.1 (Scarpignato, 2001). Após a introdução do grupo quelante, ocorre a complexação com um radioisótopo, como ${ }^{111} \mathrm{In},{ }^{68} \mathrm{Ga},{ }^{90} \mathrm{Y},{ }^{177} \mathrm{Lu}$ ou ${ }^{99 \mathrm{~m}} \mathrm{Tc}$ (Scarpignato, 2001). Os novos radiopeptídeos, como [ ${ }^{99 m} \mathrm{Tc}-\mathrm{HYNIC}$ - TOC], [ ${ }^{111} \mathrm{In}$ - DTPA - FOC] e [ ${ }^{90} \mathrm{Y}$ DOTA - TOC], dentre outros, são então utilizados para diagnosticar tumores 
com receptores 2, 3 e 5 da somatostatina através da emissão de partículas radioativas detectadas na cintilografia por imagem (Gabriel, 2007; Jong, 1997; Lamberts, 2002; Scarpignato, 2001; Schartinger, 2013; Wild, 2003). Um exemplo de tumor diagnosticado por imagem de cintilografia pode ser visto na Figura 2.2.

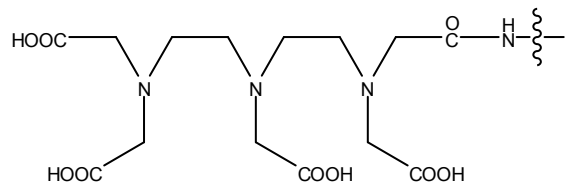

DTPA

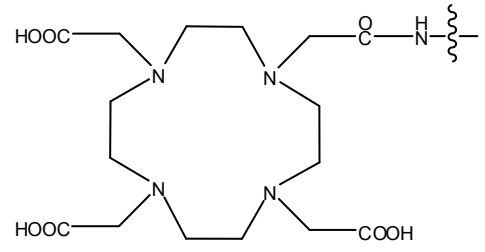

DOTA<smiles>CC(C)(C)C(=O)c1ccc(NN)nc1</smiles>

HYNIC

Figura 2.1: Estrutura dos quelantes DTPA, DOTA, HYNIC. DTPA é complexado com o radioisótopo ${ }^{111} \mathrm{In}$, DOTA com ${ }^{111} \mathrm{In},{ }^{68} \mathrm{Ga},{ }^{90} \mathrm{Y}$ e ${ }^{177} \mathrm{Lu}$ e HYNIC com ${ }^{99 \mathrm{~m}} \mathrm{Tc}$ (Scarpignato, 2001).

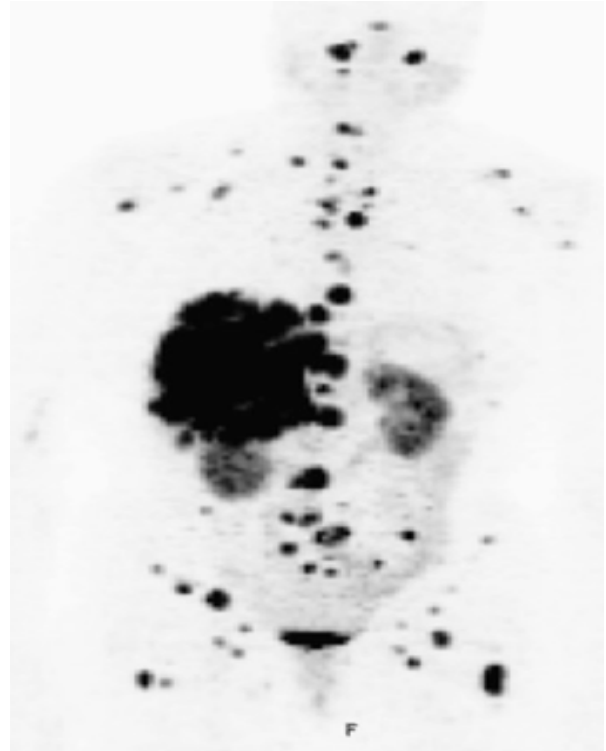

Figura 2.2: Exemplo de imagem por cintilografia para diagnóstico de tumores (metástase). As áreas mais escuras indicam a presença da lesão. Utilizou-se ${ }^{68} \mathrm{Ga}$-DOTA-TOC para tal diagnóstico (Gabriel, 2007).

Análogos à somatostatina complexados com radioisótopos além de serem utilizados no diagnóstico de determinados tumores, podem ser utilizados também no tratamento de células tumorais (Behera, 2013; Krenning, 1993; Kwekkeboom, 2008). O peptídeo com o radioisótopo pode se ligar a determinados tumores pela afinidade com os receptores 2,3 e 5 da somatostatina, e emitir partículas radioativas diretamente no tumor, controlando 
o crescimento e até diminuindo o tamanho do mesmo (Krenning, 1993; Kwekkeboom, 2008).

Existe também uma possibilidade dos peptídeos análogos à somatostatina, principalmente o TOC, apresentarem atividade em relação à enzima tirosinase. O peptídeo TOC é cíclico e apresenta uma tirosina na posição 3, deixando este aminoácido bem exposto no loop da estrutura. A enzima tirosinase consegue promover a hidroxilação e a oxidação do aminoácido tirosina, para a produção de melanina, como pode ser visto na Figura 1.1 (Nerya, 2004; Vontzalidou, 2012). Com isso, o peptídeo TOC poderia interagir com esta enzima competitivamente, visto que o peptídeo e a tirosina livre competiriam pela enzima nas reações de hidroxilação ou oxidação, diminuindo sua atividade para a produção de melanina. Este fato torna o peptídeo TOC um possível candidato para desempenhar atividades relacionadas também à enzima tirosinase.

Devido à grande importância biológica que peptídeos análogos à somatostatina apresentam, é essencial ter um conhecimento claro de sua estrutura para se estudar a relação estrutura/atividade, tornando esses peptídeos ainda mais promissores no tratamento e no diagnóstico do câncer. Para estudos de interação envolvendo peptídeos e uma proteína, é essencial obter o assinalamento completo do peptídeo (caso esteja observando os sinais do ligante) e também determinar a sua estrutura, para posteriormente proceder estudos de interação. Para tal, a RMN é uma técnica de grande importância, pois permite a determinação da estrutura de peptídeos em solução (Kay, 2011).

\subsubsection{Ressonância Magnética Nuclear (RMN) no Estudo de Peptídeos}

Para determinar a estrutura de peptídeos em solução, são realizados cálculos de estruturas utilizando parâmetros obtidos em experimentos de RMN em duas dimensões (RMN 2D), como TOCSY, HSQC, e NOESY (Sugawara, 2010).

O experimento TOCSY é utilizado para proceder o assinalamento sequencial e assinalar os átomos de hidrogênio de um determinado sistema de 
spins no peptídeo (Rule, 2006; Wüthrich, 1986). O experimento NOESY é utilizado juntamente com 0 experimento TOCSY para proceder 0 assinalamento sequencial, permitindo identificar os NOEs existentes entre os átomos de hidrogênio dos resíduos de aminoácidos vizinhos no peptídeo (Rule, 2006; Wüthrich, 1986). Experimentos de HSQC $\left({ }^{1} \mathrm{H}-{ }^{13} \mathrm{C}\right.$ e/ou $\left.{ }^{1} \mathrm{H}-{ }^{15} \mathrm{~N}\right)$ permitem assinalar os átomos de carbono e nitrogênio do peptídeo (Rule, 2006; Wüthrich, 1986).

Os valores de deslocamentos químicos dos átomos de hidrogênio, carbono e nitrogênio, em especial $H_{\alpha}, H_{\beta}, C_{\alpha}, C_{\beta}$ e $N_{H}$, são utilizados para realizar cálculos teóricos dos ângulos de diedro $\Phi$ e $\Psi$ que são essenciais para a determinação da estrutura secundária do peptídeo (Hung, 2003; Shen, 2009; Wishart, 1991; Wishart, 1992; Wishart, 1995). As intensidades dos NOEs assinalados pelo espectro NOESY podem ser convertidas em restrições de distância para o cálculo de estrutura, tornando possível estabelecer um valor aproximado de distância entre átomos de hidrogênio pela intensidade do NOE (Pavia, 2010; Rule, 2006; Wüthrich, 1986).

As restrições de distâncias e os ângulos diedro podem ser utilizados como parâmetros para cálculos estruturais de otimização de geometria, com refinamento por dinâmica molecular com o método de "simulated annealing" (Kannan, 2009; Son, 2012). Com isso, é possível a determinação da estrutura tridimensional de peptídeos e proteínas em solução. 


\subsection{Objetivos}

- Selecionar, sintetizar, caracterizar e purificar peptídeos análogos à somatostatina com possível atividade em relação à enzima Tirosinase;

- Determinar a estrutura dos peptídeos análogos utilizando RMN e cálculos teóricos;

- Proceder ensaios biológicos para verificar a atividade dos peptídeos análogos em relação à enzima Tirosinase;

- Realizar estudos de interação peptídeo-enzima por RMN, cálculos teóricos e Espectrometria de Massa. 


\subsection{Metodologia}

\subsubsection{Síntese do Peptídeo Análogo à Somatostatina}

Realizou-se a síntese do peptídeo análogo à somatostatina, denominado TOC ( $\mathrm{Tyr}^{3}$-octreotídeo), com a seguinte sequência de aminoácidos: D-Phe ${ }^{1}-$ Cys $^{2}-$ Tyr $^{3}-$ D-Trp ${ }^{4}-$ Lys $^{5}-$ Thr $^{6}-$ Cys $^{7}-$ Thr $^{8}$ (ol). Tal síntese foi realizada em fase sólida, utilizando a estratégia Fmoc (Benoiton, 2005; Chan, 2000; Fields, 1990; Pires, 2014).

A síntese foi realizada manualmente, dentro de uma seringa, com auxílio de um filtro, ambos de polipropileno. Utilizou-se a resina L-Thr-(tBu)-ol-2clorotritil como suporte para a fase sólida. A escala de síntese escolhida foi para a produção de $0,1 \mathrm{mmol}$ de peptídeo, e para isso foram utilizados 166,67 mg de resina (grau de substituição de 0,60 mmol. $\mathrm{g}^{-1}$ ).

Lavou-se a resina com 2-propanol e N,N-dimetilformamida (DMF) (três vezes cada, alternadamente), para a retirada de eventuais impurezas. Tanto o propan-2-ol como a DMF foram retirados da seringa com o auxílio de filtração a vácuo.

Em continuidade, como a síntese é realizada no sentido C-terminal para o N-terminal, e o aminoácido na posição 8 já está acoplado na resina, adicionou-se o aminoácido da posição 7, a cisteína (Fmoc-Cys(Trt)-OH), na seringa de síntese para acoplá-lo ao aminoácido 8 . Foi utilizado 0,4 mmol de derivado de aminoácido (o que equivale a um excesso molar de 4 vezes). Adicionou-se também 0,4 mmol de HBTU, 0,8 mmol de DIPEA e 1,5 $\mathrm{mL}$ de DMF. Deixou-se reagir por $1 \mathrm{~h} 30$ sob agitação moderada e constante.

Após esse período, o produto foi filtrado a vácuo e novamente lavado com 2-propanol, DMF e diclorometano (mesmo procedimento de lavagem citado anteriormente).

Para verificar se houve o acoplamento de um aminoácido a outro, realizou-se o teste da ninidrina, utilizado para a detecção de grupo amino livre (Kaiser, 1970; Pires, 2014; Troll, 1953). Para isso, adicionou-se em um tubo de ensaio alguns grãos da amostra, uma gota de uma solução feita com $2 \mathrm{~mL}$ de KCN (1 mmol. $\mathrm{L}^{-1}$ ) e $98 \mathrm{~mL}$ de piridina, duas gotas de uma solução de fenol 
$80 \%$ (em massa) em etanol, e uma gota de solução de ninidrina a $5 \%$ em etanol. A mistura foi aquecida a $110{ }^{\circ} \mathrm{C}$ por três minutos. A mudança de coloração dos grãos da amostra para marrom (ou azul) indica a presença do grupo $-\mathrm{NH}_{2}$ livre e, consequentemente, o não acoplamento. A inexistência de mudança na coloração dos grãos indica a ausência do grupo $-\mathrm{NH}_{2}$ livre, e consequentemente, o acoplamento de um aminoácido a outro (Kaiser, 1970; Pires, 2014; Troll, 1953).

Como o resíduo de aminoácido acoplado possui o grupo Fmoc como protetor temporário, foi necessário realizar a desproteção (remoção do grupo Fmoc) para proceder o acoplamento do próximo resíduo de aminoácido. Para tal, utilizou-se uma solução de 4-metilpiperidina:DMF (1:4, v:v) (adição de 2,5 a 3,0 mL), sob agitação, por 15 min, procedimento realizado duas vezes para a remoção desse grupo, possibilitando dar continuidade ao acoplamento do próximo derivado de aminoácido. Para verificar se houve a desproteção do resíduo de aminoácido, havendo a formação do grupo amino livre, realizou-se novamente o teste da ninidrina.

Com resíduo de aminoácido da posição 7 desprotegido, realizou-se 0 acoplamento do derivado aminoácido da posição 6 , a treonina. O procedimento realizado para acoplar esse segundo derivado de aminoácido foi o mesmo utilizado para a ligação do primeiro derivado de aminoácido. Uma tabela com os derivados de aminoácidos utilizados na síntese, mostrando o grupo protetor permanente (i.e., da cadeia lateral) e o temporário (Fmoc), a massa utilizada de cada aminoácido e também a massa molecular estão mostrados na Tabela 2.3.

Tabela 2.3: Massa molecular dos aminoácidos utilizados com seus respectivos grupos protetores temporários (Fmoc) e permanentes (Trt, Boc, e tButil) e massa, em miligramas, para

\begin{tabular}{ccc}
\hline Fmoc-aminoácidos & MM (g/mol) & Massa para 0,4 mmol (mg) \\
\hline Fmoc-Cys(Trt)-OH & 585,7 & 234,2 \\
Fmoc-Lys(Boc)-OH & 468,5 & 187,4 \\
Fmoc-Thr(tButil)OH & 397,5 & 159,0 \\
Fmoc-Phe-OH & 387,4 & 155,0 \\
Fmoc-D-Phe-OH & 387,4 & 155,0 \\
Fmoc-D-Trp(Boc)-OH & 526,6 & 210,6 \\
Fmoc-Tyr(tButil)-OH & 459,6 & 183,8 \\
\hline
\end{tabular}


Para os acoplamentos dos derivados de aminoácidos seguintes foi realizado o mesmo procedimento: inicialmente desprotegendo-se o resíduo de aminoácido já acoplado e, em seguida, adicionando-se 0,4 mmol do Fmocaminoácido a ser acoplado, 0,4 mmol de HBTU (156 mg), uma quantidade menor do que 0,8 mmol de DIPEA $(132 \mu \mathrm{L})$ e 1,5 $\mathrm{mL}$ de DMF, sempre com 1 h30 de reação. Esse procedimento foi empregado até o acoplamento do derivado de aminoácido da posição 1 , a fenilanalina.

Após realizar o acoplamento de todos os Fmoc-aminoácidos da sequência, iniciou-se o processo de clivagem da resina do peptídeo sintético, processo que também visa remover os grupos protetores permanentes das cadeias laterais dos resíduos de aminoácidos (Benoiton, 2005; Chan, 2000; Fields, 1990; Pires, 2014). Adicionou-se em um tubo tipo falcon de $50 \mathrm{~mL}$ a resina contendo o peptídeo sintetizado e $10 \mathrm{~mL}$ de uma solução contendo $81,5 \%$ de TFA, $5 \%$ de tioanisol, $5 \%$ de fenol, $5 \%$ de água, 2,5\% de EDT e $1 \%$ de TIS (em volume). Tampou-se o tubo e a mistura foi deixada para reagir por 1h30min sob agitação. Após reação, borbulhou-se nitrogênio gasoso na solução para evaporar o TFA e os demais solventes.

Com o auxílio de um funil com placa sinterizada acoplado a um sistema de filtração a vácuo, lavou-se o peptídeo clivado com éter diisopropílico gelado. Em seguida, o peptídeo foi extraído com $50 \mathrm{~mL}$ de água e depois com $50 \mathrm{~mL}$ de uma solução água:acetonitrila 1:1. As soluções contendo o peptídeo sintético foram recolhidas em tubos de $50 \mathrm{~mL}$, congeladas e, por fim, liofilizadas.

A síntese foi realizada também em um sintetizador automático Prelude (Protein Technologies, Inc.). Utilizou-se a mesma escala de síntese, mesma resina e os mesmos $\mathrm{Fmoc}$ aminoácidos. Como o sintetizador não realiza o teste da ninhidrina, cada etapa de acoplamento de um novo resíduo de aminoácido e cada etapa de desproteção do grupo Fmoc foi realizada duas vezes, para garantir um melhor rendimento da síntese. O peptídeo sintetizado pelo sintetizador automático foi clivado manualmente, mesmo procedimento descrito anteriormente para o peptídeo sintetizado manualmente.

Os peptídeos sintéticos foram oxidados para a formação da cistina (ciclização dos mesmos - formação de ponte dissulfeto entre as cisteínas). 
Realizou-se três diferentes estratégias para a oxidação, tanto com o peptídeo sintetizado manualmente como para o sintetizado de forma automática.

O peptídeo obtido foi dividido em três partes. Para a primeira parte, o peptídeo foi ressuspendido em $5,0 \mathrm{~mL}$ de água e deixado em contato com o ar para a oxidação com o oxigênio por 24h (Howl, 2005). Em seguida a solução foi liofilizada. Com a segunda parte do peptídeo sintético, realizou-se a oxidação com a adição de 2 equivalentes de trifluoracetato de tálio ( $\left.\operatorname{TI}(\operatorname{TFA})_{3}\right)$ e $5 \mathrm{~mL}$ de DMF, com agitação por 1h30; em seguida a solução foi liofilizada (Howl, 2005). Com a última parte do peptídeo sintético, realizou-se a oxidação com a adição de 10 equivalentes de $\mathrm{I}_{2}$ e $5 \mathrm{~mL}$ de uma solução de metanol:acetonitrila:água (2:3:1 em volume) com agitação por 1h30, e em seguida a solução foi liofilizada (Behera, 2011; Chandra, 2009; Howl, 2005)

\subsubsection{Purificação e Caracterização do Peptídeo Análogo Sintético}

O peptídeo sintetizado foi ressuspendido em água Milli-Q e purificado por cromatografia líquida ultra-rápida (UFLC) (Shimadzu LC-20AD) com um espectrofotômetro como detector. As análises foram feitas em temperatura ambiente $\left(25^{\circ} \mathrm{C}\right)$ com monitoramento em $216 \mathrm{~nm}$ (Leite, 2005).

Utilizou-se uma coluna Shim-Pack XR-ODS (Shimadzu) com partículas de $2,2 \mu \mathrm{m}$, um fluxo de $0,4 \mathrm{~mL} / \mathrm{min}$ e um gradiente de eluição com água Milli-Q e acetonitrila como solventes, ambos com 0,1 \% de TFA (Finkina, 2007; NevesFerreira, 2002). O gradiente de eluição está descrito na Tabela 2.4.

Tabela 2.4: Gradiente de eluição para a purificação por UFLC.

\begin{tabular}{cc}
\hline Tempo (min) & Acetonitrila (\%) \\
\hline $0-2,5$ & 5 \\
$2,5-17,5$ & $5-40$ \\
$17,5-20,0$ & $40-80$ \\
$20,0-23,0$ & 80 \\
\hline
\end{tabular}

As frações observadas no cromatograma foram coletadas manualmente e analisadas por espectrometria de massa do tipo Q-TOF (micrOTOF-QII, Bruker) para identificação e caracterização de qual fração seria referente ao peptídeo análogo sintetizado. Adquiriu-se espectros de massa simples (MS) e 
massa/massa (MS/MS) para caracterização, utilizando as séries y e b de fragmentação (Biemann, 1994; Cantu, 2008; Sun, 2011).

As análises de Massa foram realizadas em modo positivo de análise, utilizando apenas água Milli-Q como solvente, uma voltagem no capilar de 4,5 kV e um fluxo de 2,0 $\mu \mathrm{L} / \mathrm{min}$. Para a calibração, utilizou-se um calibrante externo próprio para ionização do tipo eletrospray (ESI) e peptídeos, ESITuning Mix (Agilent Technologies). A solução para calibrar o equipamento foi preparada utilizando $500 \mu \mathrm{L}$ do calibrante, $10 \mu \mathrm{L}$ de $\mathrm{ACN}$ e $10 \mu \mathrm{L}$ de $\mathrm{H}_{2} \mathrm{O}$.

Após caracterizar todas as frações coletadas no UFLC por espectrometria de Massa, notou-se que duas frações diferentes apresentavam a massa e a sequência de aminoácidos referentes ao peptídeo sintetizado. Tais frações, denominadas de P1 e P2, foram coletadas separadamente e novamente submetidas à UFLC em temperaturas de 30,40 e $60{ }^{\circ} \mathrm{C}$, utilizando as mesmas condições experimentais anteriores. O gradiente de eluição para as análises de P1 e P2 em diferentes temperaturas está descrito na Tabela 2.5.

Tabela 2.5: Gradiente de eluição para análises de P1 e P2 por UFLC com temperaturas de 30, 40 e $60{ }^{\circ} \mathrm{C}$.

\begin{tabular}{cc}
\hline Tempo (min) & Acetonitrila (\%) \\
\hline $0-5,0$ & 5 \\
$5,0-20,0$ & $5-40$ \\
$20,0-25,0$ & $40-80$ \\
$25,0-23,0$ & 80 \\
\hline
\end{tabular}

Realizou-se também análises por UFLC de uma amostra comercial de HYNIC-TOC (ABX - Advanced Biochemical Compounds). Estas análises foram realizadas a temperatura ambiente $\left(25^{\circ} \mathrm{C}\right)$, utilizando os mesmos solventes, coluna, equipamento e fluxo descritos anteriormente. O gradiente de eluição utilizado foi o mesmo descrito na Tabela 2.4.

\subsubsection{Determinação Estrutural do Peptídeo Análogo Sintético}

Para determinação estrutural dos octreotídeos análogos à somatostatina oriundos das frações P1 e P2 (denominados TOC1 e TOC2, respectivamente) foram realizados experimentos de RMN juntamente com cálculos. 
Os experimentos de RMN foram realizados em um espectrômetro Bruker Avance III 18,8 T (800 MHz para hidrogênio) com uma sonda de tripla ressonância de detecção inversa a temperatura ambiente (Bruker TXI $1 \mathrm{H} / 15 \mathrm{~N} / 13 \mathrm{C}$ ), com gradiente de campo e $5 \mathrm{~mm}$ de diâmetro, a uma temperatura controlada de $298 \mathrm{~K}$. Utilizou-se $\mathrm{H}_{2} \mathrm{O} / \mathrm{D}_{2} \mathrm{O}(90 \% / 10 \%)$ como solvente, e se trabalhou com a amostra a uma concentração de $1 \mathrm{mmol} / \mathrm{L}$ em um volume de 0,6 $\mathrm{mL}$.

Foram adquiridos espectros ${ }^{1} \mathrm{H}-\mathrm{RMN}$, TOCSY, HSQC $\left({ }^{1} \mathrm{H}-{ }^{13} \mathrm{C}\right)$ e ROESY. Utilizou-se o sinal da $\mathrm{H}_{2} \mathrm{O}$ a $298 \mathrm{~K}$ em 4,773 ppm para referenciar o espectros. Os experimentos de hidrogênio foram realizados com 8 scans, utilizando-se a técnica excitation sculpting para eliminação do sinal da água (Hwang, 1995). Os parâmetros de aquisição dos experimentos 2D podem ser observados na Tabela 2.6. O experimento HSQC foi dividido em região aromática e região alifática. No HSQC alifático utilizou-se uma janela espectral de 80 ppm, com o centro da janela em 39 ppm; no HSQC aromático utilizou-se uma janela espectral de 40 ppm, com o centro da janela em 124 ppm. O experimento $\mathrm{HSQC}$ adquirido foi $\mathrm{HSQC}$ editado, em que $-\mathrm{CH}$ e $-\mathrm{CH}_{3}$ são sinais positivos e $-\mathrm{CH}_{2}$ é negativo. O experimento TOCSY foi adquirido utilizando a sequência MLEV para spin-lock (Levitt, 1986) e a técnica excitation sculpting para eliminação do sinal da água (Hwang, 1995). Utilizou-se o valor de $60 \mathrm{~ms}$ de mixing time para o experimento de TOCSY. Todos os experimentos foram adquiridos no modo sensível à fase.

Tabela 2.6: Parâmetros de aquisição para os experimentos de RMN 2D. F1 corresponde ao número de scans por incremento e F2 o número de incrementos.

\begin{tabular}{ccc}
\hline Experimentos & F1 & F2 \\
\hline TOCSY & 16 & 512 \\
HSQC alifático & 128 & 128 \\
HSQC aromático & 64 & 64 \\
ROESY & 32 & 512 \\
\hline
\end{tabular}

Os FIDs obtidos foram processados utilizando os programas NMRPipe e NMRDraw (Delaglio, 1995). Para o processamento, aplicou-se a função "cosine-bells" em cada dimensão e também uma função polinomial para correção da linha base. Os ajustes de fase foram realizados manualmente 
utilizando o programa NMRDraw. Utilizou-se o programa NMRView 5.0 (Kirby, 2004) para assinalamento dos espectros.

Os parâmetros de deslocamento químico e ROE, obtidos pelos experimentos de $\mathrm{RMN}$, foram usados para cálculos estruturais utilizando o programa CNS_Solve (método de simulated annealing) (Brunger, 1997; Brunger, 1998). Os volumes dos ROEs assinalados pelo espectro de ROESY foram integrados e convertidos em restrições de distância: 2,8, 3,5 e 5,0 $\AA$ para intensidades fortes, médias e fracas, respectivamente. Os deslocamentos químicos dos átomos $\mathrm{H}_{\alpha}, \mathrm{H}_{\beta}, \mathrm{C}_{\alpha}, \mathrm{C}_{\beta}$ e $\mathrm{H}_{\mathrm{N}}$ foram utilizados para calcular os ângulos diedros pelo programa TALOS (Shen, 2009).

Os cálculos teóricos de otimização de geometria foram realizados para determinar 100 estruturas do peptídeo. As estruturas calculadas foram visualizadas no programa MOLMOL (Koradi, 1996) e as 20 estruturas mais estáveis (de menor energia) foram sobrepostas. O valor do RMSD para estas 20 estruturas sobrepostas também foi calculado pelo programa MOLMOL.

\subsubsection{Teste Biológico: Atividade com relação à Enzima Tirosinase}

Realizaram-se ensaios biológicos em relação à atividade da enzima tirosinase com os octreotídeos TOC1 e TOC2. Os testes foram feitos em microplacas de 96 poços monitorados em uma leitora de microplaca EL808 IU (Biotek) a 495 nm (Khatib, 2005; Kubo, 2003; Shin, 1998). As medidas foram realizadas a cada 16 segundos durante $30 \mathrm{~min}$. Utilizou-se a enzima tirosinase de cogumelo para os estudos (Tyrosinase from Mushroom, 3610 unidades de atividade/mg, Sigma Aldrich).

Inicialmente os testes de atividade da enzima foram realizados na presença apenas dos substratos L-dopa e L-tirosina (branco), monitorando o produto de degradação de ambos em 495 nm por 30 minutos (Khatib, 2005; Kubo, 2003; Shin, 1998). Em seguida, observou-se a atividade da enzima na presença dos peptídeos TOC1 e TOC2 com ambos os substratos, separadamente. Por fim, procedeu-se os testes também com um inibidor já conhecido na literatura, o ácido Kojic (controle positivo). Cada análise foi realizada em triplicata. 
Os testes biológicos foram realizados utilizando $40 \mu \mathrm{L}$ do composto a ser testado (TOC1, TOC2, ácido Kojic e apenas tampão no ensaio branco), 40 $\mu \mathrm{L}$ do substrato (L-dopa e L-tirosina), $80 \mu \mathrm{L}$ de tampão fosfato e $40 \mu \mathrm{L}$ da enzima, totalizando $200 \mu \mathrm{L}$ de volume final (Shin, 1998). As concentrações nos volumes finais foram de $100 \mu \mathrm{M}$ para o composto a ser testado, $100 \mu \mathrm{M}$ do substrato, 50 unidades de atividade/mL de enzima e 66,67 mM de tampão fosfato pH 6,8 (Khatib, 2005; Kubo, 2003; Shin, 1998).

Para calcular a porcentagem de atividade dos compostos TOC1, TOC2 e ácido Kojic, utilizou-se o t(1/2) (metade do tempo para alcançar a atividade máxima da enzima) do ensaio branco como parâmetro base para comparação com os compostos a serem testados.

\subsubsection{Interação do Peptídeo Análogo com a Tirosinase por RMN}

Estudos de interação dos octreotídeos TOC1 e TOC2 com a tirosinase foram realizados por RMN em um espectrômetro PremiumCOMPACT (600 $\mathrm{MHz}$ para hidrogênio), utilizando uma sonda de $5 \mathrm{~mm}$, à temperatura de $298 \mathrm{~K}$. Utilizou-se $\mathrm{H}_{2} \mathrm{O} / \mathrm{D}_{2} \mathrm{O}(90 \% / 10 \%)$ como solvente e a enzima tirosinase de cogumelo para os estudos (Tyrosinase from Mushroom, 3610 unidades de atividade/mg, Sigma Aldrich).

Foram adquiridos espectros de ${ }^{1} \mathrm{H}-\mathrm{RMN}$ e HSQC $\left({ }^{1} \mathrm{H}-{ }^{13} \mathrm{C}\right)$ dos peptídeos TOC1 e TOC2 livres, em uma concentração de $1 \mathrm{mM}$, e na presença da enzima (50 unidades de atividade/mL, aproximadamente $0,22 \mu \mathrm{M}$ ). Os espectros de ${ }^{1} \mathrm{H}$-RMN (pre-sat) foram adquiridos com 16 scans e os espectros de gHSQC $\left({ }^{1} \mathrm{H}-{ }^{13} \mathrm{C}\right)$ com 32 scans por incremento, com um total de 512 incrementos.

\subsubsection{Docking Molecular}

Os estudos de docking molecular foram realizados em colaboração com o Prof. Dr. Laurent Emmnanuel Dardenne, do Laboratório Nacional de Computação Científica (LNCC - Petrópolis, RJ).

Avaliou-se, por docking molecular, os possíveis modos de ligação dos peptídeos TOC1 e TOC2, assim como a reprodução do modo de ligação 
experimental da L-dopa e L-tirosina. Todas as análises foram feitas com a estrutura da oxy-tyrosinase de Streptomyces castaneoglobisporus (ScTyr, PDB $1 w \times 2$ ), a qual possui no sítio de ligação dois íons de $\mathrm{Cu}^{2+}$, um grupo peróxido (O-O) e uma molécula de água estrutural.

Os estados de protonação das histidinas 37, 62, 53, 193, 189 e 215 foram alterados para ND1 para coordenarem os metais (histidina neutra em ND1). Os ligantes utilizados para o estudo de redocking foram: (i) L-tirosina, PDB 4p6r e (ii) L-dopa, PDB 4p6s. Para os estudos de docking, as estruturas do peptídeo nas conformações TOC1 e TOC2, obtidas por RMN e simulated annealing, foram diretamente submetidas ao programa sem realizar nenhuma minimização de energia. Os estudos de docking foram realizados utilizando o programa DockThor (Magalhães, 2004; Magalhães, 2014) tendo como parâmetros:

- grade de energia: $X=-9.21 . Y=-29.16, Z=-44.34$ (centro de coordenadas da L-tirosina), tamanho total de $22 \AA$ em cada eixo e discretização de $0.25 \AA$.

- algoritmo genético: 1.000 .000 de avaliações, população inicial com 1.000 indivíduos, 30 execuções do algoritmo.

As cargas parciais e os tipos de átomos da proteína foram definidos para o campo de força MMFF94S utilizando a ferramenta PdbThorBox, enquanto que para os ligantes e cofatores foi utilizada a ferramenta MMFFLigand.

\subsubsection{Interação do Peptídeo Análogo com a Tirosinase por Espectrometria de Massa}

A interação do peptídeo TOC com a tirosinase foi estudada por Espectrometria de Massa do tipo MALDI-TOF/TOF (UltraFlex III, Bruker). Espectros de MS e MS/MS foram obtidos.

O equipamento foi calibrado com um calibrante externo próprio para peptídeos (Peptide Calibration Standard - Starter Kit, Tubo 4, Bruker). As análises foram feitas depositando-se em uma placa própria para 0 equipamento uma mistura da solução do peptídeo livre $(1 \mathrm{mM})$ e também do peptídeo/enzima ( $1 \mathrm{mM} / 0,22 \mu \mathrm{M}$ ) com uma solução saturada da matriz (5 mg de matriz, $200 \mu \mathrm{L}$ de $\mathrm{H} 2 \mathrm{O}, 500 \mu \mathrm{L}$ de $\mathrm{ACN}$ e $50 \mu \mathrm{L}$ de TFA $3 \%$ ) constituída 
pelo ácido a- ciano-4-hidroxicinâmico. A proporção utilizada de peptídeo/enzima para matriz foi de 1:3. Os espectros de massa foram adquiridos no método refletido/positivo, e utilizou-se argônio como gás de colisão para os espectros de fragmentação. 


\subsection{Resultados e Discussão}

\subsubsection{Síntese do Peptídeo Análogo à Somatostatina}

O peptídeo análogo à somatostatina selecionado para a síntese foi o TOC (Tyr ${ }^{3}$-octreotídeo). Tal peptídeo foi escolhido pelo fato de apresentar uma tirosina exposta na posição 3 , indicando uma possível atividade de inibição competitiva em relação à enzima tirosinase, visto que esta enzima consegue agir no aminoácido L-tirosina (Kim, 2005). Com isso, este peptídeo análogo poderia ser mais promissor em relação à atividade da enzima tirosinase quando comparado a outros peptídeos análogos, como o FOC (Phe ${ }^{3}$ octreotídeo) e o NOC (Asn ${ }^{3}$-octreotídeo), que não apresentam o aminoácido Ltirosina.

O peptídeo análogo foi sintetizado utilizando a estratégia de síntese em fase sólida, que apresenta a vantagem de, ao final de cada etapa, isolar o produto por meio de uma lavagem e uma filtração. Com isso, o excesso dos reagentes, solventes e qualquer outro composto que não esteja ligado à resina são eliminados, o que possibilita maior rendimento e facilidade na etapa de purificação do produto final obtido (Marquardt, 2001; Pires, 2014).

Para realizar a síntese em fase sólida, utiliza-se uma resina como suporte insolúvel. Utilizou-se uma resina do tipo clorotriril já acoplada com o primeiro resíduo de aminoácido visto que o peptídeo de interesse deveria apresentar o C-terminal livre e não estar na forma amidada (Pires, 2014).

Empregou-se a estratégia Fmoc (Benoiton, 2005; Chan, 2000; Fields, 1990) (Figura 2.3), em que um grupo protetor temporário do grupamento amino é removido a cada etapa da síntese pela 4-metil-piperidina, sendo um grupo base-lábil (Pires, 2014). Os grupos $t$-butila, Tritil (Trt), e terc-butiloxicarbonila (Boc) (Figura 2.3) são os grupos protetores permanentes das cadeias laterais dos aminoácidos, que permanecem ao longo de todas as etapas da síntese, sendo retirados apenas na última etapa, a da clivagem. 


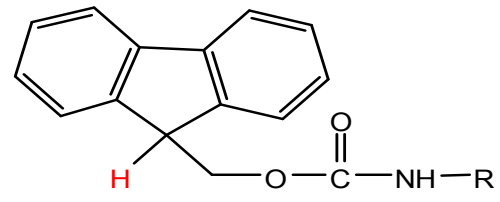

Fmoc

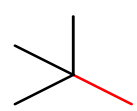

$t$-butil

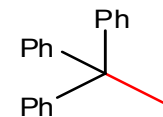

Tritil (Trt)

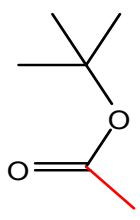

Boc

Figura 2.3: Estruturas dos grupos Fmoc (protetor temporário) e t-butil, Trt e Boc (protetores permanentes).

Tanto os protetores permanentes como os protetores temporários garantem a reação dos derivados de aminoácidos apenas no local de interesse, ajudando a evitar reações secundárias, tal como a incorporação de um dipeptídeo em vez de um aminoácido (Pires, 2014). Além disso, essa medida ajuda no processo final de purificação do produto obtido.

Após efetivar o acoplamento de todos os resíduos de aminoácidos para obter o peptídeo sintético, é preciso realizar a clivagem para a remoção da resina e dos grupos protetores das cadeias laterais (protetores permanentes), e com isso, obter os peptídeos desejados, livres de qualquer proteção ou modificação. Utiliza-se TFA para proceder a clivagem, visto que a ligação do peptídeo com a resina e com os grupos protetores permanentes são ácidos lábeis (Pires, 2014). O processo detalhado da síntese de peptídeo em fase sólida utilizando a estratégia Fmoc, incluindo o mecanismo de cada etapa, pode ser observado no artigo elaborado como resultado parcial deste trabalho (Pires, 2014), e que se encontra no Anexo 83.

\subsubsection{Purificação e Caracterização do Peptídeo Análogo Sintético}

As análises por cromatografia líquida foram monitoradas em $216 \mathrm{~nm}$, uma vez que compostos que contêm uma ligação peptídica apresentam absorbância nesse comprimento de onda (Shibue, 2005). A fase móvel utilizada não absorve no comprimento de onda selecionado (acetonitrila absorve em $190 \mathrm{~nm}$ ) para evitar interferências indesejadas durante a análise (Lanças, 2009).

Empregou-se o método de eluição por gradiente para obter melhor resolução e detectabilidade, maior simetria para as frações cromatográficas e 
um tempo menor de análise (Collins, 2009). A utilização de 0,1\% de TFA nos solventes visa obter melhor simetria dos sinais e aumentar a solubilidade do peptídeo (Conlon, 2007).

$\mathrm{O}$ octreotídeo sintético análogo à somatostatina, denominado TOC, foi fracionado por UFLC, e as frações foram coletadas manualmente para identificação da fração de interesse, referente ao peptídeo sintetizado. $O$ cromatograma do peptídeo TOC pode ser observado na Figura 2.4. As frações observadas no cromatograma foram caracterizadas por Espectrometria de Massa e observou-se que as frações P1 e P2 apresentavam a massa e estrutura primária esperadas para o peptídeo sintético (1034 Da para o peptídeo na forma ciclizada, havendo ponte dissulfeto entre as $\mathrm{Cys}^{2}$ e Cys ${ }^{7}$ ). Os espectros de massa das frações P1 e P2 podem ser observadas nas Figuras 2.5 e 2.6, respectivamente, e os de Massa/Massa nas Figuras 2.7 e 2.8 , respectivamente.

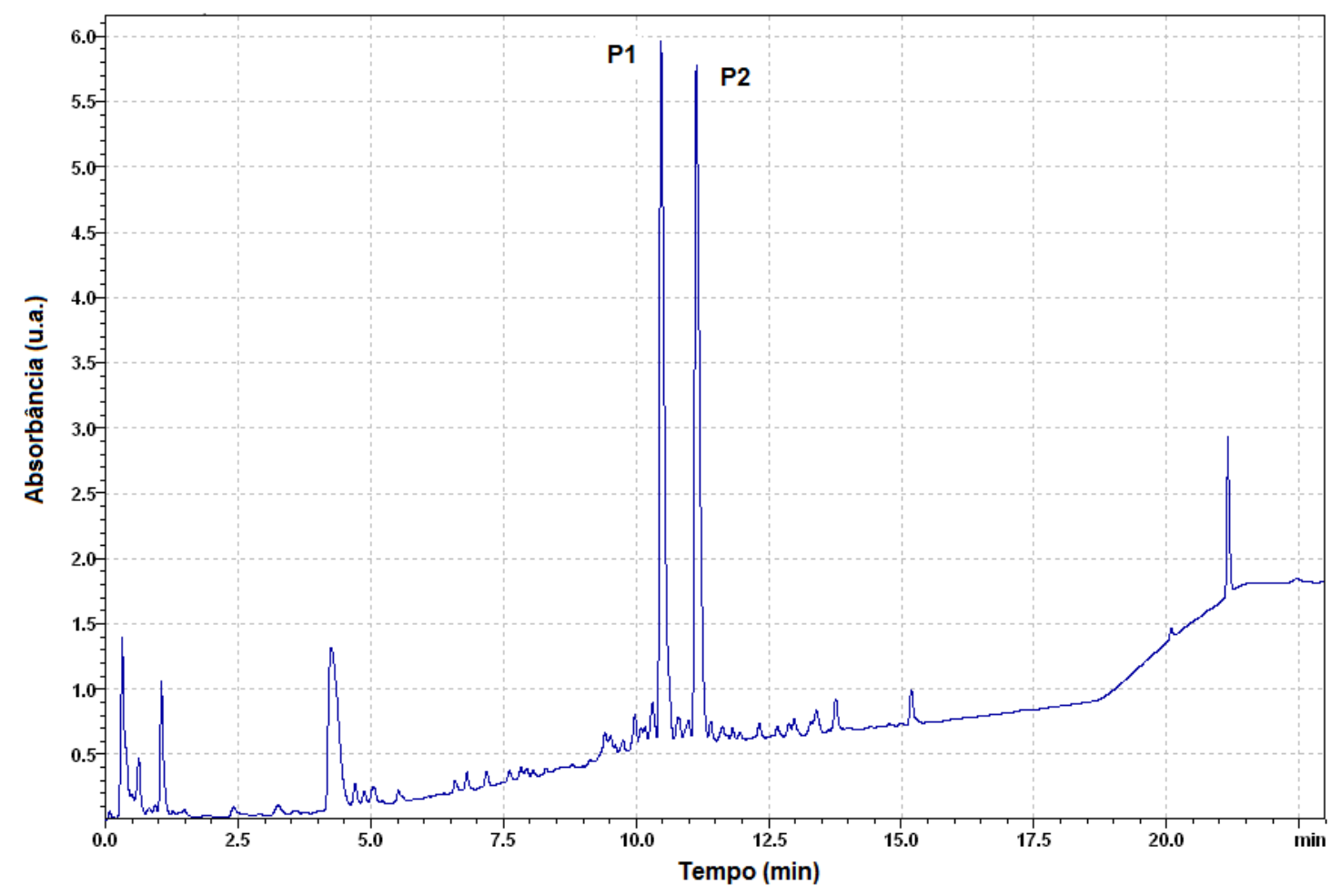

Figura 2.4: Cromatograma do peptídeo sintético TOC a $25^{\circ} \mathrm{C}$, indicando as frações P1 e P2. 


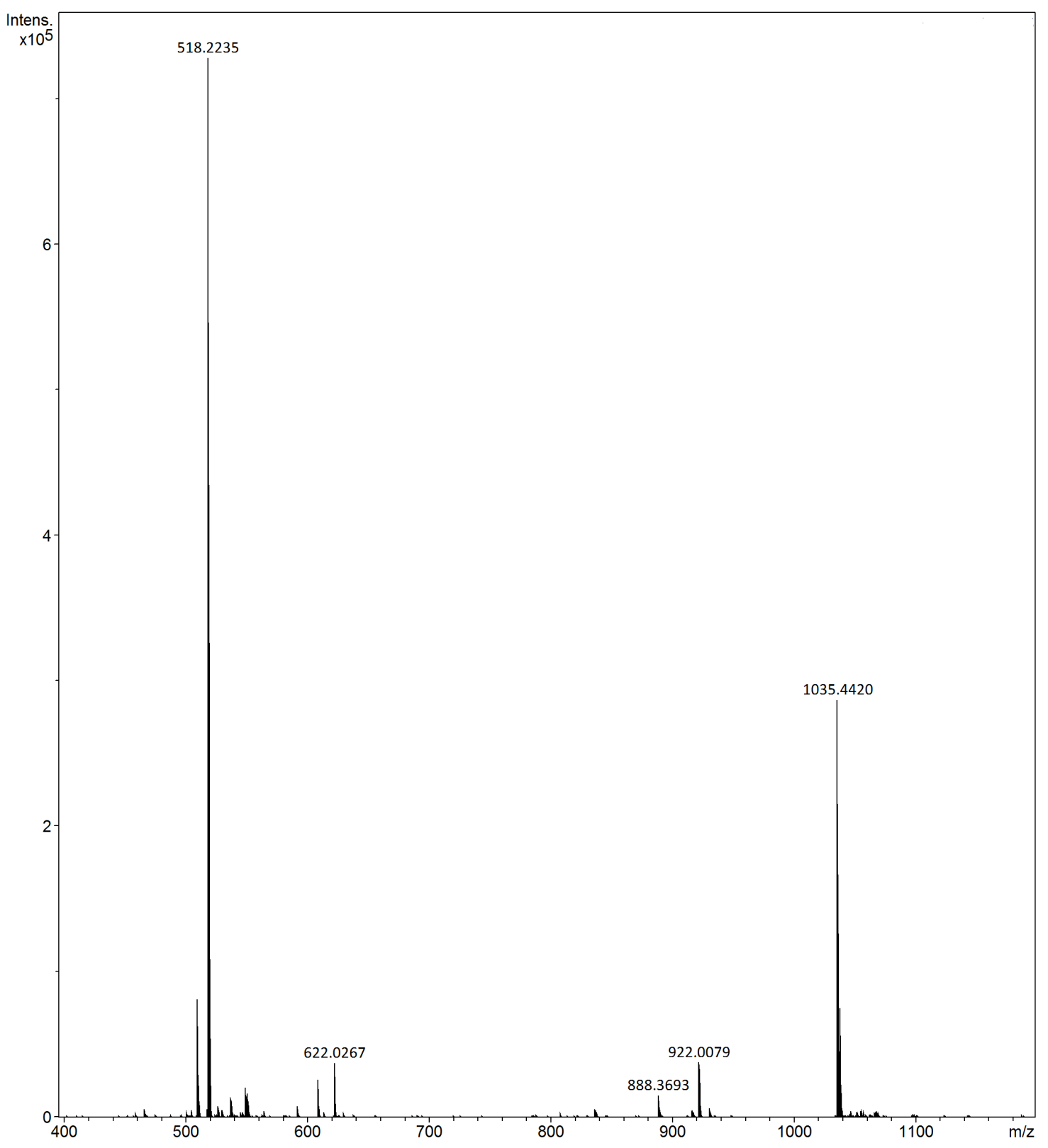

Figura 2.5: Espectro de Massa referente à fração $P 1$. Observam-se as massas $[M+2 H]^{2+}=$ 518,22 e $[\mathrm{M}+\mathrm{H}]^{+}=1035,44$ referentes ao peptídeo TOC sintético. 


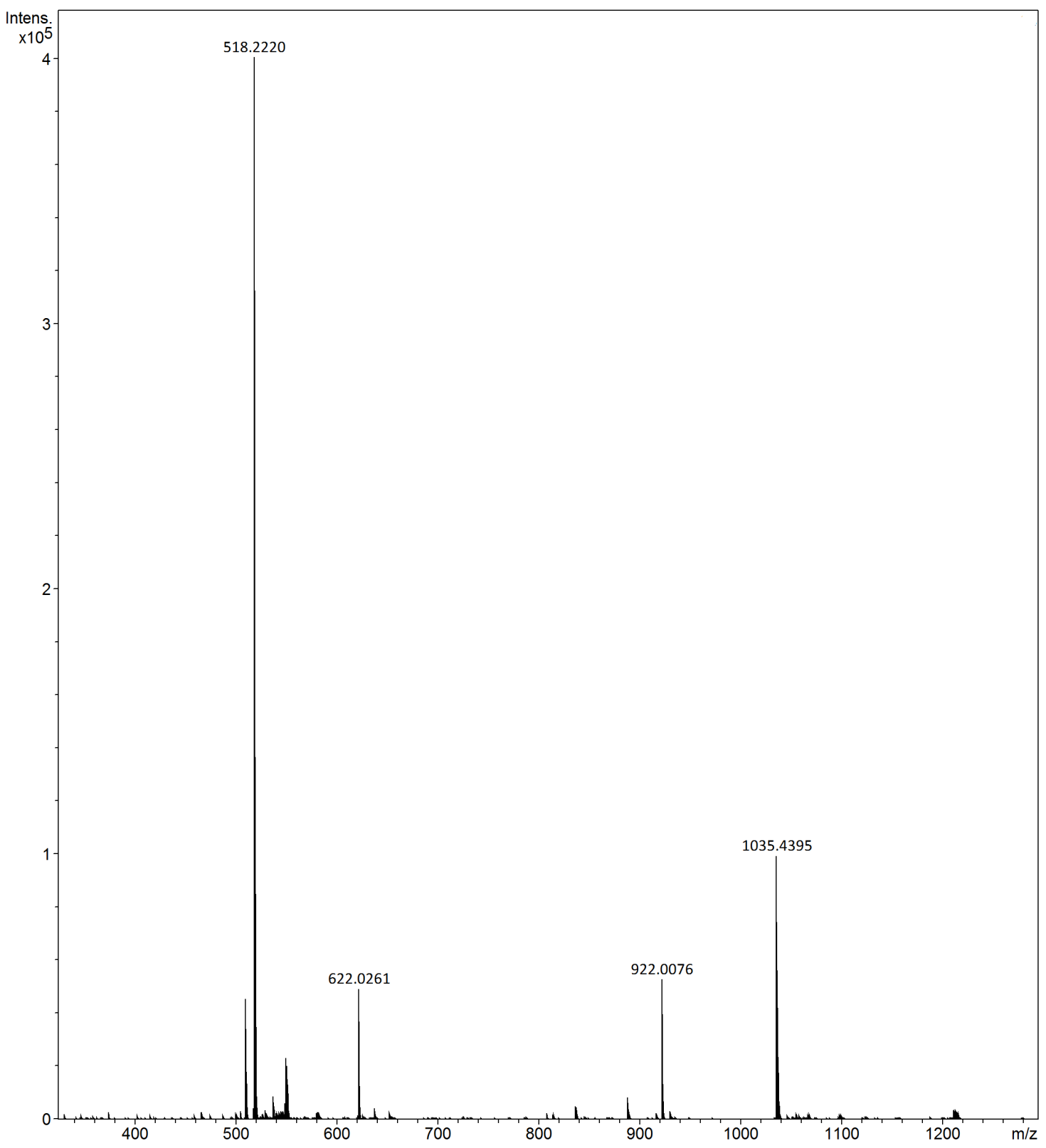

Figura 2.6: Espectro de Massa referente à fração $\mathrm{P} 2$. Observam-se as massas $[\mathrm{M}+2 \mathrm{H}]^{2+}=$ 518,22 e $[\mathrm{M}+\mathrm{H}]^{+}=1035,44$ referentes ao peptídeo TOC sintético. 


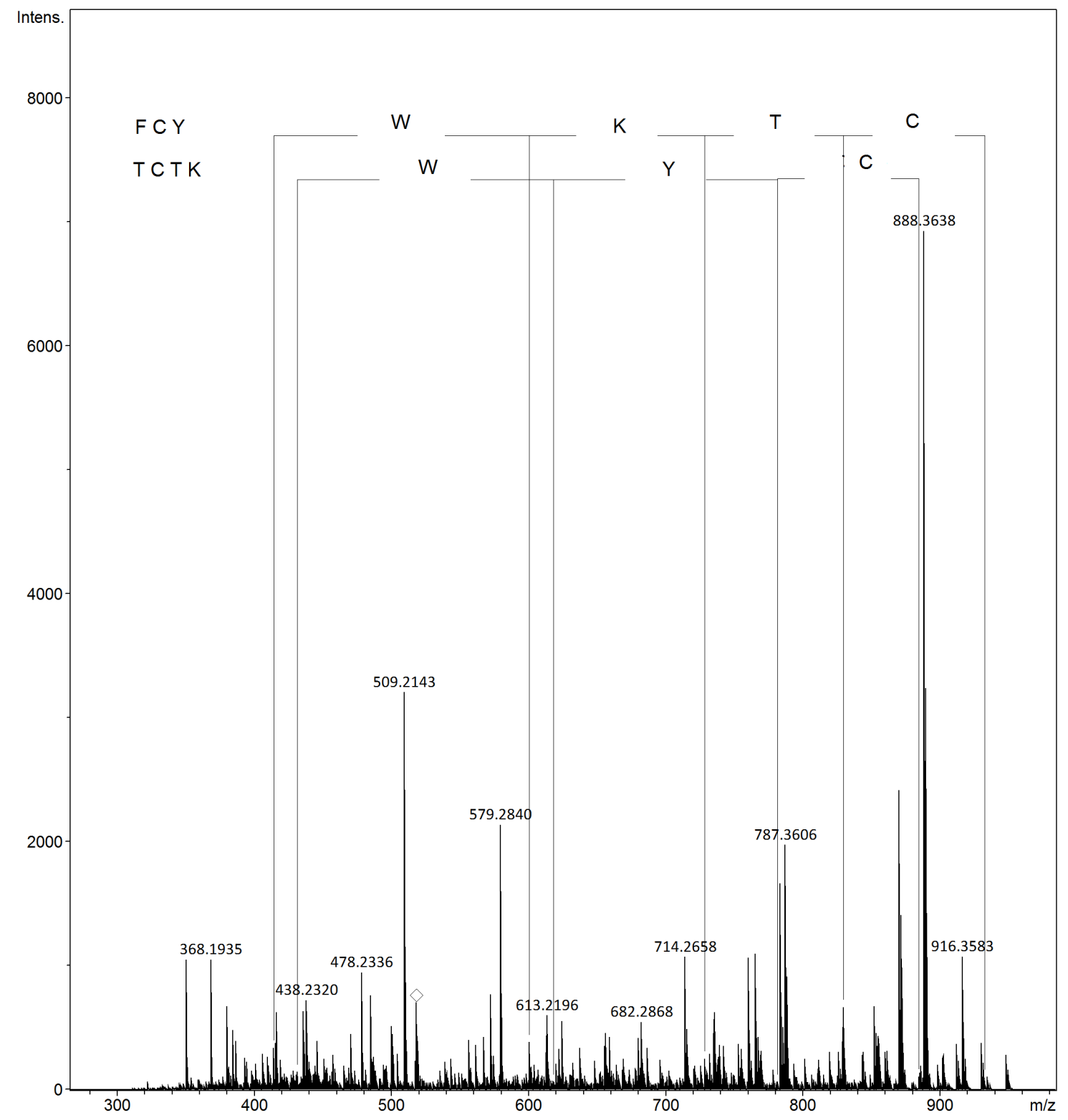

Figura 2.7: Espectro de MS/MS utilizando o íon parental $[M+2 H]^{2+}=518,22$, oriundo da fração P1. 


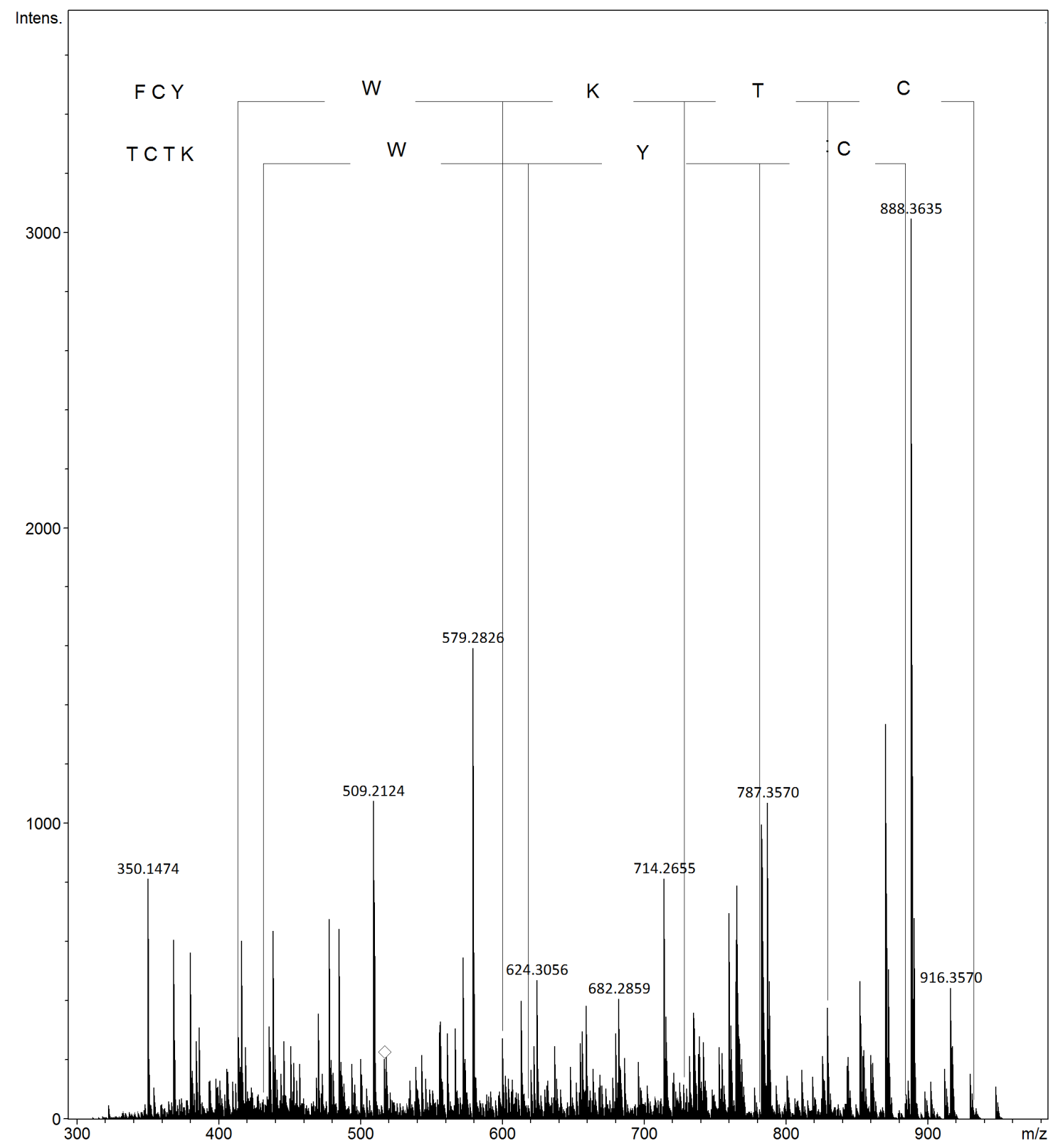

Figura 2.8: Espectro de $M S / M S$ utilizando o íon parental $[M+2 H]^{2+}=518,22$, oriundo da fração P2.

Observou-se que as amostras coletadas nas frações P1 e P2 do cromatograma apresentaram a mesma massa, sendo esta referente ao peptídeo sintetizado. Notou-se também o mesmo perfil de fragmentação do íon parental nas frações, confirmando que ambas apresentam a mesma sequência de aminoácidos referente ao peptídeo sintético.

$O$ fato de as frações P1 e P2 referentes ao peptídeo sintetizado apresentarem tempos de retenção diferentes por UFLC, sugere que o peptídeo TOC pode apresentar duas conformações diferentes, doravante denominadas 
TOC1 (peptídeo TOC oriundo da fração P1) e TOC2 (peptídeo TOC oriundo da fração P2).

Variações conformacionais em análogos à somatostatina já foram observadas para o octreotídeo FOC (Phe ${ }^{3}$-octreotídeo), em que tal peptídeo pode apresentar uma conformação em $\alpha$-hélice ou folha $\beta$ (Melacini, 1997). O peptídeo TOC (Tyr ${ }^{3}$-octreotídeo) apresenta apenas um resíduo de aminoácido diferente em relação ao FOC, sugerindo que ele também possa apresentar variações conformacionais.

As frações $\mathrm{P} 1$ e $\mathrm{P} 2$ foram submetidas a análises de cromatografia em diferentes temperaturas $\left(30,45\right.$ e $\left.60{ }^{\circ} \mathrm{C}\right)$ para observar a influência da temperatura nessa possível variação conformacional (Figuras 2.9, 2.10 e 2.11, respectivamente).

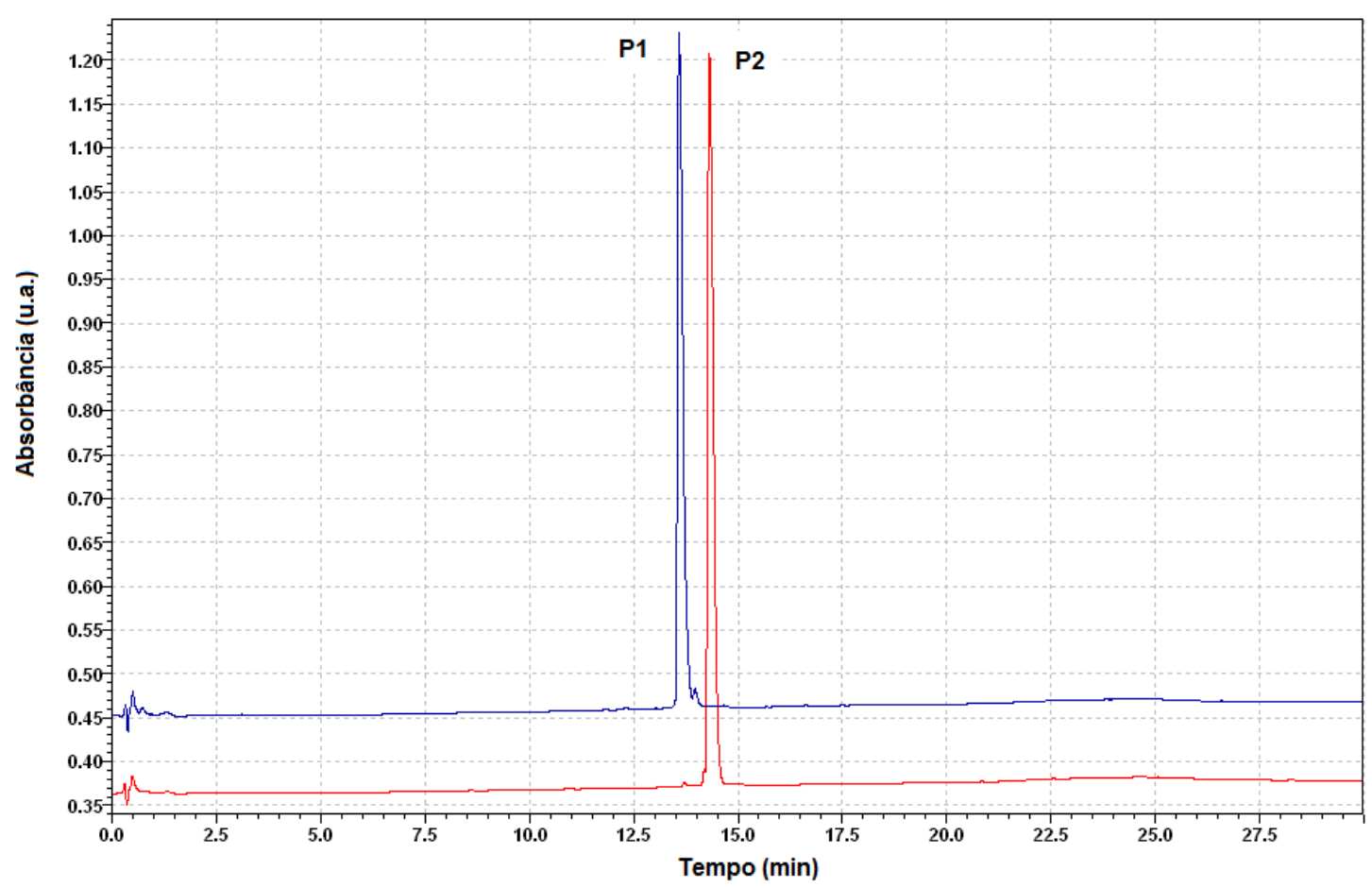

Figura 2.9: Cromatograma das frações $\mathrm{P} 1$ (TOC1) e $\mathrm{P} 2$ (TOC2) a $30^{\circ} \mathrm{C}$. 


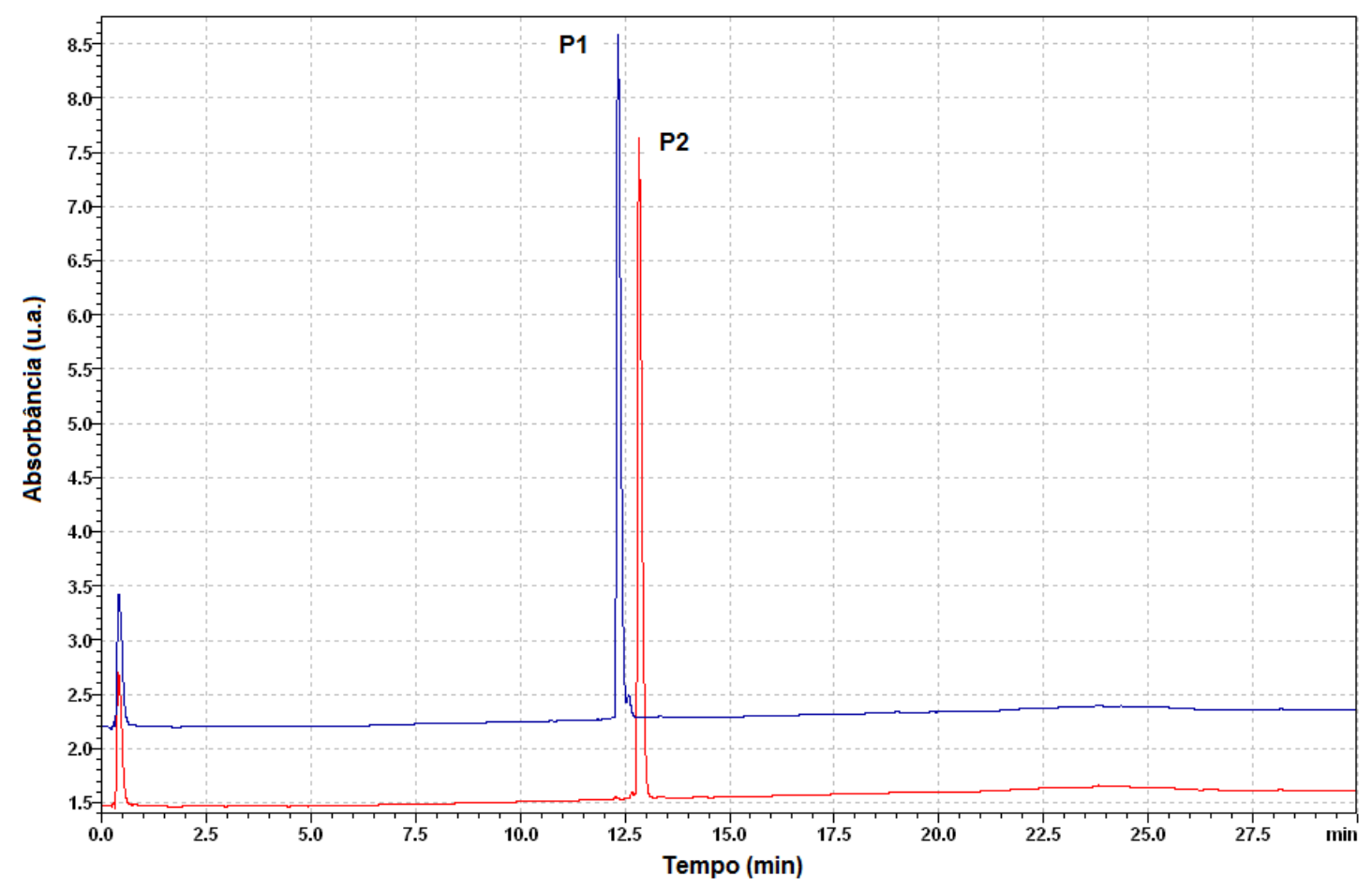

Figura 2.10: Cromatograma das frações $\mathrm{P} 1$ (TOC1) e P2 (TOC2) a $45^{\circ} \mathrm{C}$.

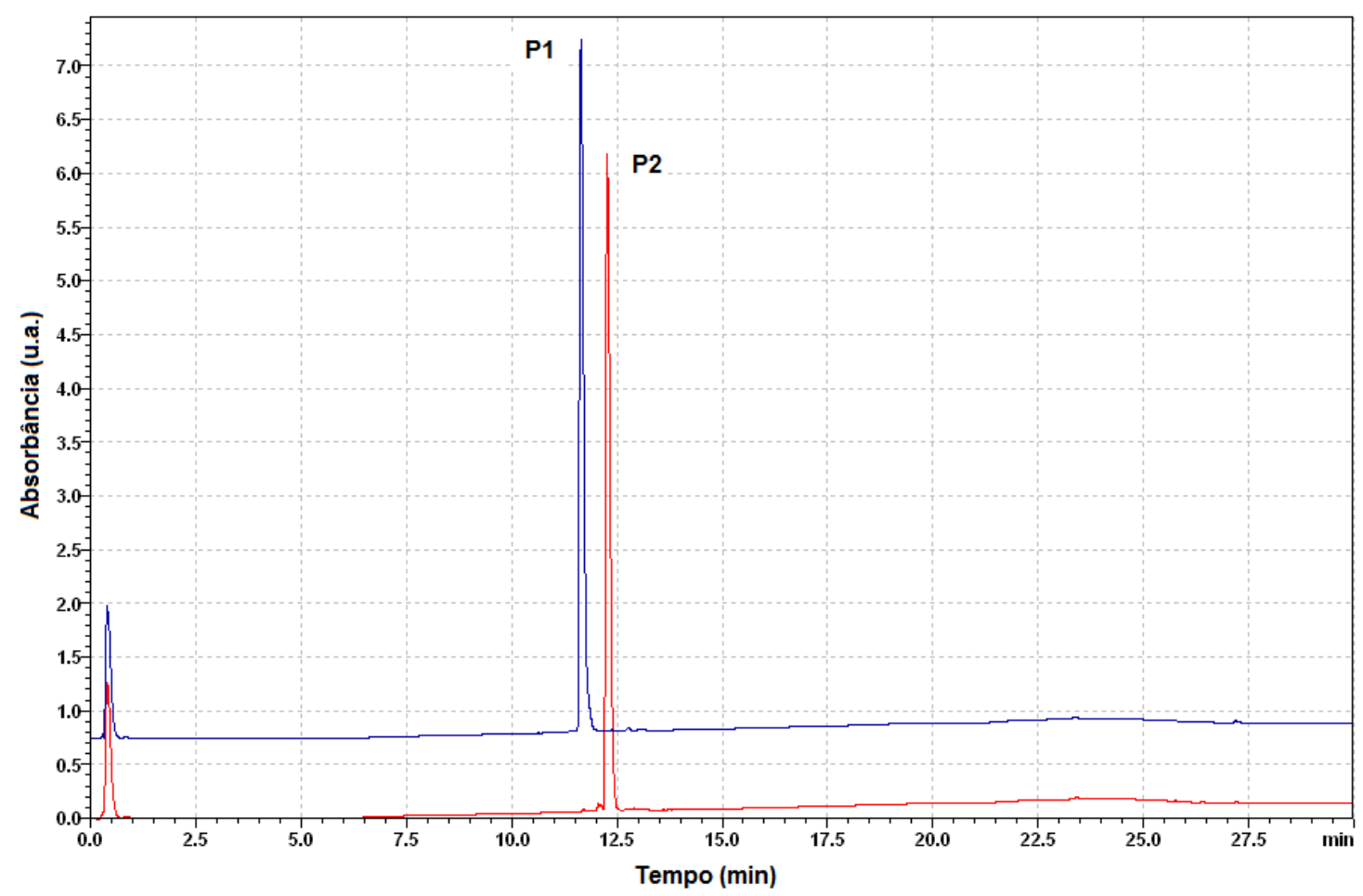

Figura 2.11: Cromatograma das frações $\mathrm{P} 1$ (TOC1) e $\mathrm{P} 2$ (TOC2) a $60{ }^{\circ} \mathrm{C}$.

Mesmo em temperaturas mais elevadas as frações P1 (TOC1) e P2 (TOC2) não apresentaram o mesmo tempo de eluição em nenhuma 
cromatograma. Isso sugere que um confôrmero não se converte no outro pelo aumento de temperatura, mostrando certa estabilidade das diferentes conformações.

O mesmo peptídeo com duas conformações diferentes pode apresentar variação na atividade biológica. Com isso, realizou-se a cromatografia do composto HYNIC-TOC comercial, utilizado para o diagnóstico de tumores quando complexado com o ${ }^{99 m} \mathrm{Tc}$, para observar se o TOC comercial apresentava também essa variação conformacional. As frações foram coletadas manualmente e caracterizadas por Espectrometria de Massa. O cromatograma do HYNIC-TOC comercial pode ser observado na Figura 2.12 e um cromatograma comparativo do HYNIC-TOC comercial com o peptídeo TOC sintético pode ser observado na Figura 2.13.

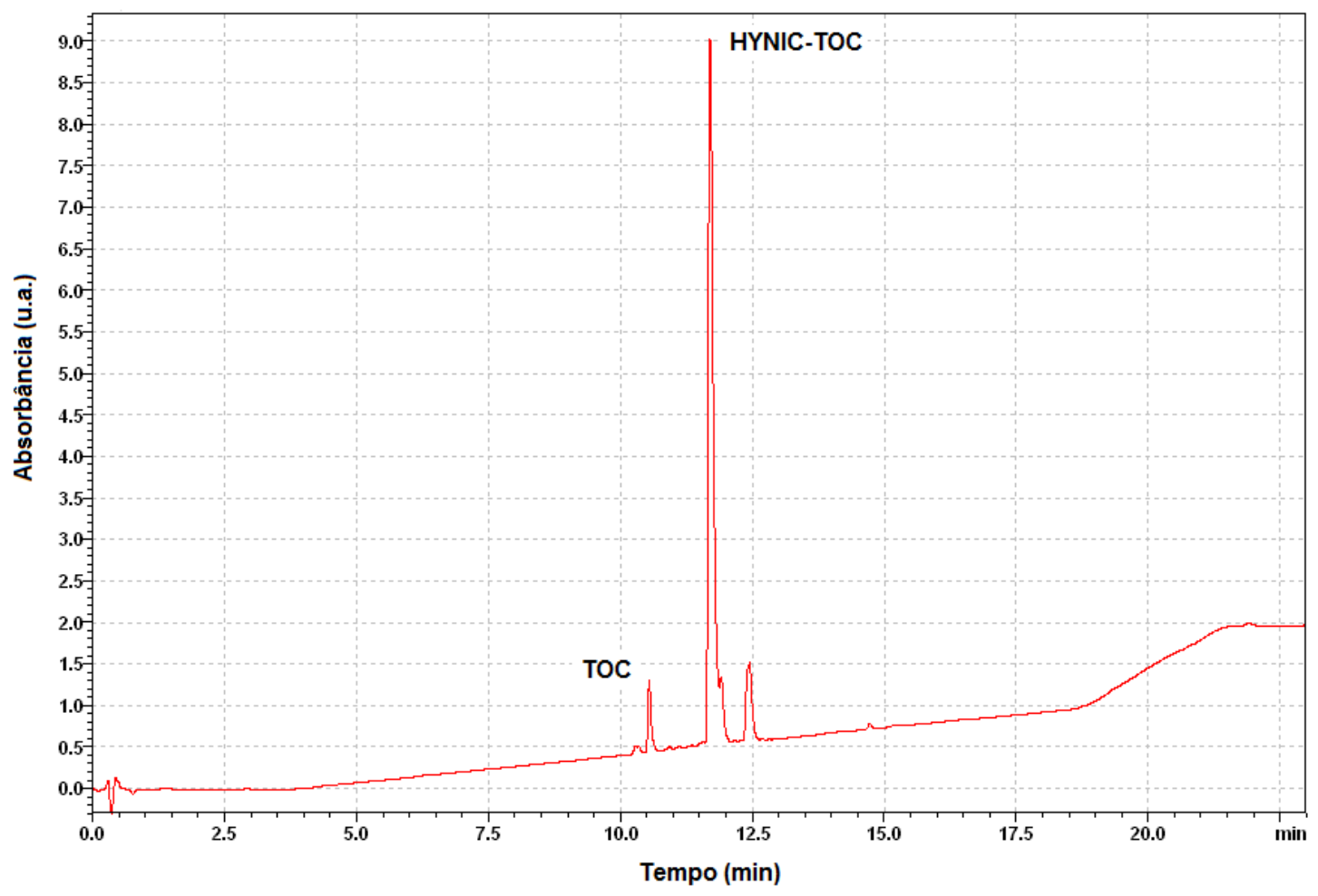

Figura 2.12: Cromatograma do composto HYNIC-TOC comercial. Foram observadas uma fração referente ao HYNIC-TOC e outra referente ao TOC livre. 


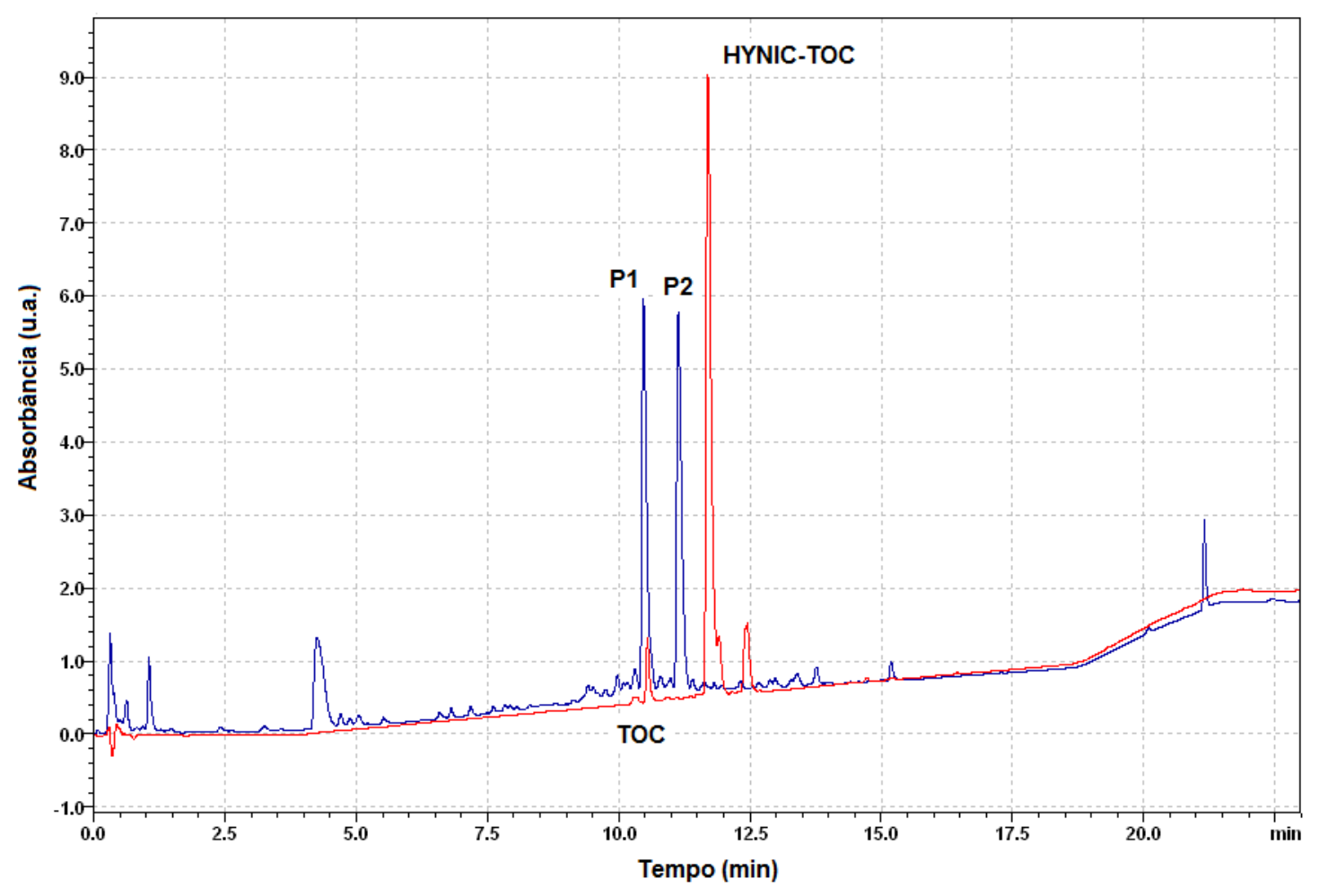

Figura 2.13: Cromatograma do HYNIC-TOC comercial em vermelho e do TOC sintético em azul. É possível observar que o TOC livre encontrado no composto comercial apresenta o mesmo tempo de eluição da fração P1 do peptídeo sintético.

Notou-se que o composto HYNIC-TOC comercial apresenta uma quantidade de peptídeo TOC livre sem estar conjugado ao HYNIC. O TOC livre presente no composto comercial apresenta o mesmo tempo de eluição da fração P1 (TOC1) do composto sintético. O TOC presente na fração 2 não foi encontrado no composto comercial, segundo os tempos de retenção detectados. Existe uma possibilidade dos compostos TOC1 e TOC2 apresentarem atividades biológicas diferentes, visto que apenas o TOC1 é encontrado no composto comercial utilizado para o diagnóstico de tumores.

\subsubsection{Determinação Estrutural do Peptídeo Análogo Sintético}

Para verificar se o octreotídeo TOC sintético identificado nas frações P1 e P2 era o mesmo peptídeo em diferentes conformações, realizou-se experimentos de $\mathrm{RMN}$ e cálculos teóricos para determinar as estruturas do TOC1 (fração P1) e TOC2 (fração P2) em solução. 
Inicialmente, realizou-se experimentos de ${ }^{1} \mathrm{H}-\mathrm{RMN}$ do TOC1 e TOC2. Os espectros da região alifática e aromática podem ser vistos nas Figuras $2.14 \mathrm{e}$ 2.15 , respectivamente.

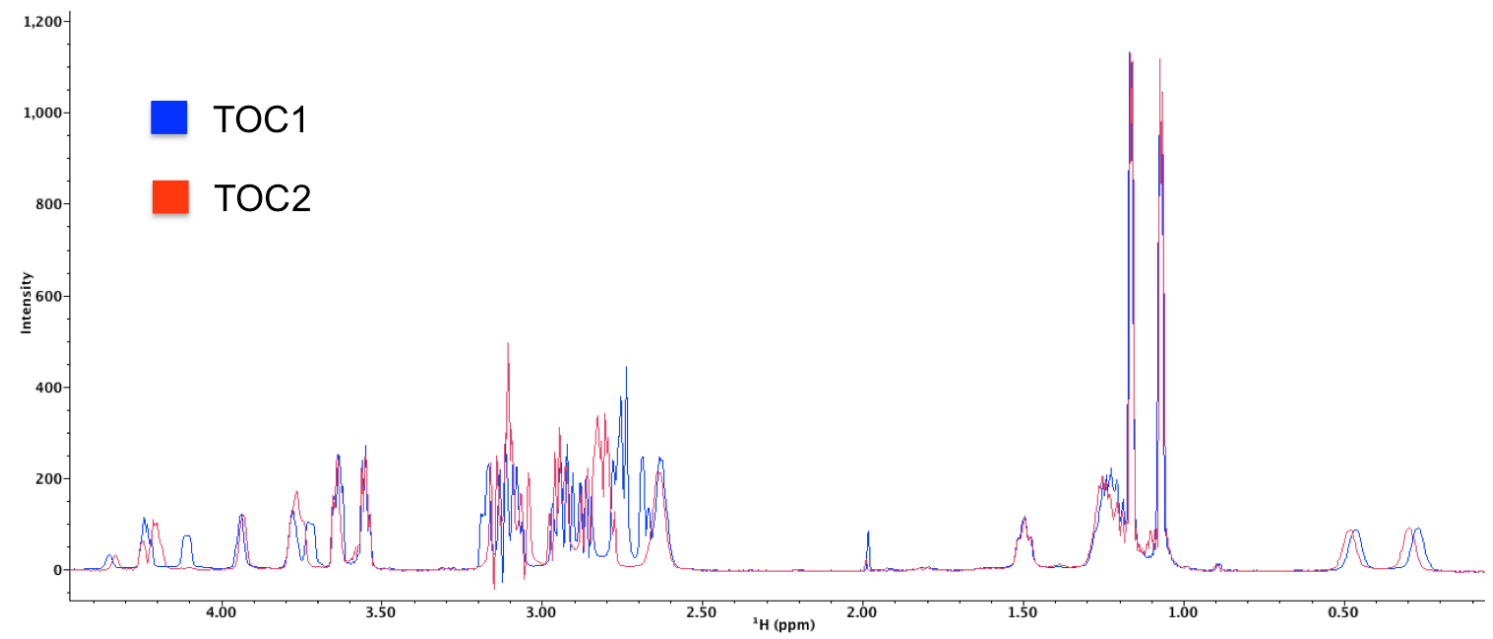

Figura 2.14: Região alifática dos espectros de ${ }^{1} \mathrm{H}-\mathrm{RMN}$ dos peptídeos TOC1 e TOC2.

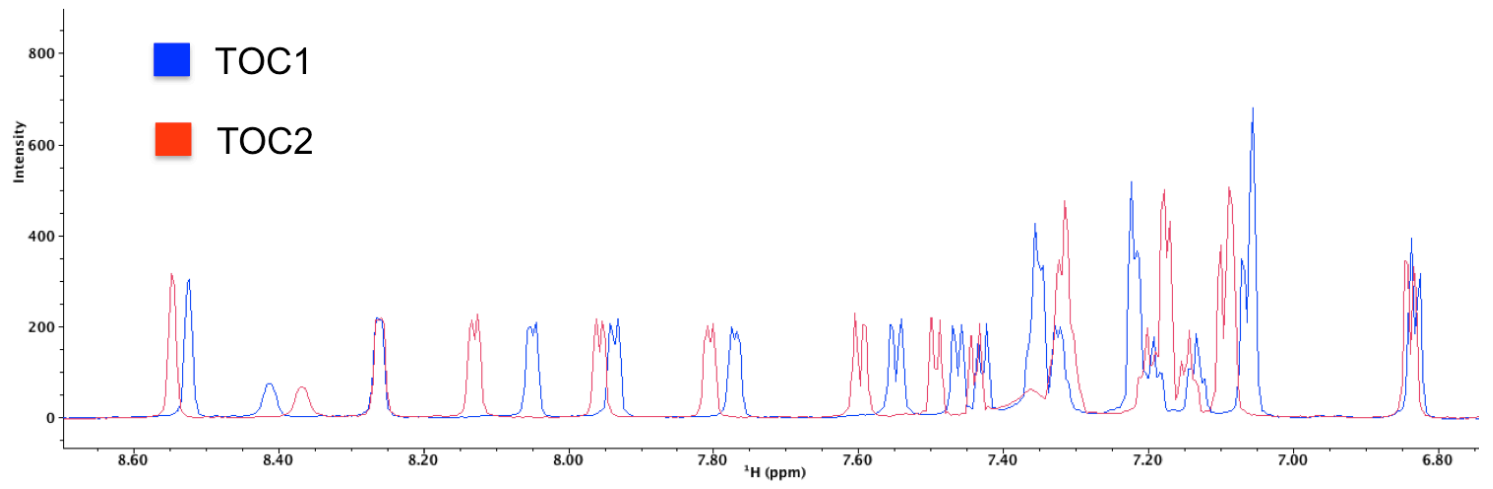

Figura 2.15: Região aromática dos espectros de ${ }^{1} \mathrm{H}-\mathrm{RMN}$ dos peptídeos TOC1 e TOC2.

Observando os espectros de ${ }^{1} \mathrm{H}-\mathrm{RMN}$ dos peptídeos TOC1 e TOC2, notou-se diferenças em relação a alguns deslocamentos químicos, tanto na região aromática como na região alifática, sugerindo que o mesmo peptídeo poderia apresentar, de fato, diferentes conformações. Para determinar a estrutura 3D dos dois peptídeos, realizou-se experimentos de RMN 2D (TOCSY, ROESY e HSQC) juntamente com cálculos teóricos.

Pelo espectro TOCSY, juntamente com o espectro ROESY, foi realizado o assinalamento dos átomos de hidrogênio. O espectro HSQC $\left({ }^{1} \mathrm{H}-{ }^{13} \mathrm{C}\right)$ permitiu o assinalamento dos átomos de carbono. Uma tabela com os assinalamentos dos átomos de hidrogênio e carbono dos peptídeos TOC1 e TOC2 pode ser 
vista nos Anexos 84 e 85, respectivamente. O espectro de ROESY permitiu assinalar os ROEs existentes entre os átomos de hidrogênio.

A combinação dos espectros de TOCSY e ROESY permite realizar um assinalamento sequencial, identificando os diferentes sistemas de spins referentes a cada resíduo de aminoácido da sequência dos peptídeos.

Uma região do espectro TOCSY, mostrando os sistemas de spins de cada resíduo de aminoácido para os peptídeos TOC1 e TOC2, pode ser vista nos Anexos 86 e 89, respectivamente. Regiões do espectro ROESY do TOC1 (Anexos 87 e 88) e do TOC2 (Anexos 90 e 91) foram ampliadas destacando alguns ROEs relevantes.

Com os valores dos deslocamentos químicos dos hidrogênios $\mathrm{H}_{\alpha}, \mathrm{H}_{\beta} \mathrm{e}$ $H_{N}$, juntamente com os assinalamentos dos carbonos $C_{\alpha}$ e $C_{\beta}$ foi possível calcular os ângulos diedros ( $\Phi$ e $\Psi$ ) para os peptídeos pelo programa TALOS (Shen, 2009). As Tabelas 2.7 e 2.8 mostram a lista com os ângulos $\Phi$ e $\Psi$ dos peptídeos TOC1 e TOC2, respectivamente. Notou-se variações entre alguns ângulos diedros para os análogos TOC1 e TOC2, sugerindo novamente uma diferença conformacional entre os peptídeos.

Tabela 2.7: Ângulos diedros $\Phi$ e $\Psi$ calculados para o peptídeo TOC1.

\begin{tabular}{ccc}
\hline Aminoácido & $\boldsymbol{\Phi}\left(^{\circ}\right)$ & $\boldsymbol{\Psi}\left(^{\circ}\right)$ \\
\hline 1.F & - & - \\
2.C & -141 & 141 \\
3.Y & -107 & 134 \\
4.W & -95 & 133 \\
5.K & -79 & 133 \\
6.T & -96 & 103 \\
7.C & -139 & 148 \\
8.T & - & - \\
\hline
\end{tabular}

Tabela 2.8: Ângulos diedros $\Phi$ e $\Psi$ calculados para o peptídeo TOC2.

\begin{tabular}{ccc}
\hline Aminoácido & $\boldsymbol{\Phi}\left({ }^{\circ}\right)$ & $\boldsymbol{\Psi}\left({ }^{\circ}\right)$ \\
\hline 1.F & - & - \\
2.C & -137 & 141 \\
3.Y & -83 & 134 \\
4.W & -61 & -26 \\
5.K & -75 & -26 \\
6.T & -64 & -39 \\
7.C & -65 & -41 \\
8.T & - & - \\
\hline
\end{tabular}


Os ROEs assinalados pelo espectro ROESY foram convertidos em restrições de distância. Estas restrições de distância, juntamente com os ângulos diedros, foram os parâmetros utilizados para realizar os cálculos estruturais e determinar a estrutura dos peptídeos TOC1 e TOC2. A sobreposição das 20 estruturas de menor energia - apenas os "backbones" pode ser vista na Figura 2.16 e com as cadeias laterais, na Figura 2.17.

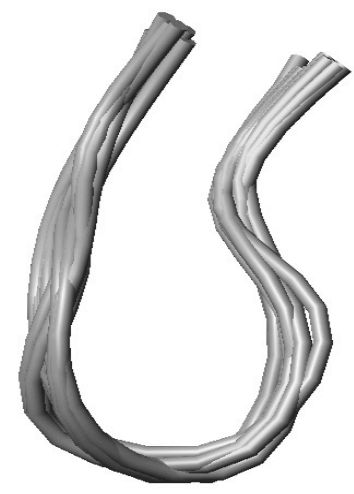

TOC-1

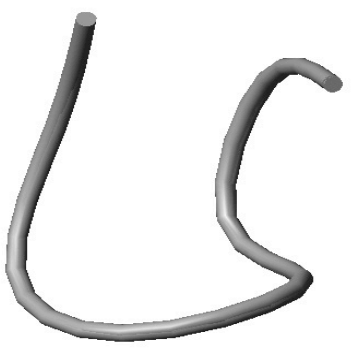

TOC-2

Figura 2.16: Sobreposição das 20 estruturas calculadas mais estáveis (backbone) para os peptídeos TOC1 e TOC2.

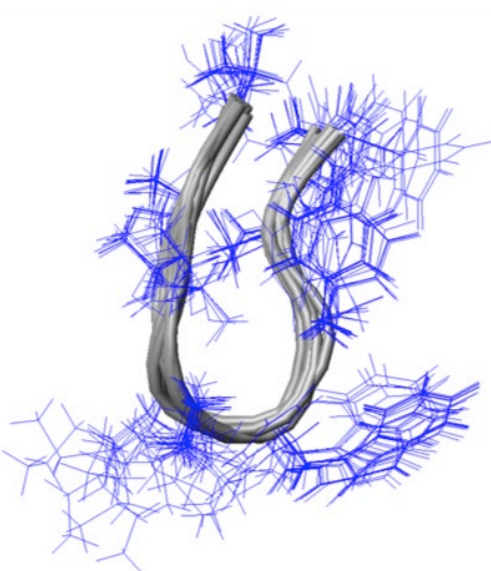

TOC-1

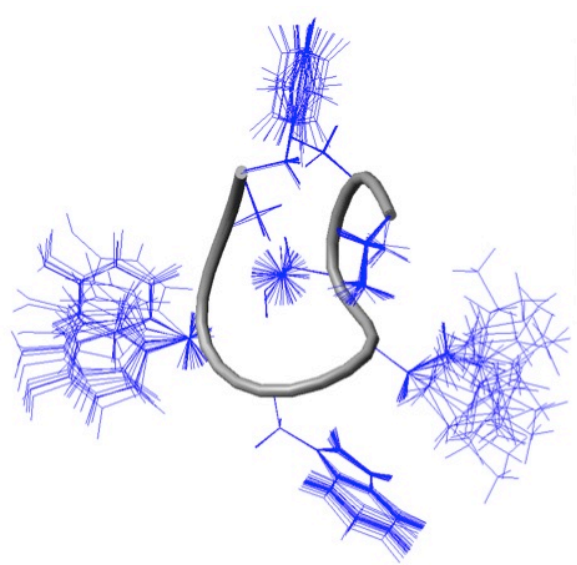

TOC-2

Figura 2.17: Sobreposição das 20 estruturas calculadas mais estáveis (backbone + cadeias laterais) para os peptídeos TOC1 e TOC2.

As estruturas calculadas para o peptídeo TOC1 foram obtidas com 138 restrições de distância, uma média de 17,25 ROEs por resíduo de aminoácido, valor acima da média de 15 ROEs por resíduo para se obter uma estrutura 
confiável (Cavanagh, 2007). O valor do RMSD para as 20 estruturas foi de $0,439 \AA$, mostrando grande estruturação para um peptídeo de apenas 8 resíduos de aminoácidos, fato este que pode se justificar pela presença da ponte dissulfeto entre as cisteínas. O RMSD obtido apresenta um valor alto quando comparado a proteínas; entretanto, para um peptídeo, este é um bom valor tendo em vista a maior mobilidade por ser uma biomolécula de menor tamanho.

As estruturas calculadas para o peptídeo TOC2 foram obtidas com 137 restrições de distâncias, uma média de 17,13 ROEs por resíduo de aminoácido. O valor do $R M S D$ para as 20 estruturas foi de $0,015 \AA$, mostrando menor mobilidade conformacional do que o TOC1.

Observou-se que o análogo à somatostatina TOC ( $\mathrm{Tyr}^{3}$-octreotídeo) pode apresentar diferentes conformações, e consequentemente, diferença em suas atividades biológicas. Além disso, o peptídeo TOC1 se mostrou mais flexível quando comparado à estrutura mais rígida do peptídeo TOC2. Essa flexibilidade do peptídeo TOC1 pode justificar o porquê de apenas esta conformação estar presente no HYNIC-TOC comercial. A estrutura extremamente rígida do TOC2 pode dificultar sua conjugação com um agente quelante, como o HYNIC. Além disso, essa rigidez pode não ser favorável à interação desse peptídeo com outras biomoléculas, como as proteínas $\mathrm{G}$ dos receptores da somatostatina. Moléculas mais flexíveis podem ser mais favoráveis para a ocorrência de reações e interações, o que pode fazer com que o peptídeo TOC1 apresente maior potencial biológico que o TOC2.

Vale ressaltar que o análogo TOC já é comercializado atualmente na forma de HYNIC-TOC para o diagnóstico de tumores. Entretanto, ainda não foi reportado na literatura essa possível variação conformacional existente para esse peptídeo, o que pode gerar atividades biológicas diferentes para os confôrmeros.

\subsubsection{Teste Biológico: Atividade com relação à Enzima Tirosinase}

Os compostos TOC1 e TOC2 foram analisados em relação à atividade da enzima tirosinase. A tirosinase consegue agir no aminoácido L-tirosina, e o peptídeo TOC (Tyr ${ }^{3}$-octreotídeo) apresenta um resíduo de tirosina na posição 
3, com uma cadeia lateral bem exposta por causa do loop formado devido à presença da ponte dissulfeto.

Inicialmente, observou-se a atividade da enzima apenas na presença dos substratos L-tirosina e L-dopa.

Utilizou-se os valores de absorbância do produto de degradação (dopaminocromo) correspondentes aos tempos de 13,06 e 6,13 minutos de atividade enzimática para os substratos L-tirosina e L-dopa, respectivamente, como $t(1 / 2)$, por estarem na parte ascendente do gráfico de atividade. Os valores de absorbância em tais tempos foram utilizados para a comparação da atividade da enzima na presença dos compostos a serem testados. Os resultados do teste biológico, utilizando L-dopa e L-tirosina como substratos, podem ser vistos na Tabela 2.9.

Tabela 2.9: Porcentagem de ativação e inibição dos compostos TOC1, TOC2 e ácido kojic em relação a atividade da enzima tirosinase, utilizando L-Tirosina e L-Dopa como substratos.

\begin{tabular}{|c|c|c|c|c|}
\hline & \multicolumn{2}{|c|}{ L-tirosina } & \multicolumn{2}{c|}{ L-dopa } \\
\hline Compostos & \% de Inibição & $\%$ de Ativação & \% de Inibição & $\%$ de Ativação \\
\hline TOC1 & - & 3,1 & - & 19,96 \\
\hline TOC2 & 7,27 & - & - & 11,64 \\
\hline Kojic & 97,47 & - & 94,49 & - \\
\hline
\end{tabular}

Um gráfico apresentando o monitoramento da atividade da enzima com L-dopa, e também os compostos testados, pode ser visto na Figura 2.18.

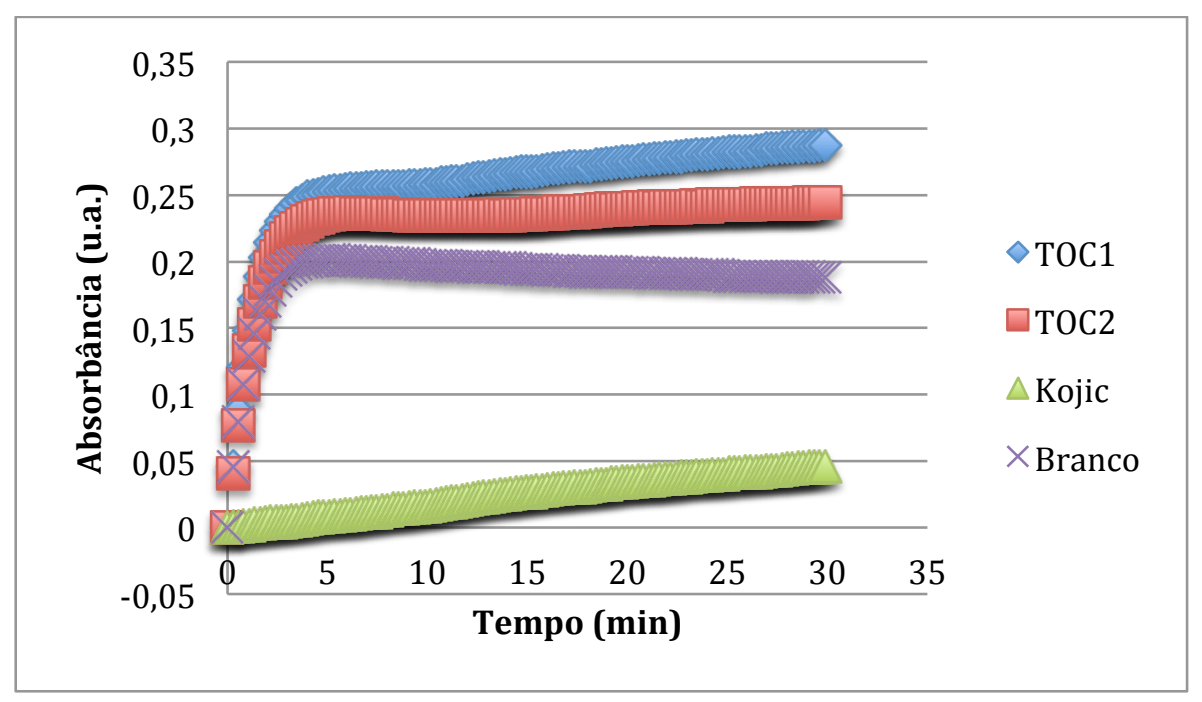

Figura 2.18: Monitoramento da atividade da enzima tirosinase apenas na presença do substrato L-dopa (Branco) e também dos compostos testados. Monitorou-se a formação do produto de degradação da L-dopa, em 495 nm, em função do tempo. 
Quando se utilizou L-Tirosina como substrato, o peptídeo TOC1 apresentou um pequena ativação $(3,1 \%)$, enquanto que o TOC2 apresentou um ligeira inibição $(7,27 \%)$. Notou-se também que, quando se utilizou L-dopa como substrato, o peptídeo TOC1 apresentou 19,96\% de ativação da enzima, enquanto que o TOC2 mostrou apenas $11,65 \%$ de ativação. O octreotídeo TOC pode apresentar diferentes conformações, como as observadas no TOC1 e TOC2, e essas variações conformacionais levaram a diferentes atividades em relação à enzima tirosinase.

Esperava-se que os peptídeos TOC1 e TOC2 inibissem a enzima tirosinase, visto que este análogo possui um resíduo de tirosina na posição 3. Com isso, a enzima poderia oxidar o substrato (L-dopa ou L-tirosina) ou o peptídeo (pela tirosina-3), diminuindo sua atividade para a produção de melanina. Entretanto, foi observada a ativação da enzima, e não sua inibição.

Ativadores da enzima tirosinase podem apresentar grande importância no combate à hipopigmentação, como vitiligo e albinismo (Guan, 2008; Seo, 2003), e também no combate ao câncer de pele (Parvez, 2007). Observou-se uma atividade aproximadamente de $20 \%$ de ativação da enzima para o TOC1 com L-dopa. Entretanto, esta é uma atividade discreta para ativadores da tirosinase já reportados na literatura, visto que atividades moderadas apresentam uma ativação de 7 a $31 \%$ e com altas atividades em $126 \%$ de ativação (Guan, 2008). Existem poucos trabalhos na literatura envolvendo peptídeos e a enzima tirosinase (Ferreira, 2015), como alguns peptídeos utilizados para inibir a enzima (Schurink, 2007; Ubeid, 2012). Mas não é comum encontrar trabalhos de peptídeos utilizados para ativar a enzima.

A atividade moderada apresentada pelo peptídeo TOC pode tornar viável o seu estudo de interação por RMN. Como os sinais do ligante não são detectados no complexo proteína/ligante, e sim na solução após se dissociar da biomolécula, interações muito fortes do ligante com o receptor podem interferir nos estudos de interação (Figueiredo, 2007; Meyer, 2003). Isso ocorre pois haverá dificuldade do ligante de se dissociar da proteína e voltar para a solução (local onde ocorre a deteç̧ão). Além disso, peptídeos podem apresentar menor toxicidade do que moléculas orgânicas de menor massa. Com isso, o peptídeo TOC1 é promissor para estudos de interação com a 
enzima, podendo ser utilizado como modelo para o planejamento de novas moléculas com maior atividade.

\subsubsection{Interação do Peptídeo Análogo com a Tirosinase por RMN}

Realizou-se o estudo de interação dos peptídeos TOC1 e TOC2 com a enzima tirosinase por RMN. Ao interagir com uma proteína, determinados átomos do ligante podem ter seus ambientes químicos alterados, causando uma mudança no valor do deslocamento químico ou simplesmente na intensidade dos picos, uma vez que passam a fazer parte da proteína e, por consequência, relaxam mais rapidamente. Comparando os espectros de HSQC $\left({ }^{1} \mathrm{H}^{13} \mathrm{C}\right)$ do peptídeo TOC1 livre e na presença da enzima, observou-se uma ligeira variação no deslocamento químico apenas no sinal referente ao hidrogênio alfa do aminoácido $\operatorname{Trp}^{4}$ (de 4,119 ppm na forma livre para 4,128 ppm na presença da enzima). A sobreposição dos espectros de HSQC do TOC1 na ausência e na presença da enzima para esse sinal pode ver visto na Figura 2.19. Para fins de comparação, a expansão desse espectro para alguns sinais que não sofreram variação de deslocamento químico, pode ser visto no Anexo 92.

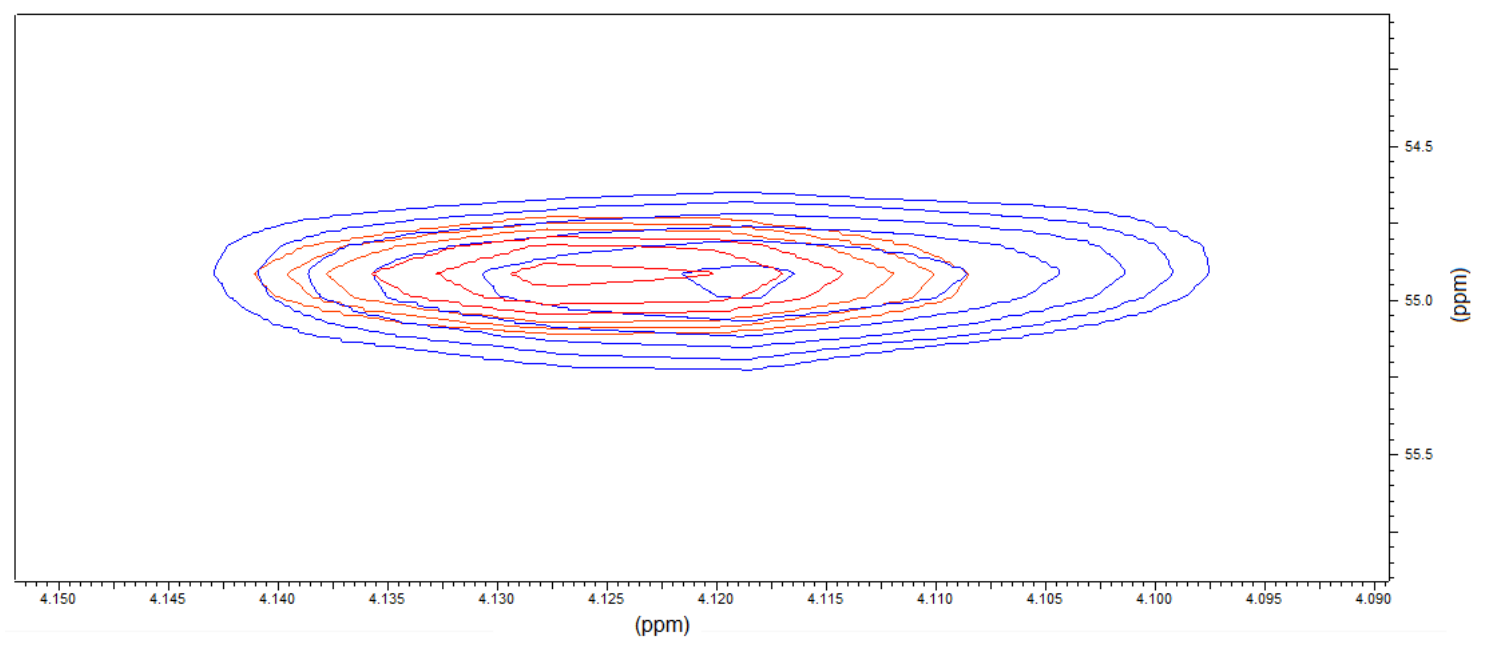

Figura 2.19: Sobreposição dos espectros de HSQC $\left({ }^{1} \mathrm{H}^{13} \mathrm{C}\right)$ do peptídeo TOC1 livre (azul) e na presença da enzima Tirosinase (vermelho). É indicado apenas o sinal referente ao hidrogênio alfa do aminoácido $\operatorname{Trp}^{4}$, único sinal que sofreu variação de deslocamento químico na presença da enzima. 
O mesmo estudo de interação por RMN foi realizado para o peptídeo TOC2. Novamente o único sinal que sofreu variação foi referente ao hidrogênio alfa do aminoácido $\operatorname{Trp}^{4}$. A sobreposição dos espectros de HSQC do TOC2 livre e na presença da enzima para esse sinal pode ver visto na Figura 2.20. Para fins de comparação, a expansão desse espectro para alguns sinais que não sofreram variação de deslocamento químico, pode ser visto no Anexo 93.

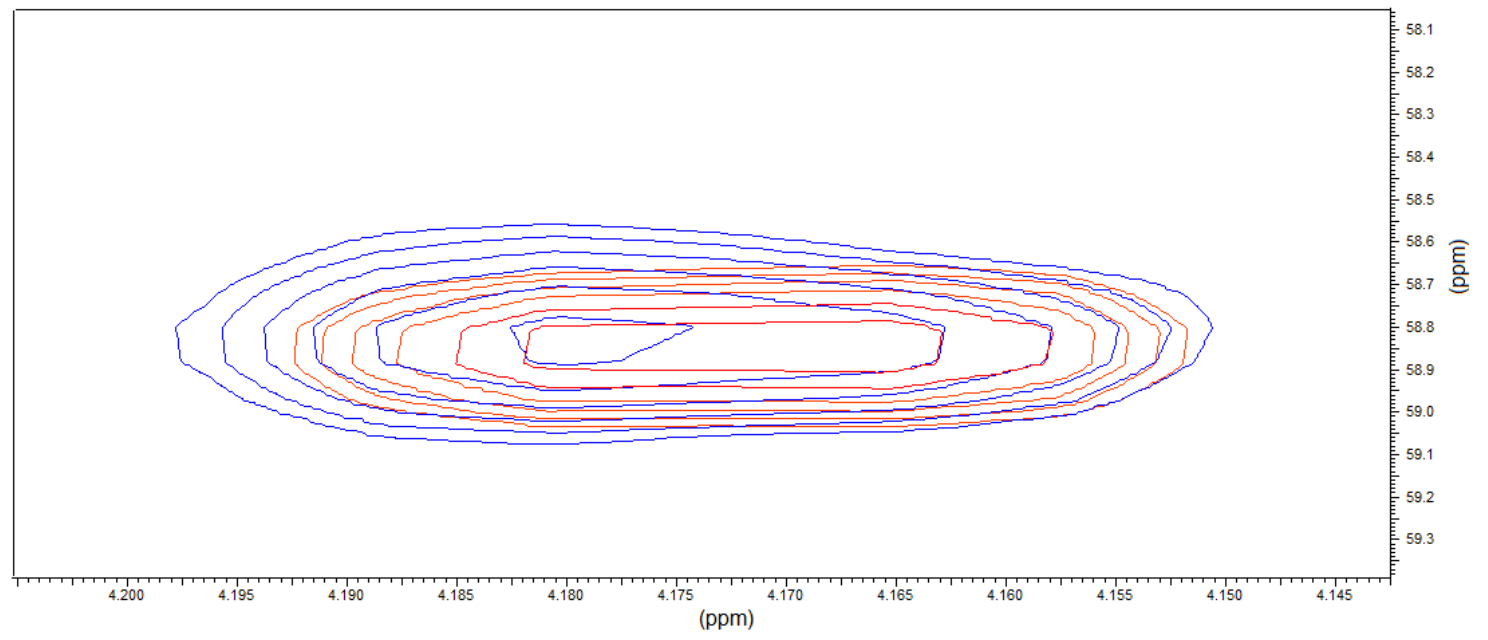

Figura 2.20: Sobreposição dos espectros de HSQC $\left({ }^{1} \mathrm{H}^{-13} \mathrm{C}\right)$ do peptídeo TOC2 livre (azul) e na presença da enzima Tirosinase (vermelho). É indicado apenas o sinal referente ao hidrogênio alfa do aminoácido $\operatorname{Trp}^{4}$, único sinal que sofreu variação de deslocamento químico na presença da enzima.

O resultado mostra que o aminoácido $\operatorname{Trp}^{4}$ está envolvido na interação com a enzima e sugere que o mesmo deve estar relacionado à atividade do peptídeo com relação à enzima. Entretanto, a não variação dos outros sinais não indica que os outros aminoácidos não interagiram com a enzima, apenas que para a escala temporal, tal variação não foi observada. Além disso, a tirosinase é capaz de oxidar a L-Tirosina para produzir a melanina, e o peptídeo TOC apresenta um resíduo de tirosina na posição 3 , o que poderia gerar uma interação do peptídeo com a enzima também pela $\mathrm{Tyr}^{3}$ ou pela região Tyr ${ }^{3}-\operatorname{Trp}^{4}$.

Além de observar variação no deslocamento químico de alguns sinais, o que dá indícios de uma possível interação, observou-se também que os sinais do HSQC na presença da enzima foram menos intensos, mesmo utilizando concentrações iguais de peptídeo, mesmo número de scans por incremento e mesmo número de incrementos. Os espectros de HSQC, mostrando os sinais 
das metilas, para o peptídeo TOC1 livre e na presença da enzima tirosinase podem ser vistos nas Figuras 2.21 e 2.22, respectivamente. Ambos os espectros apresentam o mesmo nível de corte (threshold).

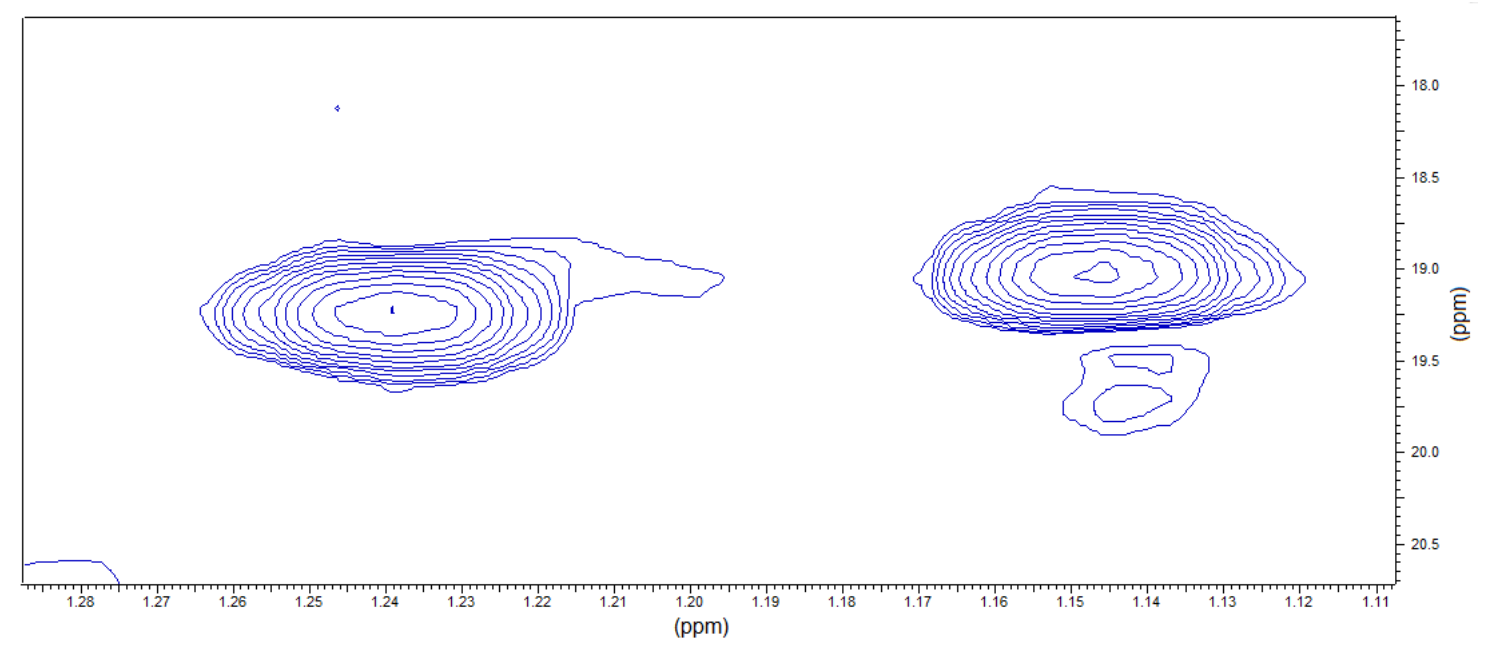

Figura 2.21: Espectro de $\mathrm{HSQC}\left({ }^{1} \mathrm{H}_{-}{ }^{13} \mathrm{C}\right)$ do peptídeo TOC1 livre, indicando os sinais referentes às metilas.

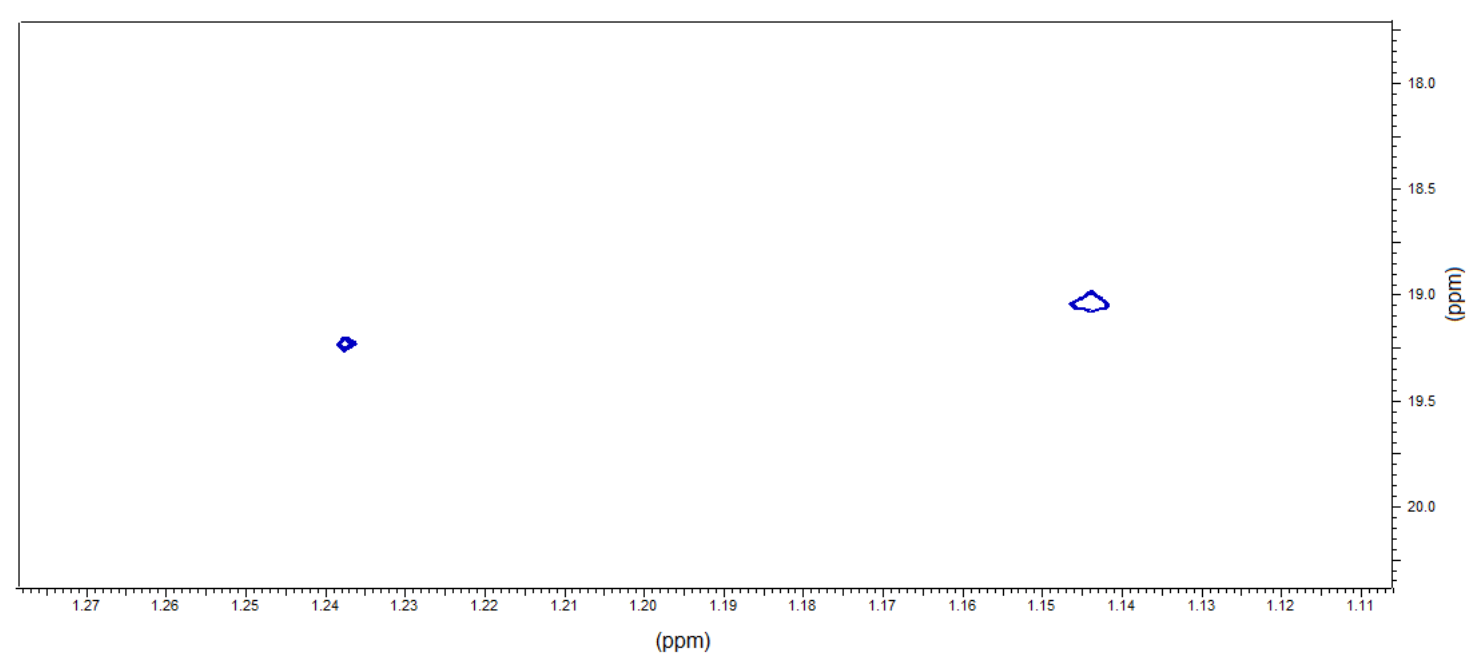

Figura 2.22: Espectro de HSQC $\left({ }^{1} \mathrm{H}^{13} \mathrm{C}\right)$ do peptídeo TOC1 na presença da enzima tirosinase, indicando os sinais referentes às metilas. Esse espectro foi adquirido utilizando exatamente os mesmos parâmetros de aquisição do espectro mostrado na Figura 2.21.

Notou-se que os sinais das metilas para o peptídeo na presença da enzima foram menos intensos. Realizando uma integração dos sinais das metilas referente ao TOC1 livre para um valor de 100, notou-se que as mesmas metilas, na presença da enzima, apresentaram um valor relativo de integração de 8,51 , mostrando que na presença da tirosinase, os sinais dos espectros foram menos intensos. Esse fato não foi observado apenas para as 
metilas, mas para todos os sinais do espectro, como pode ser observado na Figura 2.23.
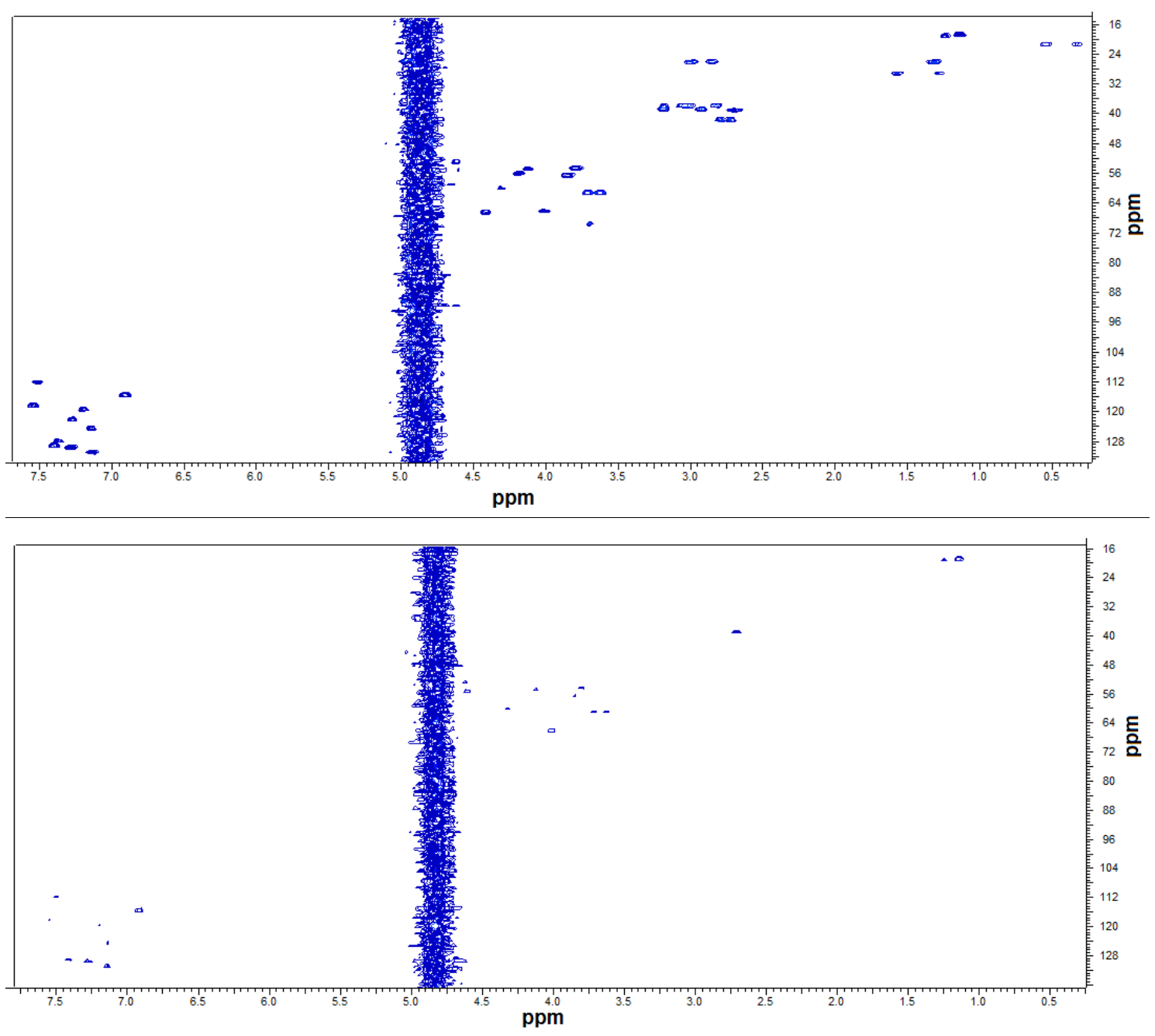

Figura 2.23: Espectros de HSQC, mostrando todos os sinais para o peptídeo TOC1 livre (espectro superior) e na presença da enzima tirosinase (espectro inferior). Ambos os espectros foram adquiridos com o mesmo número de scans e incrementos e apresentam o mesmo nível de corte (threshold).

Essa diferença de intensidade do peptídeo livre e na presença da enzima também foi observada para o peptídeo TOC2. Os espectros de HSQC, mostrando os sinais das metilas, para o peptídeo TOC2 livre e na presença da enzima tirosinase podem ser vistos nas Figuras 2.24 e 2.25, respectivamente. Novamente utilizou-se o mesmo nível de corte (threshold) para visualizar ambos os espectros. 


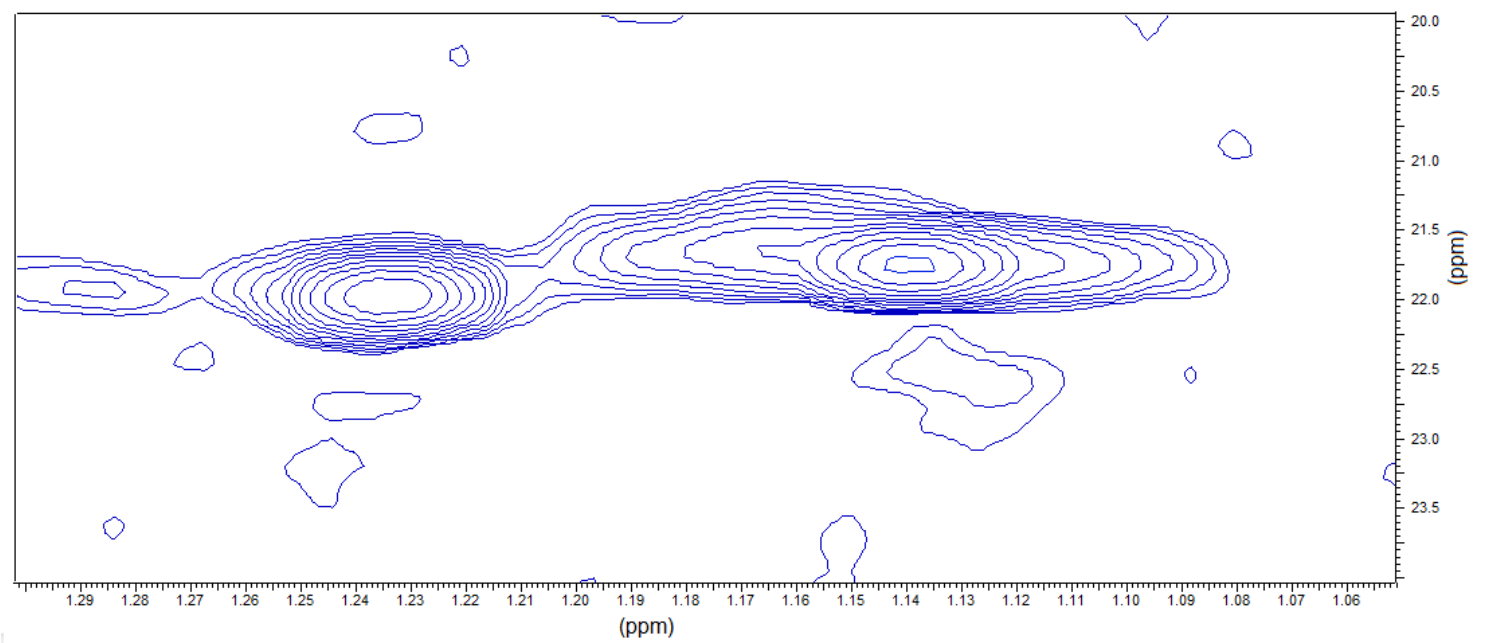

Figura 2.24: Espectro de HSQC $\left({ }^{1} \mathrm{H}^{13} \mathrm{C}\right)$ do peptídeo TOC2 livre, indicando os sinais referentes às metilas.

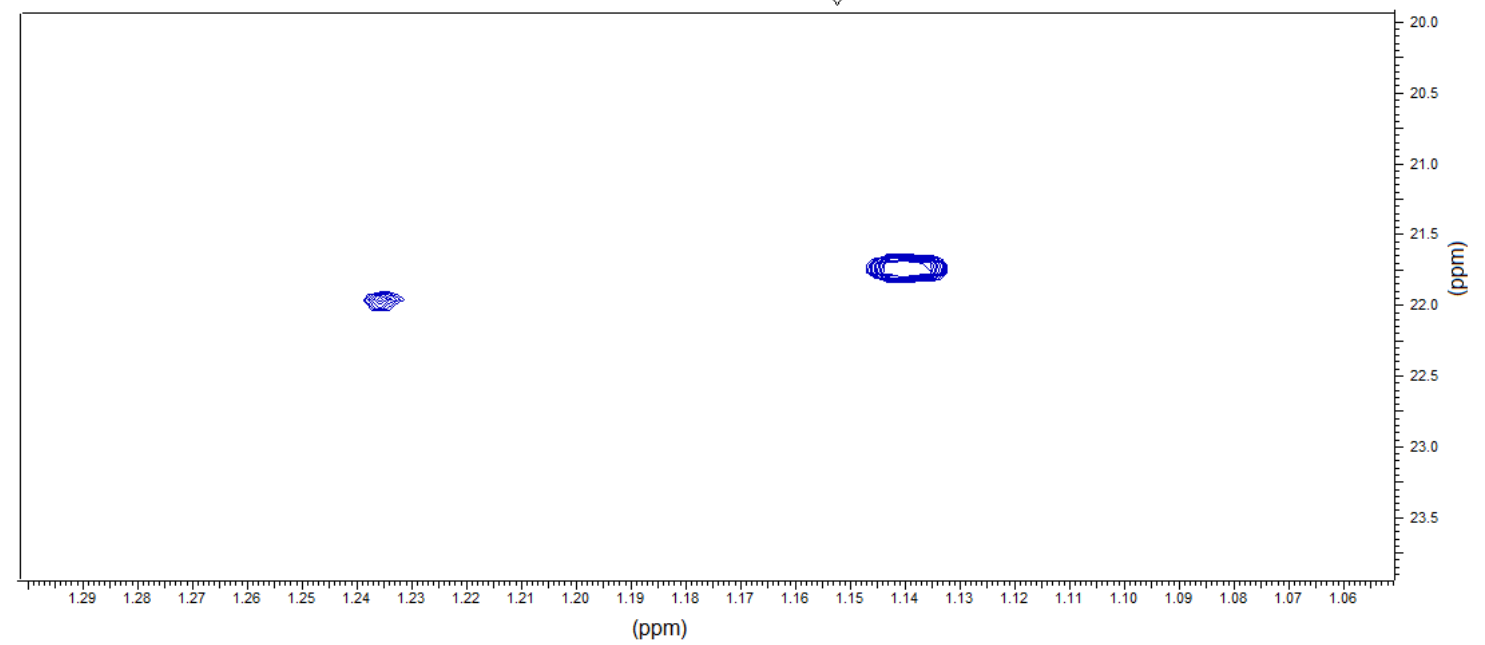

Figura 2.25: Espectro de HSQC $\left({ }^{1} \mathrm{H}-{ }^{13} \mathrm{C}\right)$ do peptídeo TOC2 na presença da enzima tirosinase, indicando os sinais referentes às metilas. Esse espectro foi adquirido utilizando exatamente os mesmos parâmetros de aquisição e mesmo nível de corte do espectro mostrado na Figura

2.24 .

Realizando uma integração dos sinais das metilas referente ao TOC2 livre para um valor de 100, notou-se que as mesmas metilas, na presença da enzima, apresentaram um valor relativo de integração de 3,44 , mostrando que na presença da tirosinase, os sinais dos espectros do peptídeo TOC2 também foram menos intensos. Novamente essa diminuição na intensidade não foi observada apenas para as metilas, mas para todos os sinais do espectro, conforme pode ser visto na Figura 2.26. 

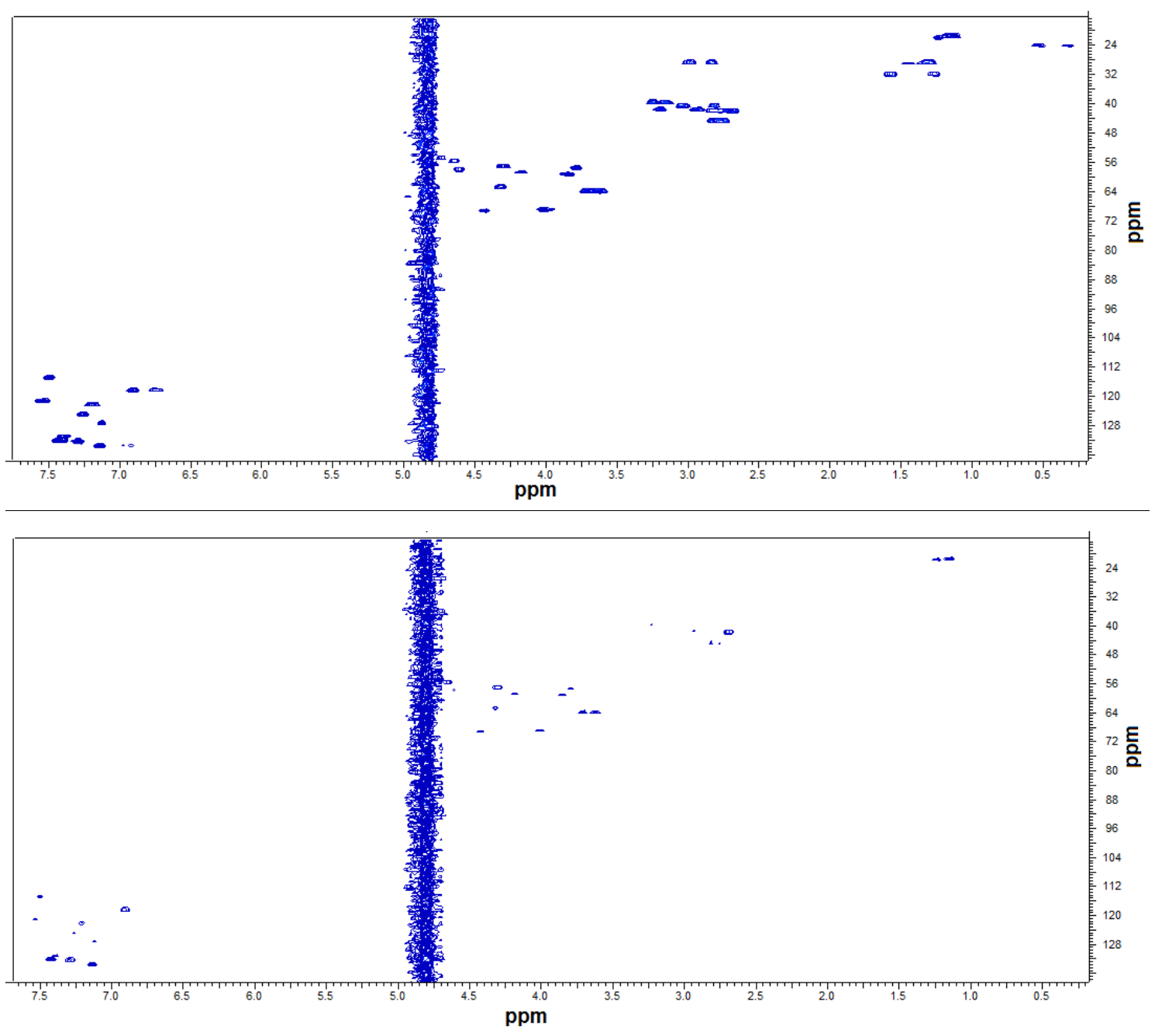

Figura 2.26: Espectros de HSQC, mostrando todos os sinais para o peptídeo TOC2 livre (espectro superior) e na presença da enzima tirosinase (espectro inferior). Ambos os espectros foram adquiridos com o mesmo número de scans e incrementos e apresentam o mesmo nível de corte (threshold).

Ao interagir com a tirosinase, o peptídeo passa a fazer parte do macrossistema ligante-enzima e, por consequência, relaxa mais rapidamente, o que pode causar uma variação na intensidade dos sinais. Este fato comprova a interação do peptídeo com a enzima.

\subsubsection{Docking Molecular}

Os estudos de redocking da L-dopa e L-tirosina foram feitos para validar o protocolo de docking utilizado. Em ambos os casos, o programa DockThor foi capaz de encontrar o modo de ligação experimental com sucesso. As soluções do redocking tanto da L-dopa como para a L-tirosina podem ser vistas nas Figuras 1.68 e 1.69, respectivamente, no capítulo anterior. 
Analisando o peptídeo TOC1, dentre os três modos de ligação de menor energia total preditos pelo programa DockThor, dois deles (o de segunda e terceira menor energia total, $119,842 \mathrm{kcal} / \mathrm{mol}$ e $121,355 \mathrm{kcal} / \mathrm{mol}$, respectivamente) possuem a cadeia lateral de tirosina interagindo no sítio de ligação do cobre, localizada na mesma região do aminoácido tirosina utilizado no redocking, e fazendo uma interação do tipo ligação de hidrogênio com o peróxido. As outras cadeias laterais do peptídeo interagem com a proteína através de ligações de hidrogênio e contatos hidrofóbicos, explorando outras cavidades menores existentes na superfície da proteína. É importante destacar que a solução de terceira melhor energia total $(121,355 \mathrm{kcal} / \mathrm{mol})$ possui a melhor energia intermolecular $(-49,752 \mathrm{kcal} / \mathrm{mol})$ entre as 10 melhores soluções preditas pelo DockThor. A solução de melhor energia total $(118,812 \mathrm{kcal} / \mathrm{mol})$ possui energia intermolecular igual a $-43,930 \mathrm{kcal} / \mathrm{mol}$ e realiza apenas interações na superfície da enzima, não possuindo nenhum grupo aromático no interior do sítio de ligação. As três soluções de menor energia para o docking do TOC1 podem ser vistas nas Figuras 2.27, 2.28 e 2.29, respectivamente. 


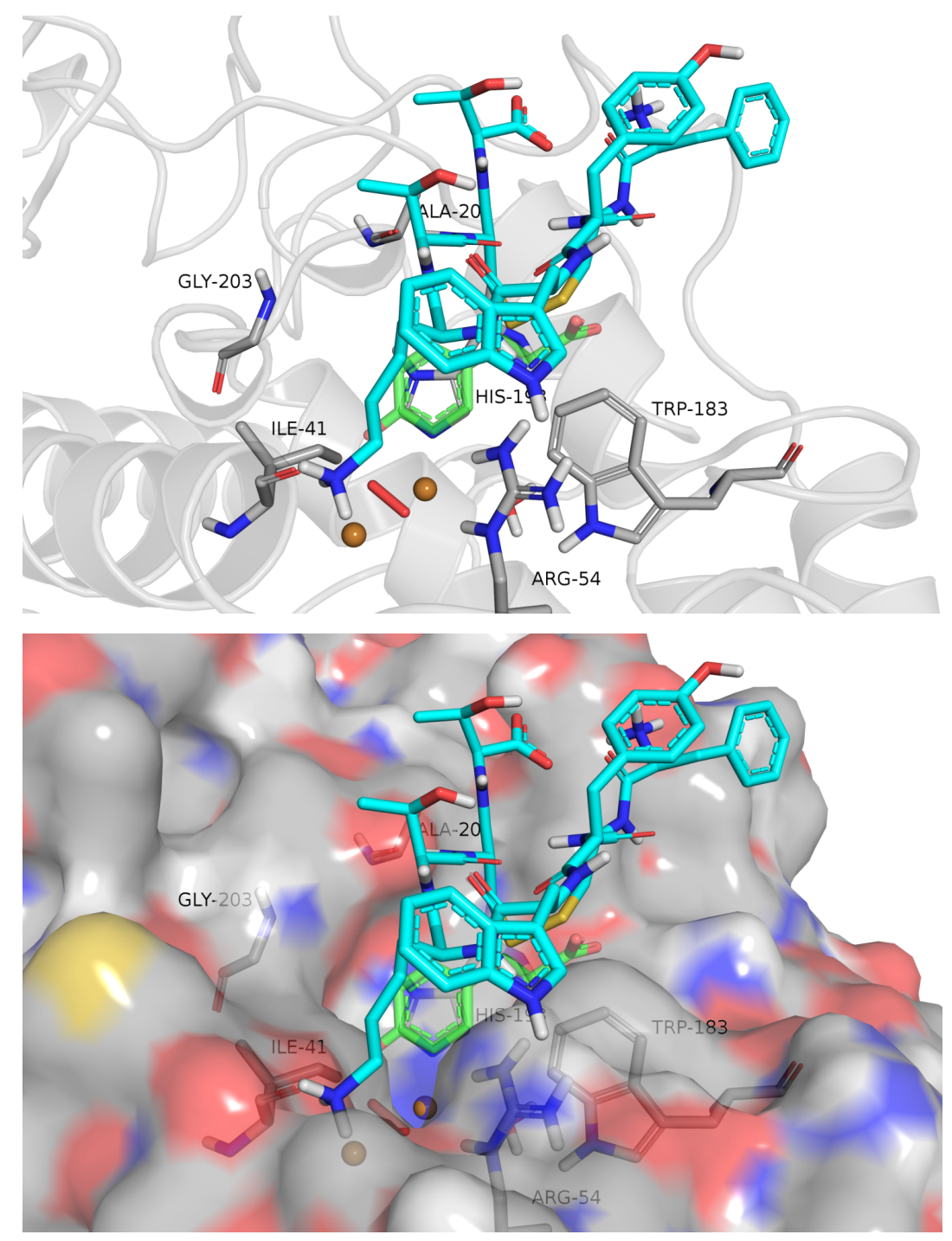

Figura 2.27: (Superior) Solução do docking da estrutura da tirosinase complexada com o modo de ligação de menor energia total do TOC1 $(\mathrm{E}$. total $=118,812 \mathrm{kcal} / \mathrm{mol}$ e E. intermolecular $=$ $43,930 \mathrm{kcal} / \mathrm{mol}$ ). A estrutura experimental da L-tirosina (complexo $4 \mathrm{p} 6 \mathrm{r}$ ) está representada em verde claro. (Inferior) Solução do docking com a superfície molecular da tirosinase. 

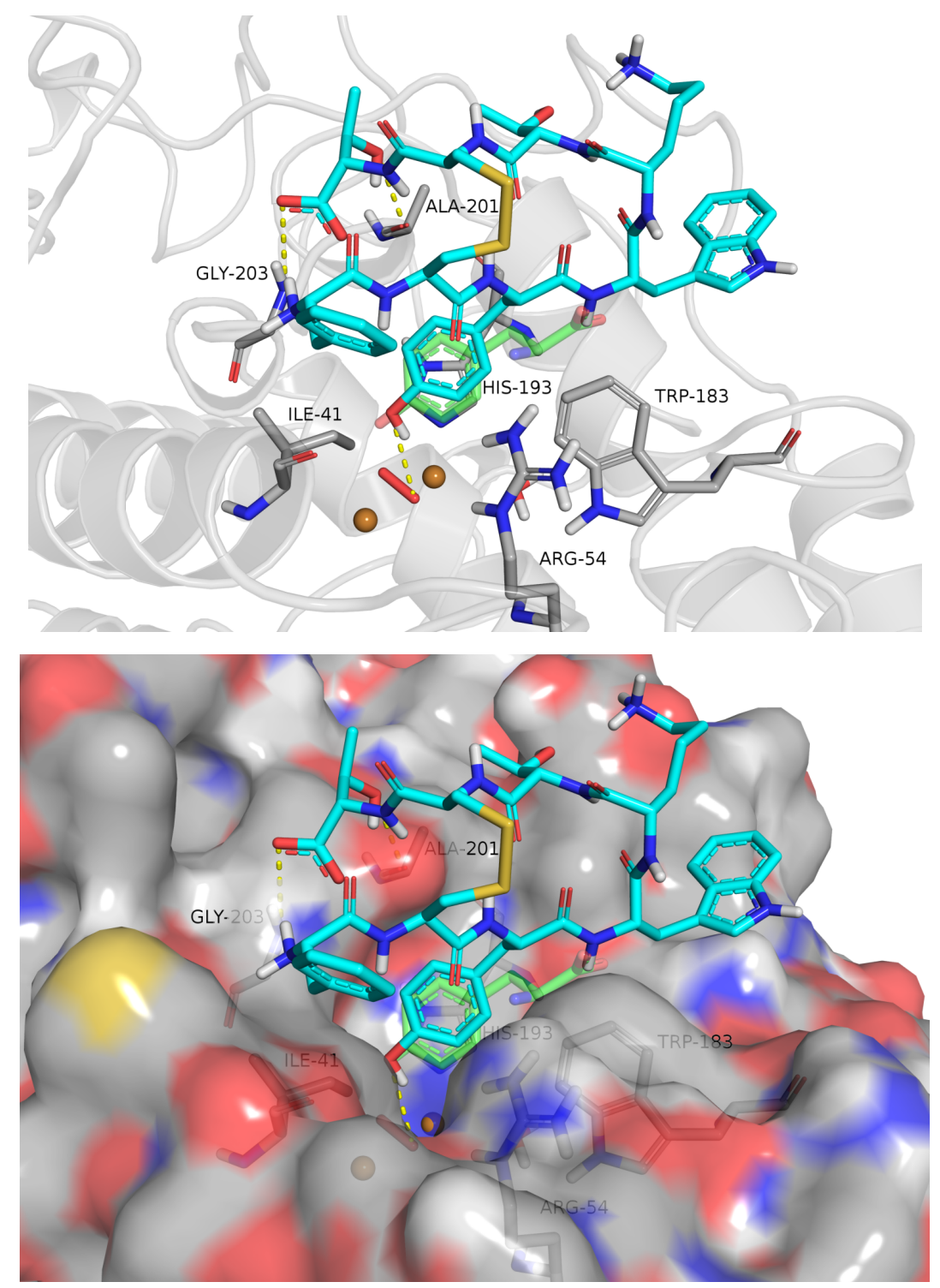

Figura 2.28: (Superior) Solução do docking da estrutura da tirosinase complexada com o modo de ligação de segunda menor energia total do TOC1 (E. total $=119,842 \mathrm{kcal} / \mathrm{mol} \mathrm{e} \mathrm{E}$. intermolecular $=-39,503 \mathrm{kcal} / \mathrm{mol}$ ). A ligação de hidrogênio da hidroxila do grupo fenol com o peróxido está representada através da linha pontilhada amarela. A estrutura experimental da Ltirosina (complexo 4p6r) está representada em verde claro. (Inferior) Solução do docking com a superfície molecular da tirosinase. 


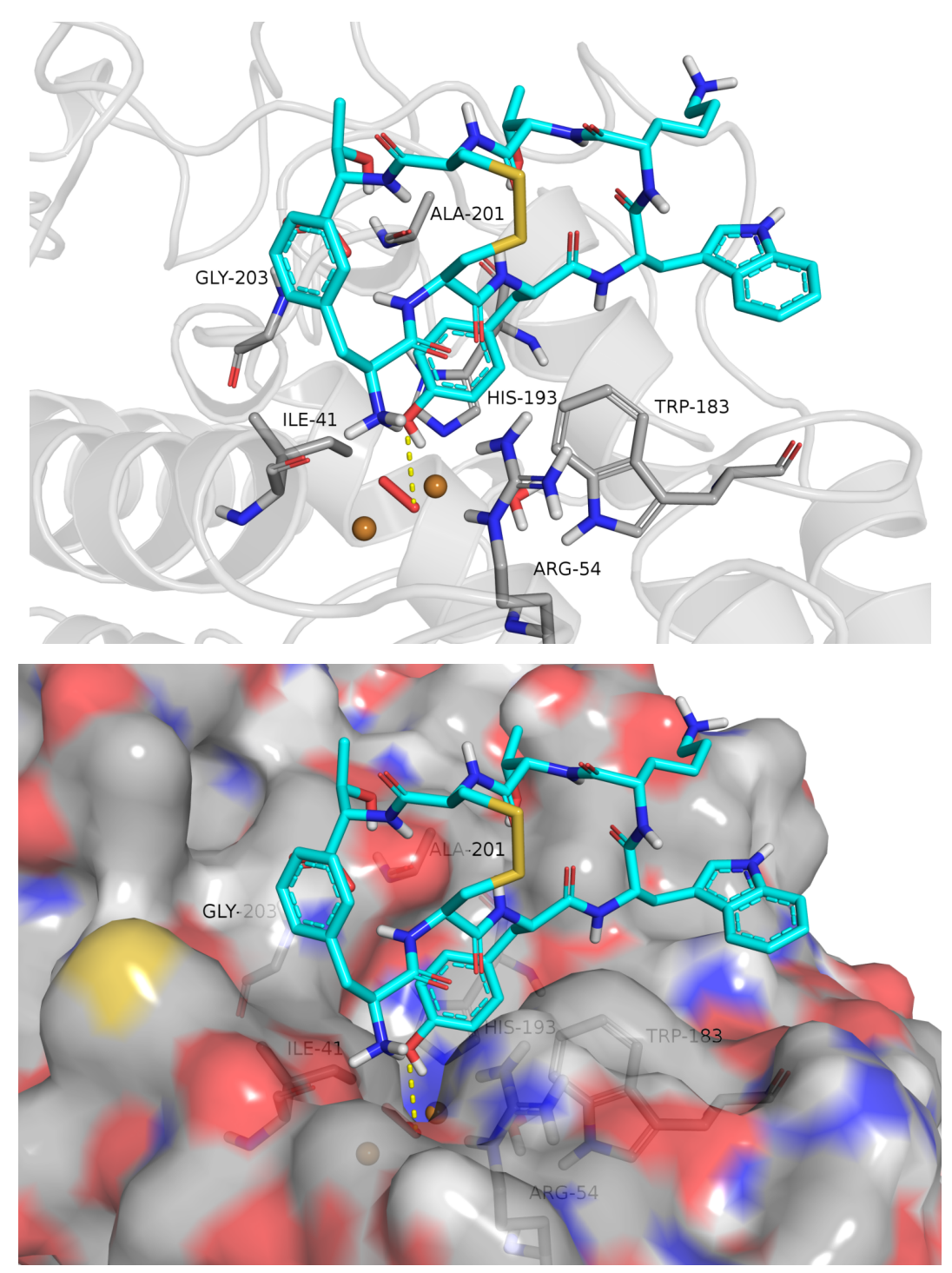

Figura 2.29: (Superior) Solução do docking da estrutura da tirosinase complexada com o modo de ligação de terceira menor energia total do TOC1 (E. total $=121,355 \mathrm{kcal} / \mathrm{mol}$ e E. intermolecular $=-49,752 \mathrm{kcal} / \mathrm{mol}$ ). A ligação de hidrogênio da hidroxila do grupo fenol com o peróxido está representada através da linha pontilhada amarela. (Inferior) Solução do docking com a superfície molecular da tirosinase.

As três soluções de menor energia total obtidas pelo programa DockThor para a TOC2 são bastantes distintas conformacionalmente, mas possuem energias totais bastante similares $(155,399 \mathrm{kcal} / \mathrm{mol}, 155,633$ $\mathrm{kcal} / \mathrm{mol}$ e $155,91 \mathrm{kcal} / \mathrm{mol})$. Dentre as três, apenas a terceira solução possui a tirosina no interior do sítio de ligação. A primeira solução possui a lisina no interior do sítio, enquanto que a segunda conformação possui a fenilalanina orientada para o interior do sítio de ligação. As três soluções de menor energia para o docking do TOC2 com a tirosinase podem ser observas nas Figuras 2.30, 2.31 e 2.32, respectivamente. 

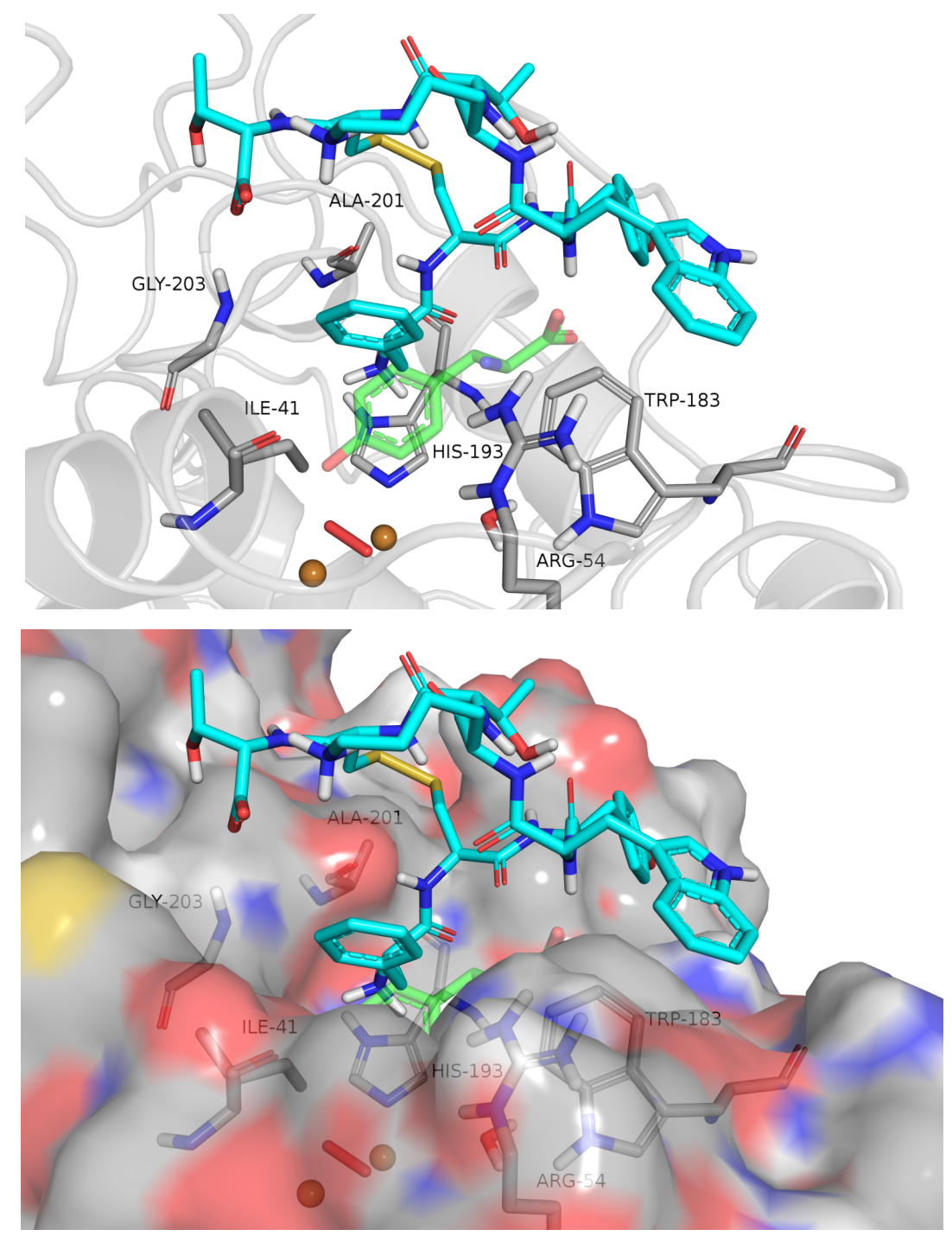

Figura 2.30: (Superior) Solução do docking da estrutura da tirosinase complexada com o modo de ligação de menor menor energia total do TOC2. A estrutura experimental da L-tirosina (complexo 4p6r) está representada em verde claro. (Inferior) Solução do docking com a superfície molecular da tirosinase. Nota-se a lisina voltada para o interior do sítio ativo. 

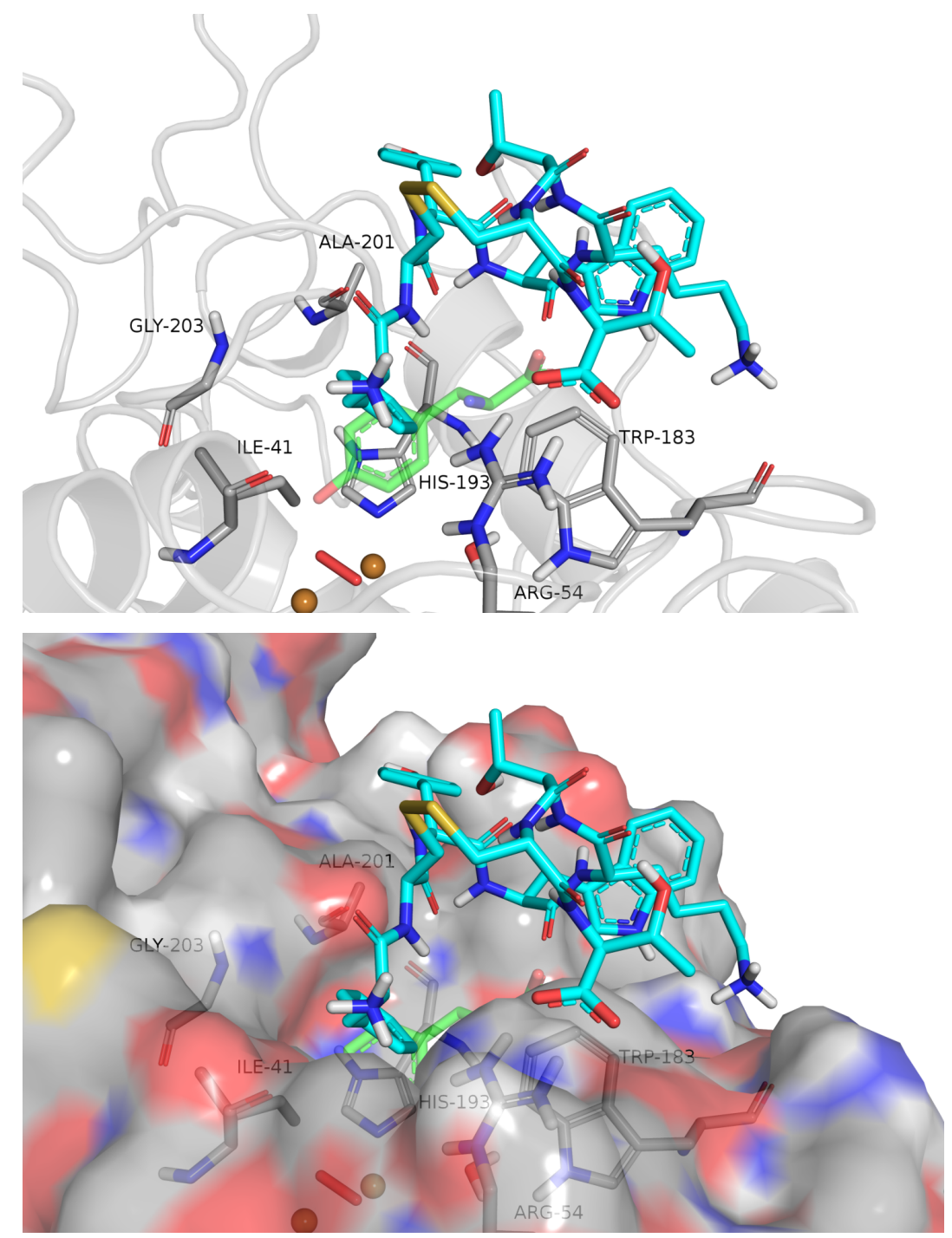

Figura 2.31: (Superior) Solução do docking da estrutura da tirosinase complexada com o modo de ligação de segunda menor energia total do TOC2. A estrutura experimental da L-tirosina (complexo 4p6r) está representada em verde claro. (Inferior) Solução do docking com a superfície molecular da tirosinase. Nota-se a fenilalanina voltada para o interior do sítio ativo. 


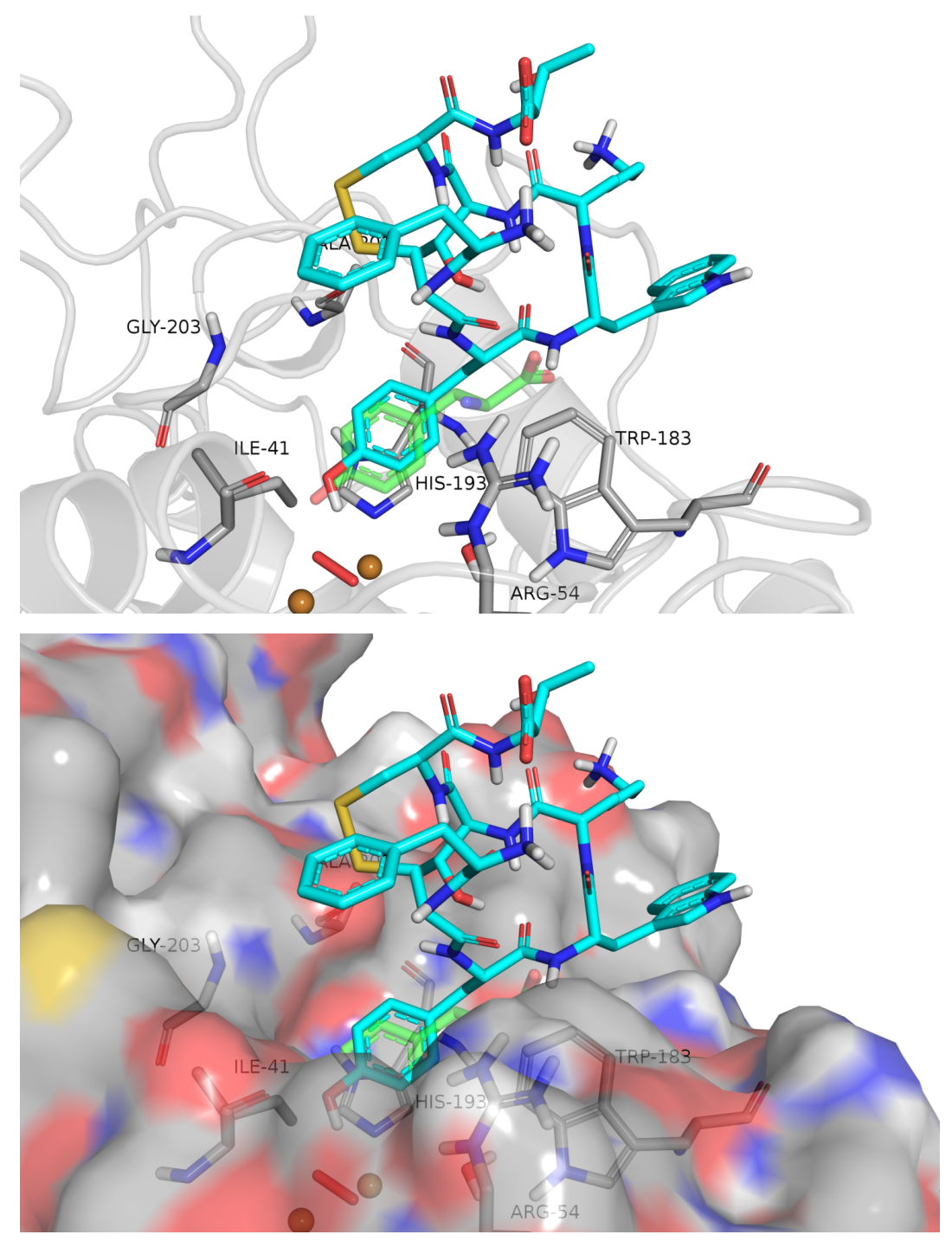

Figura 2.32: (Superior) Solução do docking da estrutura da tirosinase complexada com o modo de ligação de terceira menor energia total do TOC2. A estrutura experimental da L-tirosina (complexo 4p6r) está representada em verde claro. (Inferior) Solução do docking com a superfície molecular da tirosinase. Nota-se a tirosina voltada para o interior do sítio ativo.

É possível que o empacotamento observado na estrutura da TOC2 limite o número de interações intermoleculares possíveis de serem realizadas entre as cadeias laterais dos aminoácidos do peptídeo e os resíduos de aminoácidos da proteína. A melhor energia intermolecular obtida para TOC2 (segunda solução de menor energia total) foi de $-38,9 \mathrm{kcal} / \mathrm{mol}$, enquanto que para $\mathrm{o}$ TOC1 (terceira solução de menor energia total) foi de $-49,8 \mathrm{kcal} / \mathrm{mol}$. Esta fato pode estar relacionado com o fato de o TOC 2 apresentar uma menor atividade de ativação da tirosinase quando comparado com o TOC1.

Observa-se, em todas as soluções obtidas, uma interação tanto do TOC1 como do TOC2 pelo sítio ativo da enzima, o que poderia bloquear o sítio para a entrada dos substratos (L-tirosinase e L-dopa), causando uma 
diminuição da atividade da enzima. Entretanto, tais peptídeos são ativadores da enzima, e não inibidores. Este acontecimento pode ser justificado pelo fato dos peptídeos apresentarem um resíduo de tirosina na posição 3 bem exposto no loop da estrutura, o que poderia funcionar como fonte de tirosina para a enzima, causando uma ativação da mesma. Além disso, os dois peptídeos apresentaram soluções possíveis para o docking com a Tyr-3 voltada para o interior do sítio ativo, com orientação bastante similar com a observada para a tirosina livre (Figuras 2.28 e 2.32).

\subsubsection{Interação do Peptídeo Análogo com a Tirosinase por Espectrometria de Massa}

Realizou-se experimentos de MS e MS/MS do peptídeo TOC livre e do peptídeo em contato com a enzima. Os espectros de MS do peptídeo livre e do peptídeo na presença da tirosinase podem ser vistos na Figura 2.33.

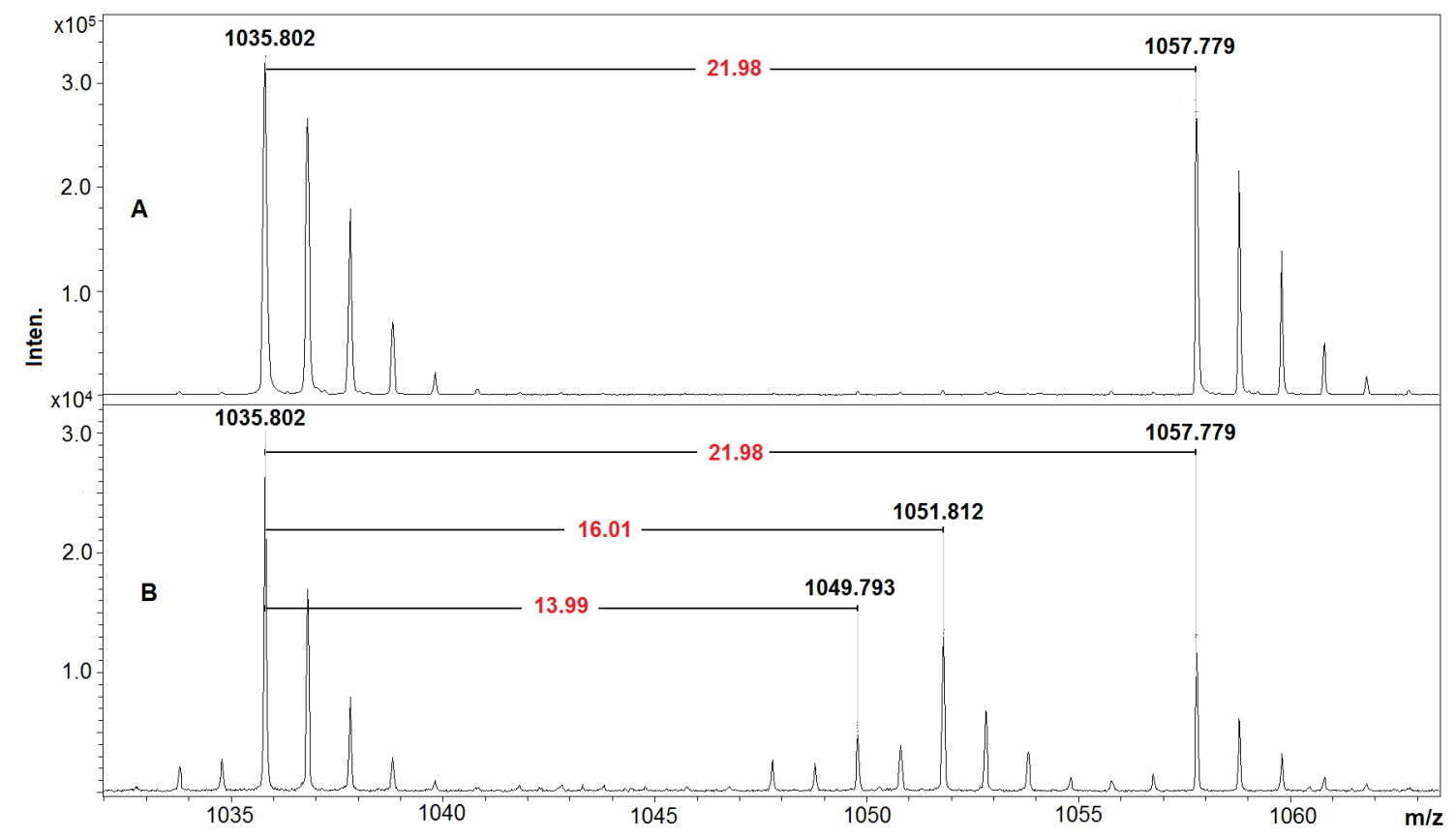

Figura 2.33: A) Espectro de Massa do peptídeo livre: $[\mathrm{TOC}+\mathrm{H}]^{+}=1035,8 \mathrm{Da}$. B) Espectro de Massa do peptídeo em contato com a enzima: $[\mathrm{TOC}+\mathrm{H}]^{+}=1035,8 \mathrm{Da}$; $[\mathrm{TOC}+\mathrm{H}+14]^{+}=$ 1049,8 e $[\mathrm{TOC}+\mathrm{H}+16]^{+}=1051,8$.

Observa-se, na Figura 2.33-A, o espectro de MS do peptídeo livre, com um sinal referente a $1035,8 \mathrm{Da}$ (massa esperada para o peptídeo). Na Figura 2.33-B, nota-se o espectro de Massa do peptídeo em contato com a enzima, 
com sinais referentes a $1035 \mathrm{Da}$ (peptídeo livre), $1049 \mathrm{Da}$ (peptídeo + $14 \mathrm{Da}$ ) e 1051 (peptídeo + 16 Da). A tirosinase é uma enzima conhecida por ser capaz de catalisar reações de hidroxilação em monofenóis e oxidação em difenóis (Kim, 2005). Essa reações são observadas quando a tirosinase atua na Ltirosina para produção de melanina. Com isso, o acréscimo observado de $16 \mathrm{e}$ 14 unidades na massa do peptídeo podem ser referentes a hidroxilação da Tyr3 (hidroxilação de fenóis) e da oxidação da Tyr-3 diidroxilada (oxidação de difenóis), conforme a Figura 2.34.

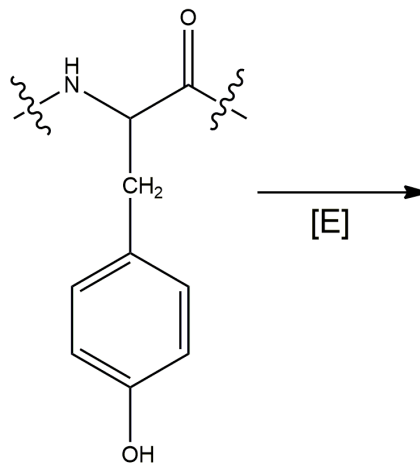

A<smiles>CCNC(=O)C(NC(C)C)C(C)(C)C</smiles>

B

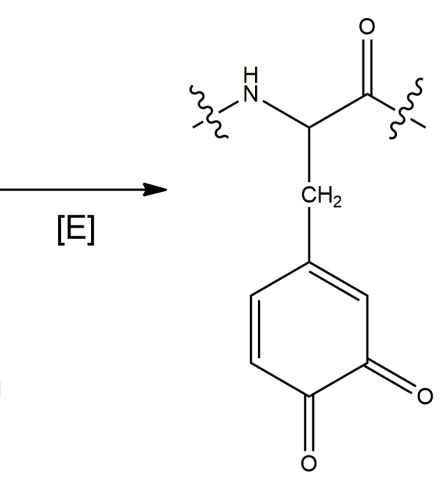

C

Figura 2.34: A) Estrutra do resído de tirosina. B) Estrutra do resíduo de tirosinase após uma hidroxilação, gerando um acréscima de 16 Da na massa. C) Estrutura da oxidação do resíduo de tirosina diidroxilada, gerando um acréscimo de $14 \mathrm{Da}$ de massa quando comparada com o resíduo de tirosina.

Observou-se que a tirosinase pode ser capaz de agir no resído de tirosina do peptídeo, e não apenas em tirosinas livres, catalizando as reações de hidroxilação e oxidação. Como o sítio do cobre da enzima é conhecido por promover essas reações (Gençer, 2012; Nerya, 2004; Kim, 2002), nota-se então a presença da Tyr-3 do TOC no sítio ativo a enzima, modo de ligação previsto pelo Docking Molecular.

Para confirmar as reações de hidroxilação e oxidação no resíduo de tirosina do TOC, realizou-se espectros de fragmentação (MS/MS) do íon referente ao peptídeo livre $\left([\mathrm{M}+\mathrm{H}]^{+}=1035,8 \mathrm{Da}\right)$, do íon referente ao peptídeo com a tirosina diidroxilada $\left([\mathrm{M}+\mathrm{H}+16]^{+}=1051,8 \mathrm{Da}\right)$ e do íon referente ou TOC com a oxidação do tirosina diidroxilada $\left([\mathrm{M}+\mathrm{H}+14]^{+}=1049,8 \mathrm{Da}\right)$. Os espectros de fragmentação podem ser observados na Figura 2.35. 


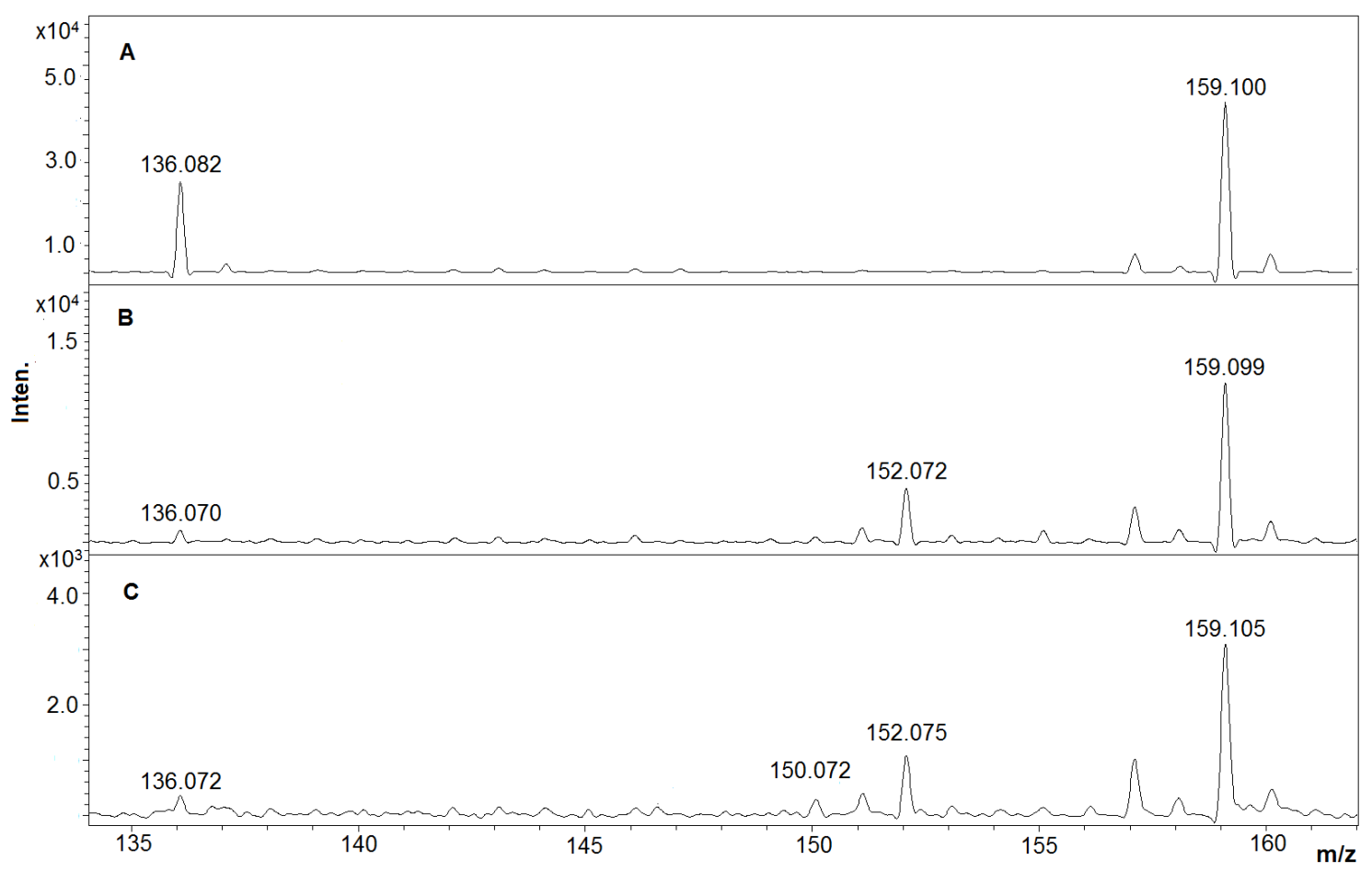

Figura 2.35: A) Fragmentação do íon $[\mathrm{M}+\mathrm{H}]^{+}=1035,8 \mathrm{Da}$, referente ao peptídeo livre, nota-se a presença dos íons imônios referentes a tirosina (136.08 Da) e ao triptofano $(159,1 \mathrm{Da})$. B) Fragmentação do íon $[\mathrm{M}+\mathrm{H}+16]^{+}=1051,8 \mathrm{Da}$, referente ao TOC com a tirosinase diidroxilada, nota-se um sinal referente ao íon imônio da tirosina diidroxilada (152,07 Da). C) Fragmentação do íon $[\mathrm{M}+\mathrm{H}+14]^{+}=1051,8 \mathrm{Da}$, referente ao TOC com oxidação da tirosinase diidroxilada, observa-se um sinal referente ao íon imônio da oxidação da tirosina diidroxilada (150,07 Da).

Para a fragmentação do íon $[\mathrm{M}+\mathrm{H}]^{+}=1035,8 \mathrm{Da}$, referente ao peptídeo livre, nota-se a presença dos íons imônios referentes a tirosina (136.08 Da) e ao triptofano (159,1 Da) (Figura 2.35-A). Para a fragmentação do íon $[\mathrm{M}+\mathrm{H}+16]^{+}=1051,8 \mathrm{Da}$, referente ao TOC com a tirosinase diidroxilada, notase um sinal referente ao íon imônio da tirosina diidroxilada (152,07 Da) e uma diminuição na intensidade do sinal referente ao íon imônio da tirosina (Figura 2.35-B), confirnando a reação de hidroxilação na tirosinase. Para a fragmentação do íon $[\mathrm{M}+\mathrm{H}+14]^{+}=1051,8 \mathrm{Da}$, referente ao TOC com oxidação da tirosinase diidroxilada, observa-se um sinal referente ao íon imônio da oxidação da tirosina diidroxilada (150,07 Da), e uma diminuição na intensidade do sinal referente ao íon imônio da tirosina, confirmando a reação. As estrutruas dos íons imônios podem ser vistas na Figuras 2.36. 


$$
\stackrel{+}{\mathrm{H}_{2} \mathrm{~N}}=\left.\right|_{\mathrm{R}} ^{\mathrm{CH}}
$$

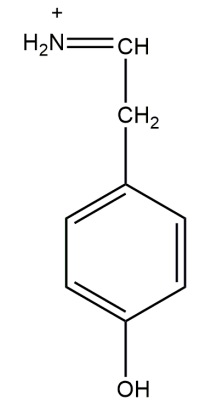

A

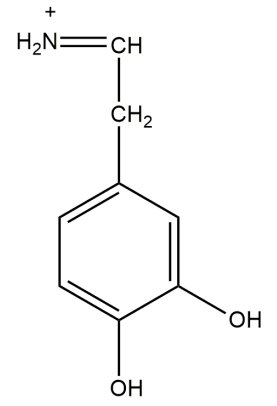

B<smiles>N=CCC1=CC(=O)C(=O)C=C1</smiles>

C

Figura 2.36: A) Estrutura do íon imônio da tirosina. B) Estrutura do íon imônio referente a tirosina diidroxilada. C) Estrutura do íon imônio da oxidação da tirosina diidroxilada.

Com isso, é possível confirmar a participação da enzima tirosinase na hidroxilação e oxidação do peptídeo TOC, sendo que estas reações estariam ocorrendo na Tyr3 do peptídeo. Observa-se que os dados de Espectrometria de Massa estão de acordo com os dados de Docking Molecular, ambos indicando a presença do resíduo de tirosina no sítio ativo.

Além disso, estes dados justificam a atividade do peptídeo TOC em ativar a enzima. Observa-se que a presença da Tyr3 do TOC no sítio ativo da enzima funciona como fonte de tirosina para a tirosinase continuar catalisando as reações de hidroxilação e oxidação, aumentando com isso a atividade catalítica da enzima. 


\subsection{Conclusão}

Dentre os diversos peptídeos análogos a somatostatina existentes, observou-se que o peptídeo TOC selecionado foi capaz de ativar a enzima tirosinase, algo até então inédito para esse peptídeo.

Durante o processo de purificação do TOC, notou-se que o mesmo poderia apresentar variações conformacionais. A RMN, juntamente com os cálculos teóricos, ajudaram a determinar a estrutura tridimensional do peptídeo, e caracterizar essa variação conformacional. O peptídeo apresentou duas estruturas, sendo a primeira, chamada de TOC1 com uma estrutura mais flexível, e uma segunda, chamada de TOC2 com uma estrutura mais rígida.

O peptídeo TOC1 (estrutura mais flexível) foi o encontrado no fármaco comercial utilizado para o diagnóstico de câncer (afinidade com receptores da somatostatina), enquanto que o TOC2 não foi encontrado nesse fármaco. Além disso, o TOC1 também apresentou uma maior atividade em relação à enzima tirosinase do que o TOC2. Isso sugere que a estrutura mais flexível do TOC1 pode ser importante para a sua atividade.

A interação do TOC com a tirosinase foi observada por RMN pelas variações de deslocamento químico e intensidade dos sinais. Notou-se uma variação no valor de deslocamento químico do $\operatorname{Trp}^{4}$ do peptídeo quando na presença da enzima, indicando uma possível essencialidade desse aminoácido para a atividade em relação à tirosinase.

Pelo estudo de docking molecular foram observados os possíveis modos de ligação do TOC1 e TOC2 com a enzima, e uma das soluções foi a Tyr-3 dos peptídeos voltada para o interior do sítio ativo. Tal fato foi confirmado por Espectrometria de Massa, em que se observou a Tyr-3 do TOC no sítio do cobre da enzima, fato que justiça a atividade de ativação da enzima promovida pelo peptídeo. Compreender os modos de ligação do peptídeo com a enzima pode ser de extrema importância para o planejamento de novos composto mais eficientes em relação à Tirosinase. 


\section{Referências}

ANGULO, J.; ENRÍQUEZ-NAVAS, P. M.; NIETO, P. M. Ligand-Receptor Binding Affinities from Saturation Transfer Difference (STD) NMR Spectroscopy: The Binding Isotherm of STD Initial Growth Rates. Chemistry- A European Journal, v. 16, n. 26, p. 7803-7812, 2010.

ASANUMA, M.; MIYAZAKI, I.; OGAWA, N. Dopamine- or L-DOPA-Induced Neurotoxicity: The Role of Dopamine Quinone Formation and Tyrosinase in a Model of Parkinson's Disease. Neurotoxicity Research, v. 5, n. 3, p. 165-176, 2003.

AZAM, S. S.; UDDIN, R.; SYED, A. A. S.; HAQ, Z. Molecular docking studies of potent inhibitors of tyrosinase and a-glucosidase. Medicinal Chemistry Research, v. 21, n. 8, p. 1677-1683, 2012.

BAIN, A. D. Chemical exchange in NMR. Progress in Nuclear Magnetic Resonance Spectroscopy, v. 43, n. 3, p. 63-103, 2003.

BARTOSCHEK, S.; KLABUNDE, T.; DEFOSSA, E; DIETRICH, V.; STENGELIN, S; GRIESINGER, C.; CARLOMAGNO, T.; FOCKEN, I.; WENDT, K. U. Drug Design for G-Protein-Coupled Receptors by a Ligand-Based NMR Method. Angewandte Chemie, v. 49, n. 8, p. 1426-1429, 2010.

BATTAINI G.; MONZANI E.; CASELLA L.; SANTAGOSTINI L.; PAGLIARIN R. Inhibition of the Catecholase Activity of Biomimetic Dinuclear Copper Complexes by Kojic Acid. Journal of biological inorganic chemistry, v. $5, \mathrm{n}$. 2, p. 262-268, 2000.

BEHERA, A.; DE, K.; CHANDRA, S.; CHATTOPADHYAY, S.; MISRA, M. Synthesis, radiolabeling and biodistribution of HYNIC-Tyr3 octreotide: a somatostatin receptor positive tumour imaging agent. Journal of Radioanalytical and Nuclear Chemistry, v. 290, n. 1, p. 123-129, 2011.

BEHERA, A.; BANERJEE, I.; DE, K.; MUNDA, R. N.; CHATTOPADHAYAY, S.; SAMANTA, A.; SARKAR, B.; GANGULY, S.; MISRA, M. Synthesis, characterization, conformational analysis of a cyclic conjugated octreotate peptide and biological evaluation of ${ }^{99 \mathrm{~m}} \mathrm{Tc}$-HYNIC-His ${ }^{3}$-Octreotate as novel tracer for the imaging of somatostatin receptor-positive tumors. Amino Acids, v. 44, n. 3, p. 933-946, 2013.

BENOITON, N. L. Chemistry of Peptide Synthesis. 1. ed. Boca Raton: Taylor and Francis, 2005.

BIEMANN, K.; PAPAYANNOPOULOS, I. A.; Amino Acid Sequencing of Proteins. Accounts of Chemical Research, v. 27, n. 11, p. 370-378, 1994.

BLOEMBERGEN, N.; PURCELL, E. M.; POUND, R. V. Relaxation Effects in Nuclear Magnetic Resonance Absorption. Physical Review, v. 73, n. 7, p. 679685, 1948. 
BOHM, H. J.; SCHNEIDER, G. Protein-Ligand Interactions From Molecular Recognition to Drug Design. 1. Ed. Weinheim: Wiley-VCH, 2003.

BOUSQUET, C.; GUILLERMET, J.; VERNEJOUL, F.; LAHLOU, H.; BUSCAIL, L.; SUSINI, C. Somatostatin receptors and regulation of cell proliferation. Digestive and Liver Disease, v. 36, n. 1, p. 2-7, 2004.

BRUNGER, A. T.; ADAM, P. D.; CLORE, G. M.; DELANO, W. L.; GROS, P.; GROSSE-KUNSTLEVE, R. W.; JIANG, J. S.; KUSZEWSKI, J.; NILGES, M.; PANNU, N. S.; READ, R. J.; RICE, L. M.; SIMONSON, T.; WARREN, G. L. Crystallography and NMR system: A new software suite for macromolecular structure determination. Acta Crystallographica Section D Structural Biology, v. 54, n. 1, p. 905-21, 1998.

BRUNGER, A. T. Version 1.2 of the Crystallography and NMR system. Nature Protocol, v. 2, n. 1, p. 2728-2733, 2007.

CANTU, M. D.; CARRILHO, E.; WULFF, N. A.; PALMA, M. S. Sequenciamento de Peptídeos Usando Espectrometria de Massas: um Guia Prático. Química Nova, v. 31, n. 3, p. 669-675, 2008.

CARLOMAGNO, T. NMR in natural products: understanding conformation, configuration and receptor interactions. Natural Product Reports, v. 29, n. 5, p.536-554, 2012.

CAVANAGH, J.; FAIRBROTHER, W. J.; PALMER, A. G.; RANCE, M.; SKELTON, N. J. Protein NMR Spectroscopy. 2. ed. London: Elsevier, 2007.

CHAN, W. C.; WHITE, P. D. Fmoc Solid Phase Peptide Synthesis. 1. ed. Oxford: PAS, 2000.

CHANDRA, S.; DE, K.; GANGULY, S.; SARKAR, B.; MISRA, M. Synthesis, radiolabeling and biological evaluation of a neutral tripeptide and its derivatives for potential nuclear medicine applications. Peptides, v. 30, n. 12, p. 23992408, 2009.

CHANG, T. S. An Updated Review of Tyrosinase Inhibitors. International Journal of Molecular Sciences, v. 10, n. 6, p. 2440-2475, 2009.

COLLINS, C. H.; BRAGA, G. L.; BONATO, P. S. Fundamentos de Cromatografia. 1. ed. São Paulo: Unicamp, 2009.

CONLON, J. M. Purification of naturally occurring peptides by reversed-phase HPLC. Nature Protocols, v. 2, n. 1, p. 191-197, 2007.

CORBINI, G.; MARTINI, S.; BONECHI, C.; CASOLARO, M.; CORTI, P.; ROSSI, C. Synthetic polymers as biomacromolecular models for studying ligand-protein interactions: A nuclear spin relaxation approach. Journal of Pharmaceutical and Biomedical Analysis, v. 40, n. 1, p. 113-121, 2006.

CROTTI, A. E. M.; FONSECA, T.; HONG, H.; STAUNTON, J.; GALEMBECK, S. E.; LOPES, N. P.; GATES, P. J. The Fragmentation Mechanism of Five- 
membered Lactones by Electrospray Ionization Tandem Mass Spectrometry. International Journal of Mass Spectrometry, v. 232, n. 1, p. 271-276, 2004.

DELAGLIO, F.; GRZESIEK, S.; VUISTER, G. W.; ZHU, G.; PFEIFER, J.; BAX, A. NMRPipe: A multidimensional spectral processing system based on UNIX pipes. Journal of Biomolecular NMR, v. 6, n. 3, p. 277-293, 1995.

DIERCKS, T.; COLES, M.; KESSLER, H. Applications of NMR in drug discovery. Current Opinion in Chemical Biology, v. 5, n. 3, p. 285-291, 2001.

DUBOIS, C.; HAUDECOEUR, R.; ORIO, M.; BELLE, C.; BOCHOT, C.; BOUMENDJEL, A.; HARDRE, E.; JAMET, H.; REGLIER, M. Versatile Effects of Aurone Structure on Mushroom Tyrosinase Activity. ChemBioChem, v. 13, n. 4, p. 559-565, 2012.

EMAMI, S.; HOSSEINIMEHR, S. J.; SHAHRBANDI, K.; ENAYATI, A. A.; ESMAEELI, Z. Synthesis and Evaluation of $2(3 \mathrm{H})$-Thiazole Thiones as Tyrosinase Inhibitors. Archiv der Pharmazie, v. 345, n. 8, p. 629-637, 2012.

FERREIRA, M. S.; PIRES, D. A. T.; FIGUEROA-VILLAR, J. D. Evaluation of Tetraketones and Xanthenediones as Tyrosinase Inhibitors or Activators. World Journal of Pharmacy and Pharmaceutical Sciences, v. 4, n. 4, p. 1705-1718, 2015.

FIELDS, G. B.; NOBLE, R. L. Solid phase peptide synthesis utilizing 9fluorenylmethoxycarbonyl amino acids. International Journal Of Peptide And Protein Research, v. 35, n. 3, p. 161-214, 1990.

FIGUEIREDO, I. M.; MARSAIOLI, A. M. Mapeamento das interações proteínaligante através de técnicas de RMN de ${ }^{1} \mathrm{H}$ utilizando detecção do ligante. Química Nova, v. 30, n. 7, p. 1597-1605, 2007.

FIGUEROA-VILLAR, J. D.; TINOCO, L. W. Spin-Lattice Relaxation Time in Drug Discovery and Design. Current Topics in Medicinal Chemistry, v. 9, n. 9, p. 811-823, 2009.

FINKINA, E. I.; BALANDIN, S. V.; SEREBRYAKOVA, M. V.; POTAPENKO, N. A.; TAGAEV, A. A.; OVCHINNIKOVA, T. V. Purification and primary structure of novel lipid transfer proteins from germinated lentil (Lens culinaris) seeds. Biochemistry (Moscow), v. 72, n. 4, p. 430-438, 2007.

GABRIEL, M.; DECRISTOFORO, C.; KENDLER, D.; DOBROZEMSKY, G.; HEUTE, D.; UPRIMNY, C.; KOVACS, P.; GUGGENBERG, E. V.; BALE, R.; VIRGOLINI, I. J. 68Ga-DOTA-Tyr3-Octreotide PET in Neuroendocrine Tumors: Comparison with Somatostatin Receptor Scintigraphy and CT. The Journal of Nuclear Medicine, v. 48, n. 4, p. 508-518, 2007.

GENÇER, N.; DEMIR, D.; SONMEZ, F.; KUCUKISLAMOGLU, M. New saccharin derivatives as tyrosinase inhibitors. Bioorganic \& Medicinal Chemistry, v. 20, n. 9, p. 2811-2821, 2012 
GIL, V. M. S.; GERALDES, C. F. G. C. Ressonância Magnética Nuclear Fundamentos, Métodos e Aplicações. 2. ed. Lisboa: Fundação Calouste Gulbenkian, 2002.

GONSALVES, A. M. R.; PINHO E MELO, T. M. V. D. Espectroscopia de Ressonância Magnética Nuclear. 1. ed. Coimbra: Universidade de Coimbra, 2007.

GUAN, S.; SU, W.; WANG, N.; LI, P.; WANG, Y. A Potent Tyrosinase Activator from Radix Polygoni multiflori and its Melanogenesis Stimulatory Effect in B16 Melanoma Cells. Phytotherapy Research, v. 22, n. 5, p. 660-663, 2008.

GUILLERMET-GUIBERT, J.; LAHLOU, H.; PYRONNET, S.; BOUSQUET, C.; SUSINI, C. Somatostatin receptors as tools for diagnosis and therapy: Molecular aspects. Best Practice \& Research Clinical Gastroenterology, v. 19, n. 4, p. 535-551, 2005.

HARRIS, R. K. Nuclear Magnetic Ressonance Spectrosopy. 1. ed. New York: Longman Sientific \& Technical, 1986.

HOWL, J. Peptide Synthesis and Applications. 1. ed. New Jersey: Humana Press, 2005.

HUNG, L. H.; SAMUDRALA, R. Accurate and automated classification of protein secondary structure with PsiCSI. Protein Science, v. 12, n. 2, p. 288295, 2003.

HWANG, T. L.; SHAKA, A. J. Water Suppression That Works. Excitation Sculpting Using Arbitrary Wave-Forms and Pulsed-Field Gradients. Journal of Magnetic Resonance - Series A, v. 112, n. 2, p. 275-279, 1995.

IULIIS, A.; ARRIGONI, G.; ANDERSSON, L.; ZAMBENEDETTI, P.; BURLINA, A.; JAMES, P.; ARSLAN, P.; VIANELLO, F. Oxidative metabolism of dopamine: A colour reaction from human midbrain analysed by mass spectrometry. Biochimica et Biophysica Acta, v. 1784, n. 11, p. 1687-1693, 2008.

JIANG, H.; SOMOGYI, A.; JACOBSEN, N. E.; TIMMERMANN, B. N.; GANG, D. $R$. Analysis of curcuminoids by positive and negative electrospray ionization and tandem mass spectrometry. Rapid Communications in Mass Spectrometry, v. 20, n. 6, p. 1001-1012, 2006.

JONG, M.; BAKKER, W. H.; KRENNING, E. P.; BREEMAN, W. A. P.; PLUIJM, W. E.; BERNARD, B. F.; VISSER, T. J.; JERMANN, E.; BEHE, M.; POWELL, P.; MATCKE, H. R. Yttrium-90 and indium-111 labelling, receptor binding and biodistribution of [DOTA ${ }^{0}, \mathrm{D}-\mathrm{Phel}, \mathrm{Tyr}^{3}$ ] octreotide, a promising somatostatin analogue for radionuclide therapy. European Journal of Nuclear Medicine, $v$. 24, n. 4, p. 368-371, 1997.

KAISER, E.; COLESCOTT, R. L.; BOSSINGER, C. D.; COOK, P. I. Color test for detection of free terminal amino groups in the solid-phase synthesis of peptides. Analytical Biochemistry, v. 34, n. 2, p. 595-598, 1970. 
KANNAN, S.; ZACHARIAS, M. Simulated annealing coupled replica exchange molecular dynamics - An efficient conformational sampling. Journal of Structural Biology, v. 166, n. 3, p. 288-294, 2009.

KAY, L. E. NMR studies of protein structure and dynamics - A look backwards and forwards. Journal of Magnetic Resonance, v. 213, n. 2, p. 492-494, 2011.

KHAN, K. M.; MAHARVI, G. M.; KHAN, M. T. H.; SHAIKH, A. J.; PERVEEN, S; BEGUM, S.; CHOUDHARY, M. I. Tetraketones: A new class of tyrosinase inhibitors. Bioorganic \& Medicinal Chemistry, v. 14, n. 2, p. 344-351, 2006.

KHATIB, S.; NERYA, O.; MUSA, R.; SHMUEL, M.; TAMIRA, S.; VAYA, J. Chalcones as potent tyrosinase inhibitors: the importance of a 2,4-substituted resorcinol moiety. Bioorganic and Medicinal Chemistry, v. 13, n. 2, p. 433441, 2005.

KIM, Y. M.; YUN, J.; LEE, C.; LEE, H.; MIN, K. R.; KIM, Y. Oxyresveratrol and hydroxystilbene compounds. Inhibitory effect on tyrosinase and mechanism of action. The Journal of Biological Chemistry, v. 277, n. 18, p. 16340-16344, 2002.

KIM, Y. J.; UYAMA, H. Tyrosinase inhibitors from natural and synthetic sources: structure, inhibition mechanism and perspective for the future. Cellular and Molecular Life Sciences, v. 62, n. 15, p. 1707-1723, 2005.

KIRBY, N. I.; DEROSE, E. F.; LONDON, R. E.; MUELLER, G. A. NvAssign: protein NMR spectral assignment with NMRView. Bioinformatics, v. 20, n. 7, p. 1201-1203, 2004.

KORADI, R.; BILLETER, M.; WUTHRICH, K. MOLMOL: A program for display and analysis of macromolecular structures. Journal of Molecular Graphics, v. 14, n. 1, p. 51-55, 1996.

KRENNING, E. P.; KWEKKEBOOM, D. J.; BAKKER, W. H.; BREEMAN, W. A. P.; KOOIJ, P. P. M.; OEI, H. Y.; HAGEN, M.; POSTEMA, P. T. E.; JONG, M.; REUBI, J. C.; VISSER, T. J.; REIJS, A. E. M.; HOFLAND, L. J.; KOPER, J. W.; LAMBERTS, S. W. J. Somatostatin receptor scintigraphy with $\left[{ }^{111}\right.$ In-DTPA-DPhe $\left.{ }^{1}\right]$ - and $\left[{ }^{123} \mid-\mathrm{Tyr}^{3}\right]$-octreotide: the Rotterdam experience with more than 1000 patients. European Journal of Nuclear Medicine, v. 20, n. 8, p. 716-731, 1993.

KRIMM, I. INPHARMA-based identification of ligand binding site in fragmentbased drug design. Medicinal Chemistry Communications, v. 3, n. 1, p. 605610, 2012.

KUBO, I.; CHEN, Q.; NIHEI, K. Molecular design of antibrowning agents: antioxidative tyrosinase inhibitors. Food Chemistry, v. 81, n. 2, p. 241-247, 2003.

KWEKKEBOOM, D. J.; HERDER, W. W.; KAM, B. L.; EIJCK, C. H.; ESSEN, M.; KOOIJ, P. P.; FEELDERS, R. A.; AKEN, M. O.; KRENNING, E. P. Treatment With the Radiolabeled Somatostatin Analog ${ }^{177} \mathrm{Lu}-$ 
DOTA $^{0}$, Tyr $^{3}$ ]Octreotate: Toxicity, Efficacy, and Survival. Journal of Clinical Oncology, v. 26, n. 13, p. 2124-2130, 2008.

LAMBERTS, S. W. J.; KRENNING, E. P.; REUBI, J. The Role of Somatostatin and Its Analogs in the Diagnosis and Treatment of Tumors. Endocrine Reviews, v. 12, n. 4, p. 450-482, 1991.

LAMBERTS, S. W. J.; HERDER, W. W.; HOFLAND, L. J. Somatostatin analogs in the diagnosis and treatment of cancer. Trends in Endocrinology and Metabolism, v. 13, n. 10, p. 451-457, 2002.

LANÇAS, F. M. Cromatografia Líquida Moderna: HPLC/CLAE. 1 ed. São Paulo: Átomo, 2009.

LEITE, J. R. S. A.; SILVA, L. P.; RODRIGUES, M. I. S.; PRATES, M. V.; BRAND, G. D.; LACAVA, B. M.; AZEVEDO, R. B.; BOCCA, A. L.; ALBUQUERQUE, S.; BLOCH Jr, C. Phylloseptins: a novel class of antibacterial and anti-protozoan peptides from the Phyllomedusa genus. Peptides, v. 26, n. 4 , p. $565-573,2005$.

LEVITT, M. H. Composite pulses. Progress in NMR Spectroscopy, v. 18, n. 1, p. 61-122, 1986.

LUDWIG, C.; GUENTHER U. L. Ligand based NMR methods for drug discovery. Frontiers in Bioscience, v. 14, n. 1, p. 4565-4574, 2009.

LUO, R.; LIU, M.; MAO, X. NMR diffusion and relaxation study of drug-protein interaction. Spectrochimica acta. Part A, Molecular and Biomolecular Spectroscopy, v. 55, n. 9, p. 1897-1901, 1999.

MAGALHÃES, C. S.; BARBOSA, H. J. C.; DARDENNE, L. E. SelectionInsertion Schemes in Genetic Algorithms for the Flexible Ligand Docking Problem. Lecture Notes in Computer Science, v. 3102, n. 1, p. 1-12, 2004.

MAGALHÃES, C. S.; ALMEIDA, D. M.; BARBOSA, H. J. C., DARDENNE, L. E. A Dynamic Niching Genetic Algorithm Strategy for Docking of Highly Flexible Ligands. Information Sciences, v. 289, n. 24, p. 206-224, 2014.

MARQUARDT, M.; EIFLER-LIMA, V. L. A Síntese Orgânica em Fase Sólida e seus Suportes Poliméricos mais Empregados. Química Nova, v. 24, n. 6, p. 846-855, 2001.

MAYER, M.; MEYER B. Group Epitope Mapping by Saturation Transfer Difference NMR To Identify Segments of a Ligand in Direct Contact with a Protein Receptor. Journal of the American Chemical Society, v. 123, n. 1, p. 6108-6117, 2001.

MCCOY, M. A.; SENIOR, M. M.; WYSS, D. F. Screening of Protein Kinases by ATP-STD NMR Spectroscopy. Journal of the American Chemical Society, v. 127, n. 22, p. 7978-7979, 2005. 
MELACINI, G.; ZHU, Q.; GOODMAN, M. Multiconformational NMR Analysis of Sandostatin (Octreotide): Equilibrium between B-Sheet and Partially Helical Structures. Biochemistry, v. 36, n. 6, p. 1233-1241, 1997.

MEYER, B.; PETERS, T. NMR Spectroscopy Techniques for Screening and Identifying Ligand Binding to Protein Receptors. Angewandte Chemie, v. 42, n. 8, p. 864-890, 2003.

MOORE, J. M. NMR screening in drug discovery. Current Opinion in Biotechnology, v. 10, n. 1, p. 54-58, 1999.

NERYA, O.; MUSA, R.; KHATIB, S.; TAMIR, S.; VAYA, J. Chalcones as potent tyrosinase inhibitors: the effect of hydroxyl positions and numbers. Phytochemistry, v. 65, n. 10, p. 1389-1395, 2004.

NEVES-FERREIRA, A. G. C.; PERALES, J.; FOX, J. W.; SHANNON, J. D.; MAKINO, D. L.; GARRATT, R. C.; DOMONT, G. B. Structural and Functional Analyses of DM43, a Snake Venom Metalloproteinase Inhibitor from Didelphis marsupialisSerum. The Journal of Biological Chemistry, v. 277, n. 15, p. 13129-13137, 2002.

NIENHAUS, G. U. Protein-Ligand Interactions. 1. ed, New Jersey: Humana Press, 2010.

ORTS, J.; GRIMM, S. K.; GRIESINGER ,C.; WENDT, K. U.; BARTOSCHEK, S.; CARLOMAGNO, T. Specific Methyl Group Protonation for the Measurement of Pharmacophore- Specific Interligand NOE Interactions. Chemistry, v. 14, n. 25, p. 7517-7520, 2008.

ORTS, J.; GRIESINGER, C.; CARLOMAGNO, T. The INPHARMA technique for pharmacophore mapping: A theoretical guide to the method. Journal of Magnetic Resonance, v. 200, n. 1, p. 64-73, 2009.

ORTS, J.; BARTOSCHEK, S.; GRIESINGER, C.; MONECKE, P.; CARLOMAGNO, T. An NMR-based scoring function improves the accuracy of binding pose predictions by docking by two orders of magnitude. Journal of Biomolecular NMR, v. 52, n. 1, p 23-30, 2012.

PARVEZ, S.; KANG, M.; CHUNG, H.; BAE, H. Naturally Occurring Tyrosinase Inhibitors: Mechanism and Applications in Skin Health, Cosmetics and Agriculture Industries. Phytotherapy Research, v. 21, n. 9, p. 805-816, 2007.

PAVIA, D. L.; LAMPMAN, G. M.; KRIZ, G. S.; VYVYAN, J. R. Introdução à Espectroscopia. 4. ed. São Paulo: Cengage Learning, 2010.

PIRES, D. A. T.; BEMQUERER, M. P.; NASCIMENTO, C. J. Some Mechanistic Aspects on Fmoc Solid Phase Peptide Synthesis. International Journal of Peptide Research and Therapeutics, v. 20, n. 1, p. 53-69, 2014.

PIRES, D. A. T.; PEREIRA, W. L.; TEIXEIRA, R. R.; FIGUEROA-VILLAR, J. D.; NASCIMENTO, C. J. Nuclear Magnetic Resonance (NMR), Infrared (IR) and Mass Spectrometry (MS) study of keto-enol tautomerism of isobenzofuran- 
$1(3 \mathrm{H})$-one derivatives. Journal of Molecular Structure, v. 1113, n. 5, p. 146152, 2016.

PREZIOSO, J. A.; EPPERLY, M. W.; WANG, N.; BLOOMER, W. D. Effects of tyrosinase activity on the cytotoxicity of 4-S-cysteaminylphenol and N-acetyl-4S-cysteaminylphenol in melanoma cells. Cancer Letters, v. 63, n. 1, p. 73-79, 1992.

RENNÓ, M. N.; FRANÇA, T. C. C.; NICO, D.; SOUSA, C. B. P.; TINOCO, L. W.; FIGUEROA-VILLAR, J. D. Kinetics and docking studies of two potential new inhibitors of the nucleoside hydrolase from Leishmania donovani. European Journal of Medicinal Chemistry, v. 56, n. 1, p. 301-307, 2012.

ROBERTS, G. C. K. Applications of NMR in drug discovery. Research Focus, v. 5, n. 1, p. 230-240, 2000.

RULE, G. S.; HITCHENS, T. K. Fundamentals of Protein NMR Spectroscopy. 1. ed. Dordrecht: Springer, 2006.

SAEWAN, N.; KOYSOMBOON, S.; CHANTRAPROMMA, K. Anti-tyrosinase and anti-cancer activities of flavonoids from Blumea balsamifera DC. Journal of Medicinal Plants Research, v. 5, n. 6, p. 1018-1025, 2011.

SANCHEZ-PEDREGAL, V. M.; REESE, M.; MEILER, J.; BLOMMERS, M. J. J.; GRIESINGER, C.; CARLOMAGNO, T. The INPHARMA Method: ProteinMediated Interligand NOEs for Pharmacophore Mapping. Angewandte Chemie, v. 44, n. 27, p. 4172-4175, 2005.

SCARPIGNATO, C.; PELOSINI, I. Somatostatin Analogs for Cancer Treatment and Diagnosis: An Overview. Chemotherapy, v. 47, n. 2, p.1-29, 2001.

SCHARTINGER, V. H.; DUDÁS, J.; DECRISTOFORO, C.; URL, C.; SCHNABL, J.; GÖBEL, G.; VIRGOLINI, I. J.; RIECHELMANN, H.; RASSE, M.; WAITZ, D.; PUTZER, D. ${ }^{68} \mathrm{Ga}-\mathrm{DOTA}{ }^{0}-\mathrm{Tyr}^{3}$-octreotide positron emission tomography in head and neck squamous cell carcinoma. European Journal of Nuclear Medicine and Molecular Imaging, v. 42, n. 1, p. 20-24, 2015.

SCHURINK, M.; BERKEL, W. J. H.; WICHERS, H. J.; BOERIU, C. G. Novel peptides with tyrosinase inhibitory activity. Peptides, v. 28, n. 3, p. 485-495, 2007.

SENDOVSKI M.; KANTEEV M.; BEN-YOSEF V. S.; ADIR N.; FISHMAN A. First Structures of an Active Bacterial Tyrosinase Reveal Copper Plasticity. Journal of Molecular Biology, v. 405, n. 1, p. 227-237, 2011.

SEO, S. Y.; SHARMA, V. K.; SHARMA, N. Mushroom Tyrosinase: Recent Prospects. Journal of Agricultural and Food Chemistry, v. 51, n. 10, p. 28372853, 2003.

SHAO, Y.; MOLNAR, L. F.; JUNG, Y.; KUSSMANN, J.; OCHSENFELD, C.; BROWN, S. T.; GILBERT, A. T. B.; SLIPCHENKO, L. V.; LEVCHENKO, S. V.; O'NEILL, D. P.; DISTASIO, J. R. A.; LOCHAN, R. C.; WANG, T.; BERAN, G. J. 
O.; BESLEY, N. A.; HERBERT, J. M.; LIN, C. Y.; VAN VOORHIS, T.; CHIEN, S. H.; SODT, A.; STEELE, R. P.; RASSOLOV, V. A.; MASLEN, P. E.; KORAMBATH, P. P.; ADAMSON, R. D.; AUSTIN, B.; BAKER, J.; BYRD, E. F. C.; DACHSEL, H.; DOERKSEN, R. J.; DREUW, A.; DUNIETZ, B. D.; DUTOI, A. D.; FURLANI, T. R.; GWALTNEY, S. R.; HEYDEN, A.; HIRATA, S.; HSU, C. P.; KEDZIORA, G.; KHALLIULIN, R. Z.; KLUNZINGER, P.; LEE, A. M.; LEE, M. S.; LIANG, W. Z.; LOTAN, I.; NAIR, N.; PETERS, B.; PROYNOV, E. I.; PIENIAZEK, P. A.; RHEE, Y. M.; RITCHIE, J.; ROSTA, E.; SHERRILL, C. D.; SIMMONETT, A. C.; SUBOTNIK, J. E.; WOODCOCK III, H. L.; ZHANG, W.; BELL, A. T.; CHAKRABORTY, A. K.; CHIPMAN, D. M.; KEIL, F. J.; WARSHEL, A.; HEHRE, W. J.; SCHAEFER, H. F.; KONG, J.; KRYLOV, A. I.; GILL, P. M. W.; HEADGORDON, M. Advances in methods and algorithms in a modern quantum chemistry program package. Physical Chemistry Chemical Physics, v. 8, n. 27, p. 3172-3191, 2006.

SHEN, Y.; DELAGLIO, F.; CORNILESEU, G. TALOS+: a hybrid method for predicting protein backbone torsion angles from NMR chemical shifts. Journal of Biomolecular NMR, v. 44, n. 4, p. 213-223, 2009.

SHIBUE, M.; MANT, C. T.; HODGES, R. S. Effect of anionic ion-pairing reagent concentration (1-60 mM) on reversed-phase liquid chromatography elution behaviour of peptides. Journal of Chromatography, v. 1080, n. 1, p. 58-67, 2005.

SHIN, N.; RYU, S. Y.; CHOI, E. J.; KANG, S.; CHANG, I.; MIN, K. R.; KIM, Y. Oxyresveratrol as the Potent Inhibitor on Dopa Oxidase Activity of Mushroom Tyrosinase. Biochemical and Biophysical Research Comunicatons, v. 243, n. 3, p. 801-803, 1998.

SILVERSTEIN, R. M.; WEBSTER, F. X.; KIEMLE, D. J. Identificação Espectrométrica de Compostos Orgânicos. 7. ed. Rio de Janeiro: LTC, 2007.

SKJAERVEN, L.; CODUTTI, L.; ANGELINI, A.; GRIMALDI, M.; LATEK, D.; MONECKE, P.; DREYER, M. K.; CARLOMAGNO, T. Accounting for Conformational Variability in Protein-Ligand Docking with NMR-Guided Rescoring. Journal of the American Chemical Society, v. 135, n. 15, p. 58195827, 2013.

SOARES, S. F. C. X.; VIEIRA, A. A.; DELFINO, R. T.; FIGUEROA-VILLAR, J. D. NMR determination of Electrophorus electricus acetylcholinesterase inhibition and reactivation by neutral oximes. Bioorganic and Medicinal Chemistry, v. 21, n. 18, p. 5923-5930, 2013.

SON, W.; JANG, S.; SHIN, S.; Simulated Q-annealing: conformational search with an effective potential. Journal of Molecular Modeling, v. 18, n. 1, p. 213220, 2012.

SOUZA, A. A.; MARSAIOLI, A. J.; FERREIRA, A. G.; LAVERDE, A.; FUJIWARA, F. Y.; FIGUEIREDO, I. M.; VIZZOTTO, L.; Fernandes, S. A. 
Fundamentos e Aplicações da Ressonância Magnética Nuclear - Difusão Molecular por RMN. 1. ed, Rio de Janeiro: AUREMN, 2009.

STAUCH, B.; ORTS, J.; CARLOMAGNO, T. The description of protein internal motions aids selection of ligand binding poses by the INPHARMA method. Journal of Biomolecular NMR, v. 54, n. 3, p. 245-256, 2012.

STOCKMAN, B. J.; DALVIT, C. NMR screening techniques in drug discovery and drug design. Progress in Nuclear Magnetic Resonance Spectroscopy, v. 41, n. 1 , p. 187-231, 2002.

SUGAWARA, M.; RESENDE, J. M.; MORAES, C. M.; MARQUETTE, A.; CHICH, J. F.; METZ-BOUTIGUE, M. H.; BECHINGER, B. Membrane structure and interactions of human catestatin by multidimensional solution and solidstate NMR spectroscopy. FASEB Journal, v. 24, n. 6, p. 1737-1746, 2010.

SULKOWSKA, A.; BOJKO, B.; ROWNICKA, J.; REZNER, P.; SUŁKOWSKI, W. $W$. The competition of drugs to serum albumin in combination chemotherapy: NMR study. Journal of Molecular Structure, v. 744-747, n. 3, p. 781-787, 2005.

SUN, S.; MA, H.; HAN, G.; WU, R.; ZOU, H.; LIU, Y. Efficient enrichment and identification of phosphopeptides by cerium oxide using on-plate matrix-assisted laser desorption/ ionization time-of-flight mass spectrometric analysis. Rapid Communications in Mass Spectrometry, v. 25, n. 13, p. 1862-1868, 2011.

TEIXEIRA, R. R.; BRESSAN, G. C.; PEREIRA, W. L.; FERREIRA, J. G.; OLIVEIRA, F. M.; THOMAZ, D. C. Synthesis and Antiproliferative Activity of C-3 Functionalized Isobenzofuran-1(3H)-ones. Molecules, v. 18, n. 2, p. 18811896, 2013.

TEIXEIRA, R. R.; PEREIRA, J. L.; SILVA, S. F.; GUILARDI, S.; PAIXÃO, D. A.; ANCONI, C. P. A.; ALMEIDA, W. B.; ELLENA, J.; FORLANI, G. Synthesis, characterization and phytotoxic activity of hydroxylated isobenzofuran-1(3H)ones. Journal of Molecular Structure, v. 1061, n. 5, p. 61-68, 2014.

TROLL, W.; CANNAN, R. K. A modified photometric ninhydrin method for the analysis of amino and imino acids. The Journal of Biological Chemistry, v. 200, n. 2, p. 803-811, 1953.

UBEID, A. A.; DO, S.; NYE, C.; HANTASH, B. M. Potent low toxicity inhibition of human melanogenesis by novel indole-containing octapeptides. Biochimica et Biophysica Acta, v. 1820, n. 10, p. 141-149, 2012.

VIEGAS, A.; MANSO, J.; NOBREGA, F. L.; CABRITA, E. J. Saturation-Transfer Difference (STD) NMR: A Simple and Fast Method for Ligand Screening and Characterization of Protein Binding. Journal of Chemical Education, v, 88, n. 7, p. 990-994, 2011.

VONTZALIDOU, A.; ZOIDIS, G.; CHAITA, E.; MAKROPOULOU, M.; ALIGIANNIS, N.; LAMBRINIDIS, G.; MIKROS, E.; SKALTSOUNIS, A. L. Design, synthesis and molecular simulation studies of dihydrostilbene 
derivatives as potent tyrosinase inhibitors. Bioorganic and Medicinal Chemistry Letters, v. 22, n. 17, p. 5523-5526, 2012.

WANG, Y.; LIU, D.; WYSS, D. F. Competition STD NMR for the detection of high-affinity ligands and NMR-based screening. Magnetic Resonance in Chemistry, v. 42, n. 6, p.485-489, 2004.

WILD, D.; SCHMITT, J. S.; GINJ, M.; MÄCKE, H. R.; BERNARD, B. F.; KRENNING, E.; JONG, M.; WENGER, S.; REUBI, J. DOTA-NOC, a high-affinity ligand of somatostatin receptor subtypes 2, 3 and 5 for labeling with various radiometals. European Journal of Nuclear Medicine and Molecular Imaging, v. 30, n. 10, p. 1338-1347, 2003.

WILLIAMS, M. A.; DAVITER, T. Protein-Ligand Interactions: Methods and Applications, Methods in Molecular Biology. 1. ed. New York: Humana Press, 2013.

WISHART, D. S.; SYKES, B. D.; RICHARDS, F. M. Relationship between nuclear magnetic resonance chemical shift and protein secondary structure. Journal of Molecular Biology, v. 222, n. 2, p. 311-333, 1991.

WISHART, D. S.; SYKES, B. D.; RICHARDS, F. M. The chemical shift index: a fast and simple method for the assignment of protein secondary structure through NMR spectroscopy. Biochemistry, v. 31, n. 6, p. 1647-1651, 1992.

WISHART, D. S.; BIGAM, C. G.; HOLM, A.; HODGES, R. S.; SYKES, B. D. 1H, $13 \mathrm{C}$ and $15 \mathrm{~N}$ random coil NMR chemical shifts of the common amino acids. I. Investigations of nearest-neighbor effects. Journal of Biomolecular NMR, v, 5, n. 1, p. 67-81, 1995.

WÜTHRICH, K. NMR of Proteins and Nucleic Acids. 1. ed. New York: Wiley Interscience Publication, 1986.

XU, Y.; STOKES, A. H.; FREEMAN, W. M.; KUMER, S. C.; VOGT, B. A.; VRANA, K. E. Tyrosinase mRNA is expressed in human substantia nigra. Molecular Brain Research, v. 45, n. 1, p. 159-162, 1997.

XU, Y.; STOKES, A. H.; ROSKOSKI, R.; VRANA, K. E. Dopamine, in the Presence of Tyrosinase, Covalently Modifies and Inactivates Tyrosine Hydroxylase. Journal of Neuroscience Research, v. 54, n. 5, p. 691-697, 1998.

YAN, J.; KLINE, A. D.; MO, H.; ZARTLER, E. R.; SHAPIRO, M. J. Epitope Mapping of Ligand-Receptor Interactions by Diffusion NMR. Journal of the American Chemical Society, v. 124, n. 35, p. 9984-9985, 2002.

YAO, S.; WESTPHAL, D.; BABON, J. J.; THOMPSON, G. V.; ROBIN, A. Y.; ADAMS, J. M.; COLMAN, P. M.; CZABOTAR, P. E. NMR studies of interactions between $\mathrm{Bax}$ and $\mathrm{BH} 3$ domain-containing peptides in the absence and presence of CHAPS. Archives of Biochemistry and Biophysics, v. 545, n. 1, p. 33-43, 2014. 
ZHOU, X.; LI, X.; CHEN, X. Binding mechanism of Orange $\mathrm{G}$ to human serum albumin: Saturation transfer difference-NMR, spectroscopic and computational techniques. Dyes and Pigments, v. 98, n. 2, p. 212-220, 2013. 
Anexos 
Anexo 1

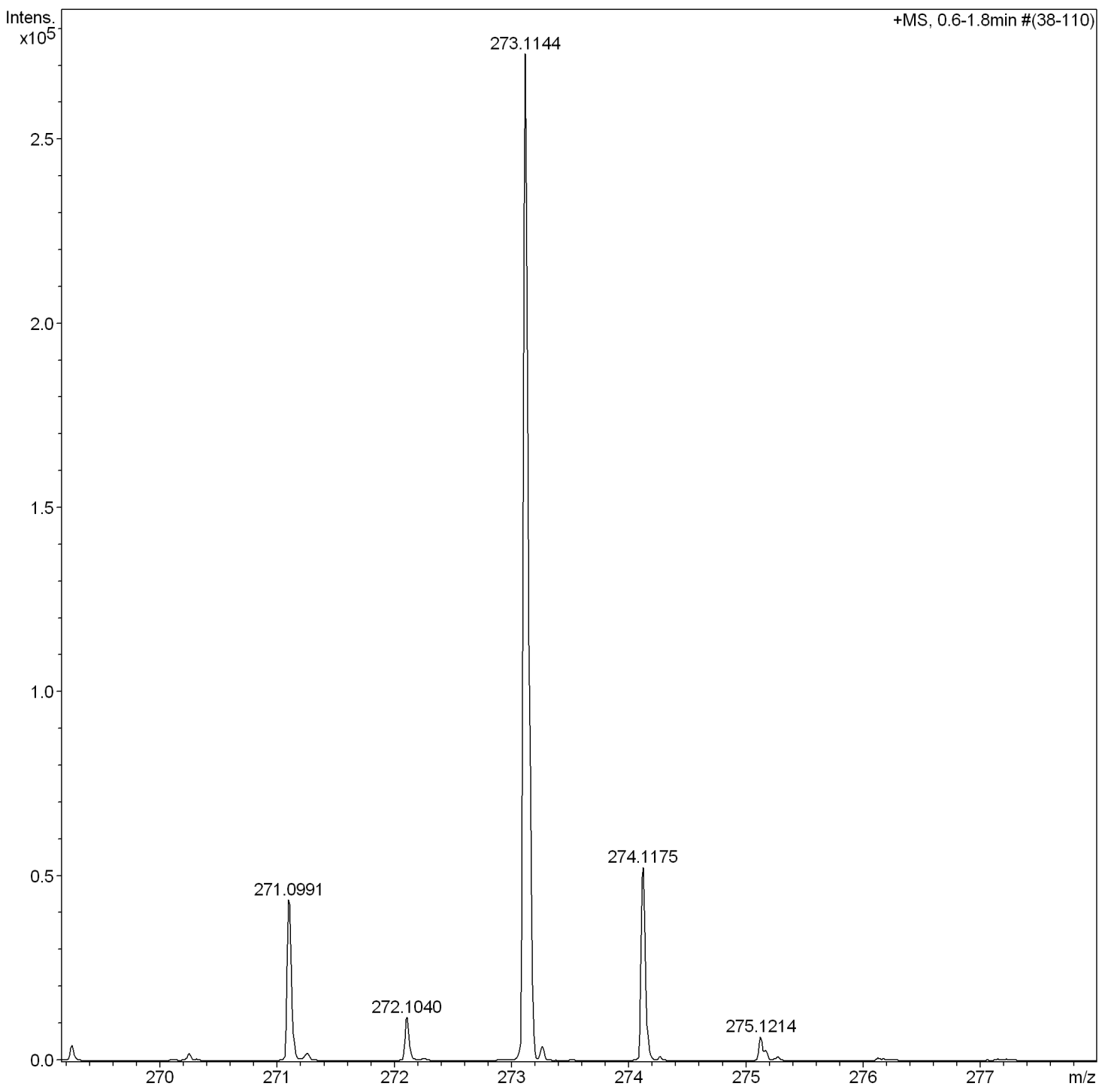

Anexo 1: Espectro de Massa do composto 1. $[\mathrm{M}+\mathrm{H}]^{+}=273,1144$, referente à massa esperada para o composto. 


\section{Anexo 2}

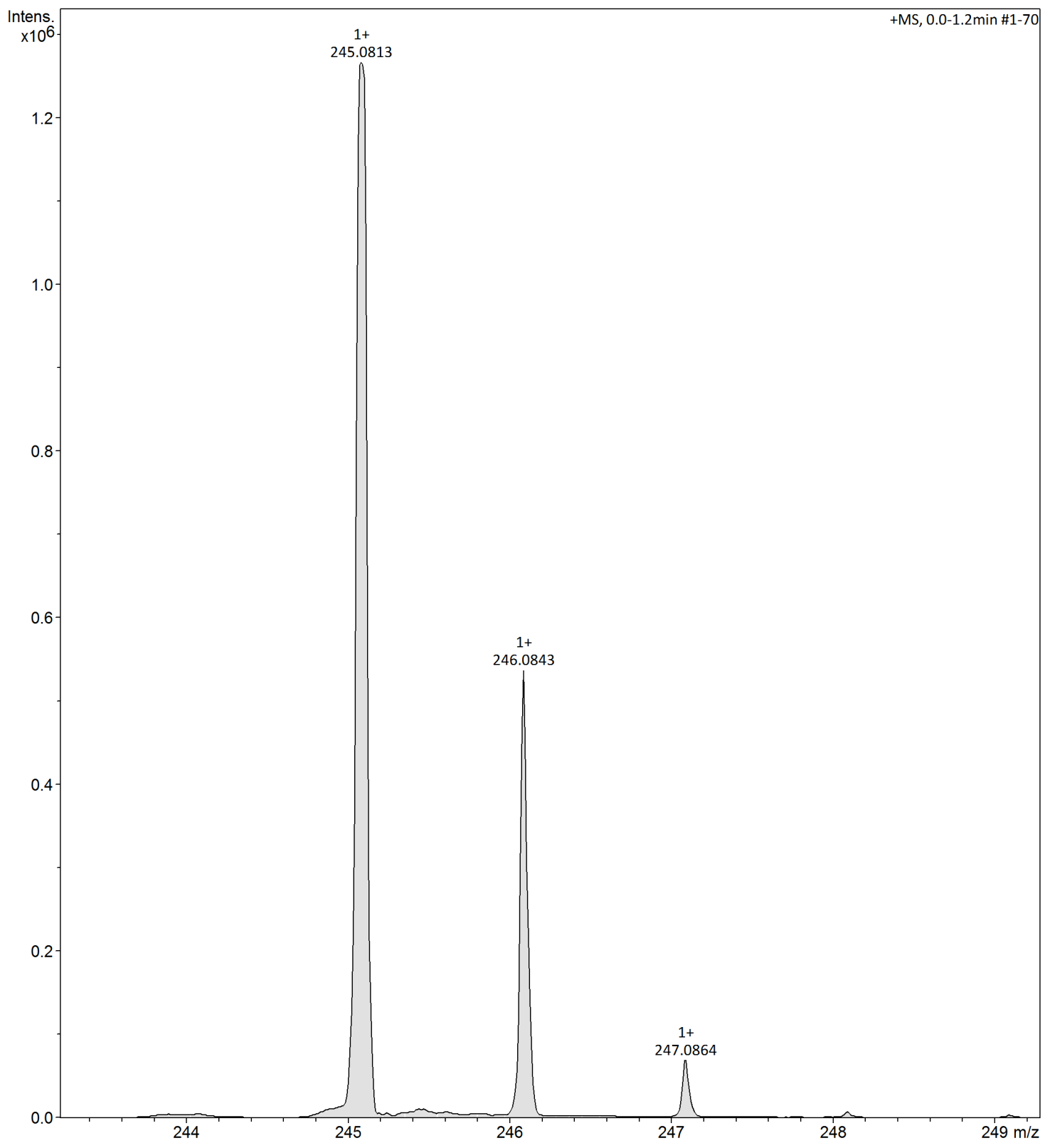

Anexo 2: Espectro de Massa do composto $2 .[\mathrm{M}+\mathrm{H}]^{+}=245,0813$, referente à massa esperada para o composto. 
Anexo 3

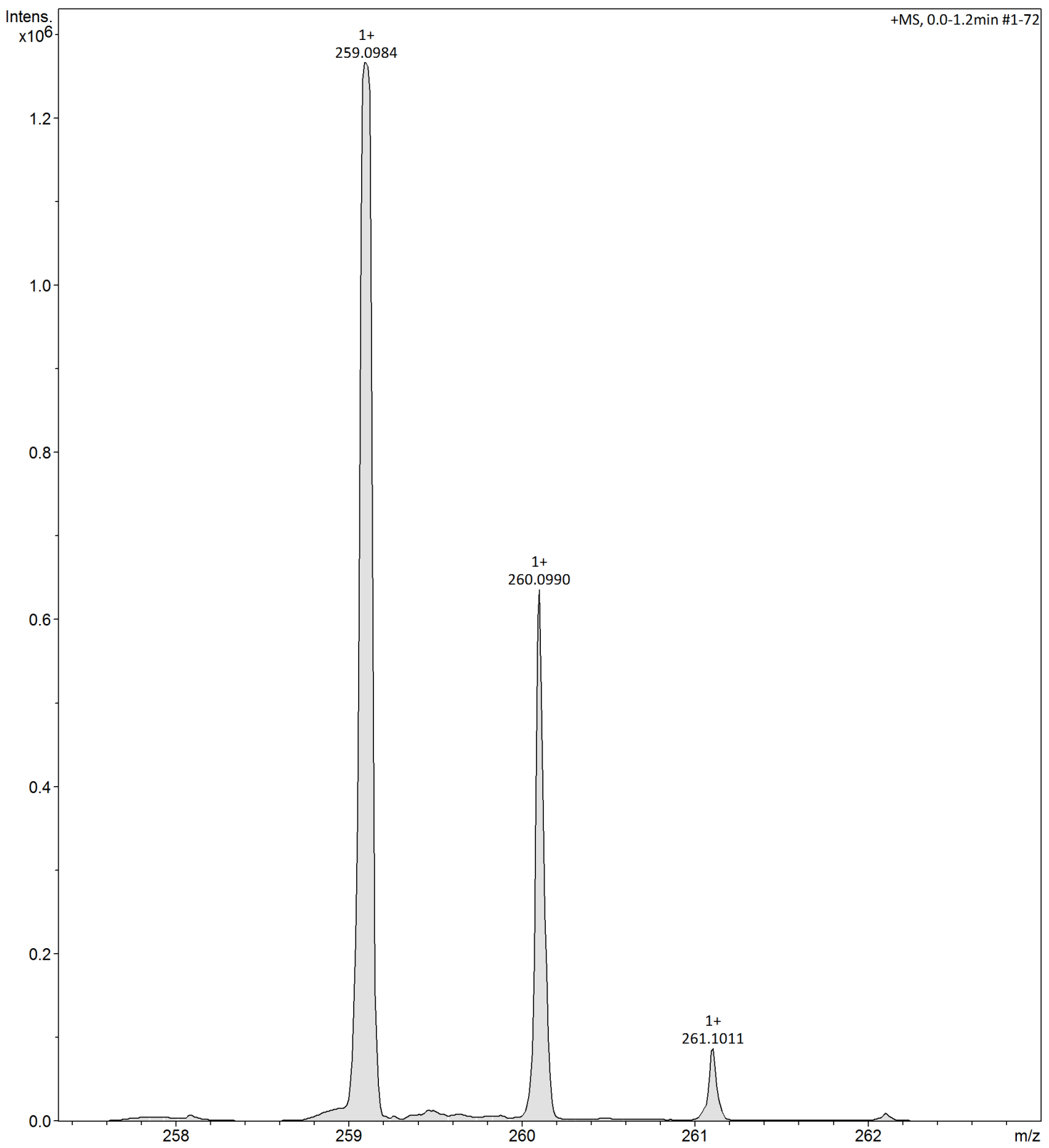

Anexo 3: Espectro de Massa do composto 3. $[\mathrm{M}+\mathrm{H}]^{+}=259,0984$, referente à massa esperada para o composto. 
Anexo 4

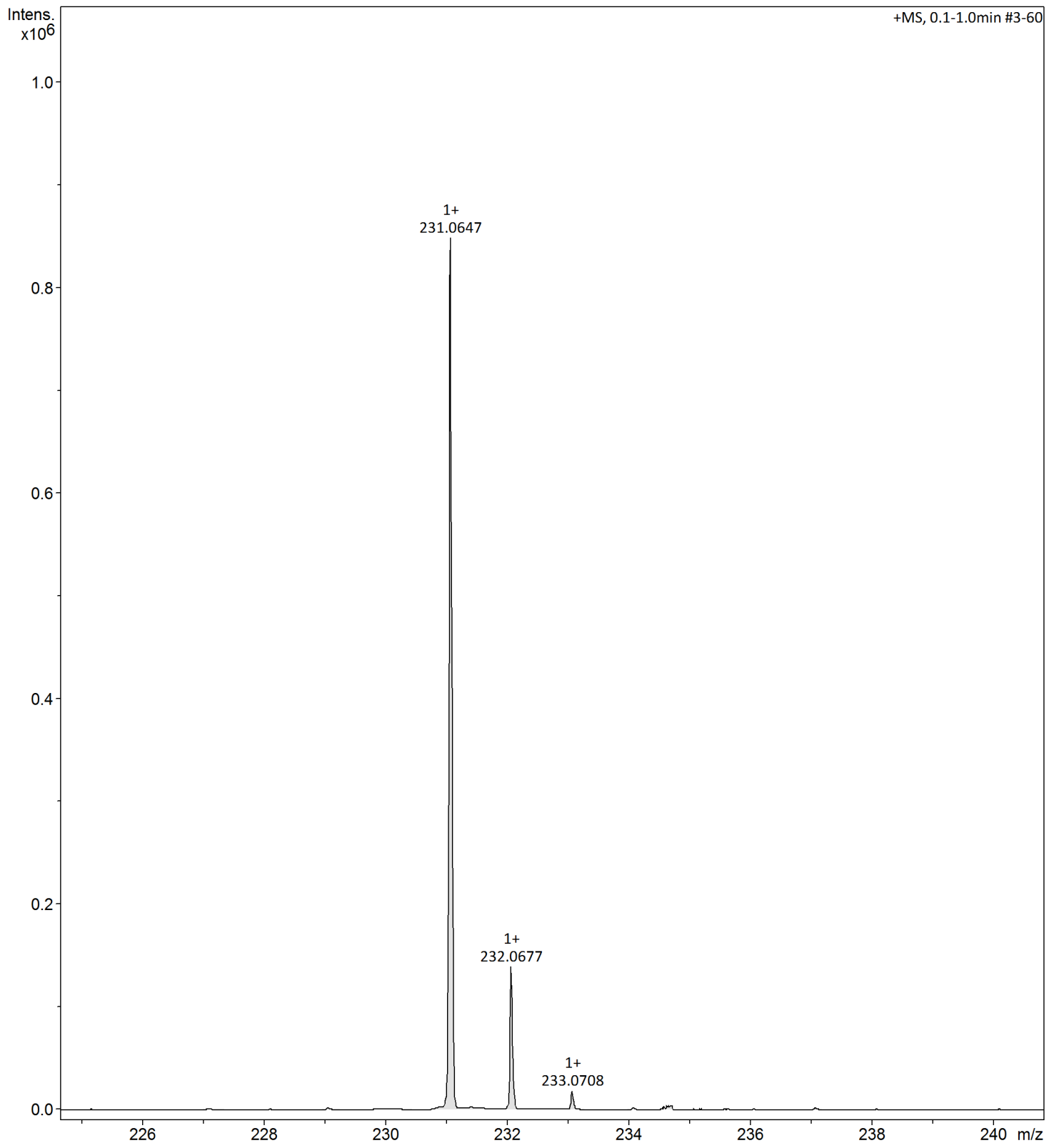

Anexo 4: Espectro de Massa do composto 4. $[\mathrm{M}+\mathrm{H}]^{+}=231,0647$, referente à massa esperada para o composto. 
Anexo 5

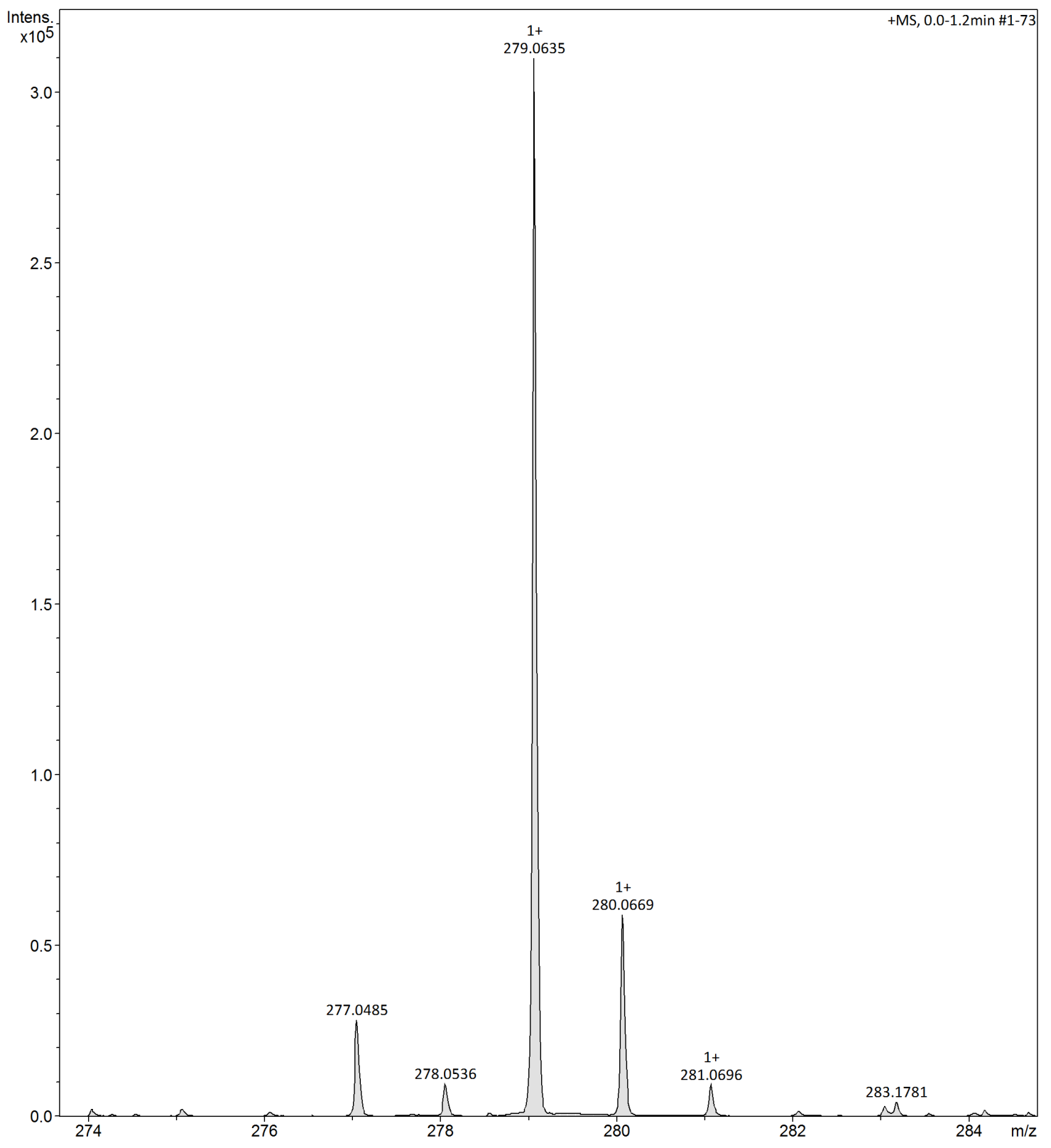

Anexo 5: Espectro de Massa do composto $5 .[\mathrm{M}+\mathrm{H}]^{+}=279,0635$, referente à massa esperada para o composto. 
Anexo 6

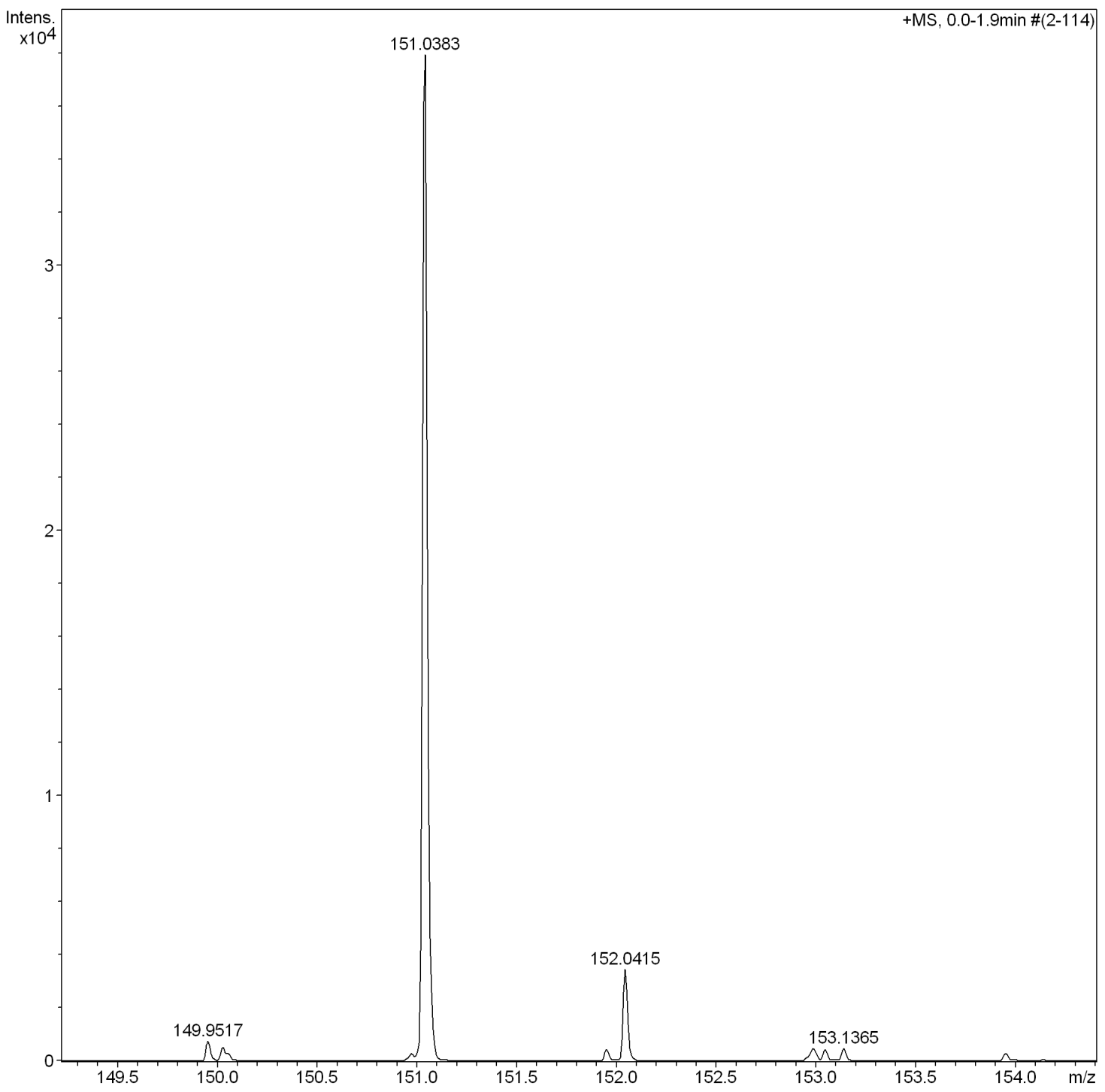

Anexo 6: Espectro de Massa do composto 6. $[\mathrm{M}+\mathrm{H}]^{+}=151,0383$, referente à massa esperada para o composto. 
Anexo 7

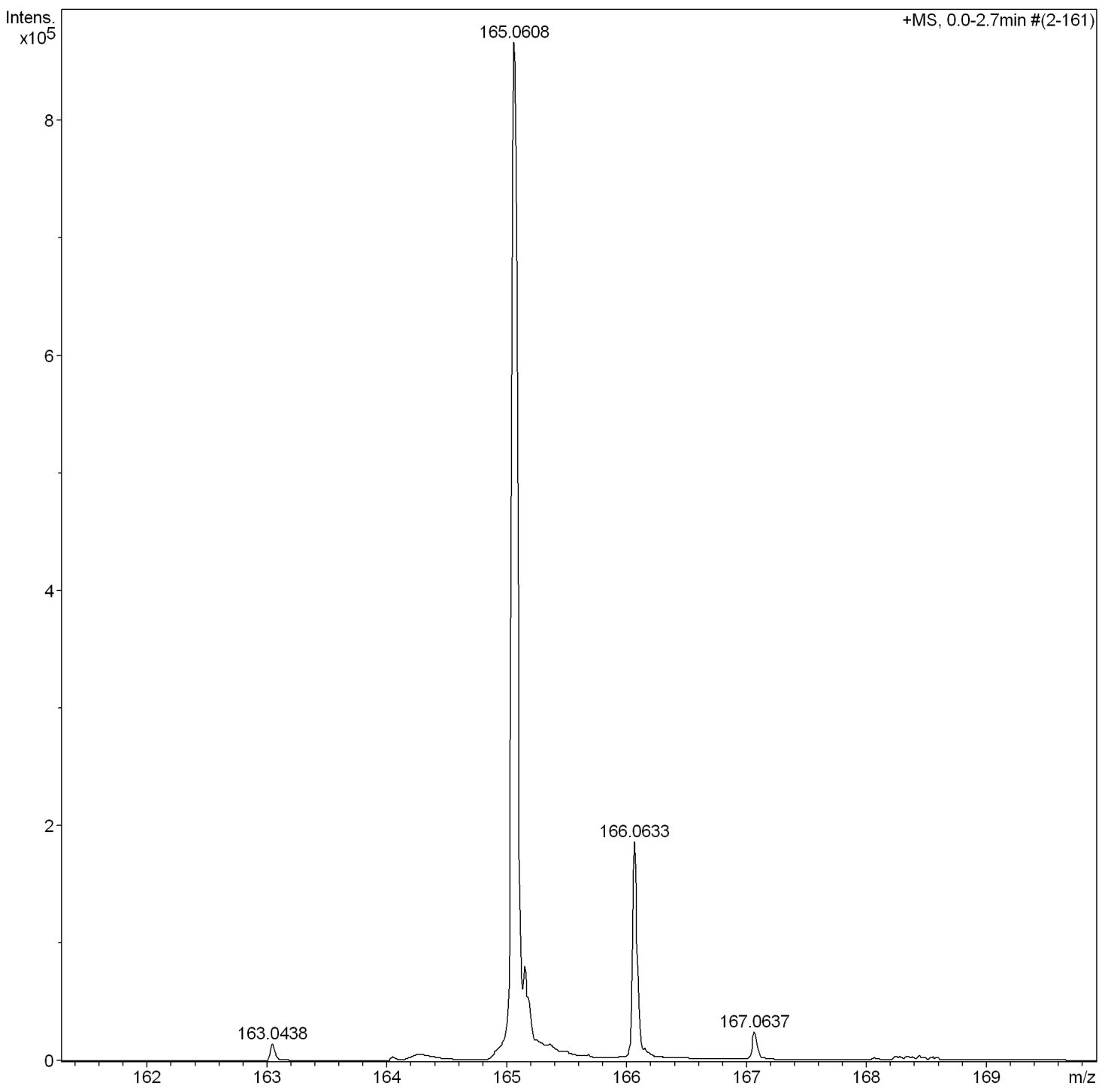

Anexo 7: Espectro de Massa do composto 7. $[\mathrm{M}+\mathrm{H}]^{+}=165,0608$, referente à massa esperada para o composto. 
Anexo 8

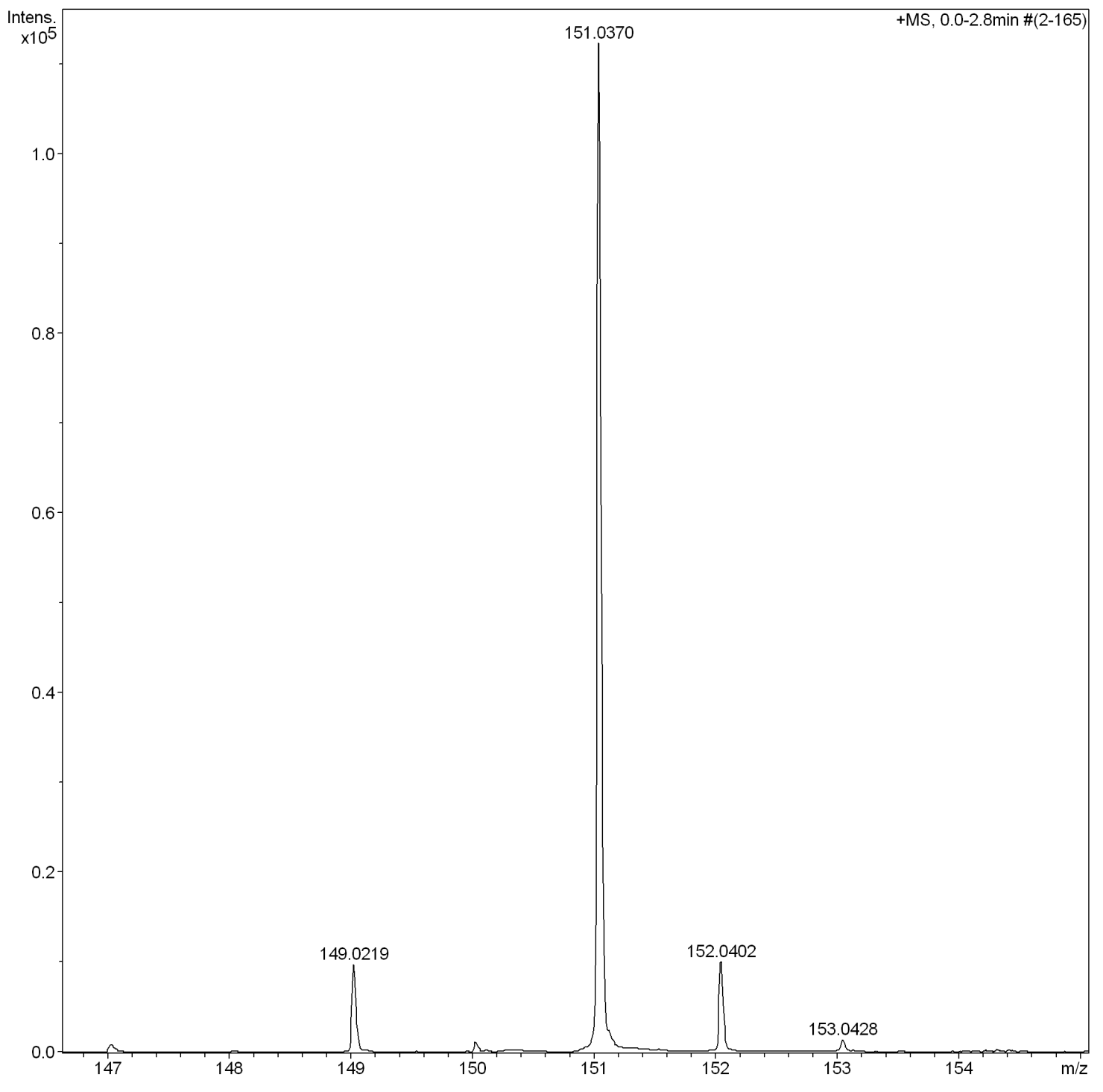

Anexo 8: Espectro de Massa do composto 8. $[\mathrm{M}+\mathrm{H}]^{+}=151,0370$; referente à massa esperada para o composto. 
Anexo 9

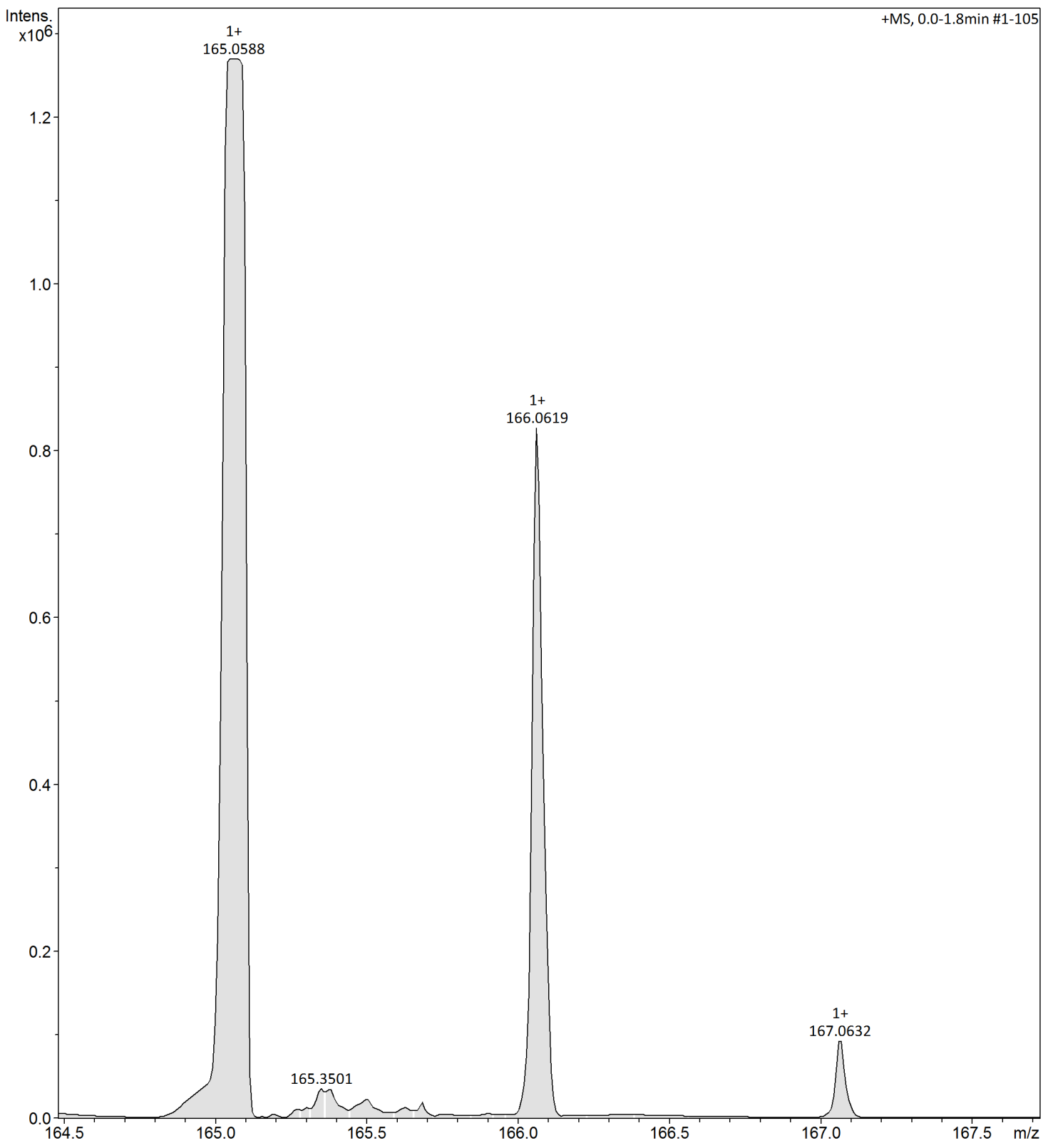

Anexo 9: Espectro de Massa do composto 9. $[\mathrm{M}+\mathrm{H}]^{+}=165,0588$; referente à massa esperada para o composto. 
Anexo 10

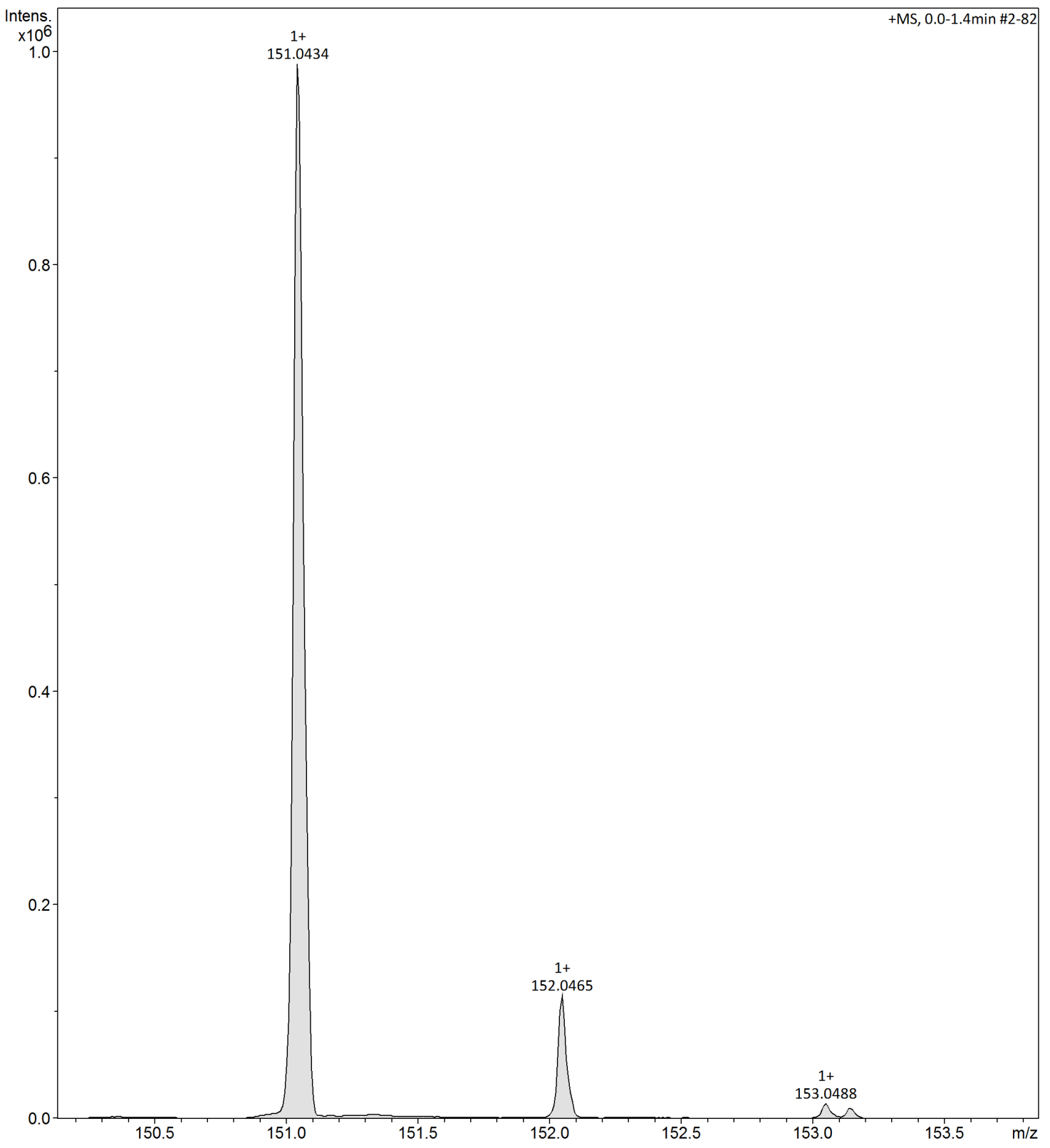

Anexo 10: Espectro de Massa do composto 10. $[\mathrm{M}+\mathrm{H}]^{+}=151,0434$; referente à massa esperada para o composto. 
Anexo 11

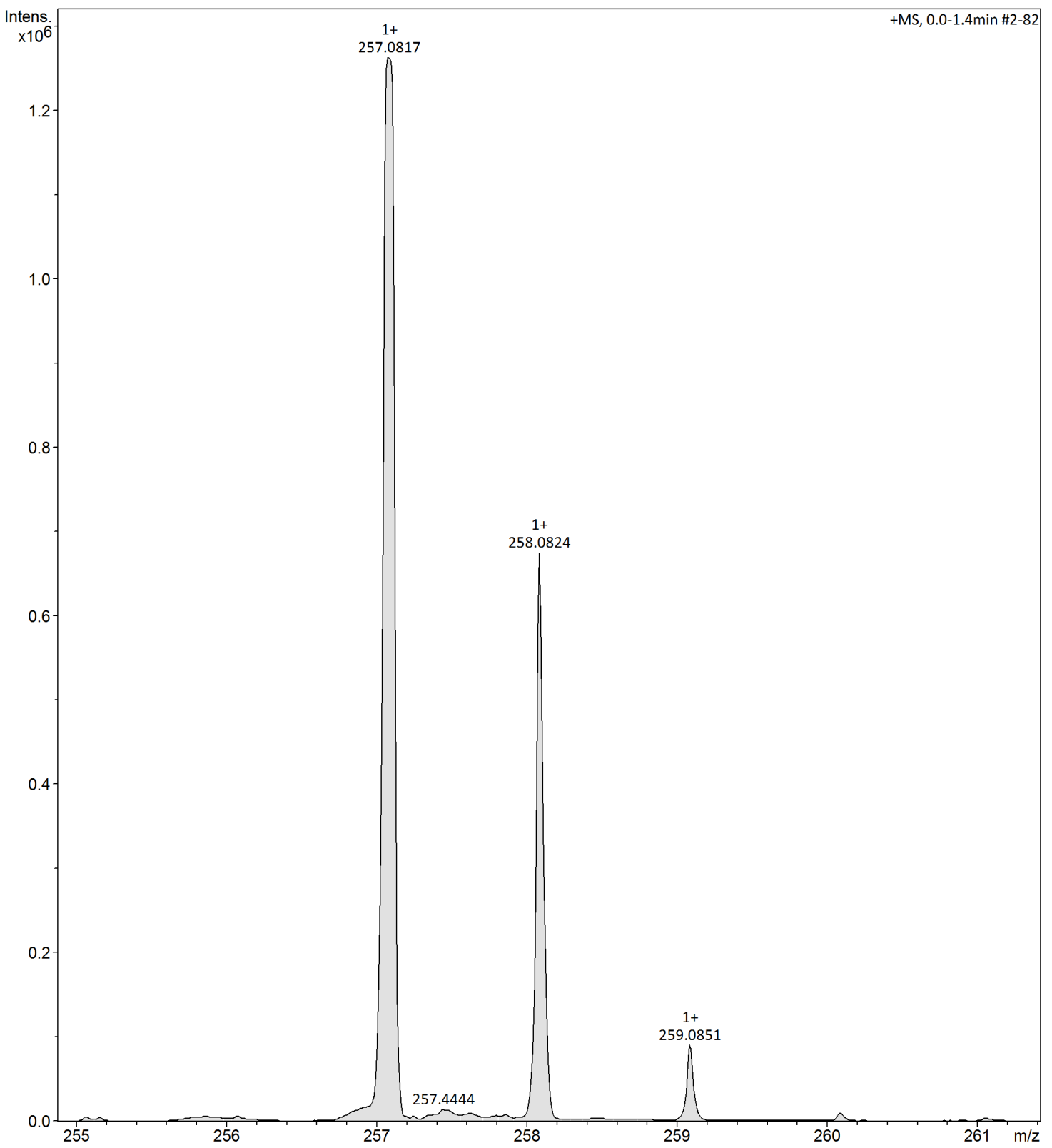

Anexo 11: Espectro de Massa do composto 11. $[\mathrm{M}+\mathrm{H}]^{+}=257,0817$; referente à massa esperada para o composto.. 
Anexo 12

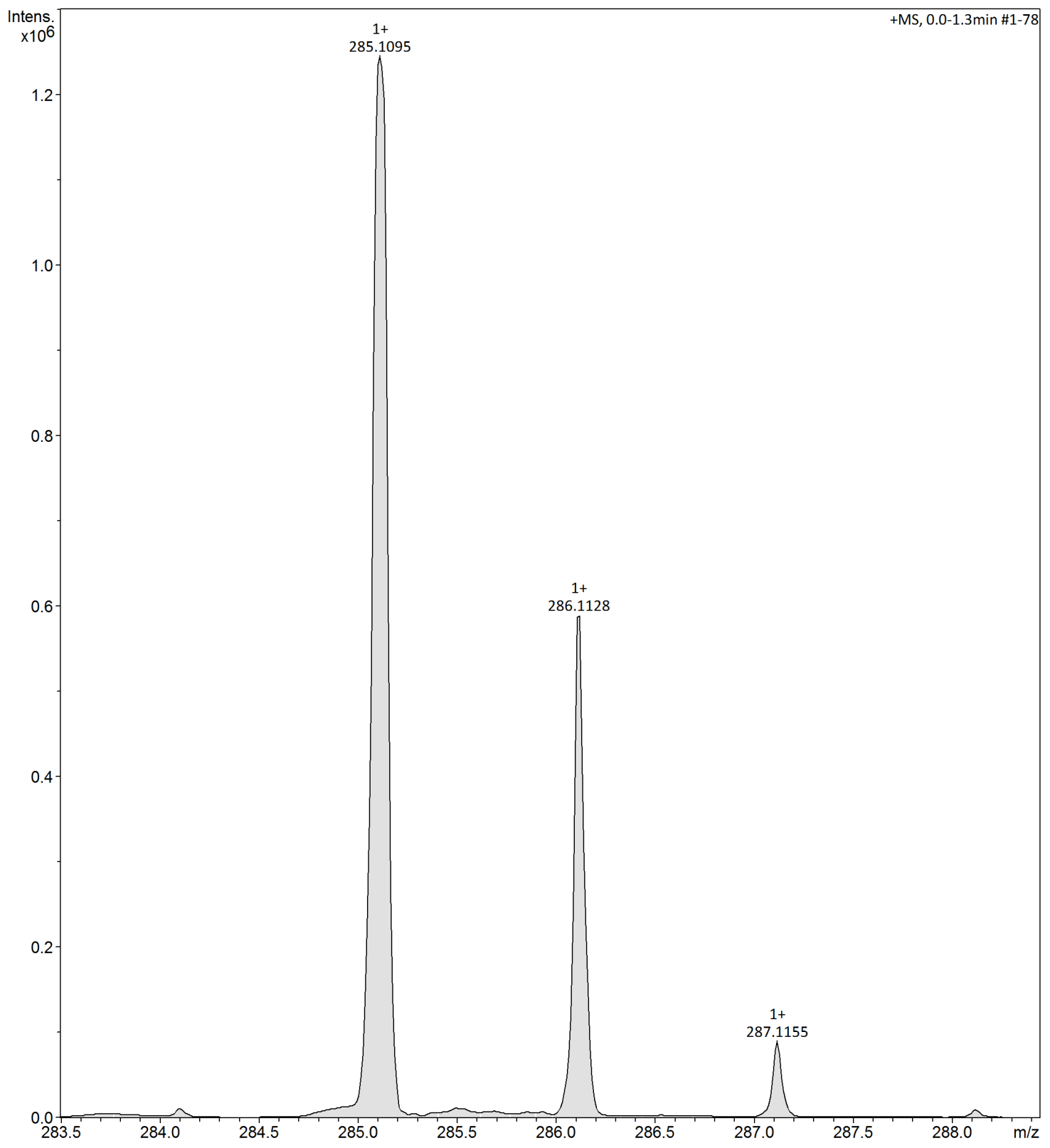

Anexo 12: Espectro de Massa do composto $12 .[\mathrm{M}+\mathrm{H}]^{+}=285,1095$; referente à massa esperada para o composto. 
Anexo 13

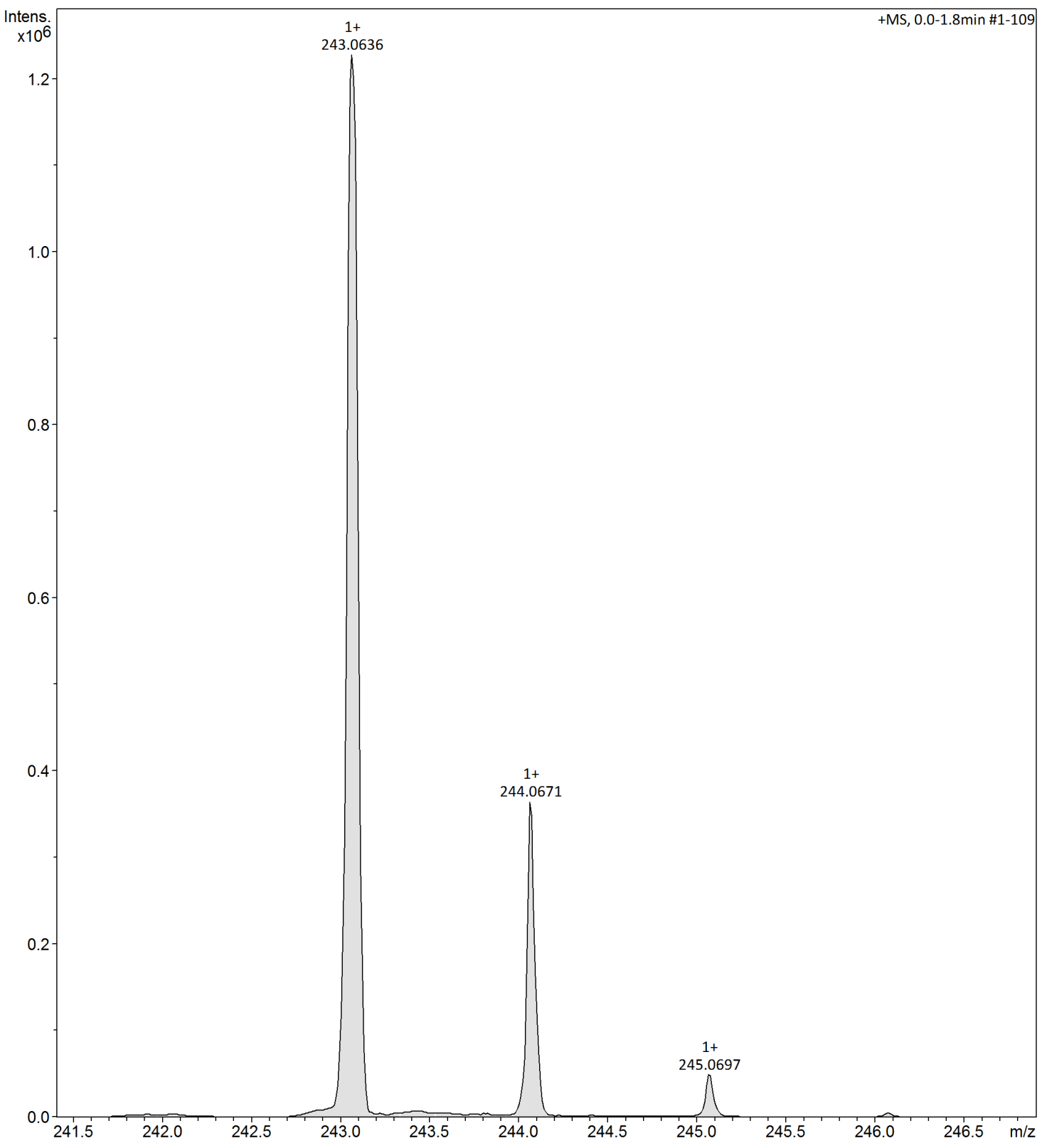

Anexo 13: Espectro de Massa do composto 13. $[\mathrm{M}+\mathrm{H}]^{+}=243,0636$; referente à massa esperada para o composto.. 
Anexo 14

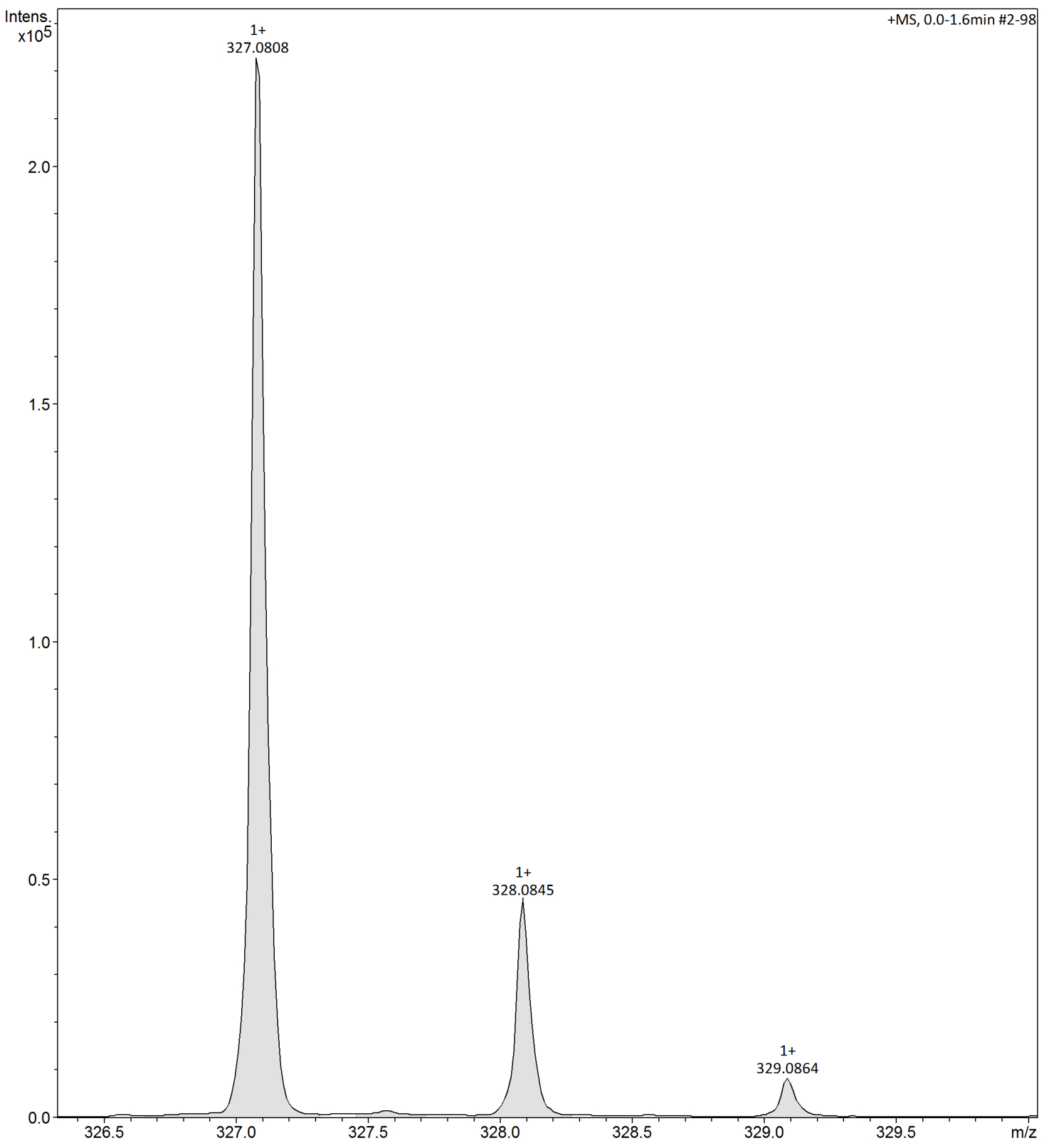

Anexo 14: Espectro de Massa do composto $14 .[\mathrm{M}+\mathrm{H}]^{+}=327,0808$; referente à massa esperada para o composto. 
Anexo 15

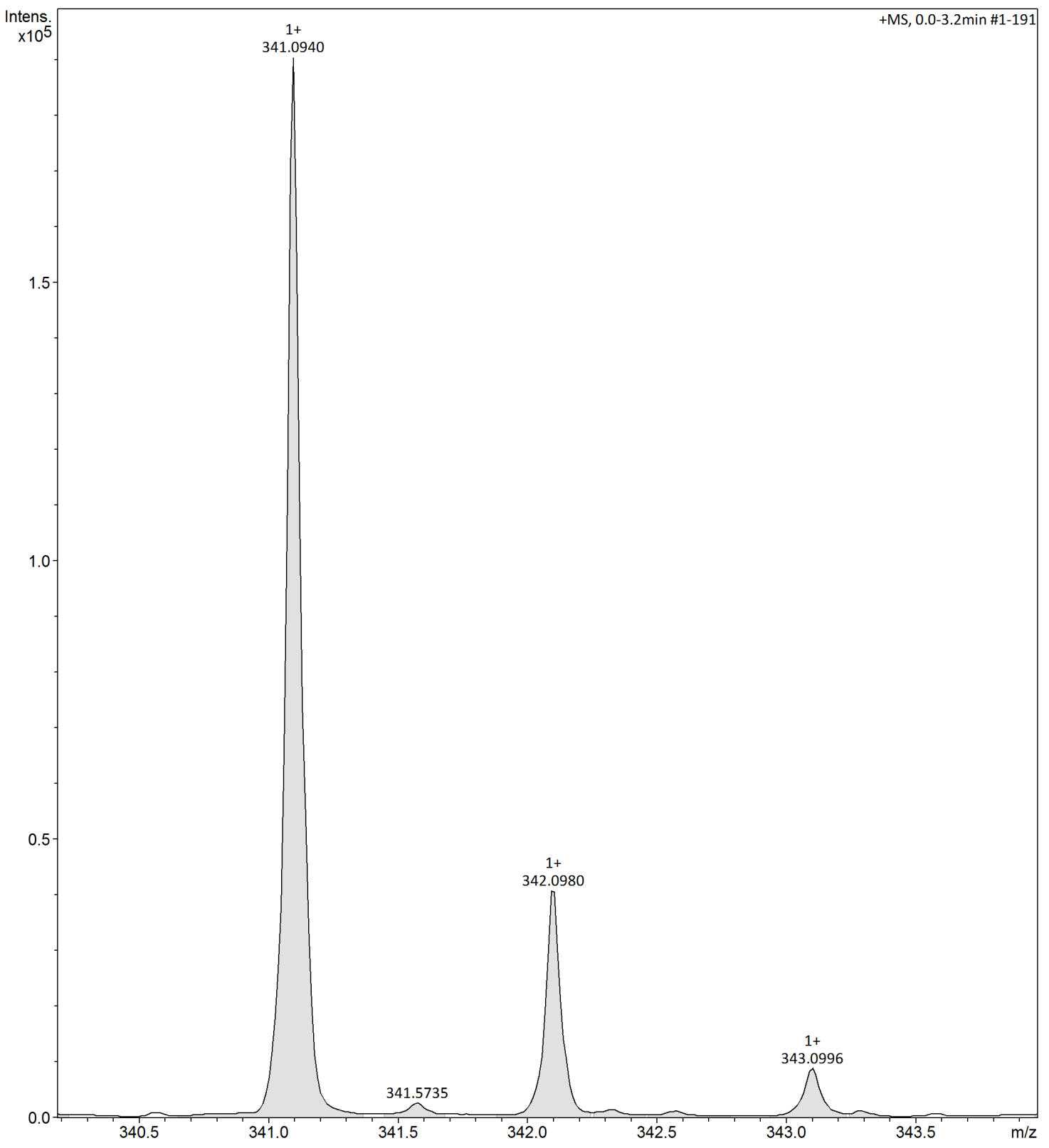

Anexo 15: Espectro de Massa do composto 15. $[\mathrm{M}+\mathrm{H}]^{+}=341,0940$ referente à massa esperada para o composto. 
Anexo 16

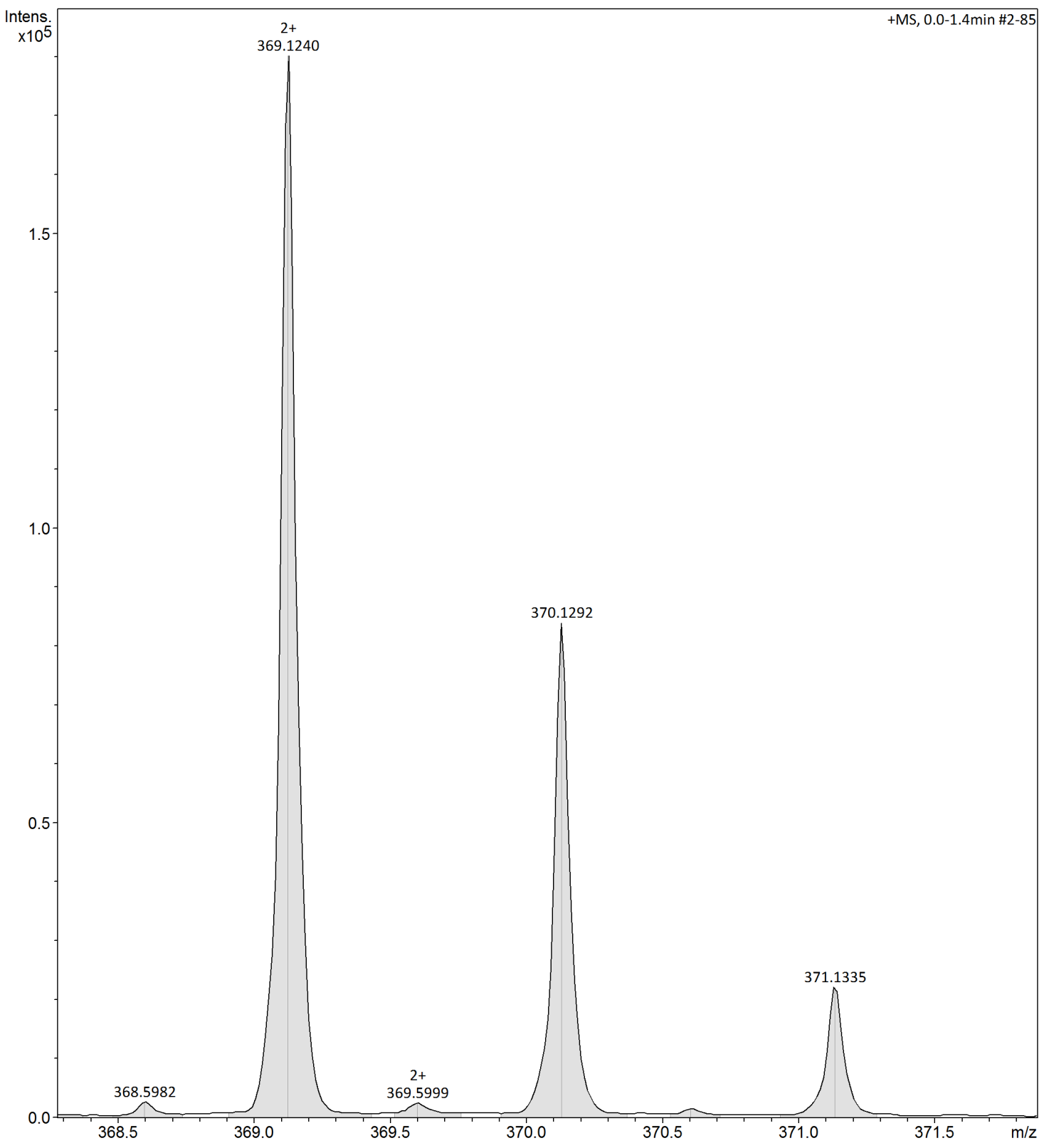

Anexo 16: Espectro de Massa do composto 16. $[\mathrm{M}+\mathrm{H}]^{+}=369,1240$; referente à massa esperada para o composto. 
Anexo 17

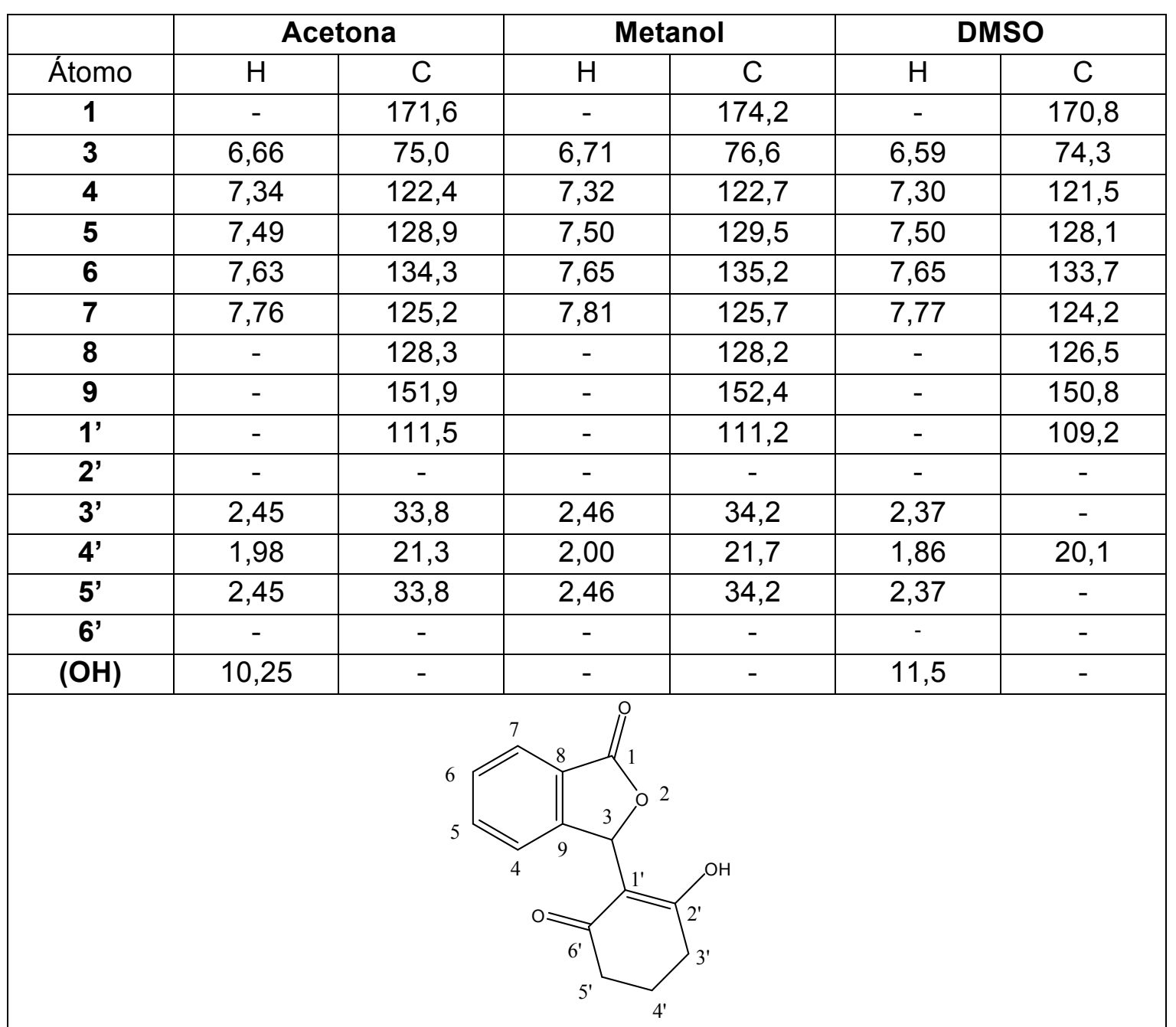

Anexo 17: Assinalamento dos átomos de hidrogênio e carbono do composto 2 em diferentes solventes: acetona, metanol e DMSO.

\section{Anexo 18}

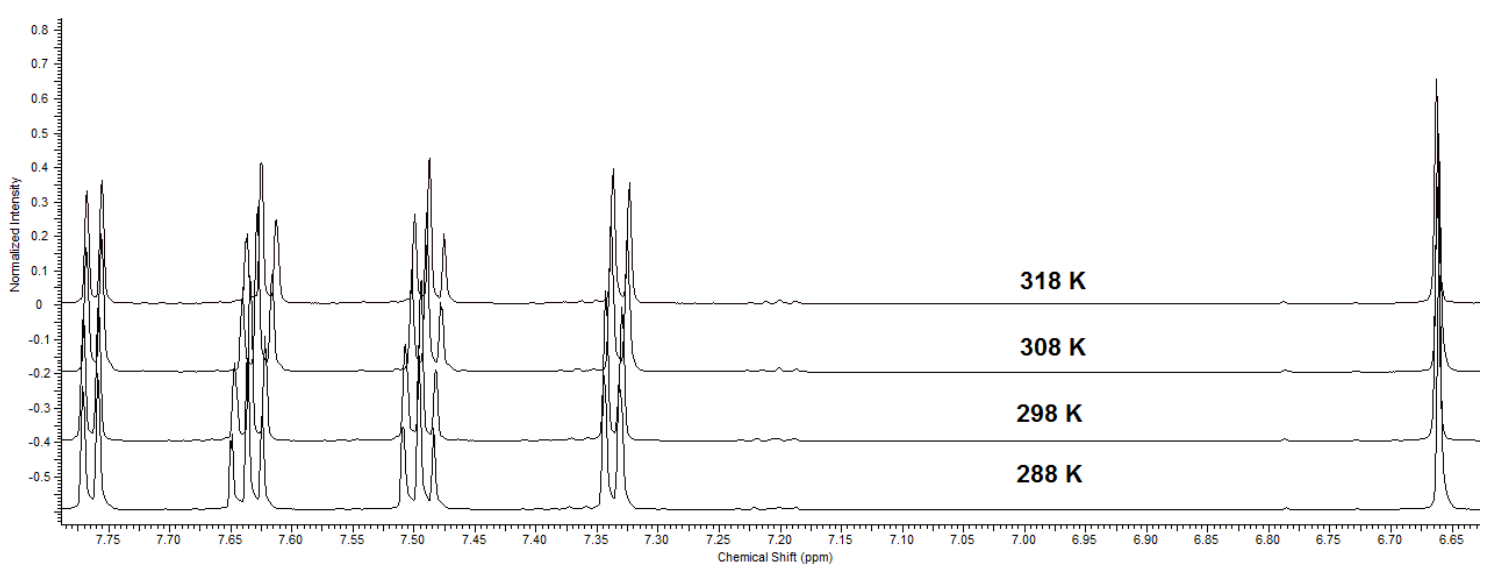

Anexo 18: Espectros de ${ }^{1} \mathrm{H}-\mathrm{RMN}$ do composto 2 em acetona, a diferentes temperaturas. Expansão da região de 6,65 a 7,80 ppm. É observado o hidrogênio 3 próximo a 6,66 ppm. 


\section{Anexo 19}

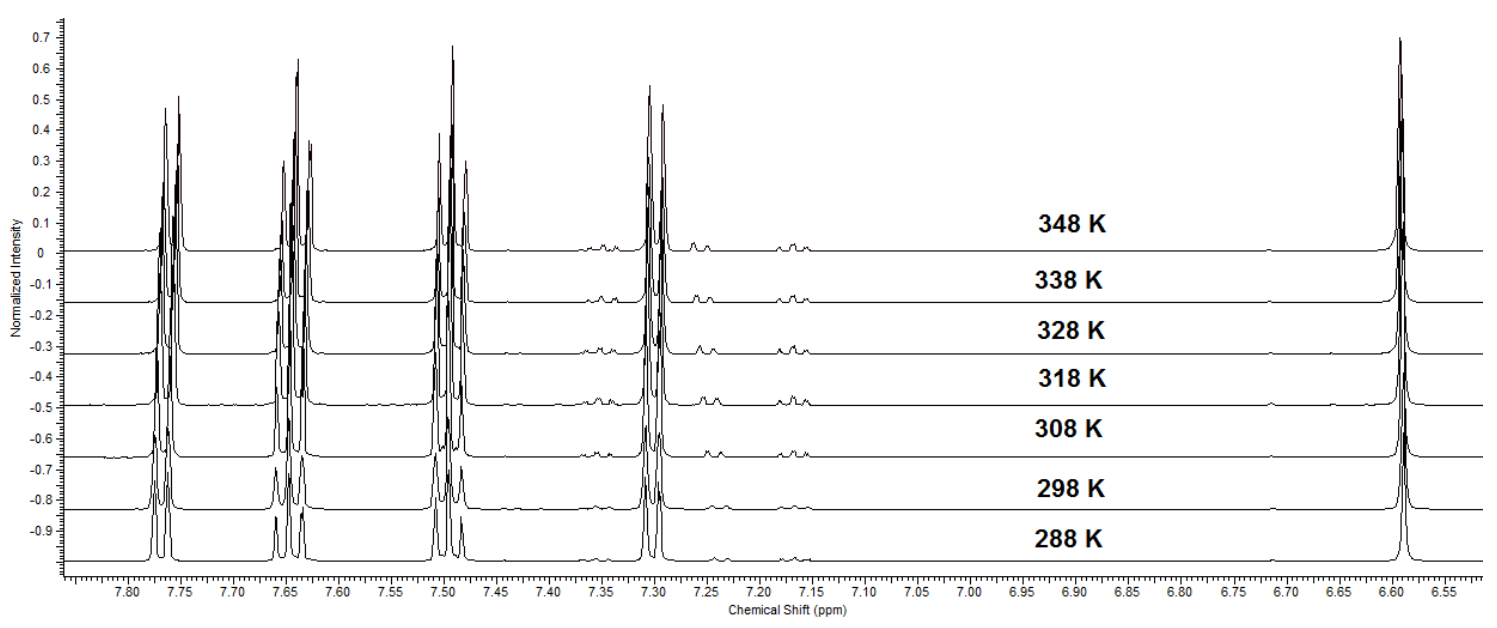

Anexo 19: Espectros de ${ }^{1} \mathrm{H}-\mathrm{RMN}$ do composto 2 em DMSO, a diferentes temperaturas. Expansão da região 6,55 a 7,85 ppm. É observado o hidrogênio 3 próximo a 6,59 ppm.

\section{Anexo 20}

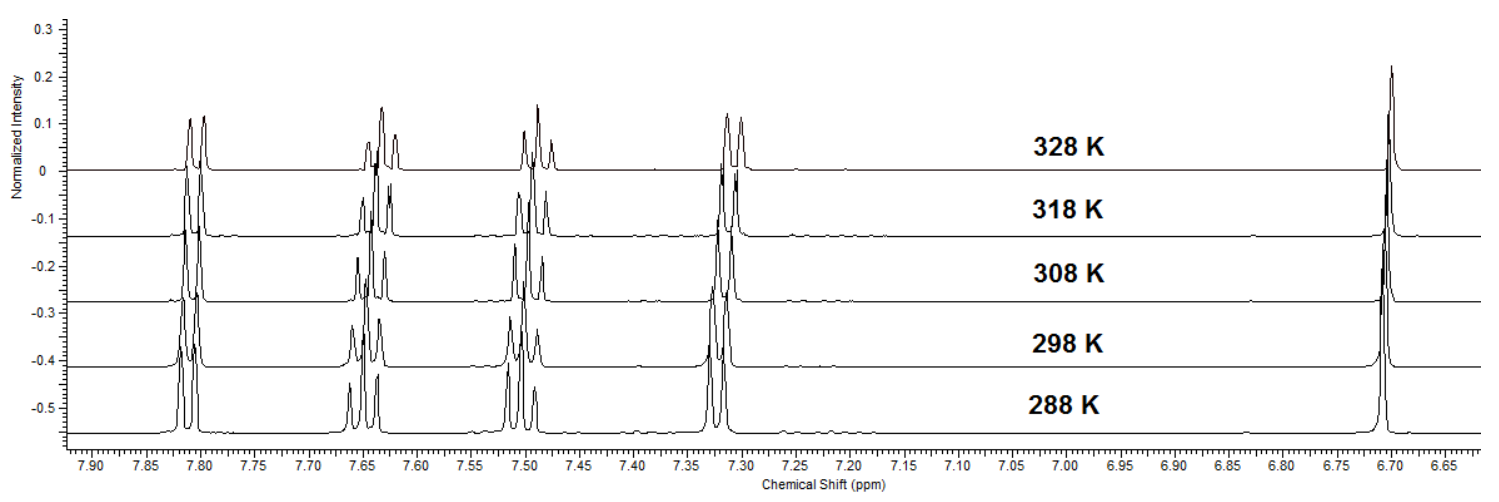

Anexo 20: Espectros de ${ }^{1} \mathrm{H}-\mathrm{RMN}$ do composto 2 em metanol, a diferentes temperaturas. Expansão da região 6,65 a 7,90 ppm. É observado o hidrogênio 3 próximo a 6,71 ppm.

\section{Anexo 21}

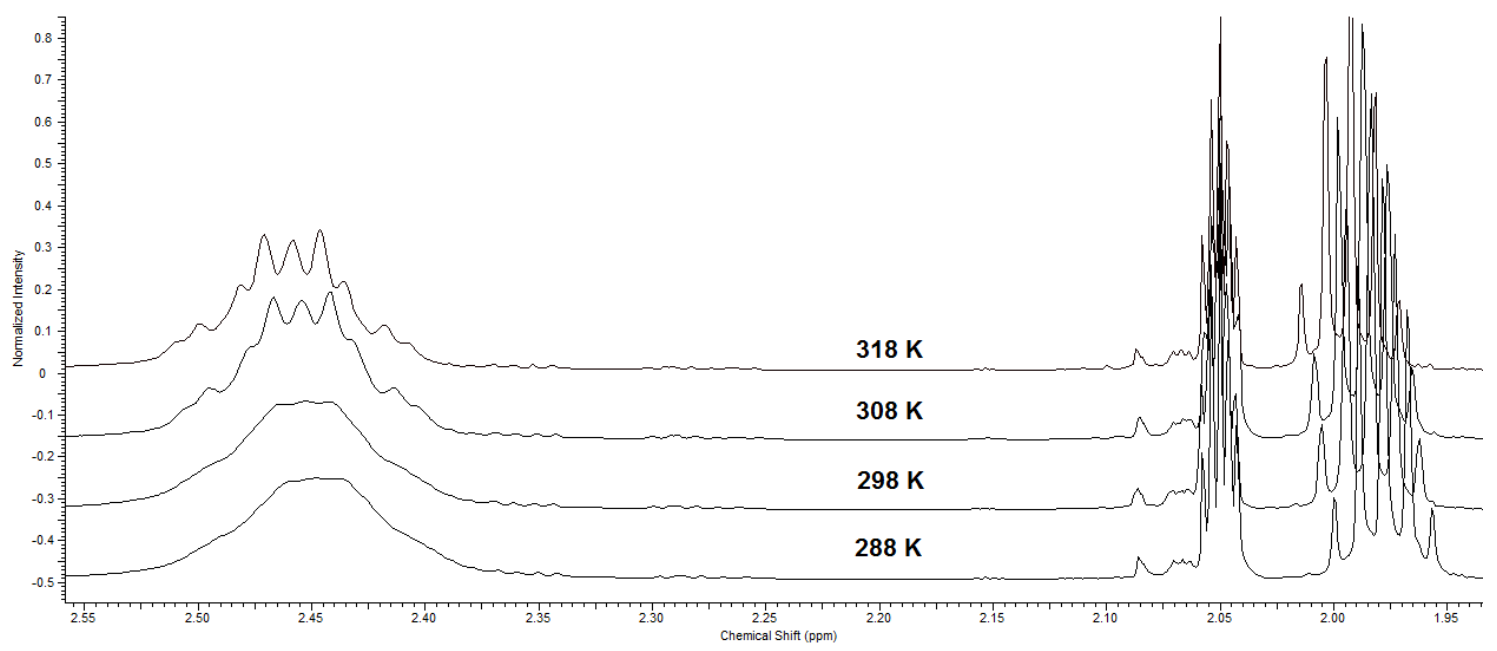

Anexo 21: Espectros de ${ }^{1} \mathrm{H}-\mathrm{RMN}$ do composto 2 em acetona, a diferentes temperaturas. Expansão da região alifática. São observados os hidrogênios 3' e 5' próximos a 2,45 ppm. 


\section{Anexo 22}

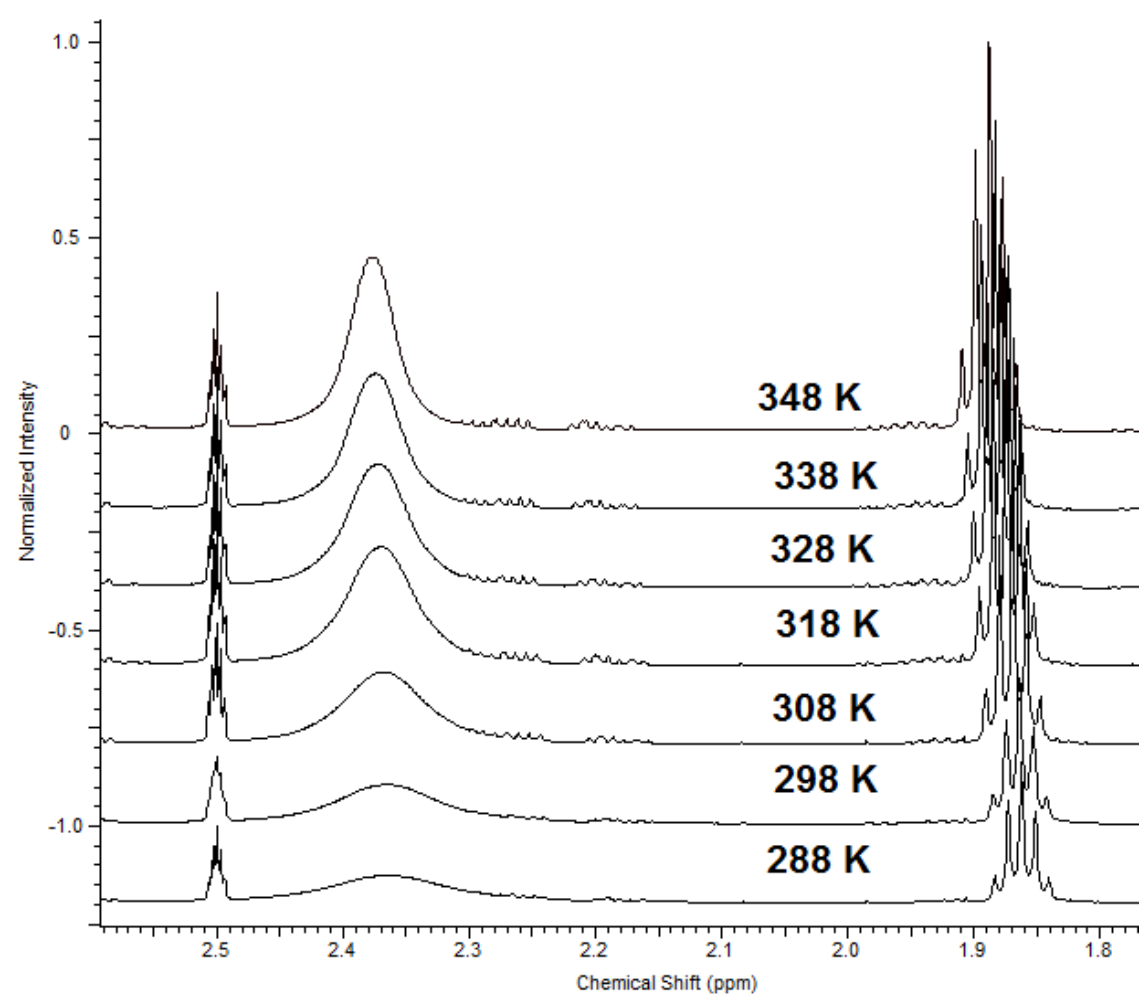

Anexo 22: Espectros de ${ }^{1} \mathrm{H}-\mathrm{RMN}$ do composto 2 em DMSO, a diferentes temperaturas. Expansão da região alifática. São observados os hidrogênios 3' e 5' próximos a 2,37 ppm.

\section{Anexo 23}

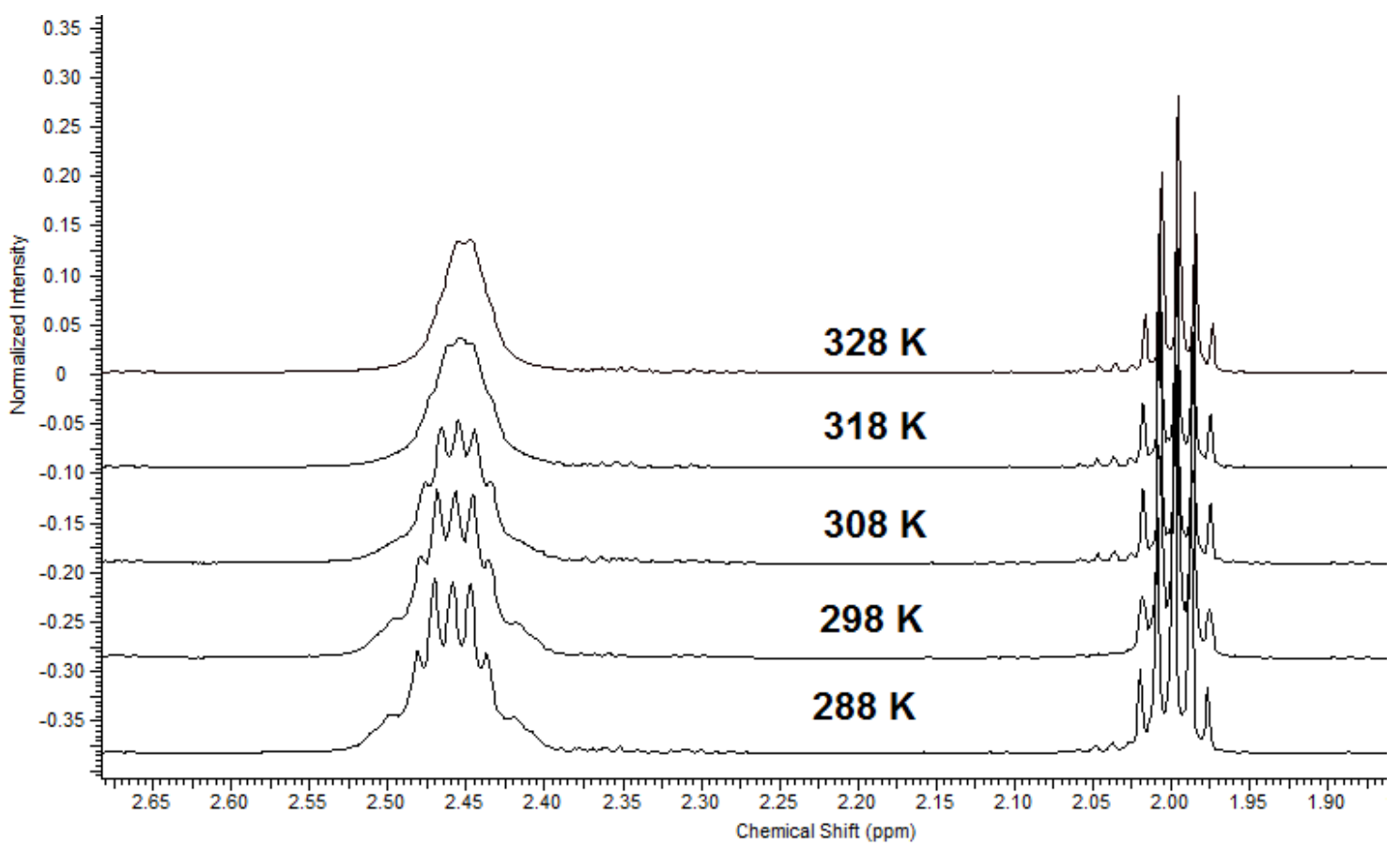

Anexo 23: Espectros de ${ }^{1} \mathrm{H}-\mathrm{RMN}$ do composto 2 em metanol, a diferentes temperaturas. Expansão da região alifática. São observados os hidrogênios 3' e 5' próximos a 2,46 ppm. 


\section{Anexo 24}

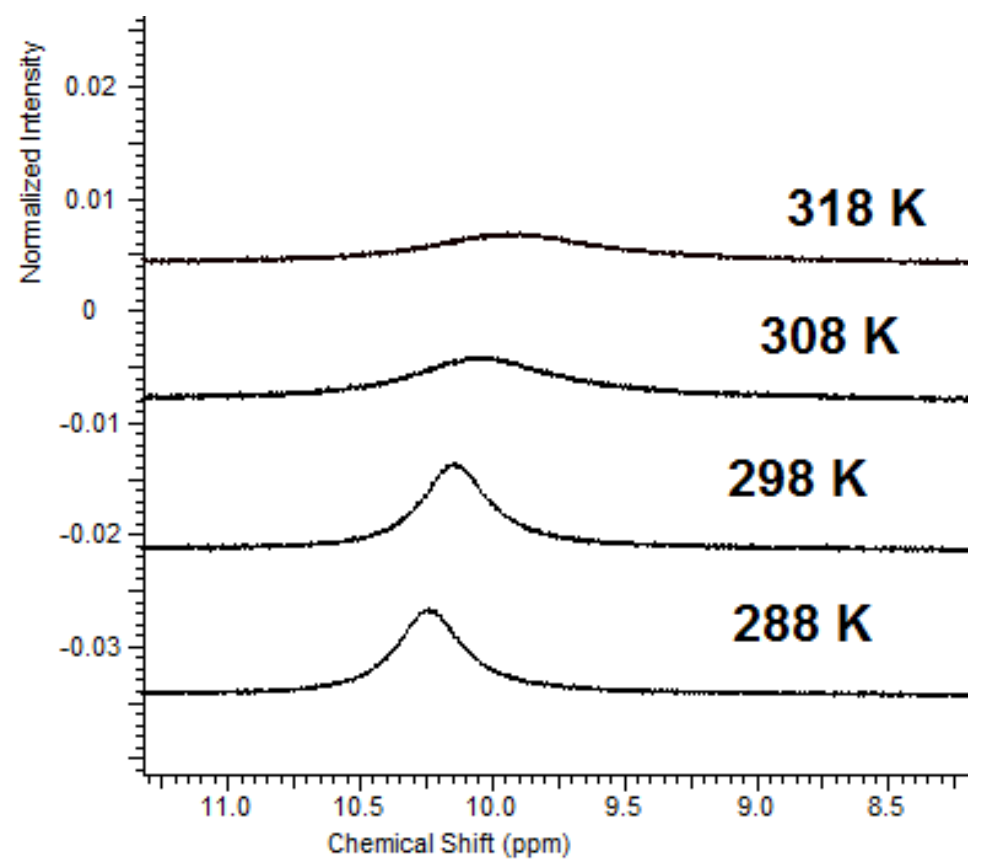

Anexo 24: Espectros de ${ }^{1} \mathrm{H}-\mathrm{RMN}$ a 15, 25, 35 e $45^{\circ} \mathrm{C}$ do composto 2, em acetona, com expansão da região de mais alto deslocamento químico. Observa-se o sinal alargado próximo a 10,25 ppm, referente ao hidrogênio do grupo hidroxila. 


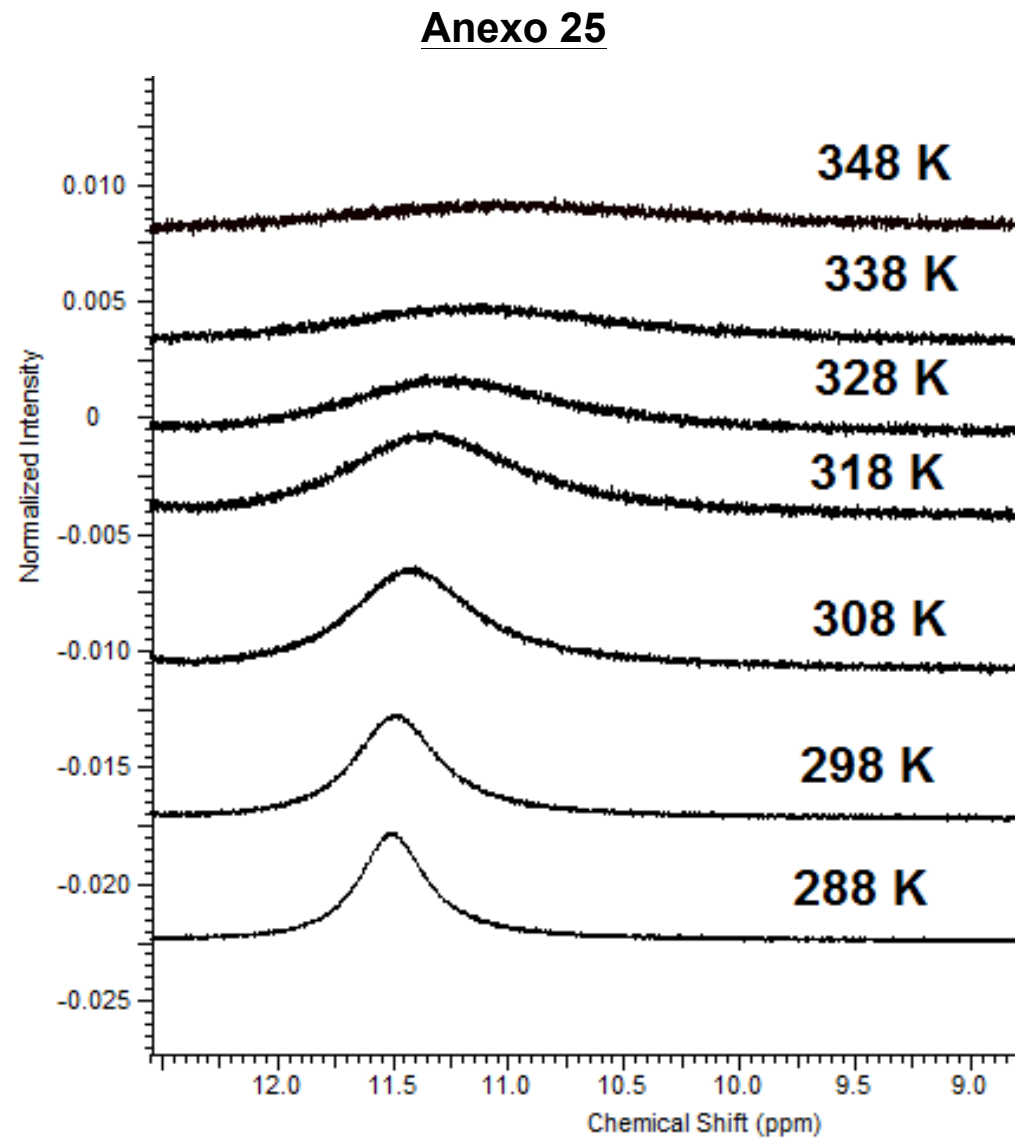

Anexo 25: Espectros de ${ }^{1} \mathrm{H}-\mathrm{RMN}$ a 15, 25, 35, 45, 55, 65 e $75^{\circ} \mathrm{C}$ do composto 2, em DMSO, com expansão da região de mais alto deslocamento químico. Observa-se o sinal alargado próximo a $11,5 \mathrm{ppm}$, referente ao hidrogênio do grupo hidroxila.

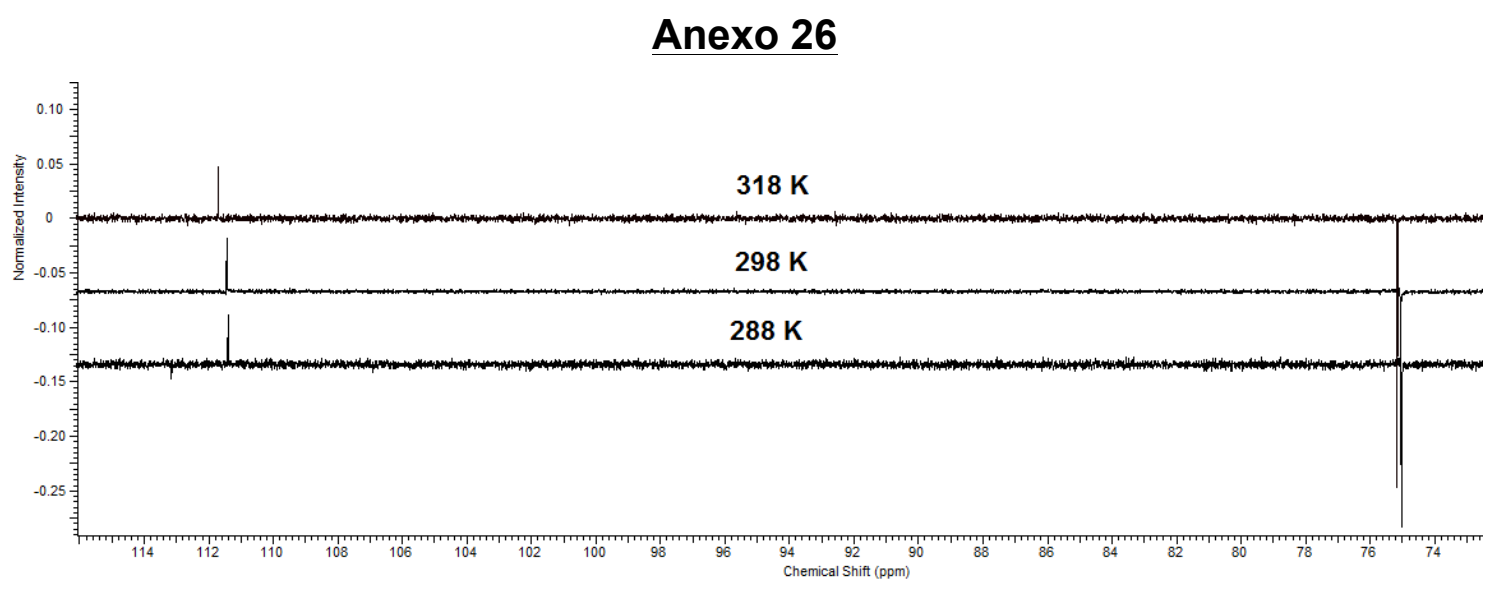

Anexo 26: Expansão dos espectros de APT do composto 2, em acetona, a diferentes temperaturas $\left(15,25\right.$ e $\left.45^{\circ} \mathrm{C}\right)$. É observado o sinal do carbono 1' próximo a 111,5 ppm. 


\section{Anexo 27}

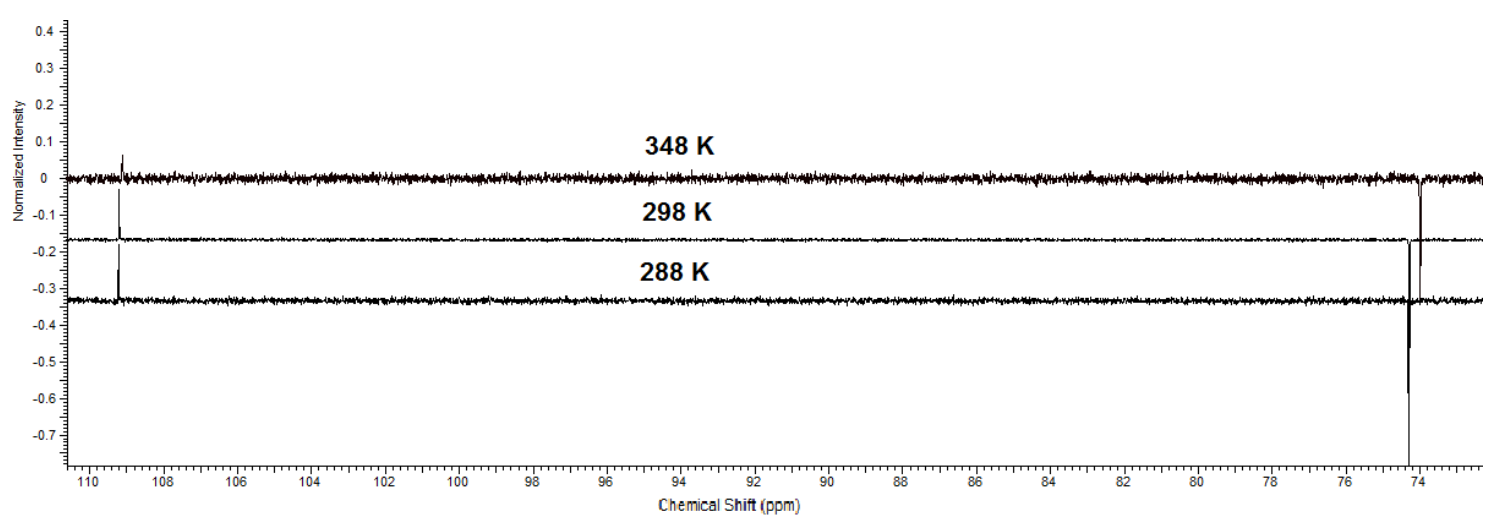

Anexo 27: Expansão dos espectros de APT do composto 2, em DMSO, a diferentes temperaturas $\left(15,25\right.$ e $\left.75^{\circ} \mathrm{C}\right)$. É observado o sinal do carbono 1' próximo a 109,2 ppm.

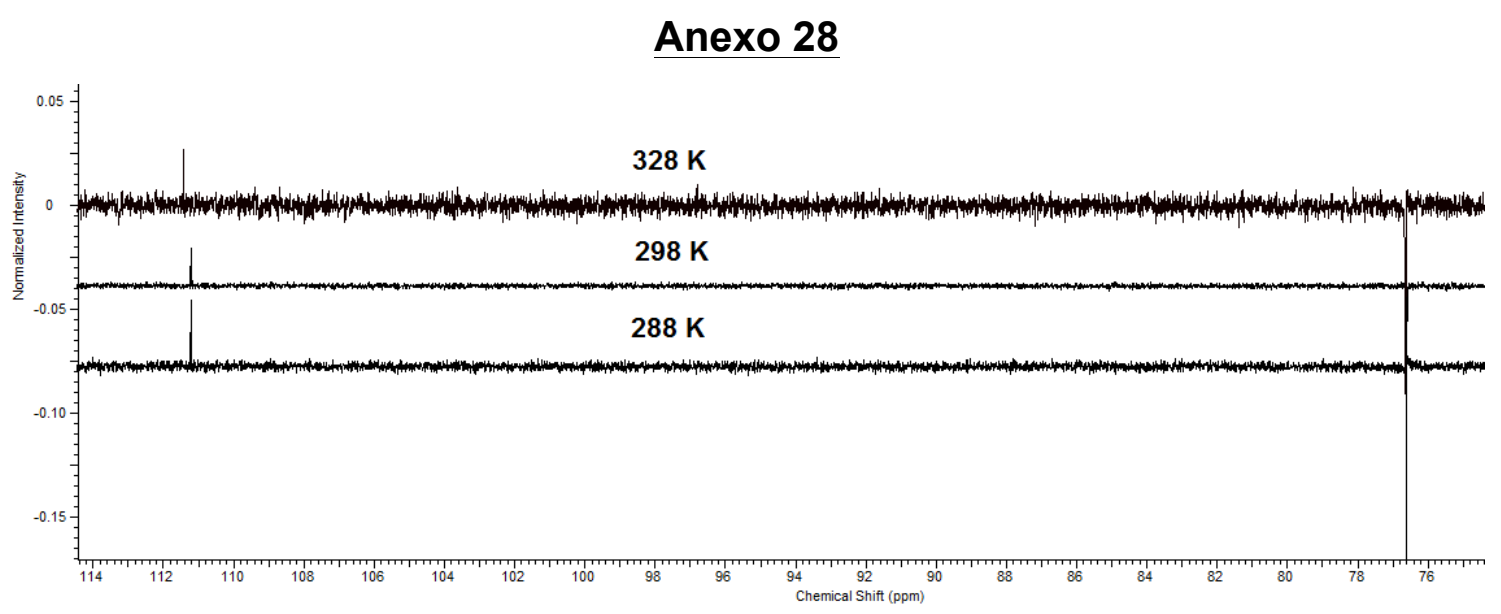

Anexo 28: Expansão dos espectros de APT do composto 2, em metanol, a diferentes temperaturas $\left(15,25\right.$ e $\left.55^{\circ} \mathrm{C}\right)$. É observado o sinal do carbono 1' próximo a 111,2 ppm. 


\section{Anexo 29}

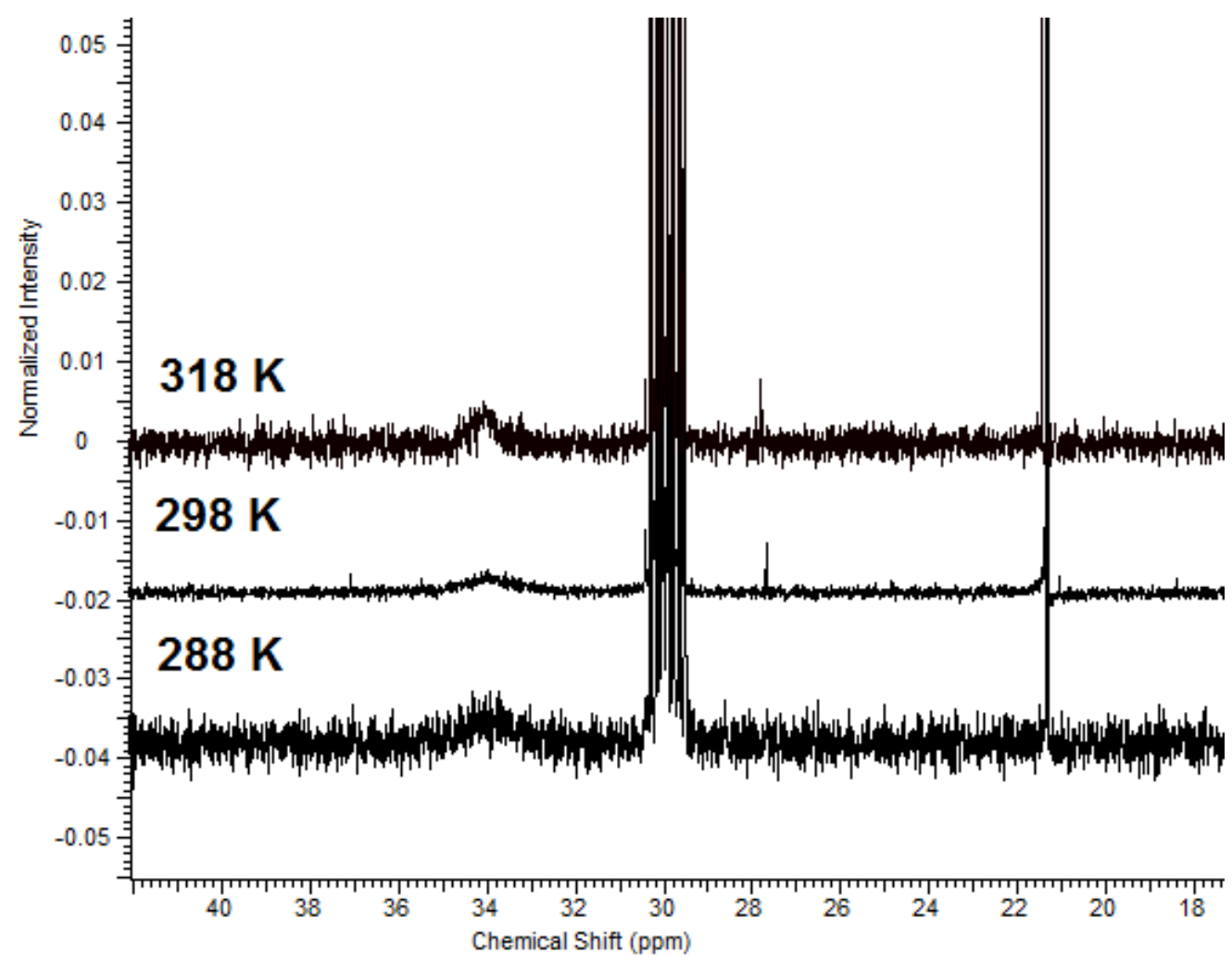

Anexo 29: Espectros de ${ }^{13} \mathrm{C}-\mathrm{RMN}$ do composto 2, em acetona a diferentes temperaturas (15, 25 e $45^{\circ} \mathrm{C}$ ). É observado o sinal referente aos carbonos 3' e 5' próximo a 33,8 ppm.

\section{Anexo 30}

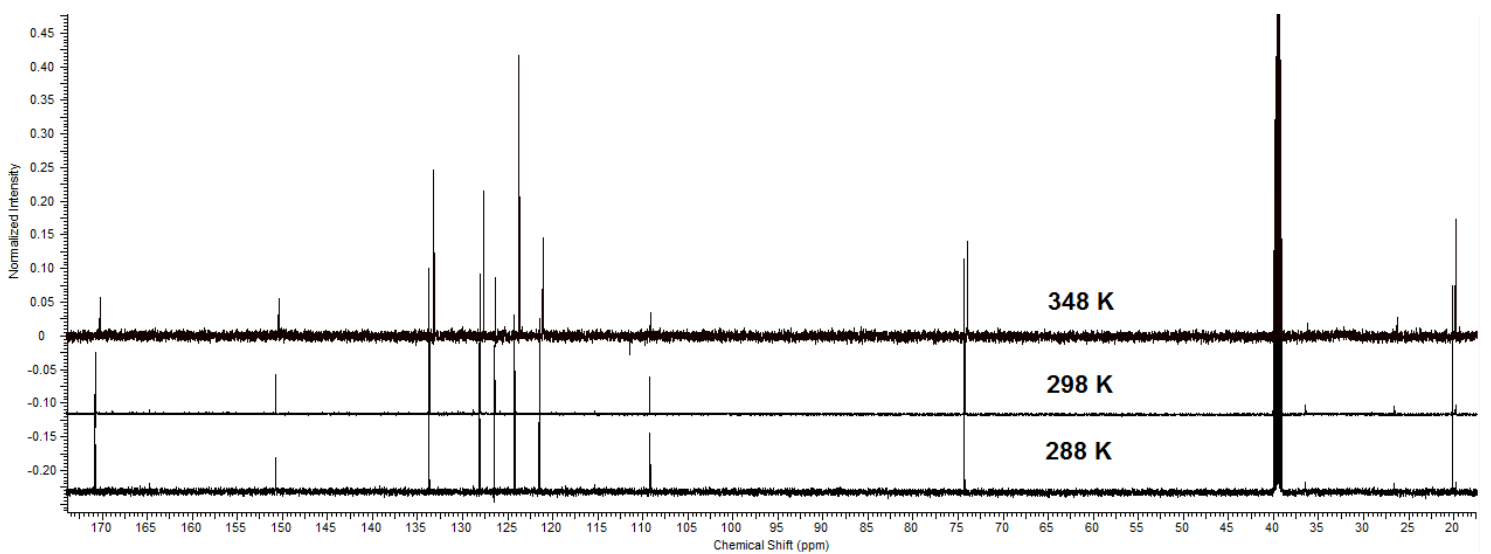

Anexo 30: Espectros de ${ }^{13} \mathrm{C}-\mathrm{RMN}$ do composto 2, em DMSO, e em diferentes temperaturas $\left(15,25\right.$ e $\left.75^{\circ} \mathrm{C}\right)$. Não é observado o sinal referente aos carbonos 3' e 5' nessas temperaturas. 


\section{Anexo 31}

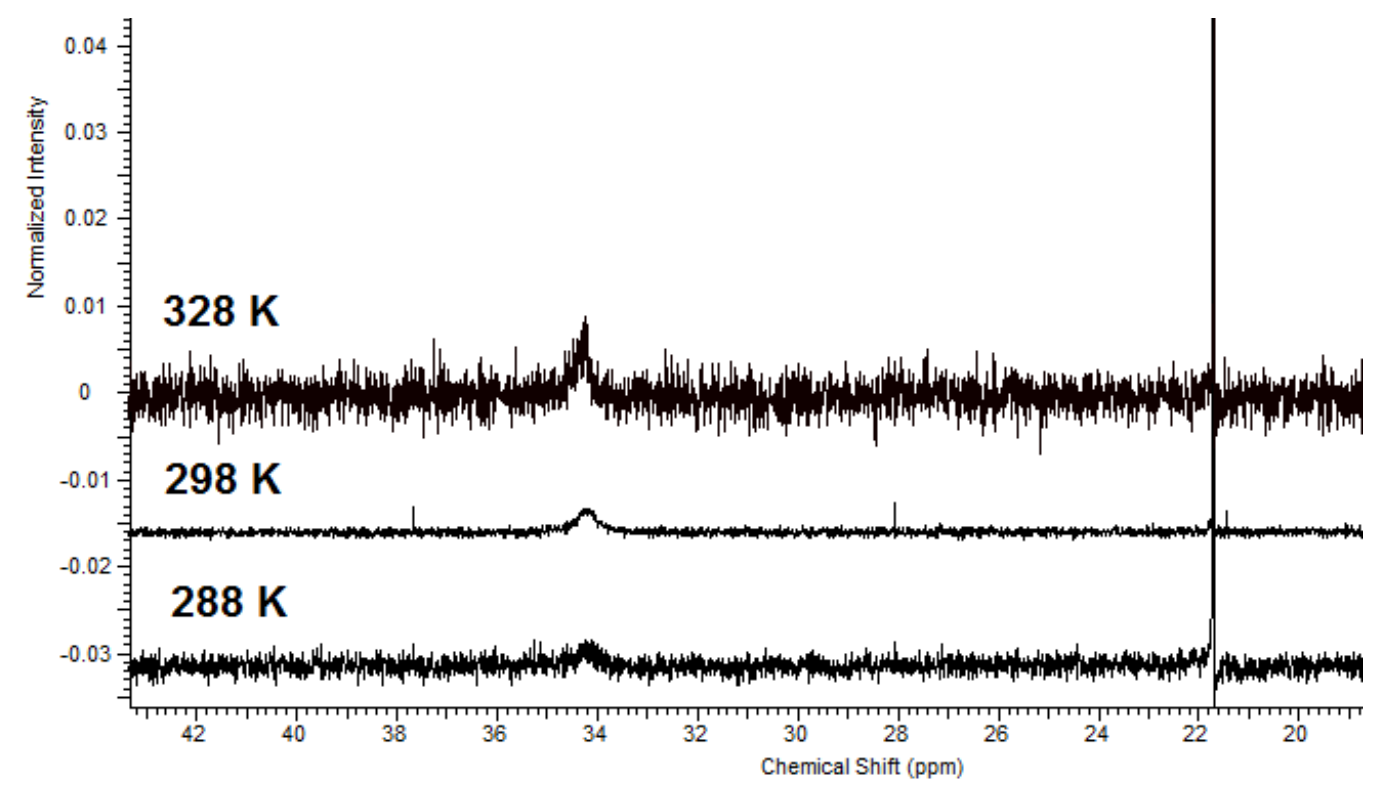

Anexo 31: Espectros de ${ }^{13} \mathrm{C}-\mathrm{RMN}$ do composto 2, em metanol, e em diferentes temperaturas $\left(15,25\right.$ e $\left.55^{\circ} \mathrm{C}\right)$. É observado o sinal referente aos carbonos 3' e 5' próximo a 34,2 ppm. 
Anexo 32

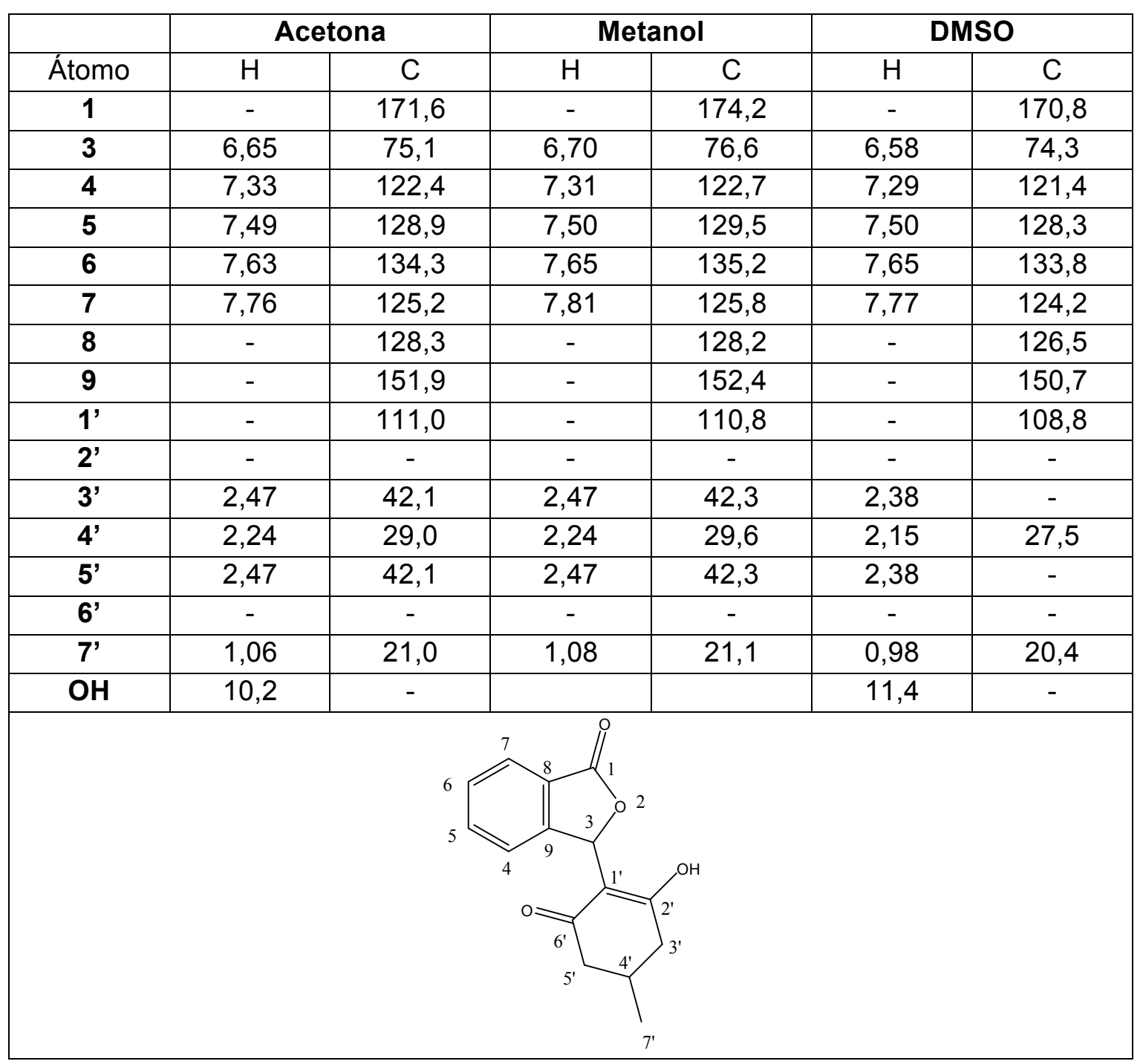

Anexo 32: Assinalamento dos átomos de hidrogênio e carbono do composto 3 em diferentes solventes: acetona, metanol e DMSO.

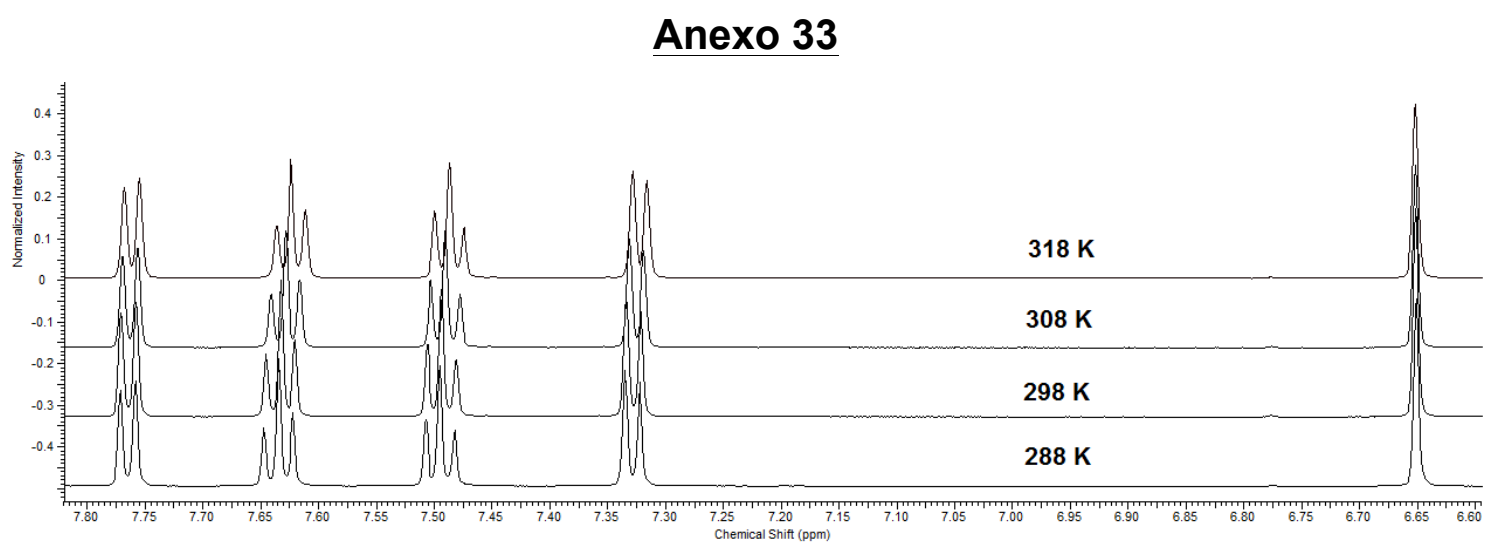

Anexo 33: Espectros de ${ }^{1} \mathrm{H}-\mathrm{RMN}$ do composto 3 em acetona, a diferentes temperaturas. Expansão da região de 6,60 a 7,80 ppm. É observado o hidrogênio 3 próximo a 6,65 ppm. 


\section{Anexo 34}

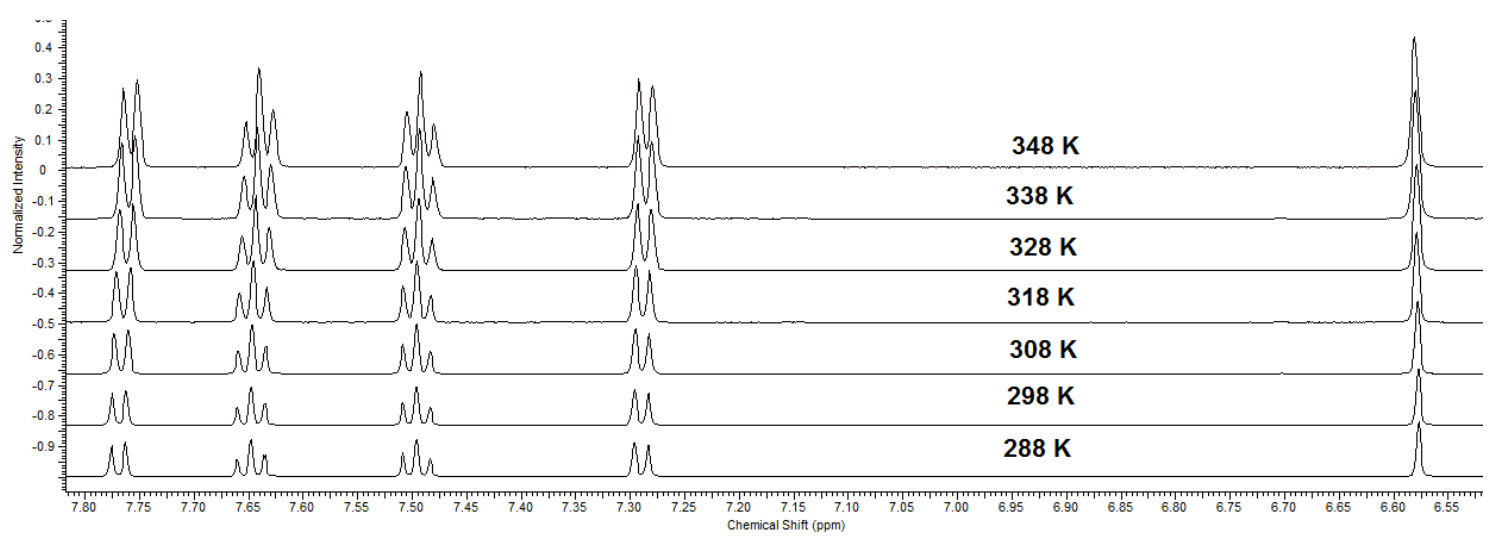

Anexo 34: Espectros de ${ }^{1} \mathrm{H}-\mathrm{RMN}$ do composto $3 \mathrm{em} \mathrm{DMSO}$, a diferentes temperaturas. Expansão da região de 6,55 a 7,80 ppm. É observado o hidrogênio 3 próximo a 6,58 ppm.

\section{Anexo 35}

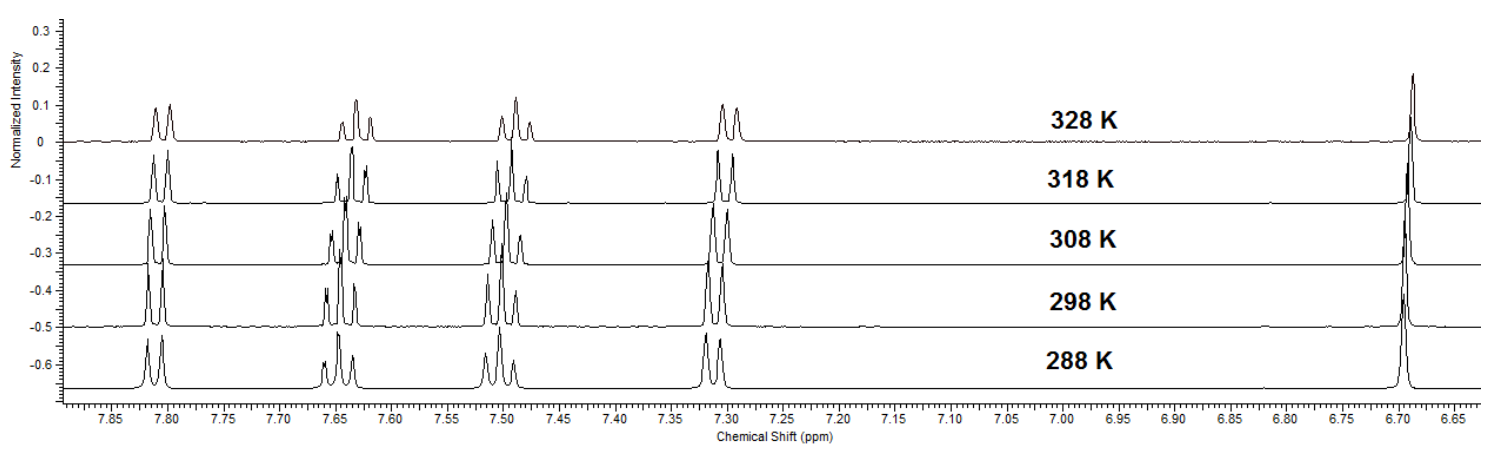

Anexo 35: Espectros de ${ }^{1} \mathrm{H}-\mathrm{RMN}$ do composto 3 em metanol, a diferentes temperaturas. Expansão da região de 6,65 a 7,85 ppm. É observado o hidrogênio 3 próximo a 6,70 ppm. 


\section{Anexo 36}

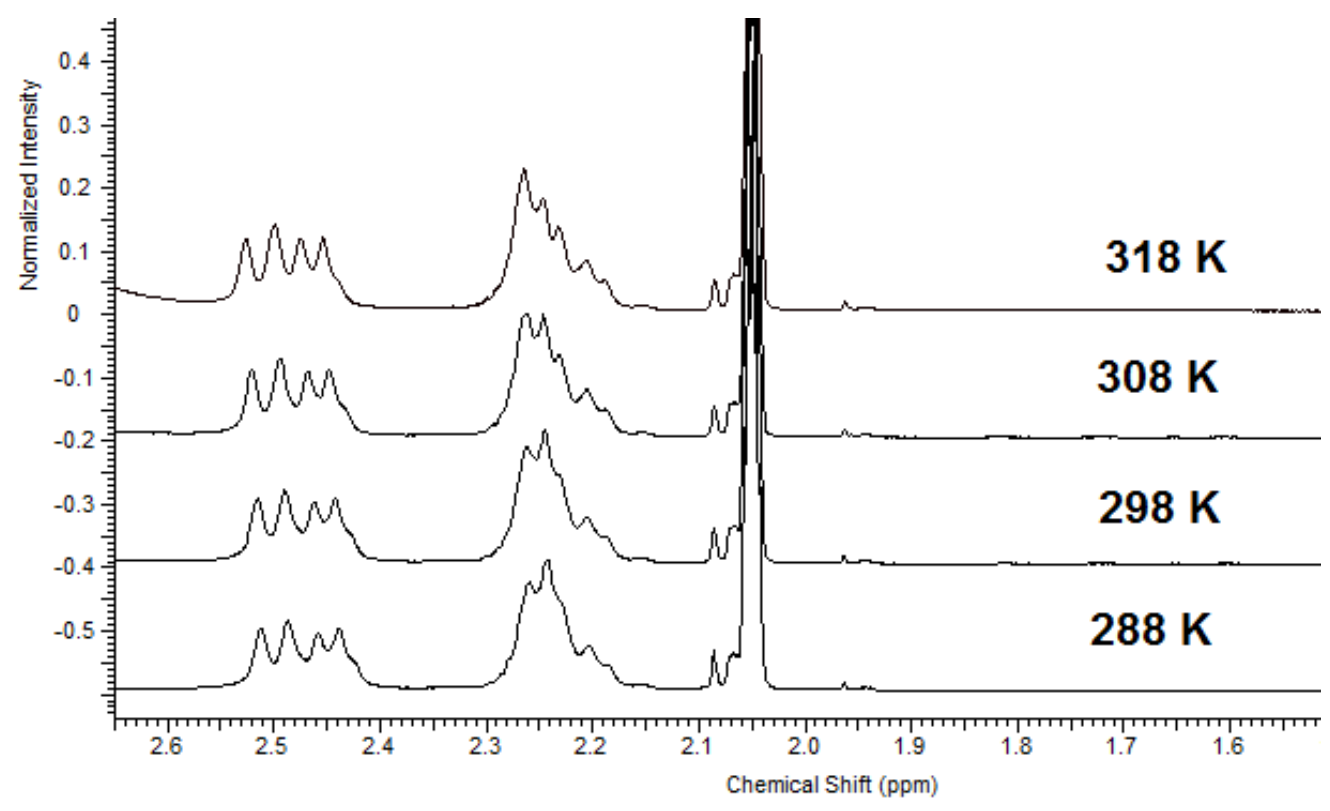

Anexo 36: Espectros de ${ }^{1} \mathrm{H}-\mathrm{RMN}$ do composto 3, em acetona, a diferentes temperaturas. Expansão da região alifática. São observados os hidrogênios 3' e 5' próximos a 2,47 ppm.

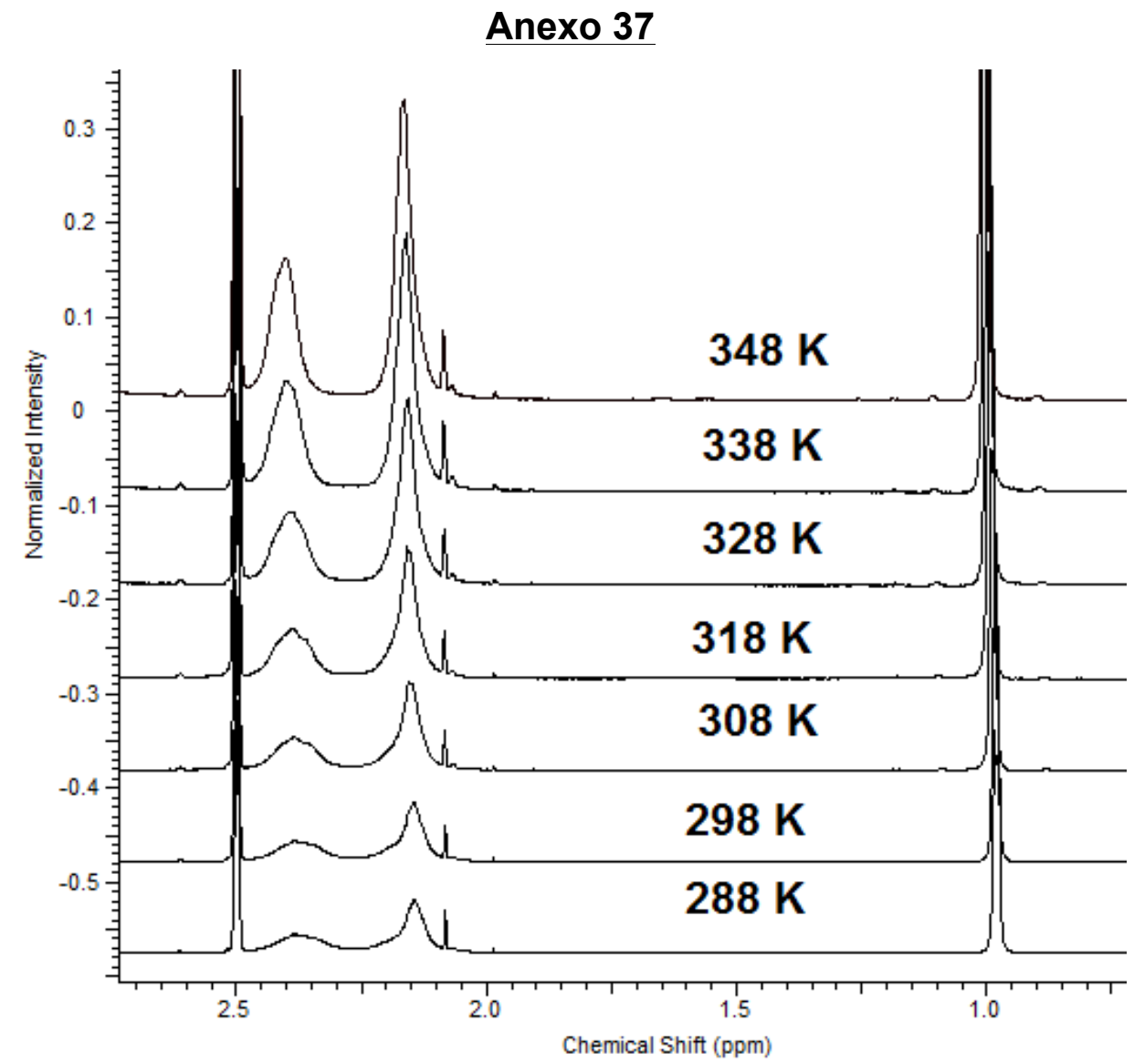

Anexo 37: Espectros de ${ }^{1} \mathrm{H}-\mathrm{RMN}$ do composto 3, em DMSO, a diferentes temperaturas. Expansão da região alifática. São observados os hidrogênios 3' e 5' próximos a 2,38 ppm. 


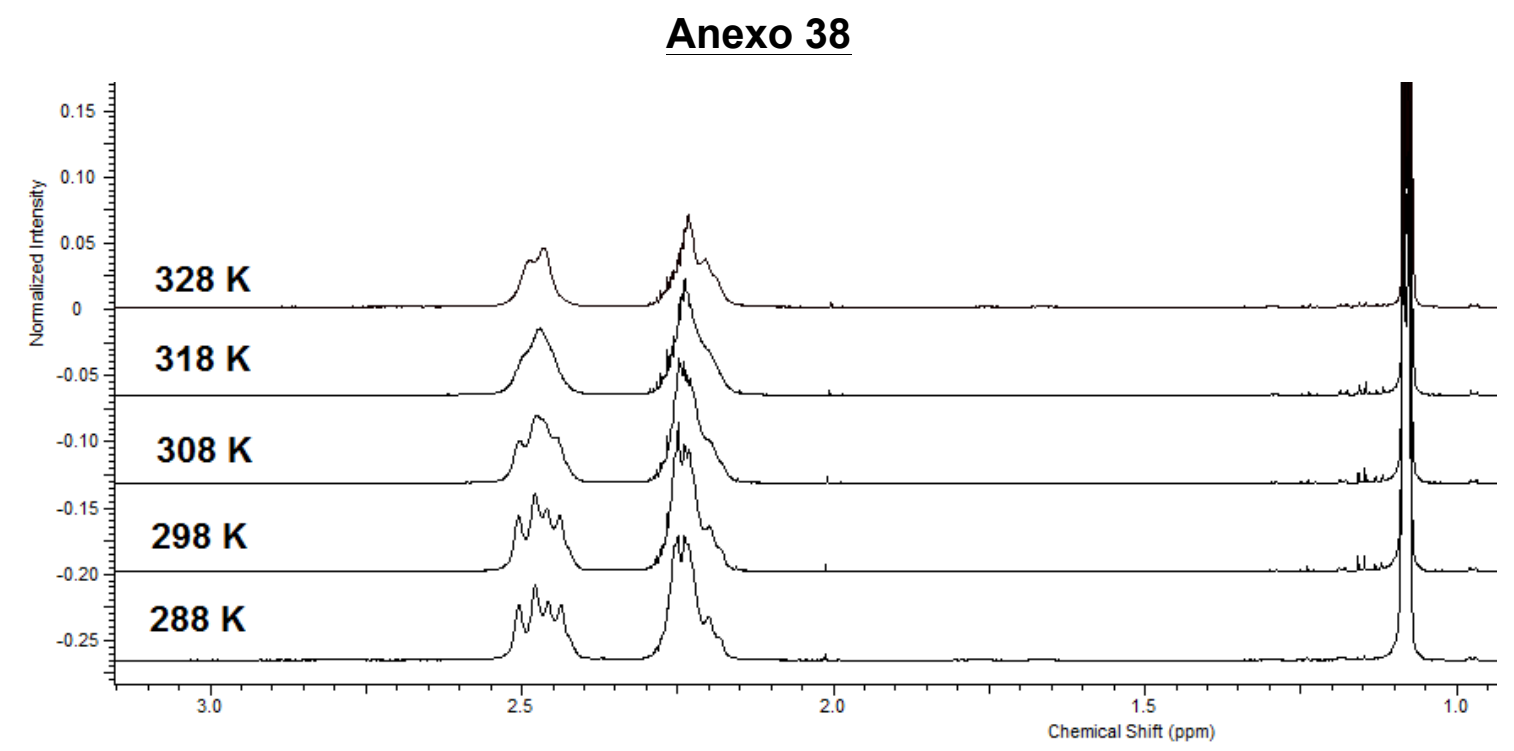

Anexo 38: Espectros de ${ }^{1} \mathrm{H}-\mathrm{RMN}$ do composto $3 \mathrm{em}$ metanol a diferentes temperaturas. Expansão da região alifática. São observados os hidrogênios 3' e 5' próximos a 2,47 ppm.

\section{Anexo 39}

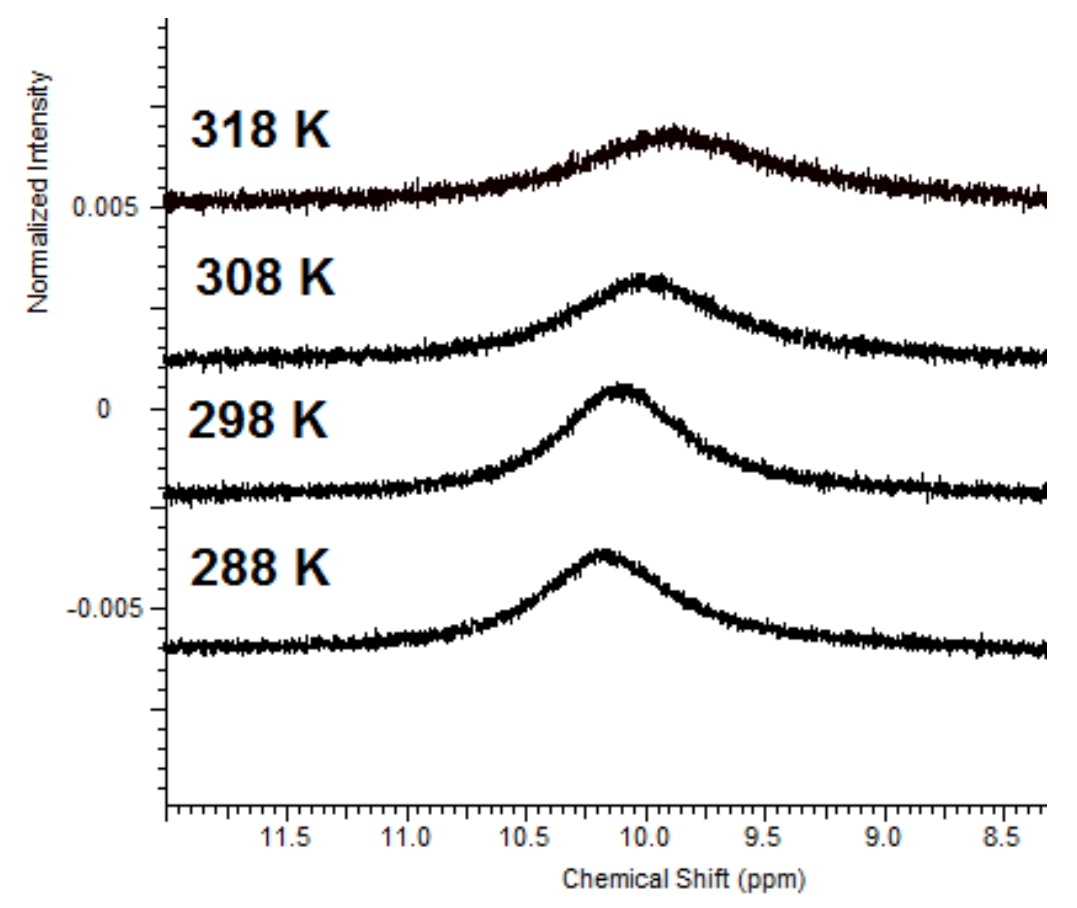

Anexo 39: Espectros de ${ }^{1} \mathrm{H}-\mathrm{RMN}$ a 15, 25, 35 e $45^{\circ} \mathrm{C}$ do composto 3, em acetona, com expansão da região de mais alto deslocamento químico. Observa-se o sinal alargado próximo a 10,2 ppm, referente ao hidrogênio do grupo hidroxila. 


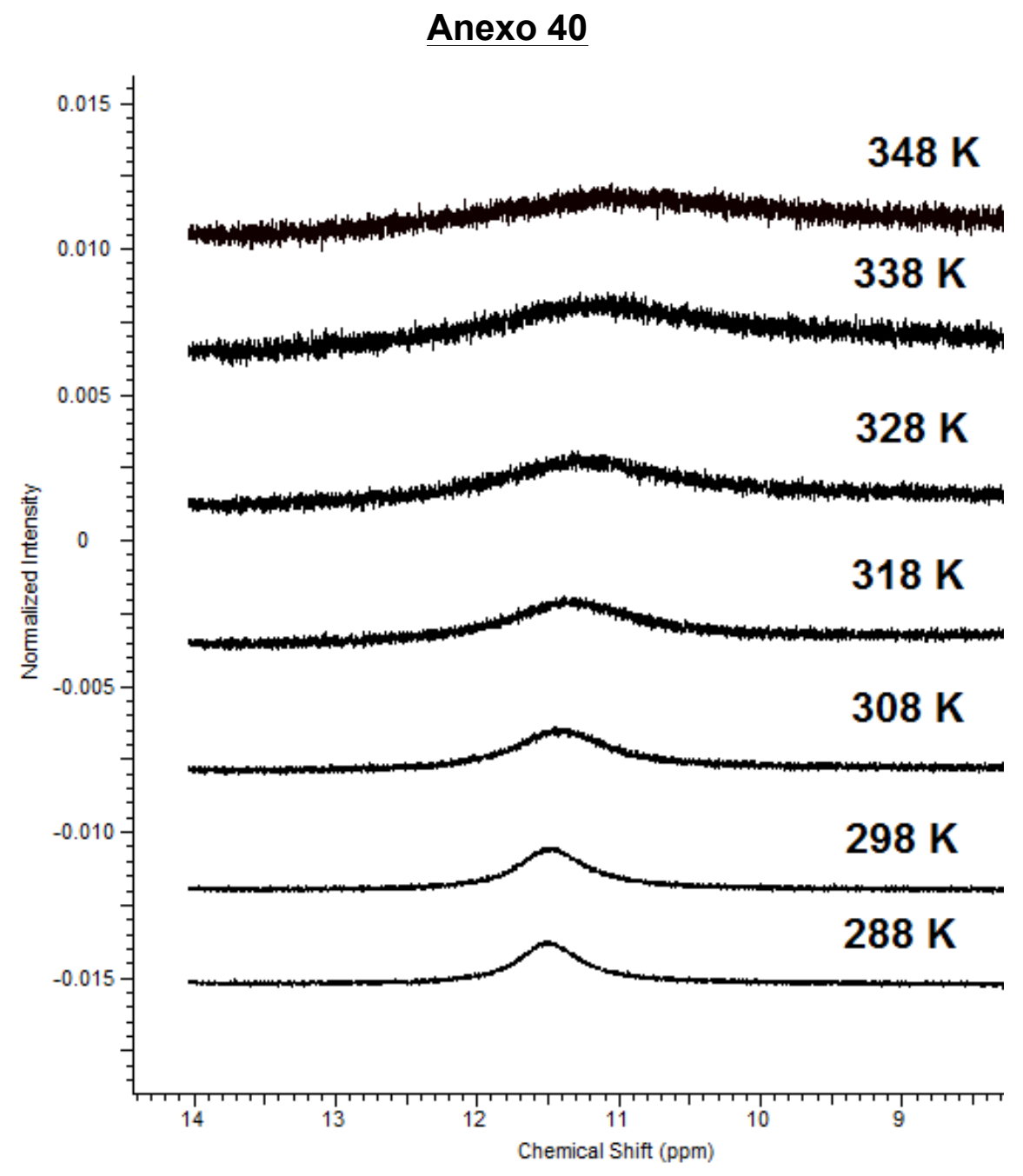

Anexo 40: Espectros de ${ }^{1} \mathrm{H}-\mathrm{RMN}$ a $15,25,35,45,55,65$ e $75^{\circ} \mathrm{C}$ do composto 3 , em DMSO, com expansão da região de mais alto deslocamento químico. Observa-se o sinal alargado próximo a 11,4 ppm, referente ao hidrogênio do grupo hidroxila.

\section{Anexo 41}

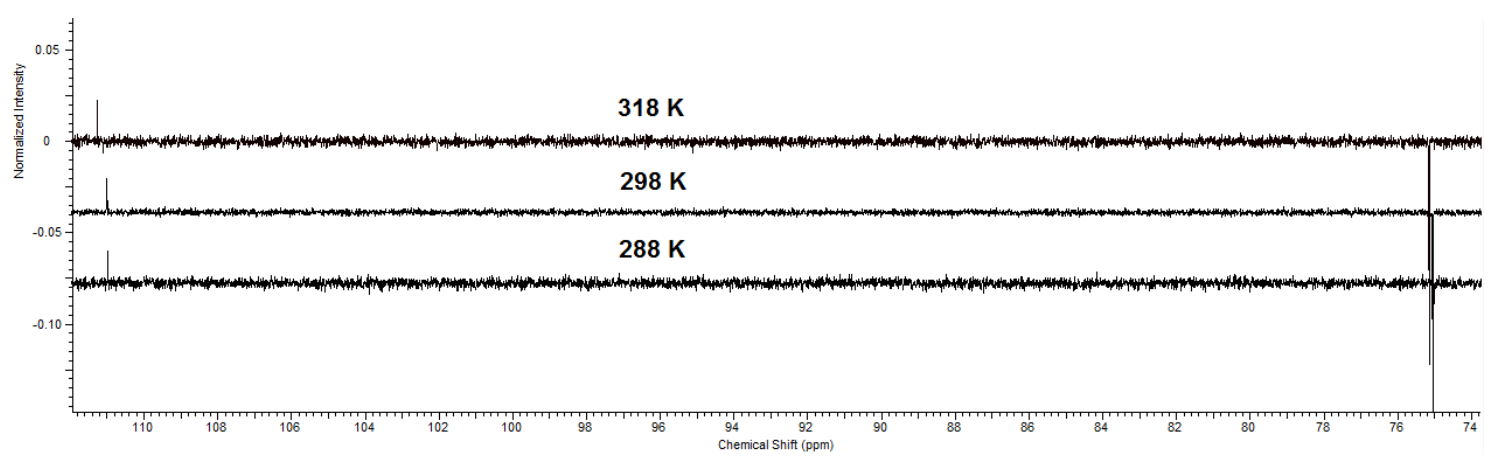

Anexo 41: Expansão dos espectros de APT do composto 3, em acetona, a diferentes temperaturas $\left(15,25\right.$ e $\left.45^{\circ} \mathrm{C}\right)$. É observado o sinal do carbono 1' próximo a 111,0 ppm. 


\section{Anexo 42}

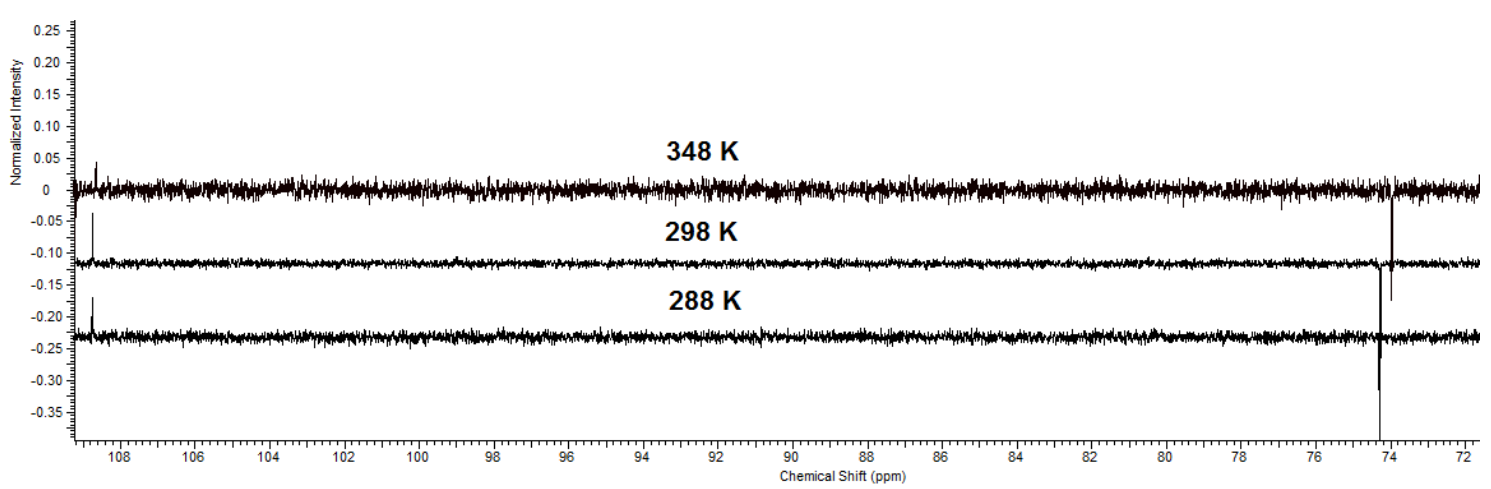

Anexo 42: Expansão dos espectros de APT do composto 3, em DMSO, a diferentes temperaturas $\left(15,25\right.$ e $\left.75^{\circ} \mathrm{C}\right)$. É observado o sinal do carbono 1' próximo a 108,8 ppm.

\section{Anexo 43}

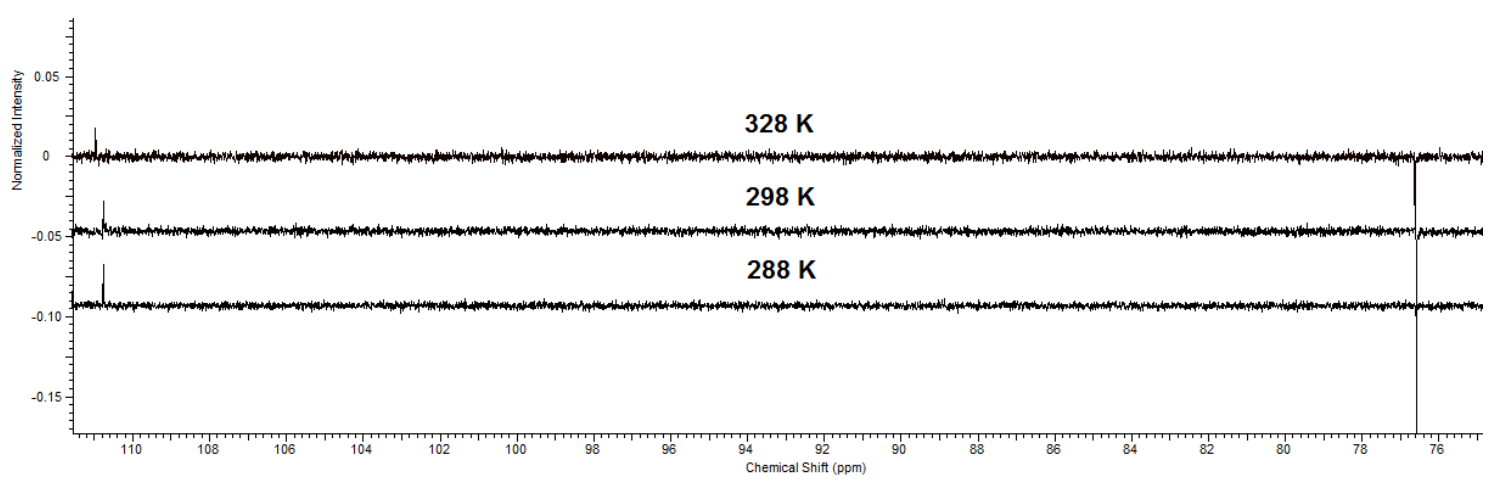

Anexo 43: Expansão dos espectros de APT do composto 3 em metanol a diferentes temperaturas $\left(15,25\right.$ e $\left.55^{\circ} \mathrm{C}\right)$. É observado o sinal do carbono 1' próximo a 110,8 ppm.

\section{Anexo 44}

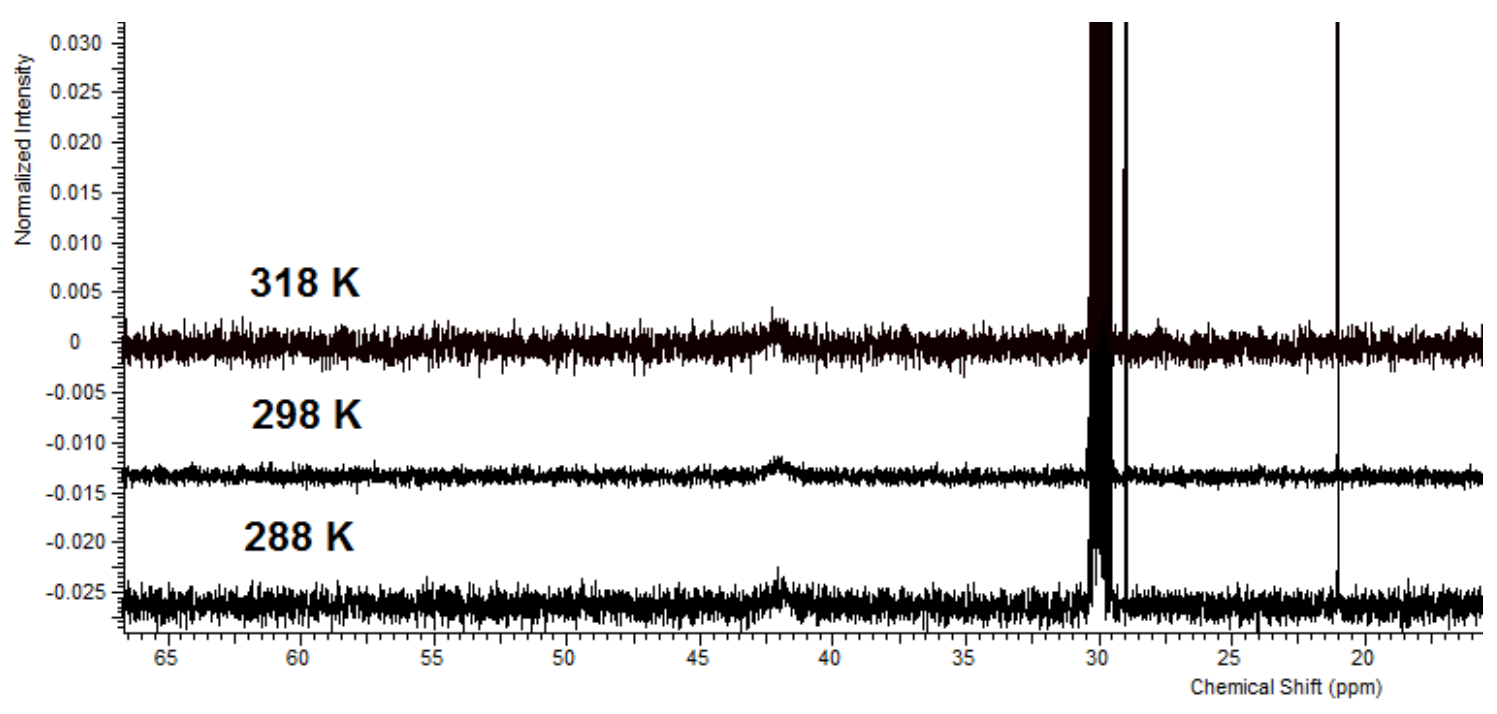

Anexo 44: Espectros de ${ }^{13} \mathrm{C}-\mathrm{RMN}$ do composto 3, em acetona, a diferentes temperaturas (15, 25 e $45^{\circ} \mathrm{C}$ ). É observado o sinal referente aos carbonos 3' e 5' próximos a $42,1 \mathrm{ppm}$. 


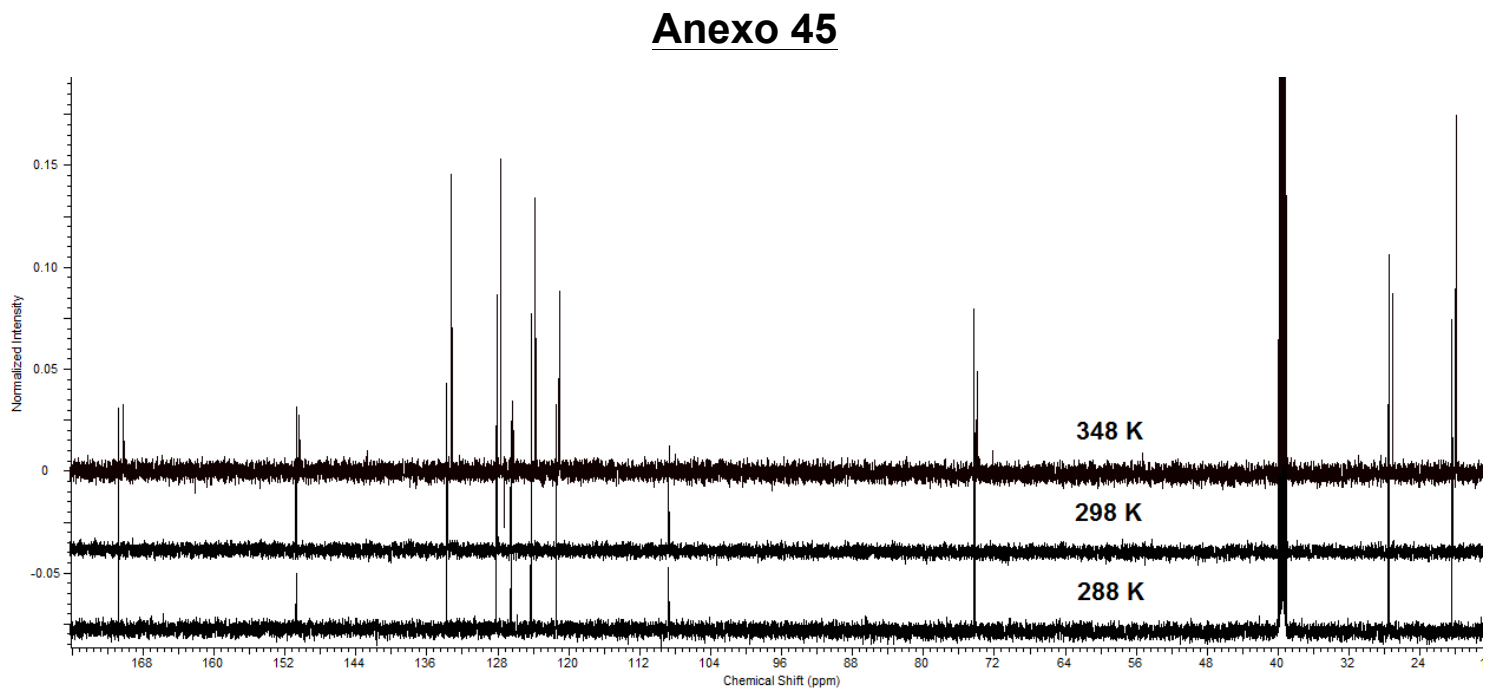

Anexo 45: Espectros de ${ }^{13} \mathrm{C}-\mathrm{RMN}$ do composto 3 em DMSO a diferentes temperaturas $(15,25$ e $75^{\circ} \mathrm{C}$ ). Não é observado o sinal referente aos carbonos 3' e 5' nas temperaturas estudadas.

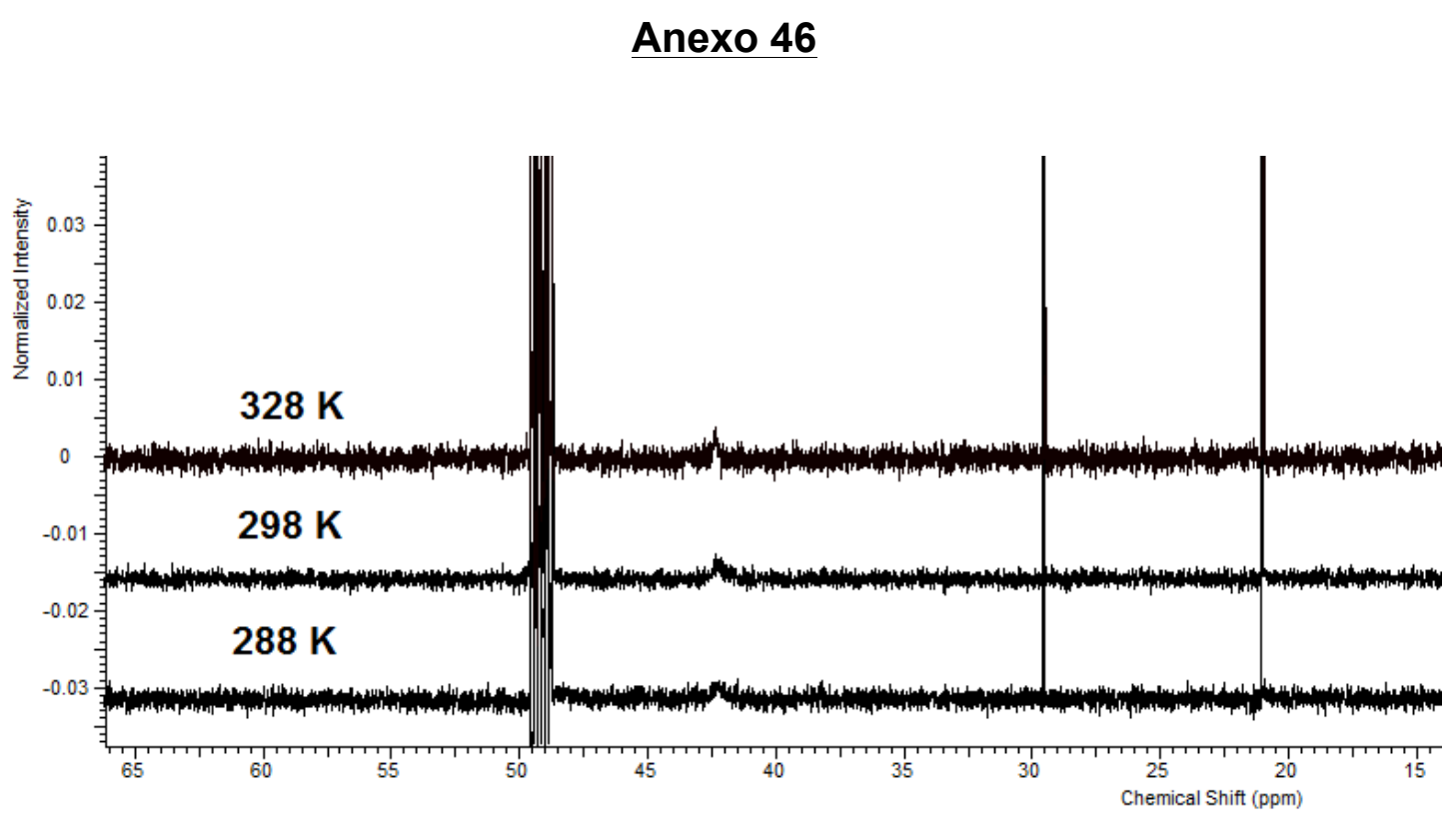

Anexo 46: Espectros de ${ }^{13} \mathrm{C}-\mathrm{RMN}$ do composto 3 em metanol a diferentes temperaturas (15, 25 e $55^{\circ} \mathrm{C}$ ). É observado o sinal referente aos carbonos 3' e 5' próximos a $42,3 \mathrm{ppm}$. 
Anexo 47

\begin{tabular}{|c|c|c|c|c|c|c|}
\hline & \multicolumn{2}{|c|}{ Acetona } & \multicolumn{2}{|c|}{ Metanol } & \multicolumn{2}{|c|}{ DMSO } \\
\hline Átomo & $\mathrm{H}$ & C & $\mathrm{H}$ & C & $\mathrm{H}$ & C \\
\hline 1 & - & 171,1 & - & 173,5 & - & 170,0 \\
\hline 3 & 6,27 & 73,7 & 6,30 & 75,1 & 6,25 & 73,1 \\
\hline 4 & 7,40 & 123,2 & 7,38 & 123,4 & 7,36 & 122,3 \\
\hline 5 & 7,55 & 129,6 & 7,55 & 130,1 & 7,55 & 128,7 \\
\hline 6 & 7,68 & 134,6 & 7,69 & 135,5 & 7,69 & 134,0 \\
\hline 7 & 7,81 & 125,4 & 7,84 & 126,0 & 7,81 & 124,5 \\
\hline 8 & - & 127,7 & - & 127,7 & - & 126,0 \\
\hline 9 & - & 150,2 & - & 150,6 & - & 149,0 \\
\hline 1 ' & - & 112,6 & - & 112,6 & - & 110,4 \\
\hline 2' & - & - & - & - & - & - \\
\hline 3 ' & 2,50 & $31,2^{*}$ & 2,55 & $31,7^{*}$ & 2,43 & 30,4 \\
\hline 4' & 2,50 & $31,2^{*}$ & 2,55 & $31,7^{*}$ & 2,43 & 30,4 \\
\hline 5 & - & - & - & - & - & \\
\hline $\mathrm{OH}$ & 9,1 & - & - & - & 9,5 & - \\
\hline
\end{tabular}

Anexo 47: Assinalamento dos átomos de hidrogênio e carbono do composto 4 em diferentes solventes: acetona, metanol e DMSO. átomos assinalados pelos espectros de HSQC, pois não foram observados no espectro de ${ }^{13} \mathrm{C}-\mathrm{RMN}$.

\section{Anexo 48}

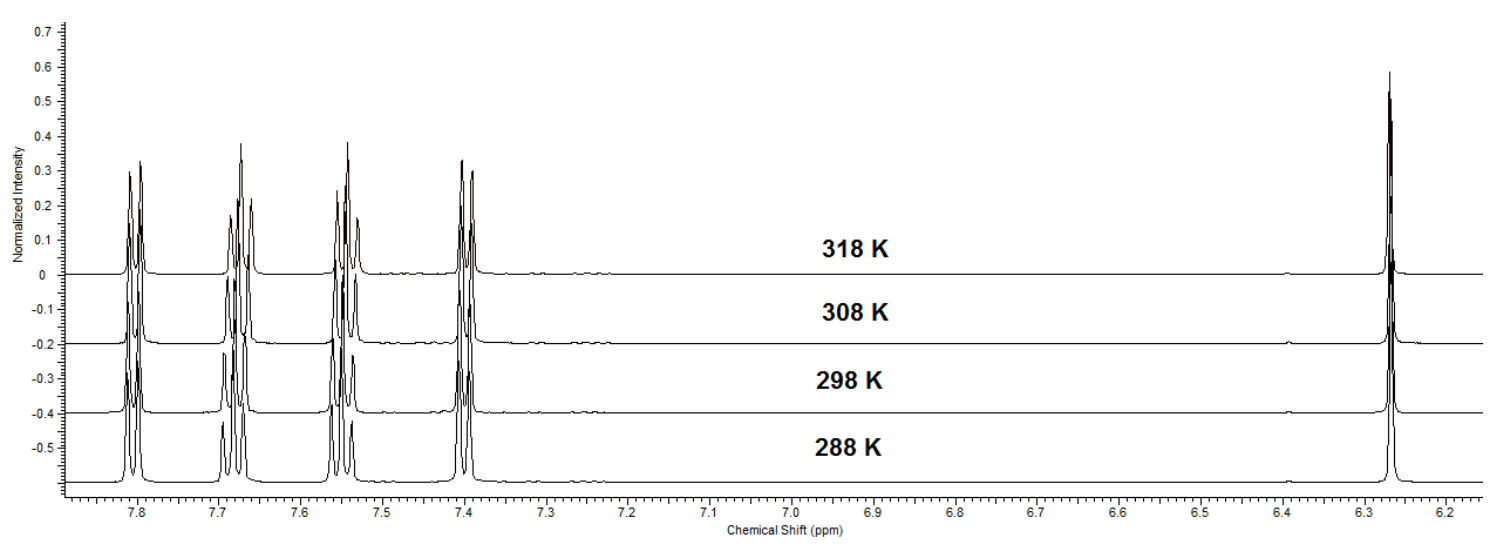

Anexo 48: Espectros de ${ }^{1} \mathrm{H}-\mathrm{RMN}$ do composto 4 em acetona, a diferentes temperaturas. Expansão da região de 6,2 a 7,9 ppm. É observado o hidrogênio 3 próximo a 6,27 ppm. 


\section{Anexo 49}

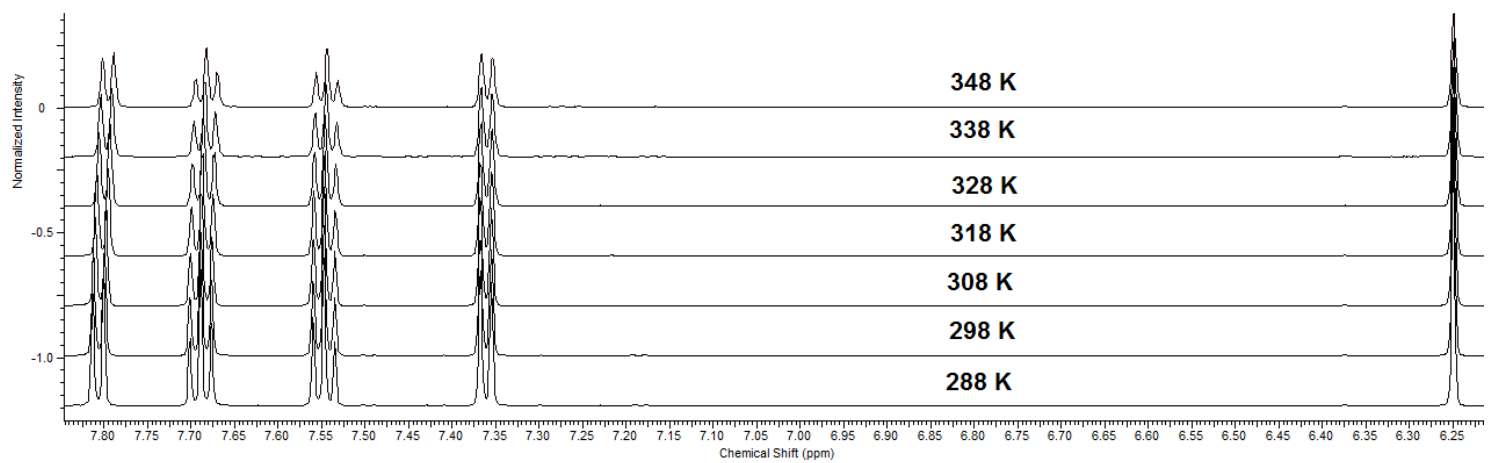

Anexo 49: Espectros de ${ }^{1} \mathrm{H}-\mathrm{RMN}$ do composto 4 em DMSO, a diferentes temperaturas. Expansão da região de 6,20 a 7,85 ppm. É observado o hidrogênio 3 próximo a 6,25 ppm.

\section{Anexo 50}

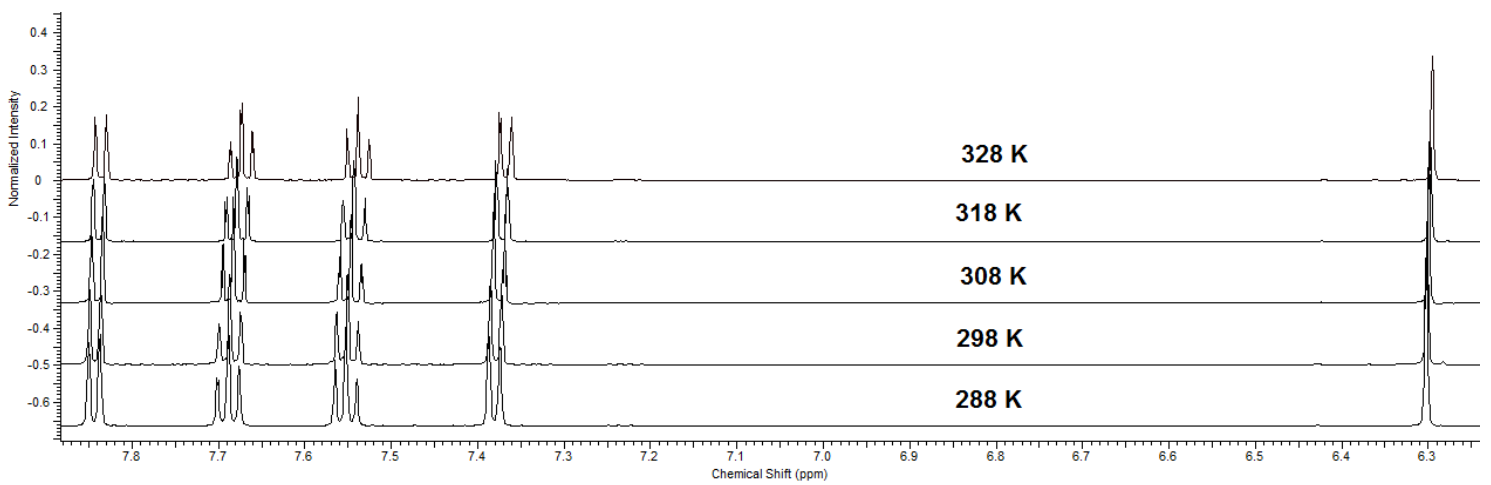

Anexo 50: Espectros de ${ }^{1} \mathrm{H}-\mathrm{RMN}$ do composto 4 em metanol, a diferentes temperaturas. Expansão da região de 6,2 a 7,9 ppm. É observado o hidrogênio 3 próximo a 6,30 ppm. 
Anexo 51

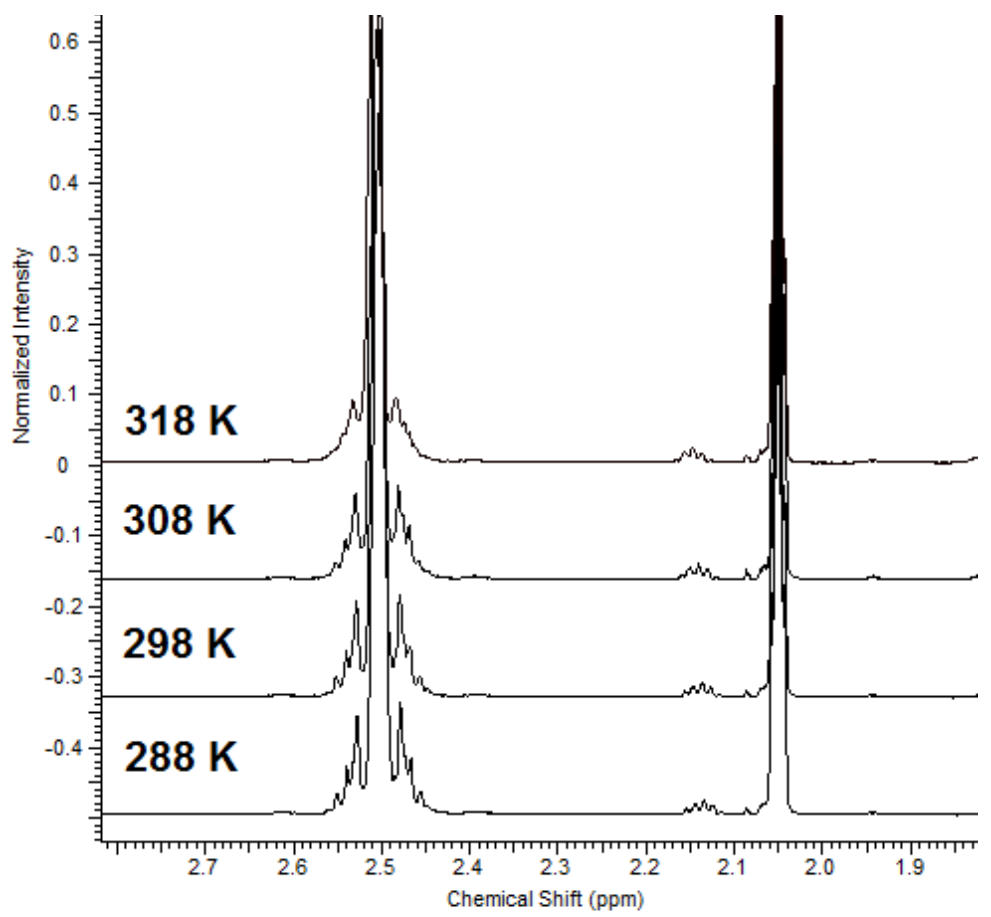

Anexo 51: Espectros de ${ }^{1} \mathrm{H}-\mathrm{RMN}$ do composto 4 em acetona, a diferentes temperaturas. Expansão da região alifática. São observados os hidrogênios 3' e 4' próximos a 2,50 ppm.

\section{Anexo 52}

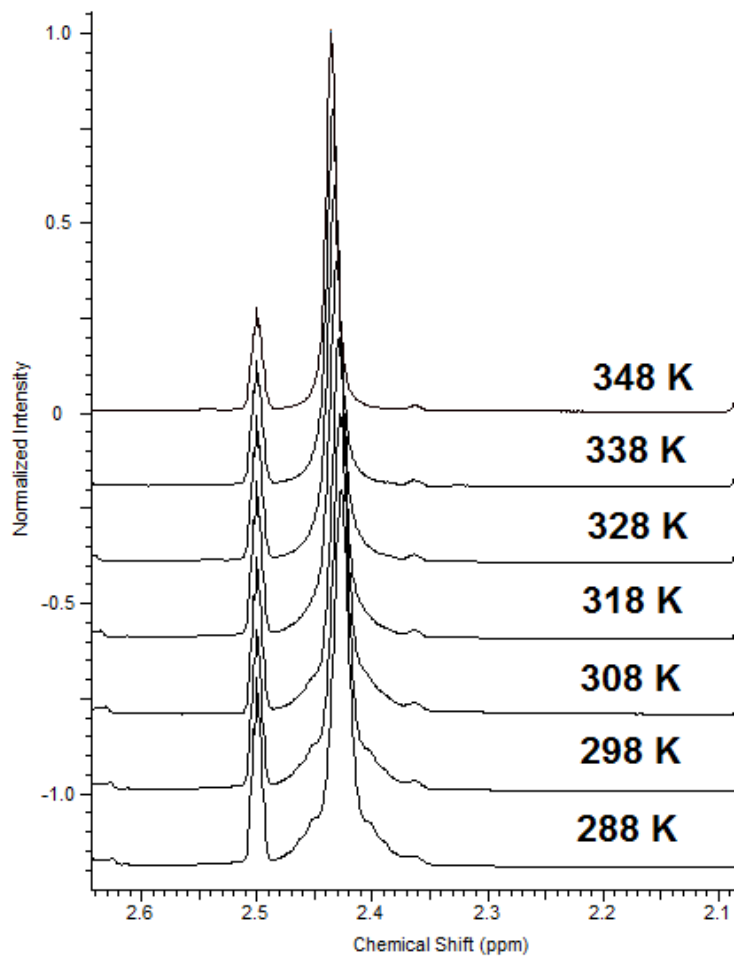

Anexo 52: Espectros de ${ }^{1} \mathrm{H}-\mathrm{RMN}$ do composto 4 em DMSO, a diferentes temperaturas. Expansão da região alifática. São observados os hidrogênios 3' e 4' próximos a 2,43 ppm. 


\section{Anexo 53}

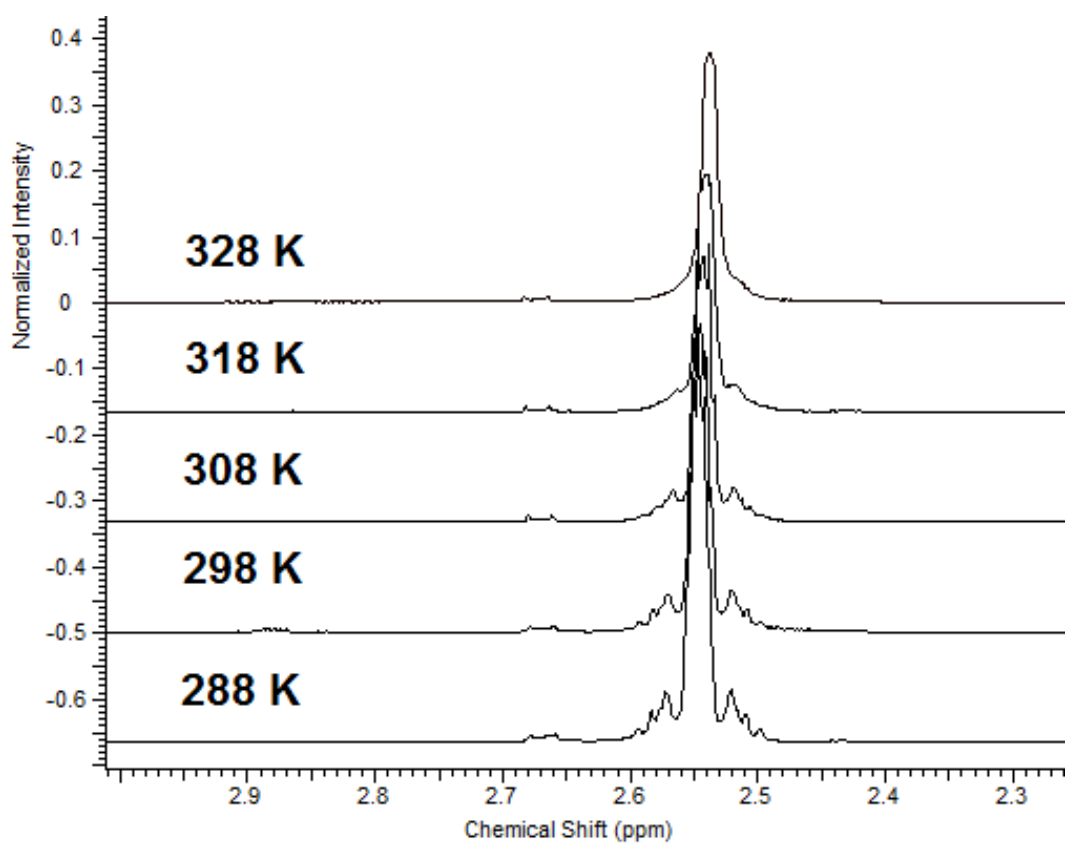

Anexo 53: Espectros de ${ }^{1} \mathrm{H}-\mathrm{RMN}$ do composto 4 em metanol, a diferentes temperaturas. Expansão da região alifática. São observados os hidrogênios 3' e 4' próximos a 2,55 ppm.

\section{Anexo 54}

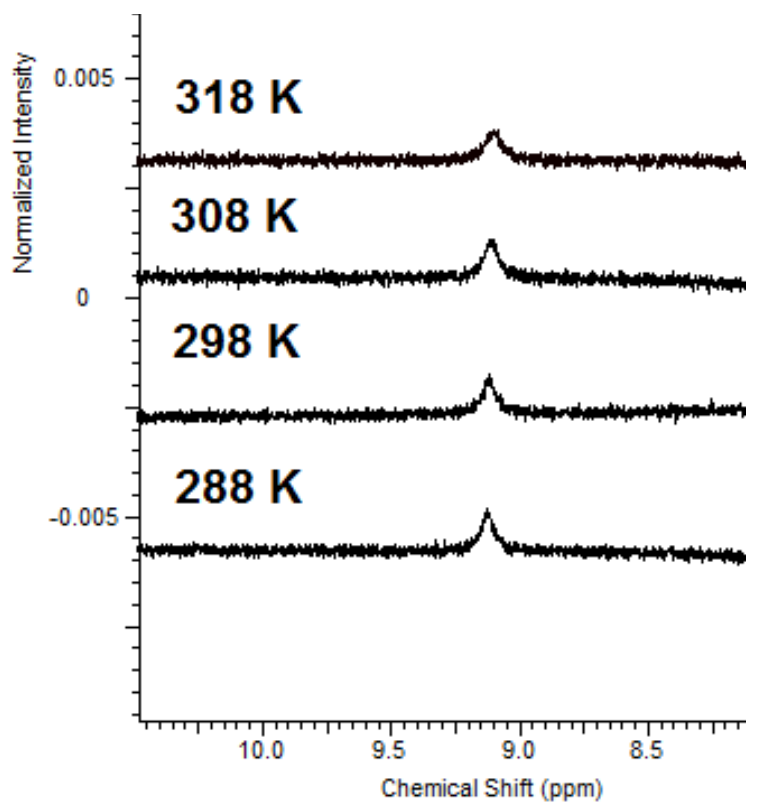

Anexo 54: Espectros de ${ }^{1} \mathrm{H}-\mathrm{RMN}$ a $15,25,35$ e $45^{\circ} \mathrm{C}$ do composto 4 em acetona, com expansão da região de mais alto deslocamento químico. Observa-se o sinal próximo a 9,1 ppm, referente ao hidrogênio do grupo hidroxila. 


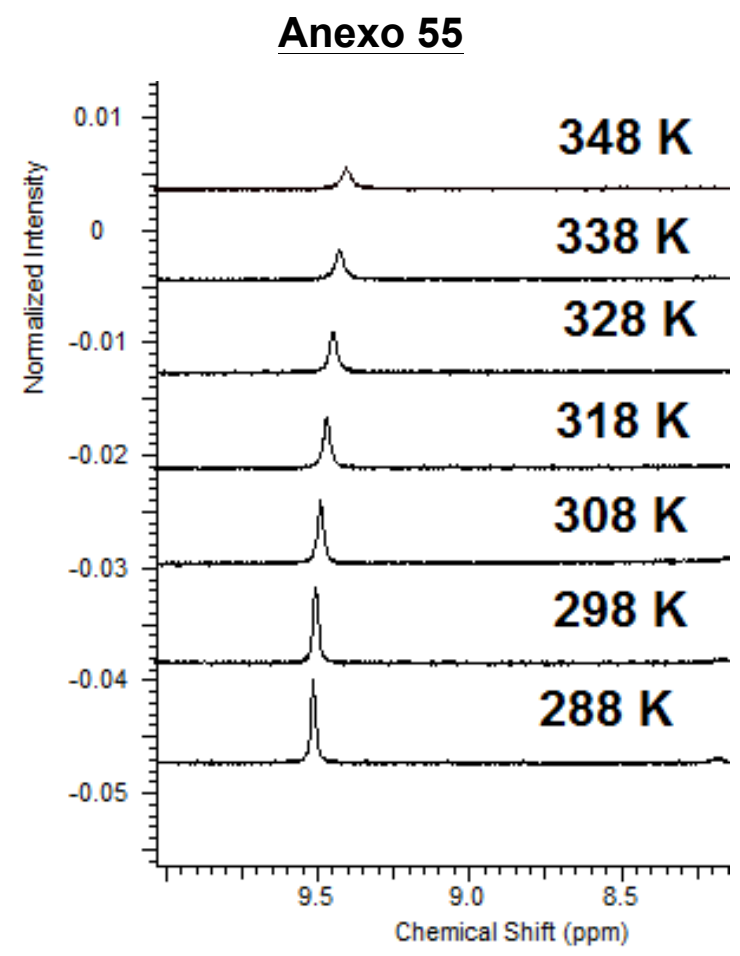

Anexo 55: Espectros de ${ }^{1} \mathrm{H}-\mathrm{RMN}$ a $15,25,35,45,55,65$ e $75^{\circ} \mathrm{C}$ do composto 4 em DMSO, com expansão da região de mais alto deslocamento químico. Observa-se o sinal próximo a 9,5 ppm, referente ao hidrogênio do grupo hidroxila.

\section{Anexo 56}

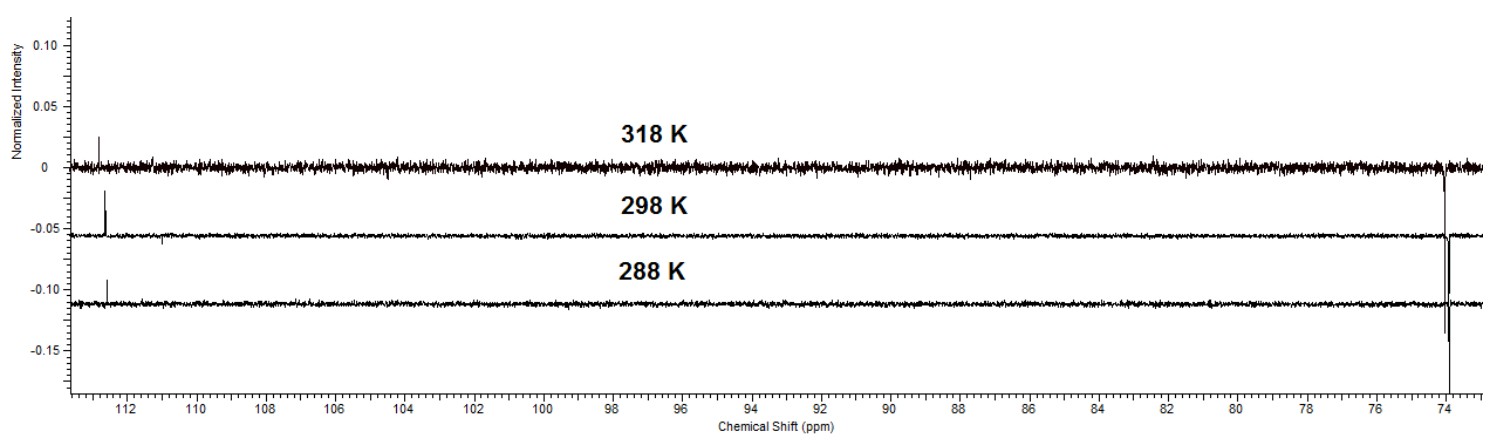

Anexo 56: Espectros de APT do composto 4 em acetona, a diferentes temperaturas (15, $25 \mathrm{e}$ $45^{\circ} \mathrm{C}$ ). É observado o sinal do carbono 1' próximo a 112,6 ppm. 


\section{Anexo 57}

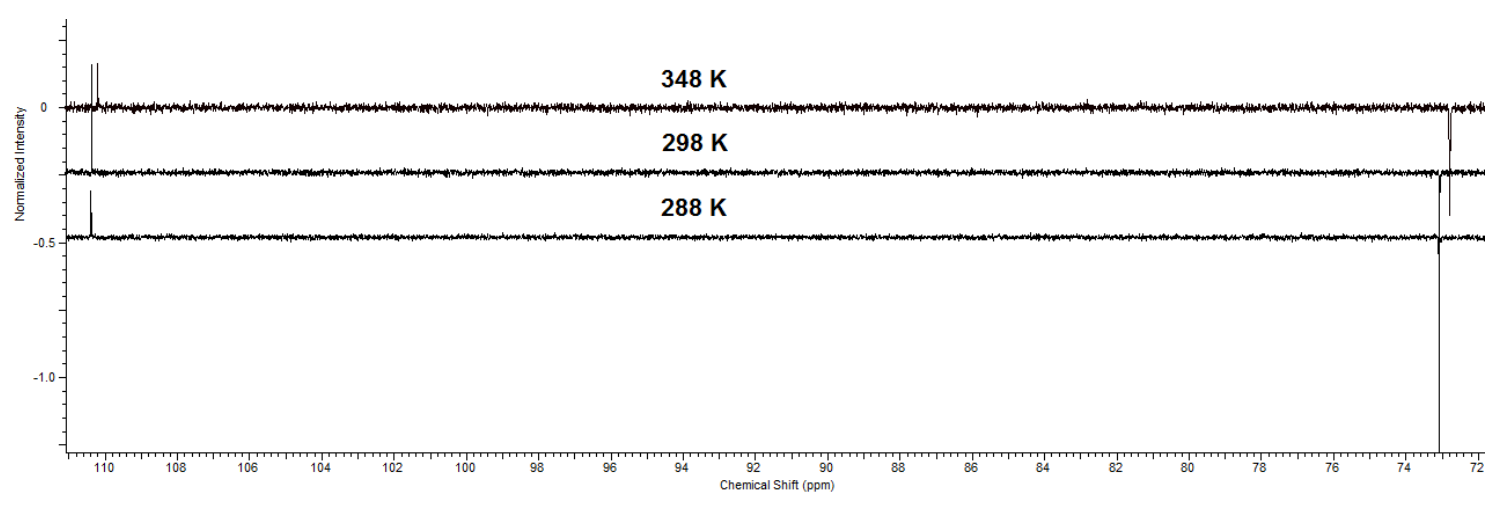

Anexo 57: Espectros de APT do composto 4 em DMSO, a diferentes temperaturas (15, 25 e 75 C). É observado o sinal do carbono 1' próximo a 110,4 ppm.

\section{Anexo 58}

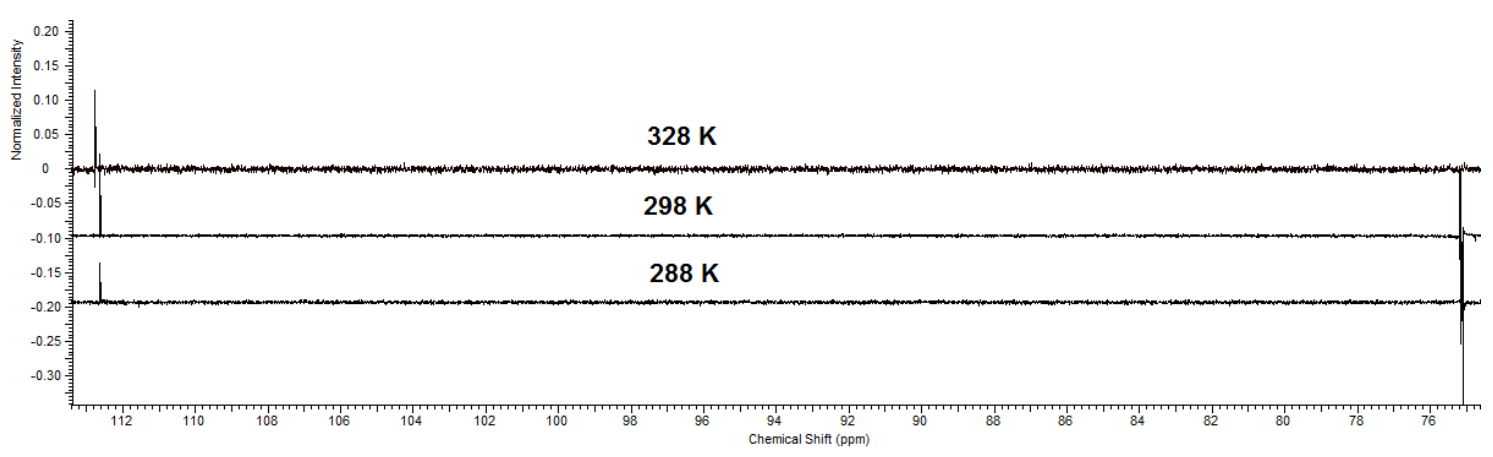

Anexo 58: Espectros de APT do composto 4 em metanol, a diferentes temperaturas (15, 25 e $55^{\circ} \mathrm{C}$ ). É observado o sinal do carbono 1' próximo a 112,6 ppm.

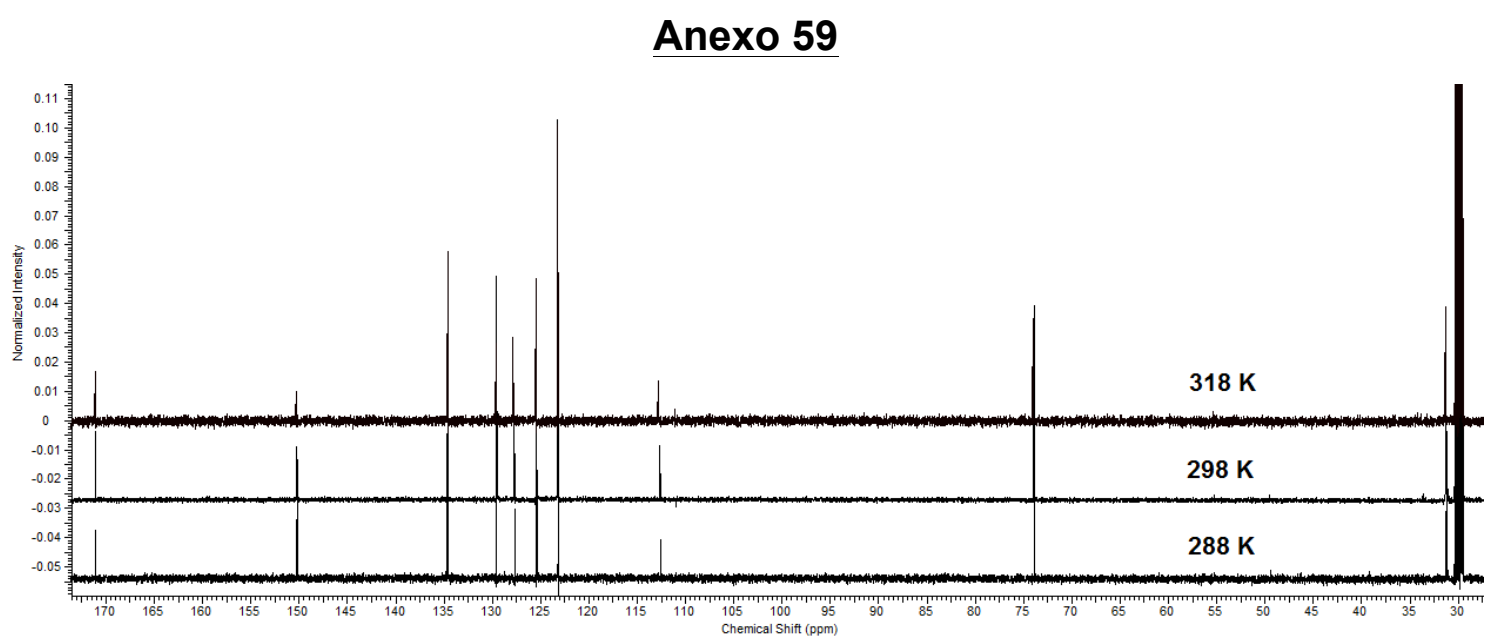

Anexo 59: Espectros de ${ }^{13} \mathrm{C}-\mathrm{RMN}$ do composto 4 em acetona, a diferentes temperaturas (15, 25 e $45^{\circ} \mathrm{C}$ ). Não é observado o sinal referente aos carbonos 3' e 4' nas temperaturas estudadas. 


\section{Anexo 60}

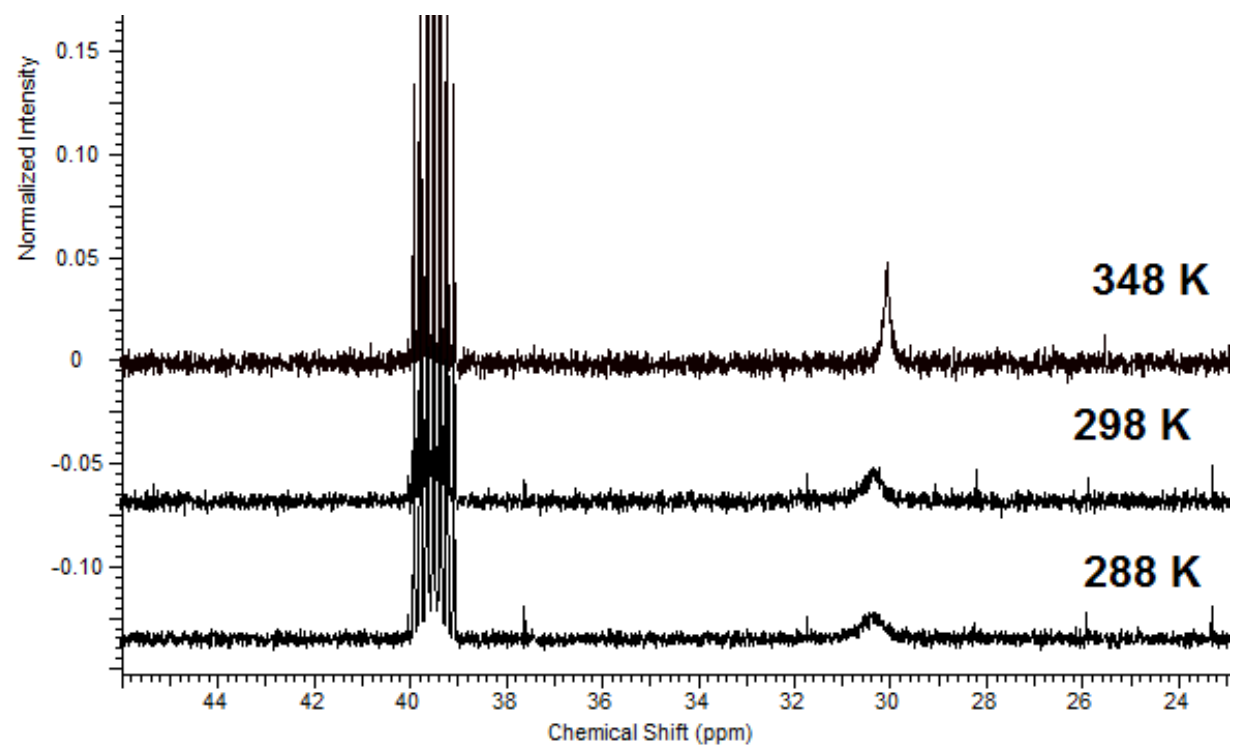

Anexo 60: Espectros de ${ }^{13} \mathrm{C}-\mathrm{RMN}$ do composto 4 em DMSO, a diferentes temperaturas $(15,25$ e $75^{\circ} \mathrm{C}$ ). É observado o sinal referente aos carbonos 3' e 4' próximo a 30,4 ppm.

\section{Anexo 61}

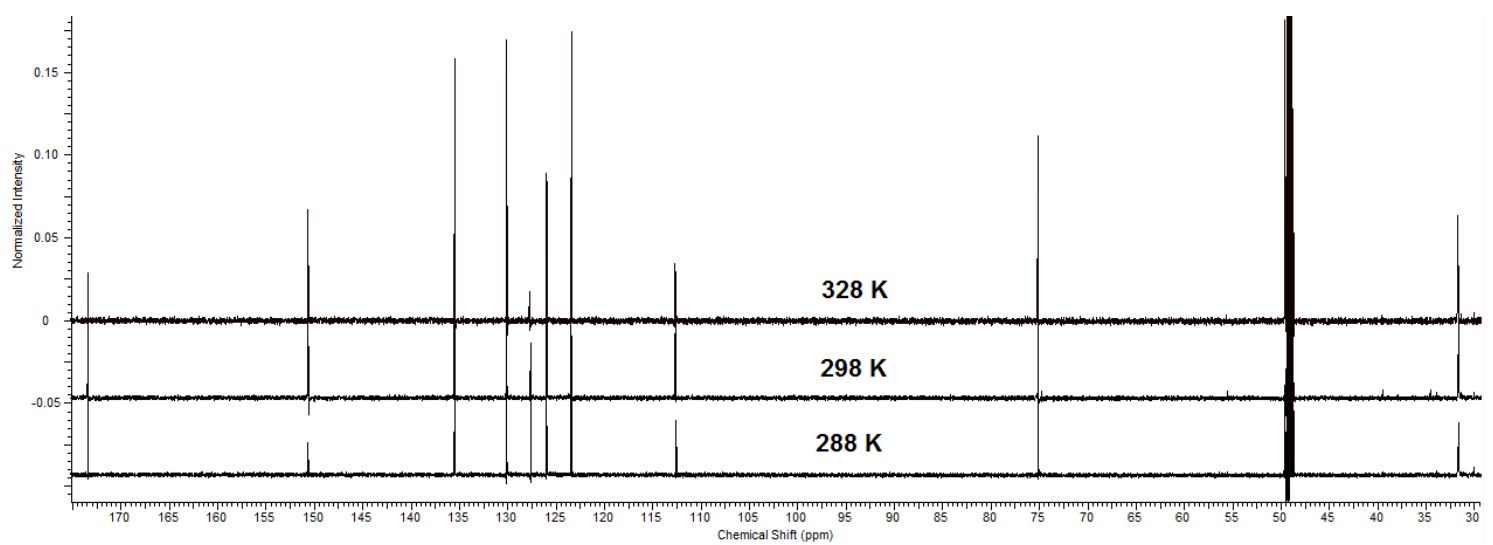

Anexo 61: Espectros de ${ }^{13} \mathrm{C}-\mathrm{RMN}$ do composto 4 em metanol, a diferentes temperaturas (15, 25 e $55^{\circ} \mathrm{C}$ ). Não é observado o sinal referente aos carbonos 3' e 4' nas temperaturas estudadas. 
Anexo 62

\begin{tabular}{|c|c|c|}
\hline 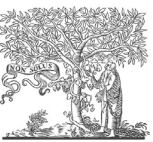 & $\begin{array}{l}\text { Contents lists available at ScienceDirect } \\
\text { Journal of Molecular Structure }\end{array}$ & $\begin{array}{l}\text { MOLECULAR } \\
\text { STRUCTURE } \\
\text { STIST }\end{array}$ \\
\hline$\overline{\text { ELSEVIER }}$ & journal homepage: http://www.elsevier.com/locate/molstruc & \\
\hline
\end{tabular}

Nuclear Magnetic Resonance (NMR), Infrared (IR) and Mass

Spectrometry (MS) study of keto-enol tautomerism of isobenzofuran-1(3H)-one derivatives

Diego Arantes Teixeira Pires ${ }^{\text {a, b }}$, Wagner Luiz Pereira ${ }^{\text {, }}$, Róbson Ricardo Teixeira ${ }^{c, *}$,

José Daniel Figueroa-Villar ${ }^{\mathrm{d}}$, Claudia Jorge do Nascimento ${ }^{\mathrm{b}}$, e, **

a Department of Chemistry, Federal Institute of Education, Science and Technology of Goias, Luziânia, Brazil

' Institute of Chemistry, University of Brasilia, Brasília, Brazil

' Department of Chemistry, Universidade Federal de Viçosa, Viçosa, Brazil

${ }^{\mathrm{d}}$ Department of Chemistry, Military Institute of Engineering, Rio de Janeiro, Brazil

${ }^{\mathrm{e}}$ Institute of Biosciences, Federal University of Rio de Janeiro State, Rio de Janeiro, Brazil

A R T I C L E I N F O

Article history:

Received 3 September 2015

3 February 2016

Accepted 3 February 2016

Available online 9 February 2016

Keywords:

Keto-enol tautomerism

Isobenzofuran-1(3H)-ones

Phtalides

Solvent effects

Physical state influence

Spectroscopy
A B S T R A C T

The keto-enol tautomerism of 3-(2-hydroxy-4,4-dimethyl-6-oxo-cyclohexen-1-yl)isobenzofuran1(3H-one (1), 3-(2-hydroxy-6-oxocyclohex-1-enyl)isobenzofuran-1(3H)-one (2), 3-(2-hydroxy4-methyl-6-oxocyclohex-1-enyl)isobenzofuran-1(3H)-one (3), 3-(2-hydroxy-5-oxocyclopent-1-enyl) isobenzofuran-1(3H)-one $(4)$ and 2-(3-oxo-1,3-dihydroisobenzofuran-1-yl)- $1 \mathrm{H}$-indene-1,3(2H)-dione isobenzofuran-1(3H)-one $(\mathbf{4})$ and 2 -(3-0xo-1,3-dihydroisobenzofuran-1-yl)-1H-indene-1,3(2H)-dione
(5) were investigated. We noticed that for compounds $\mathbf{1}$ to $\mathbf{4}$ only the enol form is observed in solid, in solution or in the gas phase. Their tautomeric equilibria are not affected by the solvent, temperature o physical state. Compound $\mathbf{5}$ was observed in its keto form in solution (NMR) and solid state (IR). The enol species of $\mathbf{5}$ was also observed upon Mass Spectrometry analysis. These findings were supported by NMR, IR, MS/MS and molecular modeling analyses.

2016 Elsevier B.V. All rights reserved.

\section{Introduction}

The keto-enol tautomerism is important in many fields of chemistry and biochemistry. The investigation of this phenomenon allows us to learn about the physicochemical properties and biological activities of the substances in which it occurs. Several factors, such as intra and intermolecular interactions, the hydrogen bond formation, solvents effects, temperature, physical state, and others, can influence the keto-enol equilibrium, favoring the keto or the enol species [1-6].

Isobenzofuran-1(3H)-ones (phtalides) are heterocyclic compounds characterized by the presence of a benzene ring fused to a $\gamma$-lactone one. Secondary metabolites containing the phtalide

* Corresponding author

** Corresponding author Institute of Biosciences - Federal University of Rio de Janeiro State (UNIRIO), Brazil. Tel.: + 5521999222021.

E-mail addresses: robsonr.teixeira@ufv.br (R.R. Teixeira), claudia.j.nascimento@ gmail.com (C.J. Nascimento). nucleus and presenting relevant biological activities have been isolated from plants, fungi, bacterias and liverworts [7]. In particular the C-3 functionalized phtalides display several significant medicinal properties [8-13]. It stands out the success story of 3-butylisobenzofuran-1(3H)-one (also known as $n$-butylphthalide), a compound which nowadays has been clinically used as antiplatelet drug for ischemia-cerebralapoplexy $[14,15]$. It also deserves comments the importance of isobenzofuran-1(3H)-ones as building blocks in organic synthesis [16,17].

Our own interest in this class of compounds led us to synthesize a series of twelve $\mathrm{C}-3$ functionalized isobenzofuran- $1(3 \mathrm{H})$-ones possessing alicyclic and aromatic groups. These compounds were evaluated in vitro for their antiproliferative activity against leukemia cell lines [18]. The obtained biologically data revealed that the antiproliferative activity of two of the evaluated compounds was superior than Etoposide (VP-16), an anticancer drug used in severa chemotheraphy regime, including leukemia. In another investigation, we also assessed the effect of the aforemention serigation, we also assessed the effect of the aforementioned series of
isobenzofuranones on the photosynthetic machinery. It was found 
Table 1

The keto and the enol structures of the investigated compounds.

\begin{tabular}{|c|c|c|}
\hline Compound & Enol form & Keto form \\
\hline 1 & & \\
\hline 2 & & \\
\hline 3 & & \\
\hline 4 & & \\
\hline 5 & & \\
\hline
\end{tabular}

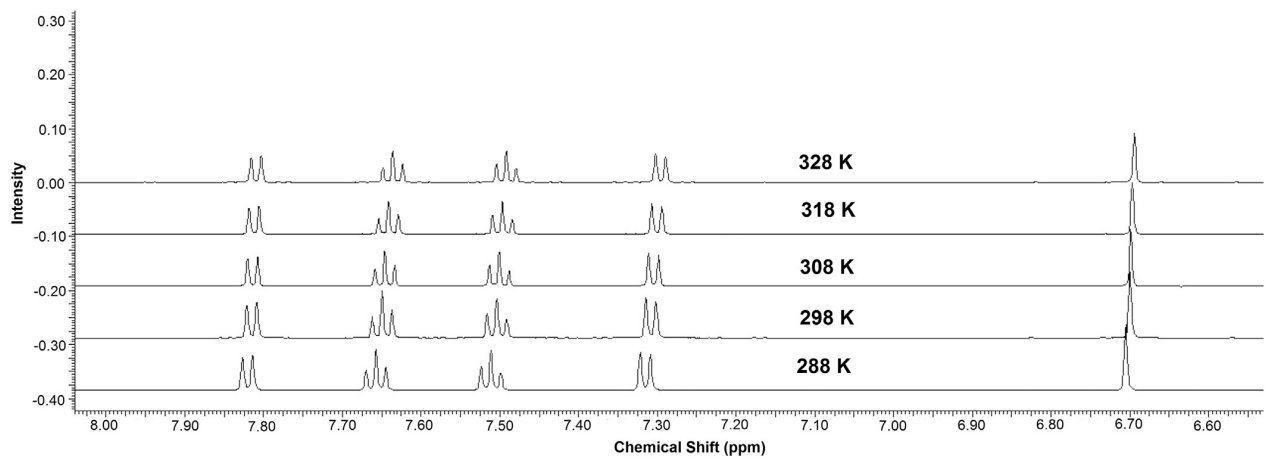

Fig. 1. ${ }^{1} \mathrm{H}-\mathrm{NMR}$ spectra of compound $\mathbf{1}$ in methanol- $d_{4}$ at different temperatures. The $\mathrm{H}-3$ signal is observed near $6.70 \mathrm{ppm}$. 


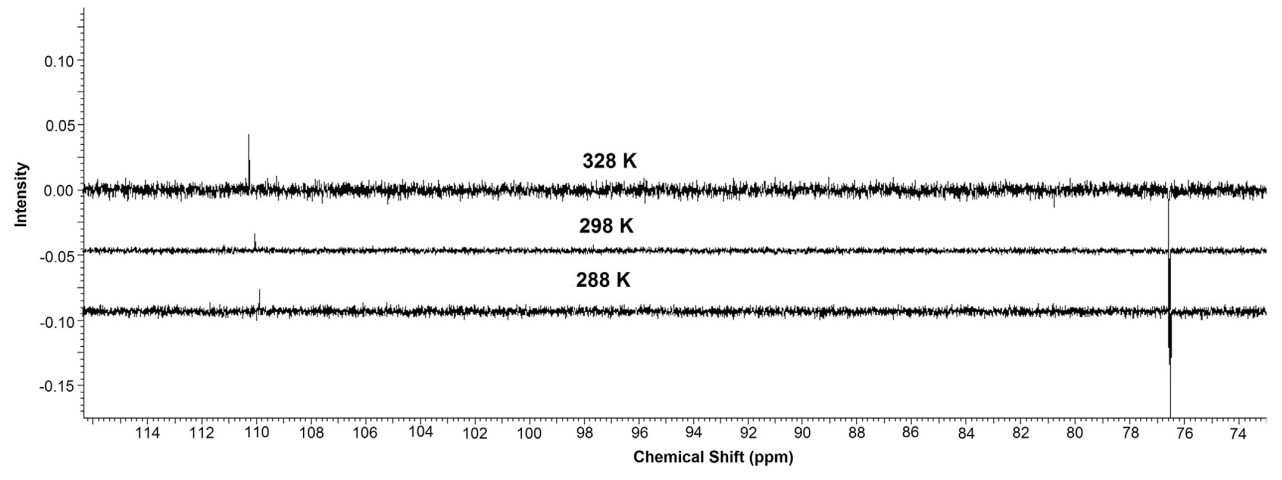

Fig. 2. APT spectra of compound $\mathbf{1}$ in methanol- $d_{4}$ at different temperatures. The $\mathrm{C}-\mathbf{1}^{\prime}$ signal is observed at $110.1 \mathrm{ppm}$.

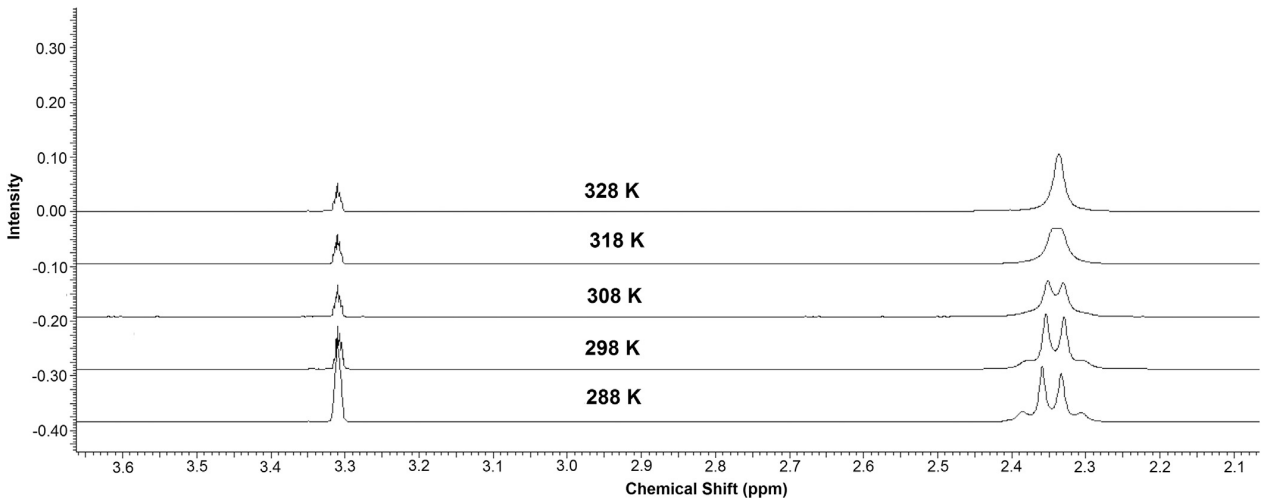

Fig. 3. ${ }^{1} \mathrm{H}-\mathrm{NMR}$ spectra of compound $\mathbf{1}$ in methanol- $\mathrm{d}_{4}$ at different temperatures. The $\mathrm{H}-\mathrm{3}^{\prime}$ and $\mathrm{H}-\mathrm{5}^{\prime}$ signals are observed around $2.34 \mathrm{ppm}$.

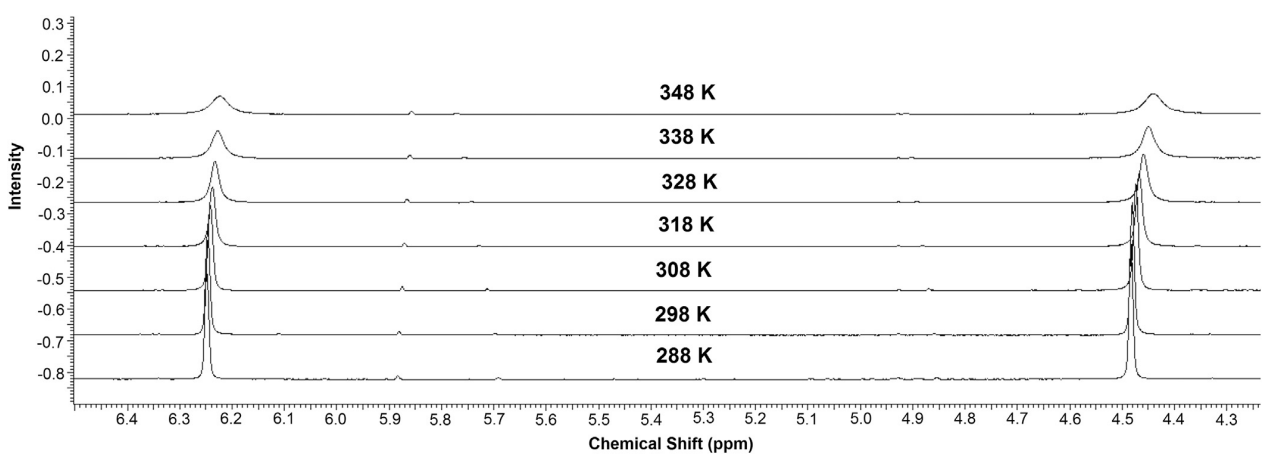

Fig. 4. ${ }^{1} \mathrm{H}-\mathrm{NMR}$ spectra of compound 5 in DMSO- $\mathrm{d}_{6}$ at different temperatures. The $\mathrm{H}-3$ signal is observed at $6.25 \mathrm{ppm}$ and the $\mathrm{H}-\mathrm{1}^{1}$ signal at $4.48 \mathrm{ppm}$. 


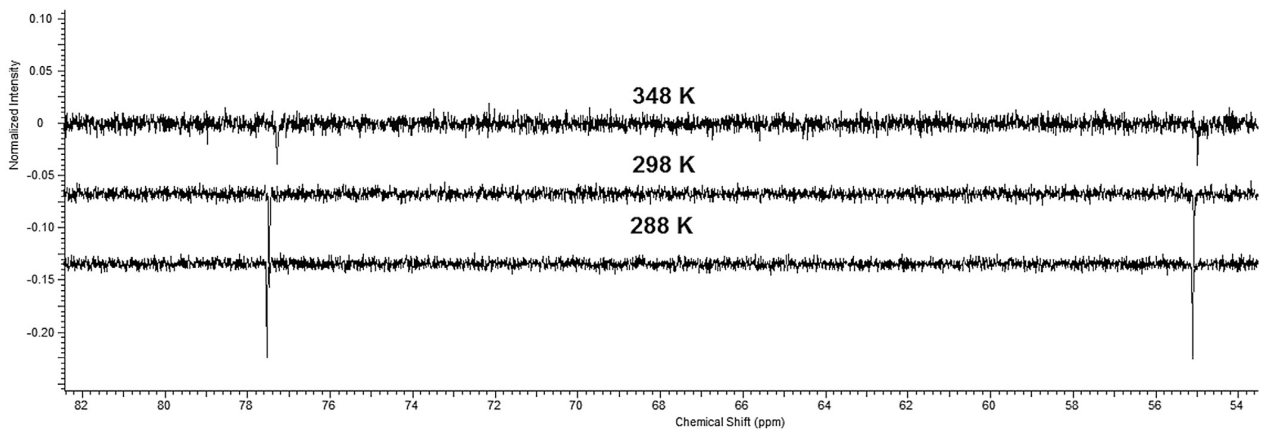

Fig. 5. APT spectra of compound 5 in DMSO- $d_{6}$ at different temperatures. The C-1' signal is observed near $55.1 \mathrm{ppm}$ and C-3 signal is near $77.5 \mathrm{ppm}$.

that the compounds are capable of interfering with electron transport chain in spinach chloroplast via two different mechanisms [19].

This paper is concerned about the investigation of keto-enol tautomerism of isobenzofuran-1(3H)-ones containing different appendages at C-3 position of isobenzofuranone nucleus (see Table 1 for numbering). The structures of the investigated compounds are presented in Table 1. The results herein described were supported by the NMR and IR spectroscopy as well as Mass
Spectrometry analyses of the species involved in the tautomerism equilibria.

\section{Experimental}

2.1. Study of the keto-enol tautomerism

The NMR studies were performed in a $600 \mathrm{MHz}$ spectrometer (Premium Compact, Varian) with a $5 \mathrm{~mm}$ probe and with

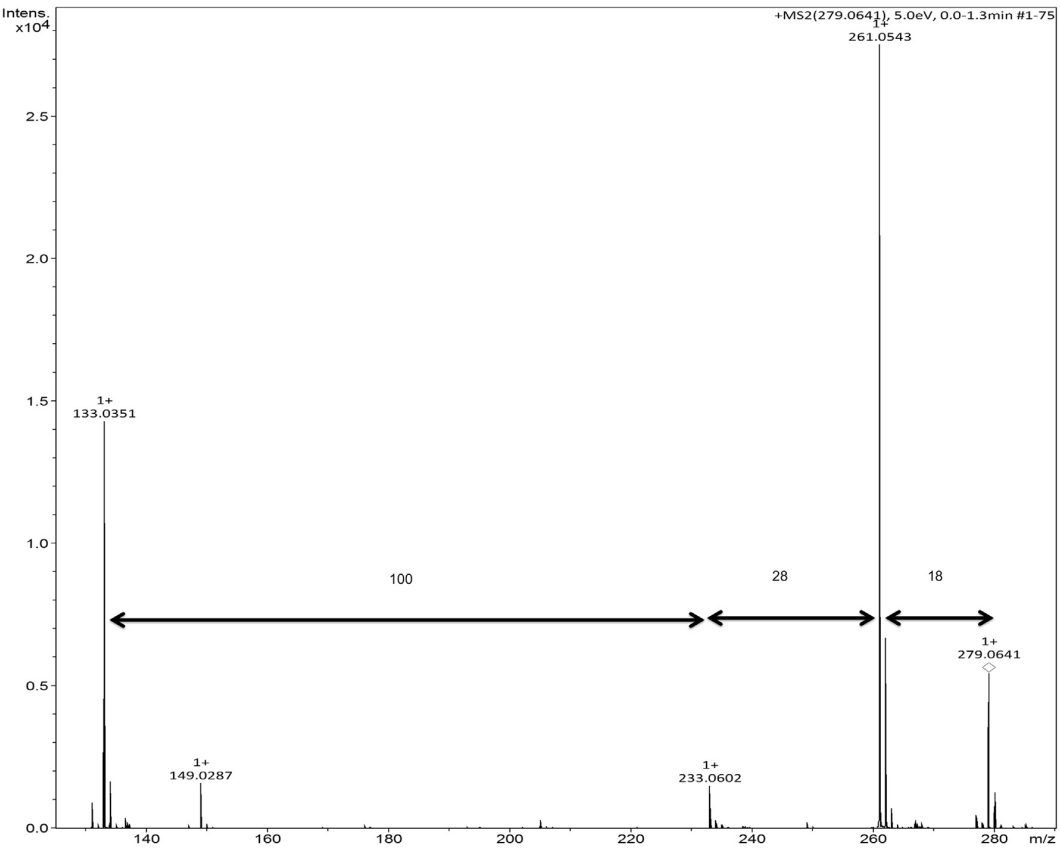

Fig. 6. MS/MS spectrum of the compound $\mathbf{5}$, showing the fragmentation of 18 Da that indicates the presence of an $\mathrm{OH}$ group. 


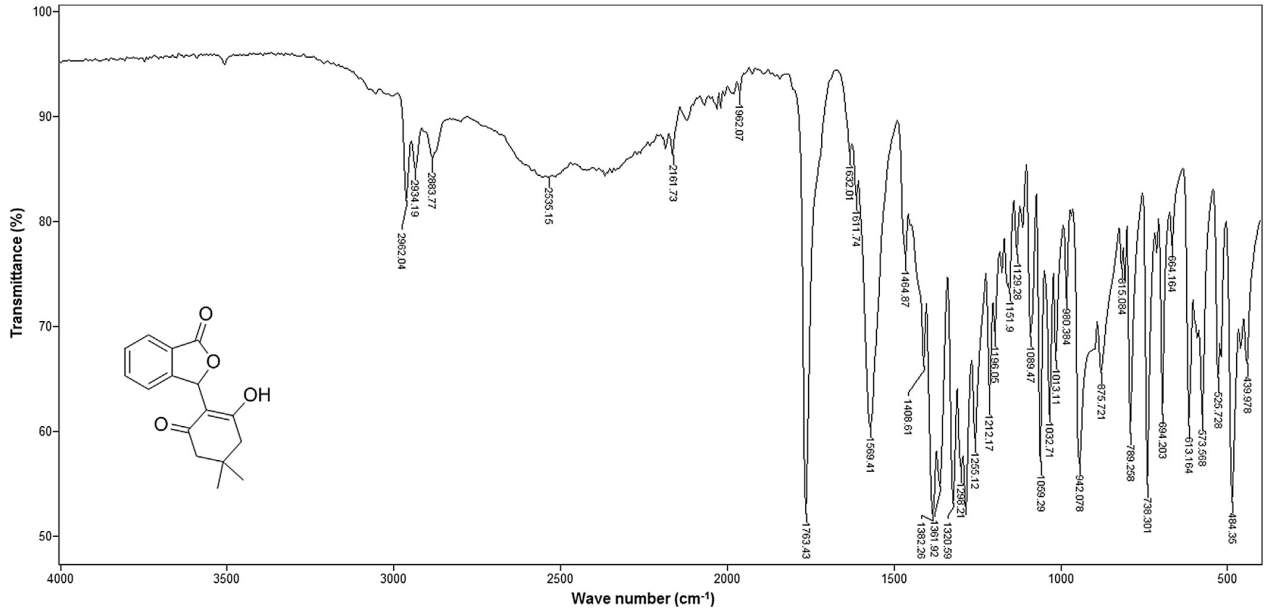

Fig. 7. IR spectrum (ATR) of the compound $\mathbf{1}$ (a broad band in the range $3200-2400 \mathrm{~cm}^{-1}$ was associated with $\mathrm{O}-\mathrm{H}$ stretching).

isobenzofuranone solutions that presented the concentration of $16.67 \mathrm{mg} \mathrm{mL} \mathrm{m}^{-1}$. ${ }^{1} \mathrm{H}-\mathrm{NMR}$ (32 scans) experiments were acquired in acetone- $d_{6}(273-318 \mathrm{~K})$, methanol- $d_{4}(288-328 \mathrm{~K})$ and DMSO- $d_{6}$ (288-348 K). APT (3000 scans) and ${ }^{13} \mathrm{C}-\mathrm{NMR}$ (2000 scans) spectra were acquired in acetone- $d_{6}(288-318 \mathrm{~K})$, methanol- $d_{4}$ $(288-328 \mathrm{~K})$ and DMSO- $d_{6}(288-348 \mathrm{~K})$.

The Mass spectra were acquired in a micrOTOF - QII (Bruker) spectrometer in the positive mode of acquisition. The samples were solubilized in acetonitrile ( $1 \%$ of formic acid), with a $4.5 \mathrm{kV}$ voltage at the capillary and a flow rate of $2.0 \mu \mathrm{L} \mathrm{min}{ }^{-1}$. MS and MS/MS experiments were performed.
The IR analyses were conducted in solid state in a Varian 660-IR with the GladiATR accessory.

The molecular modeling calculation procedures for the compounds 1 to 5 were done using the DFT/B3LYP method and 6-31G* using the Spartan'06 program [20]. The keto-enol and the diketo conformations of all compounds were calculated with the Energy Profile method in vacuum and in the presence of solvents (acetone, DMSO and methanol).

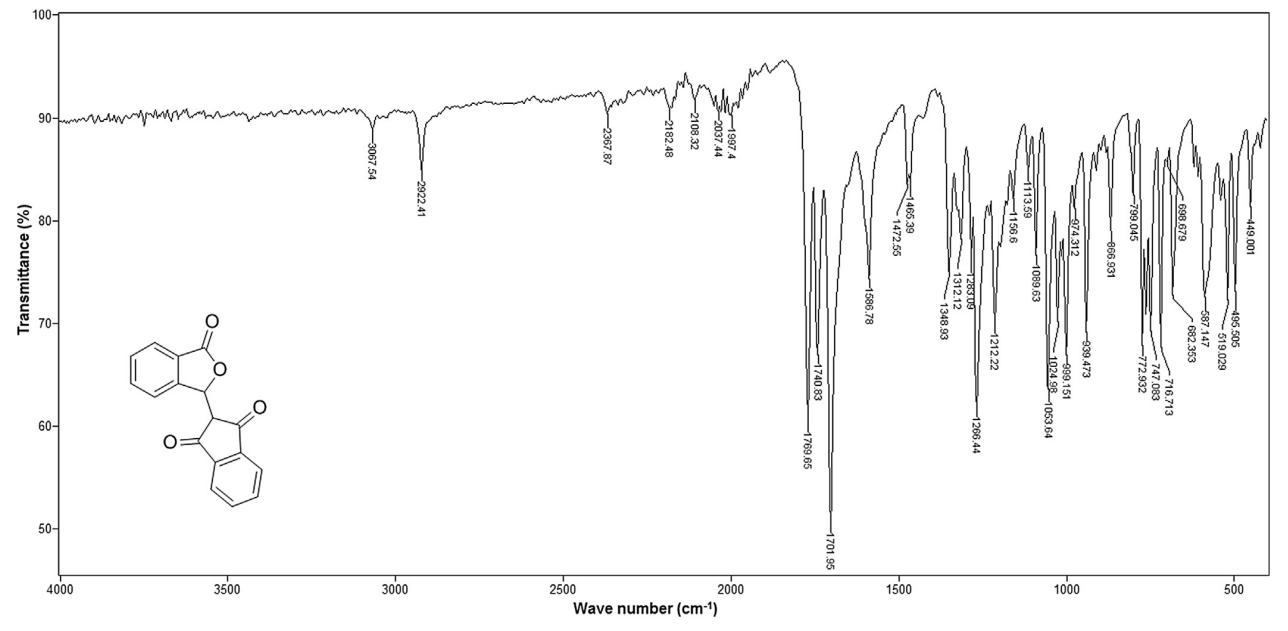

Fig. 8. IR spectrum (ATR) of compound $\mathbf{5}$ (signals in 1769, 1740 and $1702 \mathrm{~cm}^{-1}$ : $\mathrm{C}=0$ stretching). 
Table 2

Energy (minima) difference of the keto and the enol forms for each compound calculated by DFT (B3LYP)/6-31G $\mathrm{G}^{\mathrm{i}}$ in vacuum and in the presence of solvents (acetone, DMSO and methanol).

\begin{tabular}{|c|c|c|c|c|c|}
\hline Compound & & $\Delta \mathrm{E}_{\text {vacuum }}(\mathrm{kJ} / \mathrm{mol})$ & $\Delta \mathrm{E}_{\text {acetone }}(\mathrm{kJ} / \mathrm{mol})$ & $\Delta \mathrm{E}_{\mathrm{DMSO}}(\mathrm{kJ} / \mathrm{mol})$ & $\Delta \mathrm{E}_{\text {methanol }}(\mathrm{kJ} / \mathrm{mol})$ \\
\hline 1 & $\begin{array}{l}\text { Enol }{ }^{a} \\
\text { Keto }^{a}\end{array}$ & 14.43 & 6.12 & 5.19 & 7.09 \\
\hline 2 & $\begin{array}{l}\text { Enol }^{\mathrm{a}} \\
\text { Keto }^{2}\end{array}$ & 18.13 & 2.86 & 2.53 & 4.58 \\
\hline 3 & $\begin{array}{l}\text { Enol }^{a} \\
\text { Keto }\end{array}$ & 18.75 & 3.71 & 3.22 & 5.16 \\
\hline 4 & $\begin{array}{l}\text { Enol }^{a} \\
\text { Keto }\end{array}$ & 22.56 & 24.61 & 25.02 & 24.87 \\
\hline 5 & $\begin{array}{l}\text { Enol } \\
\text { Keto }^{\mathrm{a}}\end{array}$ & 23.37 & 23.29 & 22.78 & 25.10 \\
\hline
\end{tabular}

a The most stable form.

\section{Results and discussion}

As previously reported [18,19], the synthesis of compounds $\mathbf{1}$ to 5 (Table 1) were achieved via DBU-promoted condensation between phtalaldehydic acid and appropriated 1,3-diketones. For all synthesized compounds, their tautomeric equilibrium was invessynthesized compounds, their tautomeric equilibrium was inves-
tigated by NMR, IR spectroscopy, Mass spectrometry, as well as tigated by NMR, IR

The study of the keto-enol equilibria by ${ }^{1} \mathrm{H}-\mathrm{NMR}$ was performed observing the multiplicity of the $\mathrm{H}-3$ signal (singlet for the enol form and duplet for the keto form). It was also observed the presence (for the keto form) or the absence (for the enol form) of a signal due to $\mathrm{H}_{-1}{ }^{\prime}$ (see Table 1 for numbering). Furthermore, the $\mathrm{C}$ $1^{\prime}$ signal in APT spectra was also used to study the tautomeric equilibria, observing that it is a quaternary carbon in the enol form equilibria, observing that it is a quaternary carbon in the enol form
and $\mathrm{a}-\mathrm{CH}$ in the keto form. The complete assignments of compounds $\mathbf{1}$ to $\mathbf{5}$ in acetone, DMSO and methanol can be seen in the Supplementary material.

The expansion of the aromatic region of the ${ }^{1} \mathrm{H}-\mathrm{NMR}$ spectrum for compound $\mathbf{1}$ in methanol, at different temperatures, is shown in Fig. 1. The $\mathrm{H}-3$ signal is observed as a singlet, and the integration refers to a single proton. Additionally, both the multiplicity and the integration of the signals do not vary with the temperature increase.

The APT spectra of compound $\mathbf{1}$ in methanol at different temperatures show the signal concerning to the $C-1$ being a quaternary carbon at all temperatures (Fig 2). A similar trend is also observed for the spectra acquired in acetone and DMSO solvents (see Supplementary Material). Therefore, the enol form of compound 1 is favored regardless the solvent, even at higher temperatures.

It is interesting to observe the variation in the multiplicity of $\mathrm{H}-$ $3^{\prime}$ and $\mathrm{H}-5^{\prime}$ (Fig. 3) with increasing temperature. This variation can be explained by the faster rotation around $\mathrm{C}^{\prime}-\mathrm{C} 3$ bond, which leads to the coalescence of the signals at higher temperatures. This coalescence was also observed for compound $\mathbf{1}$ in acetone and DMSO (see Supplementary Material). This faster rotation also affects the signals for $C-3^{\prime}$ and $C-5^{\prime}$ (Supplementary Material)

Compounds 2, 3 and $\mathbf{4}$ showed similar behavior to that described for compound $\mathbf{1}$. For all of them, the enol form is favored in different solvents (methanol, acetone and DMSO) as well as at different temperatures (see Supplementary Material). Therefore, for these compounds, solvent and temperature did not interfere in the keto-enol equilibria. The presence of methyl groups (one or two) attached to alicyclic portion also did not affect the equilibrium. Moreover, the replacement of the six-membered ring by a five-membered one did not favor the keto form (see Supplementary Material).

Compound $\mathbf{5}$ was insoluble in methanol, which precluded NMR analyses using this solvent. The ${ }^{1} \mathrm{H}-\mathrm{NMR}$ spectrum of compound $\mathbf{5}$ in DMSO (Fig. 4), showed the signal for the $\mathrm{H}-3$ as compounds 1 to 4. However, it was also observed one signal related to $\mathrm{H}-\mathbf{1}^{\prime}$ (characteristic of keto form). The same behavior was observed for substance $\mathbf{5}$ in acetone (see Supplementary Material). The temperature did not influence the tautomeric equilibrium of $\mathbf{5}$.

The APT spectra of $\mathbf{5}$ in DMSO showed a signal at $55.1 \mathrm{ppm}$, related to $\mathrm{C}-1^{\prime}$ (Fig. 5), indicating the presence of a $-\mathrm{CH}$ group. The quaternary $\mathrm{C}-1^{\prime}$ was not observed and, consequently, confirmed the keto form for this compound. Similarly to the proton spectrum, temperature did not affect the APT spectrum. The same behavior is observed for compound $\mathbf{5}$ in acetone (see Supplementary Material).

It is worth to mention that ${ }^{13} \mathrm{C}-\mathrm{NMR}$ showed two different peaks for ketone carbonyl groups (Supplementary Materil). This observation is in agree same result was observed in acetone. The carbon spectra for compounds $\mathbf{1}$ to $\mathbf{4}$ showed only the presence of one ketone carbonyl signal.

By comparing the NMR data of compounds $\mathbf{4}$ and $\mathbf{5}$, it can be inferred that the presence of an aromatic ring fused to the 1,3diketone five membered ring changes the tautomeric equilibrium so that the keto form is observable in the case of compound $\mathbf{5}$.

Mass spectrometry experiments can provide insight about the species involved in tautomeric equilibria. Fragmentation of $18 \mathrm{Da}$ can be related to the dehydration of the $\mathrm{OH}$ group in the form of $\mathrm{H}_{2} \mathrm{O}^{+}$, and fragmentation of $28 \mathrm{Da}$ can be related to the $\mathrm{C}=\mathrm{O}$ group in the form of $\mathrm{CO}^{+}[21]$.

The MS/MS analysis of compound $\mathbf{5}$ revealed the presence of the enol form as the sole species in the equilibrium. This statement is corroborated by the obs $\mathrm{OH}$ group in the form of $\mathrm{H}_{2} \mathrm{O}^{+}$as shown in $\mathrm{Fig}$. 6 for compound 5 $[21,22]$.

The MS/MS spectra of compounds 1-4 (see Supplementary Material) also showed that fragmentation (18 Da), indicating that the enol form of these compounds is favored in the equilibria in the gas phase.

The Mass spectrometry, as well as the NMR experiments for compounds 1 to 4 , revealed only the presence of enol species in the tautomeric equilibria. On the contrary, while the NMR experiments showed the presence of keto form in the equilibrium for compound $\mathbf{5}$, the mass experiments results showed exclusively the presence of the enol form of compound $\mathbf{5}$. Thereby, the physical state of the compound, gas phase (analyzed by Mass spectrometry) and solution (analyzed by NMR) can affect the keto-enol equilibrium of the investigated compound.

We also sought information about the tautomeric equilibrium of substances $\mathbf{1}$ to $\mathbf{5}$ analyzing them in solid phase by IR spectroscopy. Regarding compounds $\mathbf{1}$ to $\mathbf{4}$, the IR spectra present a broad band which can be associated to the $\mathrm{O}-\mathrm{H}$ group of the enol form, as it is shown in Fig. 7 for compound $\mathbf{1}$ (IR spectra for compounds $\mathbf{2}$ to $\mathbf{4}$ are shown in the Supplementary Material). Thus, the enol form is 
favored in solid phase for compounds $\mathbf{1}$ to $\mathbf{4}$

The inspection of IR spectrum of the compound 5 (Fig. 8) showed only bands related to the $\mathrm{C}=\mathrm{O}$ stretching; it was not observed any band related to the $\mathrm{O}-\mathrm{H}$ stretching, characterizing this compound in the keto form in the solid phase.

The IR experiments (solid state) for compounds $\mathbf{1}$ to $\mathbf{4}$ showed only the enol form as observed with the NMR (liquid state) and Mass spectrometry (gas state) experiments. Solvent, temperature and physical state did not change their equilibrium. However, for compound $\mathbf{5}$, the keto form was observed when it was analyzed by IR (solid state) and NMR (in solution), and enol form was noticed by Mass spectrometry (gas state). The physical state could be the responsible for the changes in the keto-enol equilibrium for the compound $\mathbf{5}$.

The keto and the enol forms of all compounds were submitted to the geometry and energy optimization by molecular modeling and had their energy calculated for each form (Table 2).

According to the molecular modeling data, it was observed that solvent didn't interfere in the predominant form of the compounds in the keno-enol equilibrium when compared to the vacuum calculations. For compounds $\mathbf{1}$ to $\mathbf{4}$, the molecular modeling shows the enol form as the most stable for all the calculations, giving support to the NMR, MS and IR findings previously described. For compound 5 , the molecular modeling showed the keto form as the most stable, whic is mental data. The MS results for compound 5 (which shows only the enol form) were the only one not supported by the molecular modeling results.

\section{Conclusion}

It was showed that the keto-enol equilibrium for compounds 1 to $\mathbf{4}$ is not affected by changes in solvent, temperature and physical to $\mathbf{4}$ is not affected by changes in solvent, temperature and physical
state. Only the enol form was observed for these compounds by state. Only the enol form was observed for these compounds by
NMR, Mass Spectroctrometry, IR and Molecular Modeling. For compound $\mathbf{5}$, it was observed the enol form by Mass Spectroscopy. Interestingly, the observation of only enol form of compound $\mathbf{5}$ by Mass Spectroscopy and exclusively the keto form by IR, NMR and Molecular Modeling, indicates that the physical state can influence the tautomerism for this compound.

Comparing the structures of compounds $\mathbf{4}$ and $\mathbf{5}$, and looking at the NMR, IR and Molecular Modeling results, it can be inferred that the presence of an aromatic ring changes the tautomeric equilibrium.

\section{Acknowledgment}

The authors would like to thank to CNPq, FAPEMIG and IFG for the financial support.

\section{Appendix A. Supplementary data}

Supplementary data related to this article can be found at http:// dx.doi.org/10.1016/j.molstruc.2016.02.015.

\section{References}

[1] E. Ferrari, M. Saladini, F. Pignedoli, F. Spagnolo, R. Benassi, New J. Chem. 35 (2011) 2840-2847.

2] H. Golchoubian, E. Rezaee, V.L. Junior, M.G. Constantino, G.V.J. Silva, A.C. Neto, C.F. Tormena, J. Mol. Struct 828 (2007) $54-58$.

14] A-Martinez-Richa, G. Mendonza-Diaz, P. Joseph-Nathan, App Spectrosc. 50

5] F. Payton, P. Sandusky, W.L. Alworth, J. Nat. Prod. 70 (2007) 143-146.

[6] W. Schilf, B. Kamienski, K. Uzarevic, J. Mol. Struct. 1031 (2013) 211-215. Naturally Occurring Phthalides. Studies in Natural Products Chemistry, first ed.., Elseveir, Amsterdam, 2005.

[8] F. Ma, Y. Gao, H. Oiao, X. Hu, J. Chang. J. 328-336. $64-73$

[10] K. Yoganathan, C. Rossant, S. Ng. Y. Huang, M.S. Butler, A.D. Buss, J. Nat. Prod. 66 (2003) $1116-1117$.

11] A. Zamilpa, M.H. Kuiz, E. del Olmo, J.L.L. Perez, J. Tortoriello, A.S. Feliciano, Bioorg. Med. Chem. Lett $15(2005) 3483-3486$.

[12] H.M. Ge, Y. Shen, C.H. Zhu, S.H. Tan, H. Ding, Y.C. Song, R.X. Tan, Phyto-

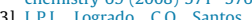

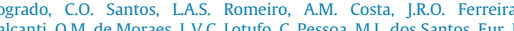
Med. Chem. 45 (2010) $3480-3489$.

14] X. Wang, Y. Li, Q. Zhao, Z. Min, C. Zhang, Y. Lai, H. Ji, S. Peng, Y. Zhang, Org.

15] X. Diao . P. Deng C. Xie, X. Li, D. Zhong Y Zhang X Chen. Drug Metab. Dispos. 41 (2013) 430-444

16] R. Karmakar, P. Pahari. D. Mal Chem. Rev 114 (2014) 6213-6284.

17] D. Mal, P. Pahari, Chem. Rev 107 (2007) 1892-1918.

8] R.R. Teixeira, G.C. Bressan, W.L. Pereira, J.G. Ferreira, F.M. de Oliveira, D.C. Thomaz, Molecules 18 (2013) 1881-1896. R.R. Teixeira, W.L. Pereira, D.C. Tomaz, F.M.
J. Agric. Food Chem. 61 (2013) 5540-5549. Y. Shao, L.F. Molnar, Y. Jung, J. Kussmann, C. Ochsenfeld, S.T. Brown A.T.B. Gilbert, L.V. Slipchenko, S.V. Levchenko, D.P. O'Neill, J.R.A. DiStasio Voorhis, SH Chien, A Sodt, R.P. Steele, V.A. Rassolov, P.E. Maslen P.P. Korambath, R.D. Adamson, B. Austin, J. Baker, E.F.C. Byrd, H. Dachsel, R.J. Doerksen, A. Dreuw, B.D. Dunietz, A.D. Dutoi, T.R. Furlani, S.R. Gwaltney, A. Heyden, S. Hirata, C.P. Hsu, G. Kedziora, R.Z. Khalliulin, P. Klunzinger, A.M. Lee, M.S. Lee, W.Z. Liang, I. Lotan, N. Nair, B. Peters, E.I. Proynov J.E. Subotnik, H. Woodcock III, W. Zhang. A.T. Bell, A.K Chakraborty, J.E. Chipman, F.J. Keil, A. Warshel, W.J. Hehre, H.F. Schaefer, J. Kong A.I. Krylov, P.M.W. Gill, M. HeadGordon, Phys. Chem. Chem. Phys. 8 (2006) 3172-3191.

[21] H. Jiang, A. Somogyi, N.E. Jacobsen, B.N. Timmermann, D.R. Gang, Rapid

[22] S. Kawano, Y. Inohana, Y. Hashi, J. Lin, Chin. Chem. Lett. 24 (2013) 685-687. 


\section{Anexo 63}
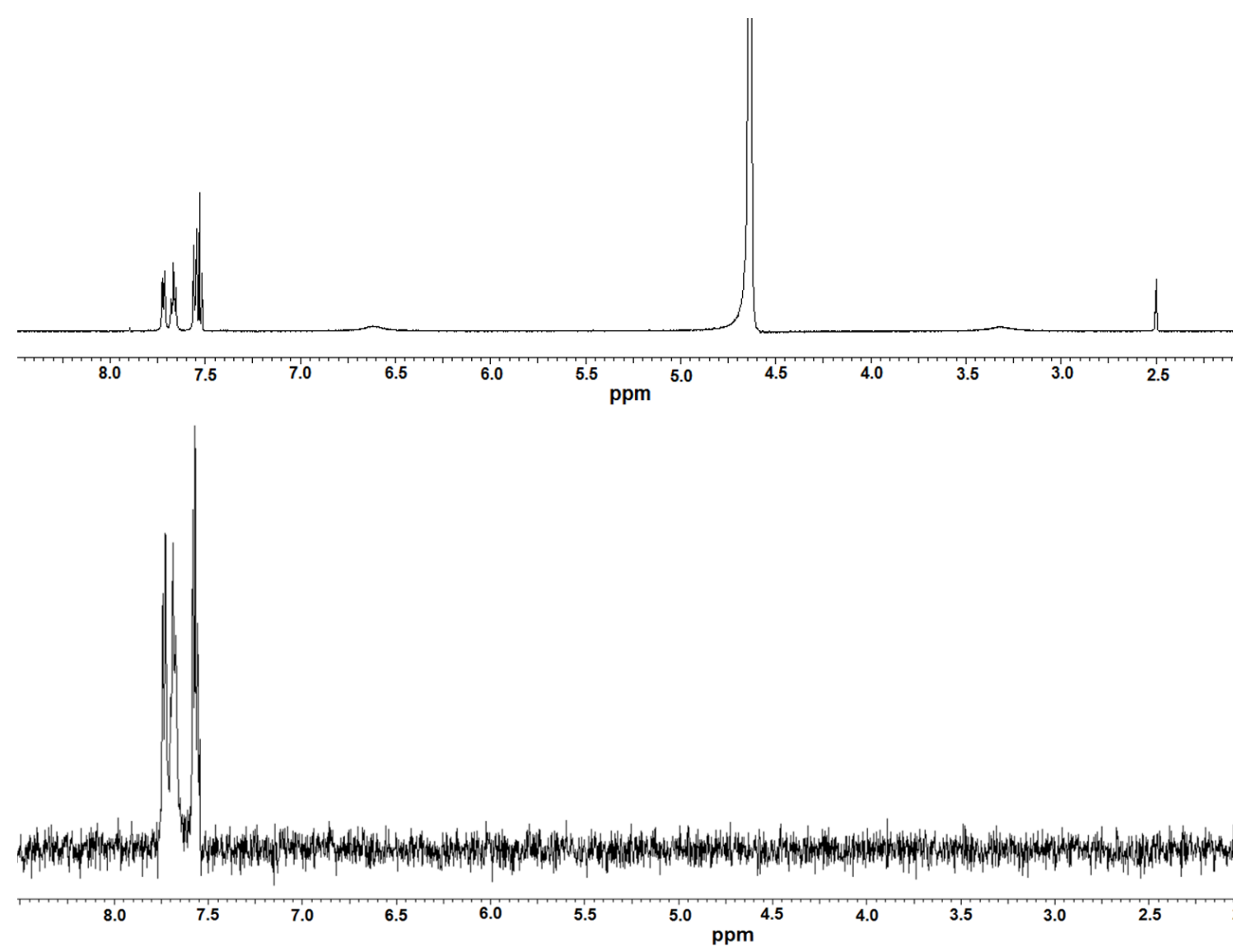

Anexo 63: Espectros de ${ }^{1} \mathrm{H}-\mathrm{RMN}$ do composto 6 na ausência da enzima (superior) e de STD (inferior). Utilizou-se $2 \mathrm{mM}$ do composto 6 e 0,26 uM da enzima. Para os dois espectros foi utilizada a mesma intensidade para a escala vertical. 


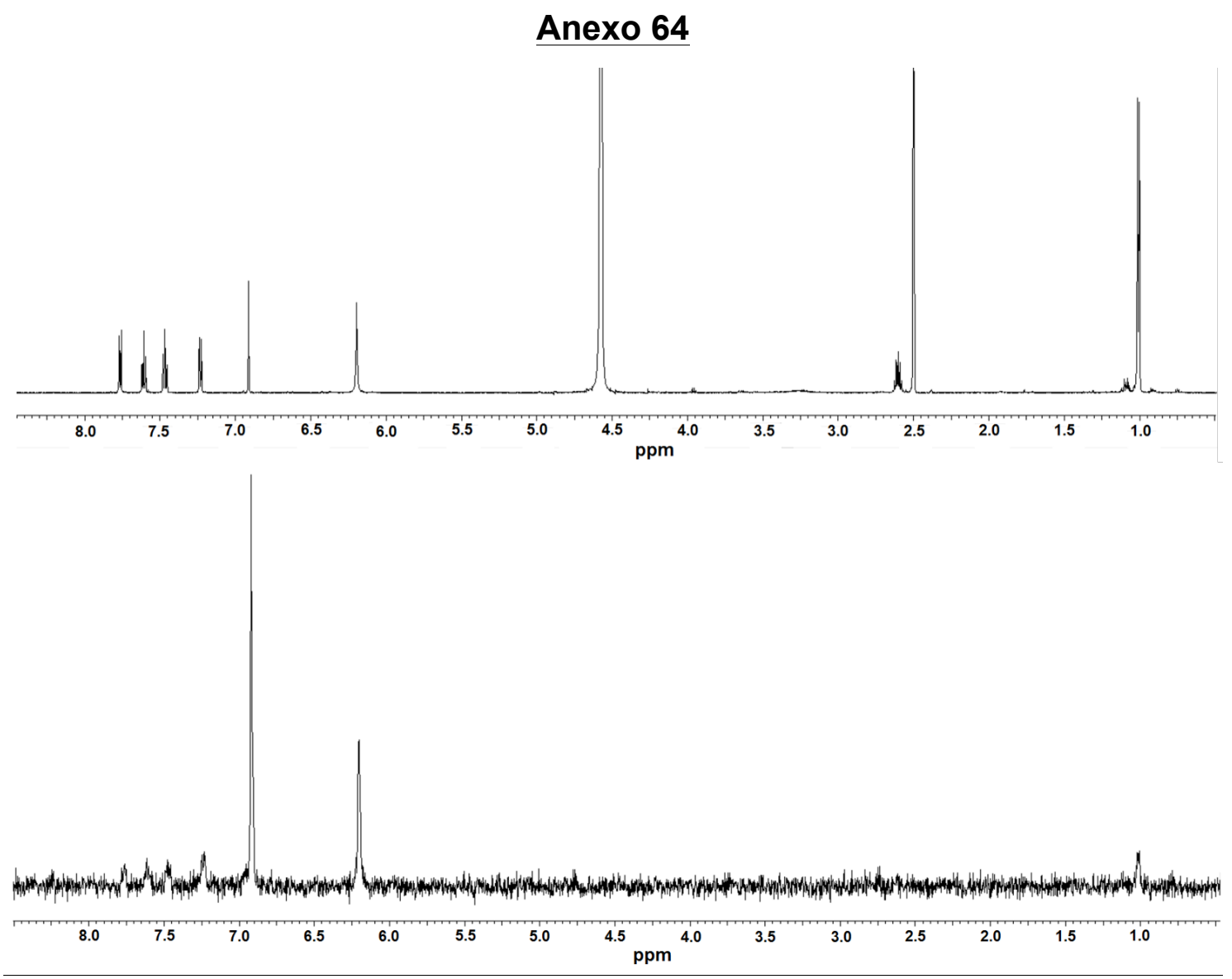

Anexo 64: Espectros de ${ }^{1} \mathrm{H}-\mathrm{RMN}$ do composto 12 na ausência da enzima (superior) e de STD (inferior). Utilizou-se $2 \mathrm{mM}$ do composto 12 e 0,26 uM da enzima. Para os dois espectros foi utilizada a mesma intensidade para a escala vertical. 


\section{Anexo 65}

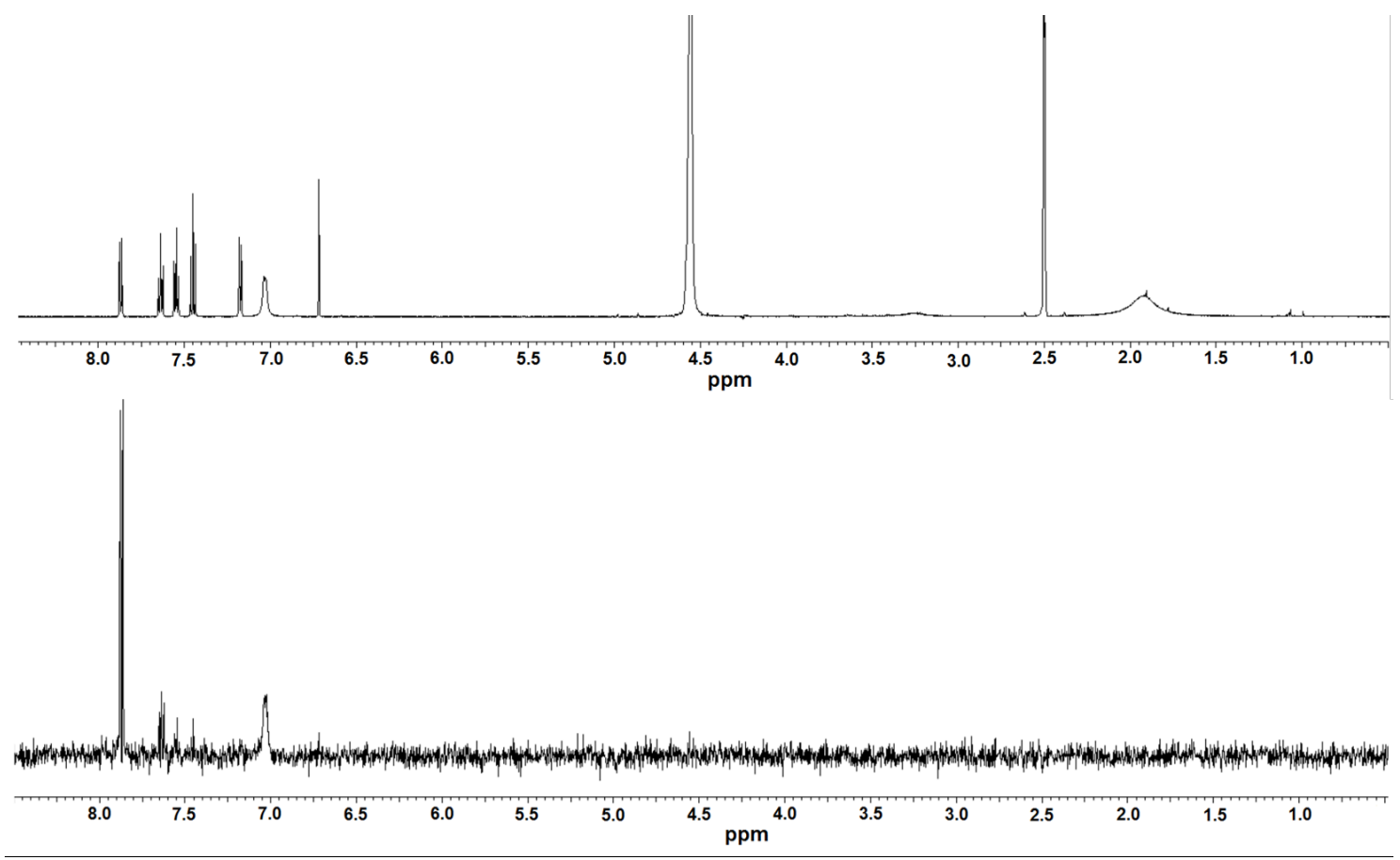

Anexo 65: Espectros de ${ }^{1} \mathrm{H}-\mathrm{RMN}$ do composto 14 na ausência de enzima (superior) e de STD (inferior). Utilizou-se $2 \mathrm{mM}$ do composto 14 e 0,26 uM da enzima. Para os dois espectros foi utilizada a mesma intensidade para a escala vertical. 


\section{Anexo 66}
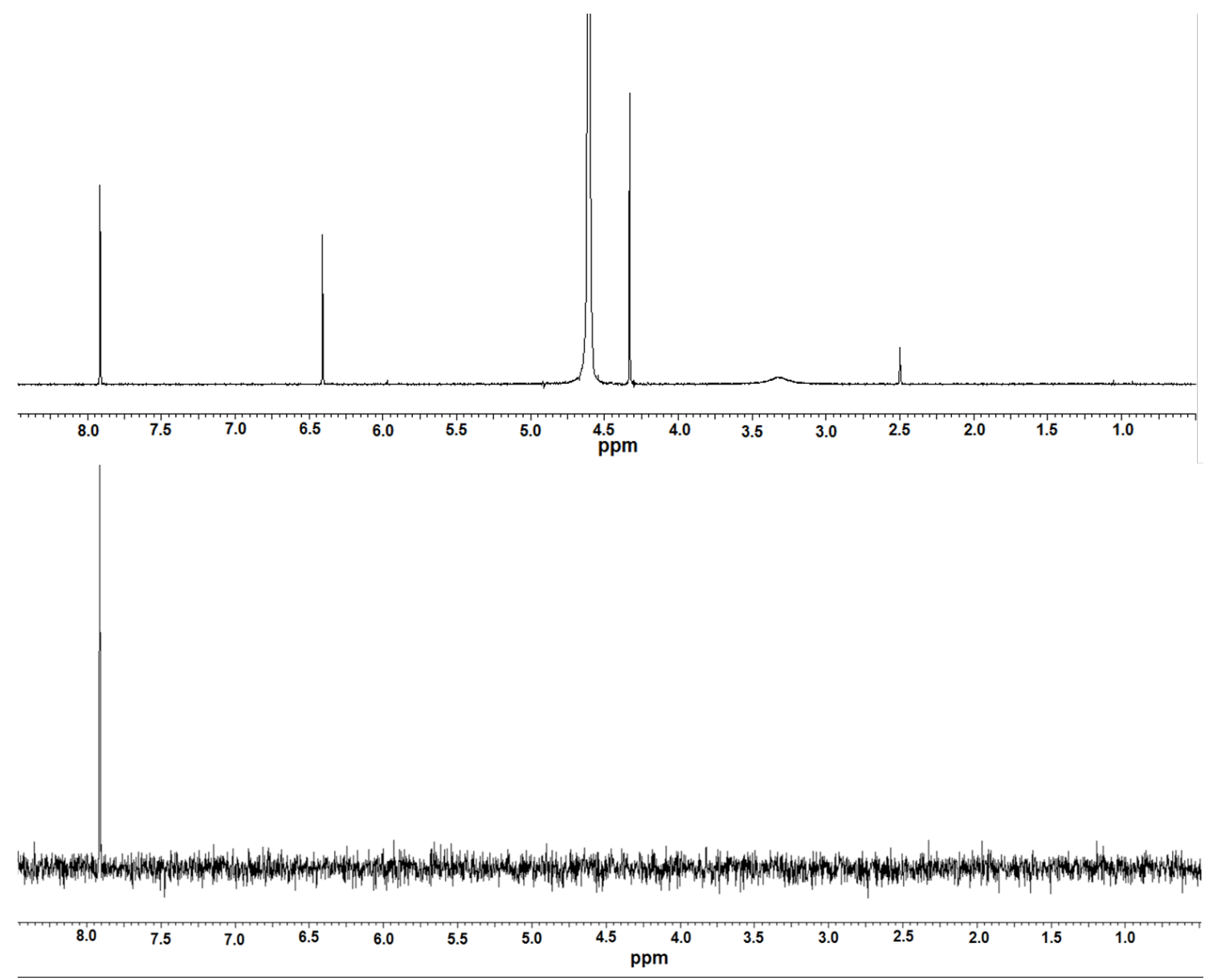

Anexo 66: Espectro de ${ }^{1} \mathrm{H}-\mathrm{RMN}$ do ácido kojic na ausência da enzima (superior) e de STD (inferior). Utilizou-se $2 \mathrm{mM}$ do ácido kojic e 0,26 uM da enzima. Para os dois espectros foi utilizada a mesma intensidade para a escala vertical. 


\section{Anexo 67}
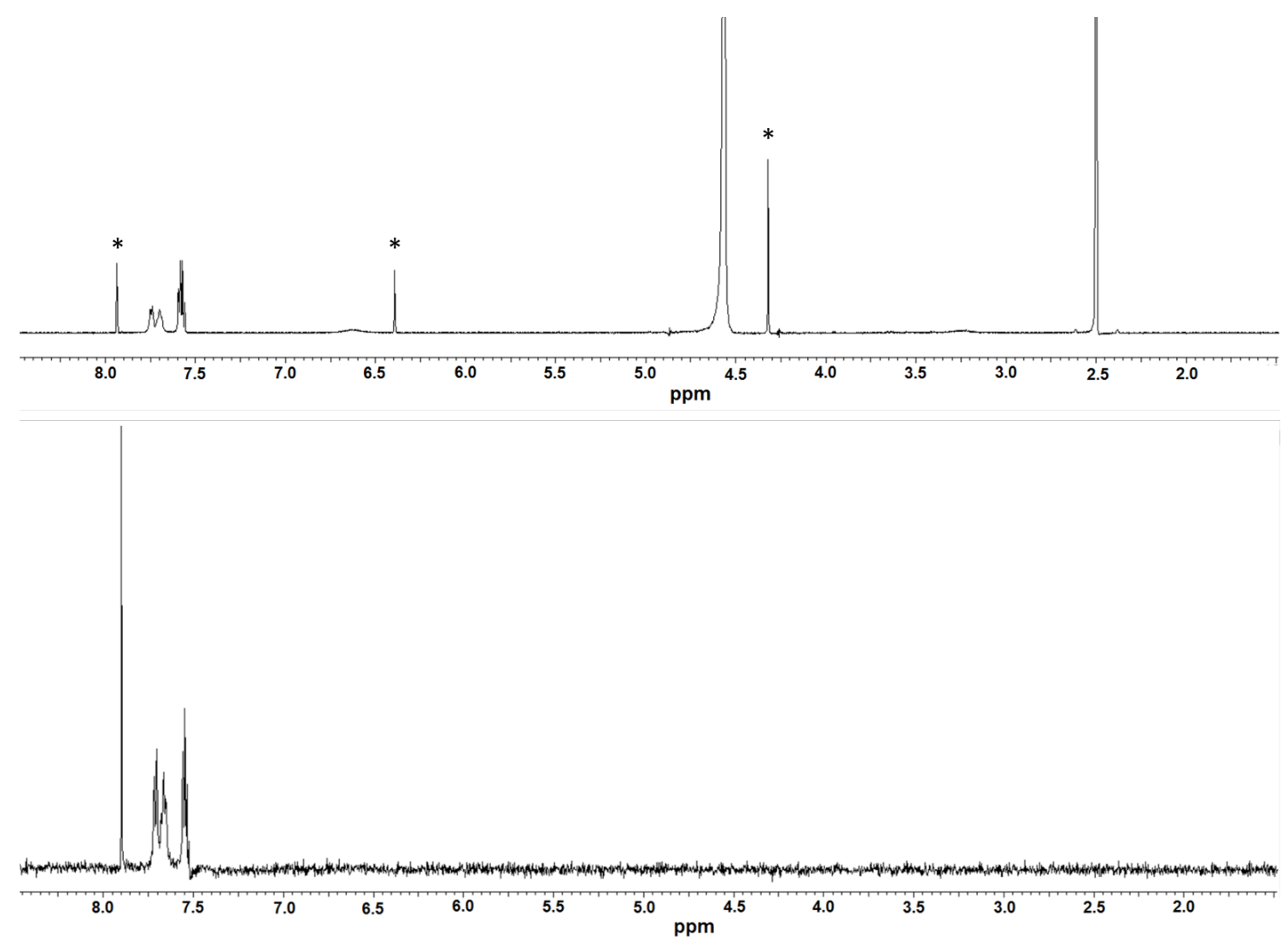

Anexo 67: Espectros de ${ }^{1} \mathrm{H}-\mathrm{RMN}$ do composto 6 e ácido kojic na ausência da enzima (superior) e de STD (inferior) do composto 6 + enzima após adição do ácido. Utilizou-se $2 \mathrm{mM}$ dos ligantes e 0,26 uM da enzima. No espectro superior, 0 * indica os sinais referentes ao ácido kojic; os demais são referentes ao composto 6. 


\section{Anexo 68}

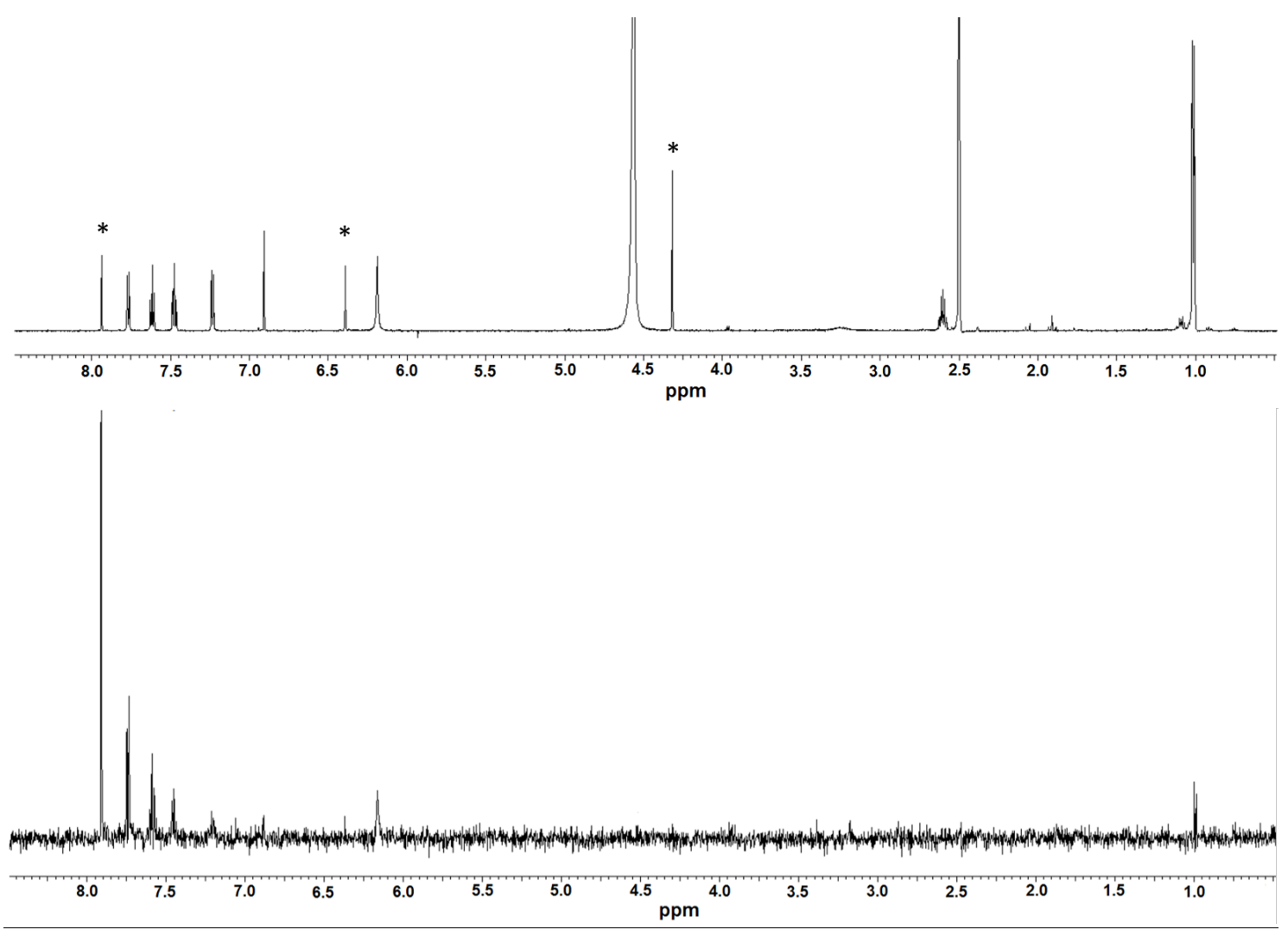

Anexo 68: Espectros de ${ }^{1} \mathrm{H}-\mathrm{RMN}$ do composto 12 e ácido kojic na ausência da enzima (superior) e de STD (inferior) do composto 12 + enzima após adição do ácido. Utilizou-se $2 \mathrm{mM}$ dos ligantes e 0,26 uM da enzima. No espectro superior, 0 * indica os sinais referentes ao ácido kojic; os demais são referentes ao composto 12. 


\section{Anexo 69}

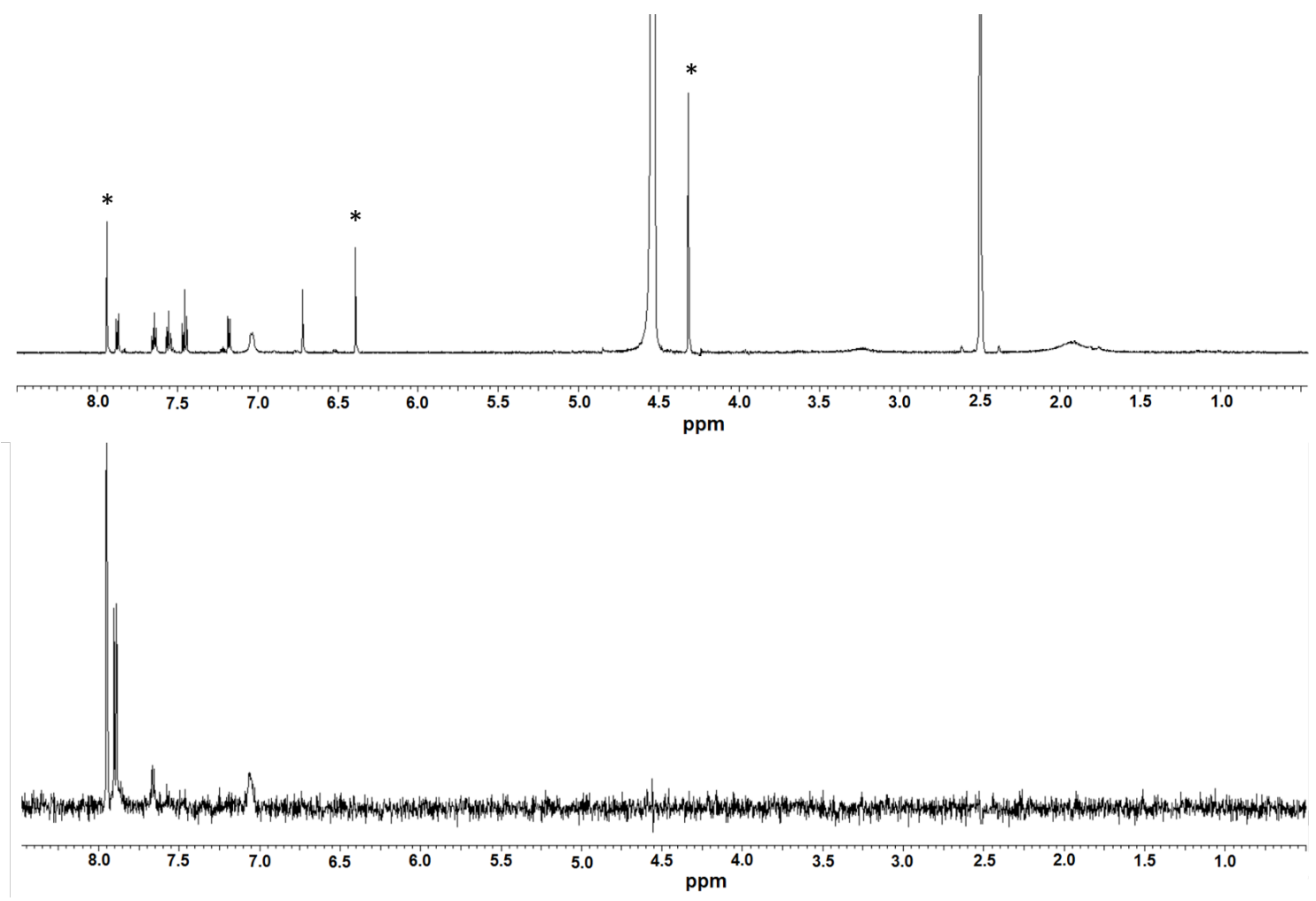

Anexo 69: Espectros de ${ }^{1} \mathrm{H}-\mathrm{RMN}$ do composto 14 e do ácido kojic na ausência da enzima (superior) e de STD (inferior) do composto 14 + enzima após adição do ácido. Utilizou-se $2 \mathrm{mM}$ dos e 0,26 uM da enzima. No espectro superior, 0 * indica os sinais referentes ao ácido kojic; os demais são referentes ao composto 14 . 


\section{Anexo 70}

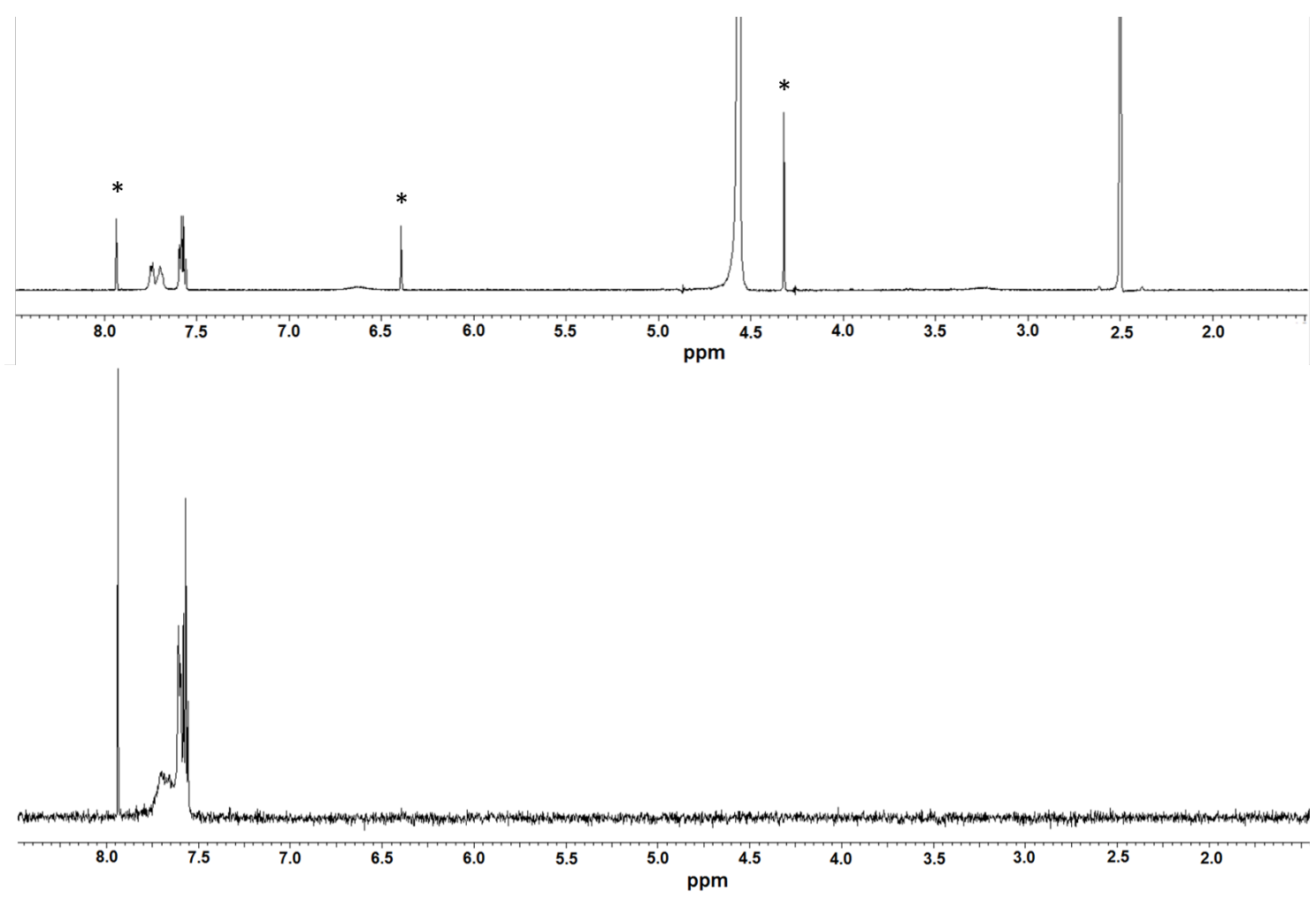

Anexo 70: Espectros de ${ }^{1} \mathrm{H}-\mathrm{RMN}$ do ácido kojic e do composto 6 na ausência da enzima (superior) e de STD (inferior) do ácido kojic + enzima após adição do composto 6. Utilizou-se 2 $\mathrm{mM}$ dos e 20 uM da enzima. No espectro superior, o * indica os sinais referentes ao ácido kojic; os demais são referentes ao composto 6 . 


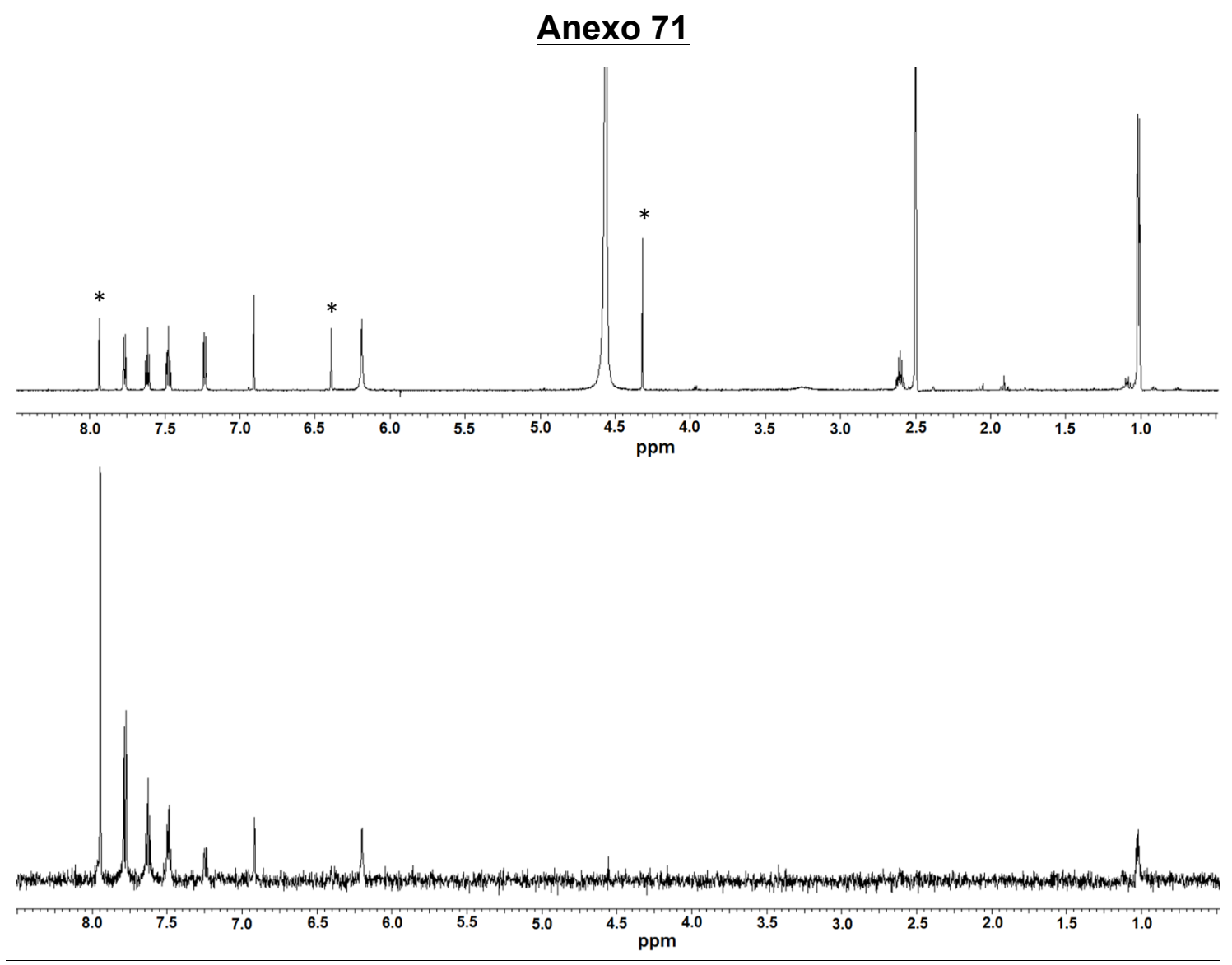

Anexo 71: Espectros de ${ }^{1} \mathrm{H}-\mathrm{RMN}$ do ácido kojic e do composto 12 na ausência de enzima (superior) e de STD (inferior) do ácido kojic + enzima após adição do composto 12. Utilizou-se $2 \mathrm{mM}$ dos ligantes e $20 \mathrm{uM}$ da enzima. No espectro superior, $\mathrm{o}$ * indica os sinais referentes ao ácido kojic; os demais são referentes ao composto 12 . 


\section{Anexo 72}
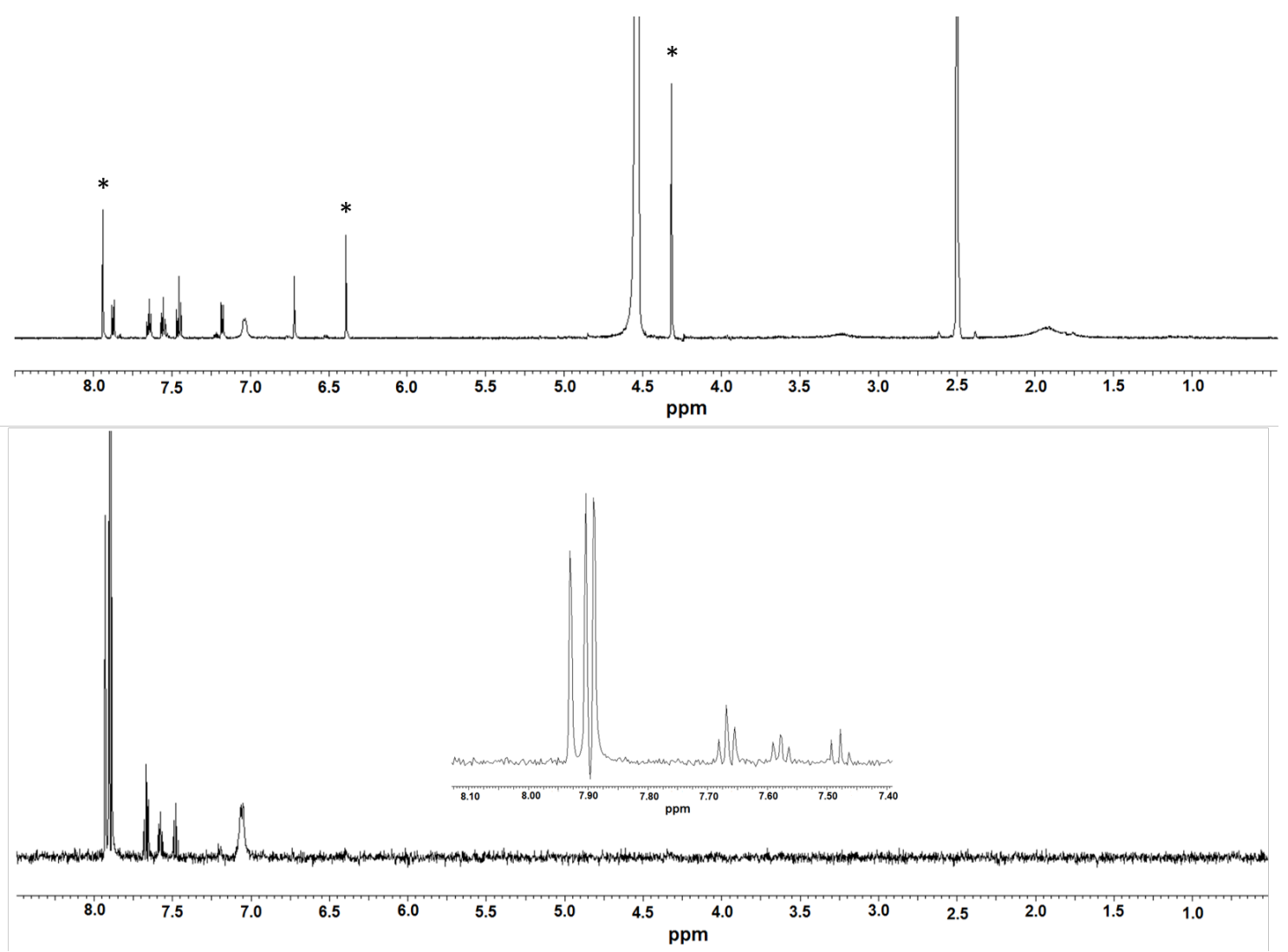

Anexo 72: Espectros de ${ }^{1} \mathrm{H}-\mathrm{RMN}$ do ácido kojic e do composto 14 na ausência da enzima (superior) e de STD (inferior) do ácido kojic + enzima após adição do composto 14. Utilizou-se $2 \mathrm{mM}$ dos ligantes e $20 \mathrm{uM}$ da enzima. No espectro superior, o * indica os sinais referentes ao ácido kojic; os demais são referentes ao composto 14. 
Anexo 73
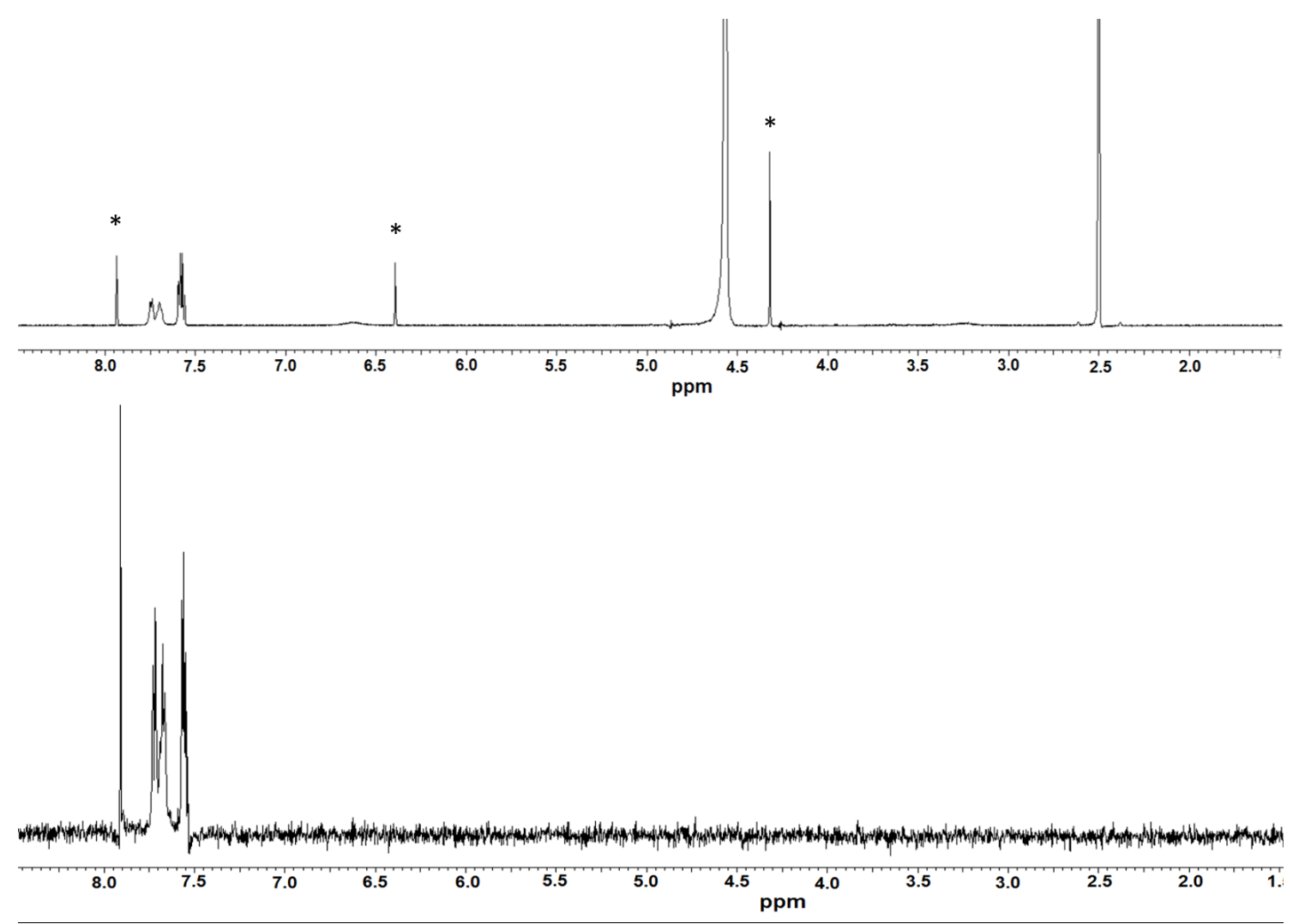

Anexo 73: Espectros de ${ }^{1} \mathrm{H}-\mathrm{RMN}$ do ácido kojic e do composto 6 na ausência da enzima (superior) e de STD (inferior) do ácido kojic + enzima após adição do composto 6 . Utilizou-se 2 $\mathrm{mM}$ dos ligantes e 0,26 uM da enzima. No espectro superior, o * indica os sinais referentes ao ácido kojic; os demais são referentes ao composto 6 . 


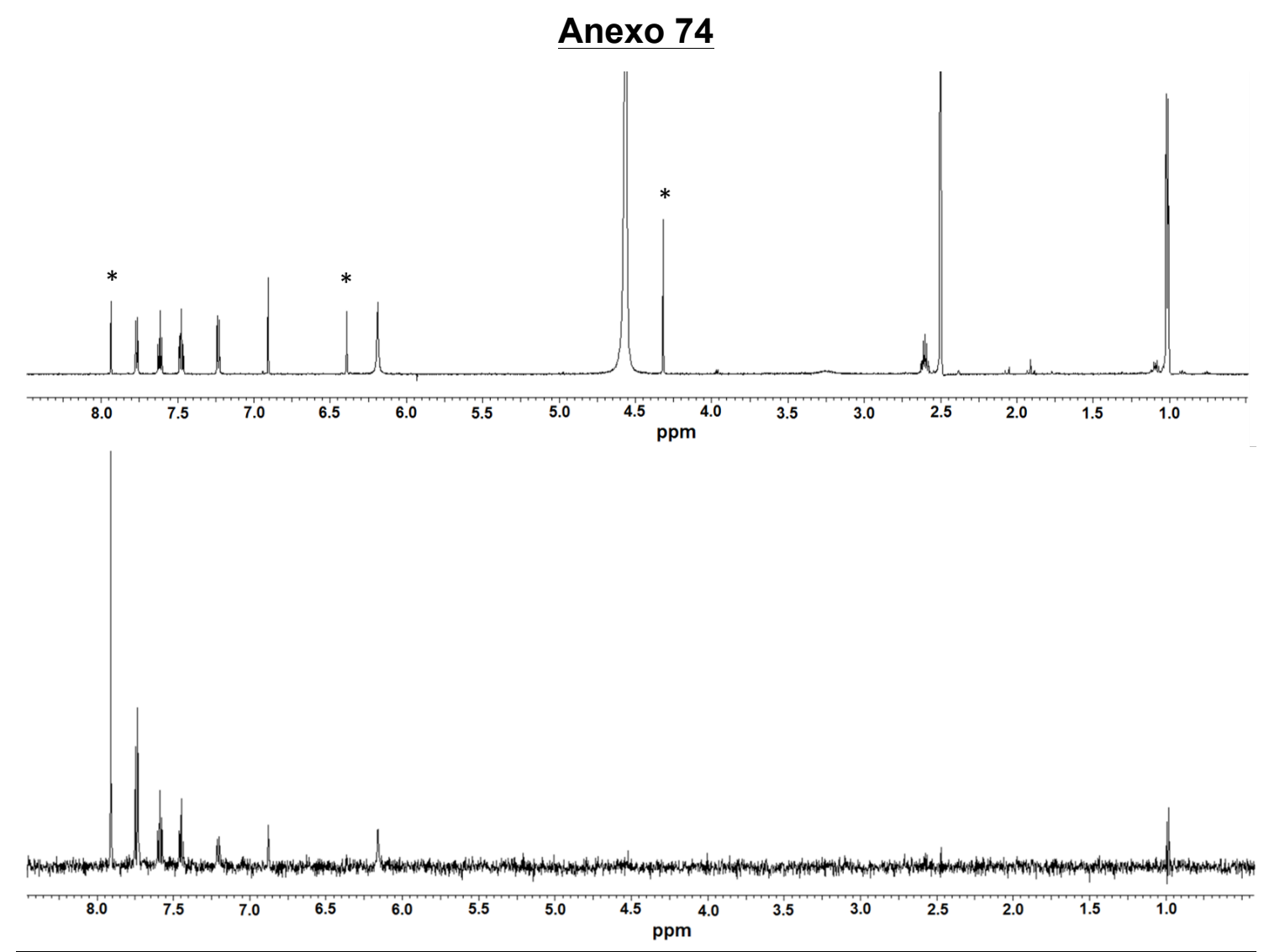

Anexo 74: Espectros de ${ }^{1} \mathrm{H}-\mathrm{RMN}$ do ácido kojic e do composto 12 na ausência de enzima (superior) e de STD (inferior) do ácido kojic + enzima após adição do composto 12. Utilizou-se $2 \mathrm{mM}$ dos ligantes e 0,26 uM da enzima. No espectro superior, o * indica os sinais referentes ao ácido kojic; os demais são referentes ao composto 12 . 


\section{Anexo 75}

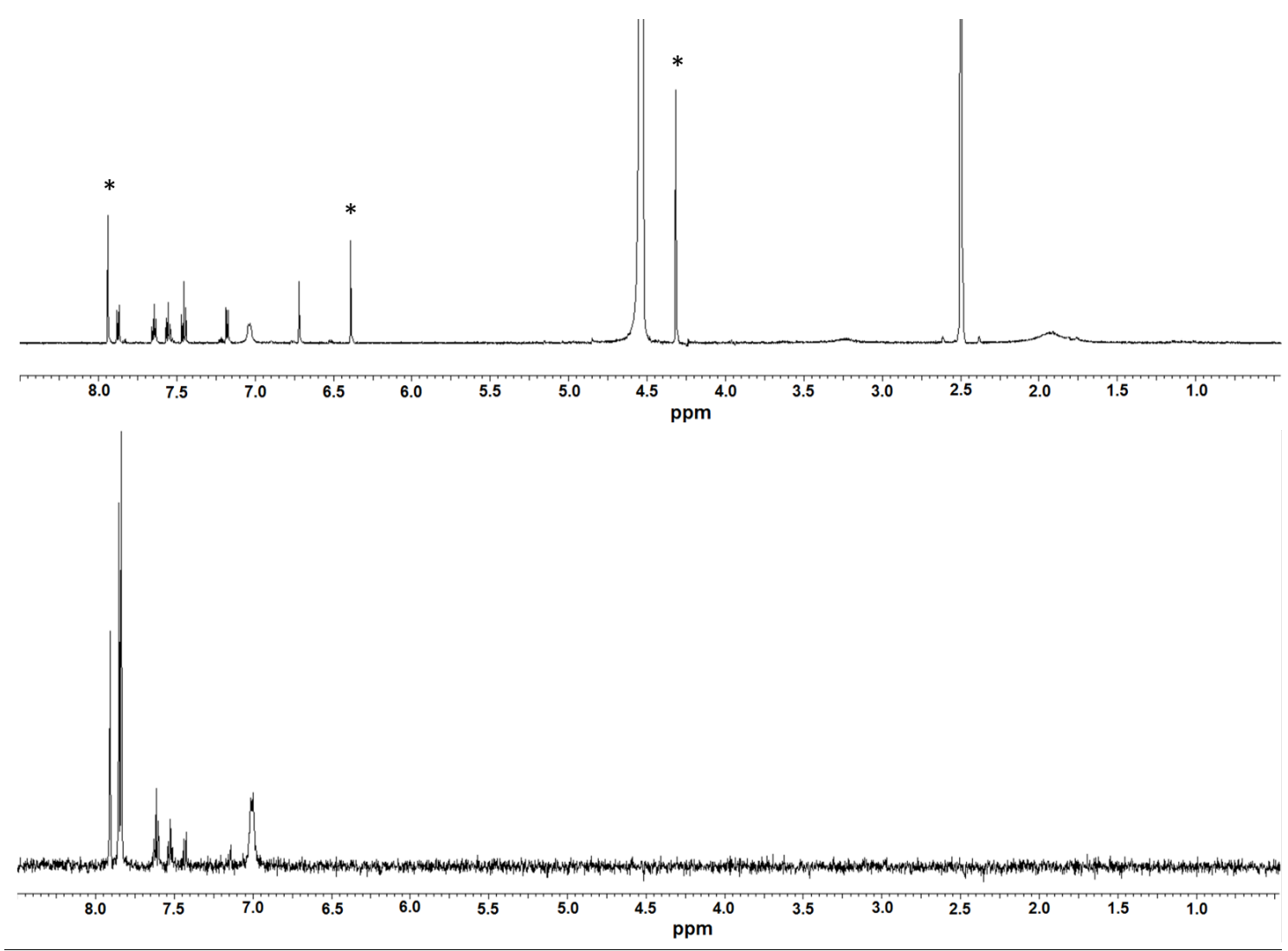

Anexo 75: Espectros de ${ }^{1} \mathrm{H}-\mathrm{RMN}$ do ácido kojic e do composto 14 na ausência de enzima (superior) e de STD (inferior) do ácido kojic + enzima após adição do composto 14. Utilizou-se $2 \mathrm{mM}$ dos ligantes e 0,26 uM da enzima. No espectro superior, 0 * indica os sinais referentes ao ácido kojic; os demais são referentes ao composto 6 . 


\section{Anexo 76}

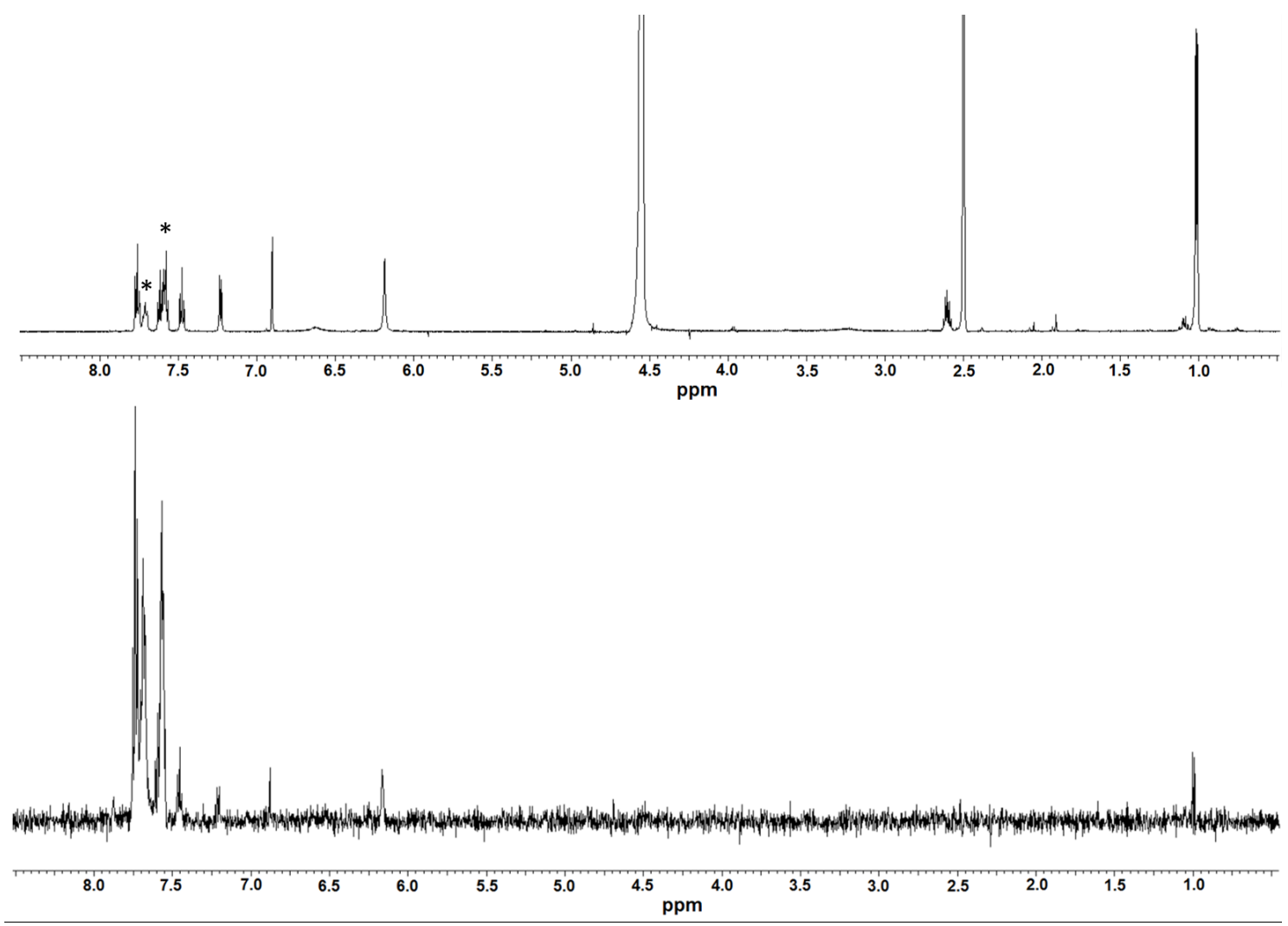

Anexo 76: Espectros de ${ }^{1} \mathrm{H}-\mathrm{RMN}$ dos compostos 6 e 12 na ausência da enzima (superior) e de STD (inferior) dos compostos 6 e $12(2 \mathrm{mM})$ na presença de tirosinase (20 uM). No espectro superior, o* indica os sinais referentes ao composto 6; os demais referem-se ao composto 12. 


\section{Anexo 77}
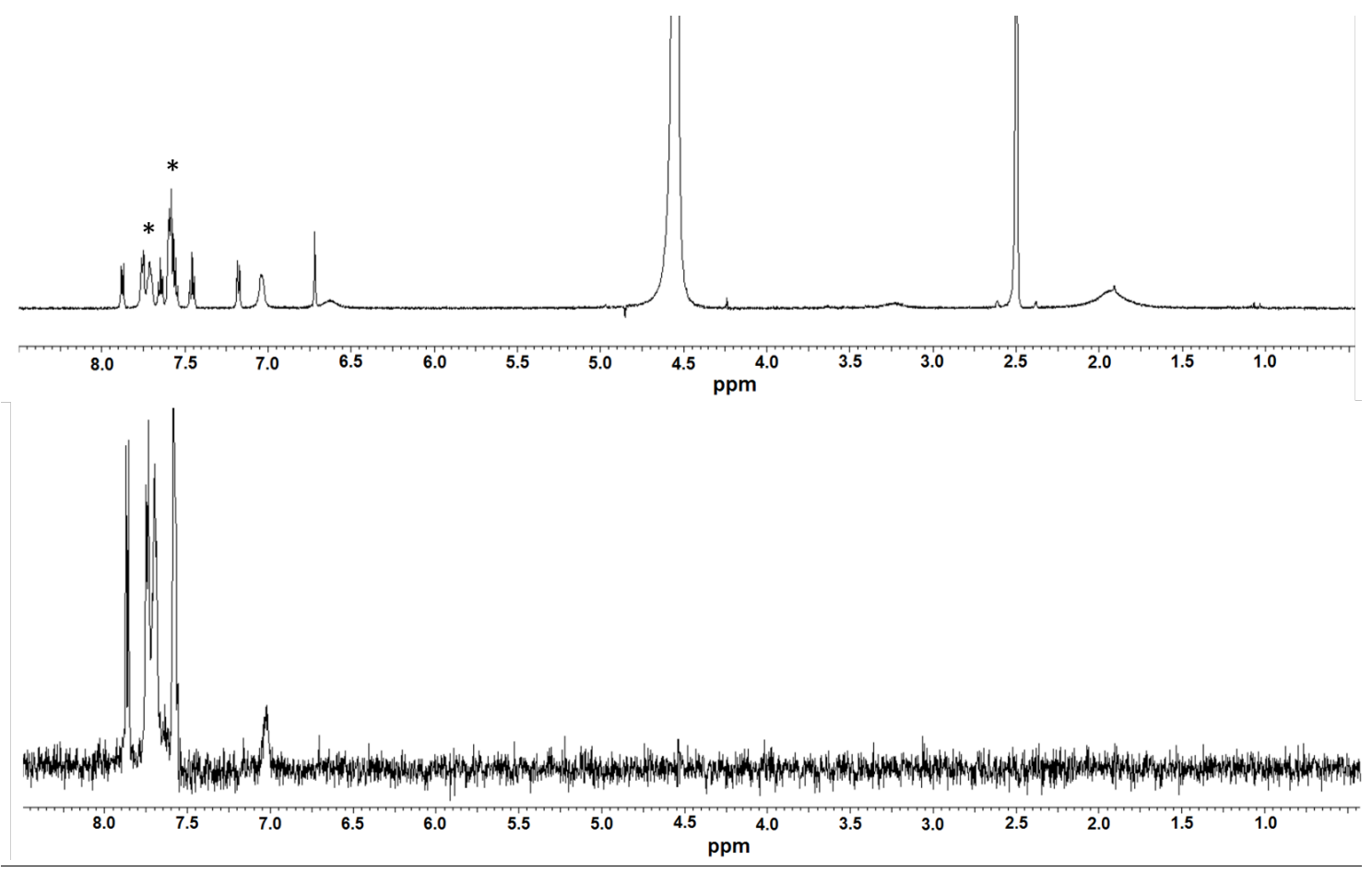

Anexo 77: Espectros de ${ }^{1} \mathrm{H}-\mathrm{RMN}$ dos compostos 6 e 14 na ausência da enzima (superior) e de STD (inferior) dos compostos 6 e $14(2 \mathrm{mM})$ na presença de tirosinase $(0,26 \mathrm{uM})$. No espectro superior, o* indica os sinais referentes ao composto 6; os demais referem-se ao composto 14. 


\section{Anexo 78}

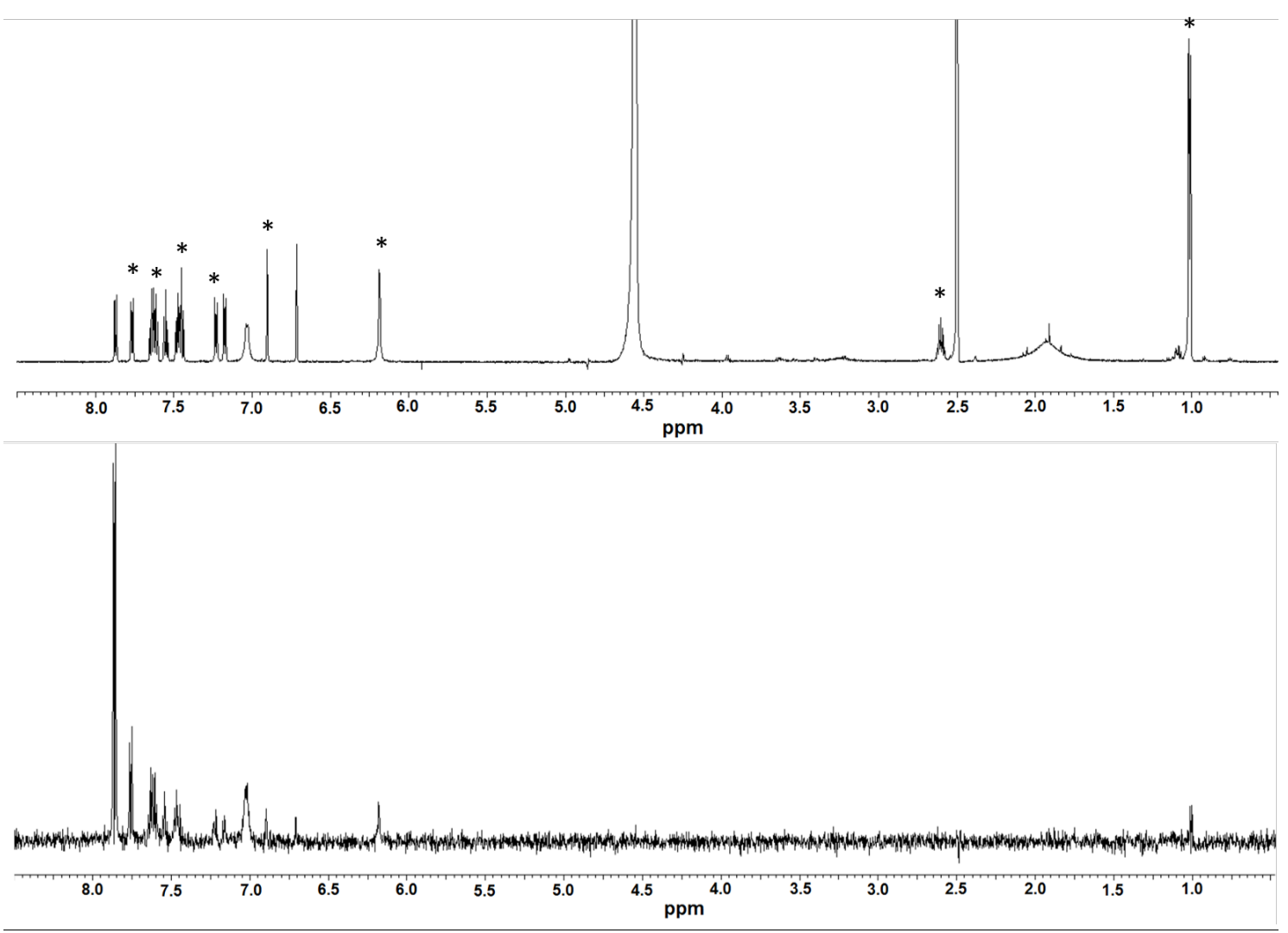

Anexo 78: Espectros de ${ }^{1} \mathrm{H}-\mathrm{RMN}$ dos compostos 12 e 14 na ausência da enzima (superior) e de STD (inferior) dos compostos 12 e 14 (2 mM) na presença de tirosinase $(0,26 \mathrm{uM})$. No espectro superior, $\mathrm{o}$ * indica os sinais referentes ao composto 12; os demais referem-se ao composto 14. 
Anexo 79

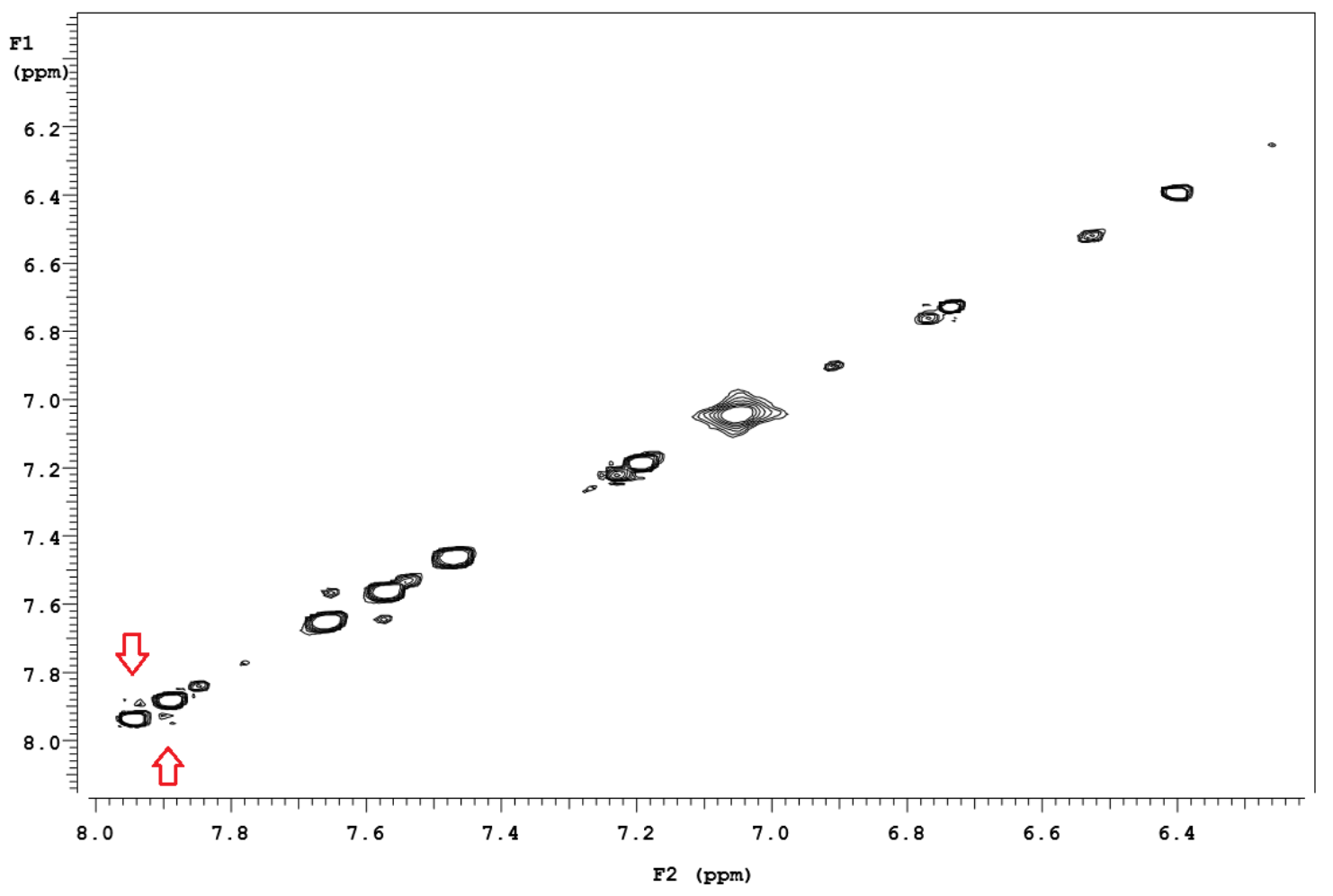

Anexo 79: Espectro de NOESY do composto 14 e kojic na presença da tirosinase. Utilizou-se 2 $\mathrm{mM}$ dos ligantes, 0,26 uM da enzima e um mixing time de $200 \mathrm{~ms}$. Destaca-se em vermelho a presença de INPHARMA NOE. 
Anexo 80

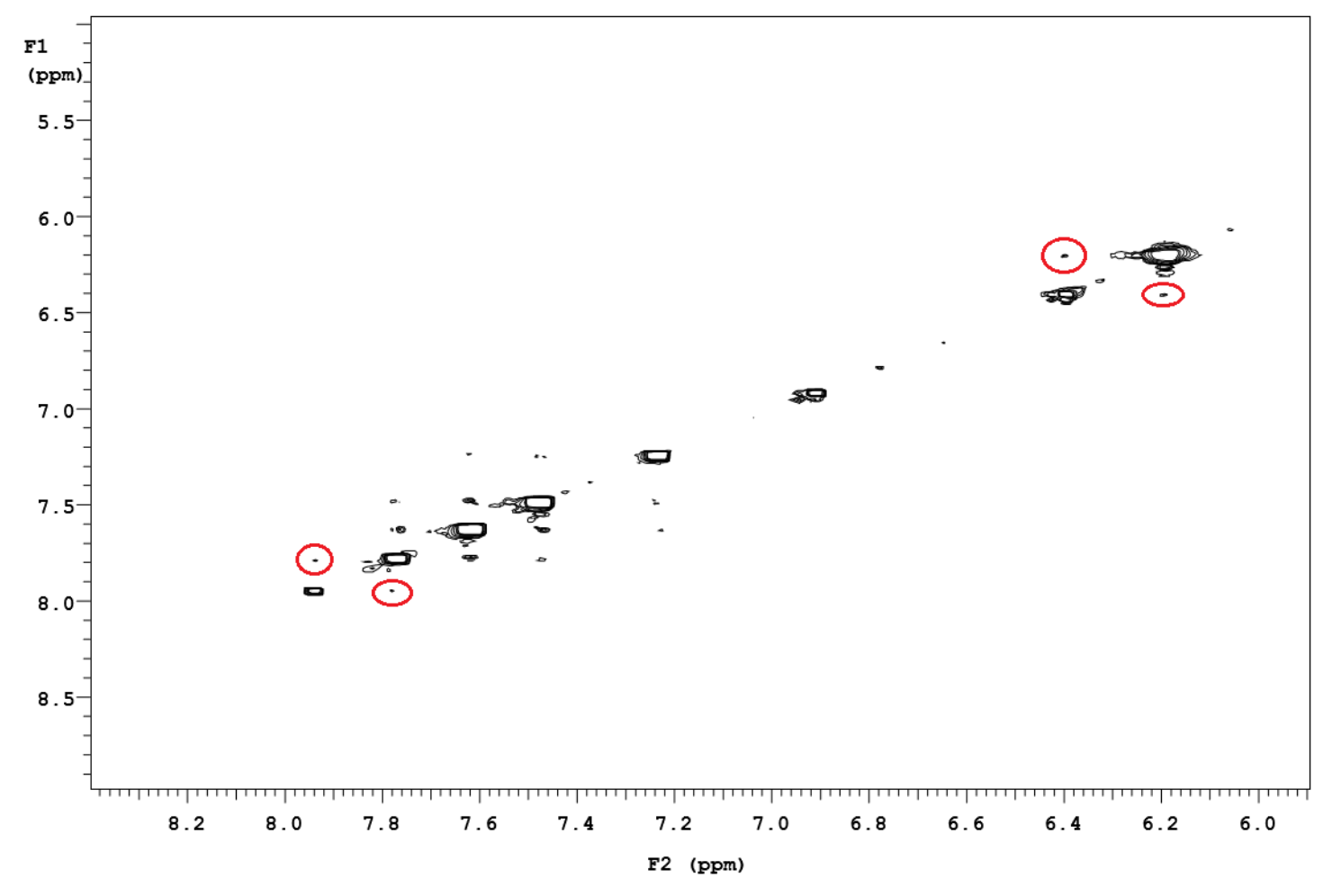

Anexo 80: Espectro de NOESY do composto 12 e kojic na presença da tirosinase. Utilizou-se 2 $\mathrm{mM}$ dos ligantes, 0,26 uM da enzima e um mixing time de $200 \mathrm{~ms}$. Destaca-se em vermelho a presença de INPHARMA NOE. 
Anexo 81

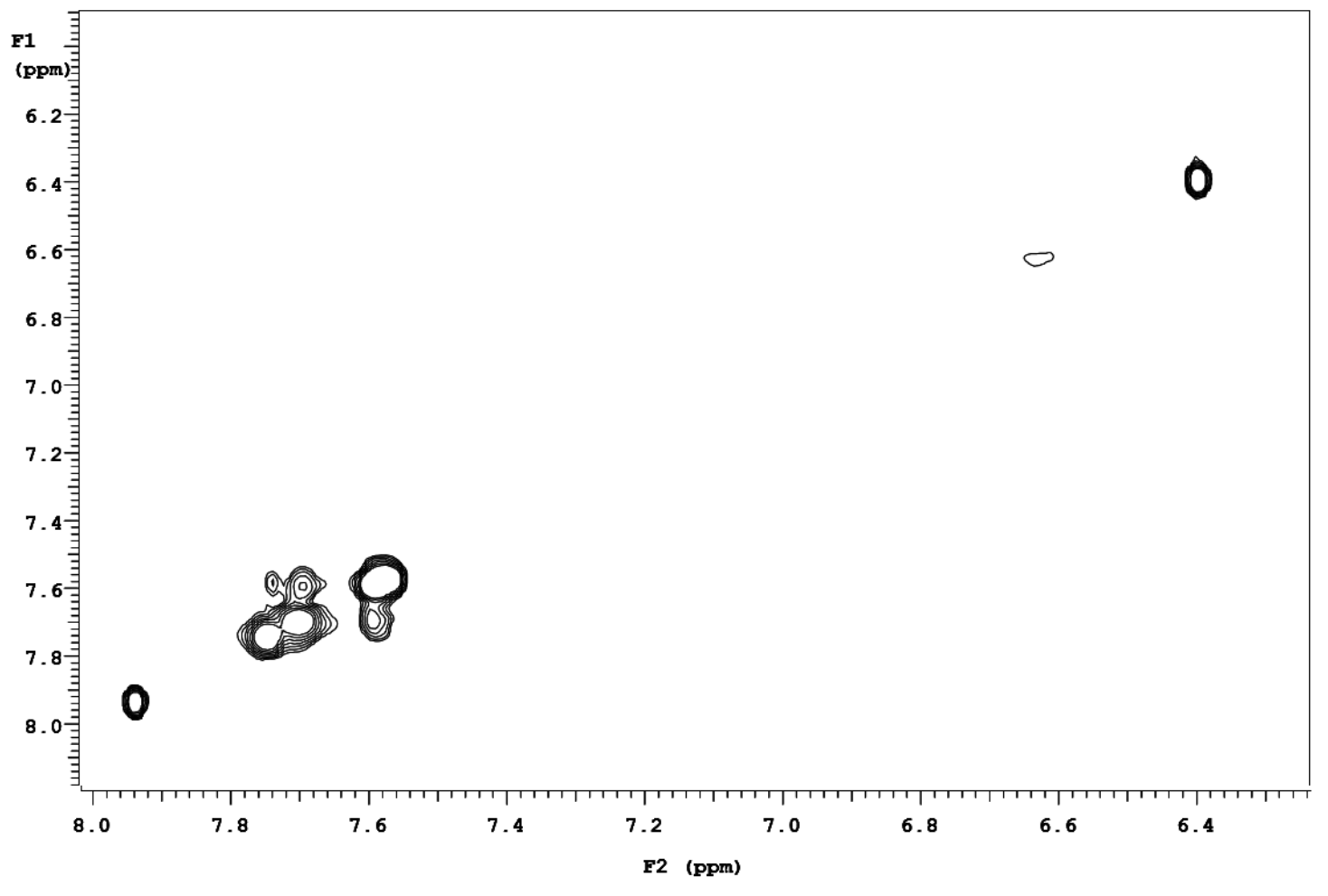

Anexo 81: Espectro de NOESY do composto 6 e kojic na presença da tirosinase. Utilizou-se 2 $\mathrm{mM}$ dos ligantes, 0,26 uM da enzima e um mixing time de $200 \mathrm{~ms}$. Não é observada a presença de INPHARMA NOE. 
Anexo 82

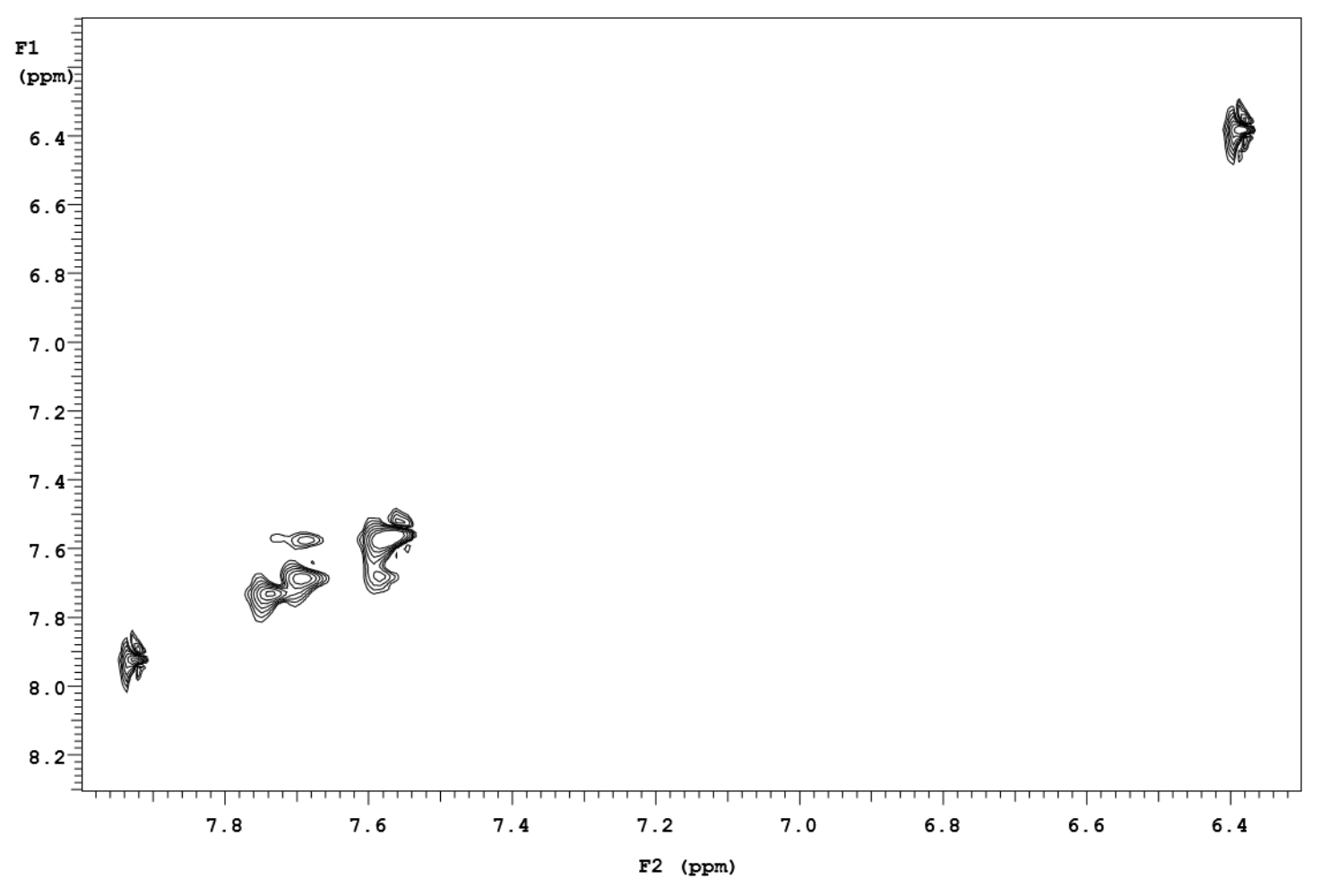

Anexo 82: Espectro de NOESY do composto 6 e kojic na presença da tirosinase. Utilizou-se 2 $\mathrm{mM}$ dos ligantes, 0,26 uM da enzima e um mixing time de $400 \mathrm{~ms}$. Não é observada a presença de INPHARMA NOE. 
Anexo 83

Author's personal copy

Int J Pept Res Ther (2014) 20:53-69

DOI 10.1007/s10989-013-9366-8

\section{Some Mechanistic Aspects on Fmoc Solid Phase Peptide Synthesis}

Diego Arantes Teixeira Pires - Marcelo Porto Bemquerer •

Claudia Jorge do Nascimento

Accepted: 21 August 2013/Published online: 29 August 2013

(c) Springer Science+Business Media New York 2013

Abstract Peptides are biomolecules that may have several biological activities which makes them important to the environment in which they operate. Sometimes it is necessary for larger amounts of peptides to carry out some studies, like biological tests, NMR structural research or even interaction studies between peptides with other molecules. Expression can be an alternative for that. However, synthesis is specially useful when unnatural modifications or introduction of site specific tags are required. Synthetic peptides have been used for different studies such as cell signaling, development of epitope-specific antibodies, in cell-biology, biomarkers for diseases etc. Many different methodologies for peptide synthesis can be found in the literature. Solid phase peptide synthesis (SPPS) has been largely used and can be an excellent alternative to achieve larger quantities of these biomolecules. In this mini review, we aim to describe the SPPS and explain some of the

\section{A. T. Pires - M. P. Bemquere}

Embrap Recursos Genéticos e Biotecnologia, Parque Estaç̃ Biológica PqEB Av. W5 Norte (Final), P.O. BOX 02372, Brasília, DF 70770-917, Brazil

D. A. T. Pires - C. J. do Nascimento $(\square)$

Instituto de Química, Universidade de Brasília, Campus

Universitário Darcy Ribeiro Instituto de Química Asa Norte,

P.O. BOX 04478, Brasília, DF 70919-970, Brazil

e-mail: claudia.j.nascimento@gmail.com

D. A. T. Pires

Instituto Federal de Educação, Ciência e Tecnologia de Goiás, Rua São Bartolomeu, Vila Esperança, Luziânia, GO 72811-580, Brazil

C. J. do Nascimento

Instituto de Biociências, Universidade Federal do Estado do Rio

de Janeiro, Av. Pasteur, 458 - Urca, Rio de Janeiro,

RJ 22290-240, Brazil

mechanistic aspects and reagents involved in all phases of the synthesis: the use of resin, the ninhydrin test, some of the protecting groups, coupling reagents for peptide bond formation and the cleavage process.

Keywords Peptides $\cdot$ SPPS $\cdot$ Fmoc $\cdot$ Chemical mechanisms

\section{Introduction}

Peptides are widespread molecules in nature, and they have several biological activities such as antimicrobial (Hancock and Scott 2000; Zasloff 2002), antithrombotic (Menezes et al. 2011), opioid (Goldberg 2010), antioxidant (Zhang et al. 2011) and so on. Therefore, peptides are important to the environment in which they operate and also as an object for the development of new drugs (Brogden 2005). Peptides are also becoming increasingly important in materials science due to their self-assembling properties (Bong et al. 2001; Chen 2005).

Usually, the amount of peptide that can be naturally extracted from plants, animals and microorganisms is too small, allowing only a few studies, as the initial identification and characterization of the biomolecule. To carry out some other studies, such as biological tests, NMR structure determination and interaction studies, it is necessary to acquire larger amounts of the molecule, which can be difficult to achieve by extractions from the natural source. Expression is a good choice if no changes in the structure are required. If this is the situation, a solution to this problem can be peptide synthesis.

The peptide synthesis may be carried out both in liquid (Takahashi and Yamamoto 2012; Gravert and Janda 1997) and solid-phase (Fields and Noble 1990; Chan and White 
2000; Benoiton 2005; Schnolzer et al. 2007). The solidphase synthesis has been the most widely used (Naidoo and Rautenbach 2012; Elsawy et al. 2012; Zhang et al. 2012; Hibino and Nishiuchi 2012; Aucagne et al. 2012; Amblard et al. 2006), as it has some advantages (such as better overall yield and fewer by-products) and it has greater acceptance when compared to the liquid-phase synthesis. More recently, the use of ionic liquids in peptide synthesis need also to be considered as a medium both for solidphase and liquid-phase synthesis (Plaquevent et al. 2008; Tietze et al. 2012).

The solid-phase peptide synthesis starts with a resin which is insoluble under the conditions of the synthesis, usually a copolymer of polystyrene with $1 \%$ divinylbenzene sometimes grafted with polyethylene glycol (Zalipsky et al. 1994), and which must also have an anchor for the synthesis to be carried out in the solid support (Merrifield 1963; Albericio 2004; Marquardt and Eifler-Lima 2001). In this synthesis, a process of washing and filtration of the sample is performed at the end of each reaction step. Thus, excess of reagents, solvents and any other compounds not bound to the resin are removed (Marquardt and Eifler-Lima 2001). This procedure can prevent unwanted reactions, allowing higher yields and producing cleaner synthesis (Marquardt and Eifler-Lima 2001).

Among the strategies for the synthesis of peptides on solid-phase, Fmoc (fluorenylmethyloxycarbonyl) and Boc (tert-butyloxycarbonyl) are most used (Miranda and Alewood 1999; Hudson 1988). In this work, our focus is the Fmoc strategy for solid phase peptide synthesis (SPPS).

Different information about the SPPS can be found in the literature (Jensen, 2013; Naidoo and Rautenbach 2012; Elsawy et al. 2012; Zhang et al. 2012; Hibino and Nishiuchi 2012; Merrifield 1963; Najera 2002; Isidro-Llobet et al. 2009), including reviews that describe details of the experimental procedures on SPPS (Shelton and Jensen 2013; Amblard et al. 2005, 2006). In all of them the main purposes are more related to practical procedures. This short review presents an overview of solid-phase peptide synthesis, describing the reagents involved throughout the chemical steps and the reaction mechanisms related to each part of the synthesis. Our focus is not on the details of the experimental procedure, but on the mechanistic aspects, describing basic mechanisms of the reactions involved in the synthesis.

\section{Resin and Protecting Group}

In the synthetic Fmoc methodology, all amino acid derivatives used during the synthesis have the 9-fluorenylmethyloxycarbonyl (Fmoc, Fig. 1) as a protecting group. It is a temporary protecting group of the amino function, removed at each step of the synthesis, being a base labile group (Isidro-Llobet et al. 2009; Carpino and Han 1972; Carpino 1987; Machado et al. 2004), which is normally removed by piperidine or the most recently added alternative to piperidine: 4-methylpiperidine (same efficiency in Fmoc group removal as piperidine) (Hachmann and Lebl 2006). 4-methylpiperidine has become an alternative to piperidine since the latter is a controlled substance and its distribution is carefully monitored (Hachmann and Lebl 2006). Fmoc can also be removed by stronger organic bases such as 1,8-diazabicyclo[5.4.0]undec-7-ene (DBU), but in a condition more prone to side reactions (Mergler and Dick 2005). This lability is due to the fact that the removal of the acidic hydrogen of the Fmoc (highlighted in red in Fig. 1) generates a conjugated base stabilized by resonance (IsidroLlobet et al. 2009). In addition to the temporary protecting group, there are also the permanent protecting groups of the amino acid residue side chains - the $t$-butyl, $O$ - $t$-butyl, trityl (Trt), 2,2,4,6,7-pentamethyldihydrobenzofuran-5-sulfonyl (Pbf), t-butyloxycarbonyl (Boc) groups (structures shown in Fig. 2), which remain linked throughout all stages of the synthesis, being removed only in the last step, the cleavage of the peptidyl-resin linkage.

Both permanent and temporary protectors will ensure the reaction of Fmoc-amino acids only in the site of interest

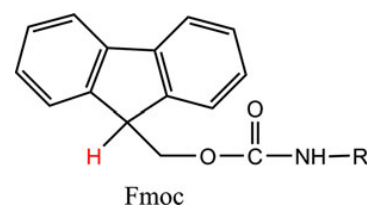

Fig. 1 Structure of Fmoc (Color figure online)
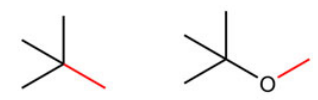

$t$-butyl

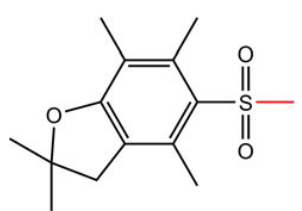

$\mathrm{Pbf}$

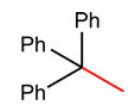

Trityl (Trt)

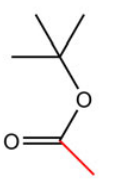

Boc
Fig. 2 Structures of $t$-butyl, O-t-butyl, Trt, Pbf and Boc (permanent protecting groups for the amino acids side chain). In red the carbon that is attached to the amino acid (Color figure online) 
Fig. 3 Structure of the resin used throughout the synthesis. used throughout the synthesis,
The amino group is shown in The amino group is shown in
red and $P$ is the polymer chain red and $P$ is the polymer chain
from the resin (Color figure from the
online)

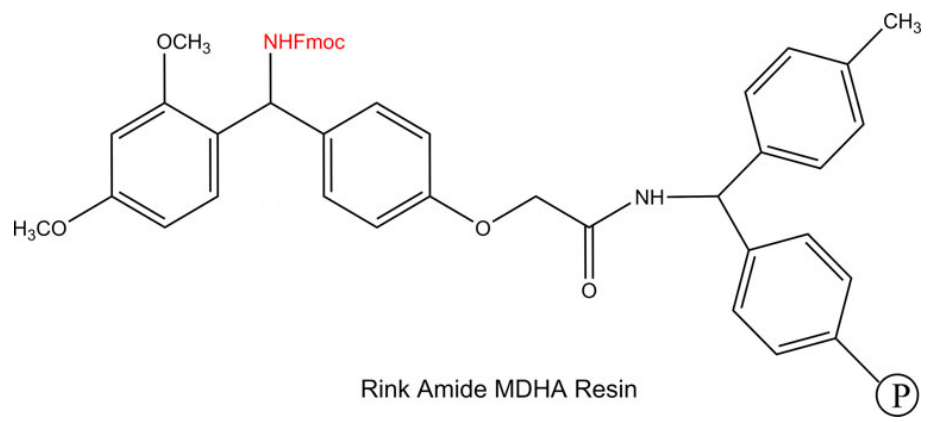<smiles>CC1CC[N+]([N])(CCNC(=O)COC(=O)NN)c2ccccc21</smiles>
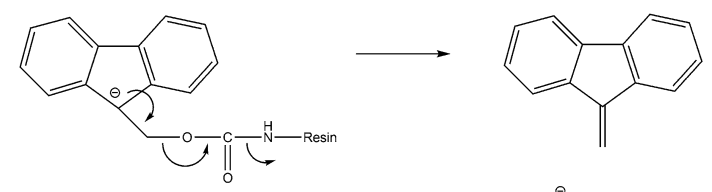

$+\stackrel{\ominus}{\mathrm{N}}-$ Resin $+\mathrm{CO}_{2}$

4-Methylpiperidine

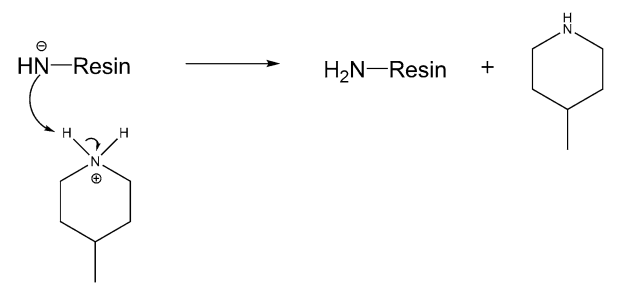

Fig. 4 Removal of the Fmoc group by 4-methylpiperidine for the formation of a free $-\mathrm{NH}_{2}$ (Chan and White 2000)

for the formation of the peptide bond. It helps to prevent secondary reactions, such as the incorporation of dipeptide derivatives instead of an amino acid derivative. In addition, it may help in the final purification of the product due to smaller amount of undesired products.

The synthesis can be performed in a syringe with a filter to retain the resin that is made either of polypropylene or of a sintered glass material. As reported before, the resin is an insoluble and inert support. Nevertheless, it is derivatized with a linker to furnish proper acid lability to the peptidylresin linkage by the presence of electron-releasing groups.
Also, the linker defines the C-terminal functional group. A Rink amide linker can be used as a support for the solid phase, as well as a Pal linker and a Sieber linker, which led to C-terminal peptide amides (Howl 2005). On the other hand, the Wang, Sasrin, 4-(4-hydroxymethyl-3-methoxyphenoxy)butyric acid (HMPB), and 2-chlorotritryl linkers can be used for the synthesis of free C-terminal peptide acids (Howl 2005; Gońgora-Benítez et al. 2013). The sasrin and the 2-Chlorotrityl chloride resin are appropriate for the synthesis of side-chain protected peptide fragments by being labile to dilute acids. Also, the 2-Chlorotrityl 


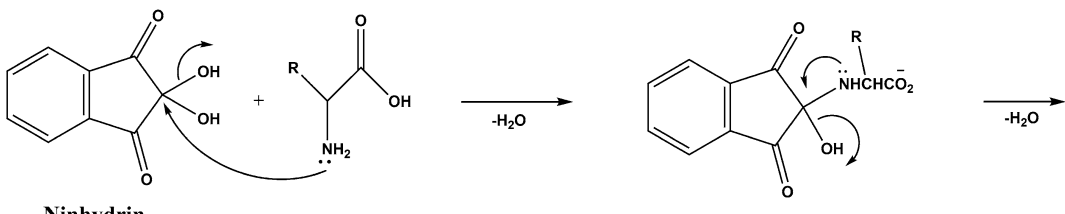

Ninhydrin

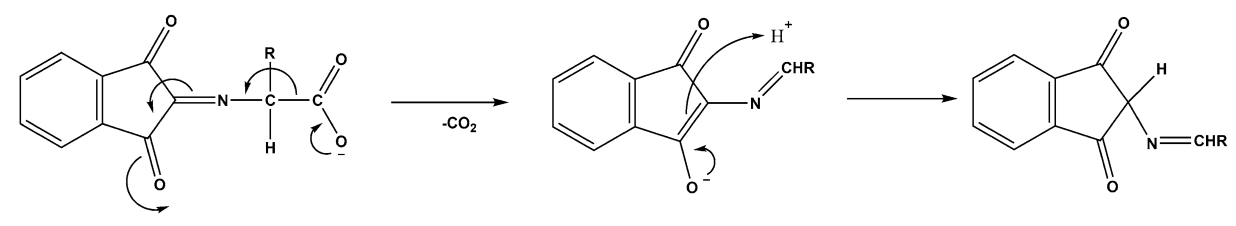<smiles></smiles><smiles>O=C1c2ccccc2C(=O)C1N=c1c(=O)c2cc[cH+]ccc2c1=O</smiles>

Ruhemann`s Blue

Fig. 5 Mechanism for the ninhydrin reaction with an $\alpha$-amino acid with a primary amino group to form the Ruhemann's blue (Friedman 2004 McCaldin 1959)

chloride resin is employed for the synthesis of C-terminal peptide acids, which may be important as modified peptide drugs, such as the somatostatin-analogue octreotide (Tailhades et al. 2010).

In this work, the synthesis will be exemplified by using the Rink amide resin (MDHA), whose linker structure is shown in Fig. 3. Since many peptides are naturally found in the amidated form and due to the fact that $\mathrm{C}$-terminal amides are generally more stable to degradation than C-terminal acids, a resin with an $-\mathrm{NH}_{2}$ group (as Rink Amide) is very widely employed. The coupling of the first Fmoc-amino acid will occur at the amino group of the resin, forming an amide bond and it will be described together to the peptide bond formation.

\section{Removing the Temporary Protecting Group Fmoc}

The Fmoc group must be removed to furnish free amino groups that will react with activated carboxyl components for peptide bond formation. For this purpose, the resin must be first washed with 2-propanol and $N, N$-dimethylformamide, DMF, for the removal of soluble impurities (Chan and White 2000; Benoiton 2005; Marquardt and EiflerLima 2001). Both the 2-propanol and DMF can be removed from the reaction vessel by filtration at reduced pressure. For removing the Fmoc protecting group from the resin, the preferable organic base now is 4-methylpiperidine, as previously explained. According to standard procedures deprotection can be conducted in a solution of 
<smiles>O=C(O)C1CCCNC1CCCCC1(O)C(=O)c2ccccc2C1=O</smiles>

Ninhydrin<smiles>O=C(O)CN1CCCC1=[N+]1CCCC1C(=O)O</smiles>

Proline<smiles>O=C(O)C1CCCN1C1(O)C(=O)c2ccccc2C1=O</smiles><smiles>O=c1c([O-])c([N+]2=CCCC2)c1=O</smiles>

Yellow Product

Fig. 6 Mechanism for the ninhydrin reaction with proline (Kaupp et al. 2002; McCaldin 1959)

4-methylpiperidine in DMF (20-30 \% by volume) for 1-5 min (2 times). Then, the resin can be washed again with 2-propanol and DMF. Finally, the resin has to be washed with dichloromethane (DCM) to easily dry the grains. Alternatively, it can be washed with a mixture of methanol/dichloromethane (MeOH/DCM), which helps to prevent losses of resin sticking to the glass or plastic syringe. Fmoc deprotection by piperidine or by 4-methylpiperidine is usually fast and clean. Slow kinetics and low Fmoc deprotection yields are clear indications of peptide aggregation (Remuzgo et al. 2009).

The reaction mechanism for the removal of Fmoc by 4-methylpiperidine is shown in Fig. 4. Initially the acidic proton from the Fmoc group is removed by the organic base. Then, there is a beta elimination step, with formation of $\mathrm{CO}_{2}$. The resin without the Fmoc group, formed in the previous step, is then protonated, resulting in the final product of resin with a free $-\mathrm{NH}_{2}$ group (Fig. 4).

This process of deprotection is performed at each stage of the synthesis for the formation of a free $-\mathrm{NH}_{2}$ group, at which the amino acid derivative coupling will occur for peptide bond formation.

\section{Ninhydrin Test}

To verify the previously described deprotection and the coupling of each amino acid derivative during all stages of synthesis, a colorimetric assay for the presence of the amino function group must be conducted. Many assays have been used such as the formation of a salt of the amino group in the resin with picric acid (2,4,6-trinitrophenol) followed by the release of the corresponding phenolate with diisopropylethylamine (Gisisn 1972) or the nucleophilic substitution of halo-1,4-naphtoquinones or nitro, halo-1,4-naphtoquinones with the amino groups linked to solid-phase resins followed by release of 2-amino-3-halo1,4-naphtoquinone by acidolysis (Blackburn 2005). However, there is no assay with so widespread use as the ninhydrin reaction (Shelton and Jensen 2013; Kaiser et al. 1970; Troll and Cannan 1952). This test consists of the reaction of a primary or a secondary amine with ninhydrin, yielding a dark blue compound known as Ruhemann's blue in the former case or a brown compound corresponding to specific non-classic products for secondary amines<smiles></smiles>

HBTU<smiles>CCN(C(C)C)C(C)C</smiles>

DIPEA<smiles>CN(C)C=O</smiles>

DMF
Fig. 7 Structures of HBTU, DIPEA and DMF 
(Friedman 2004; McCaldin 1959). In order to perform the test, after deprotection, 1-5 mg of the obtained product are added to a test tube, then one drop of a solution made with $2 \mathrm{~mL}$ of $\mathrm{KCN}\left(1 \mathrm{mmol} \mathrm{L}^{-1}\right)$ and $98 \mathrm{~mL}$ of pyridine is added, followed by two drops of a $80 \%$ (by weight) phenol solution in ethanol and by one drop of a $5 \%$ (by weight) ninhydrin solution in ethanol (Kaiser et al. 1970; Troll and Cannan 1952). The mixture is heated at $110^{\circ} \mathrm{C}$ for 3-5 min. A color change of the grain sample from faint yellow to blue or brown, for primary and secondary amines, respectively, indicates the presence of a free amino group, and consequently, the deprotection of the resin or peptidyl-resin (Kaiser et al. 1970; Troll and Cannan 1952).

The ninhydrin test can also be used in a quantitative way. For that, as described by Amblard et al. (2006), $5-10 \mathrm{mg}$ of the resin and $1.0 \mathrm{~mL}$ of $20 \%$ piperidine/DMF are added in a tube, stirred for $20 \mathrm{~min}$ and then centrifuged. $100 \mu \mathrm{L}$ of this solution is transferred to a tube containing $10 \mathrm{~mL}$ of DMF and mixed. The resulting solution can be observed by UV spectrometer at $301 \mathrm{~nm}$. The substitution of the resin can be calculated thus: $[101 \times$ (Absorbance) $] /$ $[7.8 \times($ weight in $\mathrm{mg})]$.
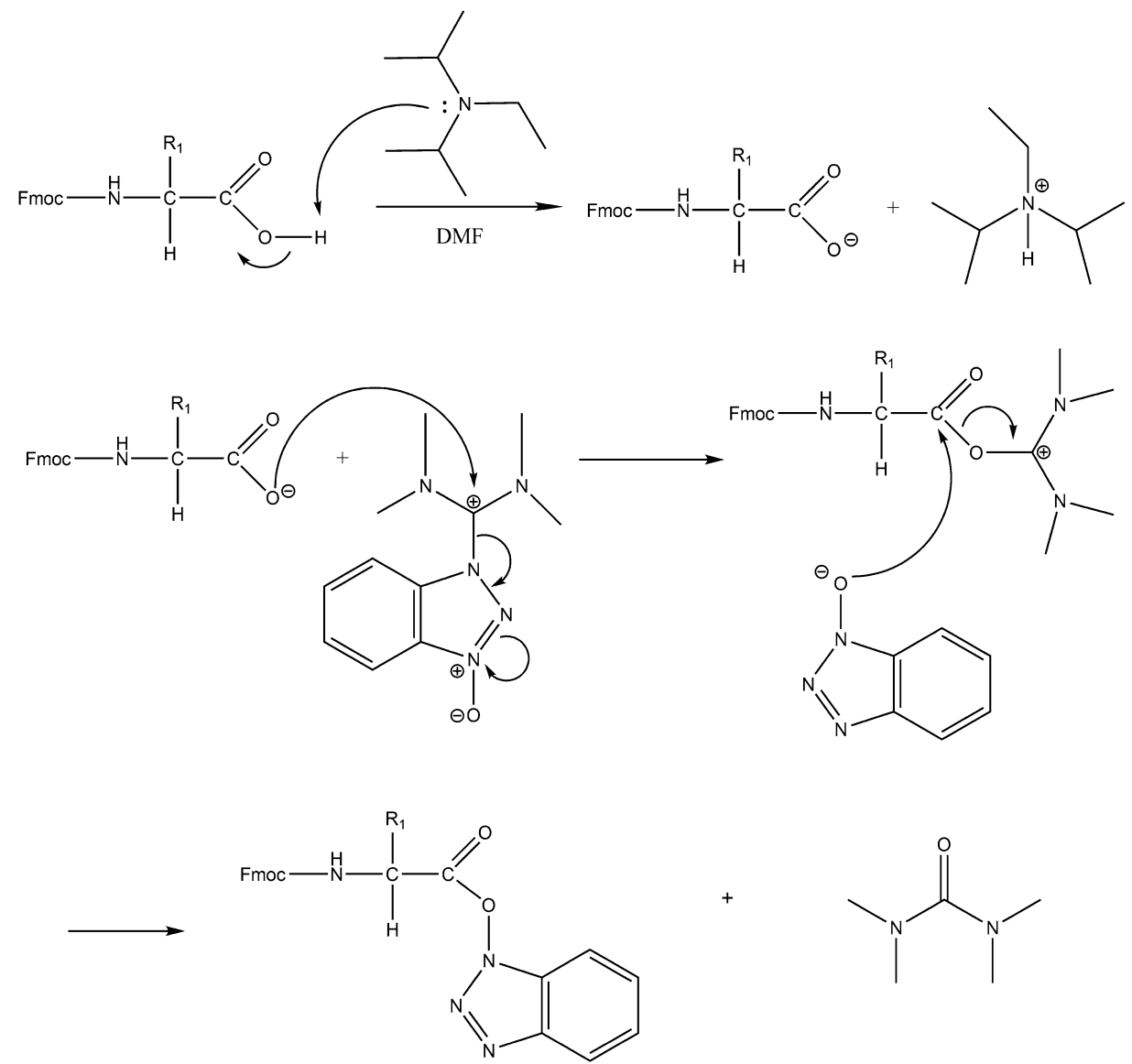

Activated Fmoc-amino acid

Fig. 8 Mechanism for the activation reaction of the Fmoc-amino acid with HBTU, wherein $R_{1}$ is the side chain of an amino acid (Najera 2002)

黑 Springer 
The use of organic solvents in the ninhydrin test, such as alcohols, pyridine and phenol, helps to accelerate the appearance of the color (Troll and Cannan 1952). The visible spectrum of Ruhemann's compound in pyridine is blue-shifted when compared to other solvents like DMF and DMSO. The heating of the mixture near to $100{ }^{\circ} \mathrm{C}$ for up to 5 min gives a quantitative yield for the appearance of color when reacting with a $-\mathrm{NH}_{2}$ of the resin or of the amino acid residue (Troll and Cannan 1952). The reaction mechanism between the primary amino group of an $\alpha$-amino acid and ninhydrin to form the Ruhemann's blue is shown in Fig. 5.

This test can be successfully used for all amino acids, except for proline. In this case, another colorimetric test, also using ninhydrin, can be used, giving a yellow product. The mechanism for the reaction of ninhydrin with proline is shown in Fig. 6.

\section{Coupling of the First Amino Acid Derivative}

\section{and Peptide Bond Formation}

After deprotection and its confirmation by quantitative nynhidrin test yielding 90-100\% of theoretical value (Kilk and Langel 2006), the synthesis can be started and the first amino acid derivative can be coupled to the resin. Since the synthesis is carried towards the N-terminus (Lloyd-Williams et al. 1993), the nucleophilic group of the resin linker
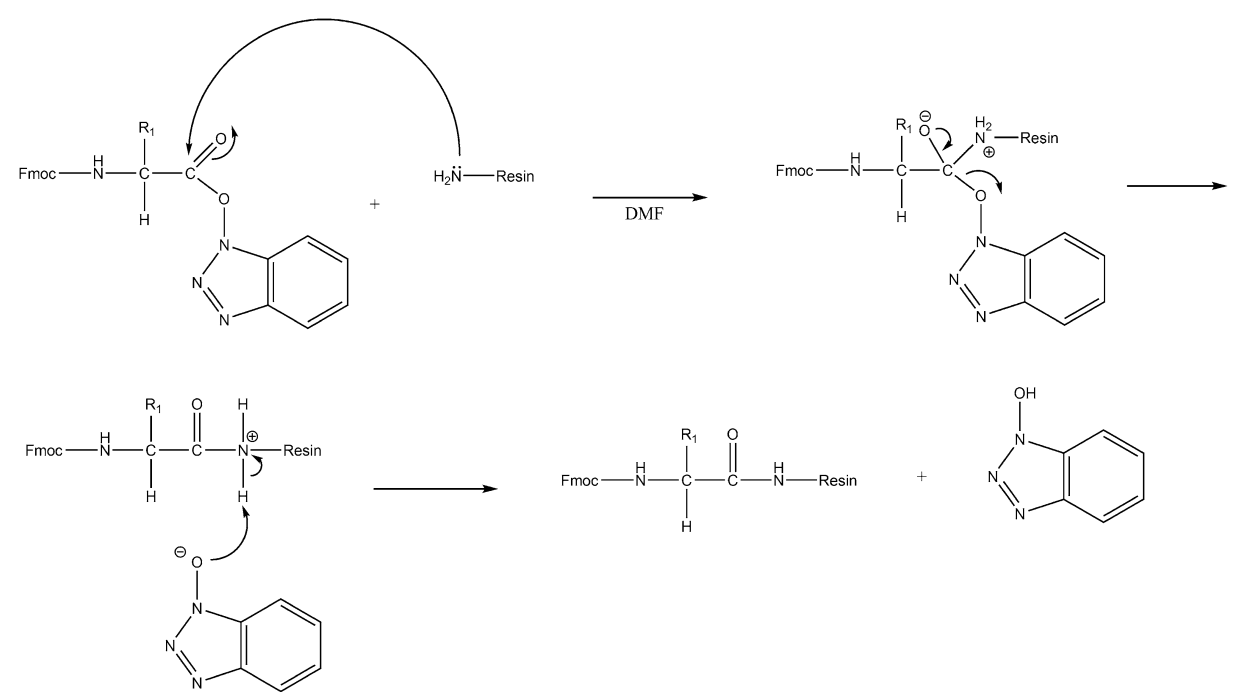

Fig. 9 Mechanism for the reaction of coupling the activated Fmoc-amino acid to the resin. $\mathrm{R}_{1}$ is the side chain of an amino acid (Montalbetti and Falque 2005) reacts with the acid group of the amino acid derivative while its amino group is protected. For this reason, the last amino acid derivative is added first in the reaction vessel for coupling to the resin. The method and the mechanism depend upon the nature of the bond being formed. For the ester bond formation to linkers such as the Wang resin and the HMPB resin it is necessary to use a base as catalyst, for which 4-dimethylaminopyridine is usually employed, with a carbodiimide as the carboxyl-activating reagent (Chan and White 2000). Other coupling reagents that furnish good yield for the esterification were also introduced, such as the chloro derivative 2-chloro, 1,3-dimethylimidazolidinium hexafluorophosphate (CIP) (Akaji et al. 1992). For the very acid-labile 2-chlorotrityl chloride linker, the carboxyl group of the amino acid derivative attacks the methyl carbon and chloride is the leaving group, which leads to the linkage of Fmoc-amino acids to the 2-chlorotrityl chloride would fulfill a number of important criteria like cost, availability, attachment of starting material should be readily achieved in high yield, stable to the chemistry used in synthesis, cleavage would be efficient under conditions that do not damage the final product(s) and should not introduce impurities that are difficult to remove (Jame 1999). The choice of the linker requires careful consideration and readers must refer to the James (1999) review for a complete description of the linkers used in solid-phase 

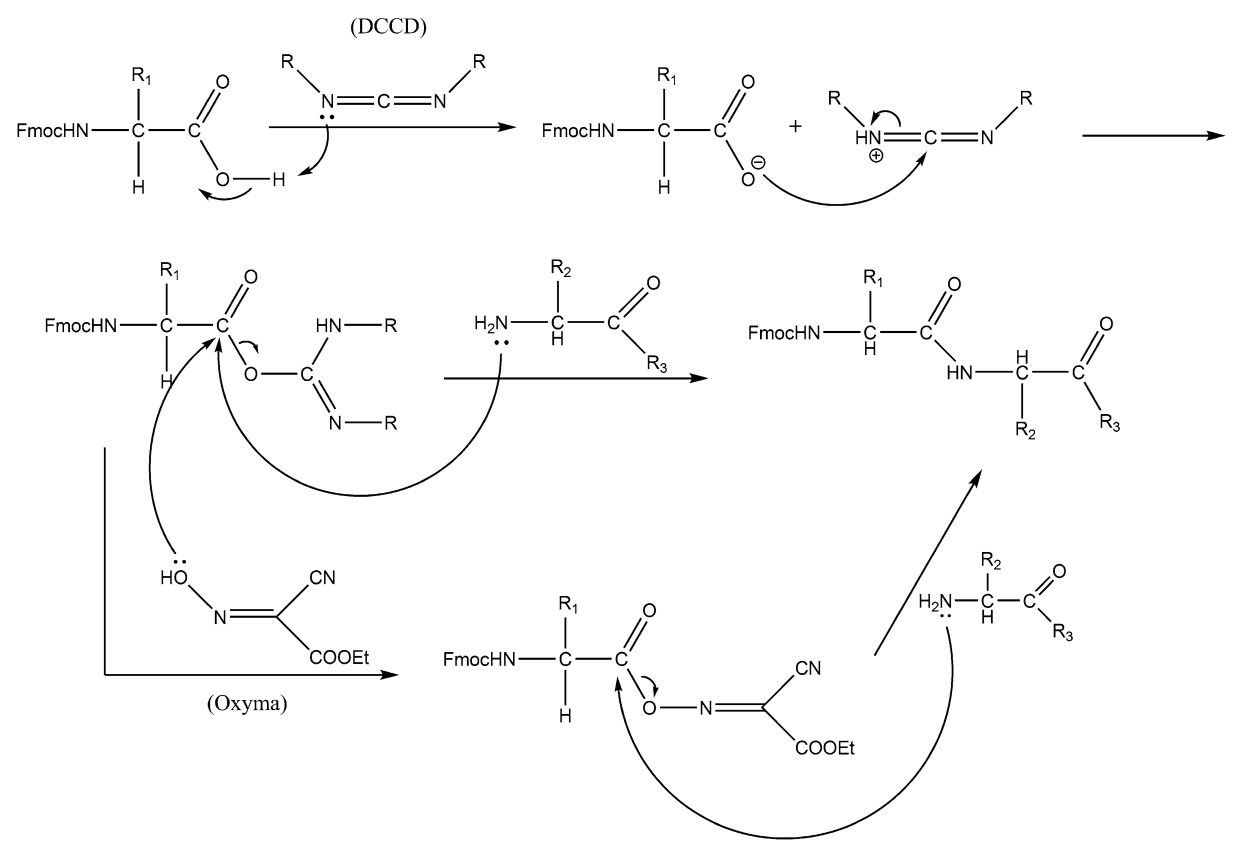

Fig. 10 Mechanism for the activation reaction by DCCD/Oxyma and the coupling of the activated Fmoc-amino acid to another amino acid. $\mathrm{R}_{1}$ is the side chain of the amino acid to be activated, $\mathrm{R}$ is radica group of DCCD (isopropyl, DIC, for example), $R_{2}$ is the side chain of

synthesis of peptides. For the synthesis of amidated peptides the anchorage of Fmoc-amino acid to resins and the peptide bond formation are very similar reactions and the mechanistic aspects of the most common methods employed are discussed in this section.

To achieve the coupling of the amino acid derivative, the use of aminium or phosphonium salts are the methods of choice. HBTU ([benzotriazol-1-yloxy(dimethylamino)methylidene]-dimethylazanium-hexafluorophosphate) is employed as a prototype of a aminium-type reagent (Al-Warhi et al. 2012). For conducting the anchorage of Fmoc-amino acid to linkers like the Rink amide resin and for performing the peptide coupling reaction during the synthesis, N,N-diisopropylethylamine (DIPEA), DMF and HBTU (structures shown in Fig. 7) are added beyond the Fmoc-amino acid to be coupled. DIPEA is used to deprotonate the acid group of the Fmocamino acid and DMF is the solvent for the reaction (Montalbetti and Falque 2005). For the amide bond formation, it is necessary to introduce an activating group in the Fmoc-amino acid to be coupled to reduce the free energy difference between the reagents and the activated complex to kinetically favor the

the second amino acid to be coupling with the first and $\mathrm{R}_{3}$ is a peptide chain. (Benoiton, 2005; Al-Warhi et al. 2012; Subirós-Funosas et al. 2009)

peptide bond formation (Najera 2002). The high kinetic barrier for peptide bond formation has as a counterpart, this is the very high stability of the peptide bond formed (Wolfenden 2006). Thus, the formation of the peptide bond and the amide bond to linkers are usually very stable even to some harsh conditions of synthesis. The added activating group is also a good leaving group that favors the reaction kinetically (Montalbetti and Falque 2005).

The suggested mechanism for the reaction of the activation of the amino acid derivative with the aminium-type reagent HBTU and the proton removal by DIPEA is shown in Fig. 8 . Initially, the acidic proton of the Fmoc-amino acid is removed by DIPEA or other organic base. Then, the deprotonated Fmocamino acid is added to HBTU, generating the elimination of a triazole derivative. Finally, this hydroxybenzotriazole derivative is added to the carbonyl group of the Fmoc-amino acid, leading to the formation of the final product, the activated Fmoc-amino acid, by nucleophilic substitution. Very similar mechanisms are valid for other aminium type reagents like TBTU ([benzotriazol-1-yloxy(dimethylamino) methylidene]dimethylazanium trifluoroborane fluoride) and HATU 
Table 1 Molecular weight of Fmoc-amino acids with protecting groups, free amino acids and amino acids within peptide

\begin{tabular}{lllc}
\hline & $\begin{array}{l}\text { MW (g/mol) } \\
\text { Fmoc-amino acid }\end{array}$ & $\begin{array}{l}\text { MW (g/mol) } \\
\text { Free-amino acid }\end{array}$ & $\begin{array}{c}\text { MW }(\mathrm{g} / \mathrm{mol}) \\
\text { Amino acid within a peptide }\end{array}$ \\
\hline Fmoc-Ala-OH & 311.3 & 89.1 & 71.1 \\
Fmoc-Arg(Pbf)-OH & 648.8 & 174.2 & 156.2 \\
Fmoc-Asn(Trt)-OH & 596.7 & 132.1 & 114.1 \\
Fmoc-Asp(OtBu)-OH & 411.5 & 133.1 & 115.1 \\
Fmoc-Cys(Trt)-OH & 585.7 & 121.2 & 103.2 \\
Fmoc-Glu(tBu)-OH & 443.5 & 147.1 & 129.1 \\
Fmoc-Gln(Trt)-OH & 610.7 & 146.1 & 128.1 \\
Fmoc-Gly-OH & 297.3 & 75.1 & 57.1 \\
Fmoc-His(Trt)-OH & 619.7 & 155.1 & 137.1 \\
Fmoc-Ile-OH & 353.4 & 131.2 & 113.2 \\
Fmoc-Leu-OH & 353.4 & 131.2 & 113.2 \\
Fmoc-Lys(Boc)-OH & 468.5 & 146.2 & 128.2 \\
Fmoc-Met-OH & 371.5 & 149.2 & 131.2 \\
Fmoc-Pro-OH & 337.4 & 115.1 & 97.1 \\
Fmoc-Phe-OH & 387.4 & 165.2 & 147.2 \\
Fmoc-Ser( $t$ Bu)-OH & 383.4 & 105.1 & 87.1 \\
Fmoc-Thr( $(t \mathrm{Bu}) \mathrm{OH}$ & 397.5 & 119.1 & 101.1 \\
Fmoc-Trp(Boc)-OH & 526.6 & 204.2 & 186.2 \\
Fmoc-Tyr(tBu)-OH & 459.6 & 181.2 & 163.2 \\
Fmoc-Val-OH & 339.4 & 117.1 & 99.1 \\
\hline
\end{tabular}

Fig. 11 Scheme for coupling an Fmoc-amino acid to another amino acid residue already attached to the resin. $R_{1}$ and $R_{2}$ attached to the resin. $R_{1}$ and $R_{2}$
are side chains of two different amino acids being linked
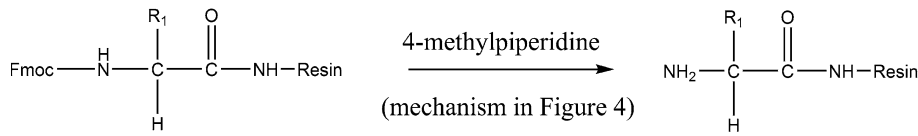<smiles>[R20]NC(=O)C([R7])N</smiles><smiles>[R]C([2H])C(=O)N[14CH2]F</smiles>

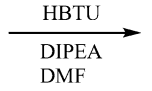

(mechanism in Figures 7 and 8)

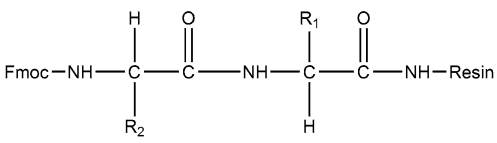

([dimethylamino(triazolo[4,5-b]pyridin-3-yloxy)methylidene]-dimethylazanium hexafluorophosphate) and phosphonium-type BOP (benzotriazol-1-yloxy-tris(dimethylamino)phosphanium hexafluorophosphate) and PyBOP (benzotriazol-1-yloxy(tripyrrolidin-1-yl)phos

phanium hexafluorophosphate)

Another method for coupling reaction can be performed by esterification of the carboxylic acid with 2,4,6-mesitylene-sulfonyl-3-nitro-1,2,4-triazol (MSNT) in the presence of 1-methylimidazol (Melm) (Blankemeyer-Menge et al. 1990). This procedure for anchoring Fmoc-amino acids to hydroxyl solid supports can achieve high yields and prevent the formation of dipeptide and racemization (Blankemeyer-Menge et al. 1990).

With the activated Fmoc-amino acid, it is possible to carry out the coupling of this activated compound to the resin or to another protected amino acid. The mechanism for the coupling reaction of an activated Fmoc-amino acid 
<smiles>CSc1ccccc1</smiles>

Thioanisole

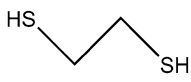

EDT
Fig. 12 Structures of thioanisole and EDT<smiles>[R]C(=O)NC(c1ccc(Br)cc1)c1ccc(OC)cc1OCC(=O)OC(F)(F)F</smiles><smiles>[R]C1CCCCCC1C(c1ccc(Br)cc1)c1ccc(OC)cc1OC</smiles>

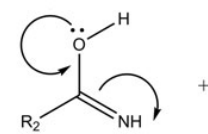

$$
\mathrm{MeO}
$$<smiles>[2H]c1ccc(C(CCCNCC)c2ccc(Br)cc2)c(OC)c1</smiles><smiles>[R]C([NH-])=[OH+]</smiles><smiles>[R]C(N)=O</smiles><smiles>[R]c1ccc(C([N])c2ccc(OC)cc2OC)cc1</smiles>
peptide bond formation.

Fig. 13 Reaction mechanism to remove the resin by TFA (Brady et al. 1977). In red, the linker structure to be removed by cleavage for

peptide chain and $\mathrm{Nu}$ is a nucleophilic compound (see Fig. 10) the formation of amidated peptide. $R_{1}$ is the resin chain, $R_{2}$ is a

to the resin is shown in Fig. 9. At first it takes place the nucleophilic substitution: the $-\mathrm{NH}_{2}$ group of the resin is added to the acyl carbon of the activated Fmoc-amino acid, followed by the elimination of 1-hydroxybenzotriazole after a proton transfer from the aminium group of the resin linker. As a result, there is the coupling of the Fmoc-amino acid to the resin. An analogous mechanism occurs for the

The other very widespread method for amino acid derivative activation is by means of carbodiimide, usually in the presence of a hydroxylamine derivative. There are 
Fig. 14 Removal of $t$-butyl group of serine. In red, the

group to be removed. $R_{1}$ and $R_{2}$

group to be removed. $\mathrm{R}_{1}$ and $\mathrm{R}_{2}$

are peptide chains and $\mathrm{Nu}$ is a

nucleophile compound present
in the cleavage process (Brady

in the cleavage process (Brady
et al. 1977) (Color figure online)
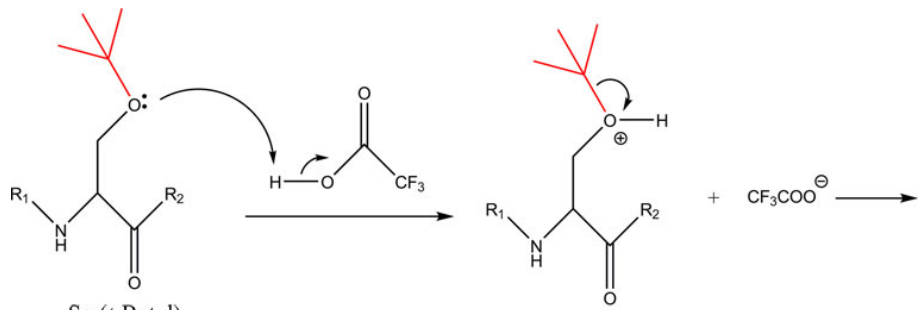

$\operatorname{Ser}(t$-Butyl)<smiles>[R]NC(CO)C([R])=O</smiles><smiles>[R]NC(CO)C([R])=O</smiles><smiles>CC(C)(C)[NH2+]</smiles>

Serine<smiles>[R]NC(Cc1cn(C)c2ccccc12)C(=O)OCCCCCCCC(=O)OC(C)(C)C</smiles>

$+\mathrm{CF}_{3} \mathrm{COO}^{\ominus}$

$\operatorname{Trp}(\mathrm{Boc})$<smiles>[R]NC(Cc1c[nH]c2ccccc12)C([R])=O</smiles><smiles>CC(C)(C)CC=N</smiles><smiles>NC(=O)C(N)Cc1c[nH]c2ccccc12</smiles>

$\mathrm{CO}_{2}$

Tryptophan

Fig. 15 Removal of Boc group from the protected tryptophan. In red, the group that will be removed. $R_{1}$ and $R_{2}$ are peptide chains and Nu is a nucleophile compound present in the cleavage process (Brady et al. 1977) (Color figure online) 
Fig. 16 Structure of TIS<smiles>CC(C)[SiH](C(C)C)C(C)C</smiles>

TIS

many carbodiimides available in the literature, but the most widely used is 1,3-diisopropylcarbodiimide, whose side product is a urea that is soluble in DMF and DCM. Nevertheless, it is not advisable to couple amino acid derivatives only in the presence of the carbodiimide since this usually leads to a high level of enantiomerization through an oxazolone intermediate (Montalbetti and Falque 2005; Wolfenden 2006; Benoiton 1996) stabilized by resonance. In fact, 2-phenyl-5-oxazolone (Yalcin et al. 1995), which is a useful reference compound for peptide fragmentation in mass spectrometry, is being prepared by activation with a carbodiimide, which clearly shows a straightforward formation of oxazolones by carbodiimide. The mechanism of carboxyl group activation is shown in Fig. 10. The carboxyl group performs a nucleophilic attack of the electrophilic carbon of carbodiimide, which occurs together with a proton transfer. Since the carbodiimide has a basic nitrogen capable of accepting the carboxyl proton, one of the advantages of this reagent compared to aminium or phosphonium salts is that it is not necessary to add an organic base to generate the carboxylate. Nevertheless, the $O$-acyl isourea formed is activated (i.e. it has a very good leaving group and a high free energy content), which favours the oxazole formation and amino acid enantiomerization. A hydroxylamine is usually added to prevent enantiomerization by converting the $O$-acyl isourea into a less active intermediate. 1-hydroxybenzotriazole and other triazole derivatives such as 1-hydroxy-7-azabenzotriazole (Chan and White 2000; Carpino 1993) are very efficient suppressors of racemization, but triazoles may be explosive under certain conditions, which made the international transport of those chemicals difficult. Fortunately, the reagent ethyl (2Z)-2-cyano-2-hydroxyiminoacetate (the socalled Oxyma) was recently introduced as a safe and efficient suppressor of enantiomerization (Subirós-Funosas et al. 2009). Like the benzotriazoles, oxyma has an hydroxylamine function which performs a nucleophilic attack on the $O$-acyl isourea amino acid derivative forming an active ester (Fig. 10).

As the first amino acid residue bound to the resin or the amino acid residue introduced has the temporary protecting group, in our case the Fmoc group, the deprotection should be carried out again with 4-methylpiperidine/DMF (1/4,<smiles>[R]NC(CC(=O)OC(C)(C)C)C([R])=O</smiles>

Asp(O-t-Butyl)
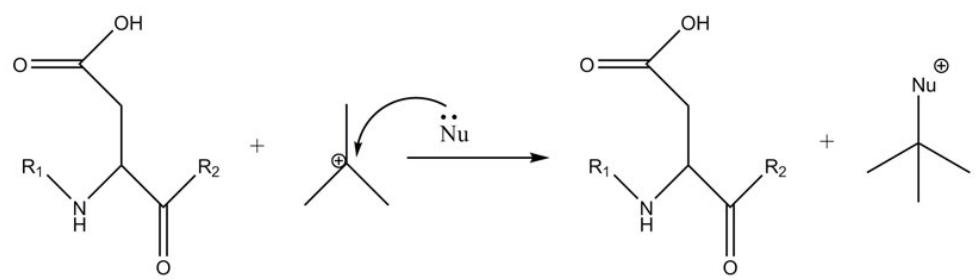

Aspartic acid

Fig. 17 Removal of O-t-butyl group from the protected aspartic acid. In red, the group that will be removed. $\mathrm{R}_{1}$ and $\mathrm{R}_{2}$ are peptide chains and $\mathrm{Nu}$ is a nucleophilic compound present in the cleavage process (Color figure online) 

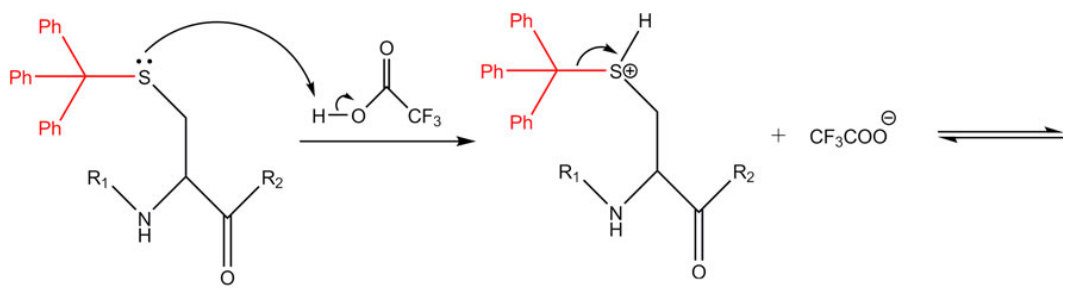

Cys(Trt)

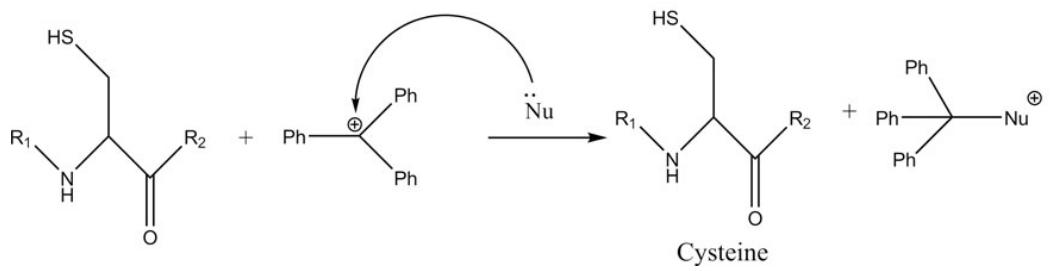

Fig. 18 Removal of Trt group from the protected cysteine. The group that will be removed is represented in red. $R_{1}$ and $R_{2}$ are peptide chains and $\mathrm{Nu}$ is a nucleophilic compound present in the cleavage process that scavengers the carbocation (Benoiton 2005) (Color figure online)

$\mathrm{v} / \mathrm{v}$ ) for the removal of this group (as previously described) and making it possible to continue the synthesis and the coupling of the following Fmoc-amino acid. To check if the amino acid residue is without the Fmoc group (i.e. with a free amino group), the ninhydrin test must be held again.

The 20 most common Fmoc-amino acids that can be used on solid-phase synthesis are listed in Table 1, showing also the permanent protecting group (i.e., side chain) and their molecular weight. The side chain permanent protecting group is only removed in the final cleavage step that is discussed in the next session. If the side chain protecting group remains bound to the peptide, the mass addition can easily be detected by mass spectrometry (Table 1).

A scheme for coupling an Fmoc-amino acid to another amino acid residue already attached to the resin is shown in Fig. 11.

\section{Cleavage}

After performing the coupling of all Fmoc-amino acids of the peptide sequence, the next step is the process of cleavage for removing the resin and the side chains protecting groups (Fig. 2) and thus obtain the desired peptide, free of any protecting group or structural modification, except for special cases when a side chain protected peptide is necessary, as in the fragment condensation, orthogonal protection or modification and folding, among others. Our discussion will be focused on the methods applied to acid-labile linkers compatible with the Fmoc strategy. For the cleavage and removal of a permanent protecting group, the experimental procedure consists of adding to a tube the peptidyl-resin and a solution containing trifluoroacetic acid (TFA) in the presence of carbocation scavengers. When the peptide contains side chains prone to alkylation, such as sulfhydryl, thioether, indole and phenol, the use of a mixture of different nucleophilic scavengers is recommended (King et al. 1990). Examples of popular mixtures are $81.5 \%$ TFA, $5 \%$ thioanisole, $5 \%$ phenol, $5 \%$ water, $2.5 \%$ ethanedithiol (EDT), and $1 \%$ TIS (by volume) or $92.5 \%$ TFA, $2.5 \%$ water, $2.5 \%$ TIS and $2.5 \%$ EDT (Fields and Noble 1990; Chan and White 2000; Benoiton 2005). The mixture is allowed to react under stirring for $90 \mathrm{~min}$. After completing the reaction, nitrogen gas is bubbled into the solution to evaporate most of the solvents. With positive pressure via nitrogen, the cleaved peptide is then washed, preferably with cold diisopropyl ether. Then, the peptide is extracted with an aqueous solution of acetonitrile ( $50 \%$ by volume $+0.1 \%$ TFA, for keeping the peptide under slight acidic condition) and freeze-dried. Upon lyophilization, the synthetic peptide can be characterized by mass spectrometry (Karas and Hillenkanp 1988; Fen et al. 1989; Biemann and Papayannopoulos 1994).

The process of cleavage by TFA leads to the formation of carbocations that are highly reactive intermediates. They may specifically react with side chains of tyrosine, 


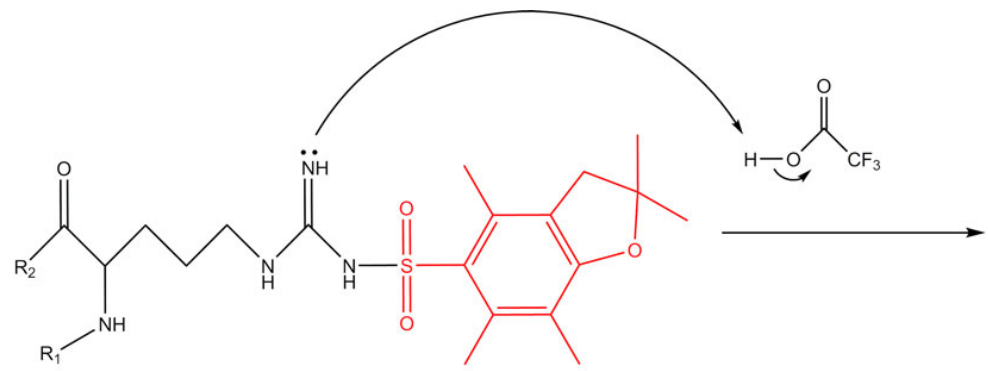

$\operatorname{Arg}(\mathrm{Pbf})$

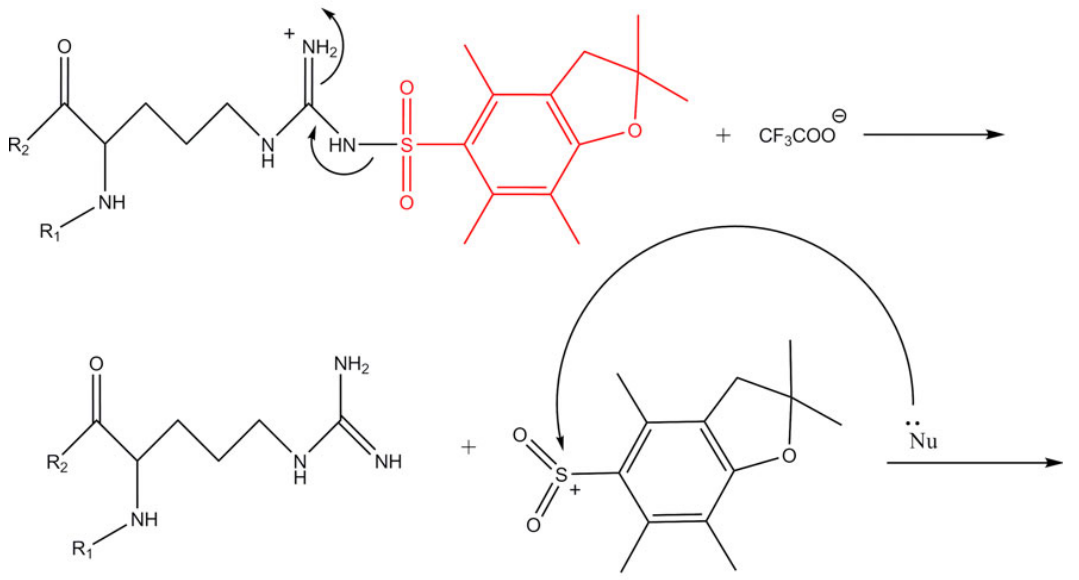<smiles>[R]NC(CCCNC(=N)N)C([R])=O</smiles>

Arginine

Fig. 19 Removal of $\mathrm{Pbf}$ group from the protected arginine. In red, the group that will be removed. $\mathrm{R}_{1}$ and $\mathrm{R}_{2}$ are peptide chains and $\mathrm{Nu}$ is a nucleophilic compound present in the cleavage process (Carpino et al. 1993) (Color figure online)

tryptophan, methionine and cysteine (which are rich in electrons) generating undesirable products (Chan and White 2000). To prevent this, good nucleophilic species are added to the cleavage reaction, such as thioanisole (methylsulfanylbenzene) and 1,2-ethanedithiol (EDT) (Chan an White 2000), whose structures are shown in Fig. 12. The reaction mechanism for the cleavage by acidolysis of a Rink-amide type peptidyl-resin linkage is shown in Fig. 13.

Fmoc-amino acids such as serine, threonine, and cysteine derivatives, among others, have not only alkyl groups in their side chain but also contain reactive functional groups that need permanent protection (Fig. 2) in order to 
prevent unwanted reactions in these groups throughout the synthesis. These protecting groups must be removed in this final process of cleavage.

The cleavage of $t$-butyl and Boc protecting groups (Fig. 2) leads to the formation of $t$-butyl cations by a $\mathrm{S}_{\mathrm{N}}$ reaction. The proposed mechanisms are shown in Figs. 14 and 15 , respectively. The t-butyl carbocation is one of the most stable among common alkyl or aryl groups (March 1992). Thus, despite still being an transient specie, it has a sufficiently long lifetime to alkylate electron-rich peptide moieties. This means these carbocations may react with tryptophan, leading to its alkylation (Fields and Noble 1990). To avoid this reaction, EDT is added to the cleavage process to sequester $t$-butyl cations. To completely prevent alkylation of tryptophan, thioanisole (methylsulfanylbenzene) is also very efficient and thus it is employed as a second scavenger (Fields and Noble 1990).

The cleavage of the Trt group from cysteine is reversible without the presence of carbocation receptors (Fields and Noble 1990). Triphenylmethyl (or Trt) is a well-studied carbocation that has a non-planar structure with a central carbon with a high charge density accordingly to its NMR carbon chemical shift data (March 1992). To avoid this reversibility, phenol and triisopropylsilane (tri(propan-2yl)silicon, TIS (structure shown in Fig. 16) are added to the cleavage process (Fields and Noble 1990). The mechanisms for the removal of the protecting groups $O$ - $t$-butyl, Trt and Pbf are shown in Figs. 17, 18 and 19, respectively.

Although (Carpino et al. 1993) gives evidences of a $S_{N}$ reaction for the removal of $\mathrm{Pbf}$ group, Han et al. (1996) suggests that some scavengers are necessary to remove this group, indicating a possibility of a $\mathrm{S}_{\mathrm{N}} 2$ reaction.

All the mechanisms showed before for the process of the cleavage for the removal of the side-chain protecting groups (Figs. 13, 14, 15, 17, 18, 19) involves the acceptance of the acidic proton from TFA by the most basic electron-pair of the protected amino acid. This leads to the elimination of the protecting group as a highly reactive carbocation, which promptly reacts with the nucleophiles scavenger present in the reaction medium (e.g. EDT, thioanisole and TIS).

\section{Conclusion}

SPPS is the method of choice to introduce non-natural peptides.

This paper presents all the stages of the synthesis using the Fmoc strategy, while also addressing the mechanisms involved in each step, which can enable a better understanding of this process. This short review can also be used in basic organic chemistry courses for biology students, contextualizing and exemplifying some organic reactions in the synthesis of peptides.

Acknowledgments The authors are thankful to Andrew William Gerard Murray for the English revision.

Conflict of interest The authors declare that they have no conflict of interest.

Compliance With Ethics This article does not contain any studies with human or animal subjects.

\section{References}

Akaji K, Kuriyama N, Kimura T, Fujiwara Y, Kiso Y (1992) Anchoring of Fmoc amino scid to 4-alkoxybenzyl alcohol resin using a new esterification reagent. Tetrahed Lett 33:3177-3180 Albericio F (2004) Developments in peptide and amide synthesis. Curr Opin Chem Biol 8:211-221

Al-Warhi TI, Al-Hazimi HMA, El-Faham A (2012) Recent development in peptide coupling reagents. J Saudi Chem Soc 16:97-116 Amblard M, Fehrentz JA, Martinez J, Subra G (2005) Fundamental of modern peptide synthesis. Methods Mol Biol 218:3-24

Amblard M, Fehrentz JA, Martinez J, Subra G (2006) Methods and protocols of modern solid phase peptide synthesis. Mol Biotechnol 33:239-253

Aucagne V, Valverde IE, Marceau P, Galibert M, Dendane N, Delma AF (2012) Towards the simplification of protein synthesis: iterative solid-supported ligations with concomitant purifications. Angew Chem Int Ed 51:11320-11324

Barlos K, Gatos D, Kallitsis J, Papaphotiu G, Sotiriu P, Yao W, Schaefer W (1989) Preparation of protected peptide fragments using triphenylmethyl resins. Tetrahedron Lett 30:3943-3946

Benoiton NL (1996) 2-Alkoxy-5(4H)-oxazolones and the enantiomerization of $\mathrm{N}$-alkoxycarbonylamino acids. Biopolymers 40:245-254

Benoiton NL (2005) Chemistry of peptide synthesis. Taylor and Francis, Boca Raton

Biemann K, Papayannopoulos IA (1994) Amino acid sequencing of proteins. Acc Chem Res 27:370-378

Blackburn C (2005) Solid-phase synthesis of 2-amino-3-chloro-5- and 8-nitro-1,4-naphthoquinones: a new and general colorimetric test for resin-bound amines. Tetrahed Lett 46:1405-1409

Blankemeyer-Menge B, Nimtz M, Frank R (1990) An efficien method for anchoring Fmoc-amino acids to hydroxyl-functionalised solid supports. Tetrahed Lett 31(12):1701-1704

Bong DT, Clark TD, Granja JR, Ghadiri MR (2001) Self-assembling organic nanotubes. Angew Chem Int 16:988-1011

Brady SF, Hirschmann R, Veber DF (1977) Some novel acid-labile amine protecting groups. J Org Chem 42:143-146

Brogden KA (2005) Antimicrobial peptides: pore formers or metabolic inhibitors in bacteria? Nature Rev 3:238-250

Carpino L (1987) The 9-fluorenylmethyloxycarbonyl family of basesensitive amino-protecting groups. Acc Chem Res 20:401-407 Carpino LA (1993) 1-Hydroxy-7-azabenzotriazole. an efficient peptide coupling additive. J Am Chem Soc 115:4397-4398

Carpino LA, Han GY (1972) The 9-Fluorenylmethoxycarbonyl amino-protecting group. J Org Chem 37:3404-3409

Carpino LA, Shroff H, Triolo SA, Mansour EME, Wenschuh H, Albericio F (1993) The 2,2,4,6,7-Pentamethyldihydrobenzofuran-5-sulfonyl Group (Pbf) as arginine side chain protectant. Tetrahedr Lett 34:7829-783 
Chan WC, White PD (2000) Fmoc solid phase peptide synthesis. PAS, Oxford

Chen P (2005) Self-assembly of ionic-complementary peptides: a physicochemical viewpoint. Colloids Surf A 261:3-24

Elsawy MA, Hewage C, Walker B (2012) Racemisation of N-Fmoc phenylglycine under mild microwave-SPPS and conventional stepwise SPPS conditions: attempts to develop strategies fo overcoming this. J Pept Sci 18:302-311

Fen JB, Man M, Meng CK, Wong SF, Whitehouse CM (1989) Electrospray ionization for mass spectrometry of large biomolecules. Science 246:64-71

Fields GB, Noble RL (1990) Solid phase peptide synthesis utilizing 9-fluorenylmethoxycarbonyl amino acids. Int J Pept Protein Res 35:161-214

Friedman M (2004) Applications of the ninhydrin reaction for analysis of Amino acids, peptides, and proteins to agricultural and biomedical Sciences. J Agric Food Chem 52:385-406

Gisisn BT (1972) The monitoring of reactions in solid-phase peptide synthesis with picric acid. Anal Chim Acta 58:248-249

Goldberg JS (2010) Stereochemical basis for a unified structure activity theory of aromatic and heterocyclic rings in selected opioids and opioid peptides. Pers Med Chem 4:1-10

Gońgora-Benítez M, Tulla-Puche J, Albericio F (2013) Handles for Fmoc solid-phase synthesis of protected peptides. ACS Comb Sci 15:217-228

Gravert DJ, Janda KD (1997) Organic synthesis on soluble polyme supports: liquid-phase methodologies. Chem Rev 97:489-509

Hachmann J, Lebl M (2006) Alternative to piperidine in Fmoc solidphase synthesis. J Comb Chem 8(2): 149-149

Han Y, Bontems SL, Hegyes P, Munson MC, Minor CA, Kates SA, Albericio F, Barany G (1996) Preparation and applications of Xanthenylamide (XAL) handles for solid-phase synthesis of c-terminal peptide amides under particularly mild conditions. J Org Chem 61:6326-6339

Hancock REW, Scott MG (2000) The role of antimicrobial peptides in animal defenses. Proc Natl Acad Sci USA 97:8856-8861

Hibino H, Nishiuchi Y (2012) 4-Methoxybenzyloxymethyl group, a racemization-resistant protecting group for cysteine in Fmoc solid phase peptide synthesis. Org Lett 14:1926-1929

Howl J (2005) Peptide synthesis and applications. Humana Press, New York

Hudson D (1988) Methodological implications of simultaneous solidphase peptide synthesis - comparison of different coupling procedures. J Org Chem 53:617-62

Isidro-Llobet A, Alvarez M, Alberico F (2009) Amino acid-protecting groups. Chem Rev 109:2455-2504

James IW (1999) Linkers for solid phase organic synthesis. Tetrahedron 55:4855-4946

Jensen KJ (2013) Solid-phase peptide synthesis: an introduction. Methods Mol Biol 1047:1-22

Kaiser E, Colescott RL, Bossinger CD, Cook PI (1970) Color test for detection of free terminal amino groups in the solid-phase synthesis of peptide. Anal Biochem 34:595-598

Karas M, Hillenkanp F (1988) Laser desorption ionization of protein with molecular masses exceeding 10,000 daltons. Anal Chem 60:2299-2301

Kaupp G, Naimi-Jamal MR, Schmeyers J (2002) Quantitative reaction cascades of ninhydrin in the solid state. Chem Eur J 8(3):594-600

Kilk K, Langel Ü (2006) Cellular delivery of peptide nucleic acid by cell-penetrating Peptides. Methods Mol Biol 218:131-142

King DS, Fields CG, Fields GB (1990) A cleavage method which minimizes side reactions following Fmoc solid phase peptide synthesis. Int J Pept Prot Res 36:255-266

Lloyd-Williams P, Albericio F, Giralt E (1993) Convergent solidphase peptide synthesis. Tetrahedron 49:11065
Machado A, Liria CW, Proti PB, Remuzgo C, Miranda MTM (2004) Síntese química e enzimática de peptídeos: princípios básicos e Sintese química e enzimática de pep
aplicacões. Quim Nova 37:781-789

March J (1992) Advanced organic chemistry. John Wiley \& Sons, New York

Marquardt M, Eifler-Lima VL (2001) A síntese orgânica em fase sólida e seus suportes poliméricos mais empregados. Quim Nova 24:846-855

McCaldin DJ (1959) The chemistry of ninhydrin. Chem Rev 1:39-51 Menezes MC, Oliveira AK, Melo RL, Ferreira ML, Rioli V, Balan A Leme AFP, Serrano SMT (2011) Disintegrin-like/cysteine-rich domains of the reprolysin HF3. site-directed mutagenesis reveal essential role of specific residues. Biochimie 93:345-351

Mergler M, Dick F (2005) The aspartimide problem in Fmoc-based SPPS. part III. J Peptide Sci 11:650-657

Merrifield RB (1963) Solid phase peptide synthesis - the synthesis of a tetrapeptide. J Am Chem Soc 85:2149-2154

Miranda LP, Alewood PF (1999) Accelerated chemical synthesis of peptides and small proteins. Proc Natl Acad Sci 96:1181-1186 Montalbetti CGN, Falque V (2005) Amide bond formation and peptide coupling. Tetrahedron 740:10827-10851

Naidoo VB, Rautenbach M (2012) Bidirectional solid phase synthesis of a model oligoglycine bolaamphiphile and purification by rapid self-assembly. J Pept Sci 18:317-325

Najera C (2002) From $\alpha$-Amino acids to peptides: all you need for the journey. Synlett 9:1388-1402

Pedersen SL, Jensen KJ (2013) Instruments for automated peptide synthesis. Methods Mol Biol 1047:43-63

Plaquevent JC, Levillain J, Guillen F, Malhiac C, Gaumont AC (2008) Ionic liquids: new targets and media for alpha-amino acid and peptide chemistry. Chem Rev 108:5035-5060

Remuzgo C, Andrade GFS, Temperini MLA, Miranda MTM (2009) Acanthoscurrin fragment 101-132: total synthesis at $60^{\circ} \mathrm{C}$ of a novel difficult sequence. Biopolym Pept Sci 92:65-75

Schnolzer M, Alewood P, Jones A, Alewood D, Kent SBH (2007) In situ neutralization in Boc-chemistry solid phase peptide synthesis. Int J Pept Res Ther 13:31-44

Shelton PT, Jensen KJ (2013) Linkers, resins, and general procedures for solid-phase peptide synthesis. Methods Mol Biol 1047:23-42 Subirós-Funosas R, Prohens R, Barbas R, El-Faham A Albericio F (2009) Oxyma: an efficient additive for peptide synthesis to replace the benzotriazole-based HOBt and HOAt with a lower risk of explosion. Chem Eur J 15:9394-9403

Tailhades J, Gidel MA, Grossi B, Lécaillon J, Brunel I, Subra G, Martinez J, Amblard M (2010) Synthesis of peptide alcohols on the basis of an $O-N$ acyl-transfer reaction. Angew Chem Int Ed 49:117-120

Takahashi D, Yamamoto T (2012) Development of an efficient liquidphase peptide synthesis protocol using a novel fluorene-derived anchor support compound with Fmoc chemistry. Tetrahed Lett 53:1936-1939

Tietze AA, Heimer P, Stark A, Imhof D (2012) Ionic liquic applications in peptide chemistry: synthesis, purification and
analytical characterization processes. Molecules 17:4158-4185

Troll W, Cannan RK (1952) A modified photometric ninhydrin method for the analysis of amino and imino acids. J Biol Chem 1:803-811

Wolfenden R (2006) Degrees of difficulty of water-consuming reactions in the absence of enzymes. Chem Rev 106:3379-3396

Yalcin T, Khouw C, Csizmadia IG, Peterson MR, Harrison AG (1995) Why are B ions stable species in peptide spectra? J Am Soc Mass Spectrom 6:1165-1174

Zalipsky S, Chang JL, Albericio F, Barany G (1994) Preparation and applications of polyethylene glycol-polystyrene graft resin supports for solid-phase peptide synthesis. React Funct Polym 22:243-258 


\section{Author's personal copy}

Zasloff M (2002) Antimicrobial peptides of multicellular organisms. Nature 415:389-395

Zhang T, Li Y, Miao M, Jiang B (2011) Purification and characterisation of a new antioxidant peptide from chickpea (Cicer arietium L.) protein hydrolysates. Food Chem 128:28-33
Zhang Y, Muthana SM, Farnsworth D, Ludek O, Adams K, Barchi JJ Jr, Gildersleeve JC (2012) Enhanced epimerization of glycosylated amino acids during solid-phase peptide synthesis. J Am ated amino acids during 


\section{Anexo 84}

\begin{tabular}{|c|c|c|c|}
\hline Átomo & $\delta$ (ppm) & Átomo & $\delta$ (ppm) \\
\hline 1.HT1 & 7.615 & 4.CZ2 & 131.846 \\
\hline 1.CA & 54.566 & 4.HZ2 & 7.416 \\
\hline 1.HA & 3.710 & 4. $\mathrm{CH} 2$ & 122.108 \\
\hline 1.CB & 61.191 & 4. $\mathrm{HH} 2$ & 7.195 \\
\hline 1.HB2 & 3.634 & 4.CZ3 & 118.241 \\
\hline 1.HB1 & 3.712 & 4.HZ3 & 6.891 \\
\hline 1.CD1 & 130.813 & 4.CE3 & 120.846 \\
\hline 1.HD1 & 7.389 & 4.HE3 & 7.527 \\
\hline 1.CE1 & 144.689 & $5 . \mathrm{HN}$ & 8.330 \\
\hline 1.HE1 & 7.501 & 5.CA & 56.545 \\
\hline 1.CZ & 124.702 & 5.HA & 3.795 \\
\hline 1.HZ & 7.260 & 5.CB & 29.442 \\
\hline 1.CE2 & 144.689 & 5. HB2 & 1.271 \\
\hline 1.HE2 & 7.501 & 5.HB1 & 1.572 \\
\hline 1.CD2 & 130.813 & 5.CG & 21.612 \\
\hline 1.HD2 & 7.389 & 5.HG2 & 0.343 \\
\hline 2.HN & 8.484 & 5.HG1 & 0.544 \\
\hline 2.HA & 4.645 & 5.CD & 26.172 \\
\hline 2.CB & 42.176 & 5.HD2 & 1.337 \\
\hline 2.HB2 & 2.755 & 5.HD1 & 1.337 \\
\hline 2.HB1 & 2.818 & 5.CE & 37.874 \\
\hline 3.HN & 8.122 & 5.HE2 & 2.700 \\
\hline 3.CA & 55.254 & 5.HE1 & 2.700 \\
\hline 3.HA & 4.606 & 5.HZ1 & 7.429 \\
\hline 3.CB & 38.992 & 6.HN & 8.008 \\
\hline 3. HB2 & 2.824 & 6.CA & 59.987 \\
\hline 3.HB1 & 3.031 & 6.HA & 4.419 \\
\hline 3.CD1 & 133.435 & 6.CB & 66.437 \\
\hline 3.HD1 & 7.131 & 6. HB & 4.320 \\
\hline 3.CE1 & 132.124 & 6.CG2 & 19.030 \\
\hline 3.HE1 & 7.278 & 6.HG21 & 1.232 \\
\hline 3.CE2 & 132.124 & 7. HN & 7.842 \\
\hline 3.HE2 & 7.278 & 7. HA & 4.733 \\
\hline 3.CD2 & 133.435 & 7.CB & 37.099 \\
\hline 3.HD2 & 7.131 & 7.HB2 & 2.938 \\
\hline 4.HN & 8.592 & 7.HB1 & 3.197 \\
\hline 4.CA & 54.931 & $8 . \mathrm{HN}$ & 7.614 \\
\hline 4.HA & 4.119 & 8.CA & 56.029 \\
\hline 4.CB & 26.172 & 8. HA & 4.016 \\
\hline 4.HB2 & 2.844 & 8.CB & 66.009 \\
\hline 4. HB1 & 2.994 & 8. HB & 3.852 \\
\hline 4.CD1 & 127.127 & 8.CG2 & 19.031 \\
\hline 4.HD1 & 7.122 & 8.HG21 & 1.143 \\
\hline
\end{tabular}

Anexo 84: Assinalamento dos átomos de hidrogênio e carbono do peptídeo TOC1. 


\section{Anexo 85}

\begin{tabular}{|c|c|c|c|}
\hline Átomo & $\delta$ (ppm) & Átomo & $\delta(p p m)$ \\
\hline 1.HT1 & 7.655 & 4.CZ2 & 131.848 \\
\hline 1.CA & 57.006 & 4. $\mathrm{HZ2}$ & 7.384 \\
\hline 1.HA & 4.264 & 4. $\mathrm{CH} 2$ & 122.066 \\
\hline 1.CB & 64.244 & 4. $\mathrm{HH} 2$ & 7.206 \\
\hline 1.HB2 & 3.614 & 4.CZ3 & 118.205 \\
\hline 1.HB1 & 3.708 & 4.HZ3 & 6.900 \\
\hline 1.CD1 & 130.651 & 4.CE3 & 120.93 \\
\hline 1.HD1 & 7.373 & 4.HE3 & 7.548 \\
\hline 1.CE1 & 144.672 & 5.HN & 8.321 \\
\hline 1.HE1 & 7.499 & 5.CA & 57.368 \\
\hline 1.CZ & 124.601 & 5.HA & 3.819 \\
\hline $1 . \mathrm{HZ}$ & 7.264 & 5.CB & 32.366 \\
\hline 1.CE2 & 144.672 & 5.HB2 & 1.265 \\
\hline 1.HE2 & 7.499 & 5.HB1 & 1.563 \\
\hline 1.CD2 & 130.651 & 5.CG & 24.240 \\
\hline 1.HD2 & 7.373 & 5. HG2 & 0.361 \\
\hline 2.HN & 8.429 & 5.HG1 & 0.554 \\
\hline 2. $\mathrm{HA}$ & 4.703 & 5.CD & 28.768 \\
\hline 2.CB & 44.299 & 5.HD2 & 1.349 \\
\hline 2.HB2 & 2.879 & 5.HD1 & 1.349 \\
\hline 2.HB1 & 3.121 & 5.CE & 41.742 \\
\hline 3.HN & 8.190 & 5.HE2 & 2.702 \\
\hline 3.CA & 57.683 & 5.HE1 & 2.702 \\
\hline 3.HA & 4.625 & 5.HZ1 & 7.429 \\
\hline 3.CB & 40.492 & $6 . \mathrm{HN}$ & 8.018 \\
\hline 3.HB2 & 2.856 & 6.CA & 69.245 \\
\hline 3. HB1 & 3.002 & 6. HA & 4.397 \\
\hline 3.CD1 & 133.445 & 6.CB & 62.618 \\
\hline 3.HD1 & 7.160 & $6 . \mathrm{HB}$ & 4.315 \\
\hline 3.CE1 & 132.056 & 6.CG2 & 21.740 \\
\hline 3.HE1 & 7.245 & 6.HG21 & 1.230 \\
\hline 3.CE2 & 132.056 & 7.HN & 7.868 \\
\hline 3.HE2 & 7.245 & 7.HA & 4.748 \\
\hline 3.CD2 & 133.445 & 7.CB & 41.742 \\
\hline 3.HD2 & 7.160 & 7.HB2 & 2.924 \\
\hline 4.HN & 8.609 & 7.HB1 & 3.218 \\
\hline 4.CA & 58.819 & 8.HN & 7.659 \\
\hline 4.HA & 4.179 & 8.CA & 68.955 \\
\hline 4.CB & 29.241 & 8.HA & 3.993 \\
\hline 4.HB2 & 2.894 & 8.CB & 59.244 \\
\hline 4.HB1 & 3.027 & 8.HB & 3.842 \\
\hline 4.CD1 & 127.259 & 8.CG2 & 21.740 \\
\hline 4.HD1 & 7.145 & 8.HG21 & 1.136 \\
\hline
\end{tabular}

Anexo 85: Assinalamento dos átomos de hidrogênio e carbono do peptídeo TOC2. 


\section{Anexo 86}

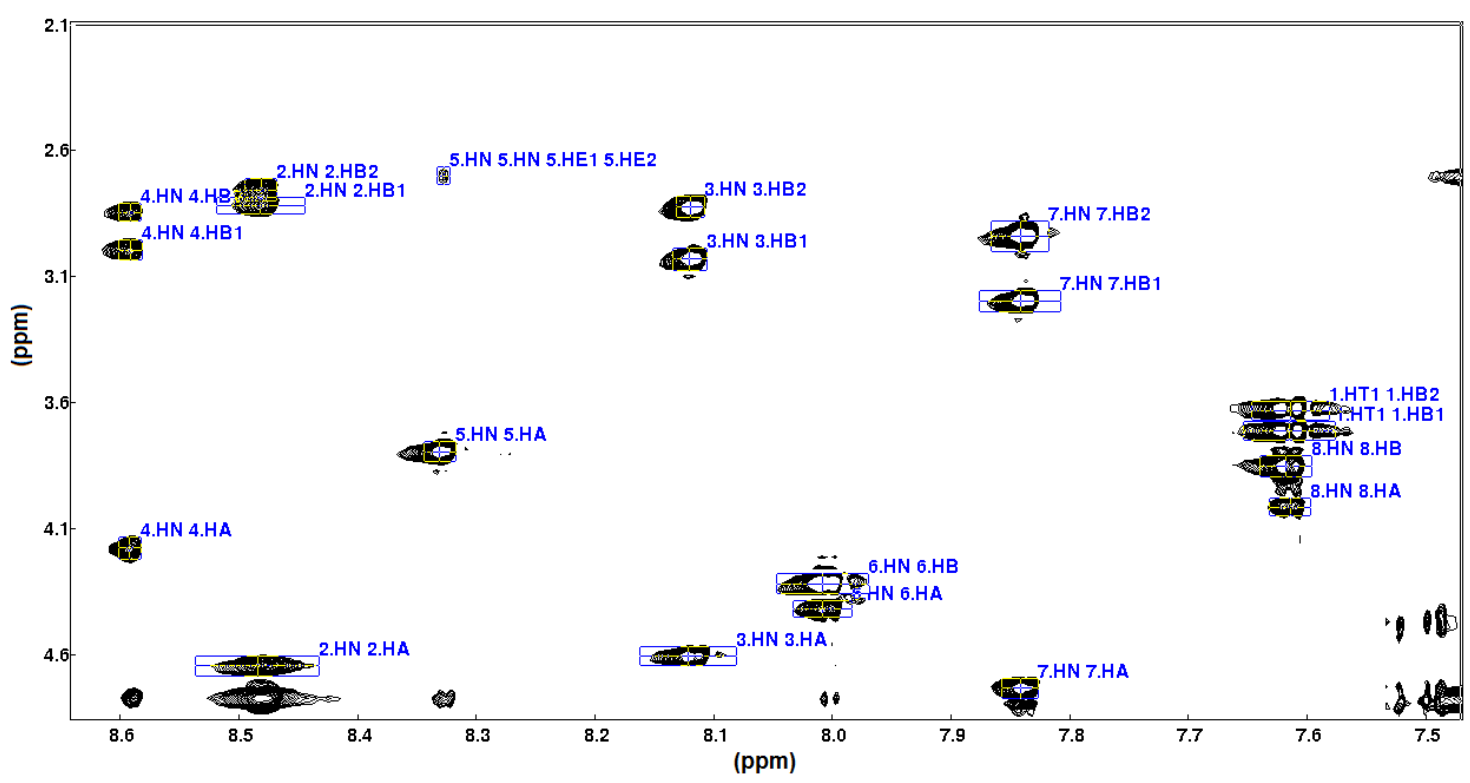

Anexo 86: Região aromática do espectro TOCSY do peptídeo TOC1, indicando parte dos sistemas de spins dos 8 resíduos de aminoácidos presentes na sequência do peptídeo.

\section{Anexo 87}

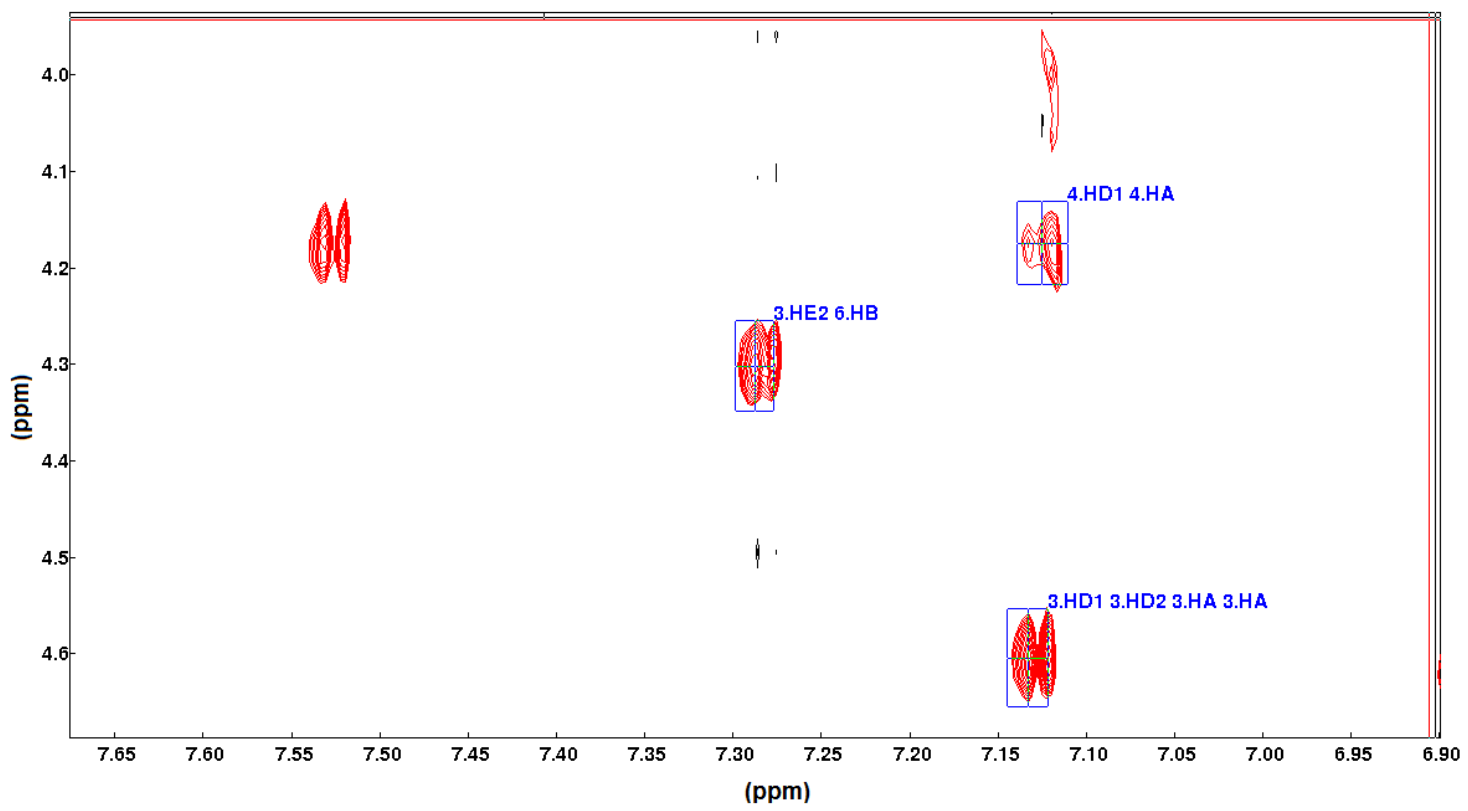

Anexo 87: Expansão de uma parte da região aromática do espectro ROESY do peptídeo TOC1. É observado ROE entre os resíduos de aminoácidos $\mathrm{Tyr}^{3}$ e $\mathrm{Thr}^{6}$, que confirma a forma ciclizada do peptídeo. 
Anexo 88

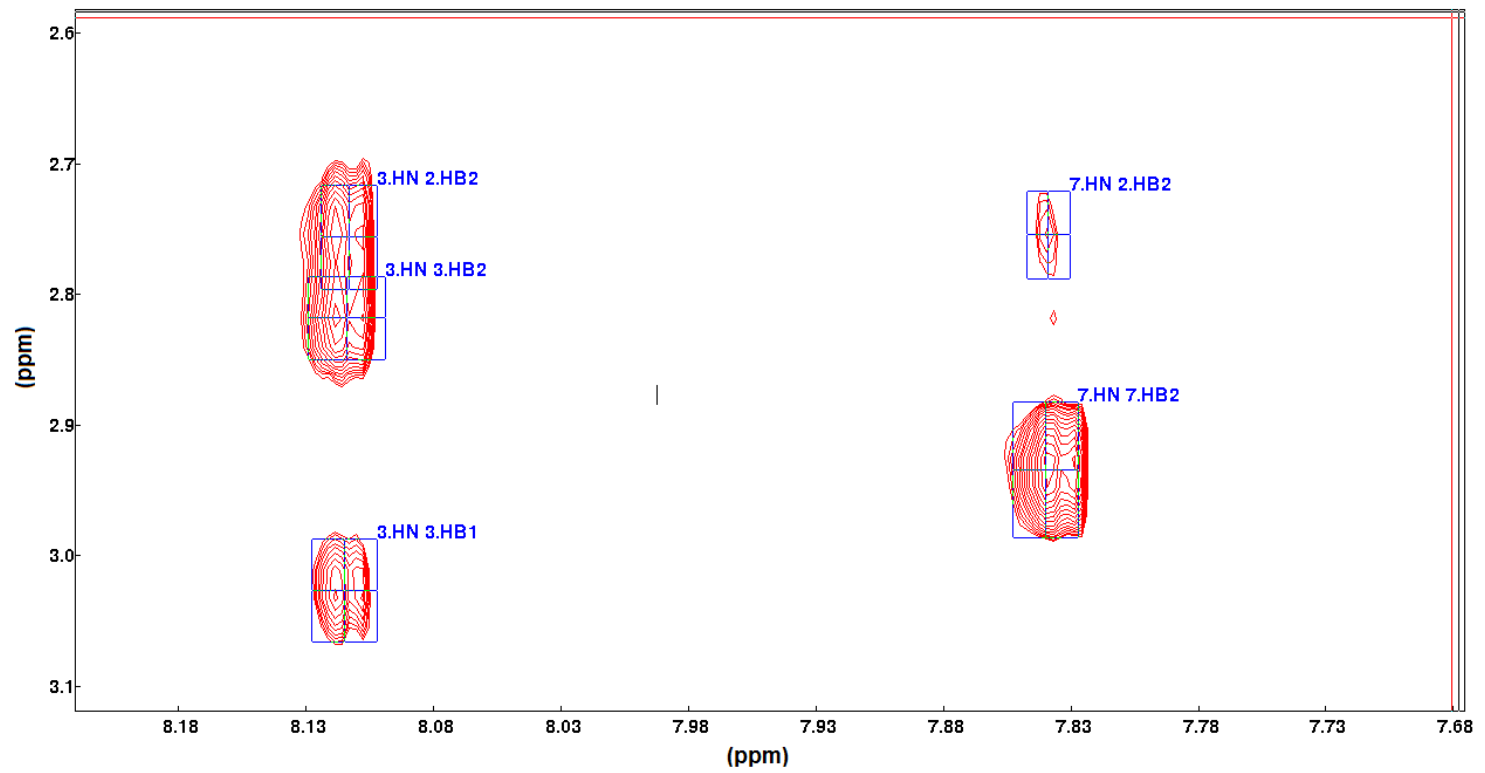

Anexo 88: Expansão de uma parte da região aromática do espectro ROESY do peptídeo TOC1. É observado ROE entre os resíduos de aminoácidos Cys ${ }^{2}$ e Cys ${ }^{7}$, que confirma a forma ciclizada do peptídeo.

\section{Anexo 89}

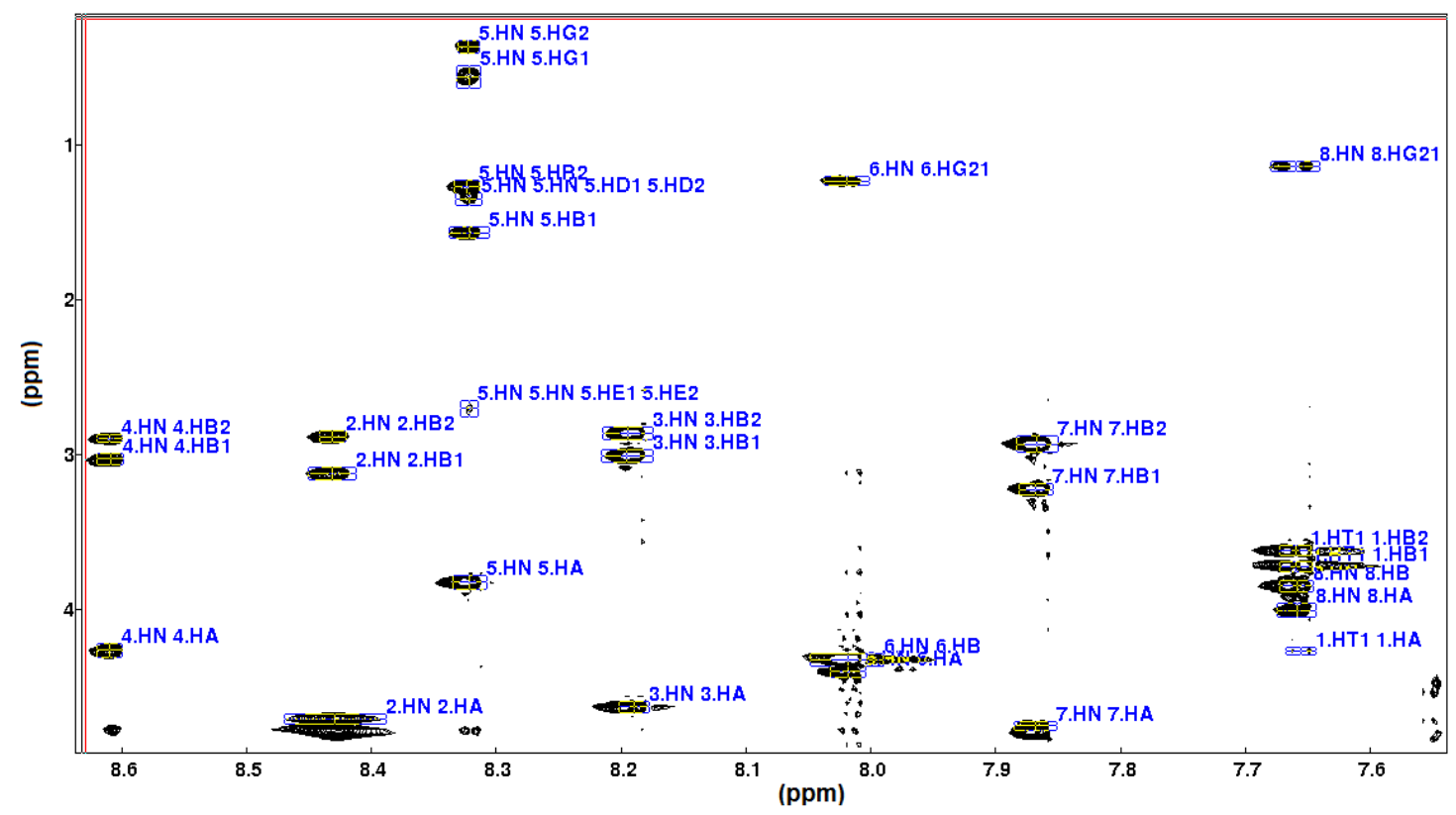

Anexo 89: Região aromática do espectro TOCSY do peptídeo TOC2, indicando parte dos sistemas de spins dos 8 resíduos de aminoácidos presentes na sequência do peptídeo. 
Anexo 90

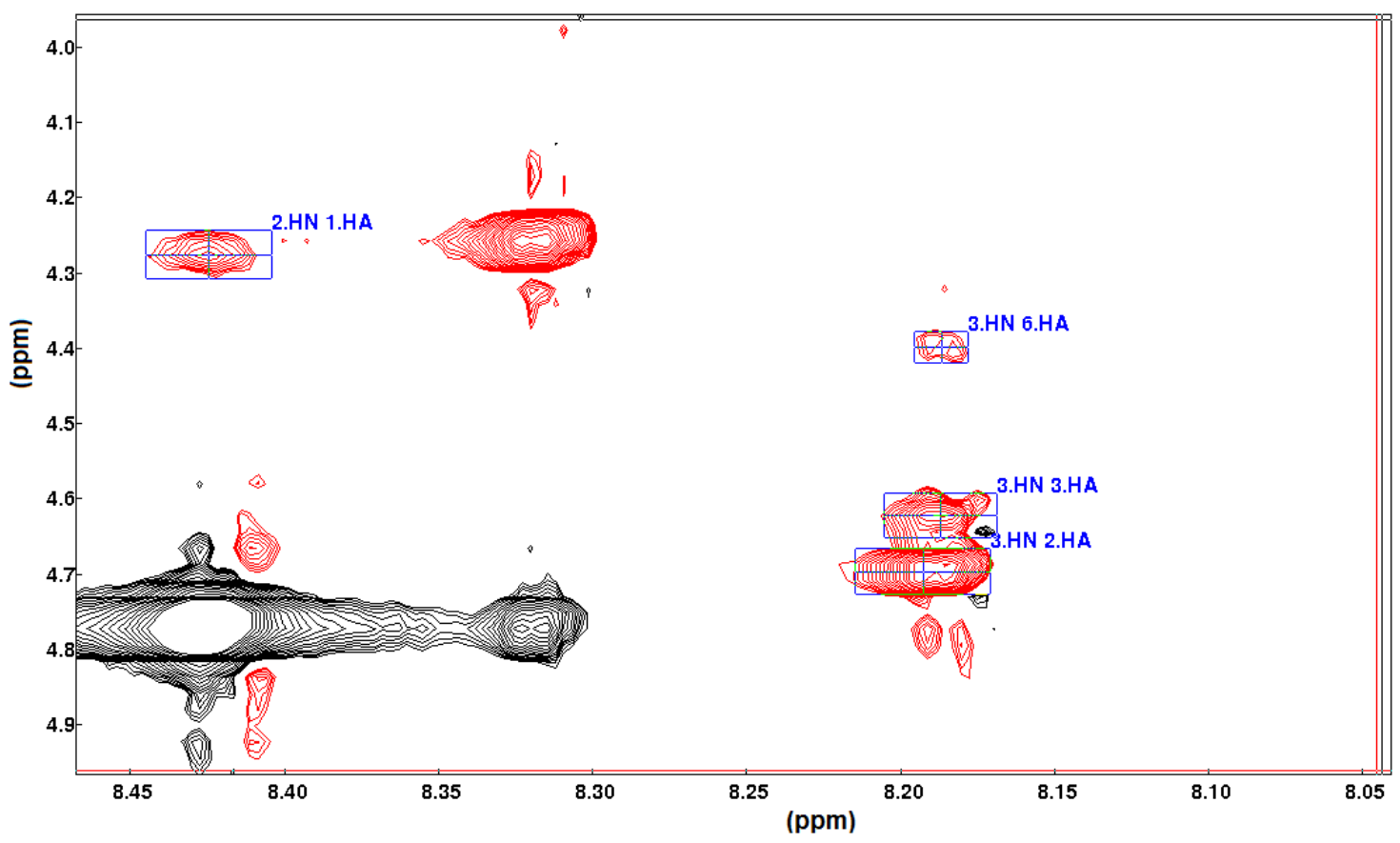

Anexo 90: Expansão de uma parte da região aromática do espectro ROESY do peptídeo TOC2. É observado ROE entre os resíduos de aminoácidos $\mathrm{Tyr}^{3} \mathrm{e} \mathrm{Thr}^{6}$, que confirma a forma ciclizada do peptídeo.

\section{Anexo 91}

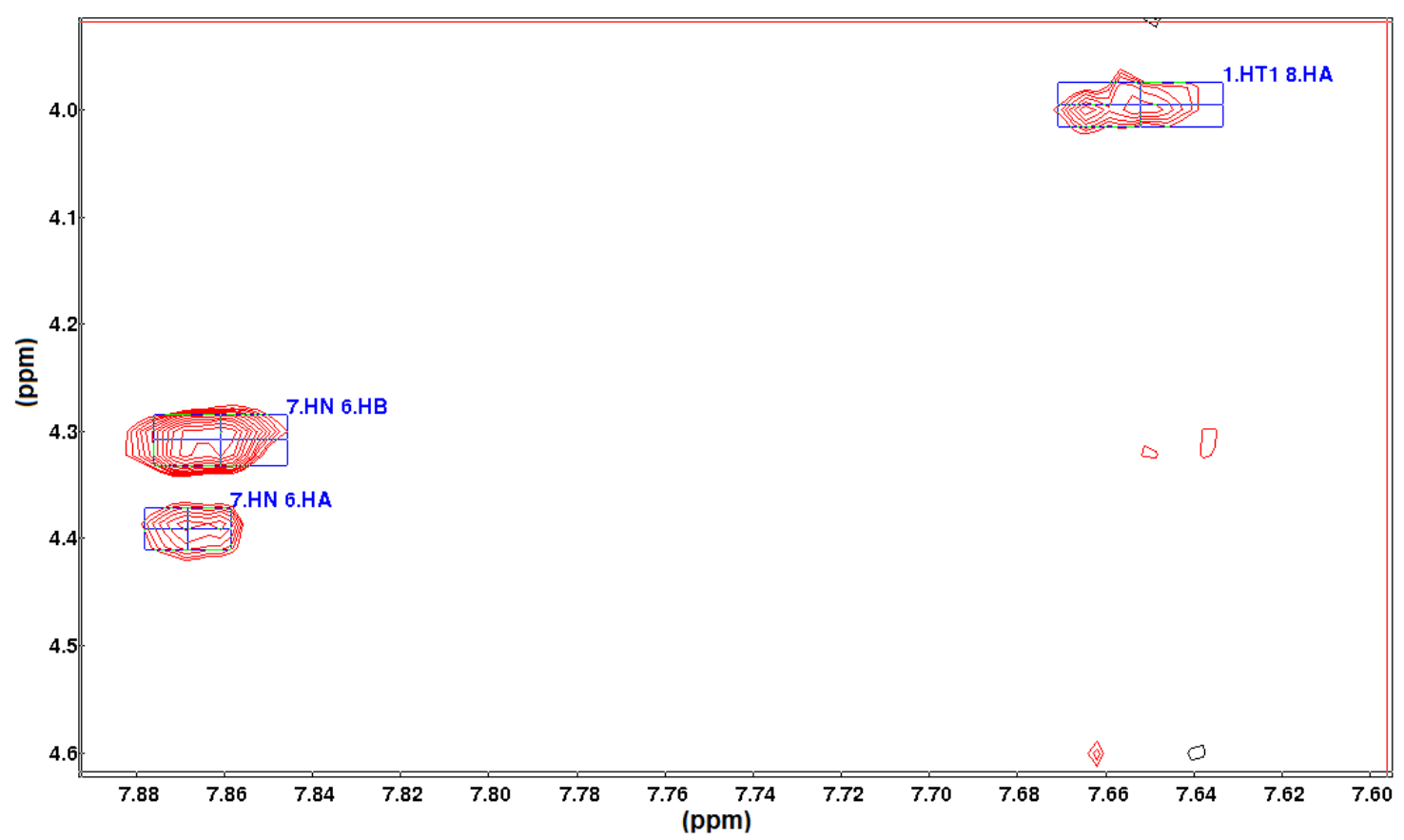

Anexo 91: Expansão de uma parte da região aromática do espectro ROESY do peptídeo TOC2. É observado ROE entre os resíduos de aminoácidos $\mathrm{Phe}^{1}$ e $\mathrm{Thr}^{8}$, que confirma a forma ciclizada do peptídeo. 
Anexo 92

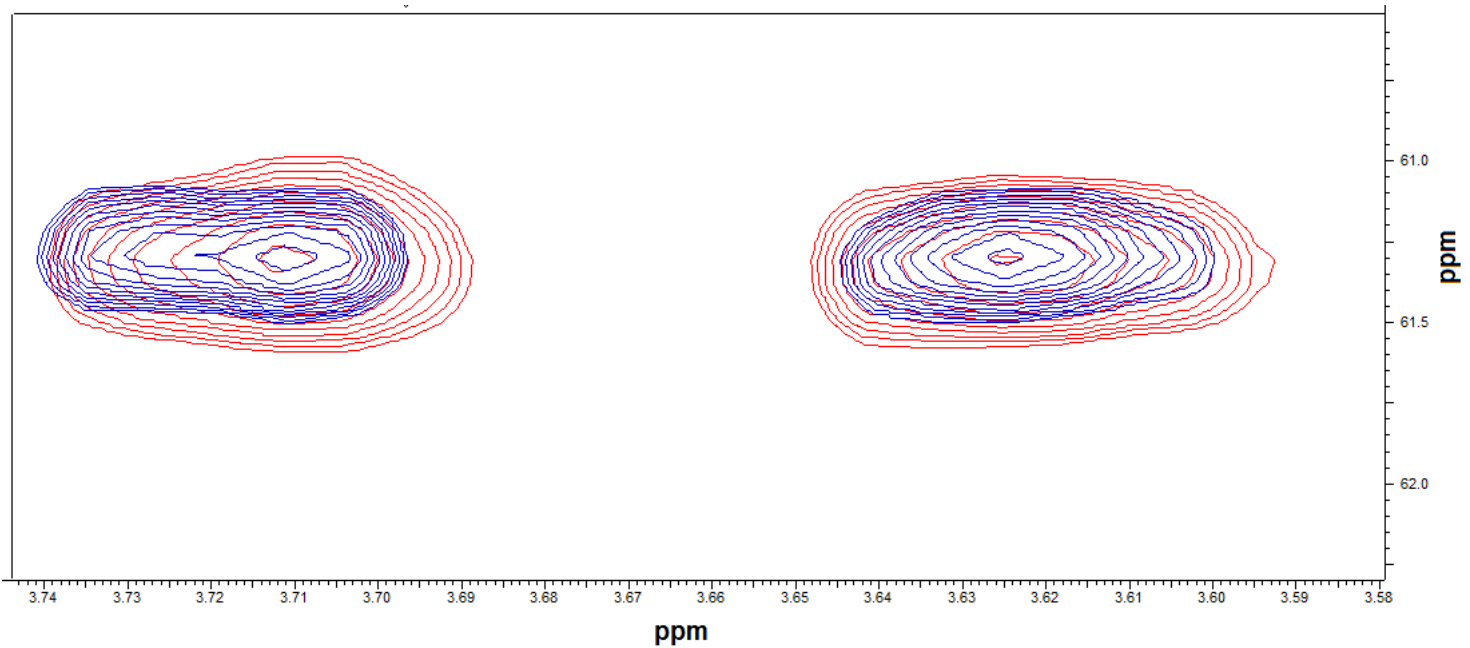

Anexo 92: Sobreposição dos espectros de HSQC do TOC1 livre (azul) e na presença da enzima (vermelho), com expansão para alguns sinais que não sofreram variação de deslocamento químico.

\section{Anexo 93}

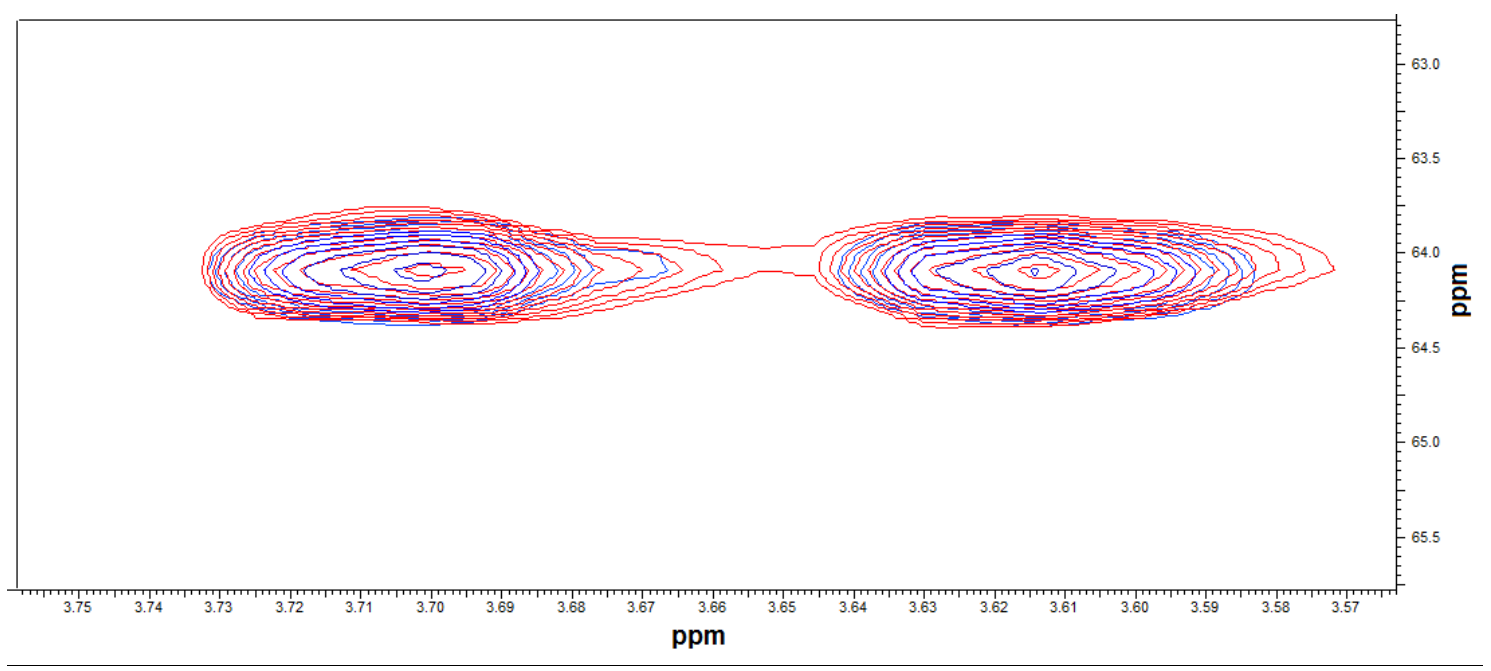

Anexo 93: Sobreposição dos espectros de HSQC do TOC2 livre (vermelho) e na presença da enzima (azul), com expansão para alguns sinais que não sofreram variação de deslocamento químico. 